\title{
Co-assistentschappen als inwijding in de medische beroepscultuur : gender in de socialisatie tot arts
}

Citation for published version (APA):

Winants, Y. H. W. (1999). Co-assistentschappen als inwijding in de medische beroepscultuur : gender in de socialisatie tot arts. [Doctoral Thesis, Maastricht University]. Thela Thesis. https://doi.org/10.26481/dis.19990630yw

Document status and date:

Published: 01/01/1999

DOI:

10.26481/dis.19990630yw

Document Version:

Publisher's PDF, also known as Version of record

\section{Please check the document version of this publication:}

- A submitted manuscript is the version of the article upon submission and before peer-review. There can be important differences between the submitted version and the official published version of record.

People interested in the research are advised to contact the author for the final version of the publication, or visit the DOI to the publisher's website.

- The final author version and the galley proof are versions of the publication after peer review.

- The final published version features the final layout of the paper including the volume, issue and page numbers.

Link to publication

\footnotetext{
General rights rights.

- You may freely distribute the URL identifying the publication in the public portal. please follow below link for the End User Agreement:

www.umlib.nl/taverne-license

Take down policy

If you believe that this document breaches copyright please contact us at:

repository@maastrichtuniversity.nl

providing details and we will investigate your claim.
}

Copyright and moral rights for the publications made accessible in the public portal are retained by the authors and/or other copyright owners and it is a condition of accessing publications that users recognise and abide by the legal requirements associated with these

- Users may download and print one copy of any publication from the public portal for the purpose of private study or research.

- You may not further distribute the material or use it for any profit-making activity or commercial gain

If the publication is distributed under the terms of Article $25 \mathrm{fa}$ of the Dutch Copyright Act, indicated by the "Taverne" license above, 
Co-assistentschappen als inwijding in de medische beroepscultuur

Gender in de socialisatie tot arts 


\section{Productiebegeleiding}

Datawyse | Universitaire Pers Maastricht

\section{ISBN}

- YHWM Winants, Maastricht 1999

Deze studies zijn uitgevoerd binnen de Nederlandse onderzoeksschool Care, Netherlands School of Primary Care Research, sinds 1995 erkend door de KNAW.

Co-assistentschappen als inwijding in de medische beroepscultuur.

Gender in de socialisatie tot arts/Winants, YHWM Thesis Maastricht.

All rights reserved. No part of this book may be reproduced or transmitted in any form or by any means, electronic or mechanical, including photocopying, recording, or by any information storage and retrieval system without written permission from the publisher, except for the inclusion of brief quotations in a review. 


\title{
Co-assistentschappen als inwijding in de medische beroepscultuur
}

\author{
Proefschrift
}

ter verkrijging van de graad van doctor aan de Universiteit Maastricht, op gezag van de Rector Magnificus, Prof. dr. A.C. Nieuwenhuijzen Kruseman, volgens het besluit van het College van Decanen, in het openbaar te verdedigen

op woensdag 30 juni 1999 om 16.00 uur

door

Yvonne Hubertina Wilhelmina Maria Winants, geboren op 14 augustus 1953 te Weert 


\section{Promotores}

Prof.dr. G.G.M. Essed

Prof.dr J.A. Knottnerus

Co-promotor

Dr. G. Noordenbos

Beoordelingscommissie

Prof.dr. H.F.P. Hillen (voorzitter)

Dr. M.L.M. Brouns (Rijksuniversiteit Groningen)

Prof.dr. G. Hofstede

Prof.dr. M.J.M. Meyer

Prof.dr. C.P.M. van der Vleuten

Publicatie van dit proefschrift is mede mogelijk gemaakt door een bijdrage van:

- VNVA Vereniging Nederlandse Vrouwelijke Artsen

- KNMG Koninklijke Nederlandse Maatschappij tot bevordering der Geneeskunst

- Glaxo Wellcome 
Opgedragen aan de lange adem 



\section{Inhoudsopgave}

1. Algemene inleiding

1.1 Vervrouwelijking van het medisch beroep 13

$\begin{array}{lll}1.2 & \text { Vrouwen als nieuwkomers } & 16\end{array}$

$\begin{array}{lll}1.3 & \text { Beroepssocialisatie in de medische opleiding } & 17\end{array}$

1.4 Doelstelling en opbouw van het proefschrift 20

Deel I: THEORETISCHE INTRODUCTIE OP HET ONDERWERP

2. Vrouwen in de geneeskunde

2.1 Historische terugblik en uitsluiting van vrouwen van het medisch beroep 27

2.2 De positie van vrouwelijke artsen in Nederland en in internationaal perspectief

2.3 Choice by constraint

2.4 Instroom van vrouwen in het medische beroep

2.5 Verschuivingen en de noodzaak tot veranderingen 33

2.6 Selectie en zelfselectie 36

2.7 Factoren die integratie van vrouwelijke artsen belemmeren 38

2.8 Samenvatting

3. Gender in de geneeskunde

3.1 Inleiding

3.2 Sekse, gender en arbeid

3.3 Ontwikkelingen in het denken over sekse en sekseverschillen 46

3.4 De gender-theorie van Scott 48

3.5 De medische professie en reproduktie van gender 50

- Sociale sluiting in de medische psychologie $\quad 52$

- Cultuur van medici en reproduktie van gender 52

3.6 Reproduktie van sociale ongelijkheid en identiteit 54

3.7 Samenvatting 
4. De medische opleiding en professionele socialisatie

4.1 Inleiding

4.2 Het doel van de medische opleiding

4.3 Inrichting en kwaliteit van de medische opleiding

4.4 Hoe tracht de medische opleiding haar eindtermen te realiseren?

4.5 Socialisatie in het algemeen

- Socialisatie als sociaal leren en identificatie met een referentiegroep

4.6 Dubbel-buitenstaanderschap. Het concept van de gevestigden en de buitenstaanders

4.7 Het initiatie-karakter van de co-assistentschappen

4.8 Socialisatie tot arts als cultuuroverdracht en de inhoud van de boodschap 71

4.9 De opvoedende werking van het ritueel van de "casuspresentatie"

- Tot slot

4.10 Samenvatting

Deel II: HET BEROEPSCULTUUR-ONDERZOEK

5 De beroepscultuur van artsen door de ogen van co-assistenten Doel, methode en variabelen

5.1 Inleiding

5.2 Socialisatie is cultuuroverdracht

5.3 Doelstelling en probleemstelling

5.4 Conceptualisering van aspecten van medische beroepscultuur

5.5 Vraagstellingen en hypothesen over sekseverschillen in perceptic en waardering

5.6 Ontwikkeling van het onderzoeksinstrument

5.7 Validiteit en interne betrouwbaarheid en operationalisaties van cultuuraspecten

5.8 Opzet en uitvoering van het onderzoek en statistische analyses 104

5.9 Statistische bewerkingen

5.10 Samenvatting

6. De beroepscultuur van artsen door de ogen van co-assistenten Resultaten en discussie

6.1 Inleiding

6.2 Respons en achtergrondgegevens respondenten

6.3 Resultaten van het beroepscultuur-onderzoek

- Perceptie en waardering van mate van machtafstand

- Perceptie en waardering van mate van onzekerheidsvermijding

- Perceptie en waardering van mate van femininiteit en masculiniteit

- Perceptie en waardering van het inwijdingsritueel

- Perceptie en waardering overige cultuuraspecten

6.4 Veranderingen in de tijd in perceptie of waardering van beroepscultuur 
6.6 Samenvattend overzicht van de bevindingen

6.7 Beschouwing

6.8 Methodische kanttekeningen

6.9 Aanbevelingen voor vorming en opleiding van jonge artsen 138

6.10 Samenvatting

\section{DEEL III: DOKTER WORDEN, GEEN ONVERDEELD GENOEGEN} Het socialisatie-onderzoek

7 De belasting van het inwijdingsproces

Doel, methode en variabelen

7.1 Inleiding

7.2 De fase van de co-assistentschappen als inwijdingsritueel

7.3 Het concept van de gevestigden en de buitenstaanders

7.4 Omgaan met problematische situaties

7.5 Probleemstelling en vraagstellingen

7.6 Model draaglast, draagkracht en outcome

7.7 Hypothesen over draaglast, draagkracht en outcome

7.8 Het onderzoekinstrument

7.9 Operationalisatie en beschrijving van de variabelen

7.10 Opzet en uitvoering van het onderzoek

7.11 Statistische technieken

8 De belasting van het inwijdingsproces

Resultaten en discussie

$8.1 \quad$ Inleiding

8.2 Respondenten

8.3 Resultaten transversaal en longitudinaal onderzoek naar draaglast 180

- Stellingen en stressoren

- Spot en denigrerende benadering

- Kwalitatieve gegevens over vormen van spot

8.4 Samenvatting resultaten draaglast

8.5 Resultaten transversaal en longitudinaal onderzoek naar draagkracht

- Coping stijlen

- Assertiviteit en examenvrees

8.6 Samenvatting resultaten draagkracht

8.7 Resultaten transversaal en longitudinaal onderzoek naar outcome 193

- Vermoeidheid en gezondheidsklachten

- Motivatie

8.8 Samenvatting resultaten outcome

8.9 Meervoudige lineaire regressie analyse met achtergrondvariabelen

- Variabelen draaglast

- Variabelen draagkracht

- Variabelen outcome 
8.10 Samenvatting van de resultaten

8.11 Beschouwing

8.12 Samenvatting

DEEL III: DE ONTWIKKELING VAN DE PROFESSIONELE IDENTITEIT Het socialisatie-onderzoek (vervolg)

9 De ontwikkeling van de professionele identiteit

Doel, methode en variabelen

9.1 Inleiding

9.2 Dynamiek van de ontwikkeling van de professionele identiteit

9.3 Gender en professionele socialisatie

9.4 Probleemanalyse en vraagstellingen

9.5 Hypothesen bij de verschillende thema's

9.6 Het onderzoekinstrument, validiteit en interne betrouwbaarheid 229

9.7 Operationalisatie en beschrijving van de variabelen 229

9.8 Samenvatting

10 De ontwikkeling van de professionele identiteit Resultaten en discussie

10.1 Inleiding

10.2 Respondenten 240

10.3 Resultaten transversaal en longitudinaal onderzoek naar (zelf)evaluatie 241

- Thema 1 identificatie

- Thema 2 expliciet onderscheid naar sekse en genderidentiteit

- Kwalitatieve gegevens over het voorkomen van ongewenste intimiteiten 247

10.4 Samenvatting resultaten (zelf)evaluatie

10.5 Resultaten transversaal en longitudinaal onderzoek naar professioneel zelfvertrouwen

- Thema 3 professioneel zelfvertrouwen

10.6 Samenvatting resultaten professioneel zelfvertrouwen

10.7 Resultaten transversaal en longitudinaal onderzoek naar aspecten van professionele identiteit

- Thema 4 ideaalbeeld en zelfbeeld

- Thema 5 beroepsoriëntatie

- Thema 6 loopbaanoriëntatie

10.8 Samenvatting resultaten professionele identiteit 258

10.9 Meervoudige lineaire regressie analyse 260

10.10 Samenvatting van de resultaten 265

$\begin{array}{ll}10.11 \text { Beschouwing } & 271 \\ 10.12 \text { Samenting } & 275\end{array}$

$\begin{array}{ll}10.12 \text { Samenvatting } & 275\end{array}$ 
11 De co-assistentschappen als broedstoof voor de professionele identiteit. Samenhangen nader beschouwd

11.1 Inleiding

11.3 Overzicht van de variabelen

11.4 Resultaten vraagstelling A over verklarende variabelen van professioneel zelfvertrouwen

11.5 Resultaten vraagstelling B over verklarende variabelen van seksebonden praktijken en genderidentiteit

11.6 Resultaten vraagstelling $\mathrm{C}$ over verklarende factoren van spot, vermoeidheid en motivatie

11.7 Samenvatting van de resultaten

11.8 Beschouwing

\section{DEEL IV: GIRLS IN WHITE} Slotbeschouwing

12 Slotbeschouwing

12.1 Tijd om de bakens te verzetten

12.2 Onderzoek naar medische beroepscultuur 302

12.3 Percepties van co-assistenten

- Masculiene of feminiene cultuur

12.4 Appreciatie van de medische beroepscultuur door co-assistenten 306

12.5 De kloof tussen ideaal en alledaagse werkelijkheid 307

12.6 Het inwijdingsproces van artsen blijkt motiverend en stimulerend 308

12.7 Attitude-verandering in de richting van meer autonomie en professioneel zelfvertrouwen

12.8 Het aanleren van de professionele distantie

12.9 Aanspreken en aangesproken worden

12.10 De mythe van de "sekseneutrale geneeskunde"

12.11 Oriëntatie op beroep en beroepsrol

$12.12 \mathrm{Zijn}$ de empirische gegevens nog accuraat en actueel?

12.13 Dubbel-buitenstaanderschap voor vrouwelijke co-assistenten? Het functioneert anders

12.14 De noodzaak van vernieuwing en innovatie

Referenties

Bijlagen: - Bijlage 1 (passend bij hoofdstuk 6)

Samenvatting

Summary

Dankwoord 



\section{Hoofdstuk 1}

\section{Algemene inleiding}

\subsection{Vervrouwelijking van het medisch beroep}

Sedert enige jaren kan men een grote verschuiving waarnemen in de sekseverhouding in zowel de medische opleiding als in de medische beroepsgroep. Het aandeel van vrouwen in de populatie artsen en geneeskunde-studenten is fors gestegen en fluctueert in Nederland rond de vijftig procent sinds 1983 (KNMG, 1989; Martens, 1990). Ook in andere Westerse landen als Verenigde Staten, Canada, Israël, Duitsland en Groot Brittannië ziet men een snelle toename van het aantal vrouwelijke studenten en artsen (Nickerson, 1990; Lorber, 1993; Woodward, 1990; Notzer en Brown, 1995; Sieverding, 1990; Elston, 1993). Vrouwelijke studenten geneeskunde ontwikkelen zich echter in de context van een beroep, dat tot voor kort werd gekenmerkt door een grote oververtegenwoordiging van mannelijke professionals.

In de geschiedenis van het medisch beroep is de rol van vrouwelijke artsen noodgedwongen bescheiden geweest (Bosch, 1994; Schoon, 1995). Vrouwen waren lange tijd uitgesloten van het artsenberoep, omdat zij geen toegang hadden tot het volgen van universitair onderwijs. Dit is sedert de invoering van de wetten van Thorbecke een voorwaarde in Nederland voor de uitoefening van de geneeskunst. In 1871 kon Aletta Jacobs (1854-1929) als eerste met de medische studie beginnen, omdat haar, dankzij een interventie van de minister president, werd toegestaan om als eerste vrouw de (exclusief aan mannen voorbehouden) universitaire collegebanken te betreden. Ook in andere Westere landen ging de instroom van vrouwen in de academie vaak niet van een leien dakje, soms moest het bastion van de academische geneeskunde zelfs frontaal bestormd worden om toegang voor vrouwen te realiseren (Blackwell,1977; Bosch, 1982). Sinds het begin van deze eeuw komen vrouwelijke artsen in Nederlandse professie voor maar vooralsnog als een zeldzaamheid. Ze vormden jarenlang een 
minderheidsgroep, die tot in de zeventiger jaren kleiner bleef dan 20\% van het totaal aantal artsen in Nederland (Bosch, 1994).

In vergelijkende studies over kenmerken van het beroepsmatige functioneren van vrouwelijke en mannelijke artsen wordt vaak gewezen op verschillen in inkomen (vrouwen verdienen minder), in hoeveelheid uren die per week worden gewerkt (vrouwen werken minder uren per week) en een verschil in de mate waarin de medische loopbaan wordt onderbroken (Hoyat et al, 1995; Woodward, 1990; Shye, 1991; Uhlenberg, 1990). De seksen zouden verder vaak andere vakgebieden of specialismen kiezen, verschillen in doorstroming naar hogere functies en een verschillend sociaal patroon laten ten aanzien van huwelijk en gezin.

Elston (1993) beschrijft de situatie van vrouwelijke artsen in Engeland als gekarakteriseerd door verticale en horizontale sekse-segregatie. Vrouwen zijn relatief oververtegenwoordigd in die sectoren met een lagere status en met een lagere salariëring. Vrouwen werken vaak in beroepen met een platte hiërarchie zodat er weinig carrière mogelijkheden zijn. Opvallend weinig vrouwelijke artsen ziet men in hogere leidinggevende functies en ook werken slechts weinig vrouwen in Engeland als chirurg (3\% in 1990) of als gynaecoloog (12\% in 1988). Elston wijst als mogelijke oorzaken van het nagenoeg ontbreken van vrouwen binnen de chirurgie op de sterke competitie, de zeer langdurige opleiding en het macho-image van "consultants" in dit vakgebied en tot slot op de grote nadruk op totale toewijding tot het vak.

Uhlenberg's onderzoek onder een representatieve steekproef van artsen in de Verenigde Staten naar carrière en gezinskenmerken liet zien dat vrouwelijke artsen minder vaak trouwen, vaker op oudere leeftijd trouwen, vaker een echtscheiding meemaken en minder vaak hertrouwen dan hun mannelijke collega's. De relatie tussen carrière en privé-leven in de VS zou bij vrouwelijke artsen een patroon vertonen, dat tegengesteld is aan dat van mannelijke artsen, die als uitgesproken "familistic" worden beschreven. Hoog inkomen en lange werkweken bleken bij mannelijke artsen samen te hangen met gehuwde staat en het hebben van kinderen, bij vrouwelijke artsen met ongehuwd-zijn of samenleven met alleen een partner (Uhlenberg, 1990).

Uit onderzoek in Nederland blijkt dat vrouwelijke artsen er minder in slagen om hun wensen ten aanzien van toekomstige beroepsuitoefening te realiseren dan mannen. Zowel de kans om een loopbaan in het geprefereerde medisch specialisme of vakgebied te realiseren bleek kleiner, als de kans om de gewenste werktijdfactor te realiseren (Hermann, 1984; Heiligers, 1996).

De rol die vrouwelijke artsen binnen de medische professie kunnen spelen in de diverse Westerse landen kan worden getypeerd als te beperkt; ze maken nog nauwelijks deel uit van de hogere kaders in de geneeskunde, stromen slechts moeizaam door naar deze functies en zijn in docenten- en opleidingsfuncties vooralsnog in de minderheid (Meyboom-de Jong, 1992; Drenthe-Schonk et al, 1995). In de medische professie blijken uitsluitingsmechanismen te functioneren, die vrouwelijke artsen op subtiele wijze buiten de hogere functies in de geneeskunde houden en buiten bepaalde medische werkvelden. Sociale dynamieken aangeduid met de termen als "het glazen plafond" en "sociale sluiting" resulteren in een onevenwichtige verdeling van vrouwen over de verschillende lagen in de beroepsgroep van artsen (Brooks, 1998; Leemeyer, 
1990; Keizer, 1997; Butter en Carpenter, 1987). De snijdende specialismen blijken in veel landen minder toegankelijk (Baxter, 1996; Walters, 1993) en ook blijken vrouwelijke artsen naar werkvelden gedrongen te zijn, die vaak in het verlengde van de traditionele vrouwenrol liggen (Kortenhoeve, 1989; Horst van der en Kruijthof, 1989). Hierbij kan gedacht worden aan vakgebieden als de jeugdgezondheidszorg, de kindergeneeskunde of assisterende klinische specialismen zoals de anethesiologie.

Onder de titel "Monopoly of middle-aged men" worden in een hoofdredactioneel commentaar in de Lancet (1991) een aantal knelpunten in de doorstroming van vrouwelijke artsen in Engeland kort maar krachtig weergegeven. Vrouwelijke artsen beginnen, aldus de auteurs, met betere academische kwalificaties dan mannen, worden in verhouding even vaak aangenomen op opleidingsplaatsen in het ziekenhuis, maar zijn ondervertegenwoordigd op de niveaus daarboven. Ze wijzen op de grote motivatie van vrouwen voor hun vak, die vervolgens geconfronteerd worden met de moeizame combinatie van ouderschap en de lange werkweken. Vaak voelen vrouwen zich dan genoopt tot een keuze voor part-time werk als assistent, sociaal geneeskundig werk of andere banen in de medische professie die minder status hebben. Ook wijzen de auteurs erop dat de "Royal Colleges"1 weinig gevolg geven aan de aanbeveling van de overheid om de mogelijkheid voor part-time opleidingen te scheppen tot huisarts of specialist. Sollicitatie-procedures blijken sterk in het voordeel te werken van blanke mannen. De medische professie bestaat uit een "gesettled" netwerk van senioren, aldus deze opiniërende bijdrage (Lancet, 1991).

Diverse auteurs wijzen op structurele belemmeringen als de beperkte toegankelijkheid van medische (vervolg)opleidingen voor vrouwen, het nagenoeg ontbreken van deeltijdopleidingen en deeltijdfuncties en het samenvallen van de biologische periode voor het baren van kinderen met de periode waarin de medische carrière gestalte moet krijgen. Daarnaast benadrukken auteurs de belemmeringen die voortvloeien uit de heersende 'cultuur' van de medische beroepsgroep (Lorber, 1993; Brooks, 1998; Nickerson, 1990; Sieverding, 1995). In deze cultuur circuleren diverse sekse-stereotype opvattingen, die de ontplooiingsmogelijkheden voor vrouwen in het veld van medische beroepsuitoefening beperken. Zij wijzen hierbij ook op de psychologische factoren die een rol spelen. Een organisatie- of beroepscultuur bevat allerlei vooronderstellingen, opvattingen en oordelen over kwaliteit, over wat waardevol is en wat juist of onjuist is, hetgeen de processen van zelfselectie en selectie van nieuwkomers sterk beinvloed (Veldman en Wittink, 1990). Op basis bovenstaande lijkt het aannemelijk te veronderstellen dat de 'beroepscultuur' van een beroep, waarin mannelijke beroepsbeoefenaren van oudsher de boventoon voeren, beter aansluit bij socialisatie als man dan bij socialisatie als vrouw.

Binnen vrouwenstudies en genderstudies is het verschil en de gelijkheid tussen mannen en vrouwen op het terrein van arbeid uitvoerig onderzocht en gedocumenteerd. Diverse theoretische kaders zijn geëxploreerd om meer inzicht te krijgen in de hardnekkigheid van de ongelijkheid tussen de seksen. Hoe komt het, om met Brouns (1993) te spreken, dat sekseverschillen steeds weer als sekse-ongelijkheid worden

${ }^{1}$ Genootschappen van medische beroepsgroepen als medisch specialisten of huisartsen die inrichting en instroom tot de beroepsopleiding reguleren en bewaken 
gereproduceerd? Daartoe is het belangrijk het gender-begrip te introduceren. Gender wordt beschreven als 'a constitutive element of social relationships based on perceived differences between the sexes; gender is a primary way of signifying relationships of power' (Scott, 1986). Gender is dus een ruimer begrip dan sekse, omdat gender (1) niet beperkt is tot zichtbare verschillen, maar ook gerelateerd kan worden aan ogenschijnlijk sekse-neutrale verschijnselen en instituties, omdat (2) het verschillen niet noodzakelijkerwijs herleidt tot een dichotomie en omdat (3) het verwijst naar een sociale structurering waarin verschillen tussen mannen en vrouwen specifieke betekenis krijgen. Gender is niet geheel terug te voeren op macht, maar macht is wel een wezenlijk bestanddeel van gender. De medische opleiding en de medische professie kunnen worden opgevat als sociale instituties, die mogelijkerwijze eveneens verschil tussen de seksen reproduceren in de vorm van machtsongelijkheid. In dit onderzoek zullen verschillen tussen de seksen in de opleiding tot arts in het brandpunt van de belangstelling staan en zal bij de interpretatie van de bevindingen de analyse verrijkt worden met theoretische inzichten over gender en identiteitsontwikkeling en de dwingende invloed van cultuuroverdracht in het proces van professionele socialisatie tot arts in de context van de co-assistentschappen.

\subsection{Vrouwen als nieuwkomers}

Algemeen gesteld zijn de mogelijkheden van vrouwen op betaalde arbeid de afgelopen jaren sterk toegenomen. Vrouwen zijn echter relatieve nieuwkomers in beroepen met een hoge maatschappelijke status (Brouns \& Schokker, 1990). Tegelijkertijd ziet men dat een herverdeling van de onbetaalde arbeid - vaak in de privésfeer -tussen mannen en vrouwen maar moeizaam op gang komt (Bruyn-Hundt, 1989). Ook binnen de betaalde arbeid blijkt de integratie van vrouwen op de diverse functieniveaus zeker nog niet probleemloos te verlopen (van der Lippe \& van Doorne-Huiskes, 1995; Brouns \& Schokker, 1990). Zowel de sterke ondervertegenwoordiging van vrouwen in de bovenste lagen van allerlei maatschappelijke instituties en instellingen, alsook het voorkomen van ongewenste intimiteiten van mannen richting vrouwelijke collega's of ondergeschikten kunnen worden opgevat als indicaties van asymmetrische verhoudingen tussen de seksen op de werkvloer.

De sociologen Elias en Scotson (1985) ontwikkelden een theorie over de relatie tussen gevestigden en buitenstaanders, over de sociogenese van gevoelens van meer- en minderwaardigheid. Deze theorie maakt duidelijk hoe ongelijke machtsverhoudingen tussen sociale groeperingen doorwerken in sociale interactie tussen leden van deze groepen en over psychologische aspecten als zelf-beeld en wij-beeld. Met het 'gevestigden-buitenstaanders' perspectief kan een 'universeel menselijk thema' geanalyseerd worden, dat mensen die tot machtige groepen behoren, de gevestigden, van zichzelf denken dat ze 'beter' zijn dan anderen en dit geloof in eigen superioriteit ook met succes weten over te brengen bij minder machtigen. dat werd ontwikkeld naar aanleiding van onderzoek in een Engelse arbeiderswijk naar de sociale dynamiek van een groep bewoners die daar van oudsher woonden en een groep nieuwkomers - Figuratieverklaringen zouden van groot belang zijn voor identiteit en zelfgevoel en voor het 
wij-gevoel. Hoe mensen over zichzelf denken - hun zelfbeeld- en hoe ze over hun eigen groep denken - hun wij-beeld - zou niet alleen te verklaard kunnen worden vanuit het individu zelf, maar ook vanuit de figuratie, of sociale vervlechtingsstruc tuur waar mensen deel van uitmaken. Dit wij-beeld en wij-ideaal zou verder evenzeer deel uit maken van het zelf-beeld en zelf-ideaal van een persoon, zichzelf belevend als uniek persoon waarna men verwijst met het woord 'ik' (Timmerman, 1990, pp 35-36).

Een andere theorie die licht werpt op de sociale dynamiek tussen de seksen in arbeidsorganisaties, is de 'token theorie' van Moss Kanter (1977). Vrouwen worden binnen het domein van de betaalde arbeid gezien als representanten van een minderheidsgroep, vergelijkbaar met andere minderheidsgroepen zoals medewerkers met een andere etnische achtergrond bijvoorbeeld. Wanneer een groep slechts in kleine getale in een organisatie aanwezig is en een minderheid vormt, zouden fenomenen als verhoogde zichtbaarheid en stereotypering optreden. En deze optredende statistische discriminatie heeft dan weer invloed op de sociale en psychologische ruimte die de minderheid ter beschikking staat.

Wanneer vervolgens het aandeel van de minderheid toeneemt, zouden de machtsverhoudingen tussen de zittende groep en de minderheid automatisch gaan verschuiven ten gunste van de minderheid. Uit onderzoek van Ott (1985) blijkt echter dat deze theorie niet direct van toepassing is op verschuivende sekseverhoudingen in mannenen vrouwenberoepen. $\mathrm{Bij}$ de politie als mannenberoep en de verpleging als vrouwenberoep onderzocht Ott de effecten van de getalsmatige toename van de andere sekse in het betreffend beroep. Uit de resultaten bleek dat de integratie van vrouwen in de politie, een mannenberoep, veel moeizamer verliep dan de integratie van mannen in de verpleging, een vrouwenberoep. De titel van haar dissertatie "Assepoesters en kroonprinsen, een onderzoek naar de minderheidspositie van agenten en verplegers" geeft uitdrukking aan de belangrijkste conclusies, dat de verschuiving in de machtsbalans aanmerkelijk moeizamer en stroever blijkt te verlopen, wanneer het aantal vrouwen toeneemt in een beroep dat van oudsher getalsmatig overheerst werd door mannen dan wanneer het omgekeerde het geval is.

\subsection{Beroepssocialisatie in de medische opleiding}

Geneeskunde studeren en opgeleid worden tot arts betekent niet alleen kennis verwerven en vaardigheden aanleren maar is tegelijkertijd een vormingsproces van de persoonlijkheid van de nieuwkomer tot iemand die in staat zal zijn deze maatschappelijke rol adequaat in te vullen. Hoewel artsen en -vaak ook onderwijskundigen- de medische opleiding voornamelijk zien als een leerproces gericht op toename van kennis en het verhogen van de cognitieve bagage van studenten als belangrijkste ingrediënt, is dit slechts een deel van het verhaal.

De medische opleiding beoogt naast overdracht van kennis en aanleren van vaardigheden, bovenal bepaalde eigenschappen bij aanstaande artsen tot ontwikkeling te brengen, die noodzakelijk zijn om de rol van arts te volbrengen (Dupuis, 1992; Dunning, 1981). Maar hoe ziet die beroepsrol van arts er momenteel eigenlijk uit? 
Een vast element in de beschrijving van de medische beroepsrol is dat een arts kennis en kunde moet inzetten in diens pogen om ziekte en gebrek van de medemens te verlichten. Maar hoe dit pogen vorm moet krijgen en hoe deze maatschappelijke rol concreet ingevuld moet worden, blijkt in sterke mate tijd- en cultuurgebonden. De voorschriften voor de professionele rol van een arts zijn het resultaat van sociale dynamiek en een lange geschiedenis van onderhandelingen en compromissen. In deze dynamiek speelt de beroepsgroep zelf uiteraard een grote rol, maar blijken ook de publieke opinie, overheid en niet in de laatste plaats de maatschappelijke ontwikkelingen een grote rol te spelen. Zeker de afgelopen jaren kan men duidelijke verschuivingen constateren in het maatschappelijk denken over rol en plaats van de geneeskunde in de moderne westerse samenleving (Dunning, 1981; Mc Keown 1979). Deze veranderingen plus verschuivingen in het morbiditeitspatroon van de bevolking in Westerse landen in de richting van meer ouderdomsziekten en meer chronische of ongeneeslijk ziekten, veroorzaken een zekere accentverschuiving in het medisch handelen van behandeling of "cure" naar zorg en begeleiding of "care" (Mulder, 1996; Mol \& Lieshout van, 1989). Metz (1993) stelt dat de medische beroepsrol momenteel aan verandering onderhevig is. De arts wordt, naar zijn mening 'alledaagser' en wordt geacht uit zijn ivoren toren te komen. Artsen kunnen het zich steeds minder permitteren om zich autoritair op te stellen maar dienen meer en meer te onderhandelen met patienten en niet te volstaan met te verwijzen naar hun, op medische expertise gestoelde, autoriteit. Dit vraagt van artsen om sociaal vaardig te zijn en sociaal intelligent en meer dan vroeger in staat te zijn adequaat met patiënten te kunnen communiceren en onderhandelen (Mulder, 1996; Goléman, 1996; Méeuwesen, 1991; Nouneac; 1999)! Ook lijken artsen tegenwoordig minder recht te kunnen doen gelden op een hoog inkomen dan vroeger en worden groepen artsen steeds vaker gedwongen door overheid of bestuurders zich te onderwerpen aan regels en financiële budgetten, hetgeen het gevoel van professionele autonomie van menige arts fors aantast (Mc. Kay, 1990). De maatschappelijke druk op de medische professie om te veranderen is groot, maar het blijft vooralsnog de vraag in hoeverre de medische professie daadwerkelijk verandert en in hoeverre de blauwdruk van de beroepsrol zoals deze momenteel wordt voorgehouden en voorgeleefd aan de toekomstige generatie artsen verschilt van vroeger. Het is in ieder geval verstandig om zich te realiseren dat professionele groepen de invloed van buitenaf vaak bijzonder klein weten te houden (Lupton, 1994; Klinkert, 1984; Krogt van der, 1981; Freidson, 1975).

Opgeleid worden tot arts betekent 'ingroeien in een doktersrol' zoals deze door de gevestigde medische professionele groep uitgewerkt en in een vorm gegoten is. En deze professie bestaat al jaren uit een meerderheid van mannelijke artsen, al stromen nu sedert enige jaren grote aantallen vrouwelijke artsen en studenten in.

Wanneer we het leerproces van aanstaande artsen opvatten als een proces van professionele socialisatie waarin de huidige beroepsgroep haar beroepscultuur overdraagt aan een generatie nieuwkomers, dan valt op dat de fase van het klinische stage-onderwijs in de laatste twee jaar van de basisarts-opleiding, ook wel de fase van de co-assistentschappen genoemd, een zeer betekenisvolle en invloedrijke periode is. In deze periode verlaat de medische student na vier jaar onderwijs de universitaire schoolbank en trekt letterlijk en figuurlijk de witte jas aan. Voor het eerst zal de medische student de 
medische beroepsrol gaan invullen, hetgeen in eerste instantie zal geschieden als gezel in een meester-gezel verhouding met de opleidende artsen in de kliniek en huisartspraktijk.

Socialisatie wordt gedefinieerd als een proces waardoor een individu lid van de maatschappij of een groep leert worden en waarin bepaalde gedragspatronen worden opgelegd. Het kan gedefinieerd worden als een inwijdingsproces in een sociale wereld, in zijn vele vormen van interactie en zingeving (Berger \& Berger, 1988). Socialisatie wordt vaak geassocieerd met het opgroeien van jonge kinderen, maar het is een proces dat in diverse levensfasen en binnen diverse contexten een rol speelt. Primaire socialisatie-processen, vooral plaatsvindend in de vroege jeugd, werken dieper in op de persoonlijkheid dan vergelijkbare processen in latere fasen, zoals bijvoorbeeld beroepssocialisatie, een vorm van secundaire socialisatie. De sociale patronen, die worden overgedragen, hebben vooral bij primaire socialisatie voor de gesocialiseerde - dit geldt zeker voor kinderen - een min of meer absoluut karakter. Dit hangt samen met de overmacht van de significante anderen, als ouders en andere opvoeders, op het kind en diens onbekendheid met alternatieve patronen. Pas later wordt het individu zich bewust van de relativiteit van overgedragen sociale patronen (Duindam, 1992). De primaire socialisatie van kinderen leert ons echter ook dat socialisatie altijd een wederzijds proces is en niet alleen "het invullen van een lege bladzijde". Kinderen verzetten zich soms heftig, zoeken grenzen en dwingen ouders vaak tot bijstelling van eisen of eigen gedrag. Van zowel ouders als kinderen wordt aanpassing verlangt, zij het dat beide zijden wel ongelijk in machtspositie zijn.

De professionele socialisatie tot arts is een vorm van secundaire socialisatie, maar vertoont overlap met primaire socialisatie (Pool en Pool, 1983). Met name de sterke afhankelijkheid van co-assistenten van hun opleiders en de indringende ervaringen die de nieuwkomer opdoet - zoals het omgaan met stervenden, ongeneeslijk zieken en de confrontatie met onmacht en de ontoereikendheid van medisch handelen - maken dat diepere lagen in de persoonlijkheid beïnvloed worden. Literatuur over effecten en ervaringen tijdens co-assistentschappen en medische vervolgopleidingen leert dat de leer- en opvoedingservaringen zeer overheersend en indringend zijn en de persoonlijkheid van de aanstaande arts beïnvloeden (Becker, 1961; Coombs, 1978; Fahrenfort, 1985; De Vries, 1988). De co-assistent zal voor het eerst ervaren wat het betekent om in de medische beroepen en in diverse werkvelden werkzaam te zijn en zal zich als persoon (zelf) tot de medische rol van "dokter" verhouden. Ook zal zij ${ }^{2}$ de ervaringen in de fase van de co-schappen gebruiken om het persoonlijke beeld van arts-zijn bij te stellen en de eigen preferenties ten aanzien van de verdere medische loopbaan te ontwikkelen en plannen voor die loopbaan verder uit te stippelen.

Hoewel het opleidingsinstituut formeel het leerproces stuurt tijdens de fase van de medische stages of co-assistentschappen, heeft dit sterk het karakter van"training on the job" en is de invloed van de werkomgeving erg groot. Het leerproces is sterk

${ }^{2}$ Om te voorkomen dat steeds $\mathrm{zij} / \mathrm{hij}$ moet worden vermeld, wordt steeds de vrouwelijk vorm gekozen. De term "zij" verwijst zowel naar een vrouwelijk individu als naar cen mannelijk individu. 
wederkerig; enerzijds ondergaat de nieuwkomer - als object - de invloed van de beroepsgroep en haar cultuur en zal ze zich aanpassen, maar tegelijkertijd neemt ze - als subject - ook zelf actief deel aan dit proces en houdt het leertraject vaak ook persoonlijke groei en ontwikkeling in voor de leerling. De co-assistent zal zich bijvoorbeeld meer of minder identificeren met de artsen-opleiders als rolvoorbeelden en zal de eigen indrukken en ervaringen aan het ziekbed en in interactie met patiënten of hun familie evalueren. Ook de manier waarop de co-assistent wordt aangesproken door de artsen-opleiders, hun manier van omgaan met elkaar, de samenwerking met de verpleegkundigen en andere werkers in de gezondheidszorg zullen gewogen en beoordeeId worden door de nieuweling in het licht van de eigen biografie. Samenvattend kan gesteld worden dat co-assistenten zijn verwikkeld in een vormings- en veranderingsproces dat zowel kenmerken van primaire als van secundaire socialisatie heeft. $\mathrm{Zij}$ zijn nieuwkomers in de medische beroepspraktijk, die bezig zijn zich te kwalificeren als professional en daarmee toegang krijgen tot het medisch beroep en lid mogen worden van deze professie. De fase van de co-assistentschappen heeft voor aanstaande artsen zowel de functie van opleidingsfase als van eerste werkervaring.

\subsection{Doelstelling en opbouw van het proefschrift}

In dit proefschrift wordt getracht licht te werpen op het proces van beroepssocialisatie van co-assistenten tot arts en wordt specifieke aandacht besteed aan de ervaringen van vrouwelijke artsen en co-assistenten. Centraal staat de wisselwerking tussen gender in de (leer)omgeving - in de sociaalculturele context - en werking van gender in het zich ontwikkelende individu. Verschillen en overeenkomsten in de ervaringen van vrouwen en mannen worden nader onderzocht en geëvalueerd in het licht van mogelijke reproduktie van (machts)verschillen tussen mannelijke en vrouwelijke artsen en impact op professionele identiteit. In het onderzoek naar percepties en waardering van co-assistenten van de beroepscultuur van de artsengroep, die hen opleidt en introduceert in de medische wereld, richten we ons onderzoek op mogelijke verschillen tussen vrouwelijke en mannelijke co-assistenten en reflecteren we op de impact van de bevindingen. In het socialisatie-onderzoek richten we de aandacht vooral op de ervaringen van vrouwelijke en mannelijke co-assistenten, de verschillen en de overeenkomsten en de veranderingen in de tijd. We staan stil bij de mogelijke gevolgen van deze socialisatie-ervaringen voor de verdere professionele ontwikkeling van deze nieuwe generatie artsen.

$W_{i j}$ veronderstellen dat meer kennis van de werking van sekse en gender in het proces van beroepssocialisatie noodzakelijk en nuttig is bij het verbeteren en veranderen van de medische scholing, op een zodanige manier dat ook het menselijk kapitaal van vrouwen, naast dat van mannen, optimaal wordt aangesproken en binnen het medische beroep tot ontwikkeling komt. We hopen dat deze onderzoeken anknopingspunten opleveren voor eventuele interventies in het medische onderwijs en de medische beroepsgroep, die het handelen van artsen in het algemeen en de ontplooiingsmogelijkheden van vrouwelijke artsen in het bijzonder ten goede komen. 
Dit proefschrift bestaat uit verschillende delen. In deze algemene inleiding wordt de centrale thematiek en de rode draad van dit proefschrift uiteengezet. Dan volgt een eerste theoretische deel, waarin verslag wordt gedaan van de verkenning van verschillende inzichten, theorieën en referentiekaders die werden bestudeerd in het kader van gender en het proces van professionele socialisatie tot arts. In deel I, de theoretische introductie van het proefschrift, komt eerst de positie van vrouwen in de geneeskunde aan de orde, die niet rooskleurig genoemd mag worden. We buigen ons over cijfers en getalsmatige verhoudingen van vrouwelijke en mannelijke artsen en de verschuivingen die zich op dit vlak momenteel voordoen. Diverse verklaringen voor de bestaande machtsasymmetrie tussen de seksen in de geneeskunde worden opgesomd en het perspectief van gender en reproduktie van genderongelijkheid in betaalde arbeid en specifiek in de medische professie wordt onderzocht. Omdat beroepssocialisatie binnen de medische opleiding niet alleen voorafgaat aan de medische loopbaan als arts, maar ook het verloop van de verdere loopbaan mede stuurt en de beleving van de professionele artsenrol mede bepaalt, wordt de laatste fase van de medische opleiding, de fase van de co-assistentschappen gedetailleerd onder de loep genomen.

Vanwege de momentane veranderingen in de medische beroepsgroep, die nopen tot meer inzicht in de sociale dynamiek binnen de professie en de medische opleidingsinstituten, werd de literatuur breed verkend en werden diverse disciplines en stromingen bestudeerd. De snelle toename van vrouwelijke studenten en artsen vraagt om herbezinning op de bestaande routines en verandering en verbetering in opleiding en professionele organisatie, die de inbreng van vrouwelijke artsen faciliteren.

In deel II het beroepscultuur-onderzoek staat het perspectief van de nieuwkomers ten aanzien van de beroepscultuur van de medische professie centraal. Hoe wordt de realiteit van de medische praktijk van alledag door co-assistenten waargenomen en geëvalueerd? De doelstelling van dit empirische onderzoek, dat beschreven wordt in hoofdstuk 5 en 6 , is om meer zicht te krijgen op de codes voor sociale omgang en de spelregels, die gelden binnen de medische beroepsgroep, soms ook wel de "hidden curriculum" genoemd. Deze spelregels en codes die worden voorgeleefd door de huidige professie, worden (vaak onbedoeld en onbewust) overgedragen op de nieuwe generatie in het socialisatietraject in de opleiding tot arts.

Het cultuurbegrip, dat in dit deel wordt gehanteerd is ontleend aan Hofstede (1991) en wordt gedefinieerd als het geheel van ideeën, opvattingen, gewoonten en gedragingen, die mensen leren, goedkeuren en overbrengen. Hofstede beschouwt cultuur als 'the collective programming of the mind, which distinguishes one group from another'. In de organisatiekunde wordt cultuur omschreven als de gemeenschappelijke verstandhouding tussen de leden van een organisatie of een beroep over hoe het in hun werkveld dagelijks toegaat. Het betreft het geheel van geschreven en ongeschreven regels dat behalve het sociale verkeer tussen medewerkers of beroepsbeoefenaren onderling, ook het verkeer met derden kanaliseert en vorm geeft (Sanders \& Neuyen, 1988).

Nadat in een kwalitatieve voorfase een karakterisering van de medische beroepscultuur was ontwikkeld, werd vervolgens een vragenlijst geconstrueerd met gebruikmaking van de begrippen en inzichten van Hofstede $(1991,1990)$ en de Cock (1985). Met 
behulp van deze beroepscultuur-vragenlijst konden wij inzicht krijgen in de perceptie van co-assistenten van de hen omringende beroepscultuur en hun waardering van deze waargenomen cultuuraspecten. We stellen ons de vraag of vrouwelijke co-assistenten verschillen in hun waarneming of hun waardering van de beroepscultuur zoals die op het ogenblik door de medische professie wordt gerepresenteerd. Zou de socialisatie-opdracht voor vrouwelijke co-assistenten moeilijker zijn dan voor mannelijke nieuwkomers, aannemende dat beroepscultuur van de medische professie mogelijk beter aansluit bij de mannelijke geslachtsrolsocialisatie? Zouden co-assistenten, die net zijn gestart met deze opleidingsfase, verschillen in perceptie of waardering van de "voorgeleefde" beroepscultuur van de gevorderde co-assistenten, die hun opleiding bijna afgerond hebben en hun basisartsexamen naderen ?

In deel III, het socialisatie-onderzoek dat aan bod komt in de hoofdstukken 7 tot en met 11, wordt de aandacht vervolgens gericht op de sociaal-psychologische interacties tussen de leerlingen en de opleidingssetting in de coassistentschappen. Welke ervaringen doen co-assistenten op en maken ze veranderingen door in de loop van dit opleidingstraject, dat zowel opleidingsfase als eerste werkervaring is ? De co-assistentschappen worden opgevat als een periode van inwijding in de beroepscultuur van de zittende professie. In andere onderzoeken (Sieverding, 1990; de Vries, 1988; Vonk, 1993) werd gevonden dat als iemand als leerling of stagiaire voor het eerst een beroepsveld betreedt dit vaak diepe indruk maakt en als confronterend en schokkend wordt ervaren. Deze auteurs spreken van een 'cultuurshock' of 'Berufeintrittshock'. Wordt iets dergelijks ook door co-assistenten ervaren? Ook blijkt dat stagiaires of nieuwkomers zich vaak moeilijk an de invloed van de opleidingsomgeving kunnen onttrekken en blijkt aanpassing aan deze "tijdelijke" maar indringende realiteit geen sinecure. Soms moeten hiervoor afweermechanismen worden gemobiliseerd die de harmonie in de menselijke psyche niet altijd ten goede komen (Fahrenfort, 1985; Krol, 1992; Groot de, 1987).

In het socialisatie-onderzoek besteden we eerst aandacht aan de mate waarin socialisatie in de medische professie als zwaar of vermoeidend wordt ervaren in hoofdstuk 7 en 8. De balans tussen draaglast, draagkracht en outcome in termen van motivatie en vermoeidheid worden onder de loep genomen evenals de verschillen en overeenkomsten op dit vlak tussen vrouwelijke en mannelijke co-assistenten.

Vervolgens staan we stil bij de ontwikkeling van de professionele identiteit en daarmee samenhangende aspecten in hoofdstuk 9 en 10 . Interacties en communicatie tussen mensen worden sterk beïnvloed door het beeld dat men van de ander heeft en door het beeld dat iemand denkt dat de ander van haar of hem heeft ('looking glass self'). 'What becomes the self, is what we imagine that others think of us, of our appearance, aims, deeds, character and so forth' (Cooley, geciteerd in De Jager \& Mok, 1971, p106). Beroepssocialisatie kan aanzienlijke veranderingen met zich meebrengen in opvattingen, normen en waarden, maar ook in identiteit of zelf-identificering. Identiteit als vrouw of man en rolvoorschriften voor vrouwen en mannen vloeien voort uit socialisatieprocessen die reeds op zeer jonge leeftijd beginnen. Alhoewel de genderrol diep in de persoonlijkheid is verankerd, moet deze echter niet als statisch of onveranderbaar worden opgevat. Het is van belang om te bestuderen of 
socialisatie tot arts interfereert met de identiteit als man of vrouw in een beroep dat kan worden getypeerd als mannenberoep.

Het empirisch onderzoek naar draaglast, draagkracht en belasting en naar de ontwikkeling van de professionele identiteit bestaat uit een transversaal onderzoek, waarin zowel bivariate als multivariate analyses werden uitgevoerd en een longitudinale onderzoek. Deze longitudinale studie bij dezelfde onderzoekspopulatie geeft inzicht in de veranderingen in de loop van de tijd bij co-assistenten. De bevindingen van transversaal en longitudinaal onderzoek zijn geïntegreerd beschreven in de resultatenhoofdstukken 8 en 10.

Tot slot werd de onderlinge samenhang van aspecten van socialisatie, die in de verschillende thema's van draaglast, draagkracht en outcome, van zelfevaluatie en professioneel zelfvertrouwen en professionele identiteit waren geoperationaliseerd, geanalyseerd met behulp multivariate analyse-methoden. Er bleken interessante verbanden tussen de onderzochte aspecten te bestaan.

In de slotbeschouwing aan het eind van het boek zullen we de voornaamste lijnen van dit boek verbinden en de belangrijkste inzichten en overwegingen weergeven. Hieruit zullen aanbevelingen voor verandering en kansen voor de medische professie en medische opleiding worden afgeleid. Het geheel overziend wordt duidelijk dat er werk aan de winkel is in de medische beroepsgroep. Deze tijd, zwanger van veranderingen vraagt om inzet van de professie en de medische opleidingen om zichzelf zodanig te vernieuwen dat de medische zorg optimaal zal kunnen profiteren van het culturele kapitaal van vrouwen. 



\section{Deel I}

Theoretische introductie op het onderwerp 



\section{Hoofdstuk 2}

\section{Vrouwen in de Geneeskunde}

\subsection{Historische terugblik en uitsluiting van vrouwen van het medisch beroep}

De eerste vrouwelijke artsen verschijnen in Nederland rond 1880 op het toneel, een periode waarin het proces van professionalisering van het medisch beroep al redelijk ver gevorderd is. In 1848 werd een grondige herziening van het gehele systeem van gezondheidszorg voorgesteld met als streven "het verkrijgen van eenheid van stand" waarbij verschillen in opleiding, bevoegdheid en geografische verdeling zouden moeten worden opgeheven. Voor die tijd functioneerden er namelijk een eerste en een tweede medische stand. De eerste stand was opgeleid aan een universiteit en daardoor meer theoretisch gericht en minder bedreven in praktijkervaring. De tweede stand was opgeleid aan klinische scholen, waar men de leerlingen schoolde op basis van empirische kennis en de dagelijkse praktijk (Schoon, 1995). Deze tweede stand had het grootste aandeel in de praktische zorg voor de zieken.

In 1849 werd de Nederlandse Maatschappij der Geneeskunst opgericht, de eerste beroepsvereniging van artsen. Deze vereniging probeerde bij de overheid maatregelen af te dwingen om "eenheid van stand" te bereiken en concurrentie te minimaliseren. In 1857 ontstond uit een bundeling van 39 verschillende tijdschriften het Nederlandsch Tijdschrift voor Geneeskunde, waarmee de meeste (meer praktisch georienteerde) tijdschriften ophielden te bestaan.

Met de wetten van Thorbecke uit 1865 - die bepaalden dat de geneeskunde uitsluitend bedreven mocht worden door diegenen die een universitaire opleiding hadden genoten - werd de machtsstrijd van de voorafgaande periode beslecht in het voordeel van de universitair opgeleide geneesheren. De klinische scholen werden opgeheven en de 
genezers van de tweede stand konden hun vak slechts uitoefenen onder toezicht en met instemming van de eerste stand.

Vrouwen hadden in die tijd geen toegang tot universitair onderwijs waardoor de wetten van Thorbecke automatisch resulteerden in een uitsluiting van vrouwen van het artsenberoep. Terwijl vrouwen steeds een groot aandeel hadden gehad in de praktische gezondheidszorg voor zieken, stervenden en barenden, werden ze in die tijd niet in staat geacht een academische opleiding succesvol te kunnen doorlopen. "Deskundigen" (vaak artsen overigens) achtten vrouwen tot dergelijke intellectuele hoogstandjes niet in staat en ze spraken menigmaal in die tijd in woord en geschrift hun bezorgdheid uit over de gezondheidseffecten van deze "overmatige" intellectuele inspanning voor vrouwen. "Haar baarmoeder zou kunnen schrompelen en haar voortplantingsfunktie zou in gevaar kunnen komen” (Bosch, 1994).

In 1871 slaagde Aletta Jacobs als eerste vrouw in Nederland erin om toegang te krijgen tot universitair onderwijs en geneeskunde te gaan studeren. In die beginjaren volgde slechts een enkele vrouw in Nederland haar voorbeeld (Schoon, 1988). In Nederland was, anders dan in Engeland waar vrouwen de toegang tot het bastion van universiteit en artsenberoep frontaal via de rechter moesten bestormen (Bosch, 1994), sprake van een meer subtiele en verhulde vorm van weerstand tegen participatie van vrouwelijke artsen. Door fatsoensregels, bijvoorbeeld dat het voor vrouwelijke artsen "not done" was om een mannelijke patiënt te behandelen, werden zij beleefd doch effectief uitgesloten uit de toenmalige ziekenhuizen. Ook vrouwelijk artsen die zich als huisarts wilden vestigen, ondervonden last van deze code, zeker toen ziekenfondsen eisten dat elk gezin slechts één huisarts mocht hebben. Uitsluitingsmechanismen en hindernissen voor vrouwelijke artsen zijn beschreven voor veel Westerse landen als de Verenigde Staten, Engeland, Duitsland (Lorber, 1984 \& 1993; Levinson, 1989; Kutner, 1990; Nadelson, 1991; Elston, 1993; Bowman \& Allen, 1991; etc). Hoewel de weerstand in Nederland minder gemakkelijk te onderkennen was, was deze in die zin effectief dat tot vlak na de tweede wereldoorlog het aandeel van vrouwelijke artsen in Nederland lager dan 10\% was (Bosch, 1994) en tot 1980 beperkt bleef tot onder de 20\% (Hermann, 1984).

\subsection{De positie van vrouwelijk artsen in Nederland en in intemationaal perspectief}

Hermann onderzocht in 1984 de arbeidspositie van vrouwelijke artsen in Nederland en constateerde "dat vrouwen wat betreft participatie aan medische vervolgopleidingen, aard van functie en werkomvang gemiddeld minder ver komen dan mannen". $\mathrm{Zij}$ constateerde dat de beroepsparticipatie van vrouwelijke artsen weliswaar de hoogste is van alle academici ( $\pm 90 \%)$, maar dat in de actuele verdeling van vrouwen over medische functies opvalt, dat ze vooral geconcentreerd zijn in bepaalde werkvelden en specialismen en in andere nagenoeg ontbreken. In het cluster klinische specialismen bleken vrouwen relatief goed vertegenwoordigd in bijvoorbeeld kindergeneeskunde en anesthesiologie en ontbraken ze totaal in andere specialismen als chirurgie, orthopedie en urologie. Verder bleken vrouwen nauwelijks aanwezig in de categorie "gevestigd huisarts", maar ze waren weer ruim vertegenwoordigd in de categorieën van assistent- 
huisarts en huisarts-waarnemer. Ook in de sociale geneeskunde bleken mannelijke en vrouwelijke artsen scheef verdeeld: mannen zaten vooral in de bedrijfsgeneeskunde en de algemene gezondheidszorg (AGZ), terwijl vrouwen vooral in de jeugdgezondheidszorg werkzaam bleken te zijn als consultatiebureau-arts en schoolarts. Een dergelijke patroon van scheve verdeling van de seksen over werkvelden wordt een patroon van borizontale sekse-segregatie genoemd.

Wanneer men klinische specialismen, huisartsgeneeskunde, sociale geneeskunde en "overige funkties" als categorieën van medische beroepsvelden onderscheidt, dan blijken vrouwelijke artsen als volgt over deze velden verdeeld te zijn (Hermann, 1984); Van de praktiserende specialisten was $23 \%$ van het vrouwelijke geslacht, van de praktiserende huisartsen is $8 \%$ vrouw, van de praktiserende sociale geneeskundigen $29 \%$ en van de categorie "overige artsen" $56 \%$. Alleen in de laatstgenoemde categorie vormden vrouwelijke artsen in 1984 de meerderheid. Verder onderstreepte Hermann haar bevinding dat meer dan $50 \%$ van een groep ondervraagde vrouwelijke artsen haar eigen wensen ten aanzien van hun beroepsuitoefening niet had kunnen realiseren bij bevraging achteraf (retrospectief). $\mathrm{Ze}$ concludeert dat hoewel de participatie van vrouwen in het medisch beroep bijzonder hoog is en deze beroepsarbeid van kwalitatief hoog niveau is, deze arbeid toch typische kenmerken van "vrouwenarbeid" vertoont. Hiermee wordt bedoeld dat de deelname aan een beroep sterker bepaald wordt door burgelijke staat en het hebben van kinderen en dan door de kwalificaties en kwaliteiten van de professionals.

Vrouwelijke artsen bleken verder nagenoeg te ontbreken op de hogere posities in de geneeskunde, een patroon dat benoemd wordt als verticale seksesegregatie (Hermann, 1984, Drenthe-Schonk et al, 1995). Overigens blijkt dit gegeven niet uniek, want in bedrijfsleven en diverse statusrijke beroepen wordt ook verticale seksesegregatie aangetroffen (Brouns, 1990; Weggelaar et al, 1988).

Uit onderzoek van Hawkings en Noordenbos (1989-1990) bleken vrouwen aan universiteiten nauwelijks vertegenwoordigd te zijn in de hogere wetenschappelijke funkties van hoogleraar of universitair hoofddocent. In vergelijking met andere landen bleek Nederland zich met slechts $4,2 \%$ vrouwelijke hoogleraren en $13,2 \%$ vrouwelijke wetenschappers anno 1990 in de onderste regionen van de internationale rangorde te bevinden. Duitsland en Engeland bleken het niet veel beter te doen dan Nederland maar Turkije, Polen en de Verenigde Staten scoren aanmerkelijk hoger met respectievelijk $20 \%, 17 \%$ en $14 \%$ vrouwelijke hoogleraren. In Frankrijk, Rusland, China en Noorwegen bleek rond $10 \%$ van de hooggeleerden vrouw te zijn.

\section{Internationaal perspectief}

Wanneer we de historische ontwikkeling van de beroepsdeelname van vrouwelijke artsen in internationaal perspectief bestuderen, dan vallen een aantal zaken op (Kortenhoeven (1989).

* Het aandeel van vrouwelijke artsen blijkt lager te zijn in die landen waar professionele autonomie van het artsenberoep hoog is, zoals in de Verenigde Staten en Nederland. Dit in tegenstelling tot bijvoorbeeld Rusland, waar medisch beroepsuitoefening ook relatief slecht gehonoreerd wordt. 
* In organisatiesystemen waar vrouwelijke artsen op gelijke voet moeten concurreren met mannelijke artsen blijken vrouwen zich systematisch in een zwakkere positie te bevinden.

* De toetreding van vrouwen tot het medische beroep lijkt te worden aangemoedigd in tijden waarin een tekort dreigt of bestaat aan mannelijke beroepsbeoefenaren, zoals bijvoorbeeld tijdens de wereldoorlogen. Vrouwelijke artsen werden zowel in de Verenigde Staten en Engeland, als in de voormalige Sovjet-Unie in economische of politieke noodsituaties als reserve gebruikt.

* Vrouwelijke artsen bezetten vaak, in vergelijking met mannelijke collega's, de minder aantrekkelijke funkties binnen het beroep. Dit blijkt onafhankelijk van de mate van professionele autonomie van de beroepsgroep op te treden in de diverse landen (Verenigde Staten, Engeland, de voormalige Sovjet-Unie).

* De beroepsarbeid van vrouwelijke artsen ligt veelal op het terrein van primaire en preventieve zorg. In de Verenigde Staten werkt het merendeel van de vrouwelijke artsen als "family-practitioner", of als "schoolphysician" of als "health service physician". In Rusland werken vrouwelijke artsen met name in sectoren als "community health" en in "family and child health clinics".

* De leidinggevende funkties binnen de gezondheidszorg worden in genoemde landen grotendeels door mannen bezet.

Kortenhoeve (1989) concludeert dat vrouwelijke artsen als regel beroepsarbeid verrichten die lager betaald wordt, minder aanzien geniet en soms wordt beschreven als meer routinematig van karakter dan de beroepsarbeid van haar mannelijke collega's.

Opvallend bij de bestudering van de literatuur was dat de positie van vrouwelijke artsen langere tijd wel nauwgezet werd gevolgd in uitgebreide cross-sectionele of trend studies zonder noemenswaardige poging tot interpretatie of theoretische analyse. Tot het optreden van de tweede feministisch golf bleven verklaringen voor de aangetroffen fenomenen betrekkelijk schaars.

\section{3 "Choice by constraint"}

Hermann trachtte in haar onderzoek (1984) de zwakkere beroepspositie van vrouwen te verklaren en wees op de scharnierwerking van de toegang tot de vervolgopleidingen voor de verschillende medische specialismen als belangrijkste oorzaak plus de beperkte toegankelijkheid van diverse werkvelden en funkties voor vrouwelijke artsen. "De scharnierfunktie van de opleiding en registratie bij toegankelijkheid voor traditionele beroepen (specialismen, huisarts) is de eerste beperking. Men kan materiële en immateriële toegankelijkheid van een werkgebied onderscheiden:

- materiële toegankelijkheid betekent dat de inrichting van de opleiding tegemoet komt aan verschillen in inrichting van de privé-situatie en variatie toestaat zoals acceptatie van deeltijdarbeid, normalisering van werktijden, spreiding van de opleiding over een langere periode;

- immateriële belemmeringen zijn vooronderstellingen over vrouwelijke en mannelijke eigenschappen en gedragingen en de daaraan gekoppelde beoordelingen en vooroordelen" (Hermann, 1984, p 139-140). 
Uit haar onderzoek bleek dat meer dan de helft van de ondervraagde vrouwelijke artsen zich achteraf beperkt voelde in de mogelijkheden om een loopbaan naar wens te realiseren en hun ontplooiingsmogelijkheden in het medische beroep als gelimiteerd te beschouwde. Diverse auteurs beschrijven de keuze voor een medische carrière voor vrouwen als moeilijk vanwege het gegeven dat vrouwelijke artsen in de beroepspraktijk nog steeds in de minderheid zijn (Lorber,1993; Allen, 1994; Nadelson, 1991;Nadelson \& Notman, 1973; Riska \& Wegar, 1993; Notzer, 1995). Deze minderheidspositie zou betekenen dat ze geconfronteerd worden met heersende mannelijke gedragspatronen en dat acceptatie door mannelijke opleiders en "peers" vaak problematisch is. Ook het nagenoeg ontbreken van vrouwelijke rolvoorbeelden, in functies van arts-opleider, praktiserend specialist, staflid of hoogleraar wordt als problematisch opgevat (Noordenbos, 1994 \& 1996; Spreeuwenberg, 1990; Leemeyer, 1991; VSNU, 1992 \& 1997).

In onderzoek naar doorstroming van vrouwen naar de verschillende medische specialismen in de Verenigde Staten werd reeds veel eerder dan in andere landen gesproken in termen een beperking van de keuzemogelijkheden van vrouwelijke artsen ten aanzien van hun loopbaan (Elston, 1993; Eisenberg, 1989). Davidson (1979) stelde al vroeg dat de keuze van vrouwelijke artsen voor specialisatie of vervolgopleiding beter betiteld konden worden als "a choice by constraint". De keuzen van de vrouwelijke respondenten in dit onderzoek leken meer "haalbare constructies" gericht op "maximizing role compatibility and minimizing conflict between two statuses" dan vervulling van de eigen beroepswensen. Hoewel zowel vrouwelijke artsen net als mannen zeiden een loopbaan in het medische vakgebied van hun keuze hevig na te streven, bleken vrouwelijke studenten zich onevenredig sterk voortgedreven te voelen naar die vakgebieden of specialisaties, die in loondienst verricht konden worden en die "limited working hours" bieden. In dat geval bleken binnen het bestaande medische systeem de range van vakgebieden en funkties, waaruit dan gekozen kan worden, beperkt te zijn. "Choices by constraint are shaped and circumscribed by a discriminatory environment" (Davidson, 1979). Ook latere publicaties wijzen op verhulde discriminatie die tot gevolg heeft dat vrouwelijke studenten en artsen, die een beroepscarrière willen opbouwen, "are being directed towards certain fields, by internal and external pressures, that are not necessarily appropriate for their interests and talents" (Nadelson, 1991; Lorber,1984,1993; Koninck de et al, 1997, Yoder, 1991). De discriminerende omgeving zou in twee componenten uiteengelegd kunnen worden namelijk de subtiele, niet openlijke discriminatie in de sociale omgang (1) en de "maleness" van het medische beroep en de medische instituties (2). Deze discriminatie zou verhuld en moeilijk aantoonbaar zijn, "it persists in part because the structure is based on an understanding of "commitment" and "success" congruent with male sex roles stereotypes and familial roles" (Bourne \& Wikler, 1978; Rinke, 1981; Heins et al, 1979).

Over de ontwikkelingen in de nabije toekomst zijn sommige auteurs niet erg optimistisch. Elston (1993) stelt dat, hoewel meer vrouwen in het medisch beroep in Engeland zijn ingestroomd, de seksesegregatie door bepaalde krachten is versterkt. Ze wijst in dit verband op de veranderde medische arbeidsmarkt, bepaald door de National Health Service, die nieuwe onderverdelingen en differentiaties heeft teweeggebracht. 
Er zou veel ontevredenheid zijn onder de jongere generatie artsen, met name onder de vrouwen en de auteur spreekt bezorgdheid uit over jonge dokters in Engeland, hun loopbaanperspectieven en huidige werkcondities in de huidige National Health Service.

Hermann eindigde in haar dissertatie over vrouwelijke artsen in Nederland eveneens een somber beeld, toen zij stelde dat "extra-polatie van de onderzoeksbevindingen, met inachtneming van toekomstige ontwikkelingen als grotere instroom van vrouwen, werkeloosheid en dergelijke, eerder lijkt te wijzen op vergroting van de verschillen tussen mannelijke en vrouwelijke artsen, dan op verkleining". Ook Butter (1987) en Kleiverda (1989) zijn niet optimistisch in dit opzicht, wanneer ze concluderen dat numerieke toename van vrouwelijke artsen nog niet betekent dat het aantal vrouwelijke artsen op invloedrijke posities toeneemt. Zij stellen dat het simplistisch is te denken dat "if we put more women on the lower rangs of various ladders, they will climb at the same rate as men". In haar onderzoek naar segregatie-patronen in de gezondheidszorg bleek dat de toegang van vrouwen tot de beroepen in de gezondheidszorg weliswaar is verbeterd, maar dat vrouwen "cluster at the bottom of whatever hierarchy or scale is chosen". Beide vormen van segregatie, verticale en horizontale seksesegregatie, zouden elkaar versterken en tot gevolg hebben dat vrouwen zich systematisch in die beroepen en posities bevinden, die tegelijkertijd lagere status, minder autonomie en minder betaling inhouden en als typisch vrouwelijk worden getypeerd. In de gezondheidszorgindustrie waar vrouwen $75 \%$ van de arbeidskracht voor haar rekening nemen, worden "valued work functions, prestigious positions and scarce resources controlled by men" (Butter, 1987).

Mijn verontrusting over deze veronderstellingen is een belangrijke prikkel geweest om dit onderzoek op te starten.

\subsection{Instroom van vrouwen in het medische beroep}

Recent ziet men echter in diverse Westerse landen een snelle toename van het aantal vrouwen in de medische professie, zowel studenten als artsen. In de Verenigde Staten is het aantal vrouwelijke artsen toegenomen tot $34 \%$ in 1989 , terwijl dit percentage van 1920 tot 1974 minder dan 10\% was (Nickerson, 1990). Er waren in de Verenigde Staten in 198715.872 medische studenten die afstudeerden; daarvan was $32,1 \%$ vrouw (5101) en 67,9\% man (10771) (Babbott et al. 1991). In 1989 is 34\% van de medische studenten vrouw en van de assistenten 28\% (Bickel, 1989). In Canada wordt sedert 1960 een toename geconstateerd van het aantal vrouwelijke geneeskundestudenten en verwacht men een toename van $22 \%$ vrouwelijke artsen in 1987 tot $35 \%$ in het jaar 2000 (Woodward et al. 1990).

Ook in Nederland is het aantal vrouwen dat in opleiding is tot arts de afgelopen jaren fors gestegen; in 1983 was $50 \%$ van de medische studenten vrouw; in 1987 was dit $60 \%$. Verder vormen vrouwen sedert 1990 minstens de helft van de uitstromende basisartsen (Rapport van de commissie problematiek van de vrouwelijke arts, KNMG 1989; Stegeman, 1990). De huidige man-vrouw verhoudingen in het medisch beroepsveld zijn in de onderstaande tabel aangegeven 
2.1 Overzicht vrouwelijke en mannelijke artsen in diverse werkvelden (percentages en absolute getallen)

\begin{tabular}{llll}
\hline & $\begin{array}{l}\text { percentages } \\
\$ \%-\delta \delta(84)\end{array}$ & $\begin{array}{l}\text { percentages } \\
\$ \%-\delta \delta(98)\end{array}$ & $\begin{array}{c}\text { absolute getallen } \\
\$ 8-\delta \delta(98)\end{array}$ \\
\hline $\begin{array}{l}\text { Huisartsen } \\
\text { Huisartsen in opleiding }\end{array}$ & $8 \%-92 \%$ & $25 \%-75 \%$ & $2163-6608$ \\
$\begin{array}{l}\text { Specialisten } \\
\text { Specialisten in opleiding }\end{array}$ & $23 \%-77 \%$ & $57 \%-43 \%$ & $591-471$ \\
$\begin{array}{l}\text { Sociaal geneeskundigen } \\
\text { Sociaal geneeskundigen }\end{array}$ & $29 \%-71 \%$ & $41 \%-81 \%$ & $2750-11612$ \\
in opleiding & & $31 \%-69 \%$ & $1162-1666$ \\
$\begin{array}{l}\text { Verpleeghuisartsen } \\
\text { Verpleeghuisartsen }\end{array}$ & & $41 \%-59 \%$ & $411-599$ \\
in opleiding & & $46 \%-54 \%$ & $396-469$ \\
Overige artsen & $56 \%-44 \%$ & $72 \%-28 \%$ & $106-41$ \\
\hline
\end{tabular}

bronnen: Hermann, 1984; Borst-Eilers, 1998 in VWS bulletin

Uit de tabel blijkt dat met name in de groepen van artsen, huisartsen en specialisten in opleiding grote verschuivingen te zien zijn, vrouwen vormen bijna $60 \%$ van de jonge generatie huisartsen-in-opleiding en ruim $40 \%$ van de groep specialisten-inopleiding. Het zal echter nog jaren duren voordat deze veranderde verhouding ook in de praktiserende groep huisartsen en specialisten zichtbaar wordt. In de sociale geneeskunde zal de vervrouwelijking sneller zijn beslag krijgen met $31 \%$ praktiserende en $41 \%$ vrouwelijke sociaal-geneeskundigen-in-opleiding evenals in de verpleeghuisgeneeskunde met $72 \%$ vrouwen in opleiding.

Uit de cijfers blijkt dat de nieuwe professionals vooralsnog worden opgeleid door beroepsgroepen die in meerderheid uit mannen bestaan; bij de huisartsen is $75 \%$ van de gevestigde artsen man, bij de specialisten $81 \%$ en bij de sociaal geneeskundigen $69 \%$ (cijfers uit 1998). Alleen de verpleeghuisartsen worden opgeleid door een beroepsgroep die half uit mannen en half uit vrouwen bestaat.

\subsection{Verschuivingen en de noodzaak tot verandering}

In arbeidsonderzoek worden beroepen soms getypeerd als meer of minder mannenberoepen of vrouwenberoep. Deze indeling kan gebaseerd worden cijfers, de kwantitatieve verdeling van mannen en vrouwen in een beroep of op basis van kwalitatieve argumenten, die vaak samenhangen met cultuur en sfeer. We zullen de medische beroepsvelden proberen in te delen op basis van de kwantitatieve gegevens over manvrouw verdeling. Een mannenberoep wordt, in navolging van het STEO trendrapport gedefinieerd als een beroep waarin meer dan $80 \%$ mannen participeren en een vrouwenberoep als een beroep waarin meer dan $80 \%$ vrouwen werken. Een door mannen, respectievelijk door vrouwen gedomineerd beroep is een beroep waarin 60 tot $80 \%$ mannen, respectievelijk vrouwen werken en een sekseneutraal beroep is een veld waar minder dan 60\% en meer dan 40\% mannen werken (Brouns \& Schokker, 1990). 
De totale populatie klinisch specialisten moet met een aandeel van $81.9 \%$ mannelijke specialisten (VWS, 1998) vooralsnog als mannenberoep worden gekenmerkt. Als we deze categorieën toepassen op de man-vrouw verdeling in de verschillende medische specialismen (SRC, 1991), dan blijken van het totaal van 28 onderscheiden klinische specialismen 15 getypeerd te kunnen worden als mannenberoep, 11 als door mannengedomineerde beroepen, 1 als sekse-neutraal beroep(revalidatie-geneeskunde) en 1 als vrouwenberoep (allergologie). Deze laatstgenoemde vakken zijn dan wel relatief nieuwe vakgebieden, die ook nog klein van omvang zijn.

\subsection{Klinische specialismen ingedeeld in mannen- of vrouwenberoepen}

\begin{tabular}{lll}
\hline percentage deelnemers & indeling & antal klinische specialismen (91) \\
\hline$>80 \%$ mannen & een mannenberoep & 15 \\
$60 \%-80 \%$ mannen & door mannen gedomineerd & 11 \\
$60 \%-40 \%$ man/vrouw & sekse neutraal beroep & 1 \\
$60 \%-80 \%$ vrouwen & door vrouwen gedomineerd & 0 \\
$>80 \%$ vrouwen & een vrouwenberoep & 1 \\
\hline
\end{tabular}

Bron: Specialisten Registratie Commissie, 1991

Wanneer men de cijfers over gevestigden huisartsen (VWS, 1998) beschouwt, blijkt de huisartsgeneeskunde met $75,3 \%$ mannelijke gevestigden huisartsen nog steeds een door mannen-gedomineerd vakgebied evenals de sociale geneeskunde, waar mannelijke artsen met $69 \%$ ook nog steeds de meerderheid vormen. De verpleeghuisgeneeskunde is anno 1998 een sekseneutraal beroep.

Wanneer we ook de recente cijfers over de artsen in opleiding (AGIO's en HAIO's) bij deze indeling betrekken, dan ziet men dat binnen nagenoeg alle medische vakken een verschuiving zal plaatsvinden van een mannenberoep naar een door mannengedomineerd beroep of van een door mannen gedomineerd vak naar een sekseneutraal vakgebied. In sommige werkvelden ziet men momenteel grote verschuivingen in de man-vrouw verhouding bij de instroom in het specialisme, zoals in de gynaecologieverloskunde, de chirurgie, de keel-neus en oor-geneeskunde bijvoorbeeld. 
Overzicht 2.3. Medische werkvelden getypeerd aan de hand van de vrouw-man verdeling

\begin{tabular}{|c|c|c|c|c|}
\hline $\begin{array}{l}\text { mannenberoep } \\
(\% \delta \delta)\end{array}$ & $\begin{array}{l}\text { door mannen gedomi- } \\
\text { neerd }(\% \delta \delta)\end{array}$ & $\begin{array}{l}\text { sekse-neutraal } \\
\text { beroep }(\% \delta \delta)\end{array}$ & $\begin{array}{l}\text { door vrouwen } \\
\text { gedomineerd } \\
\left(\% \delta^{\circ}\right)\end{array}$ & $\begin{array}{l}\text { vrouwen- } \\
\text { beroep } \\
\left(\% \delta \delta^{\prime}\right)\end{array}$ \\
\hline \multirow[t]{3}{*}{$\begin{array}{l}\text { klinische specialisten } \\
(81,9)\end{array}$} & $\begin{array}{l}\text { gevestigde huisartsen } \\
(75.3)\end{array}$ & $\begin{array}{l}\text { * huisartsen in } \\
\text { opleiding ( } 56.9)\end{array}$ & $\begin{array}{l}\text { verpleeghuis- } \\
\text { geneeskunde } \\
\text { in opleiding } \\
(27.9)\end{array}$ & \\
\hline & $\begin{array}{l}\text { " specialisten in oplei- } \\
\text { ding } \\
(58.9)\end{array}$ & $\begin{array}{l}\text { verpleeghuis- } \\
\text { geneeskunde (54.2) }\end{array}$ & & \\
\hline & $\begin{array}{l}\text { sociaal-geneeskundigen } \\
(68.8)\end{array}$ & & $\begin{array}{l}\text { "sociaalgenees- } \\
\text { kundigen in oplei- } \\
\text { ding }(59.3)\end{array}$ & . \\
\hline $\begin{array}{l}\text { chirurgen } \\
\text { (97) }\end{array}$ & $\begin{array}{l}\text { * chirurgen in opleiding } \\
\text { (79) }\end{array}$ & & & \\
\hline $\begin{array}{l}\text { KNO-artsen } \\
(95)\end{array}$ & $\begin{array}{l}{ }^{*} \text { KNO-in opleiding } \\
(79)\end{array}$ & & & \\
\hline $\begin{array}{l}\text { radiodiagnostiek } \\
\text { (92) }\end{array}$ & $\begin{array}{l}\text { " radiodiag in opleiding } \\
\text { (7T) }\end{array}$ & & & \\
\hline $\begin{array}{l}\text { cardiologen } \\
\text { (91) }\end{array}$ & $\begin{array}{l}\text { * cardiologen in oplei- } \\
\text { ding. (87) }\end{array}$ & & & \\
\hline $\begin{array}{l}\text { neurologen } \\
\text { (86) }\end{array}$ & $\begin{array}{l}\text { * neurologen in oplei- } \\
\text { ding (72) }\end{array}$ & & & \\
\hline $\begin{array}{l}\text { gynaecologen } \\
\text { (83) }\end{array}$ & $\begin{array}{l}\text { kinderartsen } \\
(63)\end{array}$ & $\begin{array}{l}\text { "gynaecologen in } \\
\text { opleiding (45) }\end{array}$ & $\begin{array}{l}\text { " kinderartsen } \\
\text { in opleiding } \\
(40)\end{array}$ & \\
\hline \multirow[t]{6}{*}{$\begin{array}{l}\text { internisten } \\
(82)\end{array}$} & $\begin{array}{l}\text { internisten in opleiding } \\
\text { (62) }\end{array}$ & & & \\
\hline & $\begin{array}{l}\text { dermatologen } \\
(78)\end{array}$ & $\begin{array}{l}\text { "dermatologen in } \\
\text { opleiding (59) }\end{array}$ & & \\
\hline & $\begin{array}{l}\text { anesthesisten } \\
\text { (77) }\end{array}$ & & & \\
\hline & $\begin{array}{l}\text { * anesthesisten in oplei- } \\
\text { ding (72) }\end{array}$ & & & \\
\hline & $\begin{array}{l}\text { oogheelkunde } \\
\text { (77) }\end{array}$ & $\begin{array}{l}\text { "oogheelkunde in } \\
\text { opleiding (54) }\end{array}$ & & \\
\hline & $\begin{array}{l}\text { psychiaters } \\
\text { (73) }\end{array}$ & $\begin{array}{l}\text { F psychiaters in } \\
\text { opleiding (56) }\end{array}$ & & \\
\hline
\end{tabular}


Uit overzicht 2.3 kan worden afgelezen dat in nagenoeg alle medisch specialistische vakgebieden een aanmerkelijke stijging optreedt van vrouwelijke specialisten met uitzondering van de anesthesiologie, waar de stijging slechts $5 \%$ bedraagt. De huisartsgeneeskunde en de verpleeghuisgeneeskunde zullen over enige tijd veranderd zijn van een door mannen-gedomineerd beroep naar een sekseneutraal beroep, evenals de dermatologie, de psychiatrie en de oogheelkunde. De gynaecologie verschuift van mannenberoep naar sekseneutraal vakgebied. Deze verwachtingen gaan wel uit van geringe drop-out of uitval na het doorlopen van de opleiding tot specialist of huisarts. Ook zal de geneeskunde over enige tijd beroepsvelden kennen die gedomineerd zullen worden door vrouwelijke artsen zoals de sociale geneeskunde, de verpleeghuisgeneeskunde en de kindergeneeskunde. Echte vrouwenberoepen zullen we binnen afzienbare tijd nog niet kunnen verwachten, zo blijkt uit de cijfers.

Resumerend kunnen we constateren dat momenteel een zeer grote groep vrouwelijke studenten in opleiding is tot arts of reeds bezig is met een van de medische vervolgopleidingen. Deze vrouwelijke aspiranten worden op dit moment klaargestoomd voor het medisch beroep door een beroepsgroep, die in nagenoeg alle velden nog gedomineerd wordt door mannelijke beroepsbeoefenaren. Omdat het belangrijk is na te denken over de gevolgen van deze verandering voor de vrouwelijke nieuwkomers en voor de huidige zittende medische professie, zullen we eerst ingaan op een aantal aspecten, die als problematisch werden beschreven voor een soepele integratie van vrouwelijke artsen in de medische beroepsgroep.

\subsection{Selectie en zelfselectie}

De toegang tot de vervolgopleidingen wordt gereguleerd door selectie en zelfselectie. $\mathrm{Bij}$ sollicitaties en selectieprocessen blijken sekse-stereotiepe opvattingen en verwachtingen van commissies vaak een grote rol te spelen (van Vianen, 1993; Baxter,1996). Omdat vrouwelijk artsen nog maar nauwelijks zijn doorgedrongen in de hogere funkties van het medische beroep en slechts $4 \%$ van de hoogleraren in de medische faculteiten vormen, zullen de sollicitatie-commissies voor specialisaties voornamelijk bestaan uit mannelijke hoogleraren en stafleden. Uit selectieonderzoek is bekend dat kandidaten met de grootste gelijkenis met de selecteurs, de grootste kans hebben om gekozen te worden (Hofstede, 1983). Mannelijke artsen blijken verder vaker meer traditionele opvattingen over gender en rolpatronen te hebben dan vrouwen (Uhlenberg, 1990; Shye, 1991; Sieverding, 1990). Ducker onderzocht de opvattingen van mannelijke artsen over de "geschiktheid" van medische specialismen voor vrouwelijke artsen (Ducker, 1980). Destijds bleken mannelijke artsen vooral kindergeneeskunde, psychiatrie en anesthesiologie als geschikt voor vrouwelijke collega's te zien. Vooral het feit dat deze specialismen de gelegenheid zouden bieden om in deeltijd te werken en het beeld dat met name deze vakken een beroep zouden doen op "vrouwelijke" kwaliteiten als koesteren en assisteren, werden als argumenten genoemd. Uit recenter onderzoek blijkt dat vooroordelen over gebrek aan "commitment" van vrouwen ten aanzien van hun beroep nog steeds een rol spelen bij de selectie van assistent-artsen die in opleiding tot specialist willen gaan (Heymans \& Noordenbos, 1995; Sieverding, 
1990). Vooral de vrees dat vrouwelijke kandidaten 'overvallen' zullen worden door een sterk verlangen naar kinderen, hetgeen de organisatie van de specialistische afdeling onder druk zal zetten, blijkt veel opleiders bezig te houden bij de selectie van arts-assistenten voor klinische specialisaties (Heymans \& Noordenbos, 1995). Daarnaast blijkt de opvatting dat vrouwen primair verantwoordelijk zijn voor de zorg voor kinderen, partner en huishouding, nog springlevend onder Nederlandse artsenopleiders en hoogleraren in de geneeskunde (Du Moulin et al, 1997).

Naast selectie speelt ook zelfselectie bij het proces van loopbaankeuze een grote rol. Omdat de toegangseisen voor de medische specialisaties vaak onduidelijk zijn, zijn deze vaak voor basisartsen, die een vervolgopleiding willen volgen, een bron van speculatie en onzekerheid (Heymans et al, 1995). Vaak worden de toegangseisen voor de vervolgopleidingen tot specialist of huisarts zo hoog ingeschat, dat veel basisartsen het noodzakelijk vinden eerst enige jaren klinische ervaring als AGNIO (assistentgeneeskundige-niet-in-opleiding) op te doen, alvorens te opteren voor de gewenste vervolgopleiding (Kozijn, 1996). Deze inschattingen blijken overigens wel een kern van waarheid in zich te dragen, omdat de kans op een schaarse opleidingsplaats daadwerkelijk groter wordt, wanneer de sollicitant medische werkervaring als AGNIO heeft opgedaan ${ }^{3}$.

Wanneer men zich vervolgens realiseert dat de lengte van de opleiding tot diverse medische beroepen reeds lang is en varieert van negen tot veertien jaar, dan roept deze gang van zaken vragen op. De extra tijdsinvestering als arts-assistent geneeskundige heeft namelijk geen invloed te hebben op de duur van de specialisatie. Met name bij onzekere basisartsen of diegenen die nog geen duidelijke beroepskeuze hebben gemaakt, is de kans groot dat zij relatief veel extra tijd investeren, alvorens het geambieerde beroep uit te gaan oefenen.

Ook is opgemerkt dat de opleidingstructuur evenals de loopbaanstructuur in het medische beroepsveld, vooral in de curatieve sector, een betrekkelijk rigide indruk maken (Keizer, 1997; Oorschot et al,1997; Dijkstra, 1992). Het devies lijkt te zijn "eens huisarts, altijd huisarts" of "eens specialist, altijd specialist" en ook is er weinig ruimte voor variatie zoals opleidingstrajecten in deeltijd of spreiding van de opleiding over langere tijd. Ook is een loopbaanverandering, zeker na een specialisatie, moeilijk en kan gemakkelijk ervaren worden als een forse "kapitaalvernietiging" onder andere vanwege het zeer langdurige opleidingstraject. In de sociale geneeskunde, de huisartsgeneeskunde en de zogenaamde "overige funkties" lijkt de flexibiliteit groter te zijn. Momenteel woedt in de beroepsgroep een discussie over voor- en nadelen van de introductie van een soort permanente allround funktie in de kliniek, die breder is dan die van de klassieke specialist maar geen volledige specialistische opleiding vereist. Deze breed-inzetbare klinisch werkzame arts zou ook een aantrekkelijker loopbaanperspectief moeten bieden dan de huidige AGNIO (assistent-geneeskundige-niet-inopleiding) funktie (Oorschot, Jaspers, Leeuwen-Seelt, 1997).

'gebaseerd op mondelinge mededelingen uit huisartsberoepsopleiding, beroepsopleiding tot cardioloog en opleiding tot psychiater 


\subsection{Factoren die integratie van vrouwelijke artsen belemmeren}

Wanneer we de beschreven literatuur samenvatten dan kunnen we stellen dat de positie van vrouwelijk artsen tot voor kort bescheiden was, dat de doorstroom van vrouwen naar hogere funkties in de geneeskunde verre van soepel verloopt en dat de instroom van vrouwelijke artsen met name in de snijdende vakken nog bemoeilijkt is (Baxter, 1996; Heymans \& Noordenbos, 1995; Heiligers, 1997). Ook blijkt er in de medische professie sprake van een glazen plafond te zijn dat vrouwen op weinig grijpbare wijze afhoudt van toegang tot de hogere en statusrijke regionen van het beroep (Lorber, 1993; Elston,1993; Leemeyer, 1990, 1991).

De verklaringen die in de loop van de tijd zijn gegeven voor de seksesegregatie en de belemmerde doorstroming naar de verschillende beroepsvelden en funktieniveaus in de geneeskunde zijn divers en uiteenlopend. Sommige auteurs wijzen op belemmeringen in de structuur of de cultuur van het beroep, anderen zoeken het meer op het individueel niveau. In de medische literatuur bleek vooral het probleem van de conflicterende rollen populair, de sociale rol als vrouw en die rol als arts of medisch professional zouden incompatibel zijn. De (traditioneel ingekleurde) geslachtsrol als vrouwen zou, zeker wanneer er ook nog sprake is van moederschap, nauwelijks gecombineerd kunnen worden met de medische beroepsrol en wanneer men dit toch gecombineerd wordt, dan zal dit resulteren in een verhoogde kans op dubbele belasting of "role strain". Deze studies blijken veelal te vertrekken vanuit de aannames van een stereotype rolverdeling tussen de seksen.

Een evenwichtige verdeling van vrouwelijke artsen over het medische beroepsveld wordt in de medische literatuur beschreven als belemmerd door 2 typen factoren, namelijk factoren die samenhangen met de inrichting en de cultuur van het beroep (1) en met factoren die samenhangen met de sociale genderrol.(2) Interessant is dat de belemmeringen in het beroep veelal worden opgevat als omgevingsinvloed en de factoren, die samenhangen met opvattingen over sociale rollen van de seksen, vaak worden opgevat als persoonlijk en op individu-niveau worden gelokaliseerd.

\section{Belemmerende beroepsfactoren}

structuur van de medische beroepen en vervolgopleidingen:

* scharnierwerking van vervolgopleidingen- die veel artsen dwingt tot een keuze tussen beroep en (tot uitstel van) ouderrol

* het ontbreken van ouderschapsregelingen

* een beperkt aanbod van funkties in deeltijd

cultuur van de beroepsgroep:

" vormen van selectie en zelfselectie, zoals "gate-keeping", “old-boys-network", gebrek aan "sponsor-ship" en subtiele en minder subtiele vormen van discriminatie (o.a. het "glazen plafond")

* "male-ness" van de doktersrol

* morele druk om geen of beperkt gebruik te maken van bestaande formele regelingen (zoals ouderschapsverlof of zwangerschapsverlof. 


\section{Belemmerende factoren samenhangend met sociale genderverschillen}

rol-verplichtingen van vrowwen

* incompatibiliteit van doktersrol en genderrol van vrouwen

* dubbele belasting, de problematische combinatie van zorgtaken met betaalde arbeid voor vrouwen; voor mannen wordt deze combinatie zelden als probleem in beeld gebracht

verschillen in motivatie of ambitie

verschillen in preferenties en lof kwaliteiten

* dubbel-levensperspectief theorie; in tegenstelling tot mannen, die slechts werk en kostwinnerschap als levensperspectief kennen, zouden vrouwen een dubbel-levensperspectief hebben, namelijk werk (of betaalde arbeid) en ouderschap plus zorgarbeid.

* preferenties van vrouwen anders dan van mannen ten aanzien van beroepsarbeid.

* persoonlijke kwaliteiten verschillend verdeeld tussen de seksen

Het is van belang zich te realiseren dat verklaringen voor probleem of knelpunt zich onwillekeurig worden gestuurd door de wijze waarop de situatie of het probleem wordt gedefinieerd. Het is derhalve interessant om zich de vraag te stellen "wie of wat eigenlijk geproblematiseerd werd" in de diverse bestudeerde onderzoeken.

Empirisch onderzoek over positie van vrouwen in het medisch beroep, waarin de bestaande sekse-segregatie in het medisch beroep wordt beschreven in termen van " vrouwelijke artsen hebben een achterstand" bevat eigenlijk een probleemdefinitie, die vrouwen meer problematiseert dan de context. Deze definitie laat de bestaande orde ongemoeid en richt de (onderzoeks)aandacht min of meer automatisch op gedragingen, eigenschappen en attitudes van vrouwelijke artsen.

Hermann spreekt van een "achterstand-situatie" voor vrouwelijke artsen en problematiseert wel de verhoudingen in het medisch beroep en professie, maar niet laat de sociale genderopvattingen vooralsnog ongemoeid (Hermann, 1984). Daardoor krijgt men geen zicht op hoe sociale opvattingen over gender het handelen van artsen zelf beinvloed. In aandacht zal vooral gericht zijn op de invloed van het beroep en de professie als omgeving.

Sieverding spreekt van "beperkte ontplooiingsmogelijkheden voor vrouwelijke artsen" (Sieverding, 1990) en problematiseert daarmee mijns inziens zowel de status-quo in het medisch beroep, maar richt eveneens de aandacht op het subject en lid van een bepaalde sociale categorie. Dergelijk onderzoek heeft vaak een Vrouwenstudies-achtergrond, hetgeen consequenties heeft voor de manier waarop de relatie tussen individu en omgeving wordt geduid. In dit proefschrift wordt vooral geput uit laatstgenoemd type onderzoek. Spreekt men van "gender" dan wordt de context op verschillend niveau geproblematiseerd en verdwijnt het onderscheid tussen subject en buitenwereld min of meer uit beeld (zie voor verdere uitwerking hoofdstuk 3).

Uit het voorgaande kunnen we concluderen dat de begrippen verticale en horizontale sekse-segregatie verwijzen naar de ongelijke (machts)verhouding van mannen en vrouwen als groepen en als sociale categorieën.

Verder blijkt onderscheid gemaakt te kunnen worden in studies of theorieën die de "status-quo" wel of niet als probleem definiëren. Binnen Vrouwenstudies is de afgelo- 
pen jaren intensief gestudeerd op het vraagstuk van vrouwen en hun ontplooiingsmogelijkheden in beroepsarbeid en opleidingen. Uitgangspunt daarbij is dat de bestaande werkelijkheid wordt geproblematiseerd en dat vanzelfsprekendheden over manne lijkheid en vrouwelijkheid, rolpatronen, sociale interactie en machtsverhoudingen worden bevraagd en geanalyseerd. 


\subsection{Samenvatting}

Jarenlang was in Nederland een vrouwelijke arts een bijzonderheid, een uitzondering die de regel "de dokter is een man" bevestigde. Het aandeel van vrouwen in de medische professie bleef hier te lande tot 1973 beperkt tot 20\% (Bosch, 1994). Tot vrouwen opeens in groten getale geneeskunde gingen studeren, zodat sinds 1990 de helft van de afstuderende basisartsen vrouw is. Het aandeel van vrouwelijke studenten bedraagt nu sedert enige jaren 60\% (Martens, 1990). Deze geleidelijke metamorfose van de medische beroepsgroep heeft zich betrekkelijk onopgemerkt voltrokken en krijgt pas recent de aandacht van medische opleidingsinstituten en beroepsgroep (Spreeuwenberg, 1990). Er wordt heel verschillend gereageerd op deze veranderingen, sommigen juichen deze toe, anderen bezien de ontwikkelingen met argus-ogen.

In een tijdsgewricht waarin patiënten mondiger zijn, meer inspraak en informatie van hun artsen wensen, zou het communicatieve en relationele potentieel van vrouwelijke artsen de medische professie wel eens goed van pas kunnen komen. Diverse onderzoeken toonden aan dat vrouwelijke huisartsen kwalitatief hoger scoren met betrekking tot de relationele en communicatieve aspecten van de medische hulpverlening (Meeuwesen, 1989; Rouneau, 1994; Bensing, 1991). Ook het gegeven dat in de maatschappij de euforie over medisch technische kunsten en kundes enigszins bekoeld is, doet in de geneeskunde een klimaat ontstaan waarin meer waardering komt voor kwaliteit van medische zorg en "care", hetgeen goed aansluit bij kwaliteiten, die bij vrouwen vaak sterker ontwikkeld zijn (Brink van der-Muiden, 1996).

Het is echter de vraag of de medische beroepsgroep de getalsmatige verschuiving, die ook wel de stille revolutie wordt genoemd, toejuicht. Uit sociaal wetenschappelijk onderzoek is bekend dat een gevestigde groep die langdurig de dienst heeft uitgemaakt, veelal niet zonder slag of stoot een nieuwe groep accepteert, die langdurig getalsmatig en qua invloed een minderheidspositie ingenomen heeft. 



\section{Hoofdstuk 3}

\section{Gender in de geneeskunde}

\subsection{Inleiding}

Bij de bestudering van de professionele socialisatie van vrouwelijke en mannelijke aanstaande artsen in dit proefschrift, willen wij niet voorbij gaan aan de huidige inzichten aangaande reproduktie van gender in opleiding en beroepscontext. De werking van gender is complex en gerelateerd aan machtsprocessen. Uit de gendertheorie van Scott wordt duidelijk dat gender via vier onderling verbonden aspecten ge(re)produceerd wordt, namelijk via culturele symbolen, normatieve concepten, sociale instituties (als gezin, school en werk) en subjectieve identiteit. Wanneer men het medisch beroepsveld vanuit dit perspectief onder de loep neemt, dan verschijnen de eerder beschreven barrières, die vrouwelijke artsen belemmeren in hun beroepsmatige ontplooiing, als aspecten van een proces waarbij sekseongelijkheid wordt geproduceerd. Ook wordt duidelijk dat vrouw-onvriendelijke structuren en cultuuraspecten gevolgen hebben voor de identiteit van leden van een organisatie of beroepsgroep, voor hun zelfbeeld en hun ideaalbeeld, dat als persoonlijke norm functioneert.

De hele geschiedenis door heeft het feit dat men als vrouw of als man werd geboren een groot stempel gedrukt op het leven dat mensen leefden, alsook op de beelden, verwachtingspatronen en interpretaties die men vervolgens ten aanzien van vrouwen en mannen hanteerde. De invloed van de sekse was lang vanzelfsprekend en daarmee onzichtbaar. De laatste jaren verdwijnt deze vanzelfsprekendheid echter en wordt meer en meer de vraag gesteld hoe de invloed nu precies verloopt. Deze vraag is een centraal thema in Vrouwenstudies, een betrekkelijk nieuw wetenschapsgebied waarin de bestaande werkelijkheid wordt geproblematiseerd. Binnen Vrouwenstudies worden vanzelfsprekendheden over mannen en vrouwen, mannelijkheid en vrouwelijkheid, 
rolpatronen, sociale interactie en machtsverhoudingen tussen de seksen bestudeerd en geanalyseerd.

De sekse van een persoon blijkt namelijk niet slechts een biologisch gegeven te zijn, maar ook en met name een sociaal gegeven dat gevormd wordt en gereproduceerd in alle dagelijkse interacties tussen mensen, groepen en organisaties (Hare-Mustin \& Marecek, 1988). Binnen Vrouwenstudies wordt onderscheid gemaakt tussen "sex" in angelsaksisch taalgebied en "sekse" in het Nederlands taalgebied, een term die verwijst naar het biologisch geslacht en de term "gender", waar geen eigen Nederlands term voor is, als men doelde op sociale en symbolische constructies van mannelijkheid en vrouwelijkheid. Het gender-concept doet met name inzicht ontstaan in hoe sekse als ordeningsprincipe functioneert in diverse maatschappelijke contexten, waarbij gender dan zowel oorzaak als uitkomst is (Oudshoorn, 1989). Beziet men bijvoorbeeld de feitelijke deelname van vrouwen en mannen aan maatschappelijke activiteiten, dan valt op dat men op de gewaardeerde plekken meestal een oververtegenwoordiging van mannen aantreft en op minder gewaardeerde plaatsen een oververtegenwoordiging van vrouwen (Vlerken en Meijers, 1993). In de openbare sfeer waar de produktie van goederen en diensten plaatsvindt, waar kennis, informatie en opinies worden ontwikkeld en waar bezit, aanzien en macht worden verdeeld, treft men vooral mannen aan. In de privé-sfeer, waartoe men zaken rekent als het onderhouden van diverse soorten relaties (met vrienden, familie en partner) en het volbrengen van diverse zorgtaken (als het grootbrengen van kinderen, huishouden en recreatie) worden veel vrouwen aangetroffen. Activiteiten in het domein van de privésfeer, die voor de individuele persoon als zeer waardevol en zinvol ervaren kunnen worden, geven in het publieke domein minder rendement, zowel in de vorm van materiële als van immateriële opbrengsten (Doorne Huiskes, 1993). Terwijl vrouwen hun sociale identiteit breder definiëren, blijven mannen deze vaak nog bijna uitsluitend aan funkties definiëren, die zij in de openbare sfeer vervullen. Hoewel bij de jongere generatie mannen op dit terrein wel iets lijkt te veranderen en vaderschap een duidelijker accent lijkt te krijgen in de psychologie van jonge mannen (Duindam, 1990; Dijkstra, 1992).

$\mathrm{Nu}$ vrouwen ook op steeds grotere schaal funkties in de openbare sfeer op zich nemen, ziet men steeds meer belangstelling ontstaan voor de effecten van sekse en sekseverschillen. Tevens wordt steeds meer aandacht geschonken aan problemen die zich voordoen in de interface tussen privé sfeer en openbare sfeer.

\subsection{Sekse, gender en arbeid}

Arbeid is van oudsher een belangrijk thema binnen de vrouwenbeweging als sociaal politieke emancipatiebeweging en ook binnen het wetenschappelijke kader van Vrouwenstudies. Aanvankelijk werden de evidente verschillen tussen de positie van mannen en vrouwen met betrekking tot betaalde en onbetaalde arbeid geconceptualiseerd als "onderdrukking van vrouwen". Begin jaren tachtig raakte de onderdrukkingshypothese meer en meer omstreden. Het begrip "onderdrukking" bleek te grofmazig en te ongenuanceerd en deed onvoldoende recht aan de werkelijkheid van de verhoudingen tussen de seksen. In deze benadering bleken ook verschillen van vrouwen onderling 
onvoldoende belicht en verklaard te kunnen worden en verschillen per werksoort en per setting. Bovendien werd macht in deze benadering als repressief gezien en werden vrouwen vaak te sterk als slachtoffer verbeeld hetgeen vaak aanleiding geeft tot cirkelredeneringen. Het concept "onderdrukking van vrouwen" werd vervangen door het begrip "asymmetrie tussen de seksen ", waarmee werd aangegeven dat beide seksen over macht beschikken, maar in ongelijke mate en dat verhoudingen tussen de seksen niet uitsluitend machtsverhoudingen zijn (Brouns en Schokker, 1990).

Cruciaal werd de vraag: hoe verloopt de omzetting van sekse-verschil in sekse-ongelijkheid? Macht werd meer en meer onderzocht als een proces, dat werkzaam is in formaties en definities van vrouwelijkheid en mannelijkheid en in de werking van deze definities in verschillende contexten. Veel aandacht werd besteed aan de machtswerking van de veel voorkomende gewoonte om vrouwelijkheid als tegendeel of negatieve variant van mannelijkheid op te vatten. Samenvattend kan men stellen dat binnen Vrouwenstudies sekseverhoudingen worden beschouwd als gekenmerkt door een machtsdimensie en dat de conceptualiseringen van macht in relatie tot sekse in de loop van de tijd zijn veranderd van onderdrukking via asymmetrie of ongelijkbeid naar constructie (Brouns, 1993).

Hoe komt het nu, om met Brouns (1993) te spreken, dat sekse-verschillen steeds weer als sekse-ongelijkheid worden gereproduceerd? Uitgangspunt in haar werk zijn de begrippen gender en sekse en de wederkerige relatie tussen arbeid, gender en genderidentiteit. Het genderconcept wordt opgevat als "a constitutieve element of social relationships based on perceived differences between the sexes and gender is a primary way of signifying relationships of power" (Scott, 1986). Gender is niet geheel terug te voeren op macht, maar macht is wél een wezenlijk bestanddeel van gender. Het is van belang om het interpretatiekader van onderzoek naar sekse en sekseverschillen te verrijken met het genderbegrip omdat gender:

1. niet beperkt is tot zichtbare verschillen, maar ook gerelateerd kan worden aan ogenschijnlijk sekse-neutrale verschijnselen en instituties;

2. verschillen niet noodzakelijkerwijs herleid worden tot een dichotomie;

3. verwijst naar een structurering waarin verschillen tussen mannen en vrouwen specifieke betekenis krijgen afhankelijk van een bepaalde context.

Genderverhoudingen liggen aldus voor een deel ten grondslag aan organisatie, inrichting, normen en waarden in arbeid en arbeidsverhoudingen, maar tegelijkertijd is ook het omgekeerde het geval dat arbeid en arbeidsverhoudingen gender en genderidentiteit vormt, oftewel een constituerende werking heeft ten aanzien van gender en genderidentiteit. 
Binnen Vrouwenstudies wordt onderzoek gedaan naar de vanzelfsprekendheid om mensen in mannen en vrouwen in te delen en hieraan allerlei betekenissen te hechten. Het blijkt dat "vrouwelijkheid" en "mannelijkheid" minder vastliggen, dan vaak wordt gedacht en dat de betekenis, die aan deze begrippen wordt gegeven niet vastligt maar afhankelijk is van de cultuur van een specifieke groep. Deze betekenissen zijn aan voortdurende verschuivingen onderhevig, ze zijn afhankelijk van de historische en culturele context waarin ze zijn ingebed. Feministische post-modernisten waarschuwden tegen een essentialistische visie waarin "vrouwelijkheid" en "mannelijkheid" worden voorgesteld als onafhankelijke essenties, onafhankelijk van tijd, cultuur en context. Niet de vraag "hoe verschillend zijn vrouwen en mannen" moet gesteld worden, maar de vraag naar hoe verschillend mannen en vrouwen worden voorgesteld en welke betekenissen mannelijkheid en vrouwelijkheid hebben in een bepaalde context en hoe deze betekenissen veranderen. In de hedendaagse benadering acht men het van groot belang niet langer te zoeken naar algemene kennis, maar naar context-gebonden, ad-hoc theorieën die geen universele pretenties hebben ${ }^{4}$. In het constructiedenken dat eind jaren tachtig een prominente invalshoek was binnen Vrouwenstudies, ging de aandacht meer uit naar vrouwelijkheid en mannelijkheid als in de cultuur in te nemen posities en de wijze waarop vrouwelijkheid wordt ge(re)produceerd en minder naar gedrag of ervaringen van vrouwen als sociale categorie. (Top \& Heesink, 1992).

Men kan rwee posities onderscheiden in de wetenschappelijke praktiik van Vrouwenstudies-onderzoek. Ofwel (1) men vat Vrouwenstudies op als een feministische wetenschap en gaat ervan uit dat vrouwen worden onderdrukt en dat er tussen vrouwen de wens tot solidariteit bestaat. In deze benadering, die men vooral terugvindt in de feministische therapie en de vrouwenhulpverlening, gaat men uit van de aanname dat vrouwen een aantal gemeenschappelijke waarden en aspiraties hebben. Het accent ligt in deze benadering vooral op de overeenkomsten tussen vrouwen. Ofwel (2) de onderzoekers gaan uit van de heterogeniteit van de sociale wereld en accepteren geen algemene theorieën over mannelijkheid of vrouwelijkheid. Deze benadering, die als postmodern wordt getypeerd, verzet zich tegen de beperking van de categorie van mannen of mannelijkheid en vrouwen of vrouwelijkheid als dualiteit.

Een nadeel van de eerste benadering (1) is het gevaar om universalistische en deterministische uitspraken te doen over de seksen en daarmee de overeenkomsten tussen de seksen onvoldoende te belichten en de verschillen tussen vrouwen (en mannen) onderling te bagatelliseren. Het nadeel van de tweede benadering (2) is dat generaliseren moeilijk wordt.

- Dit is overigens een lastige stellingname, wanneer men onderzoek gepubliceerd wenst te zien in medisch wetenschappelijke tijdschriften, die vaak een grote voorkeur hebben voor generaliseerbare, algemeen geldende kennis. 


\section{Debat}

Fischer (1993) verzet zich tegen een sterk relativistische postmoderne benadering en wijst op de dominantie en saillantie van sekse als sociale categorie. Mensen behoren nu eenmaal tot verschillende sociale categorieën, bijvoorbeeld op basis van hun leeftijd en beroepsgroep. Onze cultuur is diep doordrongen van de dimensie sekse, hetgeen op allerlei levensterreinen naar voren komt.

De hardnekkigheid van "sekse" als sociale categorie kan ook verklaard worden uit het feit dat iemands sekse nu eenmaal bijzonder zichtbaar is. Interessant is in dit verband de bevreemding die optreedt bij travestie of wanneer iemand nog verder gaat en het eigen lichaam verandert van vrouwelijk naar mannelijk of omgekeerd. Ook seksuele aantrekkingskracht en erotiek zijn gekoppeld aan de verschijning als man of als vrouw. Fischer (1993) stelt dat sekse blijkbaar een dominante sociale categorie is. Sekse bepaalt op welke wijze aan de omringende wereld betekenis verleend en ordening wordt aangebracht. Opvattingen en beelden die daardoor ontstaan hebben hun impact op de identiteit van mensen. Hiermee is niet gezegd dat het handelen van mensen gedetermineerd is, maar wel dat de sociale ruimte - net zoals de fysieke ruimte waarbinnen individuen kunnen opereren - beperkt is. Mensen worden aangesproken op deze beelden en opvattingen, ze kunnen zich niet onttrekken aan de sociale betekenissen in hun cultuur, ze worden door de omgeving geïdentificeerd als representant van sociale categorieën als vrouw, werknemer, alleenstaand ouder en zo meer.

De vorming van de identiteit staat in het teken van iemands sekse: "ik ben een jongetje, ik ben een meisje". Het is een van de eerste aspecten van een sociale categorie die kinderen in hun zelfbeeld hebben geïntegreerd. Dat wil niet zeggen dat voor iedereen sekse even belangrijk is. Bij afname van de Bem-sex-role-inventory blijkt dat mensen meer of minder mannelijk en vrouwelijk kunnen zijn (Bem, 1981). "Mannelijk" en "vrouwelijk" moeten dus niet als elkaar uitsluitende categorieën worden gehanteerd.

Bekker et al (1994) hebben getracht het gebruik van sekse als sociale categorie nieuw leven in te blazen. Deze benadering houdt zich bezig met de invloed van het groepslidmaatschap op het individu: hoe beschouwt men zichzelf als lid van de groep en hoe bezien anderen de persoon zelf. Men kan mensen indelen in sociale categorieën op basis van leeftijd, etniciteit, sekse, klasse etcetera. Binnen deze onderzoekspraktijk van vrouwenstudies in de sociale psychologie kiest men voor bestudering van "sekse als sociale categorie", met de kanttekening dat sekse als dualistische categorie wel bestaat maar tegelijkertijd ook een veelvormig begrip is.

Cognitieve categorisering van de sociale werkelijkheid wordt vanuit dit perspectief opgevat als van grote invloed op de waarneming en het gedrag van mensen. In de wijze waarop vrouwen en mannen beslissingen nemen ten aanzien van individuele mensen bespeurt men deze situatiegebonden invloed. "Vrouwelijkheid" en "mannelijkheid" zijn prototypisch gemeenschappelijke kenmerken die in het dagelijkse leven continu worden gebruikt om naar sekse te categoriseren. Ook Condor (1994) stelt dat afwezigheid van sekse in de waarneming niet klopt met studies die laten zien dat toeschrijving van geslacht aan personen altijd in het menselijk denken aanwezig is. 
Volgens haar is sekse als sociale categorie altijd relevant voor onze sociale perceptie en sociale interacties, hoewel de implicaties ervan per context kunnen verschillen.

\subsection{De gender-theorie van Scott}

Om de verstrekkendheid van sekse en gender nader toe te lichten worden nu de inzichten van de historica Scott besproken. Volgens Scott (1986) berust de kern van de genderdefinitie op een integrale connectie van twee proposities namelijk (1) dat gender een primair gebied is waarin macht wordt uitgedrukt en (2) dat gender een bepalend element van sociale relaties is en gebaseerd wodt op de gepercipieerde verschillen tussen de seksen.

Veranderingen in de organisatie van sociale relaties corresponderen altijd met veranderingen in de representaties van macht, maar de richting van de verandering gaat niet noodzakelijk een specifieke kant uit. Als bepalend element van sociale relaties, gebaseerd op gepercipieerde verschillen tussen de seksen, kent het begrip gender vier onderling samenhangende aspecten, namelijk:

1. culturele symbolen van vrouwelijkheid en mannelijkheid;

2. normatieve concepten;

3. sociale instituties;

4. de subjectieve identiteit.

Ad 1) De symbolen van vrouwelijkheid en mannelijkheid lokken vaak meervoudige en soms tegenstrijdige representaties uit, zoals bijvoorbeeld de representatie van vrouwen als maagd of als hoer (Connors, 1994).

Ad 2) Het tweede aspect van gender behelst de normatieve concepten die interpretaties van de verschillende betekenissen van symbolen van vrouwelijkheid en mannelijkheid mogelijk maken. Veelal zijn deze concepten gebaseerd op een manier van denken waarin vrouwelijkheid en mannelijkheid worden voorgesteld als tegengesteld, elkaar uitsluitend en vaststaand. Het dominante beeld, de status quo, wordt meestal afgebeeld als de enig mogelijke versie van de werkelijkheid. Vrouwelijk en mannelijk worden als essentieel anders afgebeeld en hiërarchisch zodanig geordend dat aan het vrouwelijke een minder hoge waarde wordt toegekend. Voorbeelden hiervan zijn beschreven onder andere door de Bruijn (1989), Philips en Taylor (1986). In funktieclassificatiesystemen blijkt bijvoorbeeld het tillen van zieke mensen in de verpleging nauwelijks als zware, lichamelijke arbeid gelabeld en gehonoreerd te worden, in tegenstelling tot het tillen van zware vuilniszakken in een mannenberoep als dat van vuilnisophaler (De Bruyn, 1994).

Philips en Taylor (1986) constateren in hun studie dat het arbeidsterrein van mannen eerder als geschoold wordt beschouwd dan dat van vrouwen. Ook gewoonte om huishoudelijke of zorgarbeid binnen het gezin niet als werk te beschouwen, komt nog steeds veel voor. Ook vrouwen kan men betrappen op formuleringen waaruit blijkt dat zij deze opvatting hebben verinnerlijkt. Men hoeft in dit verband bijvoorbeeld slechts een televisie-quiz te bezien, waarin de huisvrouw - gevraagd naar haar bezigheden - antwoordt "niets te doen", geen uitzondering is. Uit genoemd onderzoek naar betaald werk (Philips \& Taylor, 1986) blijkt dat vaardigheden als dienstbaarheid, 
netheid of accuratesse, die vaak aangetroffen werden bij (betaald) werkende vrouwen, frequenter worden voorgesteld als natuurlijke vrouwelijke eigenschappen dan als specifieke vaardigheden of "skills", hetgeen veelal bij kwaliteiten van mannen gebeurd. Benschop (1996) gaat in op de verschuivingen in normatieve opvattingen over vrouwen en vrouwelijkheid en mannen en mannelijkheid, die zich momenteel voordoen. Het traditionele gender-paradigma wordt beschreven als gestoeld op de aanname dat natuurlijke verschillen (biologische of psychologische) ten grondslag liggen aan de waargenomen verschijnselen. Mannen worden als groep aan het masculiene uiteinde en vrouwen aan het feminiene uiteinde van het gender-continuüm geplaatst. Vrouwen worden gezien als aanvullend aan mannen; het vrouwelijke als aanvullend aan het mannelijke. Het moderne genderparadigma, dat steeds meer aan populariteit wint gaat uit van de basisstelling van de gelijkwaardige eigenheid van mannen en vrouwen. De gepercipieerde verschillen tussen mannen en vrouwen vormen geen legitimering meer voor maatschappelijke arbeidsdeling.

Terwijl in het traditionele denken het kostwinnerschap als belangrijkste verantwoordelijkheid voor mannen en het moederschap en zorg voor het gezin als belangrijkste taakgebied voor vrouwen beschouwd, wordt in de moderne ideologie deze taakverdeling verlaten en zijn kostwinning en zorg verantwoordelijkheid voor beide seksen. Tegen de achtergrond van zowel het traditionele als moderne genderparadigma, functioneert de dagelijkse praktijk (Benschop, 1996).

Ad 3) Ook sociale instituties als gezin, arbeidsmarkt, gezondheidszorg, overheid en onderwijs reproduceren gender. In de gezondheidszorg kan men waarnemen dat de "zachte" "zorg"-kant van de hulpverlening "van oudsher is gelokaliseerd bij de verpleging, een vrouwenberoep", dat van oudsher hiërarchisch lager werd geacht dan de medische professie, zich uitend in lagere status en geringere honorering Hoewel momenteel sprake is van emancipatie en verschuiving tussen de beroepsgroepen in de gezondheidszorg, is het historische verschil in status en inkomen zeker nog niet verdwenen (Carpenter, 1993).

Ook is veel onderzoek gedaan naar mechanismen binnen de arbeidsmarkt die de machts-asymmetrie tussen de seksen reproduceren. Tijdens (1989) wees op het fenomeen van sociale uitsluiting in haar onderzoek naar verschuivingen in de man/vrouw balans bij re-organisatieprocessen in de banksector. Sociale sluiting vond plaats door de beroepstrainingen, die zo waren ingericht dat de meer prestigieuze beroepstrainingen veel toegankelijker waren voor mannen dan voor vrouwen. $\mathrm{Zij}$ waren daardoor genoodzaakt zich te beperken tot funkties met minder loopbaanperspectieven.

Ook in het domein van de wetenschappelijke arbeid werden vormen van reproduktie van genderongelijkheid beschreven. Brouns wijst op de constatering van Feldberg en Glenn (1979) dat in onderzoek van arbeid van mannen, arbeid in de betaalde sfeer meestal geïsoleerd van de privé of persoonlijke sfeer wordt bestudeerd. Het blijkt dat arbeid van mannen vanuit een "job model" wordt benaderd, waarin de relatie tussen betaalde arbeid en gezinssituatie meestal ontbreekt. Daarentegen wordt het thema vrouwen en betaalde arbeid meestal vanuit een "gender model" bestudeerd en wordt betaalde arbeid van vrouwen veelal in verband gebracht met gezinssituatie en persoonlijke eigenschappen en minder met de structuur van de arbeidsmarkt of de arbeidssituatie zelf. Dit fenomeen werd ook waargenomen bij de bestudering van de literatuur 
over vrouwelijke artsen. Opmerkelijk veel aandacht werd besteed aan de kwestie "hoe zorgtaken en moederrol te combineren zijn met de rol als arts", terwijl het vraagstuk voor vaders die een medisch beroep praktiseren nauwelijks aan de orde kwam (zie literatuur hoofdstuk 2).

Ad 4) Het vierde aspect van gender betreft de subjectieve identiteit, waarbij het van belang is deze te operationaliseren naar sekse-identiteit en naar beroeps-identiteit. Juist de verwevenheid en de spanningsverhouding tussen beide is een belangrijk analyse moment (Brouns \& Schokker, 1990). Het werk van Benschop (1996) bleek voor de wisselwerking van gender en identiteit veel aanknopingspunten te bevatten ${ }^{5}$.

Benschop onderzocht de zogenaamde "gendersubtekst" in organisaties. $\mathrm{Zij}$ doelt hierbij op een proces waardoor een systematisch genderonderscheid, dat gerelateerd is aan processen van hegemoniale genderregulering en dat deels impliciet deels expliciet naar voren komt in sociale praktijken in organisaties, als dualiteit wordt gereproduceerd via een gelaagd stelsel van arrangementen op structuur- en handelingsniveau. $\mathrm{Ze}$ laat zien hoe de reproduktie van genderongelijkheid in zijn werk gaat, ondanks expliciet beleid van emancipatie en gelijke kansen voor mannen en vrouwen. De belangrijkste mechanismen in deze blijken te zijn:

- de vanzelfsprekendheid van organisatie-arrangementen, waardoor verhuld blijft dat deze arrangementen vaak in het voordeel van mannen werken

- de instemming of aanpassing van medewerkers aan deze arrangementen op persoonsniveau

\subsection{De medische professie en de reproduktie van gender}

Professies zijn beroepsgroepen die gekenmerkt worden door zaken als het vermogen om een deel van de werkelijkheid te interpreteren, esoterische kennis, waardevolle kunde en geloofwaardigheid door certificatie en de noodzaak van een langdurige scholing voor toekomstige leden van de groep (Mulder, 1996). Beroepen die van oudsher in verband worden gebracht met het begrip "professie", zijn de geestelijkheid, de rechtelijke macht en de medische stand. Het zijn beroepsgroepen die belangrijke maatschappelijk domeinen als - respectievelijk - de toegang tot het hiernamaals, de rechtvaardigheid en de gezondheid onder hun hoede hebben. In de meeste benaderingen van het begrip "professie" blijkt een verband te worden gelegd tussen kennis en kunde. Artsen blijken het schoolvoorbeeld van professionals. De ontwikkeling van de begrippen "professie" en "professionaliteit" blijkt in een wetenschappelijke traditie van de sociologie zelfs bijna geheel voortgesproten te zijn uit bestudering van het medisch beroep en haar beroepsbeoefenaren. Artsen zijn "cracks" en maken deel uit van een beroepsgroep die recht mag doen gelden op een bijzondere status vanwege de waarde van hun expertise en de zorgvuldigheid die, naar men aanneemt, wordt betracht in de toepassing van die expertise (Freidson, 1970; Parsons, 1968; Van der Krogt, 1981).

Toch blijkt deze ietwat geïdealiseerde opvatting van de medische professie bij nadere beschouwing al langere tijd scheuren te vertonen (Mulder, 1996). In de zestiger jaren

'zie ook hoofdstuk 9 en 10 
werd het beeld van het medisch beroep als een betrouwbaar, onbaatzuchtig en dienstverlenend beroep, gegrond op langdurige en degelijke scholing, terecht autonoom en weinig beïnvloedbaar door andere actoren dan de beroepsgroep zelve, fors gerelativeerd door te wijzen op het eigenbelang van de medische stand. Perkin (1989) beschouwt het proces van professionalisering als het streven van een groep naar marktbeheersing en collectieve sociale stijging. In dit proces onderscheidt hij drie typen doelen. Ten eerste economische doelen als inkomen en bezit, ten tweede sociaal ideologische doelen zoals aanzien en gezag over een bepaald (ideologisch) domein en ten derde politieke doelen zoals politieke macht en beslissingsbevoegdheid. De medische beroepsgroep blijkt in historisch perspectief bezien, als groep bijzonder succesvol te zijn geweest in het realiseren van deze doelen. Wanneer men de wetten van Thorbecke (1865) - waarbij het praktiseren van de geneeskunde werd voorbehouden aan academisch geschoolde dokters - als vertrekpunt neemt, dan blijken inkomen, aanzien en autonomie van de medische beroepsgroep sindsdien met sprongen te zijn gestegen. Onthullend is overigens wel dat het beginpunt van de professionalisering van het moderne medisch beroep blijkt samen te vallen met een proces van uitsluiting van vrouwen van deze vorm van (door de staat) gelegitimeerde uitoefening van de gezondheidszorg. De gelijktijdige constructie van het beroep van verpleegster, wees vrouwen in de maatschappij van die dagen hun plaats. Wanneer vrouwen ontplooiing zochten voor kwaliteiten als zorgzaamheid en toewijding aan de zieke medemens, dan werden zij geacht dit te doen als verpleegster, terwijl voor mannen hiervoor het artsenberoep de meest elegante vorm was.

Dit roept de vraag op naar de precieze relatie tussen enerzijds de rol en positie van vrouwelijke artsen als medische professionals en de ups en downs van het professionaliseringsproces anderzijds. In de zestiger jaren klonk steeds meer kritiek op de geprivilegeerde positie van artsen. Met de nodige scepsis schrijft Hughes in 1971: "They profess to know better than others the nature of certain matters and to know better than their clients what ails them of their affairs".

In een kritische analyse werd de expertise van de professie gerelativeerd als zijnde pretentie en hun status en zeggensmacht geduid als privilege (Mulder, 1996). Ook in de medicaliseringsdiscussie die in de zestiger en zeventiger jaren in alle hevigheid werd gevoerd, werd gewezen op een vorm van "oneigenlijke uitbreiding van haar territorium" door de medische stand. De geneeskunde zou steeds meer levensdomeinen onder haar zeggensmacht hebben gebracht (Illich, 1975). Zo zou bijvoorbeeld sociaal onwelgevallig gedrag gemakshalve als "ziek" of "gek" worden geëtiketteerd en daarmee maatschappelijk onschadelijk gemaakt. Ook de kritische Vrouwenbeweging roerde zich in deze discussie en wees op de annexatie van vrouwenlevens door de overmatige bemoeienis van medici met de normale fysiologische processen van een vrouwenlichaam als menstruatie, zwangerschap en overgang (Baart en Baerveldt, 1986). Terwijl deze kritiek op de medische professie in de zestiger en zeventiger jaren aanzienlijke maatschappelijke resonans vindt, neemt tegelijkertijd het aantal vrouwelijke artsen toe. Een opmerkelijk coïncidentie. 


\section{Sociale sluiting in de medische professie}

Zijn in de medische beroepsuitoefening regels of procedures te onderscheiden die functioneren als mechanisme van sociale sluiting? Het werk van Schoon $(1995,1988)$ en Bosch (1994) bevat belangwekkend historisch materiaal, waarmee wordt aangetoond dat in de medische professie demarcatie en uitsluitingsstrategieën werden ingezet, die tot gevolg hadden dat de invloed van vrouwen in de geneeskunde lange tijd bijzonder klein was. Chua en Clegg (1990) hebben erop gewezen dat de laatste decennia biologische sekse als uitsluitingsmechnisme meer en meer is vervangen door culturele genderverhoudingen. Voor selectie voor hogere posities lijken status-vereisten te zijn vervangen door kennis-vereisten, die eveneens vaak een genderlading zouden bezitten. Technische of "beta" vakken worden vaak met mannelijkheid geassocieerd, waardoor vrouwen mogelijk minder aangesproken worden.

Een voorbeeld van sociale sluiting is de structurering van interne of bedrijfs-opleidingen, noodzakelijk voor hogere funkties, zoals deze wordt aangetroffen in diverse branches als bankwezen of multi-nationale bedrijven. Vaak zijn deze interne opleidingen zo gestructureerd dat ze niet gecombineerd kunnen worden met zorgverplichtingen, waardoor onevenredig veel mannen zich kwalificeren en vrouwen afvallen. Ook in de moderne geneeskunde zijn regels en procedures te ontdekken, die grosso modo meer belemmerende werking voor vrouwelijke studenten en artsen tot gevolg hebben dan voor mannen. Concreet geldt dit voor de inrichting van de vervolgoplei-

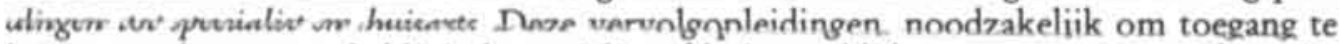
krijgen tot beroepen als klinisch specialist of huisarts, blijken zo gestructureerd te zijn dat meer dan voltijdse beschikbaarheid gedurende drie a vier jaren (of meer) vereist is, in een leeftijdsfase waarin ook kinderwens vaak een rol gaat spelen. Opmerkelijk is dat herinrichting van deze opleidingstrajecten, door artsen bijvoorbeeld in staat te stellen om (een deel van) de opleiding in deeltijd uit te voeren, tot op heden nauwelijks bespreekbaar zijn in de beroepsgroep (van Hall, 1997; Heiligers, 1997; Dijkstra, 1992). Er zijn weliswaar uitzonderingen op deze regel zoals bijvoorbeeld incidentele duo-constructies in de vervolgopleiding tot gynaecoloog of de huisartsberoeps-opleiding die incidenteel in deeltijd uitgevoerd kon worden (Rijks Universiteit Utrecht en Universiteit Maastricht). Om onduidelijke redenen werden deze arrangementen echter niet gecontinueerd.

Verder is de toegang tot de vervolgopleidingen, cruciaal voor de verdere loopbaan, een kwestie van selectie. Meestal is de situatie zo dat het aanbod van geïnteresseerden groter is dan het aantal opleidingsplaatsen. Er is dus sprake van competitie, men dient zich zodanig te kwalificeren en te presenteren dat de kans op selectie wordt vergroot. Dit roept dan meteen de vraag op welke beelden er bestaan bij opterende artsen die zich willen kwalificeren en welke beelden bestaan bij de groep "selecteurs", de gevestigde artsen-opleiders en hoogleraren.

\section{Cultuur van medici en reproduktie van gender}

"Organization is basically about control", een controle die niet alleen door de structuur van de organisatie wordt gedragen, maar ook door de cultuur die regulerend 
optreedt en een samenbindende factor vormt (Clegg \& Dunkerley, 1980). Elke organisatie heeft haar eigen verhalen over de geschiedenis en over de helden. Symbolen zijn een belangrijke bouwsteen in deze cultuur die mensen bij elkaar brengt in één organisatie. In deze cultuur circuleren beelden over wat een goede arts of werknemer is, wat een geslaagde arts is, beeldvorming over taken en funkties, over vrouwelijkheid en mannelijkheid. Deze beelden zijn zelden gearticuleerd en maken deel uit van de vanzelfsprekende achtergrond, waartegen bepaalde ideeën ontstaan en besluiten worden genomen. Mensen worden geselecteerd, maar ze selecteren ook zelf en in deze processen blijkt de cultuur van een organisatie een grote rol te spelen (Veldman en Witting, 1990; Brouns, 1993). De verhalen, symbolen en waarden van een organisatie of beroepsgroep zijn geen neutrale gegevens maar hebben vaak een genderlading en kunnen vrouwen en mannen daardoor op een specifieke manier aanspreken (of niet aanspreken) hetgeen van invloed is op hun beeld van hun mogelijkheden binnen de organisatie of het beroepsveld (Brouns, 1993 p. 173). Hoe sterker het ideaalbeeld van een aanstaand arts, die geselecteerd wil worden voor een opleidingsplaats, overeenkomt met het vigerende ideaalbeeld van de betreffende artsengroep, hoe intensiever of hardnekkiger deze arts zal proberen om een opleidingsplaats te bemachtigen, maar ook hoe meer kans deze daadwerkelijk heeft om een opleidingsplaats te bemachtigen en een loopbaan naar wens te realiseren (van Vianen, 1987).

In het vigerend ideaalbeeld van de medische professie speelt commitment of een zekere mate van roeping een rol. Dit kan zich uiten bij selectie door artsen-opleiders van kandidaten bij wie een grote bereidheid wordt verondersteld tot hard werken en de bereidheid om andere aspecten van het leven op te offeren of voor langere tijd (vaak de duur van de opleiding) op een laag pitje te zetten (Keizer, 1997). In dat opzicht lijkt de cultuur van de medische professie enigszins op die van multinationals, waar het even

eens gebruikelijk is dat potentiële medewerkers inzicht geven in de organisatie van hun privé-situatie of in ieder geval hun kansen op selectie vergroten door hun leefsituatie zo in te richten dat ze maximale energie aan hun baan kunnen geven. Bij multinationale bedrijven is het gebruikelijk om van nieuwe medewerk(st)ers maximale loyali. teit te verwachten en de bereidheid om privé-situatie ondergeschikt te maken aan de eisen die het beroep stelt. Daarmee functioneren deze aspecten als impliciete selectiecriteria. Brouns interpreteert deze gewoonte kernachtig aldus: "de disciplinering en regulering blijft niet beperkt tot de werksituatie maar omvat de inrichting van het gehele leven van de werknemers." (1993, p. 173).

Ook in de geneeskunde lijkt met name bij de selectie voor opleiding tot klinisch specialist, de kans tot selectie met name voor die novieten, die veel overeenkomst met het cultureel ideaalbeeld vertonen, groter (Heymans et al, 1994). Daardoor hebben met name deze artsen kans om in aanmerking te komen voor de belangrijke plaatsen in de beroepsgroep ${ }^{6}$. In het socialisatietraject tot arts functioneren derhalve de normen van de ideale arts en van de ideale werknemer, geënt op het traditionele kostwinnerschap, als belangrijk richtsnoer. Het is aannemelijk dat aanstaande artsen zich zullen

\footnotetext{
' Organisaties waarbii naast goede prestaties op het terrein van kennis en expertise ook toewijding aan het vak een grote rol speelt, worden organisaties met een sterk ontwikkelde cultuur genoemd.
} 
verhouden tot deze impliciete opvattingen en eisen ten aanzien van de inrichting van hun privéleven. De kans is groot dat deze opvattingen en de wensen over hun eigen privé-situatie de zelfselectie voor medische vervolgopleidingen en de succesverwachting ten aanzien van eigen loopbaanplannen beïnvloedt.

\subsection{Reproduktie van sociale ongelijkheid en identiteit}

Een opmerkelijke bevinding uit het onderzoek van Veldman en Witting (1990) was dat vrouwen zich in de setting van de multinational, getypeerd als een sterke cultuur, sterker bleken te identificeren met de norm en het ideaaltype werknemer dan mannen in deze setting. Veldman en Witting (1990) interpreteerden dit gedrag als een strategie van onzekerheidsreductie. In overheidsinstellingen, waar minder eenduidige normen en waarden heersen en die getypeerd kunnen worden als minder sterke cultuur bleken vrouwen een meer autonome stijl te hebben en zich vrijer te voelen om de cultuur en de regels zelf te interpreteren.

Brouns (1993) interpreteert deze bevindingen later als een vorm van begemonie, dat wil zeggen dat actoren in een relatieve onmachtspositie kunnen handelen in overeenstemming met de belangen van de meer machtige actoren, zonder dat er van dwang sprake hoeft te zijn. Vrouwen kunnen zich dus sterk verbinden met waarden en normen van het prototype werknemer, die tot op zekere hoogte gendered en seksestereotyperend zijn.

Soortgelijke resultaten meldde Komter (1990) in haar onderzoek naar zelfopvattingen en zelfwaardering van mannen en vrouwen in drie verschillende beroepsgroepen. $\mathrm{Bij}$ docenten, verpleegkundigen en administratief personeel werd zelfbeeld en zelfvertrouwen onderzocht in relatie tot de beleving van rechten en plichten. Komter vond dat vrouwen, ondanks hun objectief slechtere positie in termen van rechtszekerheid, salaris, funktieniveau en doorstroming, tevredener waren met hun werk en meer zelfstandigheid en ontwikkelingsmogelijkheden ervoeren dan mannen. Mannen bleken alerter op hun rechten te zijn dan vrouwen, terwijl vrouwen vaak een sterkere beleving van plichten in termen van verantwoordelijkheid verwoorden. Vrouwen vonden ook de sfeer en de contacten met collega's prettiger dan hun mannelijke collega's. Komter interpreteerde deze bevindingen als een patroon van "mindermachtigen" in de samenleving die sneller blij zijn met wat ze hebben en niet gewend zijn veel eisen te stellen; "ze kennen hun plaats". Ze moeten extra hun best doen om voor vol te worden aangezien (Komter, 1990; 215-216).

Brouns (1993) verbindt deze bevindingen met de maatschappelijk onderwaardering van de inspanningen van vrouwen en de relatieve onzekerheid waarmee vrouwen opereren in het veld van betaalde arbeid. Deze "aanpassing" van mindermachtigen aan de bestaande verhoudingen kan worden opgevat als een realistische inschatting van de gegeven mogelijkheden in die situatie, maar impliceert tegelijkertijd een herhaling en bevestiging van de bestaande hiërarchie tussen de seksen.

De voorwaarde voor aanpassing aan of instemming met bestaande ongelijke verhoudingen, is echter wel dat "minder-machtigen" zich identificeren met de ideaalbeelden, de normen en waarden, kortom met de cultuur van de organisatie. Sierksma (1981) 
spreekt in dit verband, in navolging van Foucault van een vorm van verleiding of disciplinering, die deze subjectieve identificatie en instemming met de bestaande organisatie-realiteit mogelijk maakt. Organisatieleden, zowel mannen als vrouwen worden vaak gedurende hun opleiding gesocialiseerd en rijp gemaakt om vervolgens "naadloos" te kunnen invoegen in de bestaande organisatiecultuur.

Nieuwsgierig geworden door deze inzichten hebben wij ons de vraag gesteld "hoe kan men licht werpen op het proces van vorming en aanpassing van aanstaande artsen aan de heersende cultuur van de medische professie en daarin specifieke aandacht besteden aan het perspectief van vrouwelijke nieuwkomers? Daartoe hebben wij allereerst een empirisch onderzoek verricht naar "kenmerken van de cultuur van de medische professie" zoals deze worden waargenomen door de nieuwe generatie artsen. We hebben de ervaringen en percepties van co-assistenten, die kennismaken met de praktijk van het medisch vak geïnventariseerd. Co-assistenten betreden de wereld van de medische praktijk voor het eerst en kunnen beschouwd worden als sensitieve waarnemers, die als ontdekkingsreizigers de wereld van de medische professie betreden. $\mathrm{Ze}$ zijn echter niet slechts waarnemer, maar wensen tegelijkertijd ook toe te treden tot de medische groep en lid te kunnen worden van de professie. Ze zullen zich onderdompelen en ondergedompeld worden in de cultuur van de medische professie en als een ander mens tevoorschijn komen. 


\subsection{Samenvatting}

De positie van vrouwelijke artsen in de medische professie kan niet goed begrepen worden, wanneer geen aandacht wordt besteed aan recente inzichten over sekse en gender die zijn ontwikkeld binnen Vrouwenstudies. Om vat te krijgen op manieren van reproduktie van sekse ongelijkheid in het proces van "dokter worden", werd de gendertheorie van Scott bestudeerd. Sociale instituties als onderwijs, gezondheidszorg en dergelijke reproduceren genderongelijkheid, waarbij de subtiele wisselwerking tussen culturele symbolen, normen en waarden en identiteit-arrangementen van mensen een rol speelt.

Ook in de medische professie werden mechanismen beschreven, die integratie van vrouwelijke artsen belemmeren zoals uitsluiting en culturele genderverhoudingen. Zo zijn de medische vervolgopleidingen tot specialist of huisarts zo ingericht, dat deze moeilijker uitvoerbaar en haalbaar zijn voor mensen, die een substantiële rol willen spelen in de zorg voor kinderen of andere zorgtaken. In de medische professie is het gebruikelijk om van nieuwe medewerk(st)ers maximale loyaliteit te verwachten en de bereidheid om de privé-situatie ondergeschikt te maken aan de eisen die het beroep stelt.

In het socialisatietraject tot arts functioneren normen en waarden over de ideale dokter en ideale werknemer, die deels zijn geënt op het traditionele kostwinnerschap. Ook het gegeven van de verticale seksesegregatie, het nagenoeg ontbreken van vrouwelijke artsen in hiërarchisch hogere lagen of in belangrijke rollen in de medische opleiding, zal zeker invloed hebben op het beeld van de ideale dokter. Aanstaande artsen, die zich prepareren op het beroep, zullen zich tot de "impliciete lessen" verhouden en hun opvattingen en attitudes zullen erdoor gekleurd worden. Processen van selectie en zelfselectie spelen een grote rol bij de ontwikkeling van de professionele identiteit van de nieuwe generatie artsen en van hun medische loopbaan.

In de twee empirische onderzoeken die in dit proefschrift worden beschreven, zal eerst aan de "vormende omgeving", de beroepscultuur aandacht worden besteed en dan aan de interacties van co-assistenten met die omgeving. Inzichten uit Vrouwenstudies over subjectvorming, identiteit en machtsprocessen betrokken bij de analyse van het proces van de ontwikkeling van de professionele indentiteit. 


\section{Hoofdstuk 4}

\section{Medische opleiding en professionele socialisatie}

"Can we decide to break the frame of our professional game ?"

\subsection{Inleiding}

Het proces van dokter worden is complex omdat het te maken heeft met overdracht van cultuur en noodzaak tot anpassing. Het houdt echter tegelijkertijd ook de mogelijkheid in van persoonlijke groei en ontwikkeling. Eerst zal in dit hoofdstuk worden aangegeven waarom gekozen is voor de bestudering van leerprocessen in de medisch opleiding vanuit het perspectief van socialisatie. Het belang van de ervaringskennis of "tacit knowledge" voor de kwaliteit van het medisch handelen wordt toegelicht. Deze kennis en de regels voor het "sociale spel" dat artsen geacht worden te kennen en te kunnen, worden meer of minder impliciet overgebracht in de medische opleiding door voorbeeldgedrag van artsen-opleiders en door gewoonten die vanzelfsprekend zijn en als zodanig niet bevraagd worden. Deze impliciete en meer verhulde leerprocessen, die ook wel worden aangeduid met de term "hidden curriculum" (Snijder, 1970) spelen een grote rol in de uiteindelijke identiteit van de nieuwe arts. We zullen vervolgens het profiel van de basisarts, het "eindprodukt" van de medische opleiding en de beoogde eindtermen wat nader bestuderen. De geformuleerde doelen blijken hooggestemd en de haalbaarheid ervan roept vraagtekens op. Realistischer is het om de eindtermen als ideaaltypische beschrijvingen te beschouwen die als richtsnoer kunnen functioneren voor de opleidingsinspanningen van de instituten.

Het begrip socialisatie zal geïntroduceerd worden en tevens diverse uitwerkingen van dit begrip. Als eerste wordt socialisatie besproken als een vorm van cultuuroverdracht en worden enkele auteurs aan het woord gelaten die onderzoek hebben verricht naar allerlei aspecten van de "impliciete boodschap" die in de medische opleiding worden 
overgedragen. De fase van de co-assistentschappen blijkt een gevoelige periode te zijn in het vormingsproces van nieuwe medische professionals. De co-assistent betreedt in de klinische fase een nieuwe wereld en gaat participeren in de praktijk van het medisch uitvoerend werk. De nieuweling stapt als een verbaasde reiziger deze wereld binnen en zal een sensitiever waarnemer zijn van de gebruiken en de gewoonten in de beroepsgroep dan artsen, die reeds langere tijd het medisch beroep uitoefenen. De ervaringen met de realiteit van het medische beroep zullen co-assistenten confronteren met verschillen tussen de vaak lang gekoesterde idealen en de harde werkelijkheid. Over sommige zaken zullen zij enthousiast zijn, terwijl zij andere aspecten als negatief of afkeurenswaardig zullen ervaren. In het beroepscultuuronderzoek, dat eerdt aan bod komt in dit boek, staat de co-assistent als waarnemer en beoordelaar centraal, in het socialisatieonderzoek, dat daarna aan bod komt staat het persoonlijk beleven en de eigen ervaring van de co-assistent als nieuwkomer centraal.

\subsection{Het doel van de medische opleiding}

Als men artsen vraagt naar het doel van de medische opleiding, zullen zij bijna allen antwoorden dat de inspanningen van medische faculteit en opleidingsziekenhuizen gericht zijn op het overdragen van kennis en vaardigheden, noodzakelijk om toekomstige artsen in staat te stellen de medemens te kunnen helpen bij het lenigen van haar of zijn nood. Dit type leerproces wordt veelal voorgesteld als een proces van toename van kennis en cognitieve bagage. Medische studenten leren hoe het menselijk lichaam anatomisch in elkaar zit, hoe het functioneert en hoe de funkties en vormen van het zogenaamde "somatisch substraat" bij ziekte veranderen. Studenten leren veranderingen van het menselijk lichaam te interpreteren in het kader van diagnostiek van ziekten en stoornissen. Vanuit onderwijskundig perspectief wordt het leerproces aan medisch studenten en artsen vooral bestudeerd als een proces van groei van medische expertise en het vermogen tot medisch probleemoplossend denken (Boshuizen, 1989; Schmidt, 1992). Dit is echter slechts een deel van het verhaal.

Geneeskunde studeren en opgeleid worden tot arts is een indringend vormingsproces, dat veel meer inhoudt dan het verwerven van kennis en het aanleren van vaardigheden. In de opleiding wordt immers ook nagestreefd om bij de aanstaande artsen bepaalde eigenschappen tot ontwikkeling te brengen, die noodzakelijk zijn om de rol van arts, een rol met een verantwoordelijkheid voor het levenslot van mensen, naar behoren te kunnen vervullen (Metz, 1993). Metz zegt hierover dat het uitoefenen van de geneeskunde samenhangt met een bepaalde professionele identiteit, die het individu verwerft gedurende haar professionele scholing. Deze identiteit wordt geacht van een andere orde te zijn dan de ambachtelijke of wetenschappelijke, maar hoe deze identiteit dan wel omschreven moet worden, lijkt niet eenvoudig.

Ook Stegeman (1991) geeft aan dat voor kwalitatief goed medisch handelen meer nodig is dan theoretische kennis en het hanteren van vaardigheden. Zaken als gevoeligheid voor de context van zieke en ziekte en voor wat ziekte voor het individu betekent zijn van belang naast gevoel voor de individuele nuances en variaties in reacties van mensen op ziekte, pijn, gebrek en dood. De ervaren arts zal dit bevesti- 
gen. Een arts moet allerlei soorten informatie kunnen duiden, analyseren en synthetiseren. Juist het kunnen bundelen van al deze verschillende vormen van kennis ervaringskennis, feitenkennis en intuïtie - maken een arts tot een goed arts, tot een connaisseur of expert (Stegeman, 1991). Men spreekt in dit verband dan ook over "tacit knowledge" ofwel ervaringskennis. Deze "tacit knowledge" is volgens Stegeman met name in de geneeskunde van grote betekenis. Deze stilzwijgende kennis is uit de aard van haar wezen niet expliciteerbaar, waardoor ze de nieuwkomer niet kan worden aangereikt in woord, maat of getal. De enige manier waarop men zich deze kennis eigen kan maken is om deze waar te nemen en zelf te ervaren. Deze manier van kennis verwerven wordt aangeduid met de term "professionele socialisatie".

\subsection{Inrichting en kwaliteit van de medische opleiding}

De medische opleiding bestaat in Nederland over het algemeen, net als in verschillende andere westerse landen, uit twee delen. Men begint met een predoctoraal gedeelte van vier jaar waarin het accent ligt op het opdoen van kennis van basisvakken als anatomie, fysiologie, biochemie en pathologie. Daarna volgt een periode van twee jaar waarin praktisch medisch onderwijs wordt gegeven. Studenten lopen dan stages in verschillende medische werkvelden, als de kliniek, een huisartspraktijk of de sociale geneeskunde.

In de predoctoraal fase verwerft de student zijn kennis voornamelijk via hoorcolleges of studiegroepen, met een enkel uitstapje naar de "snijzaal". Naarmate de student vordert in de opleiding, vindt er meer en meer contact met "echte" patiënten en patiëntproblemen plaats in de vorm van simulaties van patiëntencontacten en klinische lessen?

Vorming in de predoctoraalfase vindt met name plaats in de context van de universiteits- en studentencultuur. In deze fase hebben met name de ervaringen in de snijzaal een sterk vormende impact (Coombs, 1978; Smith \& Kleinman, 1989; van Welzen, 1978). In de snijzaal komen studenten vaak voor het eerst van hun leven in contact met het dode menselijke lichaam, hetgeen voor menigeen een schokkende ervaring kan zijn. ${ }^{8}$

' De roep om verbetering is onder andere opgepakt aan de Universiteit Maastricht, waar een andere opzet (thematisch en probleemgericht) is gekozen bij de inrichting van het predoctoraal gedeelte van de medische studie. In plaats van kennisoverdracht via hoorcolleges en studieboek geordend per vakgebied, tracht men in dit model de medisch studenten al in een vroeg stadium van de studie in contact te brengen met "echte" patiënten en medische problemen en leren zij een probleemgestuurde anpak bij de studie. Door middel van het analyseren van medische problemen in deelvragen, bestuderen zij de basiskennis die nodig is in het kader van het aangereikte medische probleem. Deze aanpak voorkomt in de predoctorale fase een gevoel van langdurig droogzwemmen bij studenten of een gevoel overladen te worden met grote hoeveelheden kennis, waarvan men de toepassing wel vermoedt, maar nog niet ervaart.

'Reflectie op de betekenis van deze ervaring voor de student is in de meeste curricula nauwelijks ingebouwd. Dit kan tot gevolg hebben dat bij studenten de neiging wordt versterkt om het menselijk lichaam meer te beschouwen als object of ding en de patiënt te depersonaliseren. Studenten leren het lichaam meer en meer te zien als een somatische, biologische entiteit en minder als belichaamd wezen (Smith \& Kleinman, 1989). 
Is de medisch student in de predoctoraal fase nog vooral "student" met weinig contact met de echte artsenwereld, in het tweede deel van de studie - meestal aan het einde van het vierde jaar - verandert dat, als zij begint met de co-assistentschappen of klinische stages en de medische praktijk ingaat. Het "lopen" van co-assistentschappen is een cruciale fase in de socialisatie tot medisch professional (Coombs, 1978; Fahrenfort, 1985), omdat tijdens de coschappen de overstap plaatsvindt naar de realiteit van het medische beroep en het vervullen van de artsenrol. Het onderwijs verspringt vrij abrupt van schools en theoretisch, naar praktisch en ambachtelijk, waarmee het sterk gaat lijken op het meester-gezel systeem van de gilden (Van Welzen, 1978). Behalve dat de co-assistent de systematiek van het medisch onderzoek leert, maakt zij zich ook beetje bij beetje de professionele identiteit van de arts eigen. Deze identiteit bestaat uit een groot aantal ongeschreven regels, wetten, normen en codes. Hoe dient, bijvoorbeeld, een arts zich te gedragen ten opzichte van haar patiënten? Hoe dient een afgestudeerde arts zich ten opzichte van collega's te gedragen en hoe verwerft zij zich een plaats als collega? Wat is het typische vakjargon van de arts? De stand van zaken werd in 1990 geëvalueerd in een nota Beleidsgericht Onderzoek Co-assistentschappen, ook wel genoemd B.O.C. rapport (Metz et al, 1990).

\section{Kwaliteit}

Over de kwaliteit van de medische opleiding en die van de co-assistentschappen in het bijzonder is de afgelopen jaren veel gediscussieerd (BOC rapport, 1990; Raamplan 1994 eindtermen van de arts-opleiding; Moll, 1995). Worden aanstaande artsen wel adequaat opgeleid en voldoende toegerust om aan de noden van deze moderne tijd tegemoet te komen? Zeker in moderne westerse gemeenschappen krijgen artsen meer en meer te maken met vergrijzing, chronische ziekten, patiënten met uiteenlopende culturele achtergronden en met toenemende mondigheid en consumentengedrag (Bakker, 1995). Deze maatschappelijke veranderingen vragen om vernieuwing en herijking van de medische opleiding (Dunning, 1981, Schmidt, 1993, Dupuis, 1992), evenals de toename van vrouwelijk studenten in de medische opleidingen (Elston, 1993, Lorber 1984, 1993, Allen, 1988).

De co-assistentschappen kregen veel kritiek vanwege het ontbreken van controleerbare doelen van het leerproces en de wisselende kwaliteit. De kwaliteit en inhoud van de stages zouden nogal verschillend zijn, afhankelijk van de stageplaats of het opleidingsziekenhuis. Om te voorkomen dat leerdoelen te veel bepaald zouden worden door toevalligheden of affiniteiten van klinische opleiders werd gepoogd om consensus te bereiken over de doelstellingen van de medische opleiding, die ook wel eindtermen worden genoemd. Deze handschoen werd opgepakt door een onderzoeksgroep uit Nijmegen (Metz et al, 1994), die op inductieve wijze door middel van een inventarisatie van bestaande stageprogramma's en consensusbesprekingen kwam tot een beschrijving van eindtermen van de opleiding tot basisarts (Raamplan, 1994).

Hiermee wordt een poging gedaan om het gewenste eindniveau van de medische opleiding te beschrijven en aan te passen aan deze tijd. Deze beschrijving bevat de belangrijkste eigenschappen die een basisarts, "het eindprodukt" van de medische oplei- 
ding, zou moeten hebben. Het profiel van deze basisarts (Raamplan, 1994) ziet er aldus uit:

deze beeft zich bet proces van bet medisch probleem oplossen eigen gemaakt;

deze bezit een breed kennis-en vaardighedenpakket en is daardoor in staat om elke vervolgopleiding in te gaan en in staat om met andere disciplines/hulpverleners samen te werken;

deze is wetenschappelijk gevormd;

deze bezit de juiste attitudes;

deze is flexibel: kan op ontwikkelingen inspelen;

deze is wettelijk bevoegd en bekwaam tot medisch handelen en draagt hiervoor de verantwoordelijkheid. Een basisarts houdt verder bij het medisch handelen rekening met de eigen grenzen, die bepaald zijn door opleiding en ervaring.

Omdat een aanstaande dokter gedurende de opleiding niet alleen haar medische en wetenschappelijke vaardigheden dient te ontwikkelen, maar ook als persoon een bepaalde groei moet doormaken, wordt in het Raamplan gepoogd om ook op dit vlak een streefniveau aan te geven. Deze ontwikkeling op het terrein van de persoonlijke aspecten heeft vooral betrekking op de arts-patiënt relatie (1), het eigen functioneren (2) en de wederzijds beïnvloeding van werk en privéleven (3). Over het eigen functioneren stelt het Raamplan onder andere het volgende:"De toekomstig arts zal moeten leren omgaan met onzekerheden, acute situaties, stress en gevoelens van onmacht. Zij zal verantwoordelijkheid moeten kunnen dragen, haar eigen beperkingen kunnen onderkennen, beslissingen durven te nemen, kunnen omgaan met snel veranderende situaties en financiële onafhankelijkheid moeten bewaren ten opzichte van derden" (citaat Raamplan, 1984). Opmerkelijk is dat het rapport wel uitvoerig uitweidt over persoonlijke kwaliteiten, die de jonge arts moet ontwikkelen voor de arts-patiënt relatie maar dat de wederzijdse beïnvloeding van werk en privé (3) niet verder wordt uitgewerkt.

Omdat we in dit onderzoek de aandacht willen richten op de medische opleiding als "socializing agent", gericht op een bepaalde, binnen de medische opleiding als gewenst beschouwde, professionele identiteit, gaat onze belangstelling uit naar de wijze waarop "de juiste attitudes" van de arts worden geconcretiseerd (Metz et al, 1990 en 1994).

In de medisch onderwijskundige literatuur wordt met name de term "attitude" gebruikt, wanneer men doelt op effecten van vorming en socialisatie (Batenburg, 1977). Het begrip "attitude" heeft een wijdere strekking dan beroepsmatig handelen alleen en wordt opgevat als een manier van reageren op bepaalde situaties (afwenden of toeneigen), als een reactiewijze die samengaat met een patroon van meningen, voorkeuren en ervaring, waarvan mensen zich maar ten dele bewust zijn en die men zich veelal ongemerkt heeft eigen gemaakt (Dupuis, Thung en Kerkhoff, 1992). "Attitude" blijkt niet slechts een individuele zaak te zijn, maar wordt gedeeld met een groep. Artsen dienen zich een "passende" beroepsattitude eigen te maken teneinde in de beroepsgroep opgenomen te worden. Juiste of passende attitudes voor een arts worden in het Raamplan (Metz et al, 1994) als volgt uitgewerkt: 
- de bereidheid om zich te willen inzetten en verantwoordelijk te voelen voor het lichamelijke, geestelijke en sociale welzijn van de mensen;

- respectvol om te gaan met patiënten, ongeacht diens sekse, ras, levensfase, sociale en economische status, opleiding, cultuur, seksuele geaardheid of levensovertuiging;

- de beschikking te hebben over sociale en communicatieve vaardigheden, zoals het vermogen om in duidelijke bewoordingen informatie over te brengen en zich voldoende in te leven in de patiënt en zijn omgeving;

- in staat te zijn zelfstandig beslissingen te nemen met inachtneming van medischethische aspecten;

- in staat te zijn eigen verantwoordelijkheid te dragen;

- de noodzaak in te zien van voortdurende nascholing en toetsing

- in staat te zijn de grenzen van de eigen çompetentie te kennen en erkennen.

Daarnaast moet een arts ook nog actief deelnemen aan het bevorderen en in stand houden van de volksgezondheid door zowel preventie, als genezen en verlichten van pijn en ongemak. Ook dienen artsen kritisch te zijn ten aanzien van het eigen handelen en dat van anderen en zich bewust te zijn van hun verantwoordelijkheid voor het functioneren van de gezondheidszorg als organisatie (financieel, logistiek e.d.)" (citaat Raamplan, 1994 p. 38). Verder zouden artsen goed moeten kunnen samenwerken met andere hulpverleners of disciplines vanuit het besef dat dit noodzakelijk is om een kwalitatief goede zorg te kunnen bieden en de continuiteit in die zorg te kunnen waarborgen.

De opgesomde gewenste eigenschappen en attitudes, die resultaat zouden moeten zijn van een geslaagde socialisatie tot arts, zijn ambitieus en leggen het hoge streefniveau van de medische professie door middel van de medische opleiding bloot. Het lijkt realistischer om deze eindtermen op te vatten als idealen of nastrevenswaardige doelen, die de opleidingsinspanningen richting kunnen geven of bij verbeteringen van de medische opleiding richtsnoer kunnen zijn.

\subsection{Hoe tracht de medische opleiding de eindtermen te realiseren?}

Het realiseren van eindtermen is veel moeilijker dan ze te formuleren. Met name de praktijkjaren van de medische opleiding, de co-assistentschappen onttrekken zich aan sturing en regulering terwijl van deze periode wel een sterk vormende invloed uitgaat (Coombs, 1978; Bucher \& Stelling, 1977; Pool \& Pool, 1983) Het leerproces in stages (training on the job) blijkt bijzonder moeilijk beheers- en stuurbaar te zijn (de Vries, 1992; Metz, 1990, 1993). Het aanbod aan medische problemen waaraan co-assistenten hun kennis en vaardigheden moeten ontwikkelen, blijkt vooral bepaald te worden door de grilligheid van de klinische praktijk. De leermeesters in deze fase zijn drukbezette klinici of huisartsen, wier prioriteit veelal ligt in de uitvoering van de gezondheidszorg. Een co-assistent loopt mee, volgt en poogt zo min mogelijk de voortgang van het werk in de medische praktijk te verstoren. Ze hoopt, naarmate de stages en de eigen vaardigheden vorderen, een zinvolle bijdrage te kunnen leveren aan de zorg voor patiënten. 
Anders dan in de universitaire of schoolse fase is het leerproces tijdens de klinische stages ondergeschikt aan de dynamiek van het klinisch werk. De zorg voor de patienten moet in de eerste plaats doorgang vinden. De Vries (1992) stelt dat het leerproces tijdens stages van een volstrekt andere orde is dan dat in de universitaire context. Dit leerproces tijdens stages heeft het karakter van "training on the job", dat wil zeggen dat, hoewel er opleidingsintenties zijn die boven het produktiedoel uitstijgen, het arbeidsproces praktisch ononderbroken doorgaat. Het opleidingsaspect bij "training on the job" is in de realiteit ondergeschikt aan het arbeidsproces.

Theoretisch leren op school of universiteit verschilt verder van praktijkonderwijs in stages of co-assistentschappen in die zin dat eerstgenoemde vorm wel extern beheersbaar is maar "training on the job" niet. De Vries (1992) stelt verder dat er sprake is van een fundamentele scheiding of cesuur tussen theoretisch onderwijs en leren in de beroepspraktijk. Theoretisch leren is inhoudelijk gericht op een breed bereik en op de toekomst, kennis wordt veelal aangereikt in fragmenten, terwijl de inhoudsstruktuur van stage of praktijkonderwijs gericht is op het concrete hier en nu en de over te dragen kennis niet fragmentarisch, maar geïntegreerd wordt aangeboden.

In de medische opleiding ligt deze cesuur tussen de predoctoraalfase en de fase van coassistentschappen. De Vries kiest voor de bestudering van veranderings- en leerprocessen in stages vanuit een socialisatie-perspectief, hetgeen tot dan toe weinig gebruikelijk was in de onderwijskunde.

De periode van de stages wordt opgevat als een overgangsfase van een schoolse socialisatie, waarin de opleiding en de docenten als rolzenders fungeren, naar beroepssocialisatie waarin de sociale omgeving in de beroepspraktijk de rolverwachtingen formuleert (de Vries, 1992). De co-assistent verkeert daarmee in een dubbele sociale positie namelijk in die van leerling en die van werknemer. Deze ambiguïteit is structureel verbonden met vormen van leren in een arbeidsplaats en brengt meer of minder rolspanningen met zich mee.

\section{Overgangen}

De overgang van de universitaire fase naar de fase van de co-assistentschappen is een indringende ervaring voor de student. Op de eerste plaats ervaart de co-assistent de stages vaak als een test-situatie waarin getoetst wordt of ze wel voldoende theoretische kennis bezit. Het daaruit voortvloeiend gevoel van onzekerheid en "weet ik wel genoeg" functioneert vaak als een stimulans om hard te studeren en kennis op te doen. Ook komt de medische problematiek in de praktijk vaak anders aan de orde komt, dan de student in de theoretische fase heeft geleerd. De manier waarop ziekten zich bij patiënten presenteren, houdt zich in de praktijk immers zelden aan de overzichtelijk ordening uit de leerboeken. De ervaring dat medische kennis minder eenduidig functioneert in de praktijk dan men in de theoretische fase dacht, is verwarrend evenals het gegeven dat diverse medische specialismen eenzelfde medische probleem vaak op heel verschillende wijze blijken te benaderen. Voor de praktijk van de geneeskunde is het herkennen van ziekte-patronen cruciaal. Op dit terrein zijn veel nieuwe inzichten verworven en werd het medisch onderwijs met name in de predoktoraal fase aan de Universiteit Maastricht geherstructureerd om het aanleren van de medische 
expertise effectiever te doen verlopen (onder andere: Boshuizen, 1989; Schmidt et al, 1992).

Maar het is de vraag of voorkomen kan worden dat co-assistenten onzeker worden door de andere benadering die in de klinische stages van hen gevraagd wordt.

Een volgende overgang betreft de confrontatie met "echte" patiënten en met de realiteit van menselijk lijden, verdriet en dood. Co-assistenten, die qua leeftijdsfase meestal in de adolescentie verkeren, worden gedurende de klinische fasen vaak voor het eerst geconfronteerd met existentiële zaken als dood, lijden of aftakeling, naaktheid, diverse vormen van sexualiteit en dergelijke. Omgaan met deze emotionele situaties is moeilijk voor ieder individu, maar als aanstaand arts is dit mogelijkerwijs nog ingewikkelder omdat de professionele rol van de arts vraagt om beheersing of affectieve distantie (Fox, 1993). Van Welzen (1978) stelt dat studenten vaker bij elkaar steun zoeken voor de verwerking van deze indringende of existentiële zaken, dan bij hun opleiders.

\subsection{Socialisatie in het algemeen}

"Slechts door de stemmen van anderen te internaliseren kunnen wij tegen onszelf spreken. Als niemand op significante manier van buitenaf bet woord tot ons had gericht, zou er binnen ons zelf ook stilte beersen. Alleen via anderen kunnen wij ertoe komen onszelf te ontdekken." (Berger, 1988 p. 58).

Het begrip socialisatie verwijst naar het proces waardoor een individu lid wordt van de maatschappij of een andere sociale eenheid door middel van het opleggen van bepaalde sociale patronen en gedrag. Socialisatie is een inwijdingsproces in een sociale wereld met zijn diverse vormen van interactie en zijn vele zingevingen (Berger, 1988). Een belangrijk middel in de socialisatie is de taal. Voordat wij overgaan tot bespreking van het proces van socialisatie tot medische professional, eerst enkele woorden over socialisatie bij jonge kinderen.

Socialisatie begint al in de vroegste jeugd en is vanuit verschillende denkrichtingen, als psychoanalyse, sociale leertheorie en cognitieve ontwikkelingstheorie uitvoerig bestudeerd. Voor een jong kind hebben de overgedragen sociale patronen een enigszins absoluut karakter. Dat heeft te maken met de overmacht van de volwassenen in de leefcontext van het jonge kind en de onbekendheid van het kind met alternatieve patronen. Pas later wordt een individu zich bewust van de relativiteit van sociale patronen. Beslissende stap in de socialisatie is dat het kind de houding en de rol van de belangrijke ander leert overnemen. In de vroege jeugd zullen dat met name ouders of verzorgers, broers of zusters zijn. Later breidt de kring zich uit naar leerkrachten van school, vrienden en clubgenoten.

Aanvankelijk neemt het kind de sociale patronen over door middel van imitatie, pas later zal het kind de diverse rollen internaliseren en de bijpassende houdingen aannemen. Fundamentele mechanismen bij de socialisatie zijn interactie en identificatie. Spelen wordt gezien als een belangrijk onderdeel van dit leerproces. Al spelend en experimenterend neemt het jonge kind morele geboden en verboden over, evenals de 
betekenissen die in de omringende gemeenschap worden toegekend aan vrouwelijke of mannelijk sekse, sociale klasse en huidskleur. Reflectie (- letterlijk terug-buigen) is van groot belang binnen een socialisatieproces: door het toenemende vermogen tot reflectie wordt het kind zich langzamerhand bewust van zichzelf als een "zelf" en eigen identiteit. Samenvattend kan men stellen dat socialisatie het individu binnenvoert in een bepaalde sociale wereld, maar tevens het individu kennis laat maken met zichzelf (Berger, 1988; Mavis Hetherington et al, 1993).

Men kan socialisatie volgens Berger (1988) bezien vanuit twee gezichtspunten, namelijk dat van de politieagent, waarin dwang, beloning en straf centraal staan, of dat van ontplooiing en ontwikkeling. Vanuit het gezichtspunt van de politieagent is er weinig oog voor de eigenheden van het kind, dat wordt voorgesteld als absorberend en vergaand passief; socialiseren is als het bewerken van was.

In het tweede gezichtspunt, dat vooral in de psychologie wordt aangetroffen, is socialisatie een inwijdingsproces waardoor het kind in staat is zich te ontwikkelen en uit te groeien in een wereld die voor haar klaar ligt (Duindam 1992, p. 43). Socialiseren wordt hier gezien als het bewerken van marmer of van hout, het materiaal legt de kunstenaar door zijn eigenschappen bepaalde beperkingen op. In deze benadering wordt meer aandacht besteed aan de wisselwerking tussen individu en omgeving; het proces wordt voorgesteld als een wederkerig proces, beide partijen raken beïnvloed door elkaar en veranderen aldus.

Socialisatie is een proces dat levenslang doorgaat en nooit afgelopen is. Men kan twee soorten socialisatie onderscheiden: primaire socialisatie, waarmee gedoeld wordt op het proces waardoor het jonge kind lid van zijn gemeenschap wordt en waarbinnen er sprake is van een ongelijkwaardige relatie tussen kind en belangrijke ander en secundaire socialisatie waarmee alle latere processen worden aangeduid waardoor een individu ingevoerd raakt in een specifieke sociale wereld.

Beroepssocialisatie in de geneeskunde wordt een vorm van secundaire socialisatie genoemd, maar er zijn elementen van primaire socialisatie (Fahrenfort, 1985; Pool en Pool, 1983). Met name in de klinische fase zou er sprake zijn van een afhankelijk positie van de co-assistenten, naast een sterke emotionele betrokkenheid vanwege de eerste confrontatie met lijden, menselijke ellende en dood. Ook wordt bij medische studenten soms gesproken over anticiperende socialisatie waarbij men doelt op een vorm van zelf-selectie. Zo zouden met name mensen met een hoge prestatie-motivatie en een actieve instelling in het omgaan met onzekerheden zich aangetrokken voelen tot de medische studie (Fahrenfort, 1985).

\section{Socialisatie als sociaal leren en identificatie met een referentie-groep}

Wanneer leren wordt opgevat als beïnvloeding van gedrag, kunnen verschillende vormen van gedragsbeïnvloeding worden onderscheiden namelijk conditionering (klassiek en operant), leren door blootstelling (hoe meer blootgesteld aan een prikkel hoe positiever de reactie), sociaal leren en leren door referentie-groepen. In de dynamiek van een leerproces spelen naast beloning en straf (conditionering), ook informatieuitwisseling en waarneming van het gedrag van anderen (modeling) een belangrijke rol. 
De sociale omgeving oefent invloed uit door het geven van informatie (zoals over wat wat men moet denken en doen) of door beloning en goedkeuring door belangrijke anderen. Het gedrag van een individu kan veranderd worden door sociale druk of sociale steun, die zowel op emotioneel als op materieel gebied kan zijn.

Socialisatie-processen kunnen bestudeerd worden vanuit het perspectief van sociaal leren of van het leren door middel van referentiegroepen. Bij sociaal leren observeert een persoon andere mensen en ziet hoe deze zich gedragen en welk gedrag belonend is. Het waarnemen van gedrag dat belonend is, stimuleert tot imitatie (Bandura, 1986). Sociaal leren is een manier van leren zonder direct zichtbare beloning, men identificeert zich met de ander omdat zij op een of andere manier aantrekkelijk is voor de persoon.

Ons gedrag wordt ook beïnvloed door de groep, waar we lid van zijn of van willen worden. Deze groepen functioneren als referentiegroepen: we vergelijken onszelf met leden van deze groep en identificeren onszelf met hen, waardoor deze groepen meer invloed kunnen uitoefenen dan andere sociale groepen, waar we ons niet mee identificeren.

Het veranderingsproces van co-assistenten kan dan ook op meerdere manieren begrepen worden, als een vorm van leren door identificatie met de referentiegroep (eigen sekse-groep, zittende medische professionele groep), als conditionering maar ook als leren door blootstelling aan een bepaalde cultuur.

\subsection{Dubbel-buitenstaanderschap}

Het concept van de gevestigden en de buitenstaanders

Wanneer we het leerproces van co-assistenten opvatten als een vorm van leren door identificatie met de referentiegroep van de zittende medische professie en we ons realiseren dat deze beroepsgroep vooralsnog wordt gedomineerd door mannelijke beroepsbeoefenaren, dan ontstaat de vraag hoe het veranderingstraject van vrouwelijke co-assistenten zich verhoudt tot dat van hun mannelijke collega's. Mogelijk zal deze vergelijking ook licht kunnen werpen op de minder zichtbare en meer verborgen vormen van reproduktie van genderongelijkheid in het socialisatie proces tot arts.

In het werk van Timmerman " werd het gevestigden/buitenstaandersperspectief toegepast om zicht te krijgen op man/vrouw interacties op concrete werkplekken in arbeidssituaties. Naar aanleiding van haar werk, vroegen wij ons af of vrouwelijke coassistenten zouden kunnen worden opgevat als buitenstaanders van de medische beroepsgroep?

"Timmerman (1990) paste het denkmodel van de gevestigden en de buitenstaanders toe op de sociale dynamiek en interacties tussen vrouwelijke en mannelijke medewerkers in een arbeidssituatie. De aandacht was specifiek gericht op de interactiepatronen op de werkvloer en het voorkomen van ongewenste intimiteiten richting vrouwen. Het bleek dat de kans op ervaringen van ongewenste intimiteiten groter was in contexten, waar vrouwen een kleine minderheid vormden, dan wanneer de verdeling van de seksen meer evenredig was. Verder bleek de cultuur van de werkplek ook een factor van betekenis te zijn. 
Het gevestigden/buitenstaandersperspectief werd ontwikkeld door Elias \& Scotson $(1976,1985)$ en geïntroduceerd om een "universeel menselijk thema" te analyseren. Het perspectief houdt in dat mensen die tot machtige groepen behoren (gevestigden) van zichzelf denken dat ze "beter" zijn dan anderen; zij weten dit geloof in eigen superioriteit met succes op te dringen aan minder machtigen (buitenstaanders). De theorie over gevestigden en buitenstaanders gaat over de sociogenese van gevoelens van meer- en minderwaardigheid. Ongelijke machtsverhoudingen tussen sociale groeperingen vinden hun weerslag in de identiteit van de beide groepen: gevestigden zien hun groep en zichzelf als mensen van hogere sociale waarde, buitenstaanders oriënteren zich voor hun zelfbeeld in belangrijke mate op het beeld dat de gevestigde groep van hen heeft. Elias stelt dat juist in sociale contexten waar sprake is van grote machtsongelijkheid goed waarneembaar is, hoe verstrekkend de invloed is van die machtsongelijkheid op de persoonlijkheidsstructuur van mensen (Elias, 1985). Hij benadrukt dan ook het belang van figuratieverklaringen: hoe mensen over zichzelf denken - hun zelfbeeld - en hoe ze over hun eigen groep denken - hun wij-beeld - is niet alleen te verklaren vanuit het "individu" zelf, maar ook vanuit de figuratic, de vervlechtingsstructuur waar mensen deel van uitmaken: Het wij-beeld en het wijideaal van een persoon maken evenzeer deel uit van het zelfbeeld en zelf-ideaal, als het beeld en ideaal van zichzelf als uniek persoon waarnaar zij verwijst met het woord “ik" (Timmerman, 1990).

Zijn vrouwelijke co-assistenten, analoog aan bovengenoemd onderzoek, nog meer op te vatten als buitenstaander dan hun mannelijke collega's ? Is er sprake van een soort "dubbel" buitenstaanderschap voor vrouwen ? Het antwoord op deze vraag hangt mede samen met de manier, waarop vrouwen hun vrouw-zijn beleven tijdens hun coassistentschappen en hoe zij in deze context worden aangesproken en omgekeerd hoe dit ligt voor mannelijke coassistenten en hun man-zijn.

De betekenis van vrouwelijkheid en mannelijkheid blijkt ( zoals reeds in hoofdstuk 2 uiteen werd gezet) niet eenduidig maar pluriform en de betekenissen zijn sterk afhankelijk van de context, waarin ze circuleren. Zo kan vrouwelijkheid in de context van het artsenberoep andere betekenissen en connotaties hebben dan bijvoorbeeld in de wereld van kunst, literatuur of muziek. Ook is aangetoond dat genderlading niet is voorbehouden aan personen, maar dat ook taken, funkties, afdelingen en structuren een genderbetekenis kunnen hebben (Benschop, 1996; de Bruijn, 1991a). Deze genderbetekenis of genderlading herhaalt en versterkt vaak op een onzichtbare manier de historisch gegroeide patronen van ongelijkheid tussen de seksen en machtsverhoudingen in maatschappelijke organisaties of binnen beroepsgroepen (Komter, 1986; Benschop, 1996; Brouns, 1993).

In de cultuur van een organisatie of beroepsgroep circuleren connotaties van mannelijkheid en vrouwelijkheid gekoppeld aan taken en funkties en ook aan normen; normen die gelden voor kwalitatief goede beroepsuitoefening en voor hoe een ideale arts zich dient te gedragen. Veelal zijn deze beelden niet gearticuleerd, maar maken ze deel uit van de vanzelfsprekende achtergrond waartegen ideeën ontstaan en besluiten worden genomen. In deze vanzelfsprekende weergave van de werkelijkheid binnen een organisatie blijken sommige belangen en posities minder vertegenwoordigd en 
minder beschermd te zijn door regels en procedures dan andere belangen (Brouns, 1993).

Vrouwelijkheid en mannelijkheid zijn echter ook "belichaamd", met andere woorden mensen zijn (of ze dit nu wensen of niet) steeds voor de sociale omgeving herkenbaar als vrouw of man. Mensen zullen gedwongen zijn zich te verhouden tot opvattingen en verwachtingen die circuleren in een bepaalde context aangaande vrouwelijkheid en mannelijkheid.

\subsection{Het initiatie-karakter van de co-assistentschappen}

In de sociologie bestaat een lange traditie van bestudering van het proces van aanleren van de professionele rol van artsen. Merton (1957) bestudeerde - voortbordurend op de inzichten van structureel - functionalisten als Parsons - hoe studenten gedurende hun opleiding die karakteristieken verwierven die Parsons als typisch voor artsen had beschreven. Fox (1979) ging in zijn werk in op het proces hoe studenten leren om te gaan met de onzekerheden en emoties die de medische praktijk met zich mee brengt. Studenten zouden een houding van "detached concern" ontwikkelen, een houding passend bij de door Parsons beschreven eigenschappen van de moderne arts. In dit proces zouden de ervaringen in de beginjaren op de snijzaal, met kadavers en het bijwonen van autopsieën in een latere fase van medisch onderwijs, als rituelen een rol spelen om de medische student een houding van wetenschappelijke distantie aan te leren. De betekenis van bepaalde vormen van onderwijs zou mogelijk minder liggen in de noodzaak om bepaalde kennis over te brengen, dan in het initiatie-karakter ervan, aldus Fox.

Socialisatie-problemen in de medische opleiding werden in deze beginjaren veelal gezien als individuele problemen, die werden toegeschreven aan de persoonlijkheid van de individuele student. Aan de structuur en cultuur van de opleiding en van de beroepsgroep werd geen rol in deze toegekend. Vanuit een andere sociologische stroming uit de jaren '50 werden andere accenten gelegd. Onderzoekers uit deze stroming (Becker et al, 1961) kwamen tot de conclusie dat het proces van professionele socialisatie niet onproblematisch was. $\mathrm{Zij}$ zagen de medische opleiding niet als instituut waarin iedereen hetzelfde doel nastreeft, maar als een instelling die bijna automatisch moest leiden tot een dissidente subcultuur van studenten. Studenten zouden een eigen tegencultuur vormen waarin oplossingen zijn geïncorporeerd die helpen om om te gaan met de zware belasting van de studie (zoals veel stof) en de problematische aspecten van de medische opleiding (zoals overbezette of weinig gemotiveerde opleiders). De analyse van Becker en Geer bracht de inbreng en het strategische gedrag in beeld van de student-in-opleiding en stelde daarmee het beeld bij van de passieve student die zich braaf aanpast aan de heersende omgeving (van Welzen, 1978).

Overigens vonden veel van de studies naar professionele socialisatie en het vormingsproces van de professionele identiteit binnen het medisch onderwijs plaats in de Verenigde Staten en in Canada. (Becker en Geer, 1961; Coombs, 1978; Bucher \& Stelling, 1977). De titel van één van de meest spraakmakende publikaties "Boys in White" 
(Becker en Geer, 1961) maakt overigens duidelijk dat de normale medische student en arts destijds van het mannelijke geslacht was en de kennis over artsen veelal op bestudering van mannen was gebaseerd. Sekse en gender waren nog geen punt van overweging en de vrouwelijke student en arts was de uitzondering, die de regel bevestigde. Lupton (1994) stelt dat als men wil begrijpen, hoe artsen functioneren en zij hun patienten benaderen, men inzicht moet hebben in het socialisatieproces dat artsen doormaken in hun opleiding en werkervaringen. Artsen zijn in wezen minder vrij en ongebonden dan men vaak aanneemt. $\mathrm{Zij}$ dienen zich te gedragen conform de verwachtingen van hun patiënten en van anderen in de gezondheidszorg. Artsen kunnen niet zomaar "decide to break the frame of their professional game" zonder serieuze consequenties (Maseide, 1991). Ook het medisch consult oftewel de ontmoeting tussen arts en patiënt in de spreekkamer, heeft een zeker ritueel karakter dat volgens een bepaald vast patroon verloopt. In de discussie over de wenselijke interactie van artsen met patiënten is het te simplistisch om machtsongelijkheid in deze interactie te duiden als vorm van onderdrukking. Het medisch discours kan niet simpel worden begrepen in termen van onnodige of bedoelde vormen van dominantie of arrogantie (Maseide, 1991).

In Nederland deed onder meer Fahrenfort (1985) kwalitatief onderzoek naar het ontwikkelingsproces van aanstaande artsen op een afdeling interne geneeskunde. De fase van de co-assistentschappen wordt in haar proefschrift "Een doktersroman" beschreven als een proces van medicalisering van de medische student. De student betreedt de opleidingskliniek als leek en verlaat deze als aanstaand arts. In een sfeer van "Umwertung aller Werte" en vervreemding, zou de student het lekenperspectief dat een sterke identificatie met de patiënt inhoudt - verruilen voor het artsenperspectief, dat een carrière-perspectief is. Het klimaat in het ziekenhuis beschrijft zij als een wereld van hard werken en confrontatie met emotionele zaken, waarvan het bestaan ontkend of gebagatelliseerd wordt. Ook zou de student in de klinische fase tot haar schrik ontdekken dat de mogelijkheden van de geneeskunde om mensen te genezen of te helpen betrekkelijk gering zijn.

Omdat de praktijk van klinische stages zelden de mogelijkheid geeft om deze processen te benoemen of te expliciteren, is het effect dat studenten genoopt zijn zich sterk te oriënteren op het voorbeeldgedrag van de artsen-opleiders en andere toekomstige collega's. Daarmee samenhangend zou de innerlijke noodzaak ontstaan om afstand te nemen van lijdende mensen: "detached concern". Aan een dergelijk noodlottig verloop zou niet te ontkomen zijn. Men moet constateren dat het leerproces over "hoe een aanstaand arts moet omgaan met de onzekerheden en emoties, verbonden aan de medische praktijk", veelal impliciet blijft. Positieve of negatieve bekrachtiging van gedrag, of beloning en bestraffing spelen in dit impliciete leerproces een grote rol. Het socialisatieproces in de co-assistentschappen kent enige gelijkenis met een "rite de passage" of inwijdingsproces (van Welzen 1978), zoals beschreven bij inwijding in een middeleeuws gilde, bepaalde inheemse volkeren of in een studentencorps. Net als bij deze voorbeelden, worden ook in de co-assistentschappen barrières van psychische en fysieke aard opgeworpen of in stand gehouden, die beogen de nieuweling te testen en duidelijkheid te verkrijgen over het feit of deze het lidmaatschap van de groep wel verdient. Van Gennep (1960) bestudeerde talloze inwijdingsrituelen vanuit een cultu- 
reel antropologische perspectief en kwam tot de bevinding dat een inwijdingsproces meestal wordt gekarakteriseerd door:

- het opleggen van fysieke en psychische barrières aan de nieuweling;

- het testen van de nieuweling;

- het vernederen en kleineren van de nieuweling.

Dit laatste met als doel om het oude "ik" af te breken om daarna een nieuw "ik" op te bouwen. Het creëren of in stand houden van een zekere sociale afstand in de inwijdingsfase tussen nieuwelingen en zittende groepsleden, zou als effect sorteren dat aan het eind van de periode van beproeving en inspanning de beloning in de vorm van "nu ben je een van ons" kan worden geschonken. Met andere woorden de beloning voor het doorstaan van de frustraties van een inwijdingstraject blijkt gelegen te zijn in het opgenomen worden in de groep.

Hindernissen die door de nieuwelingen in het medische domein overwonnen moeten worden zijn het overwinnen van de angst voor aftakeling, de angst voor het zieke of dode menselijk lichaam, het leren toepassen en beheersen van een grote hoeveelheid medische kennis zonder veel steun van opleiders. Een fysieke barriere als slaaptekort moet overwonnen worden, samenhangend met nacht- en avonddiensten evenals bijvoorbeeld sociale onzekerheid, die samen kan hangen met de noodzaak met veel en steeds wisselende mensen (patiënten, verpleegkundigen, artsen-opleiders etcetera) en situaties te kunnen omgaan. Voor een goede beoordeling moeten co-assistenten ook vaak blijk geven bereid te zijn hard te willen werken en te kunnen afzien. Een ritueel in de fase van de co-assistentschappen, dat vaak met spanning en onzekerheid gepaard kan gaan voor studenten is bijvoorbeeld de klinische casus-bespreking temidden van een kring van behandelend specialisten (Maheux, 1990). Ook het gegeven dat de anatomie aan de meeste medisch faculteiten nog steeds op de snijzaal aan een menselijk lijk wordt onderwezen, wordt soms beschouwd als een ritueel om medische studenten hun angst voor het dode lichaam te doen overwinnen (Lock, 1990).

Inwijdingsprocessen moeten leiden tot groepsgeest en loyaliteit van de nieuweling aan de beroepsgroep en beroepsgenoten. De gemeenschappelijke ervaring dat men dezelfde barrières overwonnen heeft, gecombineerd met het collectieve bewustzijn dat men een omvangrijke, immense inspanning heeft geleverd, bieden een uitstekende basis voor de noodzakelijke "groepsgeest" of "esprit de corps" van professionals onder elkaar. Ook zouden deze collectieve ervaringen het gevoel geven dat men behoort tot een speciaal soort mensen en zouden een legitimatie verschaffen voor privileges (Mulder, 1978). Hoe hoger de offers, hoe groter de toewijding: "Making sacrifices for an organisation can increase loyalty to it" (citaat uit Bosk, 1979). Een ander mechanisme dat ook vaak de groepsgeest van artsen nog versterkt is het functioneren van een ruilsysteem van diensten en wederdiensten, dat ontstaat aan het eind van de medische opleiding (Homans, Blau en Miller, 1961). Co-assistenten en assistenten doen de ervaring op dat men in ruil voor werkkracht, commitment en persoonlijke inzet, gelegenheid tot leren krijgt. Verder is het vaak zo dat co-assistenten die grote inzet en gewenst gedrag vertonen, meer kans hebben om het vertrouwen van opleiders of oudere groepsgenoten te krijgen en beloond worden door toenemend medische verantwoordelijkheid te mogen dragen en zelfstandiger te mogen functioneren. Voor het gevoel van zelfvertrouwen van aanstaande artsen zijn dit belangrijke en zichzelf bekrachtigend me- 
chanismen (Bucher en Stelling, 1977). Ook blijkt een plaats als mogelijke opvolger, wanneer een jonge arts blijk geeft van de vereiste inzet, vaak meer binnen bereik komen. Processen van selectie en zelfselectie zijn in de medische professie nauw met elkaar verbonden, zo blijkt.

\subsection{Socialisatie tot arts als cultuuroverdracht en de mogelijke inhoud van de boodschap}

Lupton (1994) beschrijft de inhoud van de impliciete boodschap die wordt overdragen via het onderwijs op nieuwe aanstaande artsen aldus "de medische opleiding is gebaseerd op een positivistische wetenschapsopvatting en is gecentreerd rond snelle produktie van kennis en vermeerdering van feiten met weinig ruimte en aandacht voor de menselijke communicatie of de geschiedenis en de epistemologie van de geneeskunde. Medische studenten wordt geleerd dat er voor elke situatie of ziekte een diagnose is en dat bij elke ziekte een set van behandelstrategieën hoort. Wanneer medische studenten naar een druk ziekenhuis gaan is er weinig ruimte voor onzekerheid, aarzeling en dubbelzinnigheid. De goede student wordt geacht snel te oordelen en een zaak snel af te handelen. Medisch studenten worden erin getraind om patiënten vooral te zien als ziekten en daarmee gemakkelijker te diagnostiseren en in te delen in eendimensionale hokjes" (Lupton, 1994 p 118). Medische studenten zouden in hun opleiding zodanig worden gevormd dat zij in staat zijn om met een no-nonsense aanpak en een zakelijke, neutrale houding te reageren op delicate of in verlegenheid brengende situaties in de hulpverlening aan patiënten. De aard van socialisatie-opdrachten hangen onder andere samen met de setting waarin men opgeleid wordt. De opleiding in een klinische setting dwingt studenten om in ieder geval de volgende socialisatie-opdrachten tot een goede oplossing te brengen (Lupton 1994):

1. omgangsvormen van artsen onderling;

2. persoonlijke onzekerheid over eigen vaardigheden;

3. persoonlijke onzekerheid over juridische grenzen;

4. strijd in de hiërarchie van medische professie en de verpleging.

Ook "omgaan met gebrek aan tijd" en time-management kunnen hieraan worden toegevoegd. Mizrahi (1985) vergeleek het socialisatieproces van artsen en maatschappelijk werkenden met elkaar en vond veel verschillen. In de opleiding tot maatschappelijk werkende bleek meer (1) aandacht wordt besteed aan de persoonlijke groei en bewustwording van de wijze waarop de eigen persoonlijkheid doorwerkt in het functioneren als professional. Van maatschappelijk werkenden wordt verwacht dat zij zich bewust zijn van hun reacties op personen of situaties en dat zij inzicht hebben in de impact van hun handelen als professional. In de medische opleiding is hiervoor weinig aandacht. Ook verschilt de (2) structuur van de leermomenten. De klinisch medische opleiding van de co-assistent vindt plaats op veel verschillende plaatsen en door veel verschillende docenten. Er wordt veelvuldig gewisseld zowel van omgeving als van opleider. In de opleiding van maatschappelijk werkenden wordt juist belang gehecht aan een stabiele relatie tussen leerling en opleider. Continuïteit van de relatie tussen hulpverlener en cliënt wordt gezien als een van de belangrijkste professionele kenmerken. Een volgend verschil is (3) de invulling van de supervisie. De supervisie 
van medische studenten is in handen van verschillende artsen, meestal arts-assistenten in de klinische setting, die zelf veelal nog bezig zijn met hun opleiding en daarnaast de verantwoordelijkheid dragen voor een substantieel stuk patiëntenzorg. Hierdoor worden aanstaande artsen opgeleid door een jonge staf die voortdurend onder druk staat en die slechts enkele jaren verder is dan de co-assistenten. Binnen het sociaal werk daarentegen is de supervisie toegekend aan professionals die zich voltijds bezig houden met supervisie van studenten en onderwijs.

Verder wordt volgens deze auteur in de geneeskunde (4) veel aandacht besteed aan pathologie en technologie waardoor de complexiteit van de mens wordt gereduceerd, terwijl binnen het maatschappelijk werk meer aandacht is voor de mens als totaal in interactie met de omgeving. De aard van de arbeid zou bij maatschappelijk werk (5) sterker proces-gericht zijn, terwijl deze in de geneeskunde sterker resultaat-gericht is. Medici hechten aan feiten, duidelijke data betreffende de patiënt, terwijl maatschappelijk werkenden meer waarde hechten aan de betekenis die gegevens, data of feiten voor de cliënt zelf hebben. De (6) professionele normen binnen de geneeskunde benadrukken de medische autonomie en het zelfvertrouwen van de arts, terwijl binnen het maatschappelijk werk het ondersteunen, het proces van het probleemoplossen en het luisteren en begrijpen een belangrijke rol spelen. Ook hebben beide beroepen een verschillend $(7)$ perspectief met betrekking tot de rol en de rechten van de patiënt. De medische beroepsrol zou inhouden dat de arts morele autoriteit heeft en de kennisexpert is en beslissingen neemt. De ongelijkheid in de relatie van arts en patiënt wordt beschouwd als noodzakelijk en nuttig, terwijl bij maatschappelijk werkenden ongelijkheid wordt opgevat als onvermijdbaar en zoveel mogelijk wordt tegengegaan; gelijkheid in de relatie met de cliënt wordt nagestreefd en gewaardeerd.

Ook (8) de manier van omgaan met onzekerheid is verschillend. Artsen worden opgeleid om handelend en doortastend moeilijke of onzekere situaties tegemoet te treden. Het accent ligt sterk bij handelen terwijl binnen het maatschappelijk werk bij onzekerheid overleg en multidisciplinair samenwerken zullen worden benadrukt.

\subsection{De opvoedende werking van het ritueel van de "casuspresentatie"}

Anspach (1988) poogde zicht te krijgen op de boodschap die tijdens het socialisatietraject in de kliniek wordt overgedragen en wel door het taalgebruik in mondelinge en schriftelijke casuspresentaties te analyseren op een afdeling intensieve care en gynaecologie. Onder casuspresentaties werden in dit onderzoek de mondelinge voordrachten of praatjes verstaan die artsen en co-assistenten moeten houden, naast schriftelijke uitingen in ontslagbrieven en in de briefwisseling en informatieoverdracht tussen artsen-specialisten onderling.

De opvoedende werking van deze casusbesprekingen bleek groot omdat deze een grote rol speelt bij de beoordeling van jongere artsen en co-assistenten door hun opleiders. Men kan deze presentaties beschouwen als een oefening in zelf-presentatie in de rol van aankomend arts.

Casuspresentaties - zowel geschreven als gesproken - hebben het karakter van een ritueel, bepaalde woorden en zinnen worden frequent gebruikt en het verloop van de 
presentatie en formuleringen kennen een vast patroon. Aanstaande artsen kunnen tijdens de mondelinge presentaties ten allen tijde geïnterrumpeerd worden door andere artsen voor - inhoudelijke - vragen. Jonge artsen ontwikkelen in de loop van de tijd vaardigheden en strategieën zoals "zich goed kleden" en het gebruiken van "correcte medische terminologie" om vragen te voorkomen ${ }^{10}$ (Anspach, 1988).

Een interpretatieve analyse van de casusbesprekingen leverde de volgende bevindingen op:

- in het ritueel van de casusbespreking blijken over het algemeen de sociale aspecten van de patiënt weinig aandacht te krijgen;

- in het taalgebruik blijkt men biologische processen te separeren van de persoon van de patiënt, waardoor de depersonalisatie van de patiënt wordt versterkt;

- in het taalgebruik viel het "niet benoemen of zichtbaar maken" van de handelende persoon oftewel "omission of the agent" op. Er wordt vooral aandacht besteed aan "wat" er gedaan wordt en niet "waarom" en door wie. Men gebruikt bijvoorbeeld veelvuldig de lijdende vorm zoals in "er werd bij lichamelijk onderzoek een vergrote lever gevonden". De persoon van de hulpverlener - arts, verpleegkundige of ander lid van een (para)- medische professie - blijft onzichtbaar.

- in het taalgebruik treedt een soort personificatie van de medische technologie op, bijvoorbeeld "de röntgenbeelden tonen ons een fractuur....", of "de scan laat in de bovenste deel van de tractus respiratorius een verdichting zien .....";

- ook treden veel taaluitingen op - "account markers" - die de subjectiviteit van de patiënt benadrukken; bijvoorbeeld "de patiënt zégt geen allergieën te hebben".

De gewoonte om de technologie te personaliseren en in de lijdende vorm te spreken heeft volgens Anspach het effect, dat impliciet de verantwoordelijkheid van de arts als minimaal wordt voorgesteld bij de interpretatie van patiëntgegevens. Het effect is dat gesuggereerd wordt dat de technologie en meetinstrumenten de gegevens produceren en dat de observatoren er niet toe doen. Hierdoor wordt de indruk versterkt dat het vertelde als waarheid kan gelden en niet als een vorm van interpretatie. Anspach constateert uiteindelijk in de beschouwing van zijn bevindingen, dat er sprake is van een discrepantie tussen de waarden, die impliciet verborgen zijn in de taal van de casuspresentatie en de waarden die in de medische opleiding expliciet gehanteerd worden. Sterker nog, ze zouden zelfs tegengesteld aan elkaar zijn!

\section{Tot slot}

Deze theoretisch introductie zoals in de voorafgaande hoofdstukken is beschreven, vormt de beknopte weergave van een literatuurstudie met betrekking tot de onderwerpen cultuur, feminisering van de medische beroepsgroep en professionele socialisatie van aanstaande artsen (deel I). Op basis van de hiermee verkregen gegevens werden vraagstellingen opgesteld, die tot de onderzoeken naar beroepscultuur (deel II) en naar socialisatie (deel III) hebben geleid. In het nu volgend deel van dit proefschrift wordt

${ }^{10} \mathrm{Er}$ is redelijk veel onderzoek gedaan naar communicatic en taal van artsen met patiënten, maar Anspach constateert een lacune in die zin dat er weinig is beschreven hoe artsen over patiënten praten. 
hiervan verslag gedaan. Als eerste zal in deel II verslag worden gedaan van het beroepscultuur onderzoek, waarin de vormende omgeving in het middelpunt van de belangstelling wordt geplaatst. We zullen antwoord zoeken op de vragen hoe de beroepscultuur van de medische professie door aanstaande artsen wordt waargenomen en op welke wijze deze cultuur door hen wordt gewaardeerd. De perceptie van de beroepscultuur door co-assistenten werpt vooral licht op de inhoud van de cultuuroverdracht, de uitgezonden "boodschap", waargenomen en geresorbeerd door co-assistenten. Zal het beeld van de cultuur van de medische professie dat uit het beroepscultuuronderzoek naar voren komt, de inzichten van de geciteerde auteurs bevestigen of niet ? Klopt het geschilderde beeld dat nieuwelingen weinig zachtzinnig worden ingeleid en ingewijd in de wereld van de medische beroepsuitoefening (Welzen van, 1978 ) ? Is er weinig aandacht voor persoonlijke groei van de aanstaande arts en reflectie op de vraag hoe het persoonlijke doorspeelt in de rolinvulling (Mizrahi, 1985)? Hebben nieuwelingen de ervaring dat ze de positie van "jongste bediende" innemen en waaraan merken ze dat (Mizrahi, 1985)?

De ontwikkeling van de professionele identiteit en de mate van stress en belasting die worden ervaren in deze inwijdingsfase werden onderzocht in het socialisatie-onderzoek dat wordt beschreven in deel III. In ieder onderzoek werden gegevens verzameld over het verschil tussen de ervaringen of waarnemingen van vrouwelijke en mannelijke co-assistenten en over veranderingen in de loop van de co-assistentschappen.

Ook werden de mogelijke samenhangen tussen de verkregen resultaten nader onderzocht via multiple regressie-analyse, hetgeen aan de orde komt in hoofdstuk 11.

Aan het slot van het proefschrift volgt een slotbeschouwing waarin de belangrijkste conclusies nog eens de revue passeren en aanbevelingen worden gedaan voor de medische opleiding en medische beroepsgroep. 


\subsection{Samenvatting}

In dit hoofdstuk wordt aangegeven waarom gekozen is voor de bestudering van leerprocessen in de medisch opleiding vanuit het perspectief van socialisatie. We wijzen op het belang van de overdracht in de medische opleiding van zogenaamde "tacit knowledge" of ervaringskennis voor de kwaliteit van het handelen van artsen. Deze overdracht wordt ook wel met de term "hidden curriculum" aangeduid. Binnen de medische opleidingen werden de afgelopen jaren inspanningen verricht om tot een verduidelijking te komen van de eindtermen van de medische opleiding en het profiel van de basisarts als zogenaamde "eindprodukt" van deze opleiding. Wanneer men de geformuleerde eindtermen beziet, blijken ze hooggestemd (Raamplan, 1994) en maken ze meer de indruk van ideaaltypische beschrijvingen, die bruikbaar zijn om richting te geven aan de inspanningen van medische opleidingen.

Het begrip socialisatie kent diverse uitwerkingen die worden beschreven. Professionele socialisatie en het dokter worden is een complex proces, omdat het zowel te maken heeft met de overdracht van cultuur en de noodzaak tot aanpassing, als ook met mogelijkheid tot persoonlijke groei en ontwikkeling van de student.

De fase van de co-assistentschappen blijkt een gevoelige periode te zijn in het vormingsproces van nieuwe medische professionals. De co-assistent betreedt in de klinische fase een nieuwe wereld en gaat deelnemen aan de praktijk van het medisch uitvoerend werk. Diverse auteurs worden aan het woord gelaten over de mogelijke inhoud van de "impliciete boodschappen", die in de medische opleiding worden overgedragen op de nieuwe generatie.

De nieuweling stapt als een verbaasde reiziger deze wereld binnen en zal als een sensitieve waarnemer de gebruiken en gewoonten in de medische beroepsgroep absorberen. Maar de nieuweling wil in de meeste gevallen niet verder reizen, maar ook deelgenoot worden van beroep en beroepsgroep. De confrontatie met de werkelijke praktijk en gang van zaken in het medische beroepsveld zal voor co-assistenten dan ook vaak een enerverende en emotionerende ervaring zijn. 



\section{Deel II}

\section{Het beroepscultuur onderzoek}

\section{Citaat:}

Men neme een kooi met apen. In de kooi wordt een banaan opgehangen, daaronder staat een trapleer.

Het duurt niet lang of er gaat een aap naar de trap, maar zodra hij er een voet opzet worden alle apen natgespoten. Een poosje later probeert dezelfde of een andere aap het nog eens, met hetzelfde gevolg: weer alle apen nat. Als er daarna nog een aap is die de trap op wil, zullen de anderen hem dat beletten.

Nu halen we een aap uit de kooi en brengen een nieuwe binnen. De nieuwe aap ziet de banaan en wil de trap op. Tot zijn grote schrik springen alle andere apen hem op zijn nek. Na nog een poging weet hij het: als hij de trap op wil wordt hij in elkaar geslagen.

Dan halen we een tweede aap uit de kooi en brengen een nieuwe binnen. De nieuweling gaat naar de trap en krijgt een pak slaag. De vorige nieuwe neemt enthousiast deel aan de afstraffing.

Een derde oude aap gaat eruit en een derde nieuwe komt binnen. Hij gaat naar de trap en krijgt slaag. Twee van de apen die op hem inbeuken hebben geen idee waarom je die trap niet op mag. Oude aap 4 eruit en nieuwe aap 4 erin enz. enz. enz., tot alle apen die ooit het natspuiten hebben meegemaakt vervangen zijn. Niettemin gaat nooit een aap de trap op.

Waarom niet meneer?

Dat doen we hier gewoon niet, jongeman.

Uit: De banaan wordt bespreekbaar. Cultuurveranderingen in ambtelijk en politiek Groningen.

T. Pauka \& R. Zunderdorp 



\section{Hoofdstuk 5}

\section{Beroepscultuur van de medische professie door de ogen van co- assistenten. Doel, methode en variabelen}

\subsection{Inleiding}

De medische beroepsgroep geldt van oudsher als het voorbeeld van een professie. Volgens Freidson (1975) onderscheidt een professie zich in het algemeen en de medische professie in het bijzonder, door een gelegitimeerde, georganiseerde autonomie: "profes. sions are deliberately granted autonomy, including the exclusive right to determine who can legitimately do its work and how it should be done". Klinkert (1984) beschrijft een professie in vergelijkbare bewoordingen, namelijk dat deze door middel van haar werk verantwoordelijk is voor een hoog goed en dat deze verantwoordelijkheid wettelijk is vastgelegd. Een professie doet haar werk verder met behulp van een bepaalde kennis en kunde, die wordt verworven in een langdurige opleiding. Typerend voor een professie is verder dat zowel de inhoud van de opleiding als de selectie voor deze opleiding worden beheerst door de zittende professionele groep. Deze reguleert de toegang tot het beroepsveld door middel van examens of selectie voor vervolgopleidingen (zoals beroepsopleidingen tot huisarts, specialist of sociaal geneeskundige in het geval van de geneeskunde) na de basisopleiding. Een ander kenmerk is dat het medisch werk is onderworpen aan strenge ethische regels en dat het gedrag van de leden door informele en formele sociale controle binnen de eigen professionele groep wordt gereguleerd. 
De beroepsorganisatie van de professie, in het geval van de geneeskunde is dit de Koninklijke Nederlandse Maatschappij voor de Geneeskunst, blijkt bij de instandhouding en ontwikkeling van de beroepscultuur een belangrijke rol te spelen, zeker wanneer de overheid zelfregulering als ideaal ziet.

In dit onderzoek wordt de aandacht gericht op de cultuur van de medische beroepsgroep, zoals deze wordt waargenomen en beoordeeld door nieuwkomers in deze cultuur, de co-assistenten. Ritzler beschouwt de beroepscultuur (met een eigen ethiek, eigen taalgebruik en een eigen normen- en waardensysteem) als één van de kenmerken van een professie en somt de volgende voorwaarden op waaraan moet zijn voldaan om te mogen spreken van een professionele of beroepscultuur (Ritzler, 1983).

1. Institutionalisering, dat wil zeggen dat de beroepswerkzaamheden zijn uitgekristalliseerd en een zekere mate van duurzaamheid vertonen. $\mathrm{Bij}$ alle betrokkenen bestaat een grote mate van overeenstemming en duidelijkheid omtrent deze activiteiten.

2. Legitimering, dat wil zeggen dat er een duidelijke hoeveelheid kennis en een duidelijk systeem van waarden is, zowel binnen de professie als daarbuiten, welke de activiteiten van de professie ondersteunen.

3. Autonomie, dat wil zeggen dat door de wet zelfbeschikkingsmacht wordt toegestaan, zowel ten aanzien van de beheersing van de interne sociale controle en de beheersing van de rekrutering van nieuwe toetreders tot het beroep, als met betrekking tot de bevoegdheid om de aard en omvang van dat deel van de werkelijkheid te

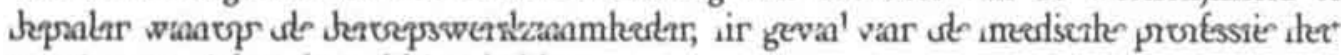
terrein van ziekte, betrekking hebben.

Omdat de medische beroepsuitoefening voldoet aan deze voorwaarden, zullen we deze professionele cultuur eens nauwkeuriger onder de loep nemen om meer inzicht te krijgen in de beroeps-werkelijkheid waarin de nieuwe generatie artsen wordt gevormd en opgroeit. Uit de literatuur, die werd beschreven in hoofdstuk 4 (Mizrahi, 1985; Anspach, 1988; Lupton, 1994; Mulder, 1978; Fahrenfort, 1985; Maseide, 1991) kunnen een aantal cultuuraspecten worden gedestilleerd, die mogelijk van toepassing zijn op de realiteit van alledag van medici in de setting van een opleidingsziekenhuis, de ambiance waarin co-assistenten het grootste deel van hun opleidings-tijd doorbrengen. Op de eerste plaats spelen in de medische beroepsgroep het ideaal van professionele autonomie en professioneel zelfvertrouwen als normen en gewenst goed een grote rol. Daarnaast lijkt er sprake van een cultuur, waarin machtsongelijkheid tussen artsen onderling als nuttig en terecht wordt gezien. Deze ongelijkheid leidt tot hiërarchie die onder andere wordt gebaseerd op verschil in lengte van de genoten opleiding, aantal ervaringsjaren als professional, mate van actief zijn in de sfeer van wetenschappelijk onderzoek en mate van hard werken casu quo meer uren in de kliniek of praktijk doorbrengen (Lupton,1994; Keizer, 1997.) Omdat co-assistenten zich in de hiërarchie van medische ervaring en expertise op de laagste sport van de ladder bevinden, is de kans groot dat zij ervaringen opdoen die gekarakteriseerd kunnen worden als die van een soort "jongste bedienden" in het medisch bedrijf.

Ook de relatie van artsen tot andere disciplines, zoals bijvoorbeeld de verpleging blijkt in de praktijk gekleurd door hiërarchie en machtsongelijkheid (Carpenter, 1993). Hoewel de afgelopen jaren, ook in Nederland, een tendens sterker wordt om 
de diverse disciplines in de gezondheidszorg meer als nevengeschikt op te vatten dan als hiërarchisch geordend (denk aan de BIG wetgeving). Deze ideologische veranderingen dringen echter vaak langzaam door in de alledaagse praktijk, waardoor oude patronen vaak lang deze praktijk kleuren (Benschop, 1996).

Ook de relatie tussen arts en patiënt in principieel ongelijk in macht, de arts beschikt over kennis die de patiënt denkt nodig te hebben voor het oplossen of hanteren van diens gezondheidsprobleem. Over de manier van omgaan met deze ongelijkheid in de arts-patiënt relatie van vrouwelijke en mannelijke artsen en de impact hiervan op de kwaliteit van de communicatie en van de medische zorg is de afgelopen veel nagedacht en geschreven (Baart en Baerveldt, 1986; Bensing, 1991; Davis, 1988; Kutner, 1990, Philipsen, 1988, Rouneau, 1987). Mizrahi (1984) constateert dat de codes voor gewenst rolgedrag van artsen in interactie met patiënten gebaseerd zijn op het beeld van de arts als kennisexpert en als morele autoriteit. Uit een dergelijke opvatting van professionaliteit vloeit logischerwijs voort dat ongelijkheid in de artspatiëntrelatie als functioneel en gewenst wordt beschouwd en dat de beslissingen worden genomen door de expert (Mizrahi 1984).

Een ander cultuuraspect heeft betrekking op de mate van proces-gerichtheid of meer op output en resultaat gericht zijn. Medische hulpverlening wordt in de literatuur meer beschreven als resultaat-gericht dan als proces-gericht, hoewel deze typering vooral van toepassing is op de klinische geneeskunde en specialistische praktijk (West,1993; Yedidia, 1996). Deze resultaat-gerichtheid komt tot uitdrukking in een sterke accentuering in de medische zorg van medische feiten en "harde" onderzoeksbevindingen en minder nadruk op de communicatie en interactie met de patiënt. Minder aandacht voor de interactie en voor ervaringen en betekenissen van de patiënt en een minder prominente plaats voor begeleiding en aandacht (Mizrahi, 1984). In deze produktie medische feiten en "harde" gegevens spelen technologische hulpmiddelen een grote rol. Anspach beschrijft de cultuur van de klinische geneeskunde als een wereld waar de technologie een grote rol speelt en een deel van de verantwoordelijkheid voor medische beslissingen meetorst (Anspach, 1988). Door een analyse van de manier van spreken van artsen-specialisten en arts-assistenten onderling in de setting van de klinische casusbesprekingen ontdekte hij fenomenen het verhullen en verschuiven van verantwoordelijk naar de techniek ("omissie" van de "agent") en personalisatie van de technologie. Verder viel in de context van de klinische specialismen de gewoonte op in de onderlinge dialoog van arts-specialisten om het somatisch substraat centraal te stellen en niet de mens als gepersonaliseerd wezen. Zo kon de subjectiviteit van de patiënt zo min mogelijk betrokken worden in het medische denkproces (Anspach, 1988).

Ook Philipsen (1988) schildert een beeld sterk overeenkomt met het bovenstaande. Hij beschrijft de gezondheidszorg als een project dat wordt gekenmerkt door functionele specificiteit, structurele differentiatie, coördinatie en autonomie. Hij stelt vervolgens dat projecten bestaan dankzij het menselijk vermogen om denoterend te denken. In denoterend denken overheerst het wereldbeeld van de objectieve werkelijkheid van oorzaak en gevolg, dat door waarneming, theorie en methodiek gekend kan worden en steeds beter gekend wordt. 
Echter gezondheidszorg is tegelijkertijd leefwereld die niet beoordeeld kan worden op grond van een instrumentele en strategische rationaliteit, die in projecten heerst. Leefwereld wordt geoordeeld op grond van kwaliteit van communicatie van wederzijdse bejegening en van strevingen als zich thuis voelen, identiteit hebben, het bestaan als zinvol ondergaan.

Deze wederzijdse bejegening kan alleen op grond van connoterend denken betekenis krijgen; in connoterend denken overheerst het bewustzijn met zijn gewaarwordingen, waarbij de dingen niet louter zijn wat ze zijn, maar ook wat ze betekenen.

Philipsen beschrijft de medisch specialist als de meest projectgerichte professional in de gezondheidszorg. "Hoewel dienstbaar en gericht op het menselijk welzijn, is zijn beroepsmatig handelen gericht op efficiency, perfectie, rechtvaardigheid zonder aanzien des persoons en de produktie van wetenschappelijk gefundeerde kennis (functionele rationaliteit). Hij prefereert als deugden zakelijkheid, moed en emotionele neutraliteit naast toewijding en plichtsbetrachting. Hij beperkt zich strikt tot een positivistische visie op ziekte en zijn denken is bijna volledig denoterend van aard." (citaat Philipsen, 1988). Huisartsen en sociaal geneeskundigen werken, volgens Philipsen, minder projectgericht maar zij claimen dit niet te doen op basis van een geheel ander perspectief.

Lupton (1994) en Dupuis (1998) spreken over de medische cultuur als een wereld, die gestoeld is op een positivistische wetenschapsopvatting en het geloof in feitelijkheid en vooruitgang van kennis. In de medische professie zou nauwelijks enig besef zijn van "geconstrueerdheid" van kennis en zou ook weinig belangsteilling bestaan voor reflectie en nuancering (Lupton, 1994).

Mizrahi typeert de medische beroepscultuur verder nog als een "doe-cultuur" sterker dan een "denk-cultuur", waar onzekerheid meer wordt beteugeld door te handelen. Anders dan in de cultuur van maatschappelijk werkenden, waar spanning en stress wordt beantwoord met overleg, multidisciplinaire samenwerking en onderlinge steun, ligt het accent bij artsen veelal sterker op ingrijpen of "iets doen" (Mizrahi 1984).

\subsection{Socialisatie is cultuuroverdracht}

Het proces waarin mensen zich de cultuur van de groep eigen maken, heet socialisatie of normatieve integratie. In de theorie van Durkheim (1960) leidt het proces van normatieve integratie ertoe dat opvattingen van individuen, oftewel hun mentaliteit en geweten, steeds meer overlap gaan vertonen met het collectieve geweten van de groep. Ook medische studenten worden gedurende hun opleiding gesocialiseerd. Dit proces wordt in dit onderzoek opgevat als een proces van invoegen in de cultuur van de medische beroepsgroep.

Nieuwe leden die gaan toetreden tot een werkorganisatie of een beroepsgroep krijgen dit patroon van niet-direct zichtbare waarden gepresenteerd, alsof dit de enig juiste manier van waarnemen, denken, en handelen in het beroep is (Sanders en Neuyen 1989, Hofstede 1993). Het begrip cultuur wordt gedefinieerd als het geheel van ideeën, opvattingen, gewoonten en gedragingen die een groep mensen leren, goedkeuren, uitdragen en overbrengen: "the collective programming of the mind, which distinguis- 
hes the members of one group or category from people from another" (Hofstede, 1991, p.5). Cultuur is een kenmerk van een groep en kan zich op elk niveau van sociale ordening, zoals op het niveau van gezin, beroepsgroep, organisatie of land, voordoen. Cultuur is aangeleerd en niet erfelijk en is gebaseerd op iemands sociale omgeving en niet op diens genetische basis.

Men kan in het proces van socialisatie of invoegen in de beroepscultuur van medici een aantal fasen onderscheiden, namelijk de inwijdingsfase, de consolidatiefase en de integratie-fase. In de periode van de co-assistentschappen worden medische studenten voor het eerst geconfronteerd met de realiteit van het medisch beroep. Zij dienen letterlijk en figuurlijk de "witte jas" aan te trekken en moeten zich gaan verhouden tot de opdrachten die het beroep van arts met zich mee brengt. In deze fase maakt de student de overgang mee van universitaire omgeving en studentenmilieu naar de sfeer van werk in de omgeving van ziekenhuis en huisartspraktijk. Hier staat niet langer het leerproces van de co-assistent centraal maar de gezondheidszorg aan patiënten.

In deze vorm van leerproces, ook wel "training on the job" genoemd, is het leerproces ondergeschikt aan de dynamiek van het werk, hetgeen hoge eisen stelt aan het aanpassingsvermogen van de nieuwelingen (de Vries, 1988). Volgens Lupton (1994) moeten aanstaande artsen tijdens het socialisatie-proces een aantal opdrachten tot een goed einde zien te brengen; ze moeten zich aanpassen aan de hiërarchie van artsen onderling en de hiërarchie van de medische groep ten opzichte van de verpleging. Ze moeten leren omgaan met de omgangsvormen van artsen onderling en hun onzekerheid leren beteugelen over hun (tekort aan) kennis en vaardigheden.

Aanstaande artsen moeten ook een zekere mate van professionele autonomie aan de dag te leggen en steeds meer zelfstandig beslissingen kunnen nemen. De structuur van het opleidingsproces van co-assistenten lijkt deze toenemende autonomie en eigenzinnigheid te faciliteren. In de co-assistentschappen moeten de leerlingen vaak wisselen van opleidingsplaats en van opleider, er is weinig continuïteit aanwezig. Deze structurering van het leerproces lijkt een oefening in zich te bergen in hechting en weer loslaten, zich verbinden en weer losmaken van de band met een stageplek, die bepaalde context en opleidingsgroep (Mizrahi, 1984).

De manier waarop co-assistenten worden opgeleid wordt beschreven als een enerverende en stressvolle opdracht, waarin nieuwelingen worden uitgetest en worden gedwongen om persoonlijke groei door te maken (van Welzen, 1978; Fahrenfort, 1985; de Groot, 1987). Tegelijkertijd blijkt in de medische opleiding weinig formele aandacht te bestaan bijvoorbeeld in de vorm van specifiek (attitude) onderwijs voor de persoonlijke ervaringen van co-assistenten (Dupuis et al,1992; Batenburg, 1977). Coassistenten zouden wel in de eigen "peergroup" ruimte ervaren voor emotionele uitingen en persoonlijke steun ontvangen, maar in hun interactie met artsen-opleiders zou dit veelal ontbreken (Bucher \& Stelling, 1977).

Men kan de fase van de co-assistentschappen dan ook beschouwen als een inwijdingsfase in de medische beroepscultuur (van Welzen, 1987; Krol, 1992) en co-assistenten als nieuwkomers in de beroepscultuur van artsen. $\mathrm{Zij}$ zullen deze cultuur leren kennen en zullen tegelijkertijd de behoefte hebben om deel te gaan uitmaken van deze cultuur. 
Co-assistenten zijn bijzonder interessant als informanten over aspecten van de medische beroepscultuur, omdat zij als nieuwkomers sensitiever en opmerkzamer zullen waarnemen, dan diegenen die reeds langere tijd in de realiteit van de medische professie functioneren. Hen zullen meer en andere zaken opvallen en ze zullen meer vanzelfsprekendheden registreren, dan diegenen die reeds in deze wereld zijn ingevoegd. Co-assistenten zullen echter niet slechts waarnemen, maar deze percepties en ervaringen ook evalueren en meer of minder waarderen. De individuele reactie op de kennismaking met de cultuur van de medische beroepsgroep is van groot belang voor professionele identiteit en het socialisatieproces van de nieuwe generatie artsen. De manier waarop de alledaagse werkelijkheid van de medische praktijk wordt gepercipieerd en gewaardeerd zal grote invloed hebben op identiteit, toekomstverwachtingen, loopbaanwensen en motivatie van aanstaande artsen voor het medisch beroep.

Hiertoe werd een transversaal survey onderzoek verricht onder een steekproef uit de populatie co-assistenten, die studeren aan de medische faculteit van de Universiteit Maastricht. Voordat het empirisch onderzoek verricht kon worden, moesten echter eerst operationele concepten worden geconstrueerd op basis van literatuur en kwalitatief vooronderzoek om de beroepscultuur van medici te operationaliseren.

\subsection{Doelstelling en probleemstelling}

De doelstelling van dit onderzoek is zicht te krijgen op karakteristieken van de medische beroepscultuur, zoals deze worden waargenomen en gewaardeerd door aanstaande artsen gedurende hun inwijdingsfase in de professie. Deze inwijding vindt plaats in het laatste deel van de medische opleiding, de periode van de klinische stages of co-assistentschappen. De beroepscultuur van de medische professie vormt mede de leeromgeving van de co-assistent.

Centrale kwesties zijn de perceptie van de medische beroepscultuur door de ogen van de co-assistenten in de realiteit van alledag en de appreciatie van deze percepties. Het Het verschil of de kloof tussen de waargenomen werkelijkheid en de waardering van die werkelijkheid door de co-assistent, zou indicatief kunnen zijn voor de omvang van de socialisatie-opdracht, de assimilatie aan de medische beroepscultuur.

Allereerst hebben we getracht het begrip "beroepscultuur" te concretiseren en te komen tot onderscheiding van operationele begrippen waarmee de gepercipieerde beroepscultuur van de medische professie bevraagd kan worden. Eerst vond een kwalitatieve voorfase plaats waarin met behulp van literatuuronderzoek, diepteinterviews en reflectie op eigen ervaringen van de arts-onderzoeker werd gepoogd antwoord te geven op de vraag: "Hoe ziet de beroepscultuur van medici er uit door de ogen van co-assistenten?" Dit kon leiden tot de ontwikkeling van concepten en het ontwerp voor een vragenlijst, waarmee perceptie en beoordeling van deze culturele aspecten onder co-assistenten verder onderzocht konden worden. 


\subsection{Conceptualisering van aspecten van medische beroepscultuur}

Het is allereerst is het noodzakelijk om een cultuur-begrip te kiezen dat het mogelijk makkt om een aantal eigenschappen van het complexe fenomeen "beroepscultuur" te selecteren en deze eigenschappen te indiceren en te operationaliseren. In de sociale wetenschappen blijkt, meer dan in de natuurwetenschappen, alleen al het kiezen van de relevante eigenschappen van een fenomeen een probleem. Het werk van Hofstede (1991 en 1980) en toepassingen van diens inzichten in het werk van Veldman en Witting (1990) en Sanders en Neuyen (1989), bleken in dit opzicht bruikbaar. In dit onderzoek wordt gekozen voor een cultuur-begrip als "software of the mind", gebaseerd op de inzichten van Hofstede. Cultuur is niet direct waarneembaar maar kan indirect worden afgeleid uit haar verschijningsvorm. Cultuur kan, net als bijvoorbeeld het karakter van een persoon, slechts indirect gekend worden; ook het karakter kan men slechts afleiden

uit uiterlijk zichtbare zaken als kleding en gedrag. Zowel tastbare zaken als aard en inrichting van gebouwen, auto's en kleding, als ook immateriēle zaken als omgangsvormen, gedragscodes, symbolen, helden en rituelen geven uitdrukking aan de cultuur van een organisatie of een specifieke groep.

Men kan derhalve de cultuur van een (professionele) groep afleiden aan de hand van verschillende eigenschappen, die weergegeven kunnen worden in een voorstelling als gelaagd van oppervlakkig naar diepgeworteld (zie figuur). Hofstede onderscheidt de volgende eigenschappen:

1. de symbolen (vlaggen, kleding meest oppervlakkig);

2. de helden (oprichters);

3. de rituelen, (vanzelfsprekendheden, routines);

4. de waarden (meest diepgeworteld).

Het is belangrijk te beseffen dat de verschijningsvorm op zichzelf niet belangrijk is, maar dat het gaat om de betekenis die leden van de organisatie of groep aan deze eigenschappen toekennen. Dit leren kennen en overnemen van deze betekenissen geschiedt in een socialisatietraject.

Figuur 5.1. Grafische voorstelling van lagen van cultuur

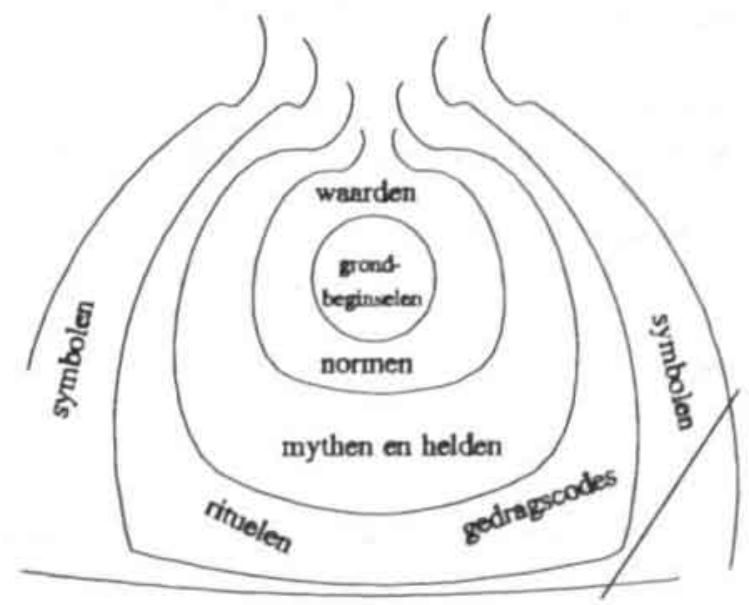


Om elementen van de beroepscultuur van medici op het spoor te komen werd als eerste stap getracht om zicht te krijgen op symbolen, rituelen, omgangsvormen en gedragscodes die gebruikelijk zijn in de medische professie. In de hoop uit deze zichtbare kenmerken iets te kunnen afleiden ten aanzien van de dieperliggende en minder zichtbare waarden en normen. Omdat cultuur slechts indirect "gekend" kan worden en slechts kan worden afgeleid uit haar verschijningsvorm, vroegen wij ons af welke betekenissen verbonden zijn met bekende symbolen van de medische professie als aesculaap of stethoscoop bijvoorbeeld. Ook uiterlijke tekenen als inrichting van spreekkamer of ziekenhuis kunnen worden beschouwd als informatief over de dieper verankerde waarden van de medische professie. De verschillende rituelen en gedragscodes in de medische beroepsgroep kunnen impliciete codes en vanzelfsprekendheden onthullen over de normen en waarden aangaande interactie van artsen met hun patiënten, aangaande wenselijke omgangsvorm van artsen onderling, van artsen met hun leerlingen enzovoorts.

Rituelen in de medische beroepsgroep zijn bijvoorbeeld "de grote visite" en de praatejs of casuspresentaties, die arts-assistenten of coasistenten moeten houden (Anspach, 1988). Ook in het medisch handelen zelf zitten rituele aspecten, zo kan bijvoorbeeld het verrichten van lichamelijk onderzoek (bijvoorbeeld het ausculteren van de longen bij een simpele verkoudheid) in de interactie tussen arts en patiënt een ritueel karakter hebben en vooral tot uitdrukking brengen, dat de arts serieus aandacht schenkt aan de klacht en zorg van de patiënt. Het reguliere medische consult kan worden opgevat als een rituele ontmoeting van een arts met patiënt, een ontmoeting die verloopt volgens een vast patronen (vraagverheldering, ananmese, lichamelijk onderzoek etcetera) met standaard formuleringen (Meeuwissen, 1991). Samenvattend kan men stellen dat de medische beroepscultuur diverse rituelen kent, die betrekking hebben op verschillende interactionele processen. Men kan rituelen en gedragscodes onderscheiden die betrekking hebben op:

1 de verbouding van artsen onderling

(denk aan volgorde van artsen bij de "grote visite", vroeger vaak een weerspiegeling van de hiërarchie in de klinische staf (hoogleraar of chef de clinique eerst, dan stafleden, dan arts-assistenten en de co-assistenten in de staart van de stoet);

2 de verhouding van de artsen-opleiders tot leerlingen

(denk aan informele regels over de zitplaatsen voor co-assistenten bij klinische werkbesprekingen;

3 de verhouding van artsen tot verpleegkundigen

(denk aan het ritueel van handen wassen op de operatiekamer en het aanreiken van groene (steriele) jassen);

4 de verhouding van artsen tot patiēnten

(denk aan het rituele beluisteren van de longen bij een simpele verkoudheid).

\section{Dimensies van cultuur}

Elke groep of organisatie dient in zijn sociale functioneren een aantal fundamentele opdrachten op te lossen namelijk "hoe verdelen we de macht" en "hoe hanteren we het gegeven van de fundamentele onzekerheid oftewel het feit dat "weinig zeker is". Ook de kwestie van "wiens belang prevaleert, dat van het individu of dat van de 
groep" en het vraagstuk van "de balans tussen competitie en rivaliteit versus ondersteuning en zorg" dient opgelost te zijn. Hofstede $(1980,1991)$ onderscheidde in zijn internationale empirische studie naar cultuurdimensies van bedrijven in diverse nationale contexten (binnen een groot multinationaal opererend bedrijt) een aantal dimensies, die als typerend voor deze culturen werden beschouwd. Deze dimensies zijn:

1. mate van machtafstand;

2. mate van onzekerheidsvermijding;

3. meer of minder individu of collectief gericht;

4. meer of minder masculien of feminien.

De dimensie mate van machtafstand werd vervolgens als volgt gedefinieerd (Hofstede, 1991) als de mate waarin de minder machtige leden van instituties of organisaties verwachten en accepteren dat macht ongelijk verdeeld is.

De dimensie mate van onzekerheidsvermijding werd gedefinieerd als de mate waarin angst of onzekerheid verdragen kan worden binnen een groep of de mate waarin leden van een cultuur zich bedreigd voelen door onzekere of onbekende situaties. Dit gevoel wordt onder andere uitgedrukt in nerveuze spanning en in een behoefte aan voorspelbaarheid door het functioneren van formele en informele regels.

Een meer collectief-versus individu-gerichte cultuur werd door Hofstede beschreven als de mate waarin individuen zijn opgenomen in een sterke hechte groep, die levenslang bescherming biedt in ruil voor onvoorwaardelijke loyaliteit. In de collectivistische samenleving gaat de persoonlijke relatie voor de taak. Eerst moet de relatie opgebouwd worden. In de individualistische samenleving gaat de taak voor de persoonlijke relatie. De cultuurdimensie masculien versus feminien werd door Hofstede in vroeger werk (1986) gedefinieerd als de mate waarin sociale sekse-rollen duidelijk gescheiden zijn. Feminiene culturen zijn culturen waarin sociale sekserollen weinig verschillen en waar zowel van mannen als van vrouwen verwacht wordt dat ze bescheiden en teder zijn en gericht op de kwaliteit van het bestaan. In masculiene culturen wordt dit uitsluitend van vrouwen verwacht en dienen mannen assertief, hard en gericht op materieel succes te zijn. In een masculiene cultuur worden de sekserollen dus haast als tegengesteld beschreven. Later beschreef Hofstede (1995) de cultuurdimensie masculiniteit-feminiteit als de mate waarin begrippen als assertiviteit, prestatiedrang, succes en competitie prevaleren boven waarden als kwaliteit van leven, dienstbaarheid, zorg voor de zwakken en solidariteit.

De beschreven cultuurdimensies naast de zes dimensies ${ }^{1}$ of praktijkwaarden die Hofstede beschreef als typering voor een organisaties, functioneerden in dit onderzoek als inspiratiebron. Als voorbeeld van de invulling van de dimensie mate van

${ }^{1}$ In onderzoek naar dimensies van organisatie-culturen onderscheidde Hofstede (1990) 6 dimensies of zogenaamde praktijkwaarden, die bruikbaar bleken om organisatieculturen te typeren, namelijk:

1. procesgerichte of resultaatgerichte cultuur; 2. werkgerichte of mensgerichte cultuur 3 . open of gesloten cultuur, 4. cultuur met strakke (sociale) controle of losse controle; 5 . normative of pragmatische cultuur en 6. professionele of organisatiegebonden cultuur. 
machtafstand in het onderzoek van Hofstede wordt diens uitwerking daarvan gegeven in onderstaand overzicht.

Overzicht 5.2. Beschrijving van belangrijkste verschillen tussen groepen met kleine en grote machtafstand ten aanzien van werk, school, gezin, algemene normen (bron: Hofstede 1993 p. 54. )

\section{KLEINE Machtafstand}

- Hoger opgeleiden hebben minder autoritaire waarden dan lager opgeleiden

- Hiërarchie in organisaties betekent een ongelijkheid in rollen die om praktische redenen is ingesteld

- Decentralisatie is populair

- Relatief kleine verschillen in inkomen tussen de top en de basis van een organisatie

* Ondergeschikten verwachten te worden geraadpleegd

- De ideale chef is een bekwame democraat

- Privileges en statussymbolen zijn ongewenst

* Op school verwachten docenten initiatieven van de leerlingen

- Docenten zijn specialisten die onpersoonlijke waarheden overdragen

* Leerlingen behandelen docenten als gelijken

* Ouders behandelen kinderen als gelijken

* Kinderen behandelen ouders als gelijken

* De ongelijkheid tussen mensen moet zo klein mogelijk gemaakt worden

* Wederzijdse afhankelijkheid tussen mensen met meer en met minder macht wordt gewenst en tot op zekere hoogte ook bereikt

\section{GROTE Machtafstand}

* Hoger en lager opgeleiden hebben ongeveer even veel autoritaire waarden

* Hiërarchie in organisaties weerspiegelt de existentiële ongelijkheid tussen hoger- en lager geplaatsten

* Centralisatie is populair

* Grote verschillen in inkomen tussen de top en de basis van een organisatie

- Ondergeschikten verwachten dat hun verteld wordt wat ze moeten doen

- De ideale chef is een welwillende autocraat oftewel een goede vader

* Privileges en statussymbolen voor managers worden zowel verwacht als toegejuicht

- Op school neemt de docent alle initiatieven

* Docenten zijn goeroes die persoonlijke wijsheden overdragen

* Leerlingen behandelen docenten met respect

* Ouders leren kinderen gehoorzaamheid

* Kinderen behandelen ouders met respect

* Ongelijkheid tussen mensen wordt zowel verwacht als gewenst

* Mensen met minder macht moeten afhankelijk zijn van mensen met meer macht; in de praktijk zijn minder machtigen gepolariseerd tussen afhankelijkheid en contra-afhankelijkheid

\subsection{Vraagstellingen en hypothesen over sekseverschillen in perceptie en waardering}

In dit onderzoek staat de vraag centraal hoe vrouwelijke en mannelijke co-assistenten de cultuur van de medische professie, die wordt "voorgeleefd" in de leeromgeving van de klinische stages waarnemen en waarderen.

Socialisatie wordt gedefinieerd als overdracht van cultuur en als het proces van het in overeenstemming brengen van individuele normen en waarden en met collectieve normen en waarden (Veldman \& Witting, 1990). We vragen ons af in hoeverre het verschil of de kloof tussen waargenomen werkelijkheid en de beoordeling of 
waardering hiervan door de co-assistent specifieke informatie geeft over het proces van socialisatie. Daarom zullen we het verschil tussen perceptie en waardering bij individuele co-assistenten exploreren. Hoe groot is de kloof tussen perceptie van de verschillende cultuuraspecten (de waargenomen werkelijkheid) en waardering van deze cultuuraspecten ? De volgende vraagstellingen zullen beantwoord worden:

1a. Nemen co-assistenten de onderscheiden aspecten van de medische beroepscultuur waar?

1b. Verschillen vrouwelijke co-assistenten in hun perceptie van mannelijke coassistenten?

2a. Hoe waarderen co-assistenten de onderscheiden aspecten van de medische beroepscultuur?

2b. Verschillen vrouwelijke co-assistenten in hun waardering van de onderscheiden cultuuraspecten van mannelijke co-assistenten ?

3a. Hoe groot is het verschil tussen de gepercipieerde werkelijkheid (perceptie) en de beoordeling (waardering) van de individuele co-assistent ?

$3 \mathrm{~b}$. Is dit verschil voor vrouwelijke co-assistenten anders dan voor mannelijke coassistenten ?

Omdat socialisatie een proces is dat in de loop van de tijd zijn beslag krijgt, zijn wij eveneens benieuwd of gevorderde co-assistenten, die langer dan 1 jaar bezig zijn met de fase van de klinische stages, meer aangepast zijn aan de voorgeleefde cultuur dan beginnende co-assistenten. De vierde vraagstelling luidt derhalve:

4a. Verschillen beginnende co-assistenten (korter bezig dan 1 jaar) van gevorderde coassistenten (langer bezig dan 1 jaar) in perceptie of waardering van de genoemde cultuuraspecten?

4b. Zijn er sekseverschillen op dit punt?

\section{Hypothesen en vooronderstellingen}

Opgroeien als meisje of jongen en gesocialiseerd worden in de vrouwen- of mannenrol, kan gezien worden als invoegen in een bepaalde (sub)cultuur (Jansen, 1992). Socialisatie als "man" in de context van een westerse moderne samenleving houdt dan ook veelal in dat men wordt voorbereid op het functioneren in de publieke sfeer. Het accent ligt in het socialisatietraject van jongens vooral op de voorbereiding op hun toekomstige rol als kostwinner, hun mogelijke rol in de privé-sfeer als partner of ouder krijgt veelal veel minder aandacht. De geslachtsrol van meisjes kent daarentegen een sterkere accentuering van de rol in de privésfeer en van zorgtaken. In de socialisatie van meisjes en vrouwen worden interactionele kwaliteit, gehoorzaamheid en mensgerichte of expressieve waarden als gevoeligheid en responsiviteit vaak sterk bekrachtigd. Socialisatie van jongens laat daarentegen vaak een sterke bekrachtiging zien van het vermogen om zich te onderscheiden, om competitie aan te gaan en te rivaliseren (Mavis Hetherington \& Parke, 1993).

De afgelopen jaren heeft zich weliswaar een fundamentele heroriëntatie in het denken over de traditionele sekserollen voltrokken, maar de praktijk van alledag blijkt toch minder snel te veranderen (Benschop, 1996). 
5.3 Overzicht van enkele accenten van de traditionele mannelijke geslachtsrol versus de traditionele vrouwelijke geslachtsrol (Tomlow, 1992).

\begin{tabular}{|c|c|c|}
\hline 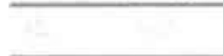 & geslachtsrol mannen & geslachtsrol vrouwen \\
\hline domein & publieke sfeer & privésfeer \\
\hline identiteit & $\begin{array}{l}\text { primair ontleend an rol } \\
\text { publieke sfeer }\end{array}$ & $\begin{array}{l}\text { primair ontleend aan rol } \\
\text { privésfeer }\end{array}$ \\
\hline $\begin{array}{l}\text { primair } \\
\text { identificatie }\end{array}$ & $\begin{array}{l}\text { algemeen maatschappelijk belang } \\
\text { abstract, onbekenden }\end{array}$ & $\begin{array}{l}\text { hier en nu } \\
\text { directe noden, bekenden }\end{array}$ \\
\hline waardering & afhankelijk van marktwaarde & afhankelijk van gebruikswaarde \\
\hline vergoeding & $\begin{array}{l}\text { materieel, financieel/betaling } \\
\text { status }\end{array}$ & $\begin{array}{l}\text { indirecte of ontbrekende financiering } \\
\text { immaterieel belang } \\
\text { dankbaarheid }\end{array}$ \\
\hline \multicolumn{3}{|c|}{ Mogelijke psychosociale gevolgen van geslachtsrol socialisaties } \\
\hline zelfhandhaving & accent op concurrentiemodel & $\begin{array}{l}\text { accent op samenwerking } \\
\text { opoffering, rekening houden met, }\end{array}$ \\
\hline waardering & $\begin{array}{l}\text { autonome-ik } \\
\text { harde ego-grenzen }\end{array}$ & $\begin{array}{l}\text { zelf-in-relatie } \\
\text { zachte ego-grenzen }\end{array}$ \\
\hline
\end{tabular}

Gilligan (1982) vond in haar onderzoek dat socialisatie tot vrouw of man een verschillende invulling van waarden kan betekenen. De waarde "zorg of zorgzaamheid" bleek voor vrouwen veel sterker verbonden te zijn met het verlenen van concrete zorg of het uitvoeren van zorgarbeid en beschikbaar zijn voor zorgvragen van anderen. Voor mannen bleek het begrip zorg meer verbonden te zijn met de betekenis van verantwoordelijkheid nemen of voorwaarden creëren.

Ander onderzoek binnen Vrouwenstudies liet zien dat vrouwen en meisjes op meerdere punten andere waarden koesteren en nastreven of een andere betekenis hechten aan bepaalde waarden en normen (Baker Miller et al, 1988). In grover contouren deze inzichten schetsend, kan men stellen dat vrouwen in hun interacties met de omgeving met name gericht zijn op "in verbinding zijn" met anderen terwijl mannen een sterkere oriëntatie op afgrenzing en individualiteit kennen. De groep psychotherapeuten en onderzoekers rond Baker Miller formuleren het concept van het "zelf in relatie" om deze levenshouding, die vaak bij vrouwen wordt aangetroffen, te beschrijven.

$\mathrm{Nu}$ heeft de overdracht van waarden, samenhangend met geslachts- of sekserollen veel vroeger in de levensloop van mensen zijn beslag gekregen en zal dit dieper in de persoonlijkheid verankerd zijn, dan de socialisatie in een professionele of organisatiecultuur. Desalniettemin houdt ook een proces van professionele socialisatie in een beroepsgroep voor het individu de opdracht in om de eigen psychologische bagage bij te stellen en zich (meer of minder) aan te passen. 
Omdat de medische beroepsuitoefening vooralsnog door mannelijke artsen wordt gedomineerd en co-assistenten nog weinig vrouwelijke rolvoorbeelden in de rol van opleider of staflid zullen aantreffen, is de kans groot dat de beroepssocialisatie voor vrouwelijke studenten moeizamer verloopt dan voor mannelijke studenten. Het is aannemelijk dat, omdat de professionele cultuur van het medisch beroep is gecreëerd door mannen, de "fit" tussen de maatschappelijke mannenrol en de beroepsrol van arts simpeler is dan de combinatie van die beroepsrol met de traditionele vrouwenrol. We nemen daarom aan dat vrouwelijke co-assistenten de spelregels en de codes, die door de zittende professie worden voorgeleefd met meer bevreemding en verbazing gade slaan dan hun mannelijke collega's en dat zij deze cultuur minder vanzelfsprekend vinden, dan hun mannelijke collega's.

In dit onderzoek bevragen we de perceptie ${ }^{2}$ van de aspecten van de beroepscultuur, zoals deze wordt getoond en voorgeleefd door de huidige professie en bevragen we telkens de individuele waardering van de co-assistent hiervan. We hebben weinig redenen om aan te nemen dat vrouwelijke co-assistenten de beroepscultuur anders zouden waarnemen dan hun mannelijke collega. Maar zoals boven beschreven zijn er wel redenen om aan te nemen dat vrouwelijke co-assistenten minder affiniteit en waardering hebben voor cultuuraspecten van de medische professie. De lange traditie van mannelijke dominantie in de geneeskunde maakt deze beroepcultuur mogelijk meer passend en acceptabeler voor mannelijke co-assistenten.

Met de constructie van het "verschil" tussen perceptie en waardering van een cultuuraspect, aangeduid met de term "kloof", proberen we zicht te krijgen op de discrepantie tussen waargenomen werkelijkheid en waardering van die werkelijkheid door co-assistenten. We vooronderstellen dat deze kloof kan worden opgevat als indicatief voor de "omvang" van de socialisatieopdracht, die rust op de schouders van co-assistenten. Wanneer de kloof tussen "gewenste werkelijkheid" of ideaal en waargenomen werkelijkheid erg groot is, nemen we aan dat de aanpassing aan deze "voorgeleefde" werkelijkheid mogelijk moeizamer zal verlopen en meer energie kosten, dan wanneer deze discrepantie klein is.

Verder vatten we socialisatie op als een proces van aanpassing dat in de loop van de tijd zijn beslag krijgt. We vragen ons dan vervolgens af of de meer gevorderde coassistenten hun waarden en normen reeds meer in overeenstemming gebracht hebben met de waarden van de medische professionele cultuur, dan hun minder gevorderde collega's. De beantwoording van de vraag of co-assistenten in het laatste jaar van hun co-assistentschappen verschillen van hun collega's in hun eerste jaar in perceptie of

\footnotetext{
${ }^{2}$ Met de term "perceptie" wordt geduid op de subjectieve beleving door het individu van wat zich in het veld van waarneming voordoet. Perceptie heeft te maken met de indruk die iets of iemand uit de omgeving op ons maakt en hangt behalve van de eigenschappen van dat "iets" of "iemand", ook samen met de innerlijke gesteldheid van de waarnemer. Percipiëren is dus een actieve innerlijke gedraging (van Doorn 1969, p. 33).
} 
waardering van de hen omringende professionele cultuur, geeft hieromtrent aanwijzingen.

We nemen an dat co-assistenten, die verder gevorderd zijn in de opleiding, meer geassimileerd zijn aan de waarden van de bestaande cultuur dan hun jongere collega's en veronderstellen dat deze assimilatie zich met name vertoont op de dimensie "waardering". Dit zou een verschil betekenen in waardering van de beroepscultuur tussen beginnende co-assistenten ten opzichte van de gevorderde co-assistenten. Concreet veronderstellen we dat het individueel waarde-oordeel van gevorderde coassistenten over de voorgeleefde cultuur positiever is dan dat van de beginnende coassistenten. Logisch gevolg hiervan is dat ook de kloof tussen perceptie en waardering bij gevorderde co-assistenten anders zou moeten zijn dan bij hun jongere collega's; we verwachten dat deze kloof bij gevorderden kleiner is dan bij beginnende coassistenten.

\section{Samenvattend}

1. Er wordt een verschil verwacht in waardering van de verschillende cultuuraspecten tussen vrouwelijke en mannelijke co-assistenten.

2. Er wordt een verschil verwacht in waardering van de verschillende cultuuraspecten tussen de groep gevorderde co-assistenten (groep 2) en de beginnende co-assistenten (groep 1)

3. Er wordt verwacht dat de kloof oftewel het verschil tussen perceptie-waardering groter is bij beginnende dan bij gevorderde co-assistenten

\subsection{Ontwikkeling van het onderzoeksinstrument}

Nadat het exploratief vooronderzoek was uitgevoerd in een voorfase, kon uiteindelijk een vragenlijst worden geconstrueerd. De voorfase bestond uit een diepte-interview met 8 co-assistenten (4 vrouwen, 4 mannen), literatuuronderzoek en reflectie op eigen ervaring door de arts/onderzoeker. Dit gaf voldoende aanknopingspunten voor het formuleren van vragenlijst-items. Bij de constructie van de vragenlijst werd dankbaar gebruik gemaakt van het empirisch werk van De Cock (1985 uitgebreide OKIPO vragenlijst) over het organisatieklimaat en van Hofstede et al $(1990,1991)$ op het terrein van meting van nationale culturen en cultuur in arbeidsorganisaties. De indicatoren die werden gekozen om de beroepscultuur van medici te typeren, werden ontleend aan de begrippen mate van machtafstand, mate van onzekerbeidsvermijding, mate van masculiniteit of feminiteit, individu- of collectief gerichtheid en manier van inwijding van nieuwelingen. Uit de verschijningsvorm van de cultuur van de medici via symbolen, rituelen, gedragscodes en voorbeelden en helden, kan men meer zicht krijgen op de dieperliggende normen en waarden die gekoesterd worden in de medische professie.

Concreet kan men dus uit symbolen als aesculaap, witte jas, stethoscoop, grootte of inrichting van de werkkamer, uitstraling van ziekenhuis of werkkamer en dergelijke iets afleiden over waarden en normen. Ook uit rituelen of gedragscodes inzake de omgang van artsen onderling of van artsen met de buitenwereld en uit de helden, 
zoals ze functioneren in de medische wereld, kan men iets leren over de cultuur zoals deze wordt overgebracht. In de medische professie kunnen symbolen, rituelen en omgangsvormen dus betrekking hebben op:

- de verhoudingen tussen artsen onderling

- de verhouding tussen artsen-opleiders en co-assistenten

- de verhouding tussen artsen en de verpleging

- de verhouding tussen artsen en patiënten

- de verhouding tussen artsen en de buitenwereld.

In dit onderzoek zijn we geïnteresseerd in de perceptie van de co-assistent en diens individuele waardering van deze cultuuraspecten. Derhalve is de vragenlijst zo geconstrueerd dat de co-assistent per item steeds op twee vragen moest beantwoorden namelijk "zie je het betreffend cultuuraspect?" (perceptie) en "hoe waardeer je dit aspect?" (waardering).

5.4 Voorbeeld van een item met antwoordmogelijkheden.

\begin{tabular}{lll}
\hline kolom 1 & kolom 2 \\
Beoordeling & Waarneming \\
Ik vind dat: & ik zie dat: \\
\hline 1: zeer wenselijk & 1: ik zie het heel sterk \\
2: wenselijk & 2: ik zie het \\
3: onwenselijk & 3: ik zie het niet \\
4: zeer onwenselijk & 4: ik zie het helemaal niet
\end{tabular}

Item:

De witte jas en de aesculaap

1234

1234

functioneren als statussymbolen.

De vertaalslag van de begrippen uit het empirisch onderzoek van Hofstede en de Cock naar de medische beroepscultuur mogelijke cultuur-aspecten van de medische professie, heeft geleid tot de constructie van een vragenlijst van 106 items. Hierin werd de co-assistenten gevraagd door middel van een score aan te geven in welke mate men het betreffend cultuurkenmerk waarnam en ook in een score uit te drukken in welke mate men het betreffend cultuurkenmerk waardeerde (zie figuur 1).

De mate van machtafstand, gedefinieerd als de mate waarin de minder machtige leden van instituties of organisaties verwachten en accepteren dat macht ongelijk verdeeld is, werd als dimensie van medische beroepscultuur als volgt geoperationaliseerd:

1 statussymbolen van de medische professie (zoals aesculaap, of witte jas)

2 mate van hiërarchie in de omgangsvormen van artsen onderling

3 mate van hiërarchie in de omgang van artsen en de verpleging

4 geringe machtafstand tussen artsen-opleiders en co-assistenten

5 geringe machtafstand tussen artsen en patiënten.

De mate van onzekerheidsvermijding wordt in de publikaties van Hofstede $(1991,1983)$ gedefinieerd als de mate waarin angst of onzekerheid verdragen kan worden binnen een groep en situaties die als ongestructureerd, onduidelijk of onvoorspelbaar worden ervaren, worden vermeden door het opstellen van strikte gedragscodes en door een 
sterk geloof in absolute waarheden. In een cultuur met een sterke onzekerheidsvermijding voelen de leden zich bedreigd door onzekere of onbekende situaties. Dit gevoel wordt dan onder andere uitgedrukt in nerveuze spanning of atmosfeer en in een behoefte aan voorspelbaarheid door het functioneren van formele en informele regels.

In het kwalitatieve vooronderzoek kwam naar voren dat de culturele oplossing van onzekerheid en ambiguïteit voor het medische professionele domein een centrale en cruciale kwestie is, die verbonden is met één van de essentiële taken van de medische professie in een samenleving. De medische professie, haar discours en praktijk spelen een belangrijke rol in het hanteerbaar maken van essentieel onzekere zaken als ziekte lijden en dood. Men kan aannemen dat codes over omgaan met onzekerheden aan de "basics" raken van medisch handelen en denken. Uit de diepteinterviews met coassistenten die in het vooronderzoek werden gehouden kwamen een aantal kenmerken van de medische beroepscultuur naar voren, die in de systematiek van Hofstede zouden worden ondergebracht in de categorie cultuur met sterke onzekerheidsvermijding. De grote rol van medische protocollen en regels voor het medisch handelen is hiervan een voorbeeld evenals de arigst en afkeuring in de professie voor fouten en vergissingen (denk hierbij aan de term "kunst-fout", die menige arts koude rillingen bezorgt) en het adagium "tijd is geld". Verder merkten de co-assistenten op dat de professie de indruk wekt weinig op te hebben met afwijkende ideeën of gedrag bij artsen. Een arts dient zich volgens bepaalde impliciete spelregels te gedragen en op de naleving van dit rolgedrag wordt door professionals onderling ook streng toegezien (Klinkert, 1984). Artsen kennen dus een professionele cultuur die meer een strenge dan een losse sociale controle kent. De mate van onzekerheidsvermijding in de medische beroepscultuur werd in dit onderzoek als volgt geoperationaliseerd:

1. de rol van medische protocollen

2. betekenis van technologie bij diagnostiek

3. beheersing van rolgedrag

4. spot als strategie van onzekerheidsvermijding

Ten aanzien van de dimensie individu gerichte of meer collectieve cultuur, gaan we op basis van de literatuur uit van een sterker accent op de collectiviteit. Lid zijn en worden van de medische beroepsgroep betekent aanpassing en een zekere loyaliteit ten opzichte van de medische professie. Dit laatste, loyaliteit van artsen onderling naar hun beroepsgroep, werd in de vragenlijst geoperationaliseerd.

De cultuurdimensie masculiniteit of feminiteit, gedefinieerd als de mate waarin sociale geslachtsrollen van mannen en vrouwen duidelijk te onderscheiden zijn, heeft enige moeite gekost. Hofstede beschreef feminiene culturen als culturen waarin de geslachtsrollen van vrouwen en mannen als weinig verschillend worden beschouwd. In feminiene culturen worden zowel mannen als vrouwen geacht bescheiden en teder te zijn en gericht op de kwaliteit van het bestaan. In masculiene culturen zouden deze zaken uitsluitend van vrouwen verwacht worden en worden mannen geacht assertief, hard en gericht op materieel succes te zijn. In een masculiene cultuur worden de sekserollen dus als tegengesteld beschreven. De mate van masculiniteit kan dan ook worden omschreven (Hofstede (1995) als de mate waarin begrippen als assertiviteit, prestatiedrang, succes en competitie prevaleren boven waarden als kwaliteit van leven, 
dienstbaarheid, zorg voor de zwakken en solidariteit. Wanneer men het begrip masculiniteit op een (werk)organisatie of professie betrekt, kan deze als masculiener worden beschouwd naarmate de volgende punten relatief belangrijk worden gevonden: inkomen, erkenning, promotie, uitdaging in het werk.

De mate van masculiniteit werd derhalve als volgt geoperationaliseerd:

- competitieve omgang tussen artsen onderling

- carrière vraagt knokken

- onderscheiden van rangen en standen

- onderscheid maken tussen co-assistenten op basis van bepaalde kenmerken.

Een (werk)organisatie of professie kan als feminiener worden beschouwd naarmate opvattingen over vrouwen en mannen en vrouwelijkheid en mannelijkheid minder als tegengesteld worden voorgesteld, maar overlap vertonen en waarin assertiviteit, prestatiedrang en competitie als onbelangrijker worden gezien en samenwerking en kwaliteit van de menselijke relaties (tussen artsen onderling en artsen met de buitenwereld) als belangrijk worden gezien. Zekerheid bieden, zodat men lang bij eenzelfde werkgever kan blijven, goede onderlinge samenwerking met collega's en een goede werkrelatie met de chef worden als wenselijk beschouwd.

De mate van femininiteit werd als volgt geoperationaliseerd:

- veel steun en aandacht voor persoonlijke zaken

- ruimte om emoties te uiten

- een toegankelijke en luisterende arts (willen) zijn (in relatie tot patiënt)

Tot slot werd gedrag van de zittende professie ten opzichte van co-assistenten geoperationaliseerd en dan met name de manier waarop de nieuwe generatie wordt ingewijd. Naar aanleiding van de literatuur hebben we dit proces zoals het door de nieuwkomers wordt ervaren, gepoogd te typeren (Fahrenfort,1985; de Groot, 1987; Coombs, 1978; van Es, 1979). Worden co-assistenten zachtzinnig en empathisch meegevoerd door de zittende beroepsgroep of vindt deze kennismaking nogal abrupt, zonder veel begeleiding plaats en gericht op "survival of the fittest"? De manier van inwijden werd geoperationaliseerd in 2 beschrijvingen van een harde aanpak (gevoel in het diepe te zijn gegooid) en 2 beschrijvingen van een meer zachtzinnige aanpak (op het gemak gesteld worden en rol van verpleging). Ook werd gevraagd naar de betekenis die wordt gehecht aan uiterlijke kenmerken als uitstraling van ziekenhuis en subtiele uiterlijke kenmerken waaraan artsen kunnen worden onderscheiden van andere hulpverlende disciplines.

\subsection{Validiteit en interne betrouwbaarheid en operationalisaties van cultuuraspecten}

Een meetinstrument kan beoordeeld worden op zijn inhoudelijke validiteit en zijn construct-validiteit. Omdat eerst een kwalitatief vooronderzoek heeft plaatsgevonden waarin interviews werden gehouden met co-assistenten die nog bezig waren met de stages en omdat de arts-onderzoeker een zekere mate van "ervaringsdeskundigheid" bezit, kan aangenomen worden dat de concepten inhoudelijk relevant en herkenbaar voor medici zijn. De variabelen kwamen op inductieve wijze tot stand op basis van 
kwalitatief materiaal dat verzameld werd met toepassing van de denkkaders en empirische instrumenten van Hofstede en de Cock. Door cultuurdimensies als mate van machtafstand, mate van onzekerheidsvermijding en mate van masculiniteit en femininiteit te vertalen en toe te passen op de beroepscultuur van medici, kwamen bruikbare concepten en vragenlijst-items tot stand. Ook de wijze waarop nieuwelingen worden ingewijd door de medische professie en de codes rond loyaliteit van artsen onderling en naar hun beroepsgroep, werden uitgewerkt in operationele concepten.

De betrouwbaarheid van een meetinstrument kan worden afgeleid door de test-hertest betrouwbaarheid en de interne betrouwbaarheid statistisch vast te stellen. De interne validiteit van de beroepscultuur-vragenlijst werd vastgesteld met behulp van de Raschanalyse (Imbos,1989). Met deze techniek kan de samenhang van groepen of clusters van items worden vastgesteld en gecontroleerd. Deze test is strikter dan de Cronbach's alfa die in de klassieke testtheorie wordt gebruikt om de homogeniteit van items te bepalen. Het Rasch model is een stochastisch model gebaseerd op de Guttman schaal. Elk cluster van items, dat een operationalisatie is van een cultuuraspect, kan als een eendimensionale meetlat beschouwd worden indien de statistische toets van Rasch homogeniteit is doorstaan.

De Rasch techniek vraagt om dichotomisering van de data. Daartoe werden de scores op de 4-puntsschaal (perceptie) omgevormd tot scores op een dichotome schaal. De Rasch-techniek, die te beschouwen is als een vorm van confirmatieve factoranalyse, onderzoekt of de nulhypothese: "er is geen samenhang tussen de items" gehandhaafd moet worden of niet. De nulhypothese is bevestigd als de testparameters van Martin Löff en/of Anderson kleiner zijn dan .05. Een cluster items kan worden aangemerkt worden als Rasch homogeen als de Martin Loff en/of de Anderson groter zijn dan .05. In dit onderzoek hebben we die grens nog iets strenger gemaakt en werd een cluster pas als Rasch-homogeen gehandhaafd wanneer de p-waarde groter is dan .10

Alleen indien een cluster van items als Rasch-homogeen kon worden aangemerkt, werd het concept gehandhaafd.

Wanneer een cluster slechts uit twee items bestond en een Rasch test niet mogelijk is, werd een correlatie-coëfficiënt bepaald. In het geval van de variabele "knokken om hogerop te komen" werd de Crohnbach's alpha berekend.

$\mathrm{Bij}$ deze statistische toetsing van de "reliability" bleken in totaal 24 variabelen overeind te blijven waarvan eenentwintig Rasch-homogeen bleken en drie andere voldeden aan andere criteria voor interne betrouwbaarheid (namelijk alpha $>.70$. of Pearson-correlatie-coëfficiënt groter dan .25 en significant $p<.010$ ).

$\mathrm{Na}$ statistische analyse op de dimensie "perceptie" met behulp van een Rasch analysis reliability test, bleken 24 operationalisaties (concepten) Rasch-homogeen te zijn en konden de volgende operationele concepten worden vastgesteld:

5 concepten op het vlak van machtafstand en 1 concept over respect (zie overzicht 1 en 2); 4 concepten op het vlak van onzekerheidsvermijding (zie overzicht 3 ); 3 concepten op het vlak van femininiteit (overzicht 4 ); 4 concepten op het vlak van masculiniteit (overzicht 5); 4 concepten op het vlak van kenmerken van het inwijdingsritueel (overzicht 6); 1 concept over loyaliteit en 2 concepten op het vlak 
van symbolen van de medische professie (overzicht 7). Alle concepten voldeden aan criteria van interne betrouwbaarheid en zullen in de navolgende pagina's worden beschreven.

Deze cultuuraspecten zijn vervolgens aan de onderzoekspopulatie, bestaande uit coassistenten voorgelegd met de tweeledige vraag: "Zie je bet beschreven fenomeen?" (perceptie) en "Hoe beoordeel je bet beschreven fenomeen?"(waardering).

\section{Overzicht 1. Operationalisaties van mate van machtsafstand van de medische beroepscultuur}

Symbolen van machtsafstand in de medische professie

- de "witte jas" en de aesculaap functioneren als statussymbolen

- hoe hoger in rang hoe minder directe patiëntenzorg

- hoe hoger in rang hoe groter de kamer

- hoe hoger in rang hoe minder tijd

- hoe hoger in rang hoe minder toegankelijk voor co's

(Martin-Löff $\mathrm{p}=.73$, Andersen: $\mathrm{p}=.73$ )

\section{De mate van hiërarchie in de omgang van artsen onderling}

- de omgang is hiërarchisch tussen specialisten, stafleden onderling

- de omgang is hiërarchisch tussen arts-assistenten onderling

- de omgang is hiërarchisch tussen co's en andere artsen

- in de medische beroepsgroep zijn hogeren in rang over het algemeen zeer bezorgd voor hun autoriteit

(Martin Loff $\mathrm{p}=.43$ )

De mate van hiërarchie in de omgang tussen artsen en met de verpleging

- de omgang tussen de verpleging en artsen is hiërarchisch

- verpleegkundigen worden door de meeste artsen als "verlengde arm" (dat wil zeggen werkend in opdracht van artsen) gezien

- bij verschil van mening tussen artsen en verpleging, heeft de arts uiteindelijk het laatste woord ( $=$ de beslissende stem)

(Martin-Löff $\mathrm{p}=.22$, Anderson $\mathrm{p}=.27$ ) 
Overzicht 2. Operationalisaties van mate van machtsafstand (vervolg) van de medische beroepscultuur

Geringe machtsafstand in de relatie tussen opleiders en coassistenten

- co's kunnen voldoende laten blijken ergens niet tevreden mee te zijn

- kritische vragen worden door de opleiders gewaardeerd

- blijken van ontevredenheid van co's worden serieus genomen

(Martin-Löff $\mathrm{p}=.43$ )

\section{Geringe machtsafstand in relatie tussen artsen met patiënten}

- patiënten kunnen beleid en behandeling van artsen meesturen en beïnvloeden

- blijken van kritiek van patiënten worden serieus genomen

- verschil van mening tussen arts en patiënt kan boven tafel komen

- patiënten hebben veel invloed op beslissingen over het verloop van hun behandeling

- de omgang tussen artsen en patiënten is niet hiërarchisch

- wat de patiënt van de behandeling vindt speelt geen ondergeschikte rol

- als het medisch noodzakelijk is, gaan diagnostische procedures niet door als de patiënt zich verzet

- er wordt in het contact met patiënten weinig gebruik gemaakt van medisch jargon

- medische vergissingen of fouten worden besproken met patiënten

- het wordt gewaardeerd als artsen hun eigen beperkingen in kennis of vaardigheden aangeven

(Martin-Löff $\mathrm{p}=.43$ )

\section{Respectvolle omgang tussen artsen onderling}

- de omgang tussen artsen onderling is respectvol

- de omgang tussen arts-assistenten onderling is respectvol

- de omgang tussen co-assistenten en andere artsen is respectvol

- de omgang tussen co-assistenten onderling is respectvol

(Martin-Löff $\mathrm{p}=.26$, Anderson $\mathrm{p}=.19$ ) 


\section{Overzicht 3. Operationalisaties van mate van onzekerheidsvermijding van de medische beroepscultuur}

\section{De rol van medische protocollen}

- het maken van een kunstfout is voor een arts zeer ernstig

- in hun medisch handelen zijn artsen veelal gebonden aan voorschriften en protocollen

- medische kennis wordt opgevat als feitenkennis

- niet correct gebruik van medische terminologie wordt afgekeurd

- het afwijken van medische protocollen wordt afgekeurd

- het blijk geven van veel medische kennis paraat te hebben wordt bij aanstaande artsen zeer gewaardeerd

(Martin-Löff p- .69, Anderson p- .93)

\section{Beheersing rolgedrag artsen}

- openlijke kritiek van artsen op elkaar wordt niet getolereerd

- artsen doen moeite om hun gevoelens te verbergen

- artsen kunnen zichzelf niet goed relativeren of lachen om zichzelf en hun werk

- artsen kunnen niet met onzekerheid omgaan

(Martin-Löff $\mathrm{p}=.43$, Anderson $\mathrm{p}=.23$ )

\section{Rol van technologie voor (medische) diagnostiek}

- bij diagnostiek spelen uitslagen van laboratoriumonderzoek, röntgen- of echo-onderzoek een hoofdrol

- informatie van laboratorium-onderzoek geeft bij diagnostiek en medische besluitvorming geeft meer zekerheid dan anamnese en lichamelijk onderzoek

$$
\text { (Pearson corr.r }=.70 \mathrm{p} \leq .01
$$

\section{Spot als strategie van onzekerheidsreductie}

- men ziet veel cynisme onder artsen

- de grappen of moppen, die gemaakt worden zijn vaak spottend van toon

- spottend of denigrerend taalgebruik hoort men het meest op of rond de operatiekamer

- veel artsen krijgen een kick van levensreddend optreden

(Martin-Löff $\mathrm{p}=.53$, Anderson $\mathrm{p}=.40$ ) 
Overzicht 4. Operationalisaties van mate van feminiteit van de medische beroepscultuur

Ruimte voor steun en persoonlijke zaken van artsen-onderling

- arts assistenten zijn toegankelijk voor co-assistenten voor steun

- arts assistenten zijn toegankelijk voor co-assistenten voor het bespreken van beleving, emoties of problemen

- wanneer men wil kan men gevoelens gemakkelijk uiten in het bijzijn van andere co-assistenten, opleiders of patiënten of verpleging

- je leert je collega's ondersteunen bij emoties die optreden in verband met het werk

- je leert je collega's ondersteunen bij problemen of het maken van persoonlijke keuzen

- er kan in het werk rekening worden gehouden met persoonlijke problemen

- privé en werk dienen strikt gescheiden te zijn

(Martin-Löff $\mathrm{p}=.79$, Anderson $\mathrm{p}=.23$ )

\section{Ruimte om emoties te uiten}

- men kan spontaan zijn ten opzichte van opleiders en andere artsen

- men kan voor zijn/haar emoties uitkomen

- men kan voor zijn/haar ideeën uitkomen

(Martin-Löff $\mathrm{p}=.36$, Anderson $\mathrm{p}=.35$ )

\section{Norm van toegankelijke en luisterende arts}

- de omgang tussen artsen-patiënten is gemoedelijk.

- de omgang tussen artsen-patiënten is respectvol

- artsen zijn toegankelijk voor patiënten voor medisch inhoudelijke vragen, voor verzoeken om steun, voor bespreking van emoties

- artsen maken niet de indruk weinig tijd te hebben

- tactloos of onvriendelijk gedrag ten opzichte van patiënten wordt afgekeurd

- aan patiënten wordt adequaat uitgelegd aan welke ziekte ze lijden

- aan patiënten wordt adequaat uitgelegd welke behandeling wordt voorgesteld

- er wordt veel waarde gehecht aan een goed contact met de patiënt.

- het vermogen om goed te kunnen luisteren is voor artsen erg belangrijk

$$
\text { (Martin-Löff = .19, Anderson p= .24) }
$$




\section{Overzicht 5. Operationalisaties van mate van masculiniteit van de medische beroepscultuur}

\section{Competitieve omgang tussen artsen onderling}

- omgang tussen artsen (specialisten, stafleden) is niet gemoedelijk

- omgang tussen artsen is competitief

- omgang tussen arts-assistenten is niet gemoedelijk

- omgang tussen arts-assistenten is competitief

- omgang tussen co's en andere artsen is niet gemoedelijk

- omgang tussen co's en andere artsen is competitief

- omgang tussen co's onderling is niet gemoedelijk

- omgang tussen co's onderling is competitief (Martin-Löff $\mathrm{p}=.58$, Anderson $\mathrm{p}=.79$ )

\section{Noodzaak van competitie}

- artsen die hogerop willen moeten knokken.

- artsen die hogerop willen moeten goede contacten met hogeren hebben.

- co-assistenten die zich profileren krijgen meer kansen

$$
\text { (alpha }-70)
$$

\section{Rangen en standen of pikorde}

- er wordt vaak schamper gedaan over vergissingen, tekortkomingen of fouten van artsen

- uit de eigen discipline

- uit andere disciplines

- er worden door artsen onderling veel sterke verhalen en "successstory's" verteld

- er wordt veel gesproken over "betere" en "minder goede" artsen

- ook onder co-assistenten bestaan rangen en standen

- sommige artsen- of specialistengroepen hebben een hogere status dan andere

- artsen hebben sterke oordelen over elkaars kwaliteit als beroepsbeoefenaar

$$
\text { (Martin-Löff } \mathrm{p}=.29 \text { ) }
$$

\section{Onderscheid maken tussen co's}

- de behandeling van co's is niet gelijk

- er wordt in de omgang met co's onderscheid gemaakt op grond van:

- sympathiek voorkomen

- sekse

- milieu of afkomst

- uiterlijk

- vertoon van intelligentie

$$
\text { (Martin-Löff } \mathrm{p}=.11 \text {, Anderson } \mathrm{p}=.14 \text { ) }
$$




\section{Overzicht 6. Operationalisaties van het inwijdingsritueel van de medische beroepscultuur}

\section{Harde aanpak van nieuwelingen}

- er wordt weinig rekening mee gehouden dat de co-assistent in opleiding is

- de overgang van pre-doctoraal naar co-schappen-fase is erg groot

- situaties waarin je als co-assistent teveel (medische) verantwoordelijkheid moet dragen (bijvoorbeeld in acute situaties) horen bij het leerproces

$$
\text { (Martin Löff } p=.36 \text {, Anderson } p=.29 \text { ) }
$$

\section{In het diepe gooien}

- arts-assistenten en stafleden zijn in het algemeen niet toegankelijk voor co's... bij vragen om medisch inhoudelijke toelichting

- idem ....... bij behoefte aan feed-back of beoordeling van verricht werk

- domme vragen worden afgekeurd

- het maken van fouten van co-assistenten wordt niet geaccepteerd

- "onvoldoende parate kennis kunnen presenteren", wordt afgekeurd

- het houden van een voordracht of praatje voor de medische staf, is voor de co-assistent zeer stress-vol

- het risico om "af te gaan" in zo'n situatie is groot

$$
\text { (Martin Löff } \mathrm{p}=.13 \text { /Anderson } \mathrm{p}=\text {.48) }
$$

\section{Zachtere aanpak}

- de meeste co's voelen zich snel thuis tijdens hun diverse stages

- nieuwelingen - zoals co's of arts-assistenten - worden in de kliniek op hun gemak gesteld

- nieuwelingen worden gemakkelijk opgenomen in het team (Martin Löff $\mathrm{p}=.13$, Anderson $\mathrm{p}=.12$ )

\section{Rol van de verpleging}

- de verpleging speelt een grotere rol bij het op hun gemak stellen van co's dan artsen

- de verpleging speelt een grote rol bij de vorming van coassistent tot arts

- de verpleging doet dit door:

- de coassistent meer of minder medische handelingen te laten verrichten (als infuus inbrengen, bevalling doen en dergelijke)

- de coassistent meer of minder verantwoordelijkheid te laten dragen

- de coassistent meer of minder serieus te nemen

(Martin Löff $\mathrm{p}=.16$, Anderson $\mathrm{p}=.53$ ) 


\section{Overzicht 7. Overige operationalisaties medische beroepscultuur}

\section{Loyaliteit van artsen onderling}

- het wordt gewaardeerd als je je als loyaal teamlid opstelt.

- je leer je collega's ondersteunen op niveau van kennis en op medisch inhoudelijk vlak.

- je leert je collega's ondersteunen op niveau van het aanleren van vardigheden.

- artsen onderling hebben goede teamgeest

(Martin Löff p-.49, Anderson p=.48).

\section{Technische uitstraling van ziekenhuizen}

- spreekkamers zijn over het algemeen zo steriel mogelijk ingericht spreekkamers zijn over het algemeen niet gezellig ingericht

- ziekenhuizen staan vol met medisch instrumentarium en apparatuur

$$
\text { (Martin Löff } \mathrm{p}=.21 \text { ) }
$$

\section{Onderscheid tussen artsen en andere disciplines}

- artsen zijn altijd goed te onderscheiden van andere hulpverleners

- uiterlijke herkenningstekens van artsen als stethoscoop of medisch zakboekje zijn zeer zichtbaar

(Pearson corr. $\mathrm{r}=.25 \mathrm{p} \leq .01$ ) 


\subsection{Opzet en uitvoering van het onderzoek}

Om antwoord te vinden op de geformuleerde onderzoeksvragen werd een transversaal onderzoek met behulp van de ontwikkelde vragenlijst uitgevoerd. Voor het beroepscultuur-onderzoek naar perceptie en waardering van de "voorgeleefde beroepscultuur" van de medische professie, werden alle co-assistenten (158) uit een bestaand respondentenbestand van 185 studenten geneeskunde Universiteit Maastricht, die per januari 1992 bezig waren met de klinische fase, angeschreven.

Dit bestaande bron-bestand bestond uit een willekeurige steekproef uit de populatie $4 \mathrm{e}$ jaars (de preco-assistenten) en $5 \mathrm{e}$ jaars, 6e jaars en hogere jaars (de co-assistenten) studenten van de medische faculteit van de Universiteit Maastricht.

\section{Werving van bet oorspronkelijke bron-bestand}

Het bron-bestand van respondenten was geworven door in april 1991 co-assistenten persoonlijk te benaderen op 'at random' gekozen onderwijsmomenten ${ }^{3}$ en hen na een korte uitleg over het "loopbaan-onderzoek" twee vragenlijsten te overhandigen met het verzoek deze binnen 14 dagen ingevuld te retourneren. De vierdejaars studenten, de preco-assistenten, werd geworven door bij het verlaten van de lokatie waar zij de voortgangstoets (laatste pre-doctorale examen) hadden afgelegd willekeurig te benaderen en te verzoeken hun medewerking te verlenen aan een onderzoek naar loopbaan. wensen van medische studenten.

Deze werving resulteerde in een bestand bestaandé uit 184 studènten, waarvan $13 \%$ mensen bezig waren met de co-assistentschappen en 48 studenten geneeskunde. Dit oorspronkelijke bestand bestond voor $57 \%$ uit vrouwelijke studenten en voor $43 \%$ uit mannelijke studenten bestond.

\section{Onderzoekspopulatie voor het beroepscultuur-onderzoek}

Uit dit bron-bestand werden voor dit beroepscultuur-onderzoek alle studenten geselecteerd die (dd.januari 1992) begonnen waren of bezig waren met de fase van de co-assistentschappen. Deze groep was 158 co-assistenten groot en bestond uit (57\%) 90 vrouwen en (43\%) 68 mannen die werden aangeschreven.

Deze co-assistenten ontvingen de beroepscultuur-vragenlijst per post met het verzoek deze binnen 2 weken ingevuld te retourneren. Ook nu werd hen een beloning in de vorm van een VVV-bon ter waarde van $f 10$,- in het vooruitzicht gesteld bij retourneren van een ingevulde vragenlijst.

\footnotetext{
'Bijvoorbeeld onderwijsgroepsbijeenkomsten van co-assistenten tijdens de stage "huisartsgeneeskunde" ( 5 groepen) en tijdens het coassistentschap "psychiatrie" ( 3 groepen) in het psychiatrische ziekenhuis Vijverdal; klinische besprekingen van (onder andere) interne geneeskunde, chirurgie en gynaecologie in het Academisch Ziekenhuis Maastricht, en via tussenpersonen ( $2 x$ co-assistenten en $1 \mathrm{x}$ opleider) in klinisch onderwijs in het perifere ziekenhuis van Sittard en Roermomd.
} 


\subsection{Statistische bewerkingen}

Nadat de interne betrouwbaarheid van het meetinstrument was onderzocht met de Rasch analyse en meerdere "unified concepts" waren geverifieerd, werden somscores berekend en rechte tellingen uitgevoerd. De gemiddelde scores van de totale groep respondenten werd als uitgangspunt genomen voor de beschrijving van perceptie en waardering van de beschreven cultuuraspecten.

$\mathrm{Na}$ de beschrijvende statistiek, werd vergelijkende statistiek uitgevoerd tussen diverse groepen die werden onderscheiden in beginnende en gevorderde co-assistenten, in in vrouwelijke en mannelijke co-assistenten in de totale groep en op het niveau van gevorderde en beginnende co-assistenten.

De volgende vergelijkingen werden onderzocht:

niveau totale groep: $\quad$ scores vrouwelijke co-assistenten $\rightarrow$ versus $\rightarrow$ scores mannelijke co-assistenten

niveau totale groep: $\quad$ scores beginners co-assistenten $\rightarrow$ versus $\rightarrow$ gevorderde coassistenten

niveau beginnende co's: scores vrouwelijke beginners $\rightarrow$ versus $\rightarrow$ mannelijke beginners co's

niveau gevorderde co's: $\quad$ scores vrouwelijke gevorderde $\rightarrow$ versus $\rightarrow$ mannelijke gevorderde co's

De verschillen tussen de groepen werden steeds getoetst met behulp van de Mann Whitney $\mathrm{U}$ test. Het significantie niveau dat werd gehanteerd is $\mathrm{p}$ kleiner of gelijk aan .05 .

De vergelijking van de scores van de beginnende co-assistenten met de gevorderden wordt opgevat als een indicatie van veranderingen die optreden in de loop van het socialisatieproces. 


\subsection{Samenvatting}

De fase van de co-assistentschappen is de periode waarin de arts in spe op indringende wijze kennismaakt met de realiteit van het medisch beroep en haar beoefenaren. De co-assistent is een nieuweling in het beroepsveld van medici en doet haar eerste concrete ervaring op als toekomstig arts. $\mathrm{Ze}$ is geen onbevoordeelde passant, maar een betrokken beschouwer die ambieert om toe te treden tot de medische professie en die bereid is te ondergaan wat noodzakelijk is om de kwaliteiten van een goed arts te verwerven.

Het leerproces in de co-assistentschappen is een proces van socialisatie tot medisch professional en wordt in dit onderzoek geconceptualiseerd als invoegen in de beroepscultuur van de medische professie. Om meer zicht te krijgen op de vraag hoe vrouwelijke en mannelijke co-assistenten reageren op deze confrontatie met de medische beroepscultuur, werd onderzocht hoe co-assistenten de medische wereld zien (perceptie) en hoe zij deze wereld evalueren (waardering). De discrepantie tussen datgene wat co-assistenten registreren als werkelijkheid en hun waardering of afkeuring van deze waargenomen werkelijkheid, kan een indicatie vormen voor de zwaarte van de socialisatieopdracht die de nieuweling op haar schouders torst.

Het begrip beroepscultuur is ontleend aan het werk van Hofstede (1980, 1991, 1993) over organisatieculturen en nationale culturen. $\mathrm{Na}$ een kwalitatieve voorfase van literatuuronderzoek, diepte-interviews met enige co-assistenten en reflectie van de ervarings-deskundige arts-onderzoeker, werden aspecten van de medische beroepscultuur geconcretiseerd in operationele concepten en vragenlijst-items. Geïnspireerd door cultuurdimensies van Hofstede als mate van machtafstand, mate van onzekerheidsvermijding, feminiteit of masculiniteit en andere als de karakteristieken van het inwijdingsritueel werd een vragenlijst ontwikkeld waarmee de beroepscultuur van medici kon worden onderzocht zoals gezien en geëvalueerd door co-assistenten. Naast deze vraagstelling naar percepties en evaluatie van aspecten van de medische beroepscultuur door co-assistenten, stellen wij de vraag of vrouwelijke co-assistenten deze cultuur anders waarnemen of waarderen dan hun mannelijke collega's. Omdat opgroeien als meisje of als jongen vergeleken kan worden met ingevoegd zijn in onderscheiden culturele werelden met andere betekenissen of waarderingen, nemen we aan dat vrouwelijke co-assistenten de voorgeleefde cultuur vaker negatief evalueren of afkeuren dan hun mannelijke collega's. Indien deze hypothesen correct zijn, zal ook de kloof tussen waarneming en waardering bij vrouwelijke co-assistenten groter zijn hetgeen zijn weerslag kan hebben op het assimilatieproces aan de medische professionele cultuur. 


\section{Hoofdstuk 6}

\section{Beroepscultuur van artsen door de ogen van co-assistenten Resultaten}

\subsection{Inleiding}

Socialisatie is cultuuroverdracht, waarbij nieuwelingen zich geleidelijk meer en meer aanpassen aan de waarden en normen van de cultuur waarin zij opgevoed worden. Hun geweten zal naarmate de tijd vordert meer en meer overlap vertonen met het collectieve geweten en de waarden en normen van de groep (Durkheim, 1960; De Jager en Mok, 1978). De medische beroepsgroep kent sedert 1985 een groeiend aandeel van vrouwelijke studenten en artsen, sommige auteurs spreken van een vervrouwelijking van het artsenberoep (van Hall, 1992, Spreeuwenberg, 1990). Wij zijn geïnteresseerd in de manier waarop vrouwelijke co-assistenten de inwijding en kennismaking met de cultuur van de medische professie ervaren in vergelijking met hun mannelijke collega's. Wij vragen ons af of vrouwelijke nieuwelingen deze cultuur anders waarnemen dan hun mannelijke collega's en of ze deze "voorgeleefde" cultuur anders waarderen dan hun mannelijke collega's. Aan socialisatie of cultuuroverdracht onderscheiden we perceptie van co-assistenten, waardering en het verschil (of de kloof) tussen perceptie en de waardering.

De opbouw van dit hoofdstuk is als volgt. Eerst worden de respons en de achtergrondgegevens van de respondenten beschreven. Daarna wordt een eerste grove schets van de resultaten gegeven in een overzichtstabel, waarna de bevindingen per cultuurdimensie gerapporteerd worden. Hierbij wordt steeds eerst de vraag naar perceptie van het cultuuraspect beantwoord, dan die naar waardering en vervolgens die naar de kloof tussen perceptie en waardering. Telkens wordt de vraag beantwoord 
of er een verschil bestaat tussen de seksen. Dit gedeelte wordt afgesloten met een overzichtstabel, waarin alle scores nog eens samenvattend zijn weergegeven.

In aansluiting hierop komt de vraag aan de orde naar mogelijke veranderingen in de tijd bij co-assistenten door een vergelijking van de scores van beginnende coassistenten met die van gevorderden. Het verschil tussen beginnende co-assistenten en gevorderden, die langer dan een jaar "blootstaan" aan de invloed van de medische beroepscultuur, wordt onder de loep genomen. Daarna volgt een beschouwing van de resultaten en van de toegepaste methoden. Tot slot worden conclusies getrokken en aanbevelingen gedaan voor vervolgonderzoek en medisch onderwijs.

\subsection{Respons en achtergrondgegevens van respondenten.}

Van de totale groep co-assistenten, die was aangeschreven $(\mathrm{N}=158$ bestaande uit $57 \%$ vrouwen en $43 \%$ mannen), stuurden 138 personen een ingevulde vragenlijst terug. Dit betekent een respons in de totale groep van $87 \%$; de respons onder vrouwen was iets hoger $(90 \%)$ dan onder mannen $(84 \%)$.

De groep respondenten bestond uit $59 \%(\mathrm{~N}=81)$ vrouwelijke en $41 \% \quad(\mathrm{~N}=57)$ mannelijke co-assistenten, hetgeen een lichte oververtegenwoordiging van vrouwen betekent in de totale populatie.

Bii de meeste vraagstellingen werd gestratificeerd naar geslacht, omdat deze betrekking hebben op verschillen of overeenkomsten tussen de seksen.

Verder werden 2 groepen onderscheiden namelijk de beginnende co-assistenten dat wil zeggen mensen die 1 jaar of korter bezig zijn met de klinische stages en de gevorderde co-assistenten, die langer dan 1 jaar bezig zijn. De groep beginners bestaat uit 51 personen, $37 \%$ van de groep respondenten en de groep gevorderden omvat 87 coassistenten, hetgeen $63 \%$ van de totale groep is.

De samenstelling van die groepen is weergeven in onderstaand overzicht.

Overzicht onderzoekspopulatie en onderscheiden (sub)groepen

\begin{tabular}{lllll}
\hline omschrijving & term & vrouw N & man N & totaal \\
\hline $\begin{array}{l}\text { totale groep respondenten } \\
\begin{array}{l}\text { respondenten, korter dan 1 jaar } \\
\text { bezig met stages }\end{array}\end{array}$ & totale groep & $81(59 \%)$ & $57(41 \%)$ & $138(100 \%)$ \\
$\begin{array}{l}\text { respondenten langer dan 1 jaar } \\
\text { bezig met stages }\end{array}$ & gevorderden of groep 2 & $48(55 \%)$ & $39(45 \%)$ & $87(100 \%)$ \\
\hline
\end{tabular}

\section{Achtergrondgegevens}

De gemiddelde leeftijd van de responderende co-assistenten is 25.5 jaar. De groep vrouwen verschilt alleen significant van de mannen ten aanzien van leeftijd in die zin dat vrouwen jonger (gemiddeld 24.8 jaar) $(\mathrm{p}=.004)$ zijn dan mannen (gemiddeld 26.3 jaar). Verder verschillen de groepen mannen en vrouwen niet op andere 
achtergrondgegevens, zoals aanvang van studie, stages die reeds zijn afgerond, duur dat men bezig is met de studie.

De groepen van beginners en gevorderden zijn alleen vergeleken ten aanzien van de achtergrondgegevens "sekse" en "leeftijd".

Kruistabel van sekse-verdeling in groep 1 en groep 2

\begin{tabular}{lll}
\hline & man $\mathrm{n}=57$ & vrouw $\mathrm{n}=81$ \\
\hline groep $1 \mathrm{n}=51$ & $35 \%$ & $65 \%$ \\
groep $2 \mathrm{n}=87$ & $45 \%$ & $55 \%$ \\
\hline
\end{tabular}

Chi square $p=0.27$; Mann-whitney toets "sexe by groep" $z=-1.093 p=.27$

Kruistabel van verdeling leeftijd ( $\geq 29$ ) in groep 1 en groep 2

\begin{tabular}{lll}
\hline & lft $<29 \mathrm{n}-57$ & lft $\geq 29 \mathrm{n}-81$ \\
\hline groep $1 \mathrm{n}-51$ & $96 \%$ & $4 \%$ \\
groep $2 \mathrm{n}-87$ & $83 \%$ & $17 \%$ \\
\hline
\end{tabular}

Chi square $p=0.02$; Mann-whitney toets "age by groep" $z=-4.573 p=.000$

In groep 2 blijkt de leeftijd significant hoger, de gemiddelde leeftijd van groep 2 26.2 en die van groep 1 is 24.2 . Verder zijn er in groep 2 vijftien (15) personen ouder dan 28 jaar en in groep 1 slechts twee (2) ouder dan 28 jaar.

\section{Aanvang medische studie}

De vragenlijst werd afgenomen in de periode januari $1991,23 \%$ van de co-assistenten die deelnamen aan het onderzoek, was toen net begonnen met de klinische stages en zat in het 5 e studiejaar, $41 \%$ zat in het 6 e studiejaar, $27 \%$ zat in het $7 \mathrm{e}$ studiejaar en een klein groepje was langer dan 7 jaar ingeschreven aan de Rijksuniversiteit. (Zie tabel 1).

Tabel 6.1a Verdeling van deelnemende co-assistenten $(\mathrm{N}=138)$ over studiejaren

Studiejaar percentage

\begin{tabular}{lr}
\hline Begin $5 e$ jaar & $23 \%$ \\
Begin 6e jaar & $41 \%$ \\
Begin 7e jaar & $27 \%$ \\
Langer dan 7 jaar bezig & $9 \%$ \\
\hline
\end{tabular}

Welke stages heeft men afgerond en met welke stages zijn de co-assistenten bezig?

Over de planning van de stages kan het volgende vermeld worden; co-assistenten beginnen met een van de 3 zogenaamde grote stages: huisartsgeneeskunde, interne geneeskunde of chirurgie, die tevens de langste duur kennen, namelijk 3 maanden. Verder is het van belang zich te realiseren dat tussen de klinische stages vaak een wachttijd of rustperiode van enkele weken kan optreden. 
In tabel $6.1 \mathrm{~b}$ is aangeven met welke stages co-assistenten op het moment van ondervraging nog bezig zijn en het percentage van co-assistenten dat de diverse stages heeft afgerond.

Uit tabel 6.1b (kolom 2) blijkt dat het merendeel van de respondenten de drie grote stages huisartsgeneeskunde, interne geneeskunde en chirurgie, achter de rug heeft. Men kan derhalve stellen dat zeker $(68 \%)$ van de respondentenpopulatie zich bij de beantwoording van de vragen over karakteristieken van de waargenomen beroepscultuur van medici baseert op indrukken, die ontleend worden aan meerdere medische werkvelden. Deze co-assistenten zullen veelal een "overall" indruk geven van de medische beroepscultuur. Van de respondenten heeft $7 \%$ alle klinische stages al achter de rug.

Tabel 6.1b Verdeling van co-assistenten over diverse co-assistentschappen: "mee bezig" + "afgerond"

\begin{tabular}{lll}
\hline Co-assistentschappen & $\begin{array}{l}\text { mee bezig } \\
\text { \% co's (totaal 100\%) }\end{array}$ & $\begin{array}{c}\text { afgerond } \\
\text { co's dat stage heeft afgerond }\end{array}$ \\
\hline le stage-jaar & 7 & 75 \\
Huisartsgeneeskunde & 11 & 71 \\
Interne Geneeskunde & 7 & 68 \\
Chirurgie & 12 & \\
Keuzeonderwijs \wachttijd & & \\
& & \\
2e stage-jaar & 7 & 25 \\
Psychiatrie & 9 & 27 \\
Gynaecologie & 6 & 25 \\
Neurologie & 3 & 28 \\
Kindergeneeskunde & 9 & 22 \\
KNO/Dermatologie/ & 9 & 18 \\
Oogheelkunde & 6 & nvt \\
Keuzeonderwijs & 14 & 7 \\
Overig (examens, wachttijd) & - & \\
Stages afgerond & & \\
\hline
\end{tabular}

Verder blijkt uit de tabel (kolom 1) dat $25 \%$, een kwart van de respondenten, bezig is met een van de eerste drie stages en dat twaalf procent van de eerstejaars respondenten wachttijd heeft of keuzeonderwijs doet. Samen vormen zij de groep beginners, co-assistenten bezig met hun eerste klinische jaar.

Van de co-assistenten bezig met het tweede klinische jaar, is $43 \%$ bezig met stages zoals psychiatrie, neurologie, gynaecologie, kindergeneeskunde en de zogenaamde "kleine vakken" als keel-neus-en oorheelkunde, dermatologie, oogheelkunde, die twee maanden of korter duren. Verder is $20 \%$ van deze gevorderde co-assistenten bezig met keuzeonderwijs, examens of wachttijd.

\subsection{Resultaten van het beroepscultuur-onderzoek}

De resultaten ten aanzien van de waarneming van de verschillende cultuuraspecten door co-assistenten en hun waardering van deze aspecten, zijn in de onderstaande 
tabel (tabel 6.2) in grove contouren geschilderd. De antwoordscores ten aanzien van perceptie respectievelijk waardering kunnen varieren van 1 tot 4 , het gevraagde cultuuraspect zeer duidelijk of sterk waarnemen (1) tot helemaal niet waarnemen (4) of van zeer wenselijk (1) tot zeer onwenselijk (4).

Tabel 6.2 Overzicht perceptie en waardering aspecten van medische beroepscultuur

\begin{tabular}{lllll}
\hline Dimensie & & Naam Variabele & perceptie & waardering \\
\hline Macht & M1 & Symbolen machtafstand & ja & negatief \\
Macht & M2 & Hiërarchie artsen onderling & ja & negatief \\
Macht & M3 & Hiërarchie artsen verpleging & ja & licht positief \\
Macht & M4 & Geringe afstand opleider-co & licht nee & positief \\
Macht & M5 & Geringe afstand arts-patiënt & licht nee & positief \\
Respect & R1 & Respectvolle artsen onderling & indifferent & positief \\
Onzek. Verm. O1 & Standaardisering medische expertise/ & ja & licht positief \\
& & rol protocollen & & \\
Onzek. Verm. O2 & Beheersing rolgedrag & licht ja & negatief \\
Onzek. Verm. O3 & Grote rol technologie & ja & negatief \\
Onzek. Verm. O4 & Spot en cynisme & licht ja & negatief \\
Loyaliteit & L1 & Loyaliteit van artsen onderling & ja & positief \\
Feminien & F1 & Ruimte steun artsen onderling & nee & positief \\
Feminien & F2 & Ruimte emoties artsen onderling & licht nee & positief \\
Feminien & F3 & Norm luisterende, toegankelijke arts & indifferent & positief \\
Masculien & ML1 & Competitie artsen onderling & indifferent & negatief \\
Masculien & ML2 & Noodzaak van competitie & ja & indifferent \\
Masculien & ML3 & Rangen en standen onder artsen & nee & negatief \\
& & (pikorde) & indifferent & negatief \\
Masculien & ML4 & Onderscheid maken & ja & negatief \\
Inwijding & I1 & Harde aanpak nieuweling & ja & negatief \\
Inwijding & I2 & In het diepe gooien & licht nee & positief \\
Inwijding & I3 & Zachtere aanpak nieuweling & indifferent & licht positief \\
Inwijding & I4 & Grote rol verpleging & licht negatief \\
Symbolen & S1 & Technische uitstraling ziekenhuis & ja & indifferent \\
Symbolen & S2 & Tekenen des onderscheids & ja & \\
\hline & & & & \\
\hline
\end{tabular}

' criteria interne betrouwbaarheid: Martin Löff of Anderson >.10; Crohnbach alpha > 0.7 of Pearson corr. coëfficiënt $>.25$ met $\mathrm{p}<0.01$ ) perceptie: kleiner of gelijk aan $2.2=$ ja, $2.3=$ licht ja, 2.4-2.6 =indifferent groter of gelijk aan $2.8=$ nee, 2.7 is licht nee waardering: kleiner of gelijk aan 2.2 - positief of wenselijk, groter dan 2.8 = negatief of onwenselijk 


\subsubsection{Resultaten perceptie en waardering ten aanzien van de mate van machtafstand}

De culturele codes over mate van machtsongelijkheid, zoals waargenomen en geevalueerd door co-assistenten zijn geconcretiseerd in de volgende aspecten:

1. statussymbolen of symbolen van machtafstand

2. de mate van hiërarchie van artsen onderling

3. de mate van machtafstand tussen artsen en verpleging

4. de mate van machtafstand tussen artsen/opleiders en co-assistenten

5. de mate van machtafstand tussen artsen en patiënten

6. respect tussen artsen onderling

\section{Perceptie}

Nemen de co-assistenten de onderscheiden cultuuraspecten die betrekking bebben op mate van machtafstand waar? Verschillen vrouwelijke co-assistenten van mannelijke co. assistenten?

Co-assistenten nemen de werking van uiterlijke kenmerken als de "witte jas", aesculaap als statussymbool enigszins waar. Ook zichtbare verschijnselen als de grootte van de kamer, de mate waarin directe patiëntenzorg verricht wordt, tijdgebrek en toegankelijkheid voor co-assistenten blijken indicatoren van de plaats in de hiërarchie van de betreffende arts. Co-assistenten nemen een hiërarchische omgang van artsen onderling waar. Zowel de omgang tussen specialisten en stafleden onderling, als tussen arts-assistenten onderling, als tussen co-assistenten en andere artsen is hiërarchisch. De hogeren in rang maken de indruk zeer bezorgd te zijn om hun autoriteit. Co-assistenten zien duidelijk een hiërarchische omgang van artsen met de verpleging en hebben de indruk dat verpleegkundigen door artsen worden gezien als werkend in opdracht van hen en dat bij verschil van mening tussen artsen en verpleging, de arts uiteindelijk het laatste woord heeft.

Op de vraag of er sprake is van een kleine machtafstand in de relatie van artsenopleiders en co-assistenten wordt licht nee geantwoord. Concreet werd gevraagd of co-assistenten voldoende kunnen laten blijken dat ze ergens niet tevreden mee zijn, of hun kritische vragen gewaardeerd worden en of hun uitingen van ontevredenheid door de opleiders serieus genomen worden.

Ook de vraag over een kleine machtafstand tussen artsen in de relatie met hun patiënten klinkt een licht ontkennend antwoord. Het betreft hier de kwestie of het aangeven van eigen beperkingen in kennis of kunde in de cultuur van artsen onderling wordt gewaardeerd, of meningsverschillen of kritische noten van patiënten in de arts-patiënt relatie boven tafel mogen komen, of medische fouten worden besproken met de patiënt, of medisch jargon zoveel mogelijk moet worden vermeden en of patiënten veel invloed kunnen hebben op medisch beleid en behandeling. Een respectvolle omgang van artsen onderling wordt wel enigszins waargenomen. Samenvattend blijken co-assistenten (status)symbolen waarnemen evenals hiërarchische omgangvormen van artsen onderling en een grote machtafstand van artsen in hun 
omgang met de verpleging (scores respectievelijk 2.2, 2.1, 1.9). De score van machtafstand ten opzichte van de verpleging wordt het meest duidelijk bevestigd. Er blijkt ten aanzien van de perceptie van deze cultuurelementen geen significant verschil te bestaan tussen de seksen; vrouwelijke en mannelijke co-assistenten nemen deze cultuuraspecten hetzelfde waar.

\section{Waardering}

Hoe waarderen co-assistenten de verschillende cultuuraspecten die betrekking bebben op mate van machtafstand; verschillen vrowwelijke co-assistenten van mannelijke co. assistenten?

Co-assistenten achten "statussymbolen" (zoals weinig tijd voor patiëntcontact, grootte van werkkamer, geringe toegankelijkheid voor studenten) niet wenselijk, noch waarderen ze de hiërarchische omgangsvormen van artsen onderling. De hierarchie tussen artsen en verpleging keuren zij niet zo duidelijk af (licht onwenselijk).

Een kleine machtafstand van artsen opleiders en co-assistenten zouden zij zeer waarderen (1.3) en ook een geringe machtafstand in de relatie van arts en patiënt vinden zijn wenselijk (1.6). Een respectvolle omgang van artsen onderling wordt eveneens als zeer wenselijk beschouwd.

Tabel $6.3 \mathrm{~W}$ aardering mate van machtafstand, vrouw/man scores van de totale groep en p-waarden sekseverschil in de totale groep en in de subgroepen

\begin{tabular}{llllll}
\hline & $\begin{array}{l}\text { gem. } \\
\text { } \odot\end{array}$ & $\begin{array}{l}\text { gem. } \\
\delta \delta\end{array}$ & $\begin{array}{l}\text { p. } \\
\text { tot.groep }\end{array}$ & $\begin{array}{l}\text { P } \\
\text { groep 1 }\end{array}$ & $\begin{array}{l}\mathrm{P} \\
\text { groep 2 }\end{array}$ \\
\hline symbolen machtafstand & 3.4 & 3.1 & .001 & .009 & .05 \\
hiërarchie artsen onderling & 3.3 & 3.1 & .04 & n.s. & n.s. \\
hiërarchie artsen verpleging & 2.7 & 2.6 & n.s. & n.s. & n.s. \\
geringe machtafstand opl./co & 1.2 & 1.4 & .02 & n.s. & n.s. \\
geringe machtsafst. arts/patiënt & 1.6 & 1.6 & n.s. & n.s. & n.s. \\
respect & 1.3 & 1.5 & ns & .02 & n.s. \\
\hline
\end{tabular}

range 1 = waardering: 1 = zeer wenselijk; 4 = zeer onwenselijk

Vrouwelijke co-assistenten blijken bij drie variabelen te verschillen in hun waardering van de voorgeleefde cultuur van de mannelijke collega's. Zij keuren de uiterlijke tekenen van grote machtafstand richting buitenwereld sterker af dan hun mannelijke collega's, evenals de hierarchische omgangsvormen, die zij nog minder waarderen dan mannen. Ook een minder grote machtafstand met de artsen opleiders juichen zij nog sterker toe dan hun mannnelijke collega's.

De waardering van de seksen verschilt niet van elkaar bij de beoordeling van grote machtafstand van artsen richting verpleging en een geringe machtafstand in de artspatiënt relatie.

In zowel subgroep 1, de beginners als in subgroep 2 hebben vrouwelijke co-assistenten een sterkere afkeuring voor symbolen van grote machtafstand. 
Verder blijken vooral jongere vrouwelijke co-assistenten uit groep 1, de beginners een respectvolle omgang van artsen onderling nog sterker te appreciëren dan hun mannelijke collega's.

\section{Kloof tussen perceptie en waardering}

Hoe groot is de discrepantie tussen perceptie en waardering ten aanzien van machtafstand? Voor alle co-assistenten is de kloof tussen gepercipieerde werkelijkheid en de individuele waardering van de genoemde vijf aspecten van machtafstand groot en significant ( $p$ $\leq .001$ ). Alleen bij de variabele "hiërarchische omgang van artsen onderling" blijkt de kloof voor vrouwelijke co-assistenten groter te zijn dan bij de mannelijke coassistenten.

\section{Conclusie}

Drie van de zes beschreven cultuuraspecten die betrekking hebben op de mate machtafstand worden daadwerkelijk waargenomen door co-assistenten. Twee van de zes cultuuraspecten worden negatief beoordeeld en vier cultuusaspecten als licht positief of wenselijk.

Vrouwen en mannen stemmen in perceptie overeen, maar verschillen in waardering. Een significant verschil in waardering tussen vrouwen en mannen bestaat bij drie variabelen. Vrouwelijke co-assistenten blijken meer moeite te hebben met de zichtbare symbolen machtafstand van medische professie en buitenwacht, met de hiërarchische omgangsvormen van artsen onderling en met de betrekkelijk grote afstand van henzelf met de artsen-opleiders. Ze keuren de voorgeleefde cultuur op deze punten sterker af dan hun mannelijke collega's.

De hiërarchische omgangsvormen geven aanleiding tot een significant grotere kloof tussen perceptie en waardering bij vrouwelijk co-assistenten.

\subsubsection{Resultaten rond perceptie en waardering van mate van onzekerheidsvermijding}

Hoe de medische professionele cultuur functioneert ten aanzien van onzekerheidsvermijding werd geoperationaliseerd in vier aspecten, namelijk:

1. standaardisering medische expertise

2. grote rol van technologie bij diagnostiek

3. beheersing rolgedrag

4. spot en cynisme als strategie van onzekerheidsvermijding 


\section{Perceptie}

\section{Nemen co-assistenten de onderscheiden cultuuraspecten waar?}

Verschillen vrouwelijke co-asssistenten van mannelijke?

Co-assistenten nemen inderdaad waar dat artsen aan protocollen gebonden zijn, dat medische kennis als feitenkennis wordt opgevat en dat men hecht aan correct gebruik van medisch vakjargon (2.0). Hier is geen verschil tussen mannen en vrouwen.

Co-assistenten zien verder eveneens (2.0) dat uitslagen van technologische hulpmiddelen als röntgenfoto's, echografie en laboratoriumgegevens een hoofdrol spelen in de diagnostiek en meer zekerheid geven dan anamnese en lichamelijk onderzoek door de dokter zelf. Mannelijke gevorderde co-assistenten (groep 2) nemen dit significant sterker waar dan de vrouwen uit die groep.

Ten aanzien van de mate van beheersing van het rolgedrag als arts geven co-assistenten een onduidelijker antwoord, ze zien enigszins dat artsen geen openlijke kritiek op elkaar mogen uiten, hun gevoelens verbergen, nauwelijks met onzekerheid kunnen omgaan en zichzelf als arts niet goed kunnen relativeren.

Ook op de vraag of co-assistenten cynisme en spot of denigrerende grappen van artsen onderling waarnemen is het antwoord minder uitgesproken $(2,3)$.

\section{Zijn er sekseverschillen in de perceptie van deze cultuuraspecten ?}

Bij de dimensie onzekerheidsvermijding, zien we dat vrouwelijke co-assistenten uit de subgroep van de gevorderde co-assistenten, de hen omringende cultuur anders waarnemen dan hun mannelijke collega's. Dit is het geval ten aanzien van de noodzaak om in de rol van arts de eigen emoties te beheersen (beheersing rolgedrag) en ten aanzien van de mogelijk prominente rol van de medische technologie bij diagnostiek. Vrouwen nemen beide zaken sterker waar. ${ }^{4}$

\section{Waardering}

\section{Hoe waarderen co-assistenten deze fenomenen? Is er een sekseverschil?}

Co-assistenten blijken het betrekkelijk wenselijk vinden dat het medisch handelen gestandaardiseerd is en dat artsen aan protocollen zijn gebonden, dat medische kennis als feitenkennis wordt opgevat en correct gebruik van jargon wordt geapprecieerd $(2,3)$.

Minder waardering hebben de co-assistenten voor de grote rol van de technologie bij de medische diagnostiek, waarbij opvalt dat vrouwelijke co-assistenten dit significant sterker afkeuren dan mannen. De noodzaak tot beheersing van de affecten in de artsenrol en eventueel cynisme en denigrerende omgang van artsen met elkaar worden

\footnotetext{
'In het navolgende wordt alleen melding gemaakt van de bevindingen bij mannelijke en vrouwelijke co-assistenten, als er sprake is van een significant verschil tussen de seksen of er sprake is van een opmerkelijke bevinding.
} 
duidelijk negatief beoordeeld door co-assistenten. Het enige sekseverschil in waardering bij deze dimensie wordt aangetroffen bij de variabele de rol van technologie. ${ }^{5}$

\section{Kloof tussen perceptie en waardering}

Hoe ziet bet verschil tussen perceptie en individuele waardering eruit? Sekseverschillen? Opmerkelijk is bij deze dimensie dat de verschillen tussen waargenomen werkelijkheid en waardering kleiner zijn dan bij de andere dimensies. Dit geldt het sterkste voor de variabele "standaardisering van medische expertise", waar een gering en niet significant verschil tussen perceptie en waardering bestaat (.03). Dit is uitzonderlijk, omdat bij alle andere variabelen in de medische beroepscultuur de kloof steeds wel significant is gebleken.

Er zijn geen sekseverschillen ten aanzien van de kloof tussen wens en werkelijkheid bij de cultuuraspecten passend bij onzekerheidsvermijding.

\section{Conclusie}

Co-assistenten blijken de beschreven cultuuraspecten passend bij de dimensie onzekerheidsvermijding wel waar te nemen, maar ze blijken over het geheel genomen minder moeite te hebben met de voorgeleefde culturele codes op dit terrein. Dit geldt vooral de variabele standaardisering medische kennis, die betrekking heeft op de rol van protocollen in het medisch handelen. Vrouwelijke en mannelijke co-assistenten nemen deze cultuuraspecten verder hetzelfde waar, behalve de aspecten "grote rol van de medische technologie" en de noodzaak om emoties in de beroepsrol van arts te beheersen ("beheersing rolgedrag"). Vrouwelijke gevorderden (groep 2) nemen deze aspecten sterker waar.

Vrouwen en mannen verschillen verder niet in waardering van de genoemde cultuuraspecten, behalve de grote rol van technologie in de geneeskunde, die door vrouwelijke co-assistenten als onwenselijker wordt beoordeeld.

\subsubsection{Resultaten ten aanzien van perceptie en waardering, femininiteit en masculiniteit}

Femininiteit als cultuurkenmerk van de beroepscultuur van medici werd geoperationaliseerd in de volgende aspecten :

- ruimte voor steun en aandacht voor persoonlijke zaken van artsen onderling

- ruimte om emoties te uiten van artsen onderling

- norm van toegankelijke en luisterende arts (in relatie tot patiënt).

Masculiniteit als cultuurkenmerk werd uitgewerkt in de volgende 4 aspecten:

- competitieve omgang artsen onderling

- noodzaak van competitie voor carrière (medische loopbaan vraagt knokken)

'Het verschil tussen gepercipieerde werkelijkheid en waardering door de co-assistent is in alle voorge legde gevallen significant. 
- rangen en standen (pikorde) onder artsen

- onderscheid maken tussen co-assistenten op basis diverse persoonskenmerken.

\section{Perceptie}

Wat zien co-assistenten aan feminiene cultuuraspecten?

Aandacht en empathie van artsen voor elkanders noden, problemen of persoonlijke zaken blijkt weinig gebruikelijk. Co-assistenten geven een ontkennend antwoord op de vraag of artsen elkaar ondersteunen, wanneer persoonlijke of privé- verwikkelingen in het geding zijn. Ook blijkt de "scheiding tussen privé en werk" vrij sterk te worden voorgeleefd (2.8).

Op de vraag of men zich onder beroepsgenoten vrij kan uiten en zijn emoties kan laten zien, wordt door co-assistenten een licht ontkennend antwoord gegeven.

Over de opstelling van artsen in hun contact met patiënten, werd gevraagd of artsen hun patiënten respectvol en geduldig tegemoet treden en of zij ruimte maken voor emoties van patiënten en hun beleving van het probleem. Het antwoord van coassistenten op deze vraag naar gemoedelijke en empathische omgangsvormen is indifferent (2.6).

Wat zien co-assistenten aan masculiene cultuaraspecten?

Op de vraag of co-assistenten veel competitie van artsen onderling waarnemen, volgt een indifferent antwoord (2.5).

Op de vraag of het in de medische beroepsgroep noodzakelijk is om te rivaliseren en te knokken om carrière in de geneeskunde te maken en hogerop te komen, wordt betrekkelijk volmondig met ja (1.6) geantwoord.

Als volgende kwestie werd aan co-assistenten gevraagd of zij grote statusverschillen zien en of ze een sterke pikorde in de medische stand waarnemen, of men schamper doet over vergissingen van andere artsen-groepen en of artsen zich sterk beoordelend uiten over elkaars kwaliteiten. Dit fenomeen bleek door co-assistenten nauwelijks $(2,8)$ te worden waargenomen.

Op de vraag of co-assistenten zien dat er er sprake is van ongelijke behandeling van co-assistenten op basis van sympathiek voorkomen of sekse, milieu/afkomst, uiterlijk of op basis van vertoon van intelligentie, volgt een indifferent antwoord (2.4).

\section{Waardering feminiene en masculiene cultuuraspecten}

\section{Wat vinden zij van de feminiene cultuuraspecten?}

Co-assistenten beoordelen de feminiene cultuuraspecten over het algemeen positief (zie tabel 6.4). Ze zouden het zeker wenselijk (1.7) vinden als artsen onderling meer aandacht hadden voor persoonlijke zaken en emotionele verwikkelingen, kortom meer zorgzame omgangsvormen met elkaar zouden kennen.

Ook de mogelijkheid van artsen om zich spontaan te kunnen uiten en emoties of ideeën te kunnen ventileren, zouden co-assistenten sterk waarderen (1.3). 
Een empathische opstelling van de arts richting patiënt, wordt eveneens als zeer wenselijk beoordeeld door co-assistenten (1.3).

Verder blijken in de (sub)groep beginners de vrouwelijke co-assistenten de drie feminiene cultuurkenmerken significant positiever te beoordelen dan hun mannelijke collega's. In de (sub)groep gevorderden co-assistenten is dit sekseverschil niet aanwezig.

Tabel 6.4 W/ardering feminiene cultuuraspecten; vrouw/man scores voor de totale groep p-waarden sekseverschil in de totale groep en de subgroepen

\begin{tabular}{llllll}
\hline & $\begin{array}{l}\text { gem. } \\
\varnothing \varnothing\end{array}$ & $\begin{array}{l}\text { gem. } \\
\delta \delta\end{array}$ & $\begin{array}{l}\mathrm{p} \\
\text { tot. groep }\end{array}$ & $\begin{array}{l}\mathrm{p} \\
\text { groep 1 }\end{array}$ & $\begin{array}{l}\mathrm{P} \\
\text { groep 2 }\end{array}$ \\
\hline ruimte voor onderlinge steun & 2.0 & 1.8 & n.s. & .017 & n.s. \\
ruimte om emoties te uiten & 1.4 & 1.4 & n.s. & .03 & n.s. \\
norm van toegankelijke luisterende arts & 1.3 & 1.3 & n.s. & .03 & n.s. \\
\hline
\end{tabular}

range 1- waardering: 1- zeer wenselijk; 4- zeer onwenselijk

\section{Kloof tussen perceptie en waardering}

Kloof tussen de gepercipieerde werkelijkheid en individueel waardeoordeel

Bij alle als feminien getypeerde cultuurkenmerken, blijkt er sprake van een aanmerkelijk verschil tussen gepercipieerde werkelijkheid en de waardering hiervan door co-assistenten (resp. 1.1. 1.35 en 1.3).

De kloof is niet verschillend voor vrouwen en mannen.

\section{Wat vinden co-assistenten van de masculiene cultuuraspecten?}

Competitieve omgang van artsen onderling wordt door co-assistenten als zeer onwenselijk gezien (3.5). De noodzaak van competitie en rivaliseren om carrière te maken in het medische beroep wordt eveneens als onwenselijk gezien (2.7); vrouwen blijken dit cultuuraspect significant negatiever te beoordelen dan de mannelijke co-assistenten. Het voorkomen van rangen en standen of pikorde, hetgeen nauwelijks door de coassistenten wordt waargenomen, wordt wél als onwenselijk beoordeeld.

Ongelijke behandeling van co-assistenten op basis van diverse persoonlijke en uiterlijke kenmerken, wordt door hen als onwenselijk beoordeeld (3.4). 
Tabel $6.5 \mathrm{~W}$ aardering mate van masculiniteit; gemiddelde scores voor mannen en vrouwen in de totale groep en p-waarde sekseverschil in totale groep en subgroepen

\begin{tabular}{|c|c|c|c|c|c|}
\hline & $\begin{array}{l}\text { gem. } \\
\$ ९\end{array}$ & $\begin{array}{l}\text { gem. } \\
\delta \delta \delta\end{array}$ & $\begin{array}{l}\mathrm{P} \\
\text { tot.groep }\end{array}$ & $\begin{array}{l}\text { p } \\
\text { groep } 1\end{array}$ & $\begin{array}{l}\text { P } \\
\text { groep 2 }\end{array}$ \\
\hline competitieve omgang artsen onderling & 3.5 & 3.5 & n.s. & .008 & .05 \\
\hline noodzaak van competitie & 2.8 & 2.5 & .002 & .007 & .03 \\
\hline rangen en standen & 1.5 & 1.6 & n.s. & n.s. & n.s. \\
\hline onderscheid maken onder co's & 3.4 & 3.4 & n.s. & n.s. & n.s. \\
\hline
\end{tabular}

range 1- waardering: 1 - zeer wenselijk; 4 = zeer onwenselijk

\section{Kloof tussen waardering en perceptie}

Competitieve omgang wordt door co-assistenten niet duidelijk waargenomen, maar het verschil tussen hun eigen beoordeling hiervan en de waargenomen realiteit blijkt groot (1.0). Bij vrouwelijke beginnende co-assistenten in groep 1 blijkt deze kloof verder nog (significant) groter dan bij hun mannelijke collega's.

Ook blijkt bij vrouwen de kloof tussen perceptie en waardering significant groter bij het cultuuraspect "noodzaak van competitie" voor een loopbaan in de geneeskunde dan bij mannen, zowel op niveau van de totale groep als in de (sub)groep beginners. $\mathrm{Er}$ is geen sprake van een kloof tussen perceptie en waardering bij het cultuuraspect "pikorde" oftewel rangen en standen, hier is het verschil tussen perceptie en waardering niet significant. Dit is wel het geval bij de dimensie "onderscheid maken onder co-assistenten op basis van uiterlijk, sekse, vertoon ven intelligentie en dergelijke.

\section{Conclusie}

De medische beroepscultuur wordt door co-assistenten niet waargenomen als een gekenmerkt door feminiene cultuuraspecten. Noch op het vlak van omgang van artsen met elkaar noch in de omgang van opleiders met co-assistenten worden feminiene karakteristieken waargenomen. Op de vraag of omgang van artsen met hun patiënten op co-assistenten de indruk maakt dat deze interactie is gebaseerd op het ideaal van een communicatieve, toegankelijke en luisterende arts, wordt een indifferent antwoord gegeven. De perceptie van feminiene cultuuraspecten door vrouwelijke en mannelijke co-assistenten vertoont geen verschillen.

Feminiene cultuuraspecten worden allemaal als zeer wenselijk door co-assistenten beoordeeld. Jongere vrouwelijke co-assistenten uit de subgroep beginners (groep1) blijken verder significant positiever in hun oordeel over deze feminiene aspecten dan hun mannelijke collega's. Dit sekseverschil is niet meer aanwezig in de groep gevorderden (groep 2).

$\mathrm{Bij}$ alle feminiene cultuuraspecten is er verder sprake van een kloof tussen perceptie en waardering.

Niet alle masculiene cultuurkenmerken worden waargenomen. Co-assistenten beamen dat carrière maken in het medisch beroep het noodzakelijk maakt om te rivaliseren en te knokken, maar een sterk competitieve sfeer tussen artsen onderling of een sterke pikorde met denigrerende of schamperende manier van spreken over artsen-collega's 
wordt niet of nauwelijks waargenomen. De vraag naar mogelijke ongelijke behandeling van co-assistenten door hun opleiders wordt indifferent beantwoord.

De 4 masculiene cultuuraspecten worden allemaal als onwenselijk beoordeeld; in het geval competitieve omgang van artsen onderling (1) en noodzaak om te rivaliseren voor een carrière in het medisch vak (2) is de afkeuring van vrouwelijke co-assistenten significant sterker dan die van mannen, in de andere gevallen niet.

$\mathrm{Er}$ is in alle gevallen een significant kloof tussen perceptie en waardering behalve behalve het cultuuraspect "pikorde of rangen en standen".

\subsubsection{Resultaten ten aanzien van perceptie en waardering van het inwijdingsritueel}

Ook hebben we de manier van bet inwijden van de nieuwe generatie door de medische beroepsgroep getracht te typeren. De ervaringen van nieuwkomers worden onderscheiden in een aantal varianten waarbij twee uitwerkingen een harde aanpak van de introductie van nieuwelingen verwoorden (het gevoel abrupt en zonder veel begeleiding in het diepe te worden gegooid) en twee uitwerkingen een zachtere en meer empathische aanpak uitdrukken.

De operationalisatie bestaat uit 4 variabelen over aanpak in het inwijdingstraject:

- harde aanpak

- in het diepe gooien

- zachtere aanpak nieuweling

- rol van verpleging

\section{Perceptie}

Zien co-assistenten de onderscheiden kenmerken van het inwijdingsritueel? Verschillen de seksen in perceptie?

Co-assistenten ervaren de overgang van predoctoraal fase naar klinische fase als een grote overgang en voelen zich als het ware in het diepe gegooid.

Op de vraag of men als co-assistent te maken heeft met weinig toegankelijke opleiders of arts-assistenten die weinig tijd hebben voor feed-back of beoordeling van verricht werk van co-assistenten, wordt bevestigend geantwoord. Ook blijkt dat het leerklimaat als enigszins onveilig wordt ervaren en dat co-assistenten menen dat men zich als stagaire het maken van fouten en het stellen van "domme" vragen eigenlijk niet kunnen permitteren; zij nemen aan dat het risico loopt om "af te gaan" groot is (scores perceptie 2.2 en 2.2 ).

Een zachte benadering van de introductie in de medische wereld treffen co-assistenten nauwelijks aan (2.7). Op de vraag of de verpleging een rol speelt in de introductie van co-assistenten geeft de totale groep een indifferent antwoord (2.5). Bij deze vraag zien we een significant sekseverschil in perceptie (hetgeen zelden werd gevonden in dit onderzoek) in de groep beginners (groep 1); beginnende vrouwelijke co-assistenten blijken de rol van de verpleging in hun opleidingsproces veel duidelijker waar te nemen dan mannelijke co-assistenten ( $\mathrm{p} \leq .05)$. 


\section{Waardering?}

Hoe waarderen co-assistenten de beschreven verschïnselen?

Co-assistenten vinden het onwenselijk dat ze als nieuwkomers zo'n grote overgang doormaken en in het diepe worden gegooid (3.1). Vrouwen en mannen stemmen overeen op dit punt, alleen in de groep beginners blijken vrouwen dit nog heviger af te keuren dan mannen $(p \leq .035)$. Weinig toegankelijke opleiders (stafleden en artsassistenten) en een hard leerklimaat met strenge normen en het risico om af te gaan, worden door co-assistenten als onwenselijk beoordeeld (3.3).

Co-assistenten zouden een zachtere aanpak van hun introductie in de medische wereld veel wenselijker vinden (1.2) evenals een grote rol van de verpleging in hun introductie in de klinische praktijk (2.1).

Tabel 6.6 Waardering van manier van inwijding, gemiddelde scores van vrouwen en mannen in de totale groep en de p-waarden van sekseverschil totale groep en subgroepen

\begin{tabular}{llllll}
\hline & $\begin{array}{l}\text { gem. } \\
\wp \wp\end{array}$ & $\begin{array}{l}\text { gem. } \\
\delta \delta\end{array}$ & $\begin{array}{l}\mathrm{p} \\
\text { totale groep }\end{array}$ & $\begin{array}{l}\mathrm{p} \\
\text { groep 1 }\end{array}$ & $\begin{array}{l}\mathrm{P} \\
\text { groep 2 }\end{array}$ \\
\hline harde aanpak nieuwelingen & 3.1 & 3.0 & n.s. & .035 & n.s. \\
in het diepe gooien & 3.4 & 3.3 & n.s. & n.s. & n.s. \\
zachtere aanpak & 1.0 & 1.3 & n.s. & n.s. & n.s. \\
rol verpleging & 2.1 & 2.1 & n.s. & n.s. & n.s. \\
\hline
\end{tabular}

range waardering: 1 = zeer wenselijk; $4=$ zeer onwenselijk

\section{Kloof tussen perceptie (werkelijkheid) en waardering (wens)}

\section{Kloof tussen perceptie en waardering}

De kloof tussen perceptie en waardering is bij alle aspecten redelijk groot, behalve bij de kwestie van de rol van de verpleging. Bij de beschrijving van een harde vorm van introductie in de medische wereld is de kloof significant $(.80)$. Deze kloof is voor mannen en vrouwen even groot. Met betrekking tot de toegankelijkheid van de opleiders is het verschil tussen perceptie en waardering eveneens significant (1.1) en verachillen vrouwen niet van mannen. Ook de behoefte aan een zachtere aanpak bij de introductie in de medische wereld is significant groter dan de realiteit (kloof 1.4 $\mathrm{p}<.001)$. Het geringe verschil tussen perceptie en waardering bij de dimensie "rol van de verpleging in de opleiding van co-assistenten" is 0.43 maar wel significant $(p<.01)$.

\section{Conclusie}

Over de kenmerken van inwijdingsproces kan men concluderen dat co-assistenten hun introductie in de beroepswereld van de geneeskunde als confronterend ervaren. Coassistenten vinden dat ze een grote overgang doormaken en dat het leerklimaat weinig ruimte biedt om open en eerlijk met vragen en onzekerheden voor de dag te komen. $\mathrm{De}$ rol van de verpleging bij de inwijding lijkt niet als groot te worden waargenomen, alhoewel vrouwen deze inbreng als groter typeren dan hun mannelijke collega's. Co-assistenten zouden wel een zachtzinniger introductie wensen en mannen verschillen in dit opzicht niet van vrouwen. 
Het verschil tussen perceptie en waardering is in bijna alle gevallen significant, behalve bij de kwestie van de "rol van de verpleging" in de opleiding van coassistenten.

Ook zijn er geen verschillen tussen de seksen ten anzien van de kloof tussen perceptie en waardering.

\subsubsection{Resultaten overige cultuuraspecten als loyaliteit en "uiterlijke kenmerken of symbolen"}

De betekenis van de culturele code van loyaliteit en de betekenis van uiterlijke kenmerken van medische beroepscultuur werd aan de orde gesteld aan de hand van de volgende operationisaties:

- loyaliteit van artsen onderling

- tekenen van medici om zich te onderscheiden van andere disciplines;

- technische uitstraling van inrichting ziekenhuizen.

\section{Perceptie van loyaliteit onder artsen?}

Loyaliteit lijkt door de co-assistenten als een belangrijke code van artsen onderling te worden. $\mathrm{Zij}$ zien dat artsen onderling goede teamgeest hebben, dat het wordt gewaardeerd als je je als loyaal teamlid opstelt. Men leert naar hun inzicht als arts om je collega's te ondersteunen op het terrein van kennis, medisch inhoudelijk vlak en het aanleren van vaardigheden (score 2.1).

\section{Waardering en kloof ten aanzien van de code loyaliteit}

Hoe waarderen zij deze codes van loyaliteit? Verschillen de seksen?

Co-assistenten vinden deze code van loyaliteit zeer wenselijk. In dit opzicht komt de voorgeleefde cultuur betrekkelijk overeen met de opvattingen van co-assistenten over wat wenselijk is onder artsen.

De kloof tussen cultuur en persoonlijke evaluatie is wel significant, maar vrouwen en mannen zijn het op alle punten met elkaar eens.

\section{Perceptie en waardering en de kloof tussen beide ten aanzien van uiterlijke tekenen?}

Co-assistenten zien wel (2.0) dat artsen aan uiterlijke zaken als stethoscoop, medisch zakboekje oa. goed te onderscheiden zijn van andere werkers in de gezondheidszorg. Ze waarderen dit indifferent (2.6). Het verschil tussen waardering en gepercipieerde werkelijkheid is minimaal $(0.5)$.

Co-assistenten zien verder dat ziekenhuizen een technische uitstraling hebben, ze keuren dit licht af $(2,8)$. Ook hier is sprake van een betrekkelijk bescheiden discrepantie tussen wens en werkelijkheid. 
Tabel 6.7 Overzicht van gemiddelde scores perceptie, waardering en kloof van aspecten van de medische beroepscultuur; p-waarden van sekseverschillen.

\begin{tabular}{|c|c|c|c|c|c|c|}
\hline DIMENSIE Naam Variabele & $\begin{array}{l}\text { Perceptie } \\
\text { (j) }\end{array}$ & $p \& / \delta$ & $\begin{array}{l}\text { Waarder } \\
\text { ing" }\end{array}$ & $p 8 / 8$ & $\begin{array}{l}\text { Kloof } \\
\mathrm{P} / \mathrm{W}^{*}\end{array}$ & p $8 / \delta$ \\
\hline $\begin{array}{l}\text { MACHT } \\
\text { Symbolen machtafstand }\end{array}$ & $2.2^{1}$ & n.s & $3.3^{2}$ & $\begin{array}{l}.001 \\
\text { totaal } \\
8 \downarrow \\
.009 \mathrm{gr} .1 \\
94\end{array}$ & 1.1 & n.s \\
\hline $\begin{array}{l}\text { MACHT } \\
\text { Hiërarchie artsen onderling }\end{array}$ & 2.1 & n.s & $\begin{array}{l}3.2 \\
\text { (s.d.0.6) }\end{array}$ & $\begin{array}{l}.04 \text { totaal } \\
.4\end{array}$ & 1.4 & $\begin{array}{l}.03 \\
\text { totaal } \\
8 \uparrow\end{array}$ \\
\hline $\begin{array}{l}\text { MACHT } \\
\text { Hiërarchie artsen verpleging }\end{array}$ & 1.9 & n.s & $\begin{array}{l}2.7 \\
\text { (s.d.0.6) }\end{array}$ & n.s & .8 & n.s \\
\hline $\begin{array}{l}\text { MACHT } \\
\text { Geringe afstand opleider-co }\end{array}$ & $\begin{array}{l}2.7 \\
\text { (s.d.0.6) }\end{array}$ & n.s & 1.3 & $\begin{array}{l}.02 \text { totaal } \\
.1\end{array}$ & 1.4 & n.s \\
\hline $\begin{array}{l}\text { MACHT } \\
\text { Geringe afstand arts-patiënt }\end{array}$ & 2.7 & n.s & 1.6 & n.s & 1.2 & n.s \\
\hline $\begin{array}{l}\text { RESPECT } \\
\text { Respectvolle artsen onderling }\end{array}$ & 2.4 & n.s & 1.4 & $.02 \mathrm{gr} .1$ & 1.0 & n.s \\
\hline $\begin{array}{l}\text { ONZE.VERM } \\
\text { Standaardisering medische expertise }\end{array}$ & 2.0 & n.s & 2.3 & n.s & .3 & n.s \\
\hline $\begin{array}{l}\text { ONZE.VERM } \\
\text { Beheersing rolgedrag }\end{array}$ & 2.3 & $.03 \mathrm{gr} .2$ & 3.4 & n.s & 1.1 & n.s \\
\hline $\begin{array}{l}\text { ONZE.VERM } \\
\text { Grote rol technologie }\end{array}$ & $\begin{array}{l}2.0 \\
\text { (s.d.0.7) }\end{array}$ & $\begin{array}{l}.03 \mathrm{gr} .2 \\
. \uparrow\end{array}$ & 2.9 & $\begin{array}{l}.02 \text { totaal } \\
.4\end{array}$ & .9 & n.s \\
\hline $\begin{array}{l}\text { ONZE.VERM } \\
\text { Spot en cynisme }\end{array}$ & 2.3 & n.s & 3.2 & n.s & .9 & n.s \\
\hline $\begin{array}{l}\text { LOYALITEIT } \\
\text { artsen onderling }\end{array}$ & 2.1 & n.s & 1.4 & n.s & .7 & n.s \\
\hline $\begin{array}{l}\text { FEMINIEN } \\
\text { Ruimte steun artsen onderling }\end{array}$ & 2.8 & n.s & 1.7 & $\begin{array}{l}.017 \mathrm{gr} .1 \\
\$ \uparrow\end{array}$ & 1.1 & n.s \\
\hline $\begin{array}{l}\text { FEMINIEN } \\
\text { Ruimte emoties artsen onderling }\end{array}$ & $\begin{array}{l}2.7 \\
\text { (s.d.0.6) }\end{array}$ & n.s & 1.4 & $.03 \mathrm{gr} .1$ & 1.4 & n.s \\
\hline $\begin{array}{l}\text { FEMINIEN } \\
\text { Luisterende, toegankelijke arts }\end{array}$ & 2.6 & n.s & 1.3 & $\begin{array}{l}.03 \mathrm{gr} \cdot 1 \\
. \uparrow^{1}\end{array}$ & 1.3 & n.s \\
\hline $\begin{array}{l}\text { MASCULIEN } \\
\text { Competitie artsen onderling }\end{array}$ & 2.5 & n.s & 3.5 & $\begin{array}{l}.008 \mathrm{gr} .1 \\
9 \downarrow\end{array}$ & 1.0 & $.05 \mathrm{gr} .1$ \\
\hline $\begin{array}{l}\text { MASCULIEN } \\
\text { Noodzaak van competitie }\end{array}$ & 1.5 & n.s & 2.7 & $\begin{array}{l}.002 \\
\text { totaal } \\
\$ \downarrow \\
.007 \mathrm{gr} .1 \\
\$ \downarrow \\
.03 \mathrm{gr} .2 \\
9 \downarrow\end{array}$ & 1.1 & $\begin{array}{l}.001 \\
\text { totaal } \\
.003 \\
\text { gr.1 } \\
.04 \mathrm{gr} .2\end{array}$ \\
\hline
\end{tabular}


Hoofdstuk 6

\begin{tabular}{|c|c|c|c|c|c|c|}
\hline DIMENSIE Naam Variabele & $\begin{array}{l}\text { Perceptie } \\
\text { (?) }\end{array}$ & p $9 / 8$ & $\begin{array}{l}\text { W/arder } \\
\text { ing" }\end{array}$ & $\mathrm{p} 9 / 8$ & $\begin{array}{l}\text { Kloof } \\
\mathrm{P} / \mathrm{W}\end{array}$ & $\mathrm{p} 9 / 8$ \\
\hline $\begin{array}{l}\text { MASCULIEN } \\
\text { Rangen en standen onder artsen }\end{array}$ & 2.8 & n.s & 3.3 & n.s & .6 & n.s \\
\hline $\begin{array}{l}\text { MASCULIEN } \\
\text { Onderscheid maken co's }\end{array}$ & 2.4 & n.s & 3.4 & n.s & 1.0 & n.s \\
\hline $\begin{array}{l}\text { INWWIJDING } \\
\text { Harde aanpak nieuweling }\end{array}$ & 2.2 & n.s & $\begin{array}{l}3.1 \\
\text { (s.d.0.6) }\end{array}$ & $.035 \mathrm{gr} .1$ & .9 & n.s \\
\hline $\begin{array}{l}\text { INWJJDING } \\
\text { In het diepe gooien }\end{array}$ & 2.2 & n.s & 3.3 & n.s & 1.1 & n.s \\
\hline $\begin{array}{l}\text { INWIJDING } \\
\text { Zachtere aanpak nieuweling }\end{array}$ & 2.7 & n.s & 1.3 & n.s & 1.4 & n.s \\
\hline $\begin{array}{l}\text { INWIJDING } \\
\text { Grote rol verpleging }\end{array}$ & $\begin{array}{l}2.5 \\
(s . d 0.6)\end{array}$ & $\begin{array}{l}.03 \mathrm{gr} .1 \\
8 \uparrow \\
.02 \mathrm{gr} .2 \\
8 \uparrow\end{array}$ & $\begin{array}{l}2.1 \\
(s . d .0 .6)\end{array}$ & n.s & .4 & n.s \\
\hline $\begin{array}{l}\text { SYMBOLEN } \\
\text { Technische uitstraling ziekenhuis }\end{array}$ & $\begin{array}{l}1.9 \\
\text { (s.d.0.6) }\end{array}$ & n.s & $\begin{array}{l}2.8 \\
\text { (s.d. } 0.6\end{array}$ & n.s & .8 & n.s \\
\hline $\begin{array}{l}\text { SYMBOLEN } \\
\text { Tekenen des onderscheids }\end{array}$ & 2.0 & n.s & 2.6 & n.s & .5 & n.s \\
\hline
\end{tabular}

$\cdot{ }^{\circ}=$ vrouwen hebben minder waardering voor dit aspect, zien het minder, of voor vrouwen is de kloof kleiner

$\uparrow$ - vrouwen hebben meer waardering voor dit aspect, zien het meer of voor vrouwen is de kloof groter

'Betekenis score perceptie: 1 - ik zie het heel sterk; 4 = ik zie het helemaal niet

${ }^{2}$ Betekenisscore waardering: 1 = ik vind het zeer wenselijk; $4=i k$ vind het zeer onwenselijk

'Standaarddeviatie is $\leq 0.5$ indien niet weergegeven in tabel.

\subsection{Veranderingen in de tijd in perceptie of waardering van beroepscultuur. Resultaten}

Om een antwoord te vinden op de vraag of bet socialisatieproces van co-assistenten veranderingen in de tijd laat zien in die zin dat perceptie of waardering veranderen naarmate zij verder vorderen in bun opleiding, zijn vervolganalyses uitgevoerd op de data van het transversale onderzoek naar medische beroepscultuur.

Omdat socialisatie beschreven is als het in overeenstemming brengen van het normen en waarden- patroon van het individu met dat van de omringende cultuur (Veldman \& Witting 1990), veronderstellen we op basis hiervan dat met name de waardering van de voorgeleefde cultuur zal veranderen.

De volgende vraagstelling staat centraal:

Verandert de perceptie of de waardering van cultuuraspecten van de beroepscultuur naarmate co-assistenten verder vorderen in bun socialisatietraject?

Verandert de kloof tussen perceptie en waardering ?

Om deze vragen te beantwoorden werden de verschillen tussen de beginnende coassistenten en de gevorderden nader geanalyseerd. Ook werden de verschillen tussen 
vrouwelijke beginners en vrouwelijke gevorderden onder de loep genomen en die tussen mannelijke beginners en mannelijke gevorderden.

\section{Resultaten}

Verschilt de perceptie van beroepscultuur van beginnende co-assistenten van die van gevorderde?

Gevorderde co-assistenten zien bij 11 variabelen een significant ander beeld:

- meer symbolen van machtafstand, totale groep en vooral bij vrouwen

- meer hiërarchie van artsen in de relatie met de verpleging, totale groep en vooral bij vrouwen

- minder ongelijkheid in relatie van arts-opleiders en co-assistent, totale groep en vooral bij mannen

- meer respectvolle omgang tussen artsen onderling, totale groep en vooral bij vrowwen

- meer spot en cynisme onder artsen, totale groep en vooral bij vrouwen

- minder loyaliteit van artsen onderling, totale groep, bij vrouwen en mannen

- minder ruimte van artsen onderling om emoties te uiten (feminien cultuuraspect) totale groep

- minder de norm van een luisterende en toegankelijke arts in de arts-patiënt relatie (feminien cultuuraspect)

afname totale groep

- meer competitie van artsen onderling (masculien cultuuraspect), totale groep en vooral bij mannen

- meer rangen en standen of pikorde (masculien cultuuraspect) alleen bij mannen

- grotere rol van de verpleging bij inwijding totale groep en vrouwen

Kortom gevorderde co-assistenten zien de cultuur van de medici "pregnanter".

Verschilt de waardering van de medische beroespcultuur van beginnende co-assistenten van die van gevorderde co's?

Algemeen valt op dat de waardering van de medische beroepscultuur door co-assistenten op bijna alle punten constant blijft. De waardering van de voorgeleefde cultuur van gevorderden komt overeen met die van beginnende co-assistenten, met uitzondering van een feminien cultuuraspect dat betrekking heeft op de attitude van de arts in de arts-patiënt relatie. Het blijkt dat vrouwelijke gevorderde co-assistenten een lagere waardering hebben voor de norm van een "toegankelijke en luisterende arts" dan hun beginnende vrouwelijke collega's. Het lijkt erop dat een langere duur van onderdompeling in de professionele medische cultuur voor vrouwelijke co- 
assistenten samenhangt met een afnemende waardering van het ideaal van een "luisterende en toegankelijke arts".

Verschilt de kloof tussen perceptie en waardering tussen beginners en gevorderde coassistenten ?

De kloof tussen perceptie en waardering blijkt in sommige gevallen voor de gevorderde co-assistenten groter te zijn dan voor beginners en niet andersom, zoals verwacht. In de volgende 6 gevallen blijkt de kloof tussen perceptie en waardering voor de gevorderden groter te zijn dan bij beginnners:

- statussymbolen (machtafstand),

totale groep en vooral mannen

- respectvolle omgang,

totale groep, vrouwen en mannen

- spot en cynisme (onzekerheidsvermijding)

totale groep en vooral mannen

- loyaliteit

totale groep

- competitieve omgang (masculien),

totale groep, vrouwen en mannen

- noodzaak van competitie (masculien),

alleen bij mannelijke gevorderde co-assistenten

Toelichting bij de resultaten (zie ook bijlage 1).

Beantwoording van deze onderzoeksvragen geeft meer zicht op de vraag of er veranderingen optreden bij co-assistenten in de loop van hun socialisatieproces tot arts op het vlak van perceptie of waardering van de hen omringende medische beroepscultuur.

Algemeen valt op dat co-assistenten meer veranderen in bun perceptie dan in bun waardering van de aspecten van de medische beroepscultuur, zoals in dit onderzoek gevraagd. Uitsluitend ten aanzien van het feminiene cultuuraspect van de norm van de luisterende en toegankelijke arts in de interactie van arts en patiënt, treedt een verandering op bij vrouwelijke co-assistenten. Gevorderde vrouwelijke co-assistenten blijken minder waarde te hechten aan dit cultuuraspect dan beginnende vrouwelijke co's. Verder zien we alleen verschuivingen in de perceptie.

Cultuuraspecten die samenhangen met omgaan met machtsongelijkheid worden door vrouwelijke co-assistenten nadrukkelijker waargenomen, naarmate ze verder vorderen in de medische opleiding. Ook verandert de waarneming van vrouwen ten aanzien van de mate waarin de omgang van artsen met elkaar loyaliteit en respect ademt. Vrouwen nemen minder loyaliteit waar, maar meer respect van artsen in hun onderlinge omgang. Verder nemen vrouwelijke gevorderde co-assistenten meer spot en cynisme onder artsen waar onderling, dan hun beginnende collega's. Tot slot nemen vrouwen, naarmate ze verder vorderen in de opleiding een grotere rol van de verpleging bij hun eigen opleidingstraject waar. 
Bij mannelijke co-assistenten zien we vooral veranderingen in de perceptie van de masculiene cultuuraspecten. $\mathrm{Zij}$ zien meer competitie van artsen onderling naarmate ze verder gevorderd zijn, meer rangen en standen en pikorde. Ook zien mannelijke co-assistenten een grotere machtsongelijkheid tussen hun eigen groep en de opleiders naarmate ze verder gevorderd zijn.

Feminiene cultuuraspecten blijken door gevorderde co-assistenten nog minder waargenomen te worden dan door beginners.

\subsection{Sekseverschillen op een rij}

\section{Worden de bypothesen bevestigd?}

De belangrijkste hypothesen ten aanzien van het verschil tussen de seksen luidde dat vrouwelijke co-assistenten wel verschillen in hun waardering van de voorgeleefde beroepscultuur van mannen maar niet in hun perceptie van die cultuur.

Wanneer de evaluatie van vrouwen anders is dan die hun mannelijke collega's dan vloeit hieruit logischerwijs voort dat waarschijnlijk ook de kloof tussen waardering en waargenomen werkelijkheid groter zal zijn bij vrouwen dan bij mannelijke co-assistenten. In het navolgende zullen we bespreken of deze hypothesen bevestigd kunnen worden of terzijde geschoven moeten worden.

Kwestie 1. Vrouwen en mannen nemen de medische beroepscultuur op dezelfde manier waar.

In de meeste gevallen blijken de seksen niet te verschillen in de perceptie van de voorgeleefde beroepscultuur. Uitzondering op deze regel is het cultuuraspect dat betrekking heeft op de rol van de verpleging bij de begeleiding van co-assistenten, element van het inwijdingsritueel. Vrouwelijke co-assistenten blijken deze rol significant duidelijker waar te nemen dan hun mannelijke collega's. Verder blijkt dat vrouwen uit de subgroep gevorderde co-assistenten duidelijker dan hun mannelijke collega's zien dat technologie een grote rol speelt in diagnostiek en medisch handelen, een aspect van de mate van onzekerheidsvermijding van de medische beroepscultuur. Eveneens zien vrouwen duidelijker dat het niet hoort om als arts onzekerheid of emotie te tonen, dat artsen hun rolgedrag dienen te beheersen, aspect van onzekerheidsvermijding.

\section{Sekseverschillen in perceptie}

- beheersing rolgedrag $\mathrm{O} 2$

- grote rol technologie $\mathrm{O} 3$

- grote rol van verpleging bij inwijdingsproces I4

Kwestie 2. Vrouwen waarderen de gepercipieerde beroepscultuur anders dan hun mannelijke collega's. Bij diverse cultuuraspecten (zie tabel) worden sekseverschillen aangetroffen in waardering van de waargenomen beroepscultuur, met name die cultuuraspecten die betrekking hebben op de mate van machtafstand en mate van femininiteit en masculiniteit van deze beroepscultuur. 
Vrouwelijke co-assistenten (op het niveau van totale groep) blijken duidelijk minder waardering te hebben voor de medische beroepscultuur op 3 variabelen van machtafstand, de symbolen waarmee de machtafstand richting buitenwacht wordt gecommuniceerd, de hiërarchische omgangsvormen van artsen onderling en de machtafstand tussen arts-opleider en co-assistent. Op deze punten blijken vrouwelijke co-assistenten meer moeite te hebben met de voorgeleefde cultuur dan hun mannelijke collega's. Ook blijken vrouwelijke co-assistenten significant afkeurender over een van de masculiene cultuuraspecten te weten de noodzaak van competitie en rivaliseren om in het medisch beroep verderop te komen. Tot slot blijken vrouwen de prominente rol van medische technologie bij diagnostiek en medisch handelen sterker af te keuren dan mannen.

\section{Sekseverschillen in waardering niveau totale groep}

\section{1. statussymbolen $\mathrm{M1}^{*}$}

2. hiërarchische omgang artsen $\mathrm{M} 2$

3. machtafstand arts-opleider en coassistent $\mathrm{M3}$

4. grote rol van medische technologie bij diagnostiek $\mathrm{O}_{3}$

5. noodzaak van competitie om in beroep verderop te komen ML2
Sekseverschillen waardering

op niveau groep 1 beginners

1. statussymbolen M1

2. respectvolle omgang van artsen onderling $R 1$

3. ruimte voor steun van artsen onderling $\mathrm{F} 1$

4. ruimte voor uiten van emoties F2

5. competitieve omgang artsen onderling ML1

6. noodzaak van competitie MI.2

7. harde aanpak bij inwijding van nieuwelingen $\mathrm{I1}$

Nadere analyse van de sekseverschillen in de subgroepen van beginnende en gevorderde co-assistenten (zie tabel $2 \mathrm{e}$ kolom) laat zien dat bij een aantal variabelen in de beginnersgroep wel een sekseverschil aanwezig is, dat niet wordt aangetroffen in de groep van de gevorderde co-assistenten. Dit bleek het geval bij alle feminiene cultuuraspecten ( zoals ruimte steun, ruimte emoties en de wenselijkheid van een luisterende en toegankelijke houding van de arts). Verder bleken vrouwelijke coassistenten uit de jongere groep (groep 1) meer waardering te hebben voor respectvolle omgang tussen artsen onderling, keurden ze competitie van artsen onderling sterker af en waarderen zij de harde aanpak van hun introductie in de medische wereld nog negatiever dan hun mannelijke collega's.

Kwestie 3. De kloof tussen waardering en waargenomen werkelijkheid is groter bij vrouwelijke co-assistenten dan bij mannelijke co-assistenten.

In de meeste gevallen blijkt de kloof voor vrouwen niet groter te zijn dan voor mannen. Uitzondering op deze regel zijn de hiërarchische omgangsvormen (onderdeel van machtafstand) en het masculiene cultuuraspect van "de noodzaak om te knokken" of te rivaliseren om loopbaan in de geneeskunde te realiseren en competitie in de omgang van artsen onderling. Vrouwen blijken bij deze drie cultuuraspecten een

${ }^{6}$ voor betekenis codes zie tabel. 
grotere kloof te ervaren tussen hun individuele waardering en de functionerende beroepscultuur.

\subsection{Samenvattend overzicht van de bevindingen}

De confrontatie met de cultuur van de medische professie biedt co-asistenten een voorbeeld van de gewenste professionele identiteit. In dit beroepscultuur-onderzoek zijn de co-assistenten vooral aan het woord als "waarnemers" en "beoordelaars" van de hen omringende wereld.

Omdat het beroepscultuuronderzoek betrekkelijk omvangrijk is, zullen we beginnen met de belangrijkste resultaten, die antwoord geven op de vier vraagstellingen samen te vatten.

\section{Co-assistenten zijn op te vatten als:}

\section{1. sensitieve en opmerkzame waarnemers}

2. evaluerende beoordelaars:

- cognitief (waardering, afkeuring etc.)

- affectief (hoop, afschuw, angst, boos etc.)

3. toekomstige deelnemers aan medische stand en en spel

De perceptie van de medische beroepscultuur

De perceptie van de co-assistenten drukt uit hoe de huidige professie de professionele rol "voorleeft". Het is belangrijk zich te realiseren dat de praktijk kan verschillen van de nagestreefde of geformuleerde idealen van de professie. Voor het opleidingssysteem is belangrijk om kennis te nemen van de "uitgezonden signalen" over gewenst gedrag en normen en waarden, omdat hiervan een sterke voorbeeldwerking uitgaat. De nieuwe generatie zal zich gewild of ongewild toch voegen naar deze praktijk en zich hieraan aanpassen.

Co-assistenten die werden bevraagd over hoe de beroepscultuur eruit ziet, waarmee zij geconfronteerd worden in hun stages, rapporteren als volgt. $\mathrm{Zij}$ geven bij 11 van de 24 variabelen over perceptie van de diverse cultuuraspecten een bevestigend antwoord; bij 2 variabelen wordt een duidelijk ontkennend antwoord gegeven. Op de resterende 11 variabelen volgt een genuanceerd ja of nee of een indifferent antwoord. Ook blijkt dat de meer gevorderde co-assistenten 11 cultuuraspecten pregnanter of duidelijker waarnemen. Wanneer we het beeld van co-assistenten, zoals we dit hebben gevonden in dit onderzoek, in woorden weergegeven, kan het volgende overzicht gegeven worden. Co-assistenten blijken een cultuur zien waar symbolen als aesculaap en witte jas uitdrukking geven de status van de beroepsgroep, evenals gebrek aan tijd, omvang van de werkkamer en de beperkte mate van toegankelijkheid voor leerlingen. Deze perceptie blijkt vooral bij vrouwelijke co-assistenten toe te nemen en sterker te 
worden, naarmate ze langer in opleiding zijn. Ook nemen co-assistenten een grote mate van machtafstand tussen artsen en verpleging waar; deze perceptie blijkt eveneens bij vrouwen een toename in de loop van de stages te vertonen. De omgangsvormen van artsen onderling worden als hierarchisch getypeerd. Coassistenten ervaren een redelijk grote afstand tot hun opleiders en beschouwen ook de relatie tussen arts en patiënt als machtsongelijk. Al met al wordt de beroepscultuur van artsen door co-assistenten gezien als een cultuur met een grote mate van machtafstand.

Co-assistenten nemen ten aanzien van de dimensie onzekerheidsvermijding een grote rol van protocollen waar, naast de noodzaak om medische regels te volgen, evenals een grote appreciatie van correct gebruik van medische termen. Ook lijkt het hen noodzakelijk om als co-assistent gedrag te vertonen dat veel parate kennis verraadt. Verder nemen zij waar dat medische technologie in brede zin een grote rol speelt in het handelen van artsen. Co-assistenten nemen spot en denigrerend taalgebruik van artsen waar in lichte mate, met name in een stressvolle setting als de operatiekamer. Deze perceptie blijkt met name bij vrouwelijke co-assistenten sterker te worden in de loop van de tijd.

Medici worden gezien als een groep met een grote onderlinge loyaliteit en loyaliteit naar de beroepsgroep. Deze perceptie blijkt af te nemen wanneer co-assistenten verder vorderen in hun opleiding.

Qp de vrayg of de medische beroępscultuur als enigszins feminien gekarakteriseerd kan worden is het antwoord ontkennend. Concreet hebben co-assistenten niet de indruk dat artsen elkaar erg steunen bij persoonlijke problemen. Men leert niet om de eigen collega's te ondersteunen in geval van persoonlijke problemen, keuzen of emoties, die samenhangen met het werk.

Co-assistenten hebben de indruk dat de code heerst dat in het werk geen rekening gehouden kan worden met persoonlijke problemen en privé en werk strikt gescheiden dienen te zijn. Co-assistenten geven wel aan dat de rol van arts enige ruimte biedt om zich vrij te kunnen uiten; in lichte mate kan een co-assistent zich spontaan uiten of voor eigen ideeën uitkomen ten opzichte van artsen-opleiders. Deze perceptie wordt minder naarmate co-assistenten langer in opleiding zijn.

De kwestie of er een feminiene norm bestaat ten aanzien van de arts-patiënt relatie wordt indifferent beantwoord. Co-assistenten blijken geen duidelijk uitspraak te doen over de kwestie of de beroepsgroep laat zien door haar voorbeeld-gedrag dat een communicatieve houding, het geven van voorlichting en een luisterende en toegankelijke houding richting patiënten van groot belang zijn in de medische beroepsrol. Wel blijken gevorderde co-assistenten (en dan vooral de vrouwelijke co's) deze feminiene en communicatieve houding minder waar te nemen dan hun jongere collega's.

Competitie en zich profileren zijn naar de waarneming van co-assistenten wel degelijk nodig, wanneer men een medische carriere nastreeft. De vraag of artsen competitief met elkaar omgaan wordt noch met ja, noch met nee beantwoord. Wel blijken vooral mannelijke co-assistenten in de loop van hun co-assistentschappen deze competitieve omgang sterker waar te nemen. De vraag of de medische beroepsgroep ook duidelijke rangen en standen kent en een cultuur heeft waar "pikorde" tussen de verschillende 
groepen artsen of specialisten een grote rol speelt, wordt ontkennend beantwoord. Opmerkelijk is wel dat mannelijke co-assistenten deze pikorde sterker gaan zien naarmate ze verder vorderen in hun opleiding.

Co-assistenten zien verder een harde vorm van inwijding van nieuwelingen. Er wordt weinig rekening mee gehouden dat de co-assistent nog in opleiding is en de overgang van pre-doctoraal fase naar de fase van de co-assistentschappen is erg groot. Coassistenten hebben de indruk het inherent aan het leerproces van artsen is dat zij als co-assistenten soms teveel (medische) verantwoordelijkheid moet dragen, zoals bijvoorbeeld in acute situaties en hieraan het hoofd moeten bieden. In dezelfde lijn met het voorgaande nemen co-assistenten ook waar, dat nieuwelingen in de kliniek nauwelijks op hun gemak worden gesteld, of snel worden opgenomen in het medisch team en zich snel thuis gaan voelen in de verschillende stageplaatsen.

Co-assistenten bevestigen het beeld dat zij deze positie moeten waarmaken en weinig steun en support ontvangen van de zijde van hun opleiders. Het maken van fouten en stellen van domme vragen wordt door co-assistenten als riskant ervaren vanwege de kans op afkeuring door de opleiders of het risico om "af te gaan". Dit geldt ook voor situaties waarin co-assistenten blijk moeten geven van voldoende parate kennis, zoals het houden van voordrachten of praatjes voor de medische staf. Verder worden artsassistenten en stafleden, die in de praktijk de begeleiding van co-assistenten invullen, als weinig toegankelijk ervaren bij vragen om medisch inhoudelijke toelichting of bij behoefte aan feedback of beoordeling van verricht werk. Volgens mannelijke coassistenten speelt de verpleging nauwelijks een duidelijke rol in hun inwijdingsproces, volgens vrouwelijke co-assistenten wel. Vrouwelijke co-assistenten zien dit in de loop van de tijd nog sterker.

Ziekenhuizen hebben in de ogen van co-assistenten een technische uitstraling en artsen zijn door uiterlijke kenmerken als stethoscoop of medisch zakboekje duidelijk te onderscheiden van andere disciplines die werkzaam in de gezondheidszorg zijn.

\section{Weinig verschillen in perceptie tussen vrouwelijke en mannelijke co-assistenten}

Bij slechts 3 variabelen (van 24) werd een verschil gevonden ten aanzien van de percepties van vrouwelijke en mannelijke co-assistenten. De drie variabelen zijn "beheersing rolgedrag" en "grote rol van de medische technologie", beide aspecten van de cultuurdimensie onzekerheidsvermijding(O2 en $\mathrm{O} 3$ ) en de rol van de verpleging bij het inwijdingsproces van nieuwelingen. Vrouwen blijken in deze drie gevallen steeds het beschreven cultuuraspect sterker waar te nemen dan hun mannelijke collega's.

\section{Een uitgesproken evaluatie en waardering van de beroepscultuur door co-assistenten}

Op de eerste plaats blijkt het waardeoordeel van co-assistenten bij nagenoeg alle cultuuraspecten die in dit onderzoek aan de orde zijn gesteld fors af te wijken van het voorbeeld dat wordt aangetroffen in de dagelijkse praktijk. Het concept van socialisatie als het in overeenstemming brengen van het normen en waarden- patroon van het individu met dat van de omringende cultuur (Veldman \& Witting 1990) wordt dan ook bevestigd.

Co-assistenten hebben uitgesproken oordelen over de beschreven cultuuraspecten. Over 17 variabelen (van in totaal 24 variabelen) bestaat een duidelijk positief (score kleiner 
of gelijk aan 2.1) of negatief oordeel (score groter of gelijk aan 2.8); over de resterende 6 variabelen is wordt een indifferent oordeel geveld.

Afgekeurd door co-assistenten;

"onwenselijk" (9 variabelen)

-statussymbolen M1

hiërarchie artsen onderling M2

beheersing rolgedrag $\mathrm{O} 2$

spot en cynisme $\mathrm{O} 4$

-competitieve omgang artsen onderling ML.1

-rangen en standen ML3

-onderscheid maken onder co-assistenten ML4

-harde aanpak nieuwelingen II

-in diepe gooien nieuwelingen 12
Goedgekeurd door co-assistenten;

"wel wenselijk" (8 variabelen)

-geringe machtafstand arts-co-assistent M4 -geringe machtafstand arts-patiënt M5 -respectvolle omgang artsen onderling R1 -loyaliteit artsen onderling L1

-ruimte voor steun artsen onderling F1

-ruimte voor uiten van emoties F2

-norm van luisterende, toegankelijke arts F3

-zachtere anpak bij inwijding I3

Het lijkt erop dat de culturele aanpak waarmee de medische professie het probleem van de intrinsieke onzekerheid, waarmee het medisch handelen verbonden is, oplost de nieuwe generatie artsen minder moeite kost dan de andere cultuuraspecten. Een verklaring hiervan zou kunnen zijn, dat een co-assistent mogelijk nog meer dan een arts die de opleiding heeft afgerond, kampt met diverse vormen van onzekerheid. Naast de basale onzekerheid, die het gevolg is van de onvoorspelbaarheid van beloop van ziekten en dysfuncties en de onzekere uitkomsten van het medisch handelen, waar alle artsen mee moeten omgaan, kampt een co-assistent ook nog met onzekerheid ten gevolge van diens wankele professionele status (weet ik wel genoeg, wordt ik wel geaccepteerd, gedraag ik mij wel zoals een arts betaamt ?) Onderbouwing van het medisch handelen door "objectieve" informatie en protocollen die het medisch handelen sturen, geven een individuele arts meer houvast. Dit wordt mogelijk door een aankomende arts nog sterker gewaardeerd dan door een meer ervaren arts.

Men kan constateren dat de confrontatie met de realiteit van de medische professionele wereld, vooral een confrontatie is op het vlak van de eigen normen en waarden. In andere woorden, wanneer men op het niveau de subjectieve identiteit een onderscheid zou willen maken in een emotioneel of voelend zelf (1), een denkend of cognitief zelf (2) en een evaluerend of normatief zelf (3), zoals Keizer (1997) in haar dissertatie deed, dan blijkt uit dit onderzoek dat met name het normatieve-zelf van co-assistenten onder druk staat.

De verschillen in evaluatie of waardering van de aangetroffen cultuur tussen de seksen Er blijken over het geheel genomen minder sekseverschillen aanwezig te zijn dan aanvankelijk werd gedacht. Het valt op dat met name bij de cultuuraspecten, die machtsongelijkheid betreffen en die betrekking hebben op feminiene en masculiene cultuuraspecten, de beoordeling van de seksen onderling sterk verschilt. Vrouwen keuren dat in de genoemde gevallen de bestaande cultuur sterker af ( 5 variabelen tonen significante verschil man/vrouw op niveau van de totale groep). Concreet laten 
statussymbolen, hierarchische omgang van artsen onderling en ervaren grotere machtafstand tussen arts-opleider en co-assistent een verschil in waardering zien tussen de seksen. Daarnaast keuren vrouwen de rol technologie bij medische diagnostiek en de noodzaak van competitie sterker af dan hun mannelijke collega's.

Over het geheel genomen valt op dat in de groep beginnende co-assistenten (groep 1) vaker significant sekseverschil wordt gevonden dan in groep 2. Deze verschillen bevinden zich met name bij de variabelen die betrekking hebben op "feminiene cultuuraspecten". Men kan zich afvragen of deze bevindingen wijzen op een socialisatie effect in die zin dat de affiniteit van vrouwelijke studenten met feminiene cultuuraspecten vermindert in de loop van de co-assistentschappen.

\section{De kloof tussen wens en werkelijkheid}

Uit ons onderzoek blijkt dat deze kloof (tussen perceptie en waardering) bij nagenoeg alle onderzochte cultuuraspecten groot en significant is, behalve bij 2 cultuuraspecten namelijk die waarbij het de machtafstand van artsen tot de verpleging betreft (M3) en waarbij het gaat over de rol en betekenis van protocollen voor de medische beroepsuitoefening (O1). Bij deze twee cultuuraspecten treffen we de relatief bijzondere situatie aan dat co-assistenten de voorgeleefde cultuur als acceptabel ervaren; de voorgeleefde cultuur ten aanzien van machtsongelijkheid ten opzichte van de verpleging en de praktijk van standaardisering in protocollen van het medisch handelen houdt voor co-assistenten geen grote confrontatie in met hun eigen normen en waarden. Verder komt de waargenomen werkelijkheid dus zelden overeen met het eigen waardeoordeel. Vooral bij de dimensies "mate van machtafstand, masculiniteit en feminiteit" is sprake van een grote kloof tussen wenselijk geachte situatie en de waargenomen praktijk van alledag.

Wanneer we deze kloof tussen voorbeeld of voorgeleefde werkelijkheid en individuele waardering als indicatie opgevatten voor de "zwaarte" of moeilijkheidsgraad van de socialisatie-opdracht voor de individuele co-assistent, dan blijken dus vooral die cultuuraspecten die betrekking hebben op het omgaan met machtsongelijkheid en de feminiene en masculiene cultuuraspecten moeilijk te zijn voor de nieuwe generatie. Vooral de bierarchische omgangsvormen van artsen onderling blijken co-assistenten voor een forse moeilijkheid te plaatsen, evenals de competitieve omgang van artsen onderling en de noodzaak van competitie en individuele profilering voor een medische loopbaan of carriere. Voor vrouwelijke co-assistenten blijken de hierarchische omgangsvormen van artsen onderling en de "noodzaak van competitie" nog moeilijker te liggen dan bij hun mannelijke collega's.

\section{De veranderingen in de loop van de co-assistentschappen.}

Door verschillen tussen beginnende en meer gevorderde co-assistenten te bestuderen, hebben we meer zicht gekregen op de verschuivingen die in de loop van de tijd optreden. We vooronderstelden dat assimilatie aan de beroepcultuur in de loop van de tijd wel een verandering op de dimensie "waardering" zou laten zien. Uit het onderzoek blijkt dat er wel verschuivingen in de tijd optreden, maar dat deze anders zijn dan verwacht. Met name de perceptie van co-assistenten blijkt te veranderen en niet de waardering. Gevorderde co-assistenten blijken diverse aspecten van de 
beroepscultuur duidelijker waar te nemen, ze nemen deze karakteristieken als het ware pregnanter waar. Dit geldt met name voor dimensies van machtafstand, feminiene cultuuraspecten en enkele masculiene cultuuraspecten. De masculiene aspecten worden door mannelijke gevorderde co-assistenten duidelijker gezien. De aspecten van macht worden vooral door vrouwelijke gevorderde co-assistenten duidelijker gezien. De geringe mate van feminiteit van de medische beroepscultuur wordt door beide seksen duidelijker gezien, naarmate ze verder gevorderd zijn in hun socialisatie.

Dit resultaat heeft onze aanname dat socialisatie en assimilatie aan de beroepscultuur in de loop van de tijd de waardering zou beïnvloeden, ondergraven. De enige uitzondering in dit verband wordt gevormd door de culturele norm van een attitude van "toegankelijkheid en luisteren" als arts in de arts-patiënt relatie. De waardering hiervoor blijkt bij vrouwelijke co-assistenten af te nemen in de loop van de tijd.

De verandering bij co-assistenten in de loop van de tijd van het socialisatieproces blijkt in eerste instantie meer het denkend of cognitieve niveau te beïnvloeden en minder het normatieve niveau. De bevindingen duiden erop dat co-assistenten vooralsnog in hun waardeoordelen betrekkelijk constant blijven gedurende hun coassistenten-periode.

Uit het onderzoek blijkt dat bij de meeste variabelen geen verschil tussen beginnende en meer gevorderde co-assistenten bestaat. Wanneer dit wel het geval is, blijkt de kloof twssen wens en werkelijkheid bij gevorderde co-assistenten groter te zijn dan bij hun minder gevorderde collega's. Een grotere kloof bestaat bij gevorderde coassistenten bij cultuuraspecten als statussymbolen, loyaliteit van artsen onderling, uitingen van spot en cynisme en competitieve omgang van artsen met elkaar en de noodzaak van competitie om een medische loopbaan naar wens te kunnen realiseren. Vrouwelijke en mannelijke gevorderde co-assistenten hebben beide moeite met de mate van respect en mate van competitie, die hen wordt "voorgeleefd" door de huidige professie.

\subsection{Beschouwing}

De praktijk die wordt voorgeleefd door de professie in de opleidingssetting, representeert het beeld van professionaliteit van de huidige beroepsgroep. Het kan worden opgevat als "de inhoud van de boodschap" van de professie aan de nieuwe generatie over professionaliteit. Professionaliteit stelt Keizer (1997) is gedrag dat men ten toon moet spreiden en aan de omgeving laten zien en laten beoordelen, maar het is ook verinnerlijkte norm - men beoordeelt zichzelf impliciet of expliciet op grond van de eigen gedachten over professionaliteit.

Het beeld van professionaliteit dat co-assistenten ontwikkelen op basis van hun impressies in de periode van de klinische stages, blijkt (uit ons onderzoek) gekleurd door hiërarchie en machtsongelijkheid en niet door feminiene gedragscodes en omgangsvormen, die samenwerking en onderlinge steun van artsen onderling ademen Codes voor onderlinge omgang van artsen met elkaar en met aspirant artsen blijken veeleer kenmerkt door onveiligheid en competitieve elementen. Dit beeld van 
professionaliteit zal op symbolisch niveau functioneren als ijkpunt voor zelfevaluatie van co-assistenten en als maat waarlangs co-assistenten en artsen zichzelf en elkaar beoordelen.

In dit verband is het interessant te wijzen op het onderzoek van Keizer (1997) naar professionaliteit en het professionele ethos, dat in een aantal klinische specialismen (o.a. chirurgie, gynaecologie, kindergeneeskunde) dominant is. Dit werk biedt aanknopingspunten om de effecten van assimilatie van vrouwen en mannen aan de huidige beroepscultuur verder te doordenken.

Keizer ontdekte in haar onderzoek een ideaal-opvatting van professionaliteit, die zij omschrijft met de term controlerende professionaliteit en die denken, voelen en handelen van klinici vergaande beïnvloedt. "Men moet als het ware alles weten, om overal zeker van te kunnen zijn“ lijkt in deze professionaliteit de onderliggende gedachte te zijn. Dit beroepsethos, door andere auteurs ook wel "esprit de corps" genoemd is als het ware de groepsnorm waaraan nieuwelingen worden afgezet.

Deze controlerende patiënt-gerichte professionaliteit houdt een streven naar perfectie in en naar het zelf onder controle houden van de situatie in alle fasen van het contact met de patiënt. Ook houdt deze professionaliteit de eis in van algehele beschikbaarheid voor het beroep en een sterke afkeuring van een nuancering van deze beschikbaarheid vanwege andere affiniteiten of sociale plichten.

Deze dominante professionaliteit is volgens Keizer (1997) doortrokken van symbolische, normatieve en persoonlijke gender-aspecten. Keizer wijst in dit verband op het autonomie-ideaal dat ten grondslag ligt aan het ideaal van de controlerende professionaliteit, een ideaal waarin een drang tot beheersing en controle besloten is en dat vaak als mannelijk of masculien wordt angeduid. Ze formuleert een alternatieve professionaliteit, die zij als relationeel aanduidt en die met de voorgaande ideaal contrasteert (Keizer 1997, p 248).

Deze relationele professionaliteit, die uitgaat van meer gelijkwaardigheid tussen arts-en patiënt en deze relatie opvat als een samenwerkingsrelatie waarin de arts kennis en expertise inbrengt en de patiënt ervaringskennis, vertrouwen en coöperatie, berust op een ander autonomie ideaal dat vaak als feminien wordt aangeduid. Dit ideaal behelst een "ik" en een "ander" die steeds op elkaar betrokken zijn, waarin steeds weer een evenwicht wordt gezocht tussen altruïsme en egoïsme, intimiteit en onafhankelijkheid van de ander en de omgeving.

Wat betekenen de bevindingen uit het beroepscultuuronderzoek voor het socialisatieproces van vrouwelijke studenten?

Fahrenfort (1985) beschrijft de confrontatie met de medische cultuur als een proces van inlijving en medicalisering, een proces dat grotendeels onvermijdelijk verloopt. Er is sprake van sociale dwang, die de nieuwelingen noopt een vorm van aanpassing aan het medisch systeem te vinden. Het gegeven dat de co-assistent zich op de laagste sport van de medische rangorde bevindt, beperkt diens mogelijkheden om zich te verzetten tegen de sociale druk van de omgeving (de Vries, 1988).

Keizer werkt als voorbeeld van een bepaald professioneel ethos het beeld van de "typische chirurg" uit. Dit professionele ethos dat ze omschrijft als een gestandaardiseerd systeem van emotionele attitudes en eigenschappen, is kenmerkend 
voor een beroepsgroep (Cassell,1987) en heeft invloed op selectie en zelfselectie. Het beroepsethos van chirurgen zou eigenschappen bevatten als lef, arrogantie, behoefte aan zekerheid en aan positieve feedback en een houding die sterker gericht is op doen dan op denken. Als co-assistenten in de stage chirurgie dit ethos als dominant patroon leren kennen, is de kans groot dat hun loopbaanwensen hierdoor beïnvloed worden. Ook zullen aanstaande chirurgen zich meer of minder bewust aanpassen aan dit beroepsethos.

Het gegeven dat vrouwelijke co-assistenten een aantal cultuuraspecten sterker afkeuren, zoals de noodzaak van competitie en rivaliseren, de hiërarchie en machtsongelijkheid in de verhoudingen van artsen onderling en met verpleging en patiënt, leidt tot de vraag of het inwijdingsproces vrouwelijke co-assistenten zwaarder valt dan hun mannelijke collega's. Betalen de seksen een andere prijs voor assimilatie aan de medische beroepscultuur? Zouden vrouwelijke nieuwkomers meer dan mannen innerlijk in verzet komen, omdat de voorgeleefde cultuur hen meer bevreemdt? Haken ze vaker psychisch af en daalt hun motivatie en "commitment" aan het medisch beroep of passen zij zich juist heel sterk aan aan de beschreven cultuur en worden ze "roomser dan de paus" (Veldman \& Witting, 1990).

Om meer zicht te krijgen op de effecten van de onderdompeling in de medische cultuur van vrouwen en mannen, hebben we een tweede onderzoek uitgevoerd dat de co-assistent als toekomstig deelnemer centraal stelt. Hoe veranderen vrouwelijke en mannelijke nieuwkomers onder invloed van deze onderdompeling?

In het tweede grote empirische onderzoek, het socialisatie-onderzoek genaamd, zullen we recente inzichten betrekken over de wijze waarop structuren en culturen van (werk)organisaties ongelijkheid tussen de seksen bekrachtigen en herhalen. Hoe werkt het collectieve niveau door op de psychologische bagage en de interactiepatronen in de opleidingssetting en daarmee op de identiteit van de nieuwe generatie dokters ? Deze kwestie wordt nog dringender wanneer men bedenkt dat momenteel grote getale vrouwelijke studenten en artsen worden opgeleid, beoordeeld en geselecteerd in de beschreven professionele cultuur, die door mannen is opgericht en die voornamelijk mannelijke helden koestert.

\subsection{Methodische kanttekeningen}

In dit onderzoek werd cultuuroverdracht onderzocht in een transversale survey. Om meerdere redenen werd gekozen voor een kwantitatief design. Ten eerste zijn er al diverse meer kwalitatieve studies verricht naar medische beroepscultuur waarop in deze studie voortgeborduurd kon worden (Becker \& Geer,1961; Coombs,1978; Fahrenfort,1985; keizer,1997). Verder bestaat in de medische wetenschap een grote voorkeur voor kwantitatieve onderzoeksmethoden, die een grotere mate van generaliseerbaarheid kennen. De absorptie van resultaten van kwalitatief onderzoek blijft in de medische professie vaak laag. Tegelijkertijd is er grote behoefte aan een meer samenhangende en integrale kijk op het leerproces in de co-assistentschappen (ICRA,1996).

Derhalve werd gepoogd om het betrekkelijke "softe" begrip beroepscultuur in meetbare termen te operationaliseren. Om de kloof tussen theorie en empirische 
specificatie te overbruggen werden theoretische concepten vertaald in operationele concepten. Bij het ontwikkelen van deze operationele concepten, die langs inductieve weg tot stand kwamen, speelde creativiteit en inventiviteit een grote rol. Hiermee is de kracht maar ook de zwakke kant van dit onderzoek aangegeven. De diverse operationele concepten zijn niet uitputtend en zullen mogelijk niet altijd de reikwijdte van de cultuurdimensie dekken.

In dit onderzoek werden percepties en waardering onderzocht van een steekproef van de populatie medische studenten van de Universiteit Maastricht die ten tijde van het onderzoek bezig waren met de klinische stages. Deze steekproef van 138 studenten vormt meer dan $45 \%$ van de totale Maastrichtse populatie $(\mathrm{N}=300)$ en kent een lichte oververtegenwoordiging van vrouwelijke co-assistenten en van gevorderde coassistenten. De resultaten op het niveau van de totale groep zullen door deze verdeling beïnvloed zijn. Omdat echter aangenomen mag worden dat de antwoorden van gevorderde co-assistenten zijn gebaseerd op een ervaringen in meerdere vakgebieden en niet slechts gekleurd zijn door indrukken van een enkele stage en omdat in dit onderzoek vooral de vergelijking van de seksen met elkaar centraal staat, zijn deze bezwaren relatief.

Over de kans van selectie-bias in het proces van werving kan opgemerkt worden dat bij de werving voor het oorspronkelijke bestand een selectie kan zijn opgetreden op grond van affiniteit met loopbaan-kwesties. Uit dit bestand werden alle co-assistenten $(\mathrm{N}=158)$ aangeschreven en namen 138 co-assistenten deel door de vragenlijst te retourneren, hetgeen een respons van $87 \%$ betekent. De non-respons groep (13\%) werd niet nader onderzocht, waardoor selectie-bias niet met zekerheid kunnen worden uitgesloten, maar vanwege de hoge respons mag worden aangenomen dat de impact hiervan gering is.

Om uitspraken te doen over veranderingen in de tijd en socialisatie-effecten hebben we nu onze toevlucht genomen tot de vergelijking van groepen beginnende en meer gevorderde co-assistenten. Longitudinaal onderzoek is echter betrouwbaarder.

Bij de vraag of de resultaten gegeneraliseerd mogen worden naar co-assistenten in Nederland, moet eerst overwogen worden welke invloed uitgaat van de aparte inrichting van het pre-doctoraal onderwijs volgens het Maastrichts onderwijs model (probleemgestuurd groepsonderwijs). Uit vergelijkend onderzoek onder co-assistenten in van de universiteiten van Nijmegen en Maastricht bleek dat de aanvankelijke verschillen tussen studenten uit beide onderwijssettingen, in de fase coassistentschappen verdwenen waren (Franssen \& Persoon et al, 1982) Omdat de inrichting en aanpak in de fase van de klinische stages minder verschillen tussen de universiteiten in Nederland laat zien, nemen we aan dat deze resultaten ook generaliseerbaar zijn naar de totale groep co-assistenten in Nederland.

Het zou evenwel zeer aan te bevelen zijn om een dergelijk onderzoek naar beroepscultuur te herhalen in een longitudinaal design met een steekproef, die wordt samengesteld uit co-assistenten uit de verschillende medische faculteiten en representatief is voor totale populatie co-assistenten, die nu in Nederland geneeskunde studeert. Een andere reden voor herhaling van onderzoek met dit instrumentarium is gelegen in het feit dat gegevens van dit type mogelijk snel verouderen 
(dataverzameling 1991). De samenstelling van de beroepsgroep verandert in snel tempo, ze vervrouwelijkt, de maatschappelijke opvattingen over genderrollen veranderen evenals de opvattingen over aard en kwaliteit van medische zorg.

\subsection{Aanbevelingen voor vorming en opleiding van jonge artsen}

De maatschappelijke veranderingen blijken de medische professie niet geheel onberoerd te laten. In het verlengde van een verschuivende vraag in medische zorg in die richting van meer care, meer patiënt-vriendelijkheid, meer noodzaak voor een heldere en transparante arts-patiënt communicatie, ziet men ook in de medische beroepsgroep en de medische faculteiten hernieuwde bezinning op het profiel van de basisarts 7 . Er blijkt een grote behoefte te bestaan aan een meer integraal en samenhangender perspectief om na te denken over het leerproces in de coassistenschappen of klinische stages. In een wetenschappelijke opleiding tot arts dient niet alleen aandacht te worden besteed aan de intellectuele vorming van de student, stelt een gezaghebbend gremium (VSNU, 1997). De ontwikkeling van algemene vaardigheden die van belang zijn voor de latere beroepsuitoefening moeten expliciet deel uitmaken van het curriculum, aldus een recente beoordeling van de kwaliteit aan Nederlandse medische faculteiten (VSNU, 1997). Kritische noten worden nog opnieuw geplaatst over de kwaliteit van de begeleiding van co-assistenten. "Bij alle opleidingen wordt de dagelijkse begeleiding van co-assistenten als wisselend beoordeeld. Het is sterk afhankelijk van het co-assistentschap, de inzet van de begeleider en de assertiviteit van de co-assistent.

Vaak geschiedt de begeleiding door een arts-assistent. Treft een co-assistent het niet, dan krijgt hij te maken met een begeleider die pas is begonnen aan een vervolgopleiding en die, begrijpelijkerwijs, weinig tijd voor begeleiding zal willen en kunnen vrijmaken. Ook kan een jonge arts-assistent geen voorbeeldfunctie in een eigen stijl van klinische beroepsuitoefening vervullen. Bij geen van de faculteiten kan de dagelijkse begeleiding aan de minimumeisen van de commissie voldoen.”

Ook stelt de commissie dat het bij alle opleidingen schort in meerdere of mindere mate aan attitudevorming, wetenschappelijke vorming, vorming in zelfstandig klinisch handelen en scholing in algemene vaardigheden, die in de arts-patiënt relatie van belang zijn. De commissie stelt verder dat de opleidingen vaak hun eindtermen formuleren als "vaardigheden", maar men moet constateren dat deze term nog teveel als een containerbegrip functioneert. "Wordt gedoeld op cognitieve - of psychologische vaardigheden, op manuele- of communicatieve of nog andere vaardigheden" (VSNU, 1997).

In dit proces van herbezinning mogen ook "attitude -aspecten" van artsen zich weer verheugen in een levendige aandacht. Sommige faculteiten gaan er zelfs toe over studenten en co-assistenten te onderwerpen aan een beoordelingsproces van hun attitude. Maar ook het "attitude-begrip" wordt in medisch onderwijs vaak ingezet, als

7. Metz et al (1994) Raamplan;

ICRA (1996) Het artsexamen, eindrapport van de interfacultaire commissie richtlijnen artsexamen

VNSU (1997) Onderwijsvisitatie genceskunde en gezondheidswetenschappen 
een "leeg" begrip zonder inhoudelijk invulling. Deze poging om voor de medische professie het begrip "cultuur" (dat door sommige als "boterzacht" wordt opgevat) te concretiseren en uit te werken, kan ons inziens van dienst zijn bij een inhoudelijke uitwerking van het begrip attitude of de bestaande uitwerkingen verrijken (Batenburg, 1977; Graat, 1995). Het is nuttig om na te denken gewoonten en vanzelfsprekendheden van artsen-opleiders, hoe deze "rolmodellen" zich gedragen, omdat dit voorbeeld cruciaal is in de vorming van cognities en attitudes van de nieuwe generatie artsen. Het onwenselijk en mogelijk zelfs risicovol, wanneer een collectief (of groep) attitudes van mensen wil beïnvloeden zonder voldoende (zelf)kennis of zicht op de "onbedoelde en onbewuste" opdrachten, die in opleiding en scholing door het eigen gedrag worden uitgezonden. Men moet zich hoeden voor "paradoxale opdrachten" aan de nieuwe generatie. Met de mond beleden idealen en doelstellingen, die niet worden voorgeleefd, beroven de nieuwe generatie van diens kritische vermogen en daarmee van diens intelligentie.

Het leereffect van "meelopen en meekijken" in een systeem, dat serieus werk maakt van reflectie op eigen geschiedenis en dynamiek, maakt meer kans om intelligente, integere en harmonische professionals te vormen dan een systeem dat de ogen hiervoor sluit. 


\subsection{Samenvatting}

Het doel van dit onderzoek was om zicht te krijgen op karakteristieken van de medische beroepscultuur, zoals deze worden waargenomen en gewaardeerd door aanstaande artsen gedurende hun inwijdingsfase in de medische beroepsarbeid en professie. De beschreven cultuurfenomenen blijken door co-assistenten veelal herkend te worden. Het beeld dat de co-assistenten opdoen van de medische professionele cultuur bij hun kennismaking met deze cultuur in de praktijk kan getypeerd worden met de termen machtsongelijk, een sterke mate van onzekerheidsvermijding, niet of nauwelijks feminien en nauwelijks masculien en met een inwijdingsritueel dat op een vrij confronterende wijze nieuwelingen laat kennismaken met de gewoonten en codes. $\mathrm{De}$ beroepscultuur van medici blijkt betrekkelijk machtsongelijk met hiërarchische omgangsvormen tussen artsen onderling, tussen artsen en verpleging en in de artspatiënt relatie. Deze grote machtsongelijkheid wordt door co-assistenten niet gewaardeerd en het sterkste door vrouwelijke co-assistenten afgekeurd. Er is een redelijk sterke mate van onzekerheidsvermijding, geoperationaliseerd als "zich moeten houden aan protocollen" en "grote rol van technologie bij diagnostiek ", hetgeen echter door co-assistenten als acceptabel en legitiem wordt ervaren. Ook de technische uitstraling van ziekenhuizen en het gegeven dat artsen door uiterlijke kenmerken, als stethoscoop en dergelijke, goed te onderscheiden zijn van andere hulpverleners wordt door co-assistenten herkend maar niet als onwenselijk beoordeeld.

Co-assistenten geven aan het onwenselijk te vinden dat de medische beroepscultuur nauwelijks feminiene cultuuraspecten vertoont.

De medische beroepscultuur kan niet als feminien worden gekarakteriseerd hetgeen door co-assistenten als onwenselijk wordt beoordeeld. Jongere vrouwelijke co's keuren dit nog sterker af dan hun mannelijke collega's en hun meer gevorderde vrouwelijke collega's.

De medische beroepscultuur is masculien in die zin van competitieve omgang van artsen onderling en de noodzaak van competitie en individuele profilering voor succes in de medische loopbaan. Deze noodzaak van competitie wordt door co-assistenten afgekeurd en roepen bij vrouwen significant sterker weerstand op.

Op de as van individu- gerichte of collectieve cultuur is geen duidelijke uitspraak te doen. Wel blijkt loyaliteit tussen artsen onderling te worden waargenomen, hetgeen door co-assistenten ook als wenselijk wordt gezien. Tot slot blijkt de manier van inwijding van nieuwelingen in de medische professie door de nieuwe generatie als weinig zachtzinnig te worden ervaren. Men voelt zich weinig gesteund en begeleid in het proces van kennismaking met de realiteit van het medisch vak.

Verder vonden wij, onverwacht, dat co-assistenten in de loop van hun co-assistentschappen veranderen in hun perceptie van de hen omringende cultuur en niet, zoals wij dachten, ten aanzien van hun waardering.

De perceptie wordt pregnanter naarmate co-assistenten verder gevorderd zijn in de coassistentschappen. Kritisch punt is dat in dit beroepscultuuronderzoek de werking van gender maar gedeeltelijk duidelijk is geworden. Dit heeft mogelijk te maken met de gekozen inspiratiebronnen (Hofstede, de Cock), waar weliswaar sprake is van 
feminiene en masculiene cultuuraspecten, maar waarin de reflectie op de machtswerking hiervan ontbreekt.

Met het denken over het leerproces in de klinische stages als proces van assimilatie aan een specifieke cultuur van een professionele groep, wordt ons inziens wel een meer integrale en meer-omvattend kader geschetst dat nuttig kan zijn bij het en verbeteren van de klinische fase van de opleiding tot arts. 



\section{DEEL III}

Dokter worden, geen onverdeeld genoegen. Het socialisatie-onderzoek 



\section{Hoofdstuk 7}

\section{De belasting van het inwijdingsproces Doel, methode en variabelen}

\subsection{Inleiding}

In de co-assistentschappen vindt de overstap plaats naar de praktijk van het medische beroep en de artsenrol. Het onderwijsmodel verspringt vrij abrupt van schools en theoretisch van aard naar een praktisch ambachtelijk model, gelijkend op het meestergezel systeem in de gilden (Van Welzen, 1978). Tijdens deze periode groeit de student/co-assistent beetje bij beetje in de artsenrol. Het is een cruciale fase wat betreft de vorming van een eigen professionele identiteit als arts (Coombs, 1978; Fahrenfort, 1985). Immers, arts worden betekent niet alleen dat men allerlei vaardigheden en medische kennis verwerft (de buitenkant van het verhaal), maar ook dat men zich de "inside-story" ofwel de medische beroepscultuur eigen maakt. Deze bestaat uit een groot aantal ongeschreven regels, wetten, normen en codes. Hoe dient een arts zich te gedragen ten opzichte van zijn/haar patiënten? Hoe dient een afgestudeerde arts zich ten opzichte van collega's te gedragen? Hoe verwerft men zich een plaats als collega? Wat is het typische vakjargon van de arts?

De arts in spé, die zich tot voor kort binnen de context van de universiteit, in de schoolbanken als het ware, betrekkelijk onbezorgd kon verdiepen in leerboek en vaardigheidstraining, dient bij aanvang van de co-assistentschappen de witte jas niet alleen letterlijk, maar ook figuurlijk aan te trekken. De nieuweling maakt bij de klinische fase de overgang van studeren naar werken, van een studentenbestaan naar dat van de jongste bediende in de medische beroepsgroep. Deze overgang blijkt voor de meesten een forse opgave. De stress en onzekerheid, het verlies van idealen en de innerlijke verwarring van co-assistenten zijn uitvoerig beschreven (Fahrenfort, 1985; Baszanger 1985; Light, 1979; Branch et al, 1990). Sommige auteurs spreken van een "cultuurshock" of "Berufseintrittshock" die zou optreden bij nieuwelingen die voor 
het eerst de realiteit van een beroep of een werkveld aan den lijve ervaren (De Vries, 1992; Sieverding, 1990).

Met uitzondering van Sieverding besteden de genoemde auteurs geen aandacht aan de impact van sekse en gender in het socialisatieproces tot arts. Wij hopen met dit onderzoek op dit punt een aanvulling te leveren.

In dit hoofdstuk wordt, na een kort overzicht van relevant geachte inzichten de aandacht gericht worden op de stress en de belasting die de co-assistentschappen voor de studenten met zich meebrengen. Dit onderzoek beoogt aanknopingspunten op te leveren voor gerichte interventies in de medische opleiding en in de medische beroepsgroep ter verbetering van het handelen van artsen en ter verbetering van de positie en ontplooiingsmogelijkheden van vrouwelijke artsen in het bijzonder.

In Nederland deed Fahrenfort (1985) kwalitatief onderzoek naar het ontwikkelingsproces van aanstaande artsen op een afdeling interne geneeskunde. De fase van de coassistentschappen wordt in haar proefschrift genaamd "Een dokters roman" beschreven als een proces van medicalisering van de medische student. De student betreedt de opleidingskliniek als leek en verlaat deze als aanstaand arts. In een sfeer van "Umwertung aller Werte" en van vervreemding, verruilt de student het lekenperspectief van identificatie van de patiënt voor het artsenperspectief. Het klimaat in het ziekenhuis beschrijft zij als een wereld van hard werken, waarin het bestaan van smatinnele heleving ontkend of gebagatelliseerd wordt. Ook ontdekt de student in de klinische fase tot haar schrik dat de mogelijkheden van de geneeskunde om mensen te genezen of te helpen betrekkelijk gering zijn.

Omdat in de praktijk van klinische stages zelden de mogelijkheid bestaat om gevoelens of ervaringen te benoemen en te onderzoeken, is de kans groot dat studenten zich sterk oriënteren op het voorbeeldgedrag van de artsen-opleiders. Daarmee samenhangend zou de innerlijke noodzaak ontstaan om afstand te nemen van lijdende mensen. Dit proces van verschuivende identificatie zou onvermijdelijk verlopen, aldus Fahrenfort (1985). Het aanleren van manieren van omgaan met de onzekerheden en emoties, ook wel attitude-ontwikkeling genoemd (Dupuis 1992), die verbonden zijn met het functioneren als arts (in de medische beroepsrol), verloopt veelal impliciet. Ook De Vries (1988) wijst in zijn onderzoek naar het leerproces in (beroepsgerichte) stages op rolspanningen en ambiguiltiteit, die structureel verbonden zijn met deze vorm van scholing. Leren in de stages, in de setting van een arbeidssituatie aangeduid met de term "training on the job", brengt rolspanningen en paradoxale opdrachten met zich mee, omdat de stagiaire zich zowel in de positie van leerling, als in die van werknemer bevindt. De stagiaire ${ }^{1}$ heeft te maken met rolzenders, die deel uitmaken van twee (grotendeels) gescheiden sociale systemen: het onderwijssysteem en het arbeidssysteem met elk eigen rolzenders (De Vries, 1988). Deze rolzenders koesteren uiteenlopende en deels strijdige rolverwachtingen. De positie van de stagiaire die als een marginale (overgangspositie) kan worden betiteld, brengt aldus antagonistische rollen met zich mee, welke een structureel rolconflict veroorzaken. Volgens De Vries treden twee type conflicten op. Het eerste type omschrijft hij als het spanningsveld

${ }^{1}$ bij voorkeur wordt de vrouwelijke vorm gebruikt 
tussen voorgeschreven verwachtingen met betrekking tot leerlinggedrag (braver, onzelfstandiger, afwachtender, afhankelijker worden) en het voorgeschreven beroepsbeoefenaar-gedrag, dat meer zelfstandigheid, autonomie en assertiviteit vraagt. Een tweede type rolconflict speelt meer op ideologisch vlak en betreft de vraag naar het gewenste beroepsgedrag oftewel "hoe het beroep eigenlijk uitgevoerd moet worden". Ook hierover zijn de verwachtingen van docenten in de universitaire setting vaak anders dan of strijdig met die van opleiders in de werksetting. Gesteld kan worden dat het socialisatieproces in stages structurele dilemma's en moeilijkheden met zich brengt die stagiaires op een of andere manier tot een oplossing moeten brengen.

Fahrenfort (1985) de Groot (1987) geven een beschrijving van de veranderingen bij coassistenten in hun proces van omgaan met (coping) en aanpassing aan de medische beroepscultuur. In dit proces van socialisatie of "medicalisering van de aanstaande dokter" wordt een reeks opeenvolgende stadia onderscheiden. Het eerste stadium zou bestaan uit identificatie met de patiënt en verzet van de co-assistent tegen de manier van handelen van de opleiders. Het tweede stadium begint wanneer de co-assistent er niet langer in slaagt zich te verzetten, maar zich nog steeds niet wil aanpassen. Een vluchtroute uit deze gespleten situatie, kan zijn het zich emotioneel terugtrekken "situational withdrawal" (Goffman 1968), de co-assistent neemt dan nog wel fysiek deel aan het gebeuren op de afdeling, maar geestelijk is men niet langer aanwezig. De identificatie met de patiënt zou in dit stadium eveneens afnemen. In het derde stadium, bet conformeren, geeft men het verzet op en aanvaardt de heersende regels binnen de professie. Dit betekent identificatie met de opleiders en kritiek op de patiënten. "De onzekerheid verdwijnt langzamerhand, om plaats te maken voor gewenning, plezier in het werk en grotere zelfstandigheid en activiteit" (Fahrenfort, 1985). Niet iedereen doorloopt alle stadia even duidelijk en in dezelfde mate. Bij de meesten is er wel een gestage evolutie herkenbaar, maar lange tijd wordt men ook tussen de verschillende stadia heen en weer geslingerd. Bovendien bestaat er ook een klein aantal co-assistenten dat zich niet, of slechts gedeeltelijk aanpast.

Fahrenfort wijst erop dat de vervreemding, waarmee de ervaring van de co-assistentschappen vaak gepaard gaat, een grote rol speelt in het socialisatie-proces. "Het afgesneden zijn van de buitenwereld door de vele uren die men in het ziekenhuis doorbrengt, de permanente kritiek die men als co-assistent te verwerken krijgt, de strenge regels, de schijnbaar doelloze handelingen en het gevoel geen inbreng meer te hebben in het eigen proces werken een gevoel van vervreemding in de hand. Men weet steeds minder wie men zelf is en waarom men dit allemaal doet. Deze factoren zouden het individu rijp maken voor de "inlijving" in de heersende beroepscultuur" (Fahrenfort 1985 , p. 212).

\subsection{De fase van de co-assistentschappen als inwijdingsritueel}

De vele beschrijvingen van het veranderingsproces en de socialisatie-ervaringen van coassistenten ondersteunen het perspectief van de fase van de co-assistentschappen als een inwijdingsritueel of een "rite de passage" (Coombs 1978, van Es 1979). Net als bij 
de inwijding in een middeleeuws gilde, een studentencorps of inheemse volkeren, worden in de fase van de co-assistentschappen barrières van psychische en fysieke aard opgeworpen die beogen om de nieuweling te testen en duidelijk te maken of deze het lidmaatschap van de groep wel verdient (Van Welzen (1978). Voorbeelden hiervan zijn het leren toepassen en beheersen van grote hoeveelheid medische kennis zonder al te veel steun van opleiders, het overwinnen van de angst voor aftakeling en voor het dode lichaam en de bereidheid om hard te werken. Wanneer de nieuweling bijvoorbeeld toont bereid te zijn om hard te werken, kan dit tevens een geïnterpreteerd worden als bereidheid tot aanpassing of offerbereidheid. De bevindingen in het be roepscultuuronderzoek, in hoofdstuk 6 (deel II) van dit proefschrift gerapporteerd, ondersteunen eveneens de conceptualisering van de co-assistentschappen als een inwijdingsfase in de medische beroepscultuur. De geïnterviewde co-assistenten van de Medische Faculteit, Universiteit Maastricht blijken het proces van introductie in de medische beroepswereld als een weinig zachtzinnige aangelegenheid te ervaren. Men voelt zich nauwelijks gesteund en begeleid in het overgangsproces van universiteit naar kliniek en heeft enigszins het gevoel in het diepe te worden gegooid.

De werking van een inwijdingsproces is dat er een soort groepsgeest ontstaat en een mate van loyaliteit naar de beroepsgroep. De gemeenschappelijke ervaring van het overwinnen van dezelfde barrières en het collectieve bewustzijn, dat een omvangrijke inspanning is geleverd, bieden een uitstekende basis bieden voor de noodzakelijke "groepsgeest" of "esprit de corps" van professionals onderling (Van Welzen 1978). Ook zouden deze collectieve ervaringen het gevoel geven te behoren tot een speciaal soort mensem, hetgeen een legitimatie vormt voor privileges voor artsen. "Making sacrifices for an organisation or group, can increase loyalty to it". Een ander mechanisme dat wordt beschreven bij inwijding is, dat een aanzienlijke sociale afstand wordt gecreëerd tussen nieuwelingen en groepsleden opdat aan het eind van de periode van beproeving en inspanning de beloning in de vorm van "nu ben je een van ons" kan worden geschonken.

Homans, Blau en Miller (1961) wijzen ook nog op het ruilsysteem dat in de medische professie de groepsgeest versterkt. Dit ruilsysteem van diensten en wederdiensten functioneert in de praktijkfase van de medische opleiding als zodanig dat co-assistent of assistent in ruil voor werkkracht, commitment en persoonlijke inzet gelegenheid tot leren krijgt. Het vertonen van grote inzet en gewenst gedrag zal vervolgens weer meer vertrouwen van artsen-opleiders genereren en daarmee de kans vergroten om meer verantwoordelijkheid te mogen dragen. Dit laatste speelt een grote rol in het groeiproces tot arts en professional. Steeds zelfstandiger als arts mogen functioneren is cruciaal voor een groeiend gevoel van competentie en professioneel zelfvertrouwen (Bucher \& Stelling 1977).

We zullen de fase van de co-assistentschappen in dit onderzoek nu verder onderzoeken vanuit het beschreven perspectief van "inwijdingsfase" en daarbij de beschrijving van van Gennep (1960) als uitgangspunt nemen. Na bestudering van talloze inwijdingsrituelen kwam deze tot de volgende karakterisering "een inwijdingsproces bestaat uit het opleggen van fysieke en psychische barrières aan de nieuweling (1), het testen van de nieuweling (2) en het vernederen en kleineren van de nieuweling (3). Dit laatste met als doel om het oude "ik" af te breken om daarna weer een nieuw "ik" op 
te bouwen. De beloning voor het doorstaan van de frustraties van zo'n traject blijkt dan gelegen te zijn in het opgenomen worden in de groep, oftewel groepslidmaatschap.

\subsection{Het concept van de gevestigden en de buitenstaanders}

Socialisatie-processen worden vooral bestudeerd vanuit het perspectief van 1) sociaal leren en 2) leren door referentiegroepen. Sociaal leren wordt als volgt beschreven. Mensen observeren anderen, zien hoe zij zich gedragen en welk gedrag belonend is. Het waarnemen van gedrag dat belonend is stimuleert tot imitatie (Bandura 1986). Sociaal leren is dus een manier van leren zonder direct zichtbare beloning. Belangrijk is dat er anderen zijn die als model fungeren, zodat gedrag wordt geïmiteerd (modeling). Doordat het model aantrekkelijk is, identificeert een groep zich met hem of haar.

Ons gedrag wordt echter ook beïnvloed door de groep waarvan we lid zijn of willen worden. Deze groepen functioneren als referentiegroepen, we vergelijken onszelf met leden van deze groep en identificeren onszelf met hen. Daardoor kunnen deze groepen meer invloed uitoefenen dan andere. Leren via referentiegroepen speelt een grote rol bij socialisatieprocessen.

De dynamiek van het veranderingsproces van co-assistenten kan onder andere begrepen worden als een vorm van leren door identificatie met de referentiegroep van de zittende medische professie. Zoals reeds eerder werd aangegeven wordt deze beroepsgroep vooralsnog gedomineerd door mannelijke beroepsbeoefenaren. Het is van verdergaande betekenis om de vraag te stellen hoe het veranderingstraject van het vrouwelijke co-assistenten zich verhoudt tot dat van hun mannelijke collega's. Deze vergelijking kan namelijk meer licht werpen op de zichtbare, maar ook op de minder zichtbare en meer verborgen vormen van reproduktie van genderongelijkheid in dit proces.

Wanneer co-assistenten leren door zich toenemend te identificeren met de leden van de medische beroepsgroep, dan kunnen zij, in termen van het concept van "de gevestigden en de buitenstaanders" van Elias, worden opgevat als relatieve buitenstaanders, die wensen toe te treden tot de wereld van de medische beroepsgroep.

De theorie over gevestigden en buitenstaanders van Elias (1985) gaat over de sociogenese van gevoelens van meer- en minderwaardigheid. Ongelijke machtsverhoudingen tussen sociale groeperingen vinden hun weerslag in de identiteit van de beide groepen: gevestigden zien hun groep en zichzelf als mensen van hogere sociale waarde, buitenstaanders oriënteren zich voor hun zelfbeeld in belangrijke mate op het beeld dat de gevestigde groep van hen heeft. Juist in sociale contexten waarin sprake is van zeer grote machtsongelijkheid is volgens Elias goed waar te nemen hoe verstrekkend de invloed is van die machtsongelijkheid op de persoonlijkheidsstructuur van mensen. Hij benadrukt dan ook het belang van figuratieverklaringen: hoe mensen over zichzelf denken - hun zelfbeeld - en hoe ze over hun eigen groep denken - hun wij-beeld - is niet alleen te verklaren vanuit het "individu" zelf, maar ook uit de figuratie, het netwerk waarvan mensen deel van uitmaken: het wij-beeld en het wij-ideaal van een persoon maken deel uit van zijn zelfbeeld en zelf-ideaal (Timmerman, 1990). 
Het gevestigden-buitenstaandersperspectief dat werd geïntroduceerd om een "universeel menselijk thema" te analyseren, namelijk dat mensen die tot machtige groepen behoren (gevestigden) van zichzelf denken dat ze "beter" zijn dan anderen en dit geloof in eigen superioriteit ook met succes weten op te dringen bij minder machtigen (buitenstaanders) is ontwikkeld door Elias \& Scotson (1976). Hun theorie werd door Timmerman (1990) toegepast in haar onderzoek naar man/vrouw interacties op de werkplek in arbeidssituaties ${ }^{2}$. Vanuit het gevestigden-buitenstaanders perspectief worden in dit onderzoek de volgende vragen gesteld: zijn vrouwelijke co-assistenten, analoog aan bovengenoemd onderzoek op te vatten meer buitenstaander dan hun mannelijke collega's? Is er sprake van een soort "dubbel" buitenstaanderschap voor vrouwen? Het antwoord op deze vraag heeft te maken met de manier waarop vrouwen hun vrouw- zijn beleven in de context van de co-assistentschappen en hoe zij hierop worden aangesproken.

\subsection{Omgaan met problematische situaties}

Wanneer we de co-assistentschappen als een uitdagende maar ook veeleisende opgave opvatten, die het individu dwingt om bepaalde moeilijkheden te overwinnen, ontstaat de vraag welke manieren het individu heeft om hiermee om te gaan.

De Vries (1988) stelt dat de oplossings-strategieën die een stagiaire ter beschikking staan om conflicterende opdrachten of rolspanningen die samenhangen met de socialisatieopdracht op te lossen, beperkt zijn. Omdat de stagiaire veelal in een ondergeschikte en tijdelijke positie verkeert, is deze zelden in staat om de eigen situatie of omgeving daadwerkelijk in de gewenste richting te veranderen. Co-assistenten, stagiaires in de geneeskunde, verkeren ten opzichte van de artsen-opleiders in een tijdelijke (duur van stages gemiddeld 2-3 maanden) en ondergeschikte positie (een meestergezelverhouding).

Ook voor co-assistenten kan gelden dat zij bij dilemma's of onvrede waarschijnlijk nauwelijks veranderingen in de omgeving kunnen bewerkstelligen via actie. Zij zullen op een problematische situatie vaak niet anders kunnen reageren dan door aan de eigen perceptie of verwerking van informatie te sleutelen. De socialisatie-opdracht van stagiaires of co-assistenten brengt volgens de Vries moeilijkheden en dilemma's met zich mee, die kunnen worden opgevat als vormen van cognitieve dissonantie, waarbij het individu een verschil ervaart tussen eigen gedrag en de eigen attitude (Festinger(1957). In een dergelijke geval kan het individu de volgende oplossings- of coping strategieën toepassen (de Vries 1988).

\footnotetext{
2 Timmermans (1990) gebruikte het denkmodel van de gevestigden en de buitenstaanders om meer zicht te krijgen op de dynamiek en interacties tussen vrouwelijke en mannelijke medewerkers op de werkvloer, waarbij de aandacht specifiek gericht was op het voorkomen van ongewenste intimiteiten. Vooral in een setting waar de getalsverhoudingen zo waren dat vrouwen slechts cen kleine minderheid waren of een setting waar een macho-cultuur bestaat (zoals op sommige afdelingen van de politie, marine) was de kans op het voorkomen van ongewenste intimiteiten reëel (Timmermans 1990, Ott 1985). Cultuur van de werkplek bleek een factor van betekenis in deze.
} 
- Aanpassing: Stagiaires passen hun opvattingen aan hun omgeving aan en nemen het voorgeleefde over. Dit gebeurt met name bij jonge mensen met weinig uitgekristalliseerde ideeën over functioneren van de beroepsbeoefenaar en arbeidsorganisatie. Ook komt het vaak voor bij organisatieculturen, waar concentratie gericht is op het overbrengen van vaktechnisch handelen van beroep/functie en waar collega's het overbrengen van attitudes niet belangrijk vinden.

- Verdringing: De stagiaire kiest ervoor de kwestie te verdringen door het onderwerp minder belangrijk te vinden en slaagt erin de eigen denkbeelden naar de achtergrond te schuiven. Deze strategie vergemakkelijkt het volgen van de stage.

- Uitstellen: De stagiaire stelt de kwestie uit. Men is zich bewust van de discrepantie tussen ideaal en werkelijkheid en van de onmogelijkbeid om in deze positie iets aan de omgeving te veranderen en kiest ervoor het veranderen van de omgeving "in gedachten" uit te stellen: "Later als ik echt klaar ben, dan zal ik het anders gaan doen".

- Verzet: De stagiaire komt in verzet tegen de omgeving.

De Vries (1988) vindt in zijn onderzoek dat bij stagiaires vooral de strategie van verdringing en uitstellen plaatsvindt ${ }^{3}$.

Uit onderzoek naar de relatie tussen stress en gezondheid (Huijbers 1992) komt naar voren dat de vatbaarheid voor ziekten sterk wordt beïnvloed door de manier waarop mensen met belastende omstandigheden omgaan. De reacties van mensen op stressvolle gebeurtenissen, zoals ingrijpende "life events", maar ook op dagelijks terugkerende problemen en moeilijkheden, worden samengevat onder de termen "coping gedrag, copingstijl of probleemoplossend vermogen". Copingstijlen worden omschreven als actiegerichte en intrapsychische pogingen om te kunnen omgaan met omgevingseisen en innerlijke eisen en de conflicten hiertussen, welke iemands persoonlijke "resources" of hulpbronnen zwaar op de proef stellen of overschrijden.

Effectieve coping strategieën zoals informatie-zoeken (monitoring), emotionele controle en positief zelfbeeld, kunnen het probleem en de stress verminderen. Minder effectieve strategieën als angst, inaktiviteit of risicovol gedrag kunnen het probleem vergroten.

Lazarus (in Schreurs, 1984), een grondlegger van het denken over omgaan met problemen of problematische situaties, onderscheidt hieraan een proces van "appraisal", een wijze van interpreteren en evalueren door het individu en een manier van gedrag of "coping", waarmee gedoeld wordt op de (re)acties van het individu. Men onderscheidt een aantal vormen van "omgaan met" problemen namelijk:

1) direct gericht op het probleem;

\footnotetext{
'De Vries noemt een sterke accentuering van het vaktechnische handelen en geringe aandacht voor de communicatieve en relationele aspecten van het beroep als aspecten die de kans op "verdringen en uitstellen" als coping stategie vergroten. De beroepscultuur van de medische professie kent eveneens een sterke nadruk op de vaktechnische aspecten en minder op communicatie en relationele aspecten (zie hoofdstuk 5 en 6). Hoewel er sterk gepleit wordt voor meer aandacht aan communicatie en attitudeaspecten, is de hoeveelheid opleidingstijd in de coassistentschappen, die hieraan besteed wordt momenteel erg gering (Raamplan 1984).
} 
2) gericht op de beïnvloeding van de perceptie en evaluatie (door interpretatie van de situatie te veranderen, door defensiemechanismen, selectief waarnemen en dergelijke);

3) gericht op directe arousal-reductie zoals roken, drinken, ontspanning zoeken, biofeedback (symptom directed palliatieve modes of coping).

Coping is te verdelen in een coping reactie, een actie, gedachte, verbalisatie of gevoel, dat wordt opgeroepen door een stressor en coping resources, de aspecten van de externe of innerlijke omgeving van een individu, die nauwelijks onder controle van het individu zijn, zoals zelfbeeld, support-systeem, demografische en sociaal-economische aspecten en vroegere ervaringen. Het type coping respons wordt mede bepaald door de coping resources die beschikbaar zijn voor het individu. De aanwezigheid van gunstige coping resources vergroot het bereik van de effectiviteit van de coping respons. Coping werkt als buffer tussen "life stress" en ziekte.

Een persoon kan diverse vormen van coping tegelijkertijd of na elkaar inzetten. Op voorhand is ook niet uit te maken, welke manier van coping effectief is; vermijding kan op korte termijn effectief zijn, maar op langere termijn niet. Effectiviteit van de copingstijl is dus oa. afhankelijk van context en van beoogd doel, maar ook van motivatie en beschikbare hulpbronnen, zoals bijvoorbeeld sociale steun.

\subsection{Probleemstelling en vraagstellingen}

In dit onderzoek zal het perspectief van inwijding empirisch worden onderzocht met als probleemstelling de aard en mate van belasting, waarmee dit inwijdingsritueel in de professionele cultuur van medici gepaard gaat. Om deze problematiek te bestuderen, introduceren we de begrippen draaglast en draagkracht en outcome. De uiteindelijke outcome wordt opgevat als maat voor de ervaren belasting die uitgaat van de co-assistentschappen.

Omdat we het inwijdingsproces, dat in de co-assistentschappen zijn beslag krijgt, opvatten als het opleggen van fysieke en psychische barrières aan de nieuweling, het testen van de nieuweling en het vernederen en kleineren van de nieuweling, zullen we deze aspecten in een empirisch design onderzoeken. Met de term draaglast wordt gedoeld op de "burden", oftewel op datgene wat de co-assistent als belastend of stresserend ervaart. Draaglast heeft in dit onderzoek betrekking zowel op stressoren als op aspecten van bejegening van de nieuwkomer door de opleidende professie. Bronnen van stress die vaak worden genoemd in verband met co-assistenten en artsen in opleiding zijn stress ten gevolge de inhoudelijke, academische eisen (zoals problemen met de hoeveelheid leerstof), de stress in verband met (mondelinge) examens en de opbouw van het curriculum, het tekort aan sociale contacten, een tekort aan vrije tijd en tijd voor familie en vrienden en gevoelens van inadequaatheid en ongeschiktheid (Bowman \& Allen 1985). Deze zaken kunnen het zelfbeeld van studenten zodanig negatief beïnvloeden dat dit effect kan hebben op motivatie en leervermogen van de toekomstige artsen (Bowman, 1985; Baneke, 1987; Batenburg, 1995).

De outcome of mate van belasting vormt de resultante van draaglast en draagkracht. Het is aannemelijk dat co-assistenten met een adequate copingstijl, een voldoende 
mate van sociale steun of andere (de persoonlijke weerbaarheid versterkende) kenmerken minder vermoeidheid of gezondheidsklachten ervaren dan studenten, die deze zaken ontberen. Naast ervaren vermoeidheid is ook de motivatie en het beeld dat men ontwikkelt over het artsenberoep een parameter van outcome.

De draagkracht wordt opgevat als een indicator van weerbaarheid en stressbestendigheid en wordt verkend door preferente copingstijlen, assertiviteit en eventuele examenvrees te onderzoeken.

Wanneer we nu dus stilstaan bij de kwestie of nieuwelingen tijdens hun entree in het medisch beroep daadwerkelijk fysieke of psychische barrières ervaren, of ze zich op de proef gesteld voelen of denigrerend en negatief bejegend, zullen we antwoord krijgen op de vraag of ze uiteindelijk vermoeid en uitgeput, of juist gemotiveerd en uitgedaagd en goed uit deze fase tevoorschijn komen. Hierbij zijn we vooral geïnteresseerd in de vraagstelling of aard en mate van belasting anders is voor vrouwelijke co-assistenten dan voor mannelijke co-assistenten.

De vraagstellingen die wij in dit onderzoek onderzoeken, luiden:

I. Welke ervaringen doen medische studenten op tijdens de fase van co-assistentschappen?

- Is er sprake van verschillen tussen de onderscheiden subgroepen?

- Is er sprake van verschillen tussen vrouwelijke en mannelijke co-assistenten?

II. Treden er veranderingen op bij medische studenten tijdens de fase van de coassistentschappen?

- Zijn de veranderingen in de tijd verschillend bij de beide seksen?

- Zijn de veranderingen in de tijd anders in de onderscheiden fasen 0,1 en 2?

III. Spelen andere achtergrondvariabelen dan sekse en subgroep een rol bij de verklaring van de bevindingen?

\subsection{Model van draaglast, draagkracht en outcome.}

De vraagstellingen worden onderzocht aan de hand van de onderscheiden thema's draaglast, draagkracht en "outcome" in termen van motivatie en vermoeidheid, die elk een aantal onderscheiden aspecten bevatten (zie model).

\section{Model}

DRAAGLAST

- belastende aspecten van stages

- stressoren

- spot of denigrerende bejegening

OUTCOME in termen van ervaren belasting

- vermoeidheid

- gezondheidsklachten

- motivatie

DRAAGKRACHT

- copingstijlen

- attitude-aspecten 
In de literatuur worden onregelmatige diensten en slaaptekort, hoog werktempo, onderbezetting, opgesplitst werk of hiërarchische verhoudingen, stress door bezuinigingen en stijgende werkdruk, onderbetaling, lage status, beschreven als veel voorkomende belastende factoren bij mensen in de verplegende en verzorgende beroepen (Overbosch, 1989). Schaufeli (1992) noemt ook een geringe mate van autonomie en intensieve en emotioneel belastende contacten met patiënten als belastend voor werkers in de gezondheidszorg.

Specifiek voor co-assisstenten worden als stressoren gebrek aan slaap en gebrek aan vrije tijd beschreven, evenals onzekerheid, gebrek aan zelfvertrouwen, angst voor examens en concentratieproblemen onder andere (Baneke, 1987; Bernstein, 1991; Butterfield, 1988; Firth, 1986). De klinische stages leveren echter niet uitsluitend negatieve stress op maar ook positieve stress, omdat ze vaak als een uitdaging worden ervaren door co-asssistenten (Baneke, 1987). Omdat een inwijdingsproces vaak gepaard gaat met denigrerende benadering en spot van de nieuweling, onderzoeken we eveneens als aspect van draaglast of co-assistenten zich gekleineerd of denigrerend behandeld voelen.

Omdat co-assistenten in het begin van deze fase vaak een sterke identificatie met de patiënt ervaren, wordt eveneens verkend of co-assistenten een denigrerende manier van spreken over patiënten opmerken. Verder blijken werkcontexten waar vrouwen een minderheid vormen, soms een zekere mate van misogynie of ambivalentie richting vrouwen te vertonen (Timmerman, 1990). We vroegen ons derhalve af of een denigrerende manier van spreken over vrouwen of vrouwelijk patiënten wordt waargenomen. In dit verband zijn ook de omgangsvormen van de medische professie met de verpleging, traditioneel een vrouwenberoep, interessant.

Concreet wordt de draaglast, zoals ervaren door co-assistenten, in kaart gebracht door een lijst van stellingen (1) over positieve stress (gevoel van uitdaging) en negatieve stress, gevoel van plichten, ervaren tijdgebrek, aanpassingsbereidheid en ervaren gevoel van buitenstaanderschap, een lijst van stressoren (2) die vaker zijn beschreven als zijnde van belang in de medische opleiding (Baneke, 1987; Bernstein, 1991; Butterfield, 1988; Firth, 1986) en vragen over ervaren denigrerende benadering en perceptie van denigrerend spreken over patiënten en vrouwen.

Om inzicht te krijgen in de draagkracht van co-assistenten wordt onderzocht op welke manieren co-assistenten omgaan met problematische aspecten van dit leertraject (zie model). Met gebruikmaking van het begrip copingstrategieën gedrag, zoals dit door Schreurs en anderen (1984) werd uitgewerkt in een aantal copingstijlen in de Utrechtse Coping Vragenlijst (UCL), werd bij co-assistenten onderzocht welke manieren zij inzetten om problematische situaties in de stages het hoofd te bieden. Daarnaast zijn individuele kenmerken als assertiviteit of faalangst van invloed op de verwerking van stress of belasting door co-assisstenten.

De outcome (zie model) van uiteindelijk ervaren belasting, kan bepaald worden door onderzoek naar de mate van vermoeidheid in geestelijke en fysieke zin, de mate waarin co-assisstenten last ondervinden van gezondheidsklachten en de motivatie. Motivatie en ervaren belasting zullen invloed uitoefenen op de uiteindelijke professionele identiteit en de gemotiveerdheid of "commitment" voor het medisch vak. 


\subsection{Hypothesen over draaglast, draagkracht en outcome}

Eerst zullen kort enige richtinggevende inzichten worden aangegeven die een rol hebben gespeeld bij de ontwikkeling van de hypothesen over eventuele verschillen in de ervaring van vrouwelijke en mannelijke co-assisstenten en hypothesen over het veranderingen en beloop in de tijd. Daarna worden de hypothesen per thema draaglast, draagkracht en outcome uitgewerkt.

Bij de ontwikkeling van hypothesen voor de vraag naar sekseverschillen in de ervaringen van co-assistenten, hebben wij gebruik gemaakt van het concept van de gevestigden en de buitenstaanders van Elias (1985). We vooronderstellen dat hoe sterker het gevoel van buitenstaanderschap, hoe zwaarder de socialisatieopdracht voor de nieuwkomer en hoe meer moeite en stress deze ervaart in het assimilatieproces aan de voorgeleefde cultuur. We veronderstellen dat de ervaringen van vrouwelijke co-assistenten op sommige punten getuigen van een sterker of "dubbel-buitenstaanderschap". Dit kan tot uiting komen in een grotere draaglast en het ervaren van meer belasting en vermoeidheid (outcome). Ook is voorstelbaar dat vrouwelijke co-assistenten de bejegening, die samenhangt met rol en positie van co-assisstent ("jongste bediende"), anders wegen of beoordelen dan hun mannelijke collega's.

Wij verwachten verder verschillen tussen vrouwelijke en mannelijke co-assistenten op basis van hun onderscheiden sekserolsocialisatie, waarin andere aspecten in de persoonlijkheid zijn geaccentueerd. Verschillen op basis hiervan verwachten we bij mate van assertiviteit en preferente copingstijlen onder andere.

Ook nemen we aan dat in de klinische setting, waar de co-assistentschappen zich afspelen de macht van de vanzelfsprekendheid functioneert (Komter 1985, 1990). In het sociaal verkeer van vrouwen en mannen binnen arbeidsverhoudingen blijkt seksestereotype beeldvorming een grote rol te spelen, zowel in de zelfopvattingen van mensen als in de manier waarop men aangesproken wordt. Impliciete seksestereotype aannames over mate van ambitie, aanleg en/of kwaliteit van vrouwelijke studenten kunnen resulteren in een sterker plichtsbesef en in een verminderd gevoel van rechten bij vrouwelijke co-assisstenten in vergelijking met hun mannelijke collega's.

Omdat socialisatie een proces van groei en aanpassing is, veronderstellen we bij de vraagstelling naar veranderingen in de loop van de tijd dat co-assistenten in diverse opzichten zullen veranderen. Co-assistentschappen hebben een inwijdingskarakter en zijn een proeve van bekwaamheid ten aanzien van het vermogen van de nieuwkomer om zich aante passen en om te gaan met de culturele normen en waarden waaraan zij (als het ware confronterenderwijs) zijn blootgesteld. Sommige auteurs (Sieverding, 1990; de Vries, 1988; Krol, 1992) gebruiken de term cultuurshock.

Nadenkend over het beloop in de tijd van de veranderingen in de belasting, die samenhangt met de co-assistentschappen, verwachten we dat vooral de start, de eerste confrontatie met de klinische stages, enerverend en stresserend zal zijn (fase 0 ).

We zullen in ons onderzoek een aantal fasen onderscheiden namelijk de startfase of fase 0 , waarin medische studenten de witte jas letterlijk en figuurlijk voor het eerst aantrekken. De stabilisatie-periode of fase 1, waarin de ervaringen in de beroepset- 
ting minder nieuw zijn en een zekere mate van gewenning optreedt. En tot slot de afrondingsfase of fase 3, waarin het afstuderen in zicht komt en de medische opleiding ten einde loopt. Verschillen in de beleving van co-assistenten in de opeenvolgende fasen zijn dus gezien het voorgaande van betekenis.

\subsubsection{Hypothesen draaglast}

Men kan drie typen hypothesen onderscheiden namelijk over het al of niet ervaren van het onderzochte aspect (algemeen), over een mogelijk gevonden verschil tussen de de seksen en over mogelijke veranderingen in de tijd. Bij de beschrijving van de hypothesen zullen in volgorde aan de orde komen de reeks stellingen (1) over belas. tende aspecten van de co-assistentschappen, de reeks stressoren (2) en mogelijke spot of denigrerende benadering (3) richting co-assistent, patiënten of vrouwen.

In de onderstaande tabel zijn de hypothesen op schematische wijze in beeld gebracht.

\section{Overzicht van de hypothesen over draaglast}

\begin{tabular}{|c|c|c|c|}
\hline aspect & ervaring & sekseverschil? & verandering in tijd? \\
\hline ervaren negatieve stress & ja & - & $\begin{array}{l}\text { ja, sterkste in fase } 0 \text {, } \\
\text { neemt toe in de tijd }\end{array}$ \\
\hline $\begin{array}{l}\text { ervaren positieve stress/ } \\
\text { gevoel van uitdaging }\end{array}$ & ja & - & \\
\hline gevoel van plichten & ja & $\begin{array}{l}\text { ja, vrouwen } \\
\text { meer }\end{array}$ & \\
\hline gebrek aan tijd & ja & - & \\
\hline aanpassings-bereidheid & ja & $\begin{array}{l}\text { ja, vrouwen } \\
\text { meer - }\end{array}$ & \\
\hline $\begin{array}{l}\text { gevoel van buitenstaan- } \\
\text { derschap }\end{array}$ & ja & $\begin{array}{l}\text { ja, vrouwen } \\
\text { meer }\end{array}$ & $\mathrm{ja}$, afname \\
\hline $\begin{array}{l}\text { perceptie spot } \\
\text { richting co-assistent }\end{array}$ & ja & $\begin{array}{l}\text { ja, vrouwen } \\
\text { meer }\end{array}$ & ja, afname \\
\hline $\begin{array}{l}\text { perceptie spot } \\
\text { richting patiënten }\end{array}$ & ja & ja & ja, afname \\
\hline $\begin{array}{l}\text { perceptie spot } \\
\text { richting vrouwen }\end{array}$ & $\begin{array}{l}\text { alleen bij } \\
\text { bepaalde } \\
\text { vakgebieden }\end{array}$ & $\begin{array}{l}\text { ja, vrouwen } \\
\text { meer }\end{array}$ & \\
\hline
\end{tabular}

Hypothesen over aard van de ervaringen

Wij vooronderstellen dat co-assistenten zich opgejaagd voelen en een negatieve impact van de co-assistentschappen op hun privéleven ervaren (Clark, 1986). We nemen aan dat de klinische stages ook als uitdagend en spannend worden ervaren, hetgeen als positieve stress benoemd kan worden. Omdat de positie van de co-assistent bescheiden 
is, vermoeden wij dat het gevoel van plichten sterker is dan dat van rechten. We vermoeden dat de norm van "hard te moeten werken" al enigszins geinternaliseerd is en dat de bereidheid om zich aan te passen bij co-assistenten groot is. Ze zullen zich wel een buitenstaander voelen van de artsen-beroepsgroep en waarschijnlijk vanwege het leven in een werkregime en de avond- of weekenddiensten een sterk gebrek aan vrije tijd ervaren (Bernstein, 1991; Fahrenfort, 1985; Hendrie, 1990; Firth, 1986).

Over mogelijke bronnen van stress blijkt uit de literatuur (Lloyd \& Gartrell, 1983, Bernstein, 1991; Butterfield, 1988) dat in deze opleidingsfase met name problemen met de planning van de studie en moeite met concentratie een rol spelen. Vanwege de verandering van leefritme in de overgang van studentenbestaan met relatief veel tijd voor sociale contacten en hobby's naar co-assistentschappen met een strak werkregime en weinig vrije tijd, kan men problemen verwachten op het relationele vlak zoals verlies van vriendschappen, eenzaamheid, schuldgevoel en dergelijke.

Voor een specifieke, waarschijnlijk kleine, risicogroep kan de ervaring van zakken voor examens en faalangst mogelijk een bron van stress zijn. Ook kunnen motivatieproblemen bij studenten en co-assistenten een rol spelen.

Co-assistentschappen, opgevat als inwijdingsritueel, leiden tot de hypothese dat nieuwelingen te maken krijgen met omgangsvormen die de sociale afstand tussen hen en de gevestigde groep van de artsen-opleiders onderstrepen. De bescheiden status van een co-assisstent zal hen mogelijk door middel van bepaalde gewoonten en omgangsvormen worden duidelijk gemaakt. Dit kan tot uiting komen in flauwe opmerkingen over co-assistenten in het algemeen of deze co-assisstent in het bijzonder of spottend taalgebruik over hun gedrag of uiterlijk (Van Welzen, 1978; Fahrenfort, 1985).

De gewoonte van artsen om onderling afstandelijk over patiënten te spreken, past in een onbewuste en impliciete strategie om de nieuwe generatie te stimuleren tot een attitude van "professionele distantie" ten aanzien van patiënten (Fahrenfort, 1985; van Welzen, 1978. In de setting van chirurgie en operatiekamer, werd een sterkere mate van denigrerend of sterk objectiverend taalgebruik over patiënten beschreven (Bosk, 1979; Lock, 1988). We nemen aan dat co-assistenten denigrerend of spottende manieren van spreken over patiënten van artsen onderling zullen beluisteren.

Op basis van onderzoek naar integratie van vrouwen in mannenberoepen zoals politie en marine (Ott, 1985; Timmerman, 1990; Burger, 1993) ontstaat de vraag of ook in de geneeskunde vormen van seksisme of denigrerend spreken van mannelijke collega's over vrouwen voorkomt. Macho-gedrag en denigrerend taalgebruik van mannen over vrouwen heeft de sociale functie van een versterking van het groepsgevoel van mannen. De sociale cohesie van mannen gaat soms gepaard met uitsluiting van vrouwen. Wanneer dergelijke fenomenen zich zouden voordoen in het werkveld van de geneeskunde, dan is de kans hierop het grootste in die beroepsvelden, die van oudsher gedomineerd zijn door mannelijke artsen en lof waar een machocultuur heerst.

\section{Vermoeden we een sekseverschil bij draaglast ?}

Ons baserend op de these van het eventuele "dubbel-buitenstaanderschap" van vrouwelijke co-assistenten, moet men veronderstellen dat vrouwelijke co-assistenten een sterker gevoel van plichten hebben (Komter, 1992), dat ze een sterker gevoel van 
buitenstaanderschap hebben en dat hun aanpassingsbereidheid nog groter is dan die van hun mannelijke collega's (Veldman \& Wittink, 1990).

Wat de bronnen van stress betreft zou men gezien de rolsocialisatie van vrouwen mogen veronderstellen dat vrouwelijk co-assistenten meer last hebben van de inbreuk op hun sociale leven, die het regime van stages kan veroorzaken.

We vooronderstellen dat vrouwelijke co-assisstenten meer dan mannen met spot en denigrerende benadering te maken krijgen. Dit heeft te maken met het gegeven dat vrouwelijke co-assistenten ondanks hun getalsmatig overwicht voor de zittende mannelijke professie waarschijnlijk niet als bedreigend of verontrustend worden ervaren, omdat ze nog in de rol van leerling zijn en niet in die van "gelijke" of concurrent.

De waarneming van spot richting patiënten zal samenhangen met de mate waarin de co-assistent zich met patiënten identificeert. De beschrijvingen van het socialisatieproces (de Groot, 1987; Fahrenfort, 1985) geven aan dat co-assistenten in de loop van de tijd hun sterke identificatie met de patiënt inruilen voor identificatie met artsen, met hun beroepsgroep. We veronderstellen dat deze verschuiving bij vrouwelijke co-assistenten in mindere mate optreedt, omdat identificatie met een door mannen-overheerste beroepsgroep mogelijk lastiger voor vrouwen is.

Ten aanzien van de perceptie van spottend of denigrerend spreken over vrouwen, vermoeden we dat, wanneer dit gedrag optreedt, vrouwelijke co-assistenten sensitiever zijn en dit dus sterker waarnemen dan hun mannelijke collega's. Vanuit de gedachte van identificatie met referentiegroepen, nemen we namelijk aan dat vrouwen en mannen zich sterker identificeren en vergelijken met hun eigen seksegenoten, dan met de andere sekse.

\section{Vermoeden we veranderingen in de tijd ten aanzien van de draaglast?}

Onder het motto "alle begin is moeilijk", veronderstellen we dat met name de start met de co-assistentschappen, fase 0 , belastend en stresserend is en dat de negatieve stress daarna weer afneemt. We nemen verder aan dat zowel de negatieve als de positieve stress in de loop van de tijd toeneemt. Het gevoel van buitenstaanderschap zal waarschijnlijk afnemen (Fahrenfort, 1985; Bucher \& Stelling, 1977).

Co-assistenten zullen zich in de loop van de stages waarschijnlijk zekerder gaan voelen van hun plaats in de beroepsgroep en meer zelfvertrouwen hebben, naarmate zij meer gevorderd zijn in hun opleiding en derhalve is aannemelijk dat zij zich minder bespot of denigrerend benaderd voelen dan in het begin van de coschappen. Wij nemen voorts aan dat vooral de startende co-assistenten (fase 0 ), nieuwkomers in de cultuur van de medische beroepsgroep sensitiever zullen zijn voor uitingen van spot of denigrerend gedrag richting patiënten of vrouwen dan hun meer gevorderde collega's. De kans dat zij eventuele uitingen van spot opmerken is groter. Perceptie van spot in fase 0 , de startfase van de coschappen zal groter zijn. 


\subsubsection{Hypothesen draagkracht}

De draagkracht van co-assistenten wordt onderzocht door in te gaan op copingstijlen of manieren van omgaan met de belasting van de co-assistentschappen en op mate van assertiviteit en examenangst en de hypothesen worden in deze volgorde beschreven. Copingstijlen kunnen worden geconceptualiseerd als persoonlijkheidskenmerken of als interactief proces. We vatten "coping" op als interactief proces, waarbij individueel bepaalde voorkeuren bestaan, maar ook omgevingsinvloeden van grote invloed zijn. Verder nemen we aan dat medische studenten gemiddeld genomen assertief en zelfbewust zijn. Volgens Fahrenfort (1985) zijn het vaak middelbare scholieren met hoge cijfers en een hoge prestatie-motivatie (de bloem van de natie), die geneeskunde gaan studeren. $W_{i j}$ nemen aan dat deze groep zich door hun eerdere succesvolle schoolervaringen redelijk zelfbewust zal opstellen.

\section{Vermoeden we een sekseverschil in draagkracht?}

Vanuit sekse-socialisatie theorieèn veronderstellen we enkele verschillen tussen vrouwelijke en mannelijke co-assistenten (Gilligan, 1982; Mavis Hetherington \& Parke, 1993). Zo zullen vrouwelijke co-assisstenten mogelijk sneller geneigd zijn om sociale steun te zoeken dan mannen en omgekeerd mannen er mogelijk meer toe neigen om problemen actief en handelend tegemoet te treden. Ook in de medische beroepsrol blijken vrouwen meer communicatief te zijn ingesteld en meer gericht op interactieve aspecten van het medische beroep (Meeuwissen, 1991; Bensing, 1991).

Omdat men vrouwen meer dan mannen in hun kinderjaren vaak socialiseert om "lief" te zijn, zullen vrouwelijke co-assistenten mogelijk minder snel hun ongenoegen uiten door boos te worden en zich ook minder assertief gedragen dan hun mannelijke collega's. Verder wees Komter (1990) erop dat mindermachtigen in een organisatie hun ongenoegen vaker horizontaal ventileren, dan in verticale richting.

\subsubsection{Hypothesen outcome}

Omdat outcome wordt onderzocht door in te gaan op mate van ervaren vermoeidheid en eventuele gezondheidsklachten (1) en motivatie (2) en inschatting van de zwaarte van het artsenberoep (3), zullen de hypothesen in deze volgorde worden beschreven. 
Overzicht bypothesen "outcome"

\begin{tabular}{llll}
\hline aspect & algemeen & sekseverschil? & verandering in de tijd? \\
\hline $\begin{array}{l}\text { psychisch vermoeid } \\
\text { fysiek vermoeid }\end{array}$ & $\mathrm{ja}$ & $\mathrm{ja}$, vrouwen meer & $\mathrm{ja}$, toename in de tijd \\
positief gestemd & $\mathrm{ja}$ & $\mathrm{ja}$, vrouwen meer & $\begin{array}{l}\mathrm{ja} \text {, toename in de tijd, } \\
\text { vooral in start fase 0 }\end{array}$ \\
gemotiveerdheid & $\mathrm{ja}$ & nee & \\
"zwaar" beroep & $\mathrm{ja}$ & nee & $\mathrm{ja}$, toename in de tijd \\
\hline
\end{tabular}

Naar aanleiding van de studies die verricht zijn op het terrein van stress gedurende de medische opleiding (Baneke, 1987; Bernstein, 1991; Butterfield, 1988; Hendrie, 1990) en van de levendige beschrijvingen van de paradoxen en rolconflicten die een stagiaire zou ervaren (Fahrenfort, 1985; de Groot, 1987; de Vries, 1988) nemen wij aan dat de co-assistentschappen als fysiek en psychisch vermoeiend worden ervaren.

Omdat een socialisatieproces niet uitsluitend vermoeiend en zwaar is maar ook een vorm van uitdaging en mogelijkheid tot ontplooiing en groei (Bucher en Stelling, 1977; Berger, 1972). Daarom nemen wij aan dat co-assistenten ook positief gestemd zijn. Ook veronderstellen we dat de motivatie van co-assistenten geen afname maar een toename laat zien. We nemen verder aan dat slechts in beperkte mate sprake is van gezondheidsklachten, omdat het een groep jonge mensen betreft.

Ook gaan we ervan uit dat co-assistenten geïmponeerd zullen zijn door de realiteit van het medisch beroep en de belasting van het beroep van arts met zijn lange werkdagen en diensten in de beginperiode als zwaar inschatten.

\section{Vermoeden we een sekseverschil in outcome?}

Op basis van de these van het "dubbel-buitenstaanderschap" van vrouwen in de geneeskunde nemen we aan dat de belasting voor vrouwelijke co-assistenten groter is dan voor mannelijke co-assistenten. $W_{i j}$ vermoeden dat aanpassen en assimileren aan een door mannen gedomineerde beroep- en werkcultuur voor vrouwen moeilijker is (Richman 1990, Bernstein 1991, Clark 1986, Hendrie 1990). We vooronderstellen dat dit met name tot uitdrukking komt in een grotere mate van psychische vermoeidheid voor vrouwelijke co-assistenten.

Ten aanzien van de motivatie vooronderstellen we geen verschillen tussen de seksen. Hoewel de confrontatie met de beroepscultuur van de medische stand voor vrouwen mogelijk zwaarder is, nemen wij aan dat vrouwen vanwege hun grote affiniteit met menselijke interactie en hun behoefte aan relatie en verbinding met andere mensen (Baker-Miller 1988) meer satisfactie beleven aan functioneren als hulpverlener hetgeen de balans zal herstellen.

Wel vermoeden we dat vrouwelijke co-assistenten het medisch vak als zwaarder inschatten dan hun mannelijke collega's, omdat ze de klem van de dubbele belasting mogelijk al voorzien. 


\section{Vermoeden we veranderingen in de tijd wat betreft outcome?}

Inwijding is, zoals reeds enige malen werd uiteengezet, geen ontspannende aangelegenheid maar vraagt om aanpassing en omgaan met paradoxen.

De psychische vermoeidheid zal toenemen vooral in fase 0 , de start van de co-assistentschappenfase. De fysieke belasting al eveneens met name in fase 0 toenemen, wanneer de overgang van universiteit naar kliniek plaatsvindt en de eerste confrontatie met de medische wereld. De vraag is welke veranderingen optreden in fase 2, wanneer de co-assisstenten de arbeidsmarkt tegemoet gaan.

De motivatie zal gedurende de klinische stages toenemen, omdat studenten eindelijk de gelegenheid krijgen om het medische beroep uit te oefenen ("role playing"), waar zij zich al die studiejaren reeds op prepareren. Wii nemen aan dat, ondanks of paradoxaal genoeg misschien dankzij, de inspanningen en moeite in het proces van inwijding, co-assistenten in principe sterker gemotiveerd worden voor het medisch vak (van Welzen, 1978).

Verder verwachten wij dat het beroepsbeeld van medisch studenten realistischer wordt wanneer ze kennismaken met de praktijk en met de realiteit van het medische vak. Het is voorstelbaar dat studenten die nog niet met de stages zijn begonnen een beeld van de zwaarte van het medisch beroep hebben dat voortspruit uit het "lekenperspectief" of sterk beïnvloed is door beeldvorming in de media. Wij nemen aan dat de praktijk een relativerend effect heeft op het aanvankelijke lekenperspectief beelden.

\subsection{Het onderzoeksinstrument}

In onderzoek naar socialisatieprocessen werd vaak een kwalitatieve onderzoeksmethode benut, hetgeen reeds veel interessante inzichten heeft opgeleverd (Fahrenfort, 1985; Becker et all, 1961; Keizer, 1997). Nu leek het ons zinnig om de waarde van deze inzichten te onderzoeken in een meer kwantitatief onderzoeksdesign. De onderzoeksvragen zijn beantwoord aan de hand van semi-kwantitatieve gegevens. De grotere onderzoeksgroep doet de generaliseerbaarheid van de bevindingen toenemen en maakt vergelijkingen tussen verschillende groepen mogelijk. $\mathrm{Er}$ zijn twee vragenlijsten ontwikkeld met een groot aantal items, die aan de onderzoekspopulatie werden voorgelegd met de vraag om op een vier of viffpuntsschaal hun ervaringen of percepties aan te geven. De vragenlijst bestaat voor het grootste deel uit gesloten vragen, aangevuld met enkele open vragen, waarin een toelichting werd verzocht bij sommige onderwerpen (zoals de aard van de denigrerende opmerkingen en dergelijke). De antwoordcategorieën van de gesloten vragen bestaan meestal uit een vierpuntsschaal varierend van 1: volledig oneens tot 4: volledig eens of 1: helemaal niet tot 4: heel goed of 1:onbelangrijk tot 4: heel belangrijk. Bij Hopkins Symptoms Checklist of HCL over vermoeidheid werd een 5-puntsschaal gehanteerd (zie voorbeeld in figuur 7.1). De variabelen moeten voor het merendeel worden gekarakteriseerd als ordinale variabelen, verder zijn er enkele nominale variabelen. 
figuur 7.1 Mate van vermoeidheid

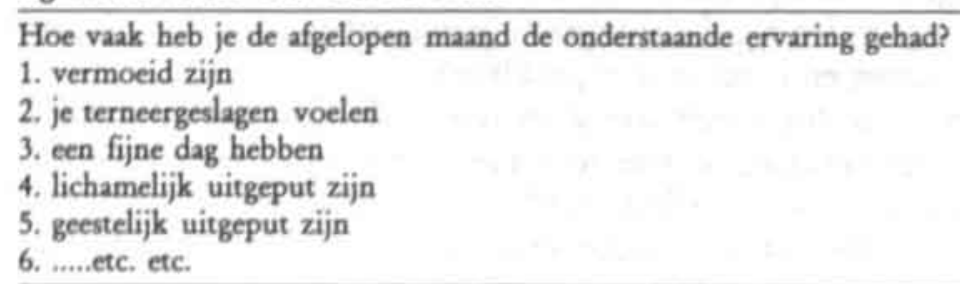

De lijst bestaat uit 24 items met antwoordcategorieen, waar op een vijfpuntschaal kan worden geantwoord; range 1- bijna nooit; 2 - zelden; 3 - soms; 4 - vaak; 5 - bijna altijd

Bron: Hopkins Symptoms Checklist (HCL), 1984

\section{Validiteit}

Om een valide vragenlijst te construeren met betrekking tot professionele socialisatie werd een uitgebreide literatuurstudie verricht. Daarnaast werd een kwalitatief, hypothese genererend vooronderzoek verricht. Dit vooronderzoek bestond uit enkele diepte-interviews met een gelijk aantal vrouwelijke en mannelijke co-assistenten. In de interviews werden de ervaringen van de co-assistenten tijdens de stages besproken. Verder vond in het kader van het vooronderzoek reflectie plaats van de onderzoekster op de eigen ervaringen tijdens de medische opleiding. Op basis van het literatuuronderzoek, diepte-interviews en de reflectie op eigen ervaringen zijn concrete vragenlijst-items ontwikkeld, die passen bij de verschillende aspecten van professionele socialisatie. Ook zijn bestaande meetinstrumenten gescreend op hun bruikbaarheid voor dit onderzoek. Dit heeft geresulteerd in de opname van de Utrechtse Coping Lijst en de Hopkins Symptons Checklist (HSL).

\section{Betrouwbaarheid}

In dit onderzoek zijn deels bestaande instrumenten en zijn deels door de onderzoeker zelf geconstrueerde items gebruikt. Van de bestaande instrumenten die gebruikt zijn, kan een redelijke tot goede betrouwbaarheid worden verondersteld. Omdat deze instrumenten zoals HCL en de UCL of Utrechtse Coping Lijst in een andere onderzoeksveld of in andere populaties werden toegepast, is de interne samenhang opnieuw bepaald met behulp van een Crohnbach's alpha. Bij de geconstrueerde items werd binnen het thema eerst een factoranalyse uitgevoerd om samenhangen op het spoor te komen en correlaties berekend. Daarna is ook in deze gevallen een Crohnbach's alpha bepaald.

\subsection{Operationalisatie en beschrijving van de variabelen.}

De vragenlijst bevat informatie over een aantal achtergrondgegevens van de respondenten en bestaat verder uit de variabelen, die geordend zijn in de thema's draaglast, 
draagkracht en outcome of uiteindelijke belasting. In de vragenlijst zijn enige achtergrondvariabelen geïnventariseerd (zie figuur 7.2).

Achtergrondvariabelen (figuur 7.2)
1. sekse
1- man; 2 - vrouw
2. groep
0 - novieten; 1 - eerstejaars co's
3. leeftijd
+ tweedejaars in jaren
4. opleiding vader
7- puntsschaal
5. opleiding moeder
7- puntsschaal
6. privé
1- ongebonden; 2- woon alleen, wel vaste relatie; 3- samenwonend met partner; 4 = samenwonend met partner en/of kind
7. familie
8. vooropleiding familieleden die arts zijn: 0 - nee; 1 - ja.
0 - geen paramedische, verpleegkundige, $\mathrm{HBO}$ of wetenschappelijke opleiding voltooid; 1 - wel zo'n vooropleiding voltooid.

In het navolgende worden de diverse variabelen beschreven.

\section{Draaglast}

De draaglast werd onderzocht aan de hand van de volgende variabelen:

- een reeks van 11 stellingen over aspecten van de co-assistenschappen (zie figuur 7.3) - een reeks stressoren (zie figuur 7.3)

- perceptie van denigrerende of spottende behandeling van co-assistent of patiënten of vrouwen (zie figuur 7.4)

De 11-stellingen bevatten indicatoren van ervaren negatieve stress, gevoelens van uitdaging of positieve stress, een indruk van de balans tussen het gevoel van plichten en rechten of plichtsgevoel en de ervaring van tijdgebrek. Ook de bereidheid van co-assistenten om offers te brengen voor hun beroep, de offerbereidheid komt aan de orde en het gevoel van buitenstaanderschap, een indicatie van identificatie met de toekomstige beroepsgroep. Daarna wordt een aantal stressoren aan de co-assistenten voorgelegd, die hun draaglast mogelijk vergroten.

De items, die de ervaring van denigrerende benadering of negatieve omgangsvormen exploreren, zijn weergegeven in figuur 7.4. Hierbij is met open vragen doorgevraagd naar de aard van de spottende of denigrerende opmerkingen en tijdens welke stages deze opmerkingen door co-assistenten worden opgemerkt.

\section{Draagkracht}

De Utrechtse Coping Lijst of UCL (Schreurs,Tellegen \& Willige, 1984) is gebaseerd op basis van de classificatie van coping gedrag van Westbrook (1979) met daarin 4 hoofdcategorieën, namelijk gedrag gericht op de situatie (zoals confrontatie, vermijding, nietsdoen), gedrag gericht op beïnvloeden van perceptie en evaluatie (zoals optimisme, aanvaarding, berusting, pessimisme), gedrag gericht op reductie van spanning, ook wel palliatie genoemd en gedrag wat het uiten van de emoties betreft. In de Utrechtse Coping Lijst worden 7 factoren of copingstrategieën onderscheiden namelijk: actief aanpakken of confronteren (A), palliatieve reactie (P), vermijdingsgedrag 
(V), sociale steun zoeken (S), depressief en vermijdend reactiepatroon (D, expressie van emoties of boosheid (E) en geruststellende en troostende gedachten (G) (Schreurs, 1984). Na statistische bewerkingen (factoranalyse en reliability) van het verkregen databestand, konden de volgende vijf copingstijlen worden onderscheiden: actieve copingstijl, sociale steun zoeken, palliatieve stijl, depressief/vermijdende stijl en het uiten van ongenoegens. Als elementen van draagkracht werden ook nog assertiviteit en examenvrees onderzocht. In de figuren 7.5 en 7.6 zijn de variabelen van draagkracht beschreven en wordt de interne betrouwbaarheid (Crohnbachs alpha) weergegeven.

\section{Outcome of uiteindelijke mate van belasting}

Om de mate van vermoeidheid te onderzoeken is gebruik gemaakt van de vermoeidheidsvragenlijst van Hopkins Symptoms Checklist (HSL). Om dit meetinstrument te valideren is een factoranalyse uitgevoerd om samenhangende clusters van items te onderscheiden en werden deze clusters statistisch getoetst op hun interne consistentie en betrouwbaarheid door middel van bepaling van de Crohnbach's alpha. Als grenswaarde werd een Crohnbach's alpha van groter of gelijk aan 0,60 aangehouden. Deze bewerking heeft geresulteerd in de constructie van de 3 samengestelde variabelen en 2 item-variabelen (zie figuur 7.7).

In de vragenlijst zijn ook items opgenomen die betrekking hebben op de motivatie voor de medische studie en het beeld van de zwaarte van bet medisch beroep. Ook in dit geval werd middels bepaling van de Crohnbach's alpha de interne consistentie van de geconstrueerde variabelen getoetst. 


\section{Figuur 7.3 Draaglast (1)}

Stellingen over belastende aspecten van de co-assistentschappen

\section{Negatieve stress}

- De hele opzet van de studie is zodanig dat ik me enorm opgejaagd voel

- De co-schappen hebben een negatieve invloed op mijn privé-leven

- Gebeurtenissen in mijn privé-leven hebben een negatieve invloed gehad op mijn studie

Positieve stress, gevoel van uitdaging

- Het werken als co-assistent vind ik wel een uitdaging

- In situaties waarin snel gehandeld moet worden voel ik mij erg op mijn gemak

Gevoel van plichten/rechten

- Een co-assistent heeft meer plichten dan rechten

- Als ik de hele dag gewerkt heb, vind ik het onzin om nog eens twee uur te gaan studeren

Gebrek aan tijd

- Ik heb in de co-schappen voldoende vrije tijd

Offerbereidheid

- Lange werktijden maken vind ik op zichzelf niet erg

- Ik zal alles op alles zetten om dokter te worden

Gevoel van buitenstaanderschap

- Als co-assistent hoor je niet echt bij het team van artsen

\section{Stressoren voor co-assisstenten}

Welke van de volgende problemen hebben je studie negatief beïnvloed?

1. ziekte

2. financiële problemen

3. huisvestingsproblemen

4. ruzie met ouders of vrienden

5. problemen met planning van de studie

6. concentratieproblemen

7. faalangst/tentamenangst

8. gebrek aan motivatie

9. relatieproblemen

10. regelmatig zakken voor tentamens

11. eenzaamheid, gebrek an sociale steun

12. overige, namelijk............ 


\section{Figuur 7.4 Draaglast (2) \\ Variabelen met betrekking tot denigrerende of spottende benadering}

\section{Spot t.a.v, eigen functioneren en uiterlijk}

bestaande uit de items:

- ben je geconfronteerd met flauwe grapjes/denigrerende opmerkingen over:
a. je functioneren als toekomstig arts
b. je optreden
c. je omgang met patiënten

- worden er regelmatig opmerkingen gemaakt over:
a. je lichaam, houding etc.
b. je kleding

\section{plus 3 losse items}

. word je geconfronteerd met vervelende opmerkingen over je uiterlijk?

- word je geconfronteerd met flauwe grapjes?

- word je geconfronteerd met denigrerende opmerkingen?

\section{Spot t.a.v. patiënten}

- word je weleens geconfronteerd met flauwe grapjes, denigrerende opmerkingen over:
a. patiënten in het algemeen
b. lichaam of lichaamskenmerkingen
$(r=0.55 p \leq .001)$

* zo ja, welke opmerkingen?

* zo ja, waar, welke afdeling?

\section{Spot t.a.v. vrouwen of vrouwenlichamen}

- word je weleens geconfronteerd met flauwe grapjes, denigrerende opmerkingen over:
a. vrouwelijke patiënten/vrouwenlichamen
$(r=0.53 p<.001$
b, vrouwen in het algemeen

** zo ja, welke opmerkingen?

* zo ja, waar, welke afdeling?

plus 2 losse items

- word je weleens geconfronteerd met flauwe grapjes, denigrerende opmerkingen over vrouwelijke artsen?

- word je weleens geconfronteerd met flauwe grapjes, denigrerende opmerkingen over de verpleging

* Met open vragen werden de items over spot t.a.v. patiënten en spot t.a.v. vrouwen of vrouwenlichamen toegelicht. 


\section{Figuur 7.5 Draagkracht (1) \\ Variabelen "copingstrategię̌n"}

vraag Hoe reageren co-assistenten/studenten over het algemeen op problemen of onplezierige gebeurtenissen in de opleidingssituatie?

Reageren op problemen of moeilijkheden door

variabele 'sociale stewn zoeken'

bestaande uit de volgende items:

- je zorgen met iemand delen

- laten merken dat je ergens mee zit

- iemand om hulp vragen

- troost en begrip zoeken

- je gevoclens tonen

variabele 'actief problemen aampukken'

bestaande uit de volgende items:

- direct ingrijpen als er moeilijkheden zijn

- verschillende mogelijkheden bedenken om het probleem op te lossen

- doelgericht te werk gaan om het probleem op te lossen

- een probleem van alle kanten bekijken

- de zaken cerst op een rij zetten

variabele 'depressief/vermijdingsgedrag'

bestaande uit de volgende items:

- je niet in staat voelen iets te doen

- je geheel en al in beslag laten nemen door problemen

- piekeren over het verleden

- de zaken somber inzien

- moeilijke situaties zoveel mogelijk uit de weg gaan

- toegeven om moeilijke situaties te vermijden

variabele 'palliatief

bestaande uit de volgende items:

- op een of andere manier proberen je prettiger te voelen

- bedenken dat anderen het ook wel eens mocilijk hebben

- afleiding zoeken

- bedenken dat na regen zonneschijn komt

- an andere dingen denken

- er even tussen uit gaan

variabele 'ongenoegen uiten'

bestaande uit de volgende items:

- je ergernis laten blijken

- laten zien dat je kwaad bent op degene die verantwoordelijk is voor het probleem. 


\section{Figuur 7.6 Draagkracht (2)}

Variabelen van assertiviteit en examenvrees

\section{variabele 'assertiviteit'}

bestaande uit de volgende items:

$$
r=0.28 ; p<0.01
$$

- als ik iets niet weet vraag ik het gewoon

- als ik ergens kritiek op heb, aarzel ik niet om dat te uiten

variabele 'examenvrees'

bestaande uit de volgende items:

$$
r=0.35 ; p \leq 0.001
$$

- als ik bij de voorbereiding van een toets of tentamen merk dat ik niet op tijd klaar ben, raak ik in paniek

- ik heb voor examens nogal eens last van slapeloosheid 


\section{Figuur 7.7 Outcome}

\section{Variabelen met betrekking tot vermoeidheid en motivatie}

Ik heb de afgelopen maand de onderstaande ervaring gehad..

variabele 'prychische vermoeidheid"

$\alpha=0.91$

- ongelukkig voelen

- verstrikt voelen

- waardeloos voelen

- lusteloos

- problemen hebben

- teleurstellingen en wrok t.o.v. anderen

- zwak voelen

- hopeloos voelen

- afgewezen voelen

- angstig voelen

variabele fysieke vermoeidheid'

$\alpha=0.91$

- vermoeid zijn

- lichamelijk uitgeput

- geestelijk uitgeput

- uitgeteld

- afgebrand

- op zijn

variabele 'positief gestemd zijn'

$\alpha=0.82$

- fijne dag

- gelukkig

- optimistisch

- energiek

Losse items :

Ik heb de afgelopen maand de onderstaande ervaring gehad...

- boofdpijn

- eetproblemen

variabele 'afnemende motivatie'

- deze studie ondergraaft mijn zelfvertrouwen

$\alpha=0.70$

- dikwijls twijfel ik eraan of ik wel met deze studie door moet gaan

- ik heb dikwijls het idee dat ik in deze studie gefaald heb

variabele 'ingeschatte belasting'

$\alpha=0.74$

- de eisen die het artsenberoep aan een persoon stelt zijn goed op te brengen

- aan de verantwoordelijkheid die je als arts hebt moet je niet te zwaar tillen

- ik zie op tegen de verplichtingen die het artsenberoep met zich meebrengt (omgepooled)

- ik verwacht dat het werken als arts mij in de praktijk wel mee zal vallen

- ik twijfel er nogal eens aan of ik wel opgewassen zal zijn tegen het werken als arts (omgepooled) 


\subsection{Opzet en uitvoering van het onderzoek}

\section{Transversale en longitudinale survey}

Om inzicht te krijgen in de mate en aard van de belasting die uitgaat van het inwijdingsproces van co-assistenten, werd een transversale survey uitgevoerd en een longitudinale survey of panelonderzoek.

Tot een survey-onderzoek is besloten om de onderzoeksvragen met enige algemene geldigheid te kunnen beantwoorden. $\mathrm{Bij}$ dit type onderzoek is het wel van belang om te controleren of gevonden samenhangen niet met andere factoren samenhangen dan de onderzochte factoren. Door statistische controle en analyse van systematische variantie kan hieraan tegemoet gekomen worden.

In het transversale onderzoek wordt de vraag naar mogelijke veranderingen bij coassistenten onder invloed van de "blootstelling aan de medische beroepscultuur" onder de loep genomen. Ook is onderzocht of er specifieke veranderingen optreden, die worden aangeduid met de term "cultuurshock", tengevolge van de overgang van de (predoktorale) fase in de universitaire leeromgeving naar de klinische fase in de setting van beroepspraktijk van ziekenhuis of huisartspraktijk,

Om recht te doen aan het procesmatig karakter van professionele socialisatie en om veranderingen bij studenten en co-assisstenten in de loop van de opleidingstijd te kunnen constateren is een longitudinale survey gedaan. De onderzoeksgroep die in 1991 had deelgenomen aan het onderzoek is een jaar later in 1992 opnieuw aangeschreven met het verzoek de beide vragenlijsten nog eens in te vullen. Dergelijke longitudinale gegevens bieden inzicht in de individuele- en groeps-verschuivingen gedurende de coassisstentschappen en daarmee in het proces van professionele socialisatie. Het nadeel is wel dat na een jaar sprake kan zijn van uitval (panel-mortality) en "re-interviewing bias" (Swanborn, 1987). De respondenten zouden de tweede meting kunnen proberen de vragen in overeenstemming met de eerste keer te beantwoorden. $W_{i j}$ verwachtten echter dat na een tijdspanne van een jaar deze tendens betrekkelijk gering is.

\section{Onderzoekspopulatie en werving}

\section{Populatie, steekproef en werving}

De onderzoekspopulatie van dit onderzoek bestaat uit een steekproef uit de groep coassistenten plus een steekproef uit de groep studenten geneeskunde in hun vierdejaar, die op het punt staan met de co-assistentschappen te beginnen.

Een steekproef van co-assistenten, groot 170 personen, studerend aan de Universiteit Maastricht van het vijfde en zesde studiejaar, werd benaderd en gevraagd om medewerking aan het onderzoek. Op het moment van werving (april 1991) waren aan de Faculteit der Geneeskunde 156 vijfdejaars studenten ingeschreven en 110 zesdejaars (totaal $\mathrm{N}=266$ ). De steekproef beslaat dus meer dan de helft van de totale populatie co-assistenten.

Daarnaast werd een steekproef van 69 studenten getrokken uit de groep vierdejaars studenten geneeskunde aan de Universiteit Maastricht, in totaliteit ongeveer 150 
studenten bevattend. Deze steekproef, die een derde deel (32\%) van de totale jaargroep beslaat, een goede afspiegeling van de groep vierdejaars studenten.

Deze groep respondenten zal worden aangeduid met de term preco-assistenten en functioneert als uitgangspunt en nulmeting voor mogelijke effecten van het socialisatieproces van de co-assistentschappen.

Bij het trekken van elke steekproef werd steeds een evenredige verhouding van mannen en vrouwen nagestreefd, de helft vrouwen en de helft mannen.

De werving van co-assistenten en preco-assistenten geschiedde door de studenten (april 1991) persoonlijk te benaderen op "at random' gekozen onderwijsmomenten ${ }^{4}$ en hen na een korte uitleg van doel en inhoud van het onderzoek twee vragenlijsten te overhandigen met het verzoek deze binnen 14 dagen ingevuld te retourneren. De co-assistenten en studenten werd als beloning een VVV-bon ter waarde van $f 10$,- in het vooruitzicht gesteld wanneer de vragenlijsten ingevuld zouden worden teruggestuurd.

De werving van de groep vierdejaars studenten, de preco-assistenten, werd uitgevoerd door studenten, bij het verlaten van de lokatie waar het laatste examen (voortgangstoets) van het vierde studiejaar (de dato 1991) werd afgenomen, willekeurig te benaderen en te verzoeken hun medewerking te verlenen aan het onderzoek naar loopbaanwensen van medische studenten.

\section{Anonimiteit}

De vragenlijsten werden anoniem verwerkt. Om data van dezelfde respondenten, die zowel aan het transversale als aan het longitudinale onderzoek deelnamen, te kunnen identificeren, werd de geboortedatum als identificatie gebruikt. Hierdoor ontstond de mogelijkheid om ontwikkelingen van individuele co-assistenten te bestuderen.

Om respondenten na de afgesproken periode van 1 jaar, die tussen meetmoment 1 en 2 lag, weer te kunnen vinden, werden naam, adres en telefoonnummer van respondenten op een aparte lijst vastgelegd. Deze lijst functioneerde los van de vragenlijsten, en kon alleen door de onderzoeker aan de geboortedatum worden gekoppeld.

\subsection{Statistische technieken}

Nadat de interne betrouwbaarheid van de diverse variabelen was vastgesteld met behulp van correlatie onderzoek, factor analyse en/of reliability analyse (Crohnbach's alpha) in het databestand van het transversale onderzoek, werd eerst beschrijvende statistiek uitgevoerd en frequentie tabellen opgesteld. Er is zoveel mogelijk naar gestreefd om somscores te berekenen.

\footnotetext{
"Bijvoorbeeld onderwijsgroepsbijeenkomsten van co-assistenten tijdens de stage "huisartsgeneeskunde" (5 groepen) en tijdens het coassistentschap "psychiatrie" (3 groepen) in het psychiatrische ziekenhuis Vijverdal; klinische besprekingen van (onder andere) interne geneeskunde, chirurgie en gynaecologie in het Academisch Ziekenhuis Maastricht, en via tussenpersonen ( $2 \mathrm{x}$ co-assistenten en $1 \mathrm{x}$ opleider) in klinisch onderwijs in het perifere ziekenhuis van Sittard en Roermond.
} 
De vraagstellingen over draaglast, draagkracht en outcome in termen van belasting, en motivatie, zijn beantwoord door verschillende (sub)groepen met behulp van statistische technieken te vergelijken.

Hoe komen wij overgangs-ervaringen, die duiden op een cultuurshock, op het spoor? Wanneer we de inwijding in de co-assistentschappen opvatten als blootstelling aan externe invloed', dan kan bovengestelde vraag beantwoord worden door de groep studenten, die nog net niet zijn begonnen aan de co-assistentschappen (vierdejaars studenten in dit onderzoek pre-co-assistenten genoemd) te vergelijken met co-assistenten. Eleganter is de methode om studenten longitudinaal te volgen en op verschillende momenten te meten. Vooral de verschuivingen, die optreden in de subgroep van de "preco-assistenten" of novieten, laten het effect zien van de eerste confrontatie met de beroepscultuur.

\section{Cultuursbock in bet transversaal onderzock}

Blootstelling aan

beroepscultuur

geen blootstelling

blootstelling korter dan 1 jaar blootstelling langer dan 1 jaar

- groep 0- vierdejaars

- pre-co-assistenten

groep 1- beginnende co's

groep 2- gevorderde co's

\section{Cultuurshock in het longitudinaal onderzoek}

De co-assistenten, zowel de totale groep als de drie onderscheiden subgroepen) worden gevolgd in de tijd.

De ervaringen in de startfase, waarbij de (preco-assistenten) of novieten worden gevolgd in de tijd, laten ervaringen zien die specifiek zijn voor het starten met de stages of de co-assistentschappen. We spreken van een cultuurshock als met name in deze fase significante verschuivingen optreden.

\section{Hoe worden de vraagstellingen beantwoord?}

De vraagstellingen, die betrekking hebben op de ervaringen, mogelijke sekseverschillen hierin en veranderingen in de tijd, werden onderzocht in een transversaal en een longitudinaal design. Het is belangrijk te weten dat in het navolgende hoofdstukken waar de resultaten worden behandeld (hoofdstuk 8 en 10) de uitkomsten van het transversale onderzoek geïntegreerd beschreven worden met de resultaten van het longitudinale (of follow up) onderzoek.

Antwoord op de vraag "zijn de ervaringen van vrouwelijke co-assistenten verschillend van die van mannelijke collega's?" komt tot stand door subgroepen vrouwelijke en

s externe invloed of interventie; de confrontatie met de medische beroepscultuur in de co-assistentschappen is de externe invloed of interventie 
mannelijke co-assisstenten uit het transversale onderzoek met elkaar te vergelijken. Hiertoe werd de Mann-Whitney U test gebruikt, geschikt voor non-parametrische variabelen. Indien er sprake is van nominale variabelen zijn chi ${ }^{2}$ toetsen uitgevoerd. Antwoord op de vraag "treden er veranderingen bij de studenten op gedurende de de fase van de co-assistentschappen?" komt tot stand door gebruikmaking van transversale data en longitudinale data.

In de transversale data worden de 3 onderscheiden subgroepen, pre-co-assistenten (groep 0), beginnende co-assistenten (groep 1) en gevorderde co-assistenten (groep 2) met behulp van de Kruskall Wallis test met elkaar vergeleken. Bij vergelijking van 2 subgroepen kan de Mann Whitney U test worden gebruikt. Uit deze analyse wordt met name het antwoord gedestilleerd op de vraag of "blootstelling" aan de co-assistentschappen een significante verandering of cultuurshock geeft.

Belangrijkste bron van informatie vormen echter de longitudinale data, die ons in staat stellen de veranderingen bij de co-assisstenten in de diverse fasen te bestuderen. Met behulp van de gepaarde Wilcoxon Sign Rank test, geschikt voor non-parametrische variabelen zijn de uitspraken van de studenten op meetmoment 1 (1991) vergeleken met die van hetzelfde individu op meetmoment 2 (1992). Deze vergelijkingen werden uitgevoerd op niveau van de totale groep plus op niveau van de 3 subgroepen de novieten (of preco-assistenten) in fase 0 , de subgroep van de beginners in fase 1 en de subgroep van de gevorderde co-assistenten in fase 2 .

Deze vergelijkingen in het longitudinale onderzoek van meetmoment 1 naar meetmoment 2, een jaar later, geven antwoord op de vraag naar eventuele verschuivingen in de tijd.

De startfase of fase 0 toont:

de verschuivingen, die optreden in subgroep 0 van de "preco-assistenten" of novieten, laten met name het effect zien van de start of eerste confrontatie met de beroepscultuur van artsen.

De stabilisatiefase of fase 1 toont:

de verschuivingen die optreden bij subgroep 1 van de "beginners". Ze demonstreren de groei en verandering bij co-assistenten wanneer die het tweede jaar van de co-assistentschappen ingaan.

De afrondingsfase of fase $\mathbf{2}$ toont:

de verschuivingen die optreden in subgroep 2 van de gevorderden ook wel de "afstuderenden" genoemd. Hier wordt het effect zichtbaar van het naderen van de arbeidsmarkt en de afronding van de medische opleiding met het basisartsexamen. 


\section{Vergelijkingen in longitudinaal onderzoek}

fase 0

"start van de klinische stages" overgang van universitaire leeromgeving naar ziekenhuis/werkcontext

\section{fase 1}

overgang "van beginnend co-assistent naar gevorderde co"

\section{fase 2}

overgang van "gevorderde co-assistent naar afgestudeerd basisarts" novieten, gevolgd in de tijd

gebruikte term: novieten

co-assistenten in cerste jaar gevolgd in de tijd

gebruikte term: beginners

co-assistenten in hun tweede jaar gevolgd in de tijd gevorderden of afstuderenden

Antwoord op de vraag "zijn er verschillen in het veranderingsproces van vrouwelijke co. assistenten in vergelijking met dat van mannelijke co's?' wordt beantwoord door de data van het longitudinale onderzoek met behulp van gepaarde Wilcoxon Sign Rank test te analyseren en steeds de vrouwelijke studenten te vergelijken met de mannelijke studenten.

Als antwoord op de vraag of de bevindingen uit de Mann Whitney testen ten aanzien van sekseverschillen toegeschreven zouden moeten worden aan andere achtergrondvariabelen, zijn lineaire regressie analyses uitgevoerd. Daarmee konden de eerdere bevindingen eventueel worden geverifieërd. 


\subsection{Samenvatting}

De fase van de co-assistentschappen wordt opgevat als een overgang van student in een universitaire setting naar de rol van arts in een beroepssetting. De co-assistent neemt de medische beroepsrol op zich en maakt kennis met de culturele wereld, die verbonden is met het bekleden van deze rol. Deze kennismaking is niet vrijblijvend, maar confronteert de nieuweling met nieuwe sociale verhoudingen, andere realiteiten en opdrachten. De positie van co-assistenten ten opzichte van de medische beroepsgroep is vergelijkbaar met die van een buitenstaander, die toegang wenst tot de gevestigde groep. Enerzijds geimponeerd en vol ontzag voor hun leermeesters zullen zij zichzelf daarmee vergeleken onbeholpen en onzeker voelen, maar ook zullen zij teleurstellingen meemaken wanneer blijkt dat zij er een geidealiseerd beeld op nahielden van artsen en het medisch handelen. Wij vatten de co-assistentschappen op als een inwijdingritueel in de beroepscultuur van de medische professie. Inwijding houdt in dat fysieke en psychische barrieres worden opgelegd. Ook wordt de nieuweling getest en op de proef gesteld en ervaart deze mogelijk een denigrerende benadering of lichte spot. Vaak wordt de nieuweling op meer of minder subtiele wijze diens bescheiden plaats in de bestaande pikorde gewezen.

Om zicht te krijgen op de belasting van het inwijdingsproces is een model gehanteerd met de elementen draaglast, draagkracht en outcome. Deze elementen zijn geoperationaliseerd in mate van vermoeidheid en gezondheidsklachten, motivatie, copingstijlen en assertiviteit, ervaren spot en stellingen over belastende aspecten van de stageperiode.

Wij stellen de vraag of de inwijdingservaringen van vrouwelijke co-assistenten anders zijn dan die van hun mannelijke collega's. Wanneer vrouwen worden ingewijd in een door mannen gedomineerde beroepscultuur, is de kans groot dat daardoor een groter beslag gelegd wordt op de draaglast met als mogelijk gevolg een grotere mate van vermoeidheid, bij gelijkblijvende draagkracht. Al met al resulterend in een problematischer outcome. In dit hoofdstuk kwamen ook de mogelijke psychologische veranderingen in de loop van de tijd aan de orde. Dit hoofdstuk was opgebouwd uit een introductie, vraagstellingen en hypothesen, gevolgd door de beschrijving van opzet en uitvoering en een overzicht van de variabelen, die de vragenlijst hebben gestructureerd. 



\section{Hoofdstuk 8}

\section{De belasting van het inwijdingsproces Resultaten en discussie}

\subsection{Inleiding}

In dit hoofdstuk worden de resultaten gerapporteerd van het empirisch onderzoek naar de aard en mate van belasting waarmee het doorlopen van de co-assistentschappen voor de nieuwelingen gepaard gaat. Dit gebeurt aan de hand van de drie subthema's draaglast, draagkracht en "resulterende effecten of outcome".

Eerst wordt de onderzoekspopulatie beschreven. Vervolgens gaan we in op de draag. last zoals deze ervaren wordt door de co-assistenten. Bestudeerd wordt hoe co-assistenten omgaan met specifieke aspecten van de co-assistentschappen en of zij problemen of stressoren ervaren die naar hun inzicht de studie negatief beïnvloeden. Ook komt aan de orde of zij zichzelf bespot of denigrerend behandeld voelen en of zij waarnemen dat anderen zoals patiënten, vrouwen of de verpleging denigrerend behandeld worden.

De draagkracht komt aan de orde de volgende paragraaf, waarin de manieren worden beschreven van omgaan met de belastende of problematische aspecten van deze fase. Welke copingstijlen worden gebruikt ? En in welke mate lijden co-assistenten aan gebrek aan assertiviteit en examenvrees?

Daarna komen de resultaten op de vraag naar de outcome of effecten van de ervaren druk uitgaande van de impliciete socialisatie-opdracht in de co-assistentschappen aan de orde. In welke mate worden vermoeidheid of gezondheidsklachten ervaren ? Maar ook komt aan de orde of de motivatie voor de studie toe- of afneemt tijdens deze inwijdingsfase en hoe zwaar co-assistenten hun toekomstige beroep eigenlijk inschatten. Bij elk thema (draaglast, draagkracht en outcome) wordt steeds antwoord gegeven op de volgende vraagstellingen: 
I. Welke ervaringen doen medische studenten op tijdens de fase van co-assistentschappen?

- Is er sprake van verschillen tussen de onderscheiden subgroepen ?

- Is er sprake van verschillen tussen vrouwelijke en mannelijke co-assistenten ?

II. Treden er veranderingen op bij medische studenten tijdens de fase van de coassistentschappen?

- Zijn de veranderingen in de tijd verschillend bij beide seksen ?

- Zijn de veranderingen in de tijd anders in de onderscheiden fasen 0,1 en 2 ?

\subsection{Respondenten}

De respons in het transversale onderzoek, waarin 170 co-assistenten en 69 vierdejaarsstudenten werden geworven, bedroeg $77 \%(n=185)$.

De respons in de onderscheiden groepen co-assistenten en preco-assistenten apart be draagt $80 \%$ en $70 \%$ respectievelijk. Van de co-assistenten stuurden 137 co-assistenten de ingevulde vragenlijsten terug, 75 vrouwelijke co-assistenten en 62 mannelijke. De non-respons onder co-assistenten bestaat uit 48 personen en laat een licht overwicht van mannen zien.

Van de preco-assistenten of vierdejaars stuurden 48 personen, waaronder 32 vrouwelijke en 16 mannelijike studenten (78\% resp. 57\%) de vragenlijisten terug. De non-respons bestaat uit 21 personen waarvan 11 vrouwen en 10 mannen.

De groep co-assistenten-respondenten is in het transversale onderzoek verder onderverdeeld in twee subgroepen namelijk in de zogenaamde "beginners", dat wil zeggen co-assistenten die korter dan een jaar bezig zijn met deze klinische fase en de "gevorderden", co-assistenten die (1) een jaar of langer bezig zijn met de fase van de co-assistentschappen.

De veranderingen in de tijd zijn bestudeerd door een longitudinaal onderzoek uit te voeren bij een deel van de bestaande steekproef, die dezelfde vragenlijst opnieuw, maar nu een jaar verder gevorderd in hun leertraject in de co-assistentschappen, voorgelegd kregen. Concreet werden alle respondenten, die de vragenlijsten voor de transversale meting hadden geretourneerd $(n=179)$, een jaar later opnieuw aangeschreven met het verzoek de vragenlijst voor de tweede maal in te vullen.

De respons van het longitudinale onderzoek bedraagt $70.4 \%$, concreet 126 personen, waarvan 76 vrouwen en 49 mannen. In tabel 8.1 staat het aantal respondenten in de verschillende subgroepen vermeld. 
Tabel 8.1. Groeps- en sekseverdeling van de respondenten

\begin{tabular}{|c|c|c|c|c|c|c|c|}
\hline \multirow[b]{2}{*}{ omschrijving } & \multirow[b]{2}{*}{ groep } & \multicolumn{3}{|c|}{ eerste meting } & \multicolumn{3}{|c|}{ tweede meting } \\
\hline & & $\begin{array}{l}\text { vrouwen } \\
\mathrm{N}(\%)\end{array}$ & $\begin{array}{l}\text { mannen } \\
\mathrm{N}(\%)\end{array}$ & $\begin{array}{l}\text { totaal } \\
\mathrm{N}(\%)\end{array}$ & $\begin{array}{l}\text { vrouwen } \\
\mathrm{N}(\%)\end{array}$ & $\begin{array}{l}\text { mannen } \\
\mathrm{N}(\%)\end{array}$ & $\begin{array}{l}\text { totaal } \\
\mathrm{N}(\%)\end{array}$ \\
\hline te jaars & 0 & $32(67)$ & $16(33)$ & $48(26)$ & $25(66)$ & $13(34)$ & $38(30)$ \\
\hline beginnende co's & 1 & $40(50)$ & $40(50)$ & $80(43)$ & $31(53)$ & $27(47)$ & $459(47)$ \\
\hline gevorderde co's & 2 & $35(61)$ & $22(39)$ & $57(31)$ & $20(69)$ & $9(31)$ & $29(23)$ \\
\hline total co's & $1+2$ & $75(55)$ & $62(45)$ & $137(74)$ & II & "I & I \\
\hline total & $0+1+2$ & $106(57)$ & 79 (43) & $185(100)$ & $76(60)$ & $49(40)$ & $* 126(100)$ \\
\hline
\end{tabular}

- 1 sekse missing. "er is geen subtotaal gebruikt in het longitudinale onderzoek.

\section{Non-respons longitudinale onderzoek}

Ook in dit onderzoek blijkt sprake van uitval tussen de twee metingen (van $n=185$ naar $n=126$ ). Hoewel de "longitudinale groep", de groep studenten die ook een tweede keer de vragenlijst invulde, kleiner is dan de "transversale groep" bleven er voldoende respondenten over om uitspraken te kunnen doen over veranderingen in de tijd. Naar de uitvallers oftewel de non-respons-groep van 59 personen, is verder onderzoek gedaan om een inschatting te kunnen maken over de representativiteit van de resterende (onderzochte) populatie (zie tabel 8.2).

Tabel 8.2 Vergelijking van respons-groep $(n-126)$ en non-respons-groep op achtergrondvariabelen (in percentages aangegeven)

\begin{tabular}{|c|c|c|c|c|c|c|c|}
\hline jaar van aanvang studie & '82 & '83 & '84 & '85 & '86 & '87 & totaal \\
\hline respons & 1 & 2 & 8 & 29 & 37 & 25 & $100 \%$ \\
\hline non-respons & - & 2 & 14 & 50 & 24 & 10 & $100 \%$ \\
\hline vooropleiding & \multicolumn{2}{|c|}{ mavo/havo } & VWO & & \multicolumn{2}{|l|}{ anders } & tot: \\
\hline respons & \multicolumn{2}{|l|}{14} & 82 & & \multicolumn{2}{|l|}{4} & $100 \%$ \\
\hline non-respons & \multicolumn{2}{|l|}{16} & 83 & & \multicolumn{2}{|l|}{1} & $100 \%$ \\
\hline beroepsopleiding & $\begin{array}{l}\text { para- } \\
\text { medisch }\end{array}$ & $\begin{array}{l}\text { verple- } \\
\text { ging }\end{array}$ & $\begin{array}{l}\text { academ. } \\
\text { voltooid }\end{array}$ & $\begin{array}{l}\text { academ. } \\
\text { onvolt. }\end{array}$ & $\begin{array}{l}\text { HBO } \\
\text { overig }\end{array}$ & overig & \\
\hline respons & 19 & 17 & 3 & 44 & 8 & 9 & $100 \%$ \\
\hline non-respons & 14 & 5 & 10 & 57 & 10 & 5 & $100 \%$ \\
\hline privé-situatie & $\begin{array}{l}\text { alleen- } \\
\text { staand }\end{array}$ & $\begin{array}{l}\text { L.A.T. } \\
\text { relatie }\end{array}$ & $\begin{array}{l}\text { samen- } \\
\text { wonend }\end{array}$ & $\begin{array}{l}\text { heeft } \\
\text { kind }\end{array}$ & anders & & \\
\hline respons & 38 & 35 & 17 & 2 & 8 & & 100 \\
\hline non-respons & 29 & 24 & 31 & 5 & 10 & & $100 \%$ \\
\hline leeftijd & \multicolumn{2}{|l|}{$<=29$} & \multicolumn{2}{|l|}{$>29$} & & & tot \\
\hline respons & \multicolumn{2}{|l|}{89} & \multirow{2}{*}{\multicolumn{2}{|c|}{$\begin{array}{l}11 \\
56\end{array}$}} & & & 100 \\
\hline non-respons & \multicolumn{2}{|l|}{44} & & & & & $100 \%$ \\
\hline sekse & vrouwen & mannen & & & & totaal & \\
\hline respons & 60 & & 40 & & & & 100 \\
\hline non-respons & 50 & & 50 & & & & $100 \%$ \\
\hline
\end{tabular}


In de non-respons groep zitten meer studenten die in 1985 of eerder met de studie begonnen zijn. Een mogelijke verklaring vormt het feit dat van deze groep al veel mensen afgestudeerd (en verhuisd) zijn. Dit wordt ondersteund wanneer gekeken wordt naar de respons per groep; deze is in groep 2 veel lager dan in de andere groepen.

De beide groepen respondenten en non-respondenten verschillen niet met betrekking tot de vooropleiding: Mavo, Havo of VWO. Van de respondenten heeft $28 \%(\mathrm{n}=36)$ vervolg- of beroepsonderwijs genoten voorafgaande aan de studie geneeskunde, van de non-respons groep is dit $36 \%(n=21)$. In de non-respons-groep zien we een grotere vertegenwoordiging van mensen met academisch voltooide of onvoltooide vooropleiding; in de responsgroep zijn verpleegkundigen en para-medici beter vertegenwoordigd.

Samenwonende studenten met partner (en kind) vallen vaker af en studenten die alleen leven en geen vaste relatie hebben blijven meer aan het onderzoek meedoen. Tussen de beide groepen is een significant verschil gevonden ten aanzien van leeftijd $(\mathrm{p}=.0005$ - Mann Whitney). In de responsgroep zijn 23-24-25 jarigen beter vertegenwoordigd dan in de non-respons groep. In de leeftijdsgroep van 26-28 jaar zien we weinig verschil tussen beide groepen. In de non-responsgroep is een groter aandeel oudere studenten (ouder dan 29 jaar), concreet 33\% tegenover 14\% in de responsgroep. Waarschijnlijk zijn deze studenten tussen de eerste en tweede meting afgestudeerd als basisarts. Relatief meer vrouwen hebben tussen de eerste en tweede meting afgehaakt.

\subsection{Resultaten transversaal en longitudinaal onderzoek naar draaglast.}

De bevindingen ten aanzien van de onderscheiden aspecten van draaglast, concreet de stellingen over de de stage-fase, de stressoren en de mogelijke ervaring van spot of denigrerende benadering, zullen aan de hand van de vraagstellingen worden beschreven.

\subsubsection{Stellingen en stressoren}

Co-assistenten blijken, wanneer hen de reeks stellingen over aspecten van de co-assistentschappen wordt voorgelegd, een aantal duidelijke uitspraken te doen (zie tabel8.3). Co-assistenten antwoorden met een duidelijk "ja, mee eens" op de volgende stellingen $^{1}$ :

- co-assistentschappen zijn een uitdaging

- een co-assistent heeft meer plichten dan rechten

- ik zal alles op alles zal zetten om dokter te worden

${ }^{1}$ score gelijk of $<2.3$ - genuanceerd nee;

2.4-2.5-2.6 - indifferent;

gelijk of $>2.7$ genuanceerd ja 
- ik voel me geen lid van het team van artsen

Ze spreken zich eveneens duidelijk in ontkennende zin uit. "Nee, oneens" luidt het antwoord op de volgende stellingen:

- ik heb in de co-schappen niet voldoende vrije tijd

- gebeurtenissen in mijn privé-leven hebben geen negatieve invloed gehad op mijn studie

- ik vind het geen onzin om nog eens twee uur te gaan studeren, als ik de hele dag al gewerkt heb

Tabel 8.3 Omgaan met aspecten van co-assistentschappen.

\begin{tabular}{lcccc}
\hline & groep 0 & groep 1 & groep 2 & p-waarde \\
\hline - ik voel me opgejaagd door studie & 1.7 & 2.4 & 2.1 & .000 \\
- na hele dag werken & & & & \\
onzin om 2 uur te studeren & 2.0 & 2.0 & 1.9 & n.s. \\
- werken als co is uitdaging & 3.4 & 2.9 & 2.9 & .003 \\
- snel handelen kan ik goed & 2.5 & 2.8 & 2.3 & .01 \\
- co heeft meer plichten dan rechten & 2.9 & 3.0 & 2.8 & n.s. \\
- ik heb voldoende vrije tijd & 3.2 & 1.8 & 1.9 & .000 \\
- lange werktijden geen probleem & 3.0 & 2.5 & 2.7 & n.s \\
- alles op alles zetten & & & & \\
om dokter te worden & 3.1 & 2.9 & 3.2 & n.s \\
- co-schappen hebben negatieve & & & & \\
invloed op privé-leven & 1.5 & 2.7 & 2.7 & .000 \\
- privé-leven heeft negatieve & & & & \\
invloed op studie & 2.1 & 2.0 & 2.2 & n.s \\
ik voel me een buitenstaander & 3.0 & 3.0 & 2.7 & .05 \\
\hline
\end{tabular}

Gemiddelde scores groep 0 (vierdejaars), groep 1 en 2 (co-assistenten) en p-waarde groepsverschillen (Kruskall-Wallis); range 1 = volledig oneens $-4=$ volledig eens.

Is er sprake van significante verschillen tussen de drie subgroepen?

De toetsing van de verschillen tussen de 3 subgroepen met de Kruskall Wallis toets heeft de volgende significante verschillen tussen deze subgroepen opgeleverd (zie tabel 8.3):

- mate van opgejaagdheid

de co-assistenten (zowel groep 1 als 2) geven aan significant meer last hiervan te hebben dan de studenten voor de co-schappen

- het ervaren van de co-assistentschappen als een uitdaging de vierdejaars studenten zijn het meer eens met de stelling dan de co-assistenten (groep 1 en 2), die bezig zijn met deze fase en de praktijk dus hebben leren kennen - het gevoel van gebrek aan tijd

de co-assistenten (zowel groep 1 als 2) hebben hier significant meer last van dan de studenten voor de co-schappen

- ervaren van negatieve effecten van de co-assistentschappen op het privé-leven de co-assistenten (zowel groep 1 als 2) hebben hier significant meer last van dan de studenten voor de co-schappen 
- het zich op zijn gemak voelen in situaties, waarin snel gehandeld moet worden $\mathrm{Er}$ is een significant verschil tussen de groep beginnende co-assistenten, die het meer eens zijn met deze stelling dan de gevorderden.

Deze verschillen kunnen een aanwijzing bevatten over veranderingen die optreden onder invloed van de socialisatie-ervaring in de klinische wereld, maar longitudinale gegevens geven de meest betrouwbare informatie.

\section{Zijn er significante verschillen tussen vrouwelijke co-assistenten en mannelijke co-assisten. ten?}

Op sommige aspecten blijken mannelijke co-assistenten te verschillen van hun vrouwelijke collega's. Mannen blijken zich significant meer opgejaagd te voelen (negatieve stress), met name de gevorderde groep co-assistenten (groep 2). Verder blijken mannen een sterker besef van plichten'te hebben dan vrouwen. Tot slot blijken mannen het significant meer eens met de stelling dat de privé-sfeer een negatieve invloed heeft op hun studie, met name in de oudste groep co-assistenten (groep 2).

\section{Veranderen co-assistenten in de tijd?}

Tabel 8.4 Aard van de draaglast in de loop van de tijd

\begin{tabular}{|c|c|c|c|c|c|c|c|c|c|c|c|}
\hline & totaal 89 & $80^{\circ}$ & faseo & 98 & $8 \delta^{\circ}$ & fase 1 & 99 & हैं & fase2 & & 80 \\
\hline - opgejaagd & . & .* & & . & & & . & . & ** & & $*$ \\
\hline - uitdaging & ** & - & & & & ** & & & & . & \\
\hline $\begin{array}{l}\text { genoeg vrije tijd } \\
\text { alles op alles }\end{array}$ & $e^{* *}$ & · & $\cdots *$ & 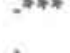 & * & & : & & $\therefore$ & $\therefore$ & \\
\hline $\begin{array}{l}\text { alles op alles } \\
\text { negatieve invloed van }\end{array}$ & & & & & & & & & & & \\
\hline $\begin{array}{l}\text { studie op privé } \\
\text { negatieve invloed van }\end{array}$ & . & . & $+* * *$ & $+4 *$ & & . & & . & . & & \\
\hline privé op studie & +* & . & . & & . & & . & & . & . & . \\
\hline
\end{tabular}

Significante verschillen in de loop van de tijd getoetst met Wilcoxon

${ }^{*} \mathrm{p} \leq 0.05 ;{ }^{* *} \mathrm{p} \leq 0.01 ;{ }^{* * *} \mathrm{p} \leq 0.001$

Co-assistenten laten een steeds krachtiger "nee, oneens" laten op de stelling "men heeft als co voldoende tijd" (zie tabel 8.4). Met name de vrouwelijke co-assistenten blijken in toenemende mate tijdgebrek te ervaren.

Op niveau van de totale groep neemt de bereidheid om "alles op alles te zetten" af tijdens de co-assistentschappen. Ook veranderen co-assistenten in die zin dat ze naarmate ze verder vorderen in hun socialisatie ze het meer eens zijn met de stelling dat privé-leven een negatieve invloed heeft op hun opleiding (stelling 10).

Wanneer men op niveau van de subgroepen kijkt, blijkt ook dit vooral toegeschreven te kunnen worden aan de gevorderde groep co-assistenten en dan nog specifieker de vrouwelijke co-assistenten. De "offerbereidheid" om dokter te worden neemt dus met name af bij de groep afstuderende vrouwelijk co-assistenten.

De mannelijk co-assistenten (niveau van totale groep) blijken verder een significante vermindering van het "zich opgejaagd voelen" te ervaren, hetgeen wanneer men ver- 
volgens op niveau van de subgroepen kijkt, vooral toe te schrijven is aan de groep gevorderde co-assistenten die in het jaar van observatie af zijn gestudeerd.

\section{Veranderen vrouwen anders dan mannen?}

Zoals uit bovenstaande tabel is op te maken, is het veranderingstraject van vrouwen op drie punten anders dan dat van mannen. Vrouwen hebben meer last van het gebrek aan tijd ten gevolge van de co-schappen, ze ervaren meer negatieve invloed van de studie op hun priveleven dan mannelijke co-assistenten en zijn minder bereid om alles op te offeren voor hun beroep aan het eind van de medische opleiding.

Bij toetsing van de verschilscore ( = delta) blijkt het sekseverschil bij de stelling overhet gebrek aan tijd bevestigd. Vrouwelijke co-assistenten beamen het gebrek aan tijd significant krachtiger dan hun mannelijke collega's.

\section{Stressoren}

Co-assistenten blijken het meest frequent last te hebben van concentratie problemen en problemen in hun sociale relaties zoals met partner, vrienden en vriendinnen en dergelijke (zie figuur 8.1). Ook het gebrek aan sociale steun en eenzaamheid evenals ruzie met ouders of vrienden, die door respectievelijk $11 \%$ en $10 \%$ van de co-assistenten als bronnen van stress worden aangegeven, kunnen als problematiek in de sociale sfeer worden aangemerkt. Dat onzekerheid over de eigen kennis en vaardigheden nog groot is bij co-assistenten kan worden afgeleid uit het gegeven dat faalangst of tentamen-angst door 20\% wordt genoemd. De motivatie voor de studie baart $19 \%$ van de co-assistenten zorgen. Verder blijken ook andere problemen, dan die werden opgesomd in reeks stressoren, nog een categorie van betekenis te vormen (36\%) (zie figuur $8.1)$

Top 12 stressoren voor co-assistenten $(n=137)$

\begin{tabular}{lll}
\hline 1 & concentratieproblemen & $37 \%$ \\
2 & relatieproblemen & $36 \%$ \\
3 & overige problemen & $36 \%$ \\
4 & financiële problemen & $21 \%$ \\
5 & problemen met studie planning & $21 \%$ \\
6 & faalangst/tentamenangst & $20 \%$ \\
7 & gebrek aan motivatie & $19 \%$ \\
8 & ziekte & $16 \%$ \\
9 & huisvestingsproblemen & $14 \%$ \\
10 & eenzaamheid & $11 \%$ \\
11 & ruzie met ouders of vrienden & $10 \%$ \\
12 & regelmatig zakken tentamens & $4 \%$ \\
\hline
\end{tabular}

figuur 8.1

Op de vraag of de bronnen van stress in de fase van de co-assistentschappen anders zijn dan daarvoor, in de universitaire fase, hebben we de antwoorden van groep 0 , de vierdejaars vergeleken met die van de co-assistenten. 
Bij vergelijking valt op dat co-assistenten vaker dan vierdejaars studenten last hebben van (1) concentratieproblemen, (2) problemen met de planning van de studie en (3) eenzaamheid en gebrek aan sociale steun (4) faalangst en (5) financiële zorgen. Coassistenten hebben minder dan vierdejaars studenten last van gebrek aan motivatie, ziekte, problemen met huisvesting en overige problemen.

\section{Hebben vrouwen andere problemen dan mannen?}

Wanneer men de top vijf van problemen met nadelige invloed op de studie, bij de vrouwelijke co-assistenten vergelijkt met de top vijf van problemen bij de mannelijke co-assistenten, dan blijken vrouwen en mannen nauwelijks te verschillen ten aanzien van de belangrijkste drie bronnen van stress (zie figuur 8.2). Moeite met studieplanning en faalangst komen meer voor bij vrouwen meer, terwijl bij mannen ziekte vaker voor studieproblemen zorgt. Vrouwen blijken vaker "overige" problemen te hebben en mannen meer financiële problemen.

\section{Top 5 stressoren: sekseverschillen?}

\begin{tabular}{|c|c|c|c|}
\hline Vrouwen & & Mannen & \\
\hline Problemen met: & & Problemen met: & \\
\hline 1 overige zaken & $42 \%$ & 1 concentratie & $39 \%$ \\
\hline 2 concentratie & $34 \%$ & 2 relaties & $39 \%$ \\
\hline 3 relaties & $30 \%$ & 3 financiën & $30 \%$ \\
\hline 4 studie piunning & $24 \%$ & 4 overige zakken & $30 \%$ \\
\hline 5 faalangst & $24 \%$ & 5 ziekte & $22 \%$ \\
\hline
\end{tabular}

figuur 8.2

\section{Welke overige problemen?}

Welke problematiek wordt bedoeld bij de categorie "overige problemen" is nader onderzocht aan de hand van open vragen. 35 Co-assistenten waarvan 13 mannen en 22 vrouwen gaven aan dat "overige problemen" een rol voor hen speelden of gespeeld hadden.

Tijdgebrek, een problematische leeromgeving en diverse relationele of psychosociale problemen zijn bedoeld met de noemer "overige problemen. Het meest frequent werd een problematische leeromgeving $(8 \mathrm{x})$ genoemd, vrouwen gaven dit vaker aan dan mannen ( 6 $\%$ en $\left.2 \delta^{8}\right)$. Ook vaak genoemd als probleem was het gebrek aan tijd ( $7 \mathrm{x}$ genoemd). Gebrek aan tijd bleek bij zowel mannen als vrouwen een rol te spelen maar de oorzaken bleken te verschillen; $\mathrm{Bij}$ mannen werden zaken als intensieve sportbeoefening, hobby of een tweede studie als redenen voor tijdgebrek genoemd, bij vrouwen familiale of sociale perikelen zoals zorg voor kleine kinderen of het zelf bevallen van een kind.

Gebrek aan zelfvertrouwen blijkt eveneens een rol te spelen maar werd wel alleen door vrouwen ervaren ( $4 \mathrm{x}$ genoemd)! Verder werden het overlijden of een ziekte van relevante andere $(5 x)$ genoemd en moeheid of depressie $(4 x)$.

"Depressie tijdens een stage neurologie: opnieuw geconfronteerd met ziekte en overlijden van mijn zusje",

Ook behoefte aan meer sociale contacten $(3 x)$ en schuldgevoel over een mogelijk tekort schieten in de sociale contacten $(3 \mathrm{x})$ werden zowel door mannen als vrouwen 
genoemd. Een somber toekomstperspectief op de arbeidsmarkt werd alleen door een mannelijke co-assistenten als problematisch ervaren en vooral vrouwelijke co-assistenten klagen over de sfeer en begeleiding in de kliniek.

"de attitude/werkwijze van de kliniek, mensonvriendelijk en onbegrijpend".

\section{Veranderen stressoren in de tijd?}

Deze vraag kan slechts worden beantwoord door de verschillen tussen de subgroepen in het transversale materiaal te bestuderen, die als indicatie voor verandering in de tijd kunnen worden opgevat. Longitudinale toetsing van deze nominale variabelen werd niet uitgevoerd. Uit de data bleek dat co-assistenten meer worstelen dan predoctoraal studenten met hun concentratie en planning van de studie maar veel minder moeite hebben met de motivatie voor de studie dan hun jongere studiegenoten.

\subsubsection{Spot en denigrerende benadering}

"Ervaren co-assistenten spot en denigrerend benadering in de co-assistentschappen?" Op de vraag of co-assistenten geconfronteerd worden met flauwe grapjes of denigrerende opmerkingen over hun optreden of hun uiterlijke verschijning (kleding, lichaam) is het gemiddelde antwoord van de groep co-assistenten nee (mean 1.5). Ook de items die deze kwestie nog verder exploreren, geven ontkennende antwoorden, vervelende opmerkingen komen niet voor (mean 1.2), denigrerende opmerkingen ook niet (1.8). Flauwe grapjes wel iets meer (mean 2.1) maar al met al toch weinig.

Daarentegen worden grapjes of denigrerend taalgebruik over patiënten wel waargenomen (mean 2.7) zowel door vrouwelijke als door mannelijke co-assistenten, met name denigrerende grapjes over "dikke" patiënten.

Minder ziet men grappen en denigrerend taalgebruik aan het adres van vrouwen in bet algemeen of vrouwelijke patiënten (mean 2.1). Over de verpleging wordt af en toe spot en devaluerend taalgebruik beluisterd (mean 2.2).

Bij toetsing van de mogelijke verschillen tussen de onderscheiden subgroepen viel op dat van de geaggregeerde variabelen slechts in het geval van de variabele "het beluisteren van grapjes of denigrerende opmerking aan het adres van patiënten" een duidelijk significant verschil $(p \leq 0.001)$ tussen de subgroepen werd geconstateerd.

Dit verschil werd met name gevonden tussen de groep vierdejaars, de groep die nog niet met de co-schappen begonnen is en de groep co-assistenten.

Verder constateerden we een significant verschil bij de items over het waarnemen van "grapjes over vrouwelijke artsen" en de waarneming van "grapjes over de verpleging" (respectievelijk van $p \leq 0.05$ en $p \leq 0.01$ ) tussen de groep vierdejaars en de beide groepen co-assistenten:

Een mannelijke co-assistent merkt op:

"Bij tijd en wijle is er wel iemand, die zich niet wist te gedragen ten overstaan van vrouwen." 
Het komt geregeld voor dat vrouwen niet in hun juiste proporties worden gezien. "Vrouwen worden aangesproken als meisje."

"Hoe vaak wordt er niet gesproken over "vrouwtje(s)" ook door mede-co-assistenten/" “'die meisjes', ze doen bun werk niet goed en kunnen beter thuis blijven".

"vrouwelijke artsen zijn vaak 'man-wijven'."

\section{Zijn er significante verschillen tussen vrouwelijke co-assistenten en mannelijke co-assisten. ten?}

De ervaringen van vrouwen en mannen blijken alleen te verschillen ten aanzien van het "waarnemen van flauwe grapjes" en bij het "waarnemen van grapjes over vrouwelijke artsen en grapjes over de verpleging" (zie tabel 8.5). In beide gevallen nemen vrouwen de grapjes vaker waar.

Tabel 8.5 Perceptie van spot. Sekseverschillen

\begin{tabular}{llllll}
\hline & & totaal & 99 & $\delta \delta$ & p-waarde \\
\hline 3 & spot eigen functioneren/uiterlijk & 1.5 & 1.5 & 1.5 & n.s. \\
4 & vervelende opmerkingen uiterlijk & 1.2 & 1.2 & 1.2 & n.s. \\
5 & flauwe grapjes & 2.1 & 2.3 & 1.9 & .01 \\
6 & denigrerende opmerkingen & 1.8 & 1.8 & 1.7 & n.s. \\
7 & spot over patiënten & 2.7 & 2.7 & 2.7 & n.s. \\
8 & spot over vrouwen/vrouwenlichamen & 2.1 & 2.2 & 2.1 & n.s. \\
9 & grapjes over vrouwelijke artsen & 1.9 & 2.1 & 1.8 & .02 \\
10 & grapjes over verpleging & 2.2 & 2.3 & 2.1 & .09 \\
\hline
\end{tabular}

Gemiddelde score totale groep en per sekse en p-waarde sekseverschil.

Range 1- helemaal niet-4- heel vaak

Veranderen co-assistenten in de tijd? Veranderen vrouwen anders dan mannen? Uit het longitudinaal materiaal (zie tabel 8.6) blijkt dat de totale groep van 126 coassis

tenten die na een jaar stages opnieuw de vragenlijst invulden, significant meer vervelende opmerkingen waarneemt en significant meer grapjes over de verpleging registreert. Dat laatste blijkt opmerkelijk genoeg vooral door mannelijk co-assistenten angegeven te worden.

Tabel 8.6 Perceptie van spot. Beloop in de tijd.

\begin{tabular}{|c|c|c|c|c|c|c|}
\hline & totaal & 오오 & $\delta \delta$ & fase 0 & 099 & $00^{\circ}$ \\
\hline 3 spot eigen functioneren/uiterlijk & - & . & - & . & . & . \\
\hline 4 vervelende opmerkingen uiterlijk & $+*$ & . & . & . & . & \\
\hline 7 spot over patiënten & . & . & . & $+* *$ & $+* *$ & . \\
\hline 10 grapjes over verpleging & $+*$ & . & $+* *$ & $+* * *$ & $+^{*}$ & $+* *$ \\
\hline
\end{tabular}

significante verschillen in de loop van de tijd, getoetst met Wilcoxon;

* $\mathrm{p} \leq 0.05 ;{ }^{* *} \mathrm{p} \leq 0.01$; *** $\mathrm{p} \leq 0.001$.

Het veranderingstraject van de novieten (groep 0) blijkt vervolgens het grootste in die zin dat er bij deze groep van een evidente toename sprake is van het registreren van 
denigrerende en spottende opmerkingen over patiënten en het registreren van grapjes over de verpleging.

De toename van het horen van spottende opmerkingen over patiënten blijkt verder vooral door vrouwelijke novieten, de groep die start met hun co-assistentschappen te worden ervaren.

Opmerkelijk is de bevinding dat de groep gevorderden een significante toename van spot aan het eigen adres waarneemt (mogelijk een effect van 2 maal dezelfde vraag voorleggen een dezelfde persoon).

Verschilt bet veranderingstraject van vrowwelijke co-assistenten van dat mannelijke? Alleen ten aanzien van het beluisteren van flauwe of vervelende opmerkingen en ten aanzien van de perceptie van grapjes over de verpleging; het eerste valt vrouwen meer op het tweede mannen.

\subsubsection{Kwalltatieve gegevens over vormen van spot}

Welke spotternijen en waar? Antwoorden op open vragen

Waar merken de co-assistenten de meeste spotternijen op ?

Spottend en denigrerend taalgebruik werd door co-assistenten in alle klinische stages opgemerkt, 46 maal werd een stagesetting genoemd. In meer dan de helft van de gevallen betrof het de snijdende vakgebieden. Een co-assistente schreef hierover:

"Overal doet bet zich voor, behalve in de buisartspraktijken. Met name chirurgen zijn belachelijk trots op zichzelf en daardoor denigrerend ten opzichte van vrouwen. Alsof vrouwen niet eeuwenlang al goed zijn geweest in handwerk."

Ondanks het gegeven dat uit de kwantitatieve data valt op te maken dat de respondenten gemiddeld vinden dat het wel mee valt met het voorkomen van spot of denigrerende benadering aan hun adres of richting patiënten of vrouwen, blijken er toch opmerkelijk veel voorbeelden te worden gegeven, die inhoudelijk veelzeggend zijn. In het transversale onderzoek gaven 68 respondenten (30\% van onderzoekspopulatie) voorbeelden van geringschattend spreken over patiënten en/of vrouwen in de kliniek; van deze groep is tweederde deel vrouw $(n=46)$.

De tweede meting, longitudinaal onderzoek, na een jaar gaf een nog groter aantal voorbeelden te zien. Door 70 respondenten, meer dan de helft van de onderzoekspopulatie van 126, werden voorbeelden gegeven van flauwe grapjes en denigrerende opmerkingen. Ook in dit geval werd het merendeel van de voorbeelden gegeven door vrouwelijke co-assistenten (45 voorbeelden door vrouwen en 24 door mannen). Hieronder volgen enkele citaten.

Flawwe opmerkingen aan bet adres van co-assistenten:

"de beste co is geen co"

"waar is de co? Fiasco-"

"examen gehaald? Wat beb je ervoor gedaan?" (aan een knappe vrouwelijke co) 
"dat zal je wel leuk vinden die vele vaginale toucher's" (aan een mannelijke co) "bij mijn interne stage werd ik uitgescholden door een internist die vond dat ik er belabberd nitzag"

"ik beb de indruk dat de verpleging van mening is (en misschien bebben ze wel gelijk) dat co-assistenten niets kunnen (b.v. lichamelijk onderzoek, en strips/infusen prikken etc."

"verpleging liet je voor de raarste dingen opdraven"

Co-assistenten onderling blijken ook geen lieverdjes, getuige de volgende opmerking: "bij stuntelig gedrag op de operatiekamer wordt je voor gek gezet door andere co-assistenten."

Ook arts-assistenten lopen niet altijd over van empathie

"een minder snelle co die bij arts-assistenten bekend staat als dom, wordt dus uitgelachen."

\section{Spot ten aanzien van patiënten}

Vrouwelijke co-assistenten gaven vaker dan mannelijke co-assistenten voorbeelden van spot die betrekking hadden op vrouwelijke patiënten of vrouwelijke artsen, namelijk in de helft van de gevallen. Bij de voorbeelden van de mannelijke co-assistenten ging het in een derde van de gevallen over spot over vrouwelijke patiënten of artsen. Inhoudelijk valt op dat bij de vraag naar voorbeelden van spot of denigrerend spreken over patiënten met name de "dikke, adipeuze patiënt" mikpunt van negatieve uitingen blijken te zijn. Dik-zijn blijkt ook gemakkelijk geassocieerd te worden met dom,

"Daar heb je weer zo'n DDD! DDD? Ja.. Dikke Domme Diabeet"

Spot ten aanzien van vrouwen of vrowwelijke lichamen

Co-assistenten beluisteren ook seksistische opmerkingen tijdens hun klinische stages

"we maken nog een sneetje"

"verstand zit in haar borsten"

"lekker stuk"

"mooie tieten" of "wat een gedrocht"

"grote vrouwenborst": "walgelijk"

Dik-zijn gecombineerd met vrouw-zijn blijkt een combinatie te zijn die opmerkingen en bespotting oproept:

"Flauwe grappen over dikke patiënten (vooral vrouwen)."

"Spot vooral over patiēnten die dik zijn, met name van vrouwen wordt dat minder geaccepteerd."

"Jeh, wat is dit een dikke vrouw zeg. Als ik zo iemand moet opereren, vraag ik altijd een vrouwelijke co-assistent. Hopelijk vergaat haar dan de lust om gebakjes te eten!" "Wat een vet wijf, dat zal lekker graven worden naar de appendix." 


\subsection{Samenvatting resultaten draaglast}

De co-assistenten ervaren co-assistentschappen als een uitdaging, vinden dat een coassistent meer plichten dan rechten heeft. Ze ervaren een gebrek aan vrije tijd en vinden het normaal om na een werkdag nog uren te moeten studeren. Ook zijn ze voornemens om alles op alles te zetten om dokter te worden, hoewel ze zich vooralsnog een buitenstaander voelen.

Ten aanzien van eventuele sekseverschillen valt op dat mannelijke co-assistenten meer last hebben van negatieve stress, zoals een gevoel van opgejaagdheid. Niet de vrouwen maar de mannelijke co-assistenten blijken een sterker gevoel van plichten te hebben. In de loop van de tijd blijkt met name het gebrek aan tijd voor co-assistenten van toenemend belang te worden. De bereidheid om alles op alles te zetten voor het vak, blijkt vooral bij afstuderende vrouwen af te nemen. Ook in de balans tussen werk en privé en hoe men deze balans ervaart, blijken veranderingen op te treden. Co-assistenten blijken in de loop van de tijd meer last te gaan ervaren van hun privé-leven; ze beschrijven de invloed van privé meer in negatieve termen. Ook de invloed van stages op het privéleven werd onderzocht en opmerkelijk is dat met name vrouwelijke novieten een negatieve beïnvloeding van de stages op hun priveleven aangeven in de longitudinale onderzoek die bij hun mannelijke collega's ontbreekt.

Wanneer gebrek aan tijd een belangrijk knelpunt is in de fase van de co-assistentschappen, is het niet verwonderlijk dat concentratieproblemen en relatieproblemen als belangrijkste stressoren worden genoemd. Dit blijkt voor mannelijke co-assistenten in nog sterkere mate te gelden dan voor vrouwelijke, hetgeen consistent is met de gevonden hogere mate aan negatieve stress bij mannen.

Co-assistenten voelen zich verder in het algemeen niet bespot, al komen flauwe grapjes over co-assistenten wel voor. Co-assistenten merken nauwelijks spot en denigrerend spreken over vrouwen en vrouwenlichamen op, maar wel over patiënten.

De perceptie van vrouwelijk co-assistenten van spot verschilt op twee punten van die van hun mannelijk collega's namelijk op het punt van de waarneming van spot richting verpleging en spot richting vrouwelijke artsen: beide worden door vrouwen sterker waargenomen.

Uit het kwalitatieve materiaal, dat werd verkregen door verder door te vragen naar de aard van de beluisterde opmerkingen over patiënten of vrouwen komt een minder prettig beeld naar voren. Er zijn veel voorbeelden waaruit blijkt dat vooral dikke vrouwelijke patiënten mikpunt van spot zijn, vooral in de snijdende vakken.

Het beloop in de tijd laat zien dat co-assistenten als totale groep slechts veranderen in perceptie van spot richting verpleging. De co-assistenten in fase 0 maken de grootste veranderingen door, namelijk een verandering in de perceptie van denigrerende en spottende uitingen over patiënten, die a fortiori door vrouwelijke novieten wordt aangegeven en de genoemde toename van perceptie van spot richting verpleging, door zowel vrouwelijke als mannelijke novieten. 
Hoofdstuk 8

\subsection{Resultaten transversaal en longitudinaal onderzoek naar draagkracht}

Coping stijlen die worden gehanteerd door co-assistenten en de mate waarin zij zich assertief opstellen, zullen in het navolgende aan de orde komen.

\subsubsection{Copingstijlen}

Welke copingstijlen worden door co-assistenten gedurende bun inwijdingstraject gehanteerd?

Wanneer men de scores van de totale groep co-assistenten beziet (tabel 8.7 kolom 2) dan kan men constateren dat co-assistenten een actieve coping stijl hanteren en daarnaast sociale steun zoeken. Ook de palliatieve stijl heeft een zekere aantrekkingskracht. Dit geldt niet voor de depressief/vermijdende stijl en ook het uiten van emoties. Dit patroon blijkt overeen te komen met dat van de vierdejaars studenten die nog niet met de co-assistentschappen zijn begonnen. Ook hier blijkt een voorkeur voor actieve coping stijl, sociale steun en in mindere mate het palliatieve reactiepatroon.

De onderscheiden subgroepen blijken in preferentie voor coping stijlen niet significant te verschillen. In tabel 8.7 staan de gemiddelde antwoorden van de verschillende groepen co-assistenten op de mate waarin zij bepaalde coping stijlen hanteren.

Tabel 8.7 Copingstijlen

\begin{tabular}{lllll}
\hline & $\begin{array}{c}\text { pre-co's } \\
\text { groep 0 }\end{array}$ & $\begin{array}{l}\text { co-assistenten } \\
\text { groep 1 }\end{array}$ & groep 2 & p-waarde \\
\hline sociale steun & 2.6 & 2.6 & 2.7 & n.s. \\
actief & 2.9 & 2.9 & 2.8 & n.s. \\
depressief/vermijdend & 1.8 & 1.9 & 1.9 & n.s. \\
palliatief & 2.6 & 2.5 & 2.5 & n.s \\
uiten & 2.3 & 2.3 & 2.3 & n.s. \\
\hline
\end{tabular}

gemiddelde scores van groep 0 (preco-assistenten), groep 1 (de beginners) en groep 2 (gevorderden) p-waarde verschil tussen subgroepen (K.W.test); Range: 1 - zelden/nooit, 2 = soms, 3 = vaak, 4 = zeer vaak.

Is er een sekseverschil in dit opzicht?

Er blijkt een duidelijk verschil tussen de seksen ten aanzien van preferentie voor het "zoeken van sociale steun" als coping stijl en palliatieve coping stijl (tabel 8.8). Vrouwen blijken significant vaker bij problemen sociale steun te zoeken en zijn sterk geneigd dan mannen om hun toevlucht te zoeken bij vrienden, familie, partner en dergelijke.

Het grootste sekseverschil in het zoeken van sociale steun wordt gevonden bij groep 1 , de beginnende co-assistenten $(\mathrm{p}<0.001)$ en bij groep 0 , de vierdejaars studenten $(p=0.02)$. Het sekseverschil blijkt op dit punt verdwenen te zijn in de groep gevorderde co-assistenten. De mannelijke co-assistenten van groep 2 bleken iets vaker dan de overige mannen sociale steun gezocht te hebben, waardoor het sekseverschil bij de gevorderde groep niet meer aanwezig is. 
Tabel 8.8 Sekseverschillen in copingstijlen

\begin{tabular}{lllll}
\hline & $\begin{array}{l}\text { studenten } \\
\text { groep } 0\end{array}$ & $\begin{array}{l}\text { co-assistenten } \\
\text { totaal }\end{array}$ & groep 1 & groep2 \\
\hline sociale steun & $.02(\$ \uparrow)$ & $.000(\$ \uparrow)$ & $.000(\$ \uparrow)$ & n.s \\
actief & n.s. & n.s. & n.s. & n.s. \\
depressief/vermijdend & n.s. & n.s. & n.s. & n.s. \\
palliatief & n.s. & $.03(\delta \uparrow)$ & n.s. & $.005(\delta \uparrow)$ \\
uiten & n.s. & n.s. & n.s. & n.s. \\
\hline
\end{tabular}

p-warde verschil vrouwen/mannen (Mann-Whitney toets). $(\& \uparrow)$ - vrouwen hebben hogere score; $(\delta \uparrow)$ - mannen hebben hogere score.

Mannen blijken een grotere voorkeur te hebben om bij moeilijkheden de zinnen te verzetten en een zogenaamde palliatieve coping strategie te gebruiken. Op niveau van de totale groep blijken mannelijke co-assistenten significant hoger te scoren, hetgeen dan met name toegeschreven moet worden aan de mannelijke gevorderde co-assistenten uit groep 2.

\section{Veranderen co-assistenten in de tijd en veranderen mannen anders dan vrouwen?}

$\mathrm{Er}$ is gekeken naar veranderingen in de manier van omgaan met stress naarmate men verder vorderde in de co-assistentschappen. In tabel 8.9 staan de significante verschillen in coping stijlen tussen de groepen co-assistenten na 1 jaar, dat wil zeggen de vierde-jaars zijn nu de beginners $(n=38)$, de beginners zijn nu de gevorderden $(n=59)$, en de gevorderden zijn inmiddels basisartsen $(\mathrm{n}=29)$.

Tabel 8.9a Copingstijlen in de loop van de tijd in de totale groep

\begin{tabular}{|c|c|c|c|}
\hline & Totaal & 99 & రठ \\
\hline sociale steun & $+* * *$ & $+* * *$ & $+* *$ \\
\hline actief & $+* *$ & $+*$ & . \\
\hline depressief & . & . & . \\
\hline palliatief & $+* *$ & . & $+*$ \\
\hline uiten & $+* * *$ & $+* *$ & $+* * *$ \\
\hline
\end{tabular}

significante verschuiving in de tijd, getoetst met Wilcoxon; totale groep co's, vrouwen en mannen; . * $\mathrm{p} \leq 0.05 ;{ }^{* *} \mathrm{p} \leq 0.01 ;{ }^{* * *} \mathrm{p} \leq 0.001$

Als eerste valt op dat gedurende het jaar van observatie de scores van de totale groep co-assistenten bij nagenoeg alle coping strategieën een toename vertonen, met uitzondering van depressief/vermijdend gedrag. Zowel mannen als vrouwen blijken vaker sociale steun te zoeken en vaker hun emoties te uiten. Vrouwen blijken daarnaast in toenemende mate actief met problemen om te gaan, terwijl mannelijke co-assistenten toenemend de zinnen verzetten en de gedachten op andere dingen trachten te richten wanneer zij zich in problematische situaties bevinden. 
Tabel $8.9 \mathrm{~b}$ Copingstijlen in de loop van de tijd in de verschillende fasen

\begin{tabular}{|c|c|c|c|c|c|c|c|c|c|}
\hline & fase 0 & 098 & 088 & fase 1 & 188 & 186 & fase 2 & 299 & 288 \\
\hline sociale steun & $+* * *$ & $+*$ & . & $+* * *$ & $+* * *$ & . & $+*$ & . & . \\
\hline actief & . & . & . & $+*$ & $+*$ & . & · & . & . \\
\hline depressief & . & . & . & $\cdot$ & . & . & . & . & . \\
\hline palliatief & +4 & $+*$ & $+*$ & . & . & . & . & . & . \\
\hline uiten & . & . & $+*$ & $+* * 4$ & $+\infty$ & + *\#* & $+*$ & . & . \\
\hline
\end{tabular}

Significante verschillen in de loop van de tijd getoetst met Wilcoxon;

$* \mathrm{p} \leq 0.05 ; * * \mathrm{p} \leq 0.01 ; * * * \mathrm{p} \leq 0.001$

Wanneer men het veranderingstraject in de verschillende fasen bestudeert, valt op dat vooral in fase 0 en fase 1 , de periode van 1 à 2 jaar stages lopen, veel verandering optreedt in het beroep dat co-assistenten op coping strategieën doen. Concreet zien we een stijging van de toepassing van vier van de vijf coping strategieën. Het zoeken van sociale steun neemt toe, evenals de actieve coping stijl en de palliatieve stijl in het van omgaan met belasting.

In fase 0 ziet men een stijging van het zoeken van sociale steun bij vooral de vrouwelijke co-assistenten en een stijgend beroep op een palliatieve coping stijl bij beide seksen in fase 0 . In fase 1 neemt het beroep van vrouwelijke co-assistenten op het zoeken van sociale steun toe evenals het beroep op een doelgerichte en actieve coping stijl. Het uiten van ongenoegen neemt in fase 1 bij beide seksen toe.

In fase 2, de periode van de afronding van de studie, treden veranderingen op in die zin dat de sociale coping stijl en het uiten van ongenoegen een toename vertonen. De sekseverschillen blijken in fase 2 verdwenen te zijn.

\subsubsection{Assertiviteit en examenvrees}

Co-assistenten en preco-assistenten blijken zichzelf gemiddeld genomen als assertief te omschrijven. Ook blijken co-assistenten en preco-assistenten gemiddeld niet geplaagd te worden door examenvrees of faalangst. Met behulp van de non-parametrische toets Kruskall-Wallis konden geen significante verschillen aangetoond worden tussen vierdejaars studenten, beginnende of gevorderde co-assistenten (tabel 8.10).

Tabel 8.10 Assertiviteit en examenvrees.

\begin{tabular}{lllll}
\hline & $\begin{array}{l}\text { studenten } \\
\text { groep 0 }\end{array}$ & $\begin{array}{l}\text { co-assistenten } \\
\text { totaal }\end{array}$ & groep 1 & groep 2 \\
\hline assertiviteit & 2.8 & 2.7 & 2.8 & 2.6 \\
examenvrees & 2.0 & 1.9 & 1.9 & 1.9 \\
\hline
\end{tabular}

Gemiddelde scores van de totale groep, groep 0, beginners (groep 1) en de gevorderden (groep 2), Range 1 . 4 (volledig oneens - volledig eens)

Is er sprake van een sekseverschil?

Er bleek geen sprake te zijn van significante sexeverschillen op de variabelen assertiviteit en examenvrees. 
Veranderen co-assistenten in de tijd en veranderen vrowwen anders dan mannen? Ook op deze punten kon geen verandering gevonden worden, met uitzondering van een significante afname van de examenvrees bij mannelijke gevorderden.

\subsection{Samenvatting resultaten draagkracht}

Co-assistenten hanteren over het algemeen een actieve coping stijl bij problemen. In iets mindere mate zoeken zij sociale steun of passen zij een palliatieve coping stijl toe. Problemen vermijden of depressief reageren komt als coping stategie bij co-assistenten weinig voor. Co-assistenten zijn enigszins huiverig om ongenoegen te uiten. $\mathrm{Ze}$ blijken wel behoorlijk assertief te zijn en weinig last te hebben van examenvrees.

$\mathrm{Er}$ is sprake van een duidelijk verschil tussen de seksen in voorkeur voor coping stijl. Vrouwen blijken significant meer hun toevlucht te zoeken tot sociale steun, mannelijke co-assistenten blijken een voorkeur te hebben voor een palliatieve stijl, als afleiding zoeken of er even tussen uit gaan. De mate van assertiviteit en examenvrees zijn gelijk bij de seksen.

Het meest opmerkelijk is dat het longitudinale materiaal op alle variabelen van coping een significante toename laat zien met uitzondering van de depressief-vermijdende stijl, die constant laag blijft in de tijd. Zowel mannen als vrouwen blijken in de loop van de co-assistentschappen meer sociale steun te zoeken en meer hun emoties te uiten. Vrouwen blijken daarnaast in toenemende mate actief en doelgericht hun problemen te lijf te gaan terwijl mannelijke co-assistenten in dergelijke gevallen toenemend de zinnen verzetten en de gedachten op andere dingen trachten te richten. Assertiviteit of last van examenvrees blijven verder constant in de tijd.

\subsection{Resultaten van transversaal en longitudinaal onderzoek naar outcome}

\subsubsection{Vermoeidheid en gezondheidsklachten}

Ervaren co-assistenten vermoeidheid of gezondheidsklachten?

Co-assistenten geven aan dat ze zich zelden psychisch vermoeid, maar soms fysiek vermoeid en vaak positief gestemd voelen. Hoofdpijnklachten en eetproblemen blijken zelden voor te komen. In tabel 8.11 zijn de gemiddelde scores weergegeven van de totale groep co-assistenten, de pre-co-assistenten, de beginners en de gevorderden. Groep 0 , de pre-co-assistenten, blijkt over de gehele linie iets gunstiger te scoren en significant minder last te hebben van fysieke vermoeidheid dan de andere groepen. Opvallend is dat de pré-co-assistenten meer last hebben van gezondheidsklachten als hoofdpijn en eetproblemen. 
Tabel 8.11 Mate van vermoeidheid

\begin{tabular}{llllll}
\hline & \multicolumn{5}{c}{ co-assistenten } \\
& groep 0 & totaal & gr.1 & gr.2 & p.waarde (K-W) \\
\hline psychisch vermoeid & 1.9 & 2.1 & 2.1 & 2.1 & n.s. \\
fysiek vermoeid & 2.6 & 2.9 & 3.1 & 2.8 & .006 \\
positief & 3.8 & 3.6 & 3.6 & 3.6 & n.s. \\
hoofdpijn & 2.0 & 1.7 & 1.7 & 1.6 & n.s. \\
eetproblemen & 1.7 & 1.5 & 1.4 & 1.5 & n.s. \\
\hline
\end{tabular}

gemiddelde scores totale groep, groep 0 , groep 1 en groep 2

Range 1-bijna nooit 2-zelden 3-soms 4 -vaak 5-bijna altijd

\section{Zijn er significante sekseverschillen ?}

De scores in het transversaal onderzoek van vrouwelijke co-assistenten vergeleken met met die van mannen (zie tabel 8.12) tonen aan dat vrouwen significant positiever gestemd zijn in de co-assistentschappen dan hun mannelijk collega's ( $p \leq 0.01$ ). Dit blijkt te berusten op het aandeel van gevorderde vrouwelijke co-assistenten (groep 2 ). In de groep 0, de pre-co-assistenten blijken vrouwen meer last te hebben van fysieke vermoeidheid en significant vaker last te hebben van hoofdpijn en eetproblemen.

$22 \%$ van de vrouwen en $15 \%$ van de mannen geeft een score van hoger of gelijk aan 3 bij "last van hoofdpijn". Bij "last van eetproblemen" blijkt $25 \%$ van de vrouwen en slechts $10 \%$ van de mannen een score van 3 of hoger te geven.

In tabel 8.12 zijn de p-waarden weergegeven van toetsing (Mann Whitney-U-test) van de man/vrouw verschillen in de totale groep en de drie subgroepen.

Tabel 8.12 Mate van vermoeidheid, sekseverschillen.

\begin{tabular}{|c|c|c|c|c|}
\hline & $\begin{array}{l}\text { studenten } \\
\text { groep } 0\end{array}$ & $\begin{array}{l}\text { co-assistenten } \\
\text { totale groep }\end{array}$ & groep 1 & groep 2 \\
\hline psychisch vermoeid & n.s. & n.s. & n.s. & n.s. \\
\hline fysiek vermoeid & $.02(9 \uparrow)$ & n.s. & n.s. & n.s. \\
\hline positief gestemd & n.s. & $.005(\$ \uparrow)$ & n.s. & $.002(\% \uparrow)$ \\
\hline hoofdpijn & $.06(8 \uparrow)$ & $.009(q \uparrow)$ & $.002(१ \uparrow)$ & n.s. \\
\hline eetproblemen & $.03(9 \uparrow)$ & $.000(q \uparrow)$ & $.001(9 \uparrow)$ & $.02(\$ \uparrow)$ \\
\hline
\end{tabular}

p-waarden getoetst met Mann-Whitney-U-test. $(\uparrow \uparrow)$ = vrouwen hebben hogere score.

Range 1 -bijna nooit 2 =zelden 3 -soms 4 =vaak 5 -bijna altijd

In de subgroepen ziet men alleen in groep 0 , de pre-co-assistenten, een significant hogere score van vrouwelijke studenten op fysieke vermoeidheid. In de andere subgroepen treft men dit sekseverschil niet aan. Men kan zich afvragen of vrouwelijke preco-assistenten meer opzien tegen de fysieke belasting van de klinische fase.

Veranderen co-assistenten in de tijd en veranderen vrouwen anders dan mannen? Op niveau van de totale groep co-assistenten blijkt (zie tabel 8.13) dat in de loop van de co-assistentschappen een significant afname optreedt van de fysieke vermoeidheid en een significante stijging van het ervaren van positieve gevoelens. Psychische vermoeidheid vertoont geen verandering in de tijd. De afname van de fysieke vermoeid- 
heid berust met name op het aandeel van de vrouwelijke co-assistenten en de stijging van de positieve stemming met name op de mannelijke co-assistenten.

Tabel 8.13 Mate van vermoeidheid. Beloop in de tijd.

\begin{tabular}{|c|c|c|c|c|c|c|c|c|c|c|c|c|}
\hline & totaal & $9 \%$ & $\delta \delta$ & faseo & $09 \%$ & 0ठర & fase! & 198 & $18 \delta$ & fase2 & 289 & 280 \\
\hline psy.verm. & . & . & . & . & . & . & . & . & . & *** & .* & $\therefore$ \\
\hline m. & 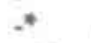 & $\therefore$ & . & $+*$ & . & $+*$ & *** & $*^{*}$ & . & $*$ & $*$ & . \\
\hline positief & $+^{*}$ & . & $+^{*}$ &. & . & . & . & . & . & $+* *$ & . & $+*$ \\
\hline hoofdpijn & , & . & . & . & . & . & . & . & . & . & . & . \\
\hline eetprobl. & . & . & . & . & . & . & . & . & . & . & . & . \\
\hline
\end{tabular}

significante verschuivingen in de loop van de tijd, getoetst met Wilcoxon.

* $\mathrm{p} \leq 0.05 ;{ }^{* *} \mathrm{p} \leq 0.01 ;{ }^{* * *} \mathrm{p} \leq 0.001$

Wanneer men vervolgens het veranderingstraject in de verschillende fasen bestudeert (zie tabel 8.13) valt op dat met name veranderingen optreden in de positieve gestemdheid en in de mate van fysieke vermoeidheid. Het starten met de co-assistentschappen, fase 0 gaat gepaard met een significante stijging van de fysieke vermoeidheid bij mannelijke novieten. In fase 1 ziet men een significante afname van de fysieke vermoeidheid bij vrouwelijke beginners.

In fase 2, wanneer het einde van de medische opleiding in zicht is, ziet men een afname van de psychische vermoeidheid optreden, zowel bij vrouwelijke als mannelijke co-assistenten en een afname van de fysieke vermoeidheid bij de vrouwelijke gevorderde co-assistenten. Bij de mannelijke afstuderende co-assistenten ziet men verder een significante toename van de positieve gestemdheid.

\subsubsection{Motivatie}

Zijn co-assistenten gemotiveerd voor bun studie en schatten zij het medisch beroep als belastend in?

In het algemeen (zie tabel 8.14) blijkt dat de totale groep co-assistenten geen last heeft van twijfels of gebrek aan motivatie voor de studie (score 1.8). De pre-co-assistenten hebben hiervan nog minder last dan de co-assistenten. Op de vraag of men het medisch beroep als belastend en zwaar beschouwt en of men opziet tegen de verantwoordelijkheid en verplichting die het artsenberoep met zich meebrengt, is het antwoord indifferent (geen ja, geen nee).

Tabel 8.14 Motivatie

\begin{tabular}{llllll}
\hline & $\begin{array}{l}\text { pre-co's } \\
\text { groep 0 }\end{array}$ & $\begin{array}{l}\text { co-assistenten } \\
\text { total }\end{array}$ & groep 1 & groep 2 & K-W \\
\hline twijfel studie & 1.5 & 1.8 & 1.8 & 1.7 & .009 \\
belasting vak & 2.5 & 2.5 & 2.5 & 2.5 & n.s \\
\hline
\end{tabular}

Gemiddelde scores groep 0, totale groep co-assistenten en groep $1=$ de beginners en groep 2 = de gevorderden. p-waarde (K.W test). Range 1 - bijna nooit, 2 - zelden, 3 - soms, 4 - vaak, 5 bijna altijd. 


\section{Zijn er sekse-verschillen?}

Er is geen verschil tussen de seksen in motivatie voor de studie. Vrouwelijke studenten die nog niet begonnen zijn aan de co-assistentschappen blijken verder de belasting van het medisch beroep als zwaarder in te schatten dan mannelijke studenten (zie tabel 8.15).

Tabel 8.15 Sekseverschillen in motivatie

\begin{tabular}{lllll}
\hline & $\begin{array}{l}\text { studenten } \\
\text { groep } 0\end{array}$ & $\begin{array}{l}\text { co-assistenten } \\
\text { totale groep }\end{array}$ & groep 1 & groep 2 \\
\hline twijfel studie & n.s. & n.s. & n.s. & n.s. \\
belasting vak & $.05(Q \uparrow)$ & n.s. & n.s. & n.s.
\end{tabular}

p-warden getoetst met Mann-Whitney-U-test; $(q \uparrow)$ - vrouwen hogere score

Veranderen co-assistenten in de tijd en veranderen vrouwen anders dan mannen? Wanneer we de ontwikkelingen in de tijd beschouwen (zie tabel 8.16), dan zien we dat over alle fasen heen co-assistenten minder gaan twijfelen aan hun studie in de loop van de stages. De motivatie voor de studie neemt dus toe. De sterkste afname van twijfel treedt op bij de vrouwen in fase 1, de consolidatie-fase, wanneer de startfase van de co-schappen achter de rug is.

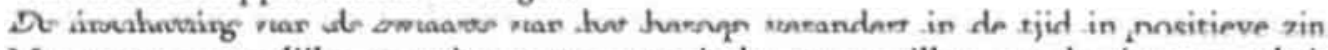
Met name mannelijke co-assistenten gaan minder zwaar tillen aan de eisen en relativeren de verantwoordelijkheden verbonden aan het arts zijn. Met name in fase 2 bij het naderen van het afstuderen en arbeidsmarkt geeft bij de mannelijke co-assistenten een significante relativering van de zwaarte van het artsenvak.

Tabel 8.16 Motivatie in de loop van de tijd

\begin{tabular}{|c|c|c|c|c|c|c|c|c|c|c|c|c|}
\hline & totaal & 99 & 80 & fo & $09 \%$ & $0 \delta \delta^{\circ}$ & f1 & $1 \% ?$ & $1 \delta \delta^{\circ}$ & f2 & 299 & 280 \\
\hline twijfel st & ${ }^{*}$ & . & 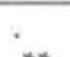 & . & . & . & *** & ${ }^{*}$ & . & & . & . \\
\hline belast vak & $* *$ &. & *** & . & . & . &. &. & . &.$^{*}$ &. &.$^{*}$ \\
\hline
\end{tabular}

significante verschuivingen in de loop van de tijd getoetst met Wilcoxon.

* $\mathrm{p} \leq 0.05 ;{ }^{* *} \mathrm{p} \leq 0.01 ;{ }^{* * *} \mathrm{p} \leq 0.001$

\subsection{Samenvatting resultaten outcome}

De fase van de co-assistentschappen wordt niet als psychisch belastend ervaren en slechts in lichte mate als fysiek zwaar en gezondheidsklachten als hoofdpijn of eetproblemen spelen bij co-assistenten geen noemenswaardige rol. Co-assistenten ervaren wel duidelijk positieve gevoelens.

Er blijken minder sekseverschillen dan verwacht. Vrouwelijke co-assistenten blijken significant positiever gestemd dan hun mannelijke collega's maar ze kampen ook meer met lichte gezondheidsklachten als hoofdpijn of eetproblemen. De mate van psychische of fysieke vermoeidheid laat nauwelijks sekseverschillen zien en ook de motivatie voor de studie is gelijk. Vrouwelijke studenten die nog niet met de co-assistentschap- 
pen begonnen zijn blijken wel het medisch beroep als zwaarder in te schatten en hebben meer last van fysieke vermoeidheid.

De veranderingen in de ervaring van vermoeidheid zijn anders dan verwacht. De fysieke vermoeidheid blijkt over alle fasen heen een afname te vertonen bij met name de vrouwelijke co-assistenten. Wanner we de verschillende fasen bezien blijkt het beloop te fluctueren. In de startfase blijken mannelijke co-assistenten zich toenemend moe in fysieke zin te voelen. In de consolidatie-fase en de afstudeer-fase blijkt deze vorm van vermoeidheid bij vrouwelijke co's af te nemen. De psychische vermoeidheid vertoont uitsluitend in fase 2 de afstudeerperiode een duidelijke afname en wel bij beide seksen. Het positieve gevoel en gevoel van welbevinden neemt bij coassistenten toe in de loop van de tijd, met name bij de mannelijke co-assistenten! Deze toenemende positieve gestemdheid blijkt vooral toegeschreven te moeten worden aan de mannelijke co-assistenten uit de gevorderde groep.

\subsection{Meervoudige lineaire regressie analyse met achtergrond variabelen}

Verificatie van de gevonden sekseverschillen en verschillen tussen subgroepen in de trans. versale data.

Om de verschillen tussen de groep vrouwen en mannen en de verschillen tussen subgroepen, die werden gevonden in de transversale data met behulp van bivariate analyses (als Mann-Whitney testen en Kruskall-Wallis toets) te controleren en te onderzoeken of andere achtergrondvariabelen (zie tabel 8.17) een rol spelen in de verklaring van de variantie van de afhankelijke variabelen, hebben we in tweede instantie meer. voudige lineaire regressie analyses uitgevoerd. Hierdoor ontstaat een beeld van de onafhankelijke invloed van de diverse variabelen tegelijk.

Door de samenhang van de belangrijkste (afhankelijke) variabelen uit het thema "stress en vermoeidheid" met de achtergrond variabelen te onderzoeken, proberen we antwoord te geven op de vraagstelling:

Spelen andere achtergrondvariabelen dan sekse en subgroep een rol bij de verklaring van de bevindingen van bet transersale onderzoek naar draaglast, draagkracht en outcome ? Steeds is gecontroleerd of voldaan was aan de voorwaarden van de lineaire regressie, te weten lineariteit en normaliteit. Indien dit niet het geval was, is dat bij de desbetreffende variabele aangegeven.

Eerst wordt een overzicht gegeven van de achtergrondvariabelen en hun onderlinge samenhang en daarna de relatie van de onderzochte variabelen uit de drie thema's draaglast, draagkracht en outcome met die achtergrondvariabelen.

De bevindingen worden gerapporteerd aan de hand van de volgende vragen :

- Worden de eerdere bevindingen ten aanzien van sekseverschillen en verschillen tussen de subgroepen (preco-assistenten, beginners en gevorderden) door de regressie-analyse bevestigd?

- Zijn andere achtergrondvariabelen van invloed op de genoemde kwestie? 
Tabel 8.17 Overzicht achtergrondvariabelen met antwoordcategorieën

\begin{tabular}{|c|c|}
\hline variabelen & antwoordcategorieën \\
\hline 1. sekse & $1=\operatorname{man} ; 2=$ vrouw \\
\hline 2. subgroep & 0 - preco-assistenten; 1 - eerstejaars co-assistenten + tweedejaars \\
\hline 3. leeftijd & in jaren \\
\hline 4. opleiding vader ( $(9.2)$ & 7. puntschaal \\
\hline 5. opleiding moeder ( $(9.4)$ & 7. puntschaal \\
\hline 6. privé (v7) & $\begin{array}{l}1 \text { - ongebonden; } 2 \text { - woon alleen, wel vaste relatie; } 3 \text { - samenwonend } \\
\text { met partner; } 4 \text { - samenwonend met partner en/of kind. }\end{array}$ \\
\hline 7. far & familieleden die arts zijn: $0=$ nee; 1 - ja. \\
\hline 8. vooropleiding ( $\mathrm{v} 4.2)$ & $\begin{array}{l}\text { - geen paramedische, verpleegkundige, HBO of wetenschappelijke } \\
\text { opleiding voltooid; } 1 \text { - voltooid. }\end{array}$ \\
\hline
\end{tabular}

Bij toetsing van de onderling samenhang van de achtergrondvariabelen onderling bleek dat de volgende variabelen een significante correlatie met elkaar vertonen sekse en leeftijd: $(p=.024)$

De vrouwelijke respondenten blijken jonger te zijn dan mannelijke.

sekse en privé-situatie: $(p=.031)$

$\mathrm{De}$ vrouwelijke respondenten zijn vaker alleenstaand en ongebonden en mannelijke respondenten vaker samenlevend en gebonden

subgroep en leeftijd: $(p=, 000)$

De co-assistenten zijn ouder dan preco-assistenten (logisch!).

leeftijd met extra vooropleiding: $(p=.012)$

Hoe ouder de respondent is, hoe groter de kans is dat de respondent een extra vooropleiding heeft gevolgd

opleiding vader en opleiding moeder: $(p=.000)$

Hoe hoger opleiding van de vader van de respondent, hoe hoger die van de moeder is. opleiding vader en privé-situatie: $(p=.032)$

Een lagere opleiding van de vader hangt samen met de privé-situatie in die zin dat men dan vaker samenwoont en gebonden is. Omgekeerd hangt een hogere opleiding van de vader samen met een ongebonden en alleenstaande leefsituatie.

opleiding vader en arts in de familie: $(p=.002)$

Een hogere opleiding van de vader hangt samen met hogere frequentie van een arts in familie

opleiding moeder en arts in de familie: $(p=.001)$

Ook hogere opleiding van de moeder hangt samen met vaker een arts in de familie privé situatie en extra vooropleiding: $(p=.001)$

Respondenten die samenwonend en gebonden zijn, hebben vaker een extra vooropleiding genoten.

Onderzochte variabelen

draaglast 3 variabelen:

spot 1

spot 2 richting patiënt

spot 3 richting vrouw

spot ervaren door co-assistent

perceptie van spot richting patiënten

draagkracht ( 7 variabelen)

verschillende copingstijlen te weten:

coping 1

coping door actie en daadkrachtig naar oplossingen te zoeken 
coping 2

coping 3

coping 4

coping 5

assertiviteit

examenvrees

outcome (5 variabelen)

vermoeidheid 1

vermoeidheid 2

vermoeidheid 3

twijfel studie

beroepsbeeld 4 coping door het zoeken van sociale steun

coping door palliatieve strategieën

coping door depressief en vermijdende strategieën

coping door uiten van gevoelens

wel of geen assertieve opstelling

wel of geen examenvrees

psychische vermoeidheid

fysieke vermoeidheid

tegendeel van vermoeid, positief gestemd en energiek

negatieve motivatie

inschatting van zwaarte van medisch beroep

\subsubsection{Variabelen uit het thema "draaglast"}

Tabel 8.18 Draaglast. P-waarden uit de regressie-analyses in relatie tot de achtergrondvariabelen.

\begin{tabular}{lllll}
\hline afh. variabele & sekse & subgroep & vooropl. & privé \\
\hline spot co & n.s. & n.s. & n.s & n.s. \\
spot patiënt & n.s. & .000 & n.s. & n.s. \\
spot vrouw & n.s. & n.s. & $.037^{*}$ & $.025^{*}$
\end{tabular}

achtergrondvariabelen die niet genoemd worden, geven geen significante bijdragen

De regressie-analyses bevestigen de eerder gerapporteerde resultaten ten aanzien van de ervaring van spot en de perceptie van spottende benadering van patiënten of van vrouwen van de non-parametrische toetsen. Pas wanneer studenten de klinische wereld binnentreden in de co-assistentschappen beluisteren ze spottende uitingen over patiënten.

Als toegevoegde informatie leert deze analyse dat co-assistenten, die reeds een andere (para-medische) vooropleiding genoten en zij die alleen leven en geen vaste partner of relatie hebben meer denigrerende opmerkingen over vrouwen waarnemen (zie tabel 8.18).

\subsubsection{Variabelen uit het thema draagkracht}

Tabel 8.19 Draagkracht. P-waarden regressie-analyses in relatie tot de achtergrondvariabelen.

\begin{tabular}{lllllll}
\hline afh. variabele & sekse & subgroep & vooropl. & privé & fam. & opl.moe. \\
\hline copingstijlen & & & & & & \\
actief & n.s. & n.s. & n.s. & n.s. & n.s. & n.s. \\
steun & .000 & .007 & n.s. & n.s. & .006 & n.s. \\
palliatief & .012 & .017 & n.s. & n.s. & n.s. & .019 \\
vermijdend & n.s. & n.s. & .010 & .015 & n.s. & n.s. \\
uiten ongenoegen & n.s. & n.s. & n.s. & n.s. & n.s. & n.s. \\
assertiviteit & n.s. & n.s. & n.s. & n.s. & n.s. & n.s. \\
examenvrees & n.s. & n.s. & n.s. & n.s. & n.s. & n.s. \\
\hline
\end{tabular}

de achtergrondvariabelen, die niet genoemd worden, geven geen significante bijdrage 
Bij de variabelen die betrekking hebben op de diverse coping stijlen blijken de resultaten over het geheel genomen in overeenstemming te zijn met de eerdere analyses (tabel 8.19).

Een actieve coping stijl hangt noch met "sekse" noch met "subgroep" samen.

Op het zoeken van sociale steun, zo blijkt uit de regressieananalyse, hebben "sekse" en "subgroep" wel invloed: vrouwen zoeken eerder sociale steun dan mannen en coassistenten (-meer gevorderd in de studie) eerder dan pre-co-assistenten. De regressieanalyse leert verder dat studenten zonder arts in de familie eerder sociale steun zoeken dan respondenten die wel artsen in de familie hebben. De eerdere gerapporteerde transversale data toonden wel het sekseverschil, maar niet het verschil tussen de sub. groepen. Dit werd in de longitudinale data echter overduidelijk gevonden.

Zowel "sekse" als "subgroep" blijken van invloed te zijn op de palliatieve coping stijl: mannen passen dit meer toe dan vrouwen en preco-assistenten meer dan co-assisten. ten. Uit de eerdere analyses is wel een sekseverschil gevonden maar geen groepsverschil. Uit de regressieanalyse blijkt verder dat een moeder met een "lagere opleiding" de kans op het hanteren van palliatieve coping stijl vergroot.

Uit de regressie analyse blijkt dat "sekse" en "subgroep" geen invloed hebben op een depressief-vermijdende coping stijl. Dit is in overeenstemming met eerder gevonden resultaten. Verder reageren personen met een vooropleiding en personen die geen partner hebben eerder depressief. $\mathrm{Er}$ is, conform eerdere bevindingen, geen invloed gevonden van "sekse" en "subgroep" op "ongenoegen uiten".

Ten aanzien van assertiviteit is er geen invloed van "sekse" en geen van "subgroep" gevonden. Evenmin is dit het geval bij de variabele examenvrees. Dit komt overeen met de eerdere bevindingen.

\subsubsection{Variabelen uit het thema outcome}

Tabel 8.20 Outcome. P-waarden regressie-analyses in relatie tot achtergrondvariabelen

\begin{tabular}{lllllll}
\hline afh. variabele & sekse & subgroep & vooropl. & privé & fam. & opl.moe. \\
\hline psychisch vermoeid & n.s. & n.s. & n.s. & n.s. & n.s. & n.s. \\
lichamelijk vermoeid & n.s. & .057 & n.s. & n.s. & n.s. & n.s. \\
positieve gevoelens & .001 & n.s. & n.s. & .012 & n.s. & n.s. \\
belasting vak & n.s. & n.s. & n.s. & .023 & n.s. & n.s. \\
twijfel studie & n.s. & n.s. & n.s. & .019 & n.s. & n.s. \\
\hline
\end{tabular}

achtergrondvariabelen die genoemd worden, geven geen significante bijdrage

Uit de regressie analyse (tabel 8.20) blijkt dat het gevoel van psychische vermoeidheid niet wordt beïnvloed door "sekse" of "subgroep". De bevinding dat mannen en vrouwen en pre-co-assistenten en co-assistenten in gelijke mate last hiervan hebben, is in overeenstemming met de transversale data, niet met longitudinale.

Uit de regressieanalyse blijkt verder dat vrouwelijke en mannelijke co-assistenten ook in gelijke mate fysiek vermoeid zijn. De invloed van "subgroep" is niet significant, terwijl bij de non-parametrische analyses er wel een significant groepsverschil is gevonden. De longitudinale data hebben hier duidelijkheid verschaft: overall blijkt een 
afname in de tijd van de fysieke vermoeidheid. Fysieke vermoeidheid vertoont een fluctuerend beloop, in fase 0 de start van de co-assistentschappen neemt de fysieke vermoeidheid toe bij de mannen, in fase 1 neemt deze weer af bij de vrouwen evenals in fase 2 ook bij de vrouwen.

Ook met de regressieanalyse werd een sekseverschil gevonden ten aanzien van de positieve gevoelens die worden ervaren bij het functioneren als co-assistent: vrouwen zijn vaker positief gestemd dan mannen. Dit komt overeen met de eerdere bevindingen. Verder blijkt als extra informatie, dat studenten die meer gebonden zijn of samenleven (privé-situatie) zich vaker positief en energiek voelen.

Uit de analyses blijkt verder dat de mannelijke en de vrouwelijke co-assistenten even weinig aan hun studie twijfelen en ook de belasting van bet vak in gelijke mate inschatten. Vierdejaars studenten of preco-assistenten verschillen hierin niet van de co-assistenten. Dit resultaat is anders dan dat uit de non-parametrische groepsvergelijkingen, waar een groepsverschil werd gevonden ten aanzien van twijfel aan de studie. Ook in dit geval geven de longitudinale gegevens uitsluitsel, en hieruit blijkt dat de motivatie gedurende de co-assistentschappen toeneemt, met name in fase 1.

Verder blijkt uit de regressieanalyses dat de privé-situatie significante invloed heeft op motivatie en beroepsbeeld, de laatste twee aspecten van dit subthema. Zo blijkt dat personen die een partner en/of kinderen hebben minder twijfelen aan hun studie en een minder relaxte opvatting hebben over de zwaarte van het vak.

\subsection{Samenvatting van de resultaten}

In dit hoofdstuk worden de vragen over de beproevingen die co-assistenten in het inwijdingstraject moeten doorstaan, beantwoord in termen van draaglast, draagkracht en outcome. We hebben drie typen hypothesen onderscheiden namelijk over het ervaren van het onderzochte aspect (ervaring), over een mogelijk verschil tussen de de seksen en over mogelijke verandering in de tijd.

In het navolgende zal besproken worden in hoeverre de verschillende hypothesen bevestigd zijn of verworpen moeten worden. Soms geven de bevindingen zelfs blijk van het tegendeel.

\section{Hypothesen over draaglast}

De hypothesen bij draaglast hadden betrekking op het ervaren van negatieve en positieve stress, de aanpassingsbereidheid van co-assistenten, het gevoel van gebrek aan tijd, van buitenstaanderschap en van plichten. Ook het ervaren van spot, het beluisteren van spottende opmerkingen over patiënten of over vrouwen werd onderzocht.

Uit de resultaten is gebleken dat de hypothesen die betrekking hebben op de ervaringen van draaglast (zie tabel 8.21 kolom 1) in zijn algemeenheid bevestigd zijn met uitzondering van de ervaring van negatieve stress en de ervaren van spot richting coassistenten zelf. Wel blijken co-assistenten gevoelens van uitdaging te ervaren en zijn ze bereid zich aan te passen. Ze ervaren gebrek aan tijd, hebben meer een gevoel van plichten dan van rechten en voelen zich een buitenstaander van de medische beroeps- 
groep. Ook nemen zij enigermate een spottende en denigrerende manier van spreken over patiënten waar.

Co-assistenten blijken verder vooral te worstelen met concentratie-problemen en verwikkelingen in de relationele sfeer, meer dan in de fase van voor de stages waar de motivatie voor de studie soms een bron van zorg kon zijn.

Tabel 8.21 Overzicht. Hypothesen over draaglast, wel of niet bevestigd ?

\begin{tabular}{|c|c|c|c|}
\hline aspect & $\begin{array}{l}\text { hypothese over } \\
\text { ervaring bevestigd? }\end{array}$ & $\begin{array}{l}\text { hypothese over sekse- } \\
\text { verschil bevestigd? }\end{array}$ & $\begin{array}{l}\text { hypothese over verandering } \\
\text { in de tijd bevestigd ? }\end{array}$ \\
\hline $\begin{array}{l}\text { ervaren } \\
\text { negatieve } \\
\text { stress }\end{array}$ & $\begin{array}{l}\text { geen bevestiging; } \\
\text { nauwelijks negatieve } \\
\text { stress }\end{array}$ & & $\begin{array}{l}\text { ja bevestigd; } \\
\text { afname bij } \delta \delta \text { co's + meeste } \\
\text { stress in preco's in startase }\end{array}$ \\
\hline $\begin{array}{l}\text { ervaren } \\
\text { positieve } \\
\text { stress/ } \\
\text { gevoel van } \\
\text { uitdaging }\end{array}$ & $\begin{array}{l}\text { ja bevestiging; } \\
\text { wel positieve stress }\end{array}$ & & \\
\hline $\begin{array}{l}\text { gevoel van } \\
\text { plichten }\end{array}$ & $\begin{array}{l}\text { ja bevestiging; } \\
\text { wel gevoel van plich. } \\
\text { ten }\end{array}$ & $\begin{array}{l}\text { nee verworpen; } \\
\text { niet vrouwen maar } \\
\text { mannen meer }\end{array}$ & \\
\hline $\begin{array}{l}\text { gebrek aan } \\
\text { tijd }\end{array}$ & $\begin{array}{l}\text { ja bevestiging; } \\
\text { gebrek aan tijd }\end{array}$ & & \\
\hline $\begin{array}{l}\text { aanpassings- } \\
\text { bereidheid }\end{array}$ & $\begin{array}{l}\text { ja bevestiging; } \\
\text { wel anpassingsbe- } \\
\text { reid }\end{array}$ & $\begin{array}{l}\text { nee verworpen; } \\
\text { vrouwen niet meer }\end{array}$ & \\
\hline $\begin{array}{l}\text { gevoel van } \\
\text { buitenstaan- } \\
\text { derschap }\end{array}$ & ja bevestiging; & $\begin{array}{l}\text { nee verworpen; } \\
\text { vrouwen niet meer } \\
\text { van buitenstaander- } \\
\text { schap }\end{array}$ & $\begin{array}{l}\text { nee verworpen; } \\
\text { gevoel blijft constant }\end{array}$ \\
\hline $\begin{array}{l}\text { perceptie } \\
\text { spot } \\
\text { richting co- } \\
\text { assistent }\end{array}$ & $\begin{array}{l}\text { nee verworpen; } \\
\text { zelf geen spot erva- } \\
\text { ren }\end{array}$ & $\begin{array}{l}\text { nee verworpen; } \\
\text { vrouwen niet meer }\end{array}$ & $\begin{array}{l}\text { nee verworpen; } \\
\text { geen afname in tijd }\end{array}$ \\
\hline $\begin{array}{l}\text { perceptie } \\
\text { spot } \\
\text { richting } \\
\text { patiënten }\end{array}$ & $\begin{array}{l}\text { ja bevestiging; } \\
\text { wel spot richting pa- } \\
\text { tiënt }\end{array}$ & & $\begin{array}{l}\text { nee verworpen; } \\
\text { geen afname maar toename in } \\
\text { fase } 0, \mathrm{mn} \text {. vrouwen }\end{array}$ \\
\hline $\begin{array}{l}\text { perceptie } \\
\text { spot } \\
\text { richting } \\
\text { vrouwen }\end{array}$ & deels & $\begin{array}{l}\text { ja bevestigd; } \\
\text { in geval spot over } \\
\text { verpleging en } 9 \% \\
\text { artsen }\end{array}$ & \\
\hline
\end{tabular}

De hypothesen over mogelijke sekseverschillen (zie tabel kolom 2) moeten bijna allemaal worden verworpen. Een uitzondering hierop vormt de bevinding dat vrouwelijke co-assistenten meer dan hun mannelijke collega's denigrerend taalgebruik en flauwe 
grapjes over vrouwelijke artsen en verpleegkundigen beluisteren. Verder blijken mannelijke co-assistenten (en niet vrouwelijke) zich opgejaagd te voelen en meer een gevoel van plichten dan van rechten te hebben. Vrouwelijke co-assistenten blijken niet meer bereid tot offers en aanpassing; bij vrouwelijke gevorderde co-assistenten blijkt zelfs het tegendeel het geval en blijkt de bereidheid om voor het beroep offers te brengen aan het eind van de medische opleiding zelfs afgenomen. Vrouwelijke coassistenten voelen zich niet meer buitenstaander en ervaren evenmin in sterkere mate een denigrerende benadering dan mannen.

Mannen blijken het significant meer eens met de stelling dat de privésfeer een negatieve invloed heeft op de studie, hetgeen met name door de oudste groep co-assistenten (groep 2) wordt aangegeven. Vrouwelijke co-assistenten blijken vooral in beginfase van de co-assistentschappen het omgekeerde aan te geven en een negatieve invloed van de studie op hun privéleven te ervaren.

Over de veranderingen in de tijd ontstaat een genuanceerd beeld. De verwachte toename van de negatieve stress in de startfase van de co-assistentschappen, die wel wordt gevonden in het transversale materiaal (bij vergelijking van de subgroepen), treedt niet op in het longitudinale onderzoek. Wel zien we een verschuiving in de tijd bij mannelijke co-assistenten bij wie met name in fase 2 de negatieve stress afneemt.

Co-assistenten blijken in de loop van de tijd vooral toenemend gebrek aan tijd te ervaren, vooral de vrouwelijke co-assistenten geven dit aan. Vrouwelijke novieten geven verder in de startfase van de klinische stages aan toenemend last van de studie op hun priveleven te ervaren.

Anders dan verwacht neemt het gevoel van buitenstaanderschap niet af tijdens de coassistentschappen en vertoont ook het ervaren van mogelijke denigrerende bejegening geen verandering in de tijd.

Co-assistenten blijken wel een denigrerende manier van spreken over patiënten te beluisteren; Met name de vrouwelijke novieten maken in fase 0 op dit punt een cultuurshock door bij hun kennismaking met de realiteit van de medische beroepscultuur.

Het kwalitatieve materiaal bevat een groot aantal citaten en voorbeelden van zowel vrouwelijke als mannelijke co-assistenten waaruit blijkt dat vooral de combinatie "dik, vrouw en patiënt" het meest aanleiding is voor spottende uitingen. De voorbeelden die zijn gegeven spreken voor zich en geven aanleiding tot reflectie over het mogelijke effect. Zouden deze opmerkingen over lichaam en uiterlijk van dikke patiënten en dikke vrouwen onbedoeld een stimulans zijn tot verdere objectivering van de patienten en het menselijke lichaam ? De meeste voorbeelden worden door vrouwelijke studenten gegeven en veelal worden ze beluisterd bij de snijdende vakken.

Uit de regressie-analyse uitgevoerd op het transversale materiaal blijkt dat de perceptie van denigrerende uitingen over vrouwen beïnvloed wordt door de manier van inrichting van de privé-situatie (alleengaand, dan meer opmerkingen worden) en door het gegeven of de co-assistent reeds een andere vooropleiding heeft gedaan (meer vooropleiding geeft verhoogde perceptie van dergelijke opmerkingen). 


\section{Worden de bypothesen over draagkracht bevestigd?}

Medische studenten blijken in het algemeen geneigd te zijn om op een actieve manier te reageren op problemen en problematische situaties. Ook zoeken zij vaak sociale steun bij problemen, hetgeen als coping stijl bij uitstek de voorkeur van vrouwelijke studenten en co-assistenten geniet. Een palliatieve coping stijl is minder populair maar wordt meer aangetroffen bij mannelijke co-assistenten. De depressief-vermijdende stij] komt weinig voor onder medische studenten.

Het gevonden sekseverschil ten aanzien van het toepassen van sociale steun stemt overeen met de verwachting op basis van de genderrol van vrouwen. Het gevonden sekseverschil ten aanzien van palliatieve aanpak was onverwacht. De hypothese dat vrouwelijke leerlingen minder assertief zijn moet worden verworpen.

Overzicht. Hypothesen over draagkracht, wel of niet bevestigd ?

\begin{tabular}{lll}
\hline aspect & $\begin{array}{l}\text { hypothese over sekseverschil } \\
\text { bevestigd ? }\end{array}$ & $\begin{array}{l}\text { hypothese over verandering in de } \\
\text { tijd bevestigd ? }\end{array}$ \\
$\begin{array}{l}\text { coping stijlen } \\
(5 \text { varianten) }\end{array}$ & $\begin{array}{l}\text { ja bevestigd, } \\
\$ 8 \text { meer sociale steun en } \delta 8 \\
\text { meer palliatief }\end{array}$ & $\begin{array}{l}\text { nee verworpen; } \\
\text { tegendeel, toename bij coping stijlen }\end{array}$ \\
assertiviteit & $\begin{array}{l}\text { nee verworpen; } \\
\text { vrouwen niet minder assertief }\end{array}$ & ja bevestigd; \\
& geen verschurving \\
\hline
\end{tabular}

In de inwijdingsperiode wordt gedurende de tijd een stijging gevonden ten aanzien van nagenoeg alle coping strategieën gevonden is. Zowel het doelgericht naar oplossingen zoeken, als het zoeken van sociale steun als het inzetten van een palliatieve coping stijl als het uiten van emoties, blijken door co-assistenten steeds meer toegepast te worden in de loop van de co-assistentschappen. Alleen het depressief en vermijdend reageren op problemen blijft constant in de tijd. Deze stijging kan een indirecte aanwijzing zijn dat de stress en belasting gedurende de fase van de stages wel degelijk toeneemt. Het gegeven dat co-assistenten groeien in een actieve handelende houding ten aanzien van problemen en hun toenemende vermogen om sociale steun te zoeken, zijn mogelijke tekenen van een geslaagde socialisatie in de richting van zelfbewuste en autonome professionals.

Beroep op coping stijlen blijkt vooral in fase 0 en 1 een stijging te vertonen en minder in fase 2. Mogelijk doen met name de overgang van universiteit naar kliniek (fase 0) en de consolidatiefase, wanneer de co-assistenten volop geinvolveerd zijn in hun stages (fase 1) het grootste beroep op de stressbestendigheid van de co-assistent. In fase 2 belanden co-assistenten mogelijk in minder woelige periode en hoeven zij mogelijk minder problematische situaties het hoofd te bieden.

Examenvrees vertoont onverwacht een daling bij mannelijke gevorderde co-assistenten. De mate van assertiviteit blijkt constant in de tijd.

Uit de regressie-analyse komt als nieuwe informatie naar voren dat, wanneer een coassistent een dokter in de familie heeft, zij minder geneigd zijn om bij problemen hun toevlucht te zoeken tot de copingstategie van het zoeken van sociale steun. Verder 
blijkt het genoten hebben van extra vooropleidingen en leven als alleenstaande de meer kans te geven op een depressief-vermijdende stijl.

Worden de bypothesen over outcome bevestigd?

Co-assistenten ervaren de fase van de co-schappen over het geheel genomen niet als vermoeiend maar ze ervaren vooral positieve gevoelens.

Vrouwelijke co-assistenten blijken zich, in tegenstelling tot de hypothesen, niet meer fysiek vermoeid of psychisch belast te voelen dan hun mannelijke collega's. Alleen het starten met de co-assistentschappen blijkt voor vrouwelijke novieten in fysieke zin vermoeiender te zijn. Maar tegelijkertijd blijken vrouwen zich, in tegenstelling tot de verwachting, zelfs significant positiever te voelen.

In de loop van het inwijdingstraject blijkt, eveneens anders dan verwacht, bij de totale groep de fysieke vermoeidheid af te nemen in plaats van toe te nemen en blijft grossomodo de psychische vermoeidheid gelijk gedurende het jaar van observatie (behalve in fase 2). De positieve gevoelens blijken eveneens te veranderen in de tijd en blijken bij mannelijke co-assistenten toe te nemen. Interessant zijn de bevindingen in fase 2 waar de psychische vermoeidheid bij beide seksen afneemt, bij vrouwelijke co's de fysieke vermoeidheid afneemt en bij mannelijke co's de positieve gestemdheid toeneemt in de periode van het afronden van de studie.

De verwachting dat de belasting met name toeneemt in de startfase van de co-assistentschappen, wordt bevestigd voor de fysieke belasting die met name bij de mannelijke novieten toeneemt. Gezondheidsklachten zoals hoofdpijn en eetproblemen blijken gedurende de inwijdingsperiode niet toe- of af te nemen. Ze worden dus niet wezenlijk beïnvloed door deze fase.

Hypothesen "outcome" in termen van vermoeidheid en motivatie

\begin{tabular}{|c|c|c|c|}
\hline aspect & $\begin{array}{l}\text { hypothese over erva- } \\
\text { ring bevestigd ? }\end{array}$ & $\begin{array}{l}\text { hypothese over sekse- } \\
\text { verschil bevestigd? }\end{array}$ & $\begin{array}{l}\text { hypothese over } \\
\text { verandering in de tijd } \\
\text { bevestigd? }\end{array}$ \\
\hline psychisch vermoeid & $\begin{array}{l}\text { nee verworpen; } \\
\text { nauwelijks }\end{array}$ & $\begin{array}{l}\text { nee verworpen; } \\
\text { geen sekseverschil }\end{array}$ & $\begin{array}{l}\text { nee verworpen; } \\
\text { geen stijging maar } \\
\text { afname in fase } 2\end{array}$ \\
\hline fysiek vermoeid & $\begin{array}{l}\text { nee verworpen; } \\
\text { nauwelijks }\end{array}$ & $\begin{array}{l}\text { deels bevestigd, } \\
\& \& \text { in groep } 0 \text { meer }\end{array}$ & $\begin{array}{l}\text { nee verworpen; } \\
\text { afname bij vrou- } \\
\text { wen;toename bij man- } \\
\text { nen fase } 0\end{array}$ \\
\hline positief gestemd & $\begin{array}{l}\text { ja bevestigd; } \\
\text { wel positief gestemd }\end{array}$ & $\begin{array}{l}\text { nee verworpen; } \\
\text { wel sekseverschil, } \\
\$ \& \text { co positiever }\end{array}$ & \\
\hline gemotiveerd & $\begin{array}{l}\text { ja bevestigd; } \\
\text { gemotiveerd }\end{array}$ & $\begin{array}{l}\text { ja bevestigd; } \\
\text { geen sekseverschil }\end{array}$ & $\begin{array}{l}\text { ja bevestigd; } \\
\text { toename motivatic }\end{array}$ \\
\hline "zwaar" beroep & $\begin{array}{l}\text { nee; } \\
\text { antwoord indifferent }\end{array}$ & $\begin{array}{l}\text { deels bevestigd; } \\
\text { bij } \$ \& \text { groep } 0\end{array}$ & $\begin{array}{l}\text { deels bevestigd; } \\
\text { alleen bij mannen }\end{array}$ \\
\hline
\end{tabular}


De motivatie voor de studie blijkt, conform de hypothesen, wel in positieve zin te veranderen naarmate co-assistenten vorderen in hun studie. Bij nadere bestudering blijkt de motivatie-toename het duidelijkste te zijn in fase 1, wanneer de perikelen van de start van de co-assistentschappen achter de rug zijn. Interessant is dat in deze groep met name de vrouwen gemotiveerder raken.

De inschatting van de zwaarte van het beroep blijkt conform de hypothesen in de loop van de tijd gerelativeerd te worden door co-assistenten. Deze relativering treedt op bij mannelijke co-assistenten.

Als extra informatie komt uit de regressie-analyse dat 'zich positief voelen' behalve met sekse (vrouwen meer) ook samenhangt met de inrichting van de privé-situatie. Alleengaand en zonder partner of kind(eren) blijkt een negatieve invloed te hebben op de positieve gestemdheid. Ook de motivatie (twijfel aan studie) en de inschatting van de "zwaarte" van het medisch beroep blijken samen te hangen met de inrichting van de privé-situatie. Samenleven met partner (of kinderen) blijkt ook hierop een positief effect te hebben.

\subsection{Beschouwing}

Co-assistentschappen worden meer als uitdaging dan als belasting ervaren, luidt een in het oog springende conclusie. Dit onderzoek levert empirische onderbouwing op voor de geneeskunde als "gulzige institutie“. Deze onderbouwing blijkt uit de worsteling van de co-assistenten met het gebrek aan tijd, de verschillende stressoren, die worden ervaren, maar nog het sterkst uit de stijging van het beroep van co-assistenten op allerlei vormen van coping, uitgezonderd de depressief vermijdende copingstijl. Een gulzige institutie, beschreven door Coser (1974) en Goffman (1977) is een sociaal systeem, dat gebaseerd is op grote toewijding en loyaliteit van de leden. Een dergelijk systeem is zeer dwingend in de eis van toewijding en aanpassing aan de groepsnorm maar in ruil hiervoor worden de leden beloond met een bepaalde (begerenswaardige) sociale identiteit, in dit geval de maatschappelijke rol van arts. Deze conclusie sluit aan bij de het werk van Fahrenfort (1985) en Keizer (1997).

Dokter worden "leert" dat tijd een schaars goed is! Wat dat gebrek aan tijd betreft, doet zich verder een opmerkelijke verschuiving in de tijd voor. Behalve het feit dat co-assistenten meer last ervaren van het gebrek aan tijd voor andere zaken dan hun medisch werk, blijken studenten in het begin de inbreuk van het werk of de stages op hun privé, hun vrienden en hobby's als lastig te ervaren. Maar naarmate hun socialisatie vordert blijken co-assistenten zaken anders te gaan beleven; Er lijkt een verandering van attitude op te treden. Naarmate ze verder vorderen in de opleiding blijken zij privéleven of sociale verplichtingen omgekeerd als inbreuk op hun beschikbare tijd voor studie en opleiding te gaan ervaren. Dit is een verbazingwekkende ommekeer die aangetroffen wordt bij beide seksen die eveneens geïnterpreteerd worden als invoegen in de geneeskunde als gulzige institutie.

Verder is opmerkelijk dat co-assistenten zich ook in de loop van deze periode niet meer insider van de medische professie gaan voelen. Blijkbaar beleeft men het bereiken van het basisartsexamen, toch nog niet als een daadwerkelijke entree. 
Ook de beroepsoriëntatie verandert bij co-assistenten in die zin dat ze de zwaarte van het medisch beroep gaan relativeren in de loop van de co-assistentschappen. Deze relativering blijkt op te treden bij mannelijke co-assistenten en dan met name in de fase van het afronden van de studie. Mannelijke co-assistenten blijken meer opgelucht te zijn aan het eind van de studie dan hun vrouwelijke collega's. Als mogelijke verklaring kan men zich afvragen of mannen harder worden ingewijd of als andere verklaring dat het naderen van de arbeidsmarkt en het perspectief van het uitoefenen van het beroep aantrekkelijker voor hen is dan voor vrouwen.

Vrouwelijke en mannelijke co-assistenten blijken anders te reageren op de confrontatie dan wij aannamen. De bevindingen bij draaglast wijzen verrassend in de richting van meer negatieve stress en een sterk gevoel van plichten bij mannelijke co-assistenten in de inwijdingsfase en niet bij vrouwen. Vrouwelijke co-assistenten blijken verder niet meer maar minder bereid zich aan te passen aan de culturele mores dan hun mannelijke collega's en vooral in de fase van het afronden van de studie zijn ze minder bereid om offers te brengen voor hun beroep.

Dit roept de vraag op of mannelijke nieuwkomers mogelijk harder worden ingewijd in de medische beroepscultuur, vooralsnog een mannencultuur. Zou een vrouwelijke co-assistent toch meer als buitenbeentje worden gezien door de opleidende medische professie ? Het optreden van flauwe opmerkingen richting vrouwelijk co-assistenten en vrouwelijke artsen wijzen enigszins in deze richting. Evenals de perceptie van spot over de verpleging.

Inwijding als concept beschreven door Van Gennep (1960) bevat het bespotten van nieuwelingen door de gevestigde groep. Uit ons empirisch onderzoek blijkt dit aspect van inwijding, het afbreken van het "ik" door spot of beschimpen, in de geneeskunde niet van toepassing, al komen minder directe vormen van spot als flauwe grapjes over co-assistenten wel voor. Co-assistenten nemen wel vaker een spottende en denigrerende manier van spreken van artsen over patiënten waar. Uit de longitudinale gegevens blijken co-assistenten bij hun entree van deze fase van klinische stages opeens deze manier van spreken over patiënten waar te nemen. Deze ervaring heeft het karakter van een cultuurshock, een nieuwe en onverwachte ervaring van co-assistenten waar ze niet op voorbereid zijn. Vooral vrouwelijke co-assistenten blijken op dit punt sensitief en merken deze benaderingswijze sterker op. Het kwalitatieve materiaal geeft in dit verband een pregnant beeld waaruit blijkt dat vooral dikke vrouwelijke patiënten dergelijke uitingen oproepen in de setting van de snijdende vakken.

Het verdient aanbeveling om als opleidende professie na te denken over de impact van deze (veelal) onbewuste en onbedoelde uitingen, die vaak een stress-reducerende functie hebben voor de praktiserende artsen. De betekenis van deze uitingen wordt vaak door de "zender" als veel onschuldiger ervaren dan door een onbevangen waarnemer, in dit geval de co-assistent. Deze uitingen kunnen echter een aanstaand arts opzadelen met een dilemma en dwingen zich te verhouden de paradoxale situatie om loyaliteit richting patiënt te combineren met loyaliteit aan de medische professie.

Uit het kwalitatieve materiaal spreekt verder een zekere mate van ambivalentie van artsen richting vrouwelijke professionals. Vaker blijken vrouwelijke co-assistenten (zowel door opleiders als door mede-co-assistenten) te worden aangesproken met 
termen als "meisje" of "vrouwtje" of worden stereotiepe opmerkingen geventileerd als "zonde van zo'n knap meisje als jij om dokter te worden" of "die meisjes, ze doen hun werk niet goed, ze kunnen maar beter thuis blijven".

Algemeen hechten wij bij het beantwoorden van de vraag naar de impact van socialisatie de meeste waarde aan de longitudinale data. De verschuivingen die aldaar blijken, geven het meeste zicht op de "verborgen" lessen. Opmerkelijk is dan dat de periode van de co-assistentschappen in de tijd beschouwd niet als vermoeiend of zwaar worden ervaren en wel als uitdagend en positief. De psychische vermoeidheid blijft gelijk en de fysieke vermoeidheid fluctueert maar de positieve gestemdheid en de motivatie nemen toe in de loop van de tijd. Deze bevindingen blijken echter in een ander licht te komen, wanneer we de ontwikkeling van de draagkracht in de tijd erbij betrekken.

Uit ons onderzoek blijkt namelijk dat alle vormen van coping systematisch toenemen in de loop van de co-assistentschappen. Er lijkt sprake te zijn van een systematisch verandering mogelijk een uiting van het appèl van het inwijdingsproces doet op de draagkracht en persoonlijke weerbaarheid van co-assistenten. De toename van inzet van actieve coping, het zoeken naar sociale steun, een meer extroverte houding en de toename van palliatieve stijl kunnen worden geïnterpreteerd als een stijging van de persoonlijke effectiviteit van de medische student op weg naar de artsenrol.

Men kan zich ook nog de vraag stellen of hieruit soms een zeker taboe spreekt yan de medische professie op uiten en ervaren van stress of belasting als arts.

Stel dat er een "redders-ideologie" in de medische beroepscultuur functioneert die kwetsbaarheid van de redder onmogelijk makkt, dan zou het niet ervaren van vermoeidheid door co-assistenten ook geïnterpreteerd kunnen worden als aanpassing aan een culturele norm. Dan zou hieruit het verborgen karakter van de "opgelegde stress" kunnen spreken.

Interessant is het inzicht uit de regressie-analyse dat de inrichting van de privé situatie, dus de manier van leven van de co-assistenten van grote betekenis is voor de mate van ervaren stress en belasting. Van samenleven met een partner en lof kinderen blijkt een beschermende werking uit te gaan en alleenstaand zijn, geeft een grotere kwetsbaarheid hiervoor. Hierbij dient men zich wel te realiseren dat mannelijk co-assistenten in dit onderzoek gemiddeld iets ouder zijn en vaker gehuwd of samenwonend met partner of kinderen.

\section{Methodische opmerkingen}

De respons in het transversale onderzoek is goed (77\%); de onderzochte populatie coassistenten vormt ongeveer $45 \%$ van de totale groep Maastrichtse co-assistenten en de groep onderzochte pre-co-assistenten of vierdejaars studenten vormt ongeveer $30 \%$ van deze populatie.

De respons in het longitudinale onderzoek is eveneens goed $(70 \%)$. Uit de non-respons analyse, die werd uitgevoerd bleek dat de uitval voor het grootste deel verklaard kan worden door het afstuderen van de betrokken co-assistenten tussentijds (tussen meting 1 en 2). Daadoor waren deze afgestudeerden moeilijker vindbaar door verhui- 
zing, veranderde werkkring en dergelijke. De co-assistenten in de non-responsgroep waren vaker vrouw, iets ouder en vaker samenwonend met partner en/of kind.

Bij het transversale onderzoek kon de non-respons analyse niet worden uitgevoerd, waardoor selectie-bias niet geheel uitgesloten kunnen worden. Vrouwen zijn licht oververtegenwoordigd en lijken zich door dit onderzoek iets meer aangetrokken te hebben gevoeld. Omdat bij nagenoeg alle analyses werd gestratificeerd naar sekse, heeft deze oververtegenwoordiging nauwelijks effect, slechts op de scores op niveau van de totale groep.

\section{Generaliseerbaarbeid}

De bevindingen van dit onderzoek kunnen gegeneraliseerd worden naar Maastrichtse co-assistenten, maar om uitspraken te doen over de generaliseerbaarheid naar Nederlandse co-assistenten in het algemeen, moet de vraag beantwoord worden of de student die geneeskunde studeert aan de Universiteit Maastricht niet afwijkt van die aan andere universiteiten. Omdat de pre-doctoraal fase van de studie geneeskunde aan de Universiteit Maastricht anders is ingericht dan elders (probleemgestuurd en onderwijs in groepen) is het aannemelijk, dat Maastrichtse preco-assistenten wel sterk verschillen. Maar omdat de inrichting van de co-assistentschappen in Maastricht niet wezenlijk verschilt van die aan andere Nederlandse medische faculteiten, kunnen de bevindingen die betrekkingen hebben op veranderingen gedurende de fase van de klinische stages (de longitudinale bevindingen) naar alle waarschijnlijkheid wel worden generaliseerd naar Nederlandse co-assistenten in het algemeen.

\section{Aambevelingen}

In het kader van de preventie van psychische nood of drop-out, verdient het aanbeveling om de stress in de opleiding vroegtijdig op te sporen en kwetsbare co-assistenten te ontdekken en extra support te geven. Uit dit onderzoek blijkt dat co-assistenten met een depressief-vermijdende copingstijl meer risico lopen evenals co-assistenten zonder steunend sociaal netwerk.

Ook is uit dit onderzoek gebleken dat een mogelijk "dubbel-buitenstaanderschap" van vrouwelijke co-assistenten in ieder geval niet tot uitdrukking komt een hogere mate van ervaren belasting of stress. 


\subsection{Samenvatting}

In dit hoofdstuk worden de vragen over de beproevingen die co-assistenten in het inwijdingstraject moeten doorstaan, beantwoord. De inwijdelingen blijken niet onder een hoge mate van vermoeidheid gebukt te gaan. Ook blijkt hun motivatie gedurende de co-assistentschappen een positieve impuls te ondergaan. De veronderstelling dat vrouwelijke co-assistenten mogelijk een grotere belasting zouden ervaren dan hun mannelijk collega's wordt niet bewaarheid. Vrouwelijke co-assistenten blijken de psychische belasting van de inwijding net als hun mannelijke collega's niet als hoog te ervaren, de fysieke belasting wordt wel als iets hoger ervaren door vrouwen net als hoofdpijn en eetproblemen. Daarentegen blijken vrouwelijke co-assistenten echter tegelijkertijd ook meer positieve gevoelens te ervaren.

Het beloop in de tijd van belasting en vermoeidheid ten gevolge van de co-assistentschappen laat interessante verschuivingen zien. Vooral de eindfase van de co-assistentschappen gaat gepaard met gevoelens van opluchting, de ervaren psychische belasting daalt bij beide seksen, de fysieke belasting daalt bij de vrouwelijke co-assistenten en de positieve stemming neemt met name bij de mannelijke co-assistenten toe wanneer de eindstreep van de medische opleiding in zicht komt. De motivatie voor het medische vak is ondertussen alleen maar toegenomen.

Arwarwach an vactassend is de hevinding in dit onderzoek dat de draagkracht van co-assistenten gedurende het volgen van de co-assistentschappen in alle groepen een toename laat zien op alle dimensies van coping met uitzondering van de depressiefvermijdende copingstijl. De weerbaarheid en het vermogen om actief en adequaat persoonlijke problemen te lijf te gaan, blijkt in deze inwijding een sterke impuls te hebben gekregen, zowel bij vrouwelijke als bij mannelijke co-assistenten. Alleen de manier waarop vrouwen en mannen hun weerbaarheid invullen blijkt te verschillen; vrouwen geven sterker de voorkeur aan sociaal georiënteerde strategieën zoals het zoeken van sociale steun en het uiten van emoties en mannelijk studenten prefereren meer een palliatieve stijl als hun aandacht op vrolijker zaken richten.

Ook werd de aard van de belasting van het inwijdingsproces onderzocht door in te gaan op het gevoel van gebrek aan tijd, de mogelijke gevoelens van stress en ervaringen van denigrerende benadering en behandeling als jongste bediende in de medische beroepswereld. Onverwacht bleken mannelijke co-assistenten meer stress en onlust te ervaren dan vrouwelijke co-assistenten. Co-assistenten bleken zelf over het algemeen geen denigrerend of spottend behandeling te ervaren maar merkten wel een denigrerende manier van omgaan met patiënten op. Vooral de studenten, die starten met de co-assistentschappen merken dit fenomeen opeens op; deze ervaring kan men opvatten als aspect van een cultuurshock, die vooral vrouwelijke co-assistenten treft. Zij blijken een denigrerende benadering van patiënten nog sterker waar te nemen dan hun mannelijke collega's. Dit roept de vraag op of vrouwelijke co-assistenten zich mogelijk sterker of langer blijven identificeren met patiënten.

Naar aanleiding van de bevindingen ontstaat de gedachte dat mannelijke co-assistenten mogelijk "straffer en zwaarder" worden ingewijd dan hun vrouwelijke collega's. 
Speculaties over of dit nu beschouwd moet worden als een positieve of een negatieve zaak in het licht van de veranderingen in medische beroepsgroep, vindt $u$ in de beschouwing. Bij deze beschouwing moet dan ook de kwalitatieve bevindingen betrokken worden waaruit een sterke ambivalentie van de zittende medische professie spreekt richting vrouwelijkheid en vrouwenlichamen. 



\section{Deel III}

De ontwikkeling van de professionele identiteit

Het socialisatie-onderzoek (vervolg) 



\section{Hoofdstuk 9}

\section{De ontwikkeling van de professionele identiteit. \\ Doel, methode en variabelen}

Slechts door de stemmen van anderen te internaliseren kunnen wij tegen onszelf spreken. Als niemand op significante manier van buitenaf het woord tot ons had gericht, zou er binnen ons zelf ook stilte beersen. Alleen via anderen kunnen wij ertoe komen onszelf te ontdekken (Berger, 1988 p. 58).

\subsection{Inleiding}

In dit hoofdstuk staat de ontwikkeling van de professionele identiteit van dokters centraal en de mogelijke reproduktie van genderongelijkheid in dit proces. Zowel sekseverschillen als mogelijke verandering in de tijd als reproduktie van genderongelijkheid worden onderzocht. Co-assistenten betreden als relatieve nieuwelingen de praktijk van de medische professie en worden als het ware ondergedompeld in de cultuur van de professie in het proces van professionele socialisatie. We vatten dit proces op als een inwijdingsproces waarin diverse aspecten van de persoon in beweging komen en veranderingen kunnen ondergaan. Er ontstaat als gevolg van dit onderdompelingsproces een "nieuwe" identiteit waarbij verschillende lagen van het "zelf" in beweging komen. Het denken van co-assistenten en hun oordelen, het voelen en het willen worden beroerd. Keizer (1997) spreekt in haar beschrijving het professionaliseringsproces van een beïnvloeding van het normatieve zelf, het rationele zelf en het emotionele zelf. In dit onderzoek zullen we deze (zich ontwikkelende) subjectieve identiteit, die diverse aspecten kent, aanduiden met de term van professionele identiteit. 
Ons geslacht blijkt een van de belangrijkste bouwstenen te zijn voor onze identiteit, enerzijds omdat het een primair sociaal onderscheid is waarvan onze cultuur diep doordrongen is, maar ook omdat iemands sekse andere identiteitskenmerken als leeftijd, etniciteit of klasse doorkruist. (Benschop, 1996 p. 62). Het is onmogelijk om een mens sekse-neutraal te benaderen, denk als voorbeeld aan de impact van onjuiste kennis van het geslacht van een baby op het gedrag van diens verzorgers (Fischer et al, 1993) De kennis omtrent iemands sekse is zo vanzelfsprekend en impliciet dat het bijna gênant is deze te expliciteren. In de socio-cognitieve benadering van sekse wordt ervan uitgegaan dat sekse een sociaal construct is en dat dit construct gepaard gaat met proto-typische kenmerken, die vergaande implicaties kunnen hebben voor het denken, het beleven, het voelen en het gedrag van mensen, omdat deze prototypische kenmerken de verwachtingen in sociale interacties structureren (Fischer et al, 1993). Allerlei sociale categorieezn, zoals bijvoorbeeld het prototype van een ambtenaar of een onderwijzer kunnen aanleiding geven tot prototypering. Ook vrouwelijkheid of mannelijk. heid kunnen worden opgevat als prototypen die worden gedefinieerd aan de hand van illustratieve voorbeeldfiguren, die met elkaar verbonden zijn op basis van zogenaamde familiegelijkenissen. Hiermee wordt gedoeld op elkaar kruisende en overlappende eigenschappen, waarvan er wel een of meerdere op mannelijke dan vrouwelijke personen van toepassing zijn, maar geen van alle afzonderlijk een essentiële voorwaarde zijn om iemand in een van beide categorieën in te delen.

Prototypen zijn cultuurspecifiek en hebben weinig van doen met mannelijk en vrouwelijke essenties. Mensen kunnen in meerdere of mindere mate aan een mannelijk of vrouwelijk proto-type voldoen. Betekenissen van mannelijkheid en vrouwelijkheid zijn dus niet rigide universeel of contextloos, maar evenmin eindeloos gefragmenteerd. Wat als mannelijk en vrouwelijk wordt beschouwd, geschiedt volgens een glijdende schaal afhankelijk van de in die cultuur vigerende prototypen.

Uit onderzoek blijkt dat aangesproken worden als man of vrouw, dus het gebruiken van prototypen of sekse-stereotypen niet te pas of te onpas gebeurt, maar als de context erom vraagt (Top \& Heesink, 1992). Stereotypen worden niet slechts gebruikt vanwege de beperktheid van het menselijke informatie-verwerkingssysteem, maar ook op grond van motivationele of sociale motieven. "Stereotype informatie" wordt bijvoorbeeld vaak gebruikt als mensen zich bedreigd of onzeker voelen (Van Vianen, 1987). Prototypen en genderindelingen hebben dus psychologische consequenties, ze constitueren onze waarneming en beoordeling in sociale interactie. Ze hebben effect op onze verwachtingen over hoe mannen en vrouwen behoren te zijn. Sekse als sociale categorie wordt begrensd door in een bepaalde cultuur vigerende seksegebonden praktijken, dat wil zeggen gedrag, sociale rollen en de daarbij beborende opvattingen en regels voor mannen en vrouwen.

Een culturele context roept dus niet alleen een bepaald soort betekenisverleningsproces op, maar kan mensen of groepen bovendien motiveren om bepaalde prototypen van mannelijkheid en vrouwelijkheid te veranderen of te onderstrepen. Het belang van een kenmerk waarmee mensen zichzelf en anderen aanduiden, vertoont dus samenhang met de sociale context. De bevinding dat vrouwelijke advocaten hun gender-identiteit moeilijk konden integreren in hun professionele identiteit (Marshall 
\& Wetherell, 1989), kan derhalve geïnterpreteerd worden als veelzeggend en betekenisvol voor die specifieke beroepscontext. Ook de bevinding van Benschop (1996) dat vrouwelijke medewerkers met name op de hogere posities binnen de onderzochte bankorganisatie zich niet wilde laten aanspreken op hun vrouwelijke identiteit, roept vragen op over de betekenis van vrouwelijkheid in die specifieke setting. Wij zullen ons in het navolgende empirische onderzoek dan ook afvragen, welke betekenis vrouwelijkheid en mannelijkheid krijgen in het medische beroep. Wat betekent dit voor de verhouding tussen gender-identiteit en professionele identiteit van co-assistenten?

Identiteit als differentie

"Identiteit verwijst dus tegelijkertijd naar posities in een maatschappelijke ordening en naar de wijze warop mensen in deze posities 'huizen', met andere woorden, hoe zij de positic beleven, hun zelfopvattin. gen en hun waarneming en definities van de werkelijkheid (Bourdieu, 1989). Deze identiteit blijkt nooit eenvoudig te zijn, maar vol van tegenstrijdigheden en inconsistenties, ingegeven door de vele posities die mensen innemen in wisselende contexten. Niettemin ervaren mensen zichzelf als een zelf, beleven zij zichzelf als een coherent geheel. Deze eenheid is echter niet vanzelfsprekend, maar moet steeds weer opnieuw geconstrueerd worden. De posities die mensen innemen ten aanzien van sekse/gender en ten anzien van beroep kunnen in dit verband stabiliserende effecten hebben. Mensen (re)presenteren zichzelf als vrouw of man, als lid van een bepaald beroep en vormen daarin een zelf.- (aitat Brouns, 1993 p. 160).

\subsection{Dynamiek van de ontwikkeling van de professionele identiteit}

Bucher en Stelling (1977) analyseerden het proces van professionele socialisatie in de medische opleiding op extern structureel niveau, op intern structureel niveau en op situationeel-interactief niveau. Structurele variabelen zoals de inrichting van de medische beroepen en vakgebieden en de manier waarop de medische basisopleiding en de vervolg- of specialistische opleidingen zijn georganiseerd hebben invloed op de interactie in de concrete leersituatie van co-assistenten. Ook de sociale structuur van de socialiserende instantie, zoals een hiërarchische ordening van functies en rollen binnen de medische beroepsgroep beïnvloeden de identiteit en de interactieprocessen. De dynamiek in de concrete leer- en werksituatie is dus niet los te zien van de structuur van het beroep en de opleiding en van de cultuur van de medische professie. Zo zullen bijvoorbeeld door het grote aantal co-assistentschappen (of stages) in de klinische setting loopbaantrajecten van medisch specialisten een sterker accent krijgen dan andere domeinen van de geneeskunde, zoals wetenschappelijk onderzoek en onderwijs, sociale en preventieve geneeskunde, management en dergelijke, die relatief onzichtbaar blijven. Het is aannemelijk dat de volgorde van de diverse klinische stages en de duur van deze stages in de co-assistentschappen bepaalde effecten hebben op de gesocialiseerde. Omdat culturen tussen medische beroepsgroepen onderling verschillen vertonen, denk aan het verschil tussen de cultuur van chirurgen en die van huisartsen bijvoorbeeld, zal het voor co-assistenten mogelijk verschil maken of haar inwijding in het medisch vak begint met een van de medische specialismen in een klinische context of met huisartsgeneeskunde, een extramuraal medisch vakgebied.

De cultuuraspecten van de medische professie, die werden gevonden in het beroepscultuuronderzoek (zie hoofdstuk 5 en 6) zullen eveneens gevolgen hebben voor het 
vormingsproces van de nieuwe generatie, zoals bijvoorbeeld een grote mate van machtsafstand en hiërarchie van artsen onderling en het taboe op het uiten van gevoelens of emoties voor artsen. Ook het gegeven dat vrouwelijke stafleden in de klinische context sterk in de minderheid zijn, waardoor vrouwelijke rolvoorbeelden van arts. opleider schaars zijn, en het feit dat de loopbaanstructuur van de meeste medische beroepen nauwelijks ruimte laat om beroep te combineren met zorgtaken en kinderwens (Drenthe-Schonk et al, 1995, Heiligers et al, 1997) zal effecten hebben op de ontwikkeling van de professionele identiteit.

Figuur 9.1 DYNAMIEK VAN PROFESSIONELE SOCIALISATIE (Bucher \& Stelling, 1977)

EXTERNE STRUCTURELE VARIABELEN
professionele gemeenschappen
grote formele organisaties

- INTERNE STRUCTURELE VARIABEI.EN

professionele organisaties

structuur van opleiding

SITUATIONELE/INTERACTIONELE VARIABELEN

role playing

modeling peergroup coaching/examination|

OUTCOME -professionele identiteit - loopbaan

- commitment

Wij zullen in dit onderzoek met name de aandacht richten op het situationele en interactionele niveau. Wanneer we zicht willen krijgen op de werking van gender en de reproduktie van genderongelijkheid in de socialisatie tot arts, zullen we het situationele en interactionele niveau van socialisatie steeds in nauwe samenhang met de karakteristieken van het collectief (cultuur en structuur) moeten beschouwen.

Bucher en Stelling (1977) stellen dat in het ontwikkelingsproces van artsen de volgende processen een grote rol spelen 1 . het oefenen van het rolgedrag van arts en ervaring hiermee opdoen (role playing) 2.het nabootsen van rolvoorbeelden (modeling) 3 . de interacties als het ontvangen van sociale steun maar ook de competitie binnen de eigen referentiegroep (peergroup) en 4. de ervaringen met de opleiders zoals de kwaliteit en de mate van begeleiding en de formele en informele beoordelingen door opleiders (coaching). Het oefenen van het rolgedrag van arts (role playing) spelen in genoemd onderzoek (1977) een bijzonder grote rol. De kwaliteit van de "role playing" die de opleidingsituatie biedt, blijkt afhankelijk van de mate van verantwoordelijkheid die de co-assistent of trainee mag dragen en de mate waarin de rol van de trainee inhoudelijk duidelijk wordt omschreven.

Voor de ontwikkeling van de professionele identiteit blijken rolvoorbeelden van belang, bijvoorbeeld die welke inspireren en noden tot een zekere mate van navolging en identificatie, maar ook negatieve of partiële rolmodellen (Pool \& Pool, 1983). Wanneer niet alle eigenschappen van een rolmodel tot voorbeeld dienen, spreekt men van een partieel rolvoorbeeld en wanneer de student absoluut niet op een betreffend 
voorbeeld-arts wil lijken, spreekt men van een negatief rolvoorbeeld (Bucher \& Stelling, 1977; Fahrenfort, 1985).

In het socialisatieproces zijn formele beoordeling als examens evenals informele beoordeling als het houden van voordrachten, praatjes en referaten voor opleiders van grote betekenis. Zowel het moment, waarop de beoordelingen worden gegeven als de personen die hierbij betrokken zijn, zijn in dit verband van belang. Ook de sociale invloed van de eigen peergroup als de onderlinge verhoudingen en de normen en waarden binnen deze groep spelen een grote rol in het ontwikkelingsproces tot arts, evenals de sociale steun die ook van deze groep uitgaat.

Al de genoemde processen (role playing, modeling, coaching etc.) worden gefilterd en geinterpreteerd door de co-assistent of student en zijn in figuur 9.1 met de termen "evaluatie en zelfevaluatie" aangeduid. Dit resulteert in een bepaalde mate van subjectieve competentie en bekwaamheid, aangeduid met de term "mastery" (zie schema). Bekwaamheid en competentie blijken cruciaal te zijn in de uiteindelijke uitkomsten van het socialisatieproces, uitkomsten zoals professionele identiteit, mate van commitment of gemotiveerdheid voor het medisch beroep en de wensen en plannen voor de verdere loopbaan (Bucher \& Stelling, 1977). Naarmate co-assistenten en assistentartsen verder vorderen in opleiding en socialisatie blijkt het gevoel van "mastery" of competentie steeds minder afhankelijk te worden van de feedback van anderen als patiënten of collega's; het gevoel van competentie wordt steeds autonomer.

\subsection{Gender en professionele socialisatie}

Het model van Bucher en Stelling is weliswaar bruikbaar om het proces van professionele socialisatie te ontrafelen, maar schiet tekort wanneer we de werking van gender zichtbaar willen maken. Derhalve is ook gebruik gemaakt van het werk van Benschop over gender in arbeidsorganisaties (1996). $\mathrm{Zij}$ introduceerde het begrip gendersubtekst van een organisatie ${ }^{1}$ en laat zien hoe de reproduktie van genderongelijkheid in zijn werk gaat, ondanks expliciet beleid van emancipatie en gelijke kansen voor mannen en vrouwen. De belangrijkste mechanismen in deze blijken te zijn:

- de vanzelfsprekendheid van organisatie-arrangementen, waardoor verhuld blijft dat deze arrangementen vaak in het voordeel van mannen werken

- de instemming of aanpassing van medewerkers aan deze arrangementen op persoonsniveau

In de huidige organisatiepraktijk zou, ondanks de verschuivingen in ideologie en maatschappelijke opvattingen over de verhoudingen tussen de seksen, nog steeds een stereotype en traditionele karakterisering van mannen en vrouwen en van masculiniteit en femininiteit dominant zijn (Benschop, 1996). Hoewel steeds meer mensen een modern genderparadigma aanhangen, blijken deze ideologische verschuivingen nog

\footnotetext{
${ }^{t}$ De gendersubtekst in organisaties is een proces waardoor een systematisch genderonderscheid, dat gerelateerd is aan processen van hegemoniale genderregulering en dat deels impliciet deels expliciet naar voren komt in sociale praktijken in organisaties, als dualiteit gereproduceerd wordt via een gelaagd stelsel van arrangementen op structuur- en handelingsniveau.
} 
onvoldoende in de praktijk doorgedrongen te zijn. Het moderne genderparadigma is eigenlijk nog niet geïmplementeerd te zijn in de praktijk en heeft nog niet de sociale en praktische gevolgen er logischerwijs uit voortvloeien.

\section{Recente ideologische verschuivingen in het denken over sekse en gender}

De ideologische visie ten aanzien van de manier waarop vrouwen en mannen zich tot elkaar verhouden is de afgelopen jaren veranderd. De traditionele opvattingen, hieromtrent luiden dat mannen en vrouwen fundamenteel verschillend zijn. In het traditionele gender-paradigma wordt aangenomen dat natuurlijke verschillen (biologische of psychologische) ten grondslag liggen aan de waargenomen verschijnselen (Benschop 1996). Mannen worden als groep aan het masculiene uiteinde en vrouwen aan het feminiene uiteinde van het gender-continuüm geplaatst. Vrouwen worden gezien als aanvullend aan mannen; bet vrouwelijke als aanvullend aan het mannelijke. Het moderne genderparadigma, dat steeds meer aan populariteit wint gaat uit van de basisstelling van de gelijkwaardige eigenheid van mannen en vrouwen. De gepercipieerde verschillen tussen mannen en vrouwen vormen geen legitimering meer voor maatschappelijke arbeidsdeling.

Terwijl in het traditionele denken het kostwinnerschap als belangrijkste verantwoordelijkheid voor mannen en het moederschap en zorg voor het gezin als belangrijkste taakgebied voor vrouwen be schouwd, wordt in de moderne ideologie deze taakverdeling verlaten en zijn kostwinning en zorg verantwoordelijkheid voor beide seksen. Tegen de achtergrond van zowel het traditionele als moderne genderparadigma, functioneert de dagelijkse praktijk.

De praktijk valt niet samen met deze ideologische beelden, het is veeleer zo dat deze ideologische opvattingen, ook wel de "gelijkheidsideologie" genoemd, de normen en waarden van mensen kleuren en hun percepties van de dagelijkse praktijk sterk beïnvioeden (Benschop, 1996).

Om de werking van de gendersubtekst van de onderzochte organisatie te ontrafelen, makkt Benschop gebruik van een model van arrangementen op het niveau van de organisatie en op niveau van het individu. $\mathrm{Zij}$ onderscheidt, in navolging van Acker (1991) een stelsel van arrangementen die doelen op uitgangspunten, maatregelen en praktijken, die erop gericht zijn om de organisatiepraktijk in banen te leiden en die als neveneffect kunnen hebben dat het genderonderscheid wordt herhaald. Acker onderscheidt vier typen van arrangementen namelijk structuur- en cultuurarrangementen op het niveau van de organisatie en interactie- en identiteitarrangementen op het persoonsniveau (zie onderstaand schema).

cultuur

\section{ORGANISATIE-ARRANGEMENTEN} structuur

\section{PERSOONSARRANGEMENTEN}

interactie identiteit

De organisatiearrangementen worden geacht in wederzijds producerende verhouding te staan tot de persoonsarrangementen (Benschop 1996). Met andere woorden de cultuur en structuur beïnvloeden de interacties in de organisatie en de persoonlijke identiteit van werkenden in die organisatie, maar ook het omgekeerde is het geval. Met deze benadering kan tegemoet gekomen worden aan de voorwaarden die Brouns 
(1993) stelde aangaande het actor/structuur vraagstuk wanneer theorieën worden toegepast om genderwerking te onthullen.

Uit het onderzoek van Benschop (1996) bleken vooral de volgende zaken van belang bij de reproduktie van genderongelijkheid op niveau van persoonsarrangementen:

* ambities

* de noodzaak om de formele gelijkheidsideologie ("gelijke kansen voor vrouwen en mannen") van de organisatie te onderschrijven

* de wijze waarop mannen en vrouwen zichzelf identificeren en geïdentificeerd worden

De ambities van vrouwen bleken sterk gerelateerd te zijn aan de praktische mogelijkheden in de organisatie, de ambitie werd neerwaarts bijgesteld wanneer de haalbaarheid van de wensen in de praktijk gering was. Verder bleek de filosofie van "gelijke kansen voor de seksen", die in de onderzochte organisatie met zijn expliciet emancipatiebeleid werd omarmd, het zicht op reële inkomens- en statusverschillen en evidente verschillen in doorstroming naar hogere functies van vrouwen en mannen te belemmeren. Deze verschillen werden door de respondenten vaak gebagatelliseerd, vergoelijkt of ontkend. Een voorbeeld van de wijze waarop ook identificatie en geidentificeerd worden gevolgen heeft voor genderongelijkheid, wordt in het volgende fragment gegeven. Vrouwelijke organisatieleden, die carrière wilden maken of gemaakt hadden, bleken, opmerkelijk genoeg, in de interacties met anderen niet het vrouwzijn maar bij voorkeur persoonlijke kwaliteiten, genoten opleiding of ervaring (de zogenaamde specifieke statuskarakteristieken) naar voren te brengen. Ze leken hun vrouwelijke identiteit, een van de diffuse statuskarakteristieken zoals ook klasse of etnische achtergrond, haast te verhullen. Benschop interpreteert deze houding als zinvolle en begrijpelijke strategie van mensen in een dergelijke context, waar vrouwzijn en vrouwelijkheid nogal sterk beladen zijn met stereotype beelden. Door de specifieke statuskarakteristieken als opleiding en eigen kwaliteiten te accentueren en een beroep te doen op de formele gelijkheid tussen de seksen (ook wel de "gelijkheidsideologie"), kunnen individuele vrouwen er in slagen om zich te onttrekken aan de beperkingen die de sekse-stereotypen hen opleggen. De claim om slechts op kwaliteiten beoordeeld te worden, maakt het hen mogelijk om te ontsnappen aan geïdentificeerd worden met beknellende opvattingen over vrouwen en vrouwelijkheid, die vaak resulteerde in minder aangesproken worden op hun identiteit als organisatielid dan als lid van een privé of gezins-systeem.

\subsection{Probleemanalyse en vraagstellingen}

In dit hoofdstuk vragen we ons af hoe de professionele identiteit van co-assistenten zich ontwikkelt. Wanneer we de inzichten van Bucher \& Stelling (1977) pogen te verbinden met die van Benschop (1996) dan komen we tot het volgende schema: 
Professionele cultuur en structuur

II

II

II

interactie-

identiteit

(zelf)evaluatie "mastery"

outcome

*identificatie

"rolvoorbeelden en sociale steun

"seksestereotypering op de werkvloer "professioneel zelfvertrouwen "competentie "professionele identiteit -zelfbeeld-ideaalbeeld -oriëntatie op beroep -oriëntatie op loopbaan "genderidentiteit

De ontwikkeling van de professionele identiteit zullen we bestuderen door eerst de evalatie en zelfevaluatie van de co-assistent te bevragen. In het thema "identificatie" zullen we bestuderen met wie co-assistenten zich identificeren, hoe zij hun rolvoorbeelden ervaren en eventuele sociale steun uit hun omgeving. De medische opleidingscontext zendt naast impliciete ook expliciete boodschappen uit over de betekenis van sekse. In het licht van de seksegebonden praktijken wordt onderzocht welke expliciete "boodschappen" over vrouwelijkheid en mannelijkheid door co-assistenten worden waargenomen in het thema "expliciet onderscheid naar sekse". Deze praktijken resulteren in een bepaalde mate van bewustzijn van de eigen sekse, een aspect van genderidentiteit. In het thema "professioneel zelfvertrouwen" gaan we in op het zelfvertrouwen en het subjectief gevoel van competentie, aspecten van het beschreven fenomeen "mastery" (Bucher \& Stelling, 1977).

De genderlading van de professionele identiteit van arts wordt onder de loep genomen door te bestuderen in welke mate het ideaalbeeld van een arts overlap vertoont met prototypische vrouwelijkheid of mannelijkheid (thema "ideaalbeeld $\backslash z e l f b e e l d ")$. Ook beroepsoriëntatie is een aspect van professionele identiteit. Speelt maatschappelijke status en inkomen voor co-assistenten een belangrijke rol in hun denken over het medische beroep of ligt het accent sterker op zelfontplooiing als arts. Tot slot zal ook de loopbaanoriëntatie aan bod komen, in hoeverre is reeds bezig is met planning en voorbereiding van de eigen loopbaan en welke attributies hebben co-assistenten over de oorzaken van succes in de beroepscarriere.

De probleemstelling "hoe ontwikkelt zich in de fase van de co-assistentschappen de professionele identiteit van co-assistenten" zal op basis van het voorgaande bestudeerd worden aan de hand van de volgende thema's (zie figuur 9.2). 
Figuur 9.2 Persoonsarrangementen: Interactie en identiteit

$\begin{array}{ll}\text { Concepten } & \text { Thema's } \\ \text { (Zelf)evaluatie } & \text { 1. Identificatie } \\ \text { (Zelf)evaluatie } & \text { 2. Expliciet onderscheid naar sekse } \\ \text { Mastery } & \text { 3. Professioneel zelfvertrouwen } \\ \text { Identiteit } & \text { 4. Ideaalbeeld-zelfbeeld } \\ \text { Identiteit } & \text { 5. Beroepsoriëntatie } \\ \text { Identiteit } & \text { 6. Loopbaanoriëntatie }\end{array}$

De ervaringen, percepties en zelfopvattingen van co-assistenten worden opgevat als persoonsarrangementen, die in wederzijds producerende relatie staan met professionele cultuur en structuur-arrangementen (Benschop, 1996) en worden onderzocht op hun mogelijke genderwerking.

Deze ervaringen, percepties en opvattingen zullen worden bestudeerd aan de hand van de volgende vraagstellingen, die per thema beantwoord worden:

I. Welke ervaringen doen medische studenten op tijdens de fase van co-assistentschappen?

- Is er sprake van verschillen tussen de onderscheiden subgroepen ?

- Is er sprake van verschillen tussen vrouwelijke en mannelijke co-assistenten

II. Treden er veranderingen op bij medische studenten tijdens de fase van de coassistentschappen?

- Zijn de veranderingen in de tijd verschillend bij de beide seksen ?

- Zijn de veranderingen in de tijd anders in de onderscheiden fasen 0, 1 en 2 ?

III. Spelen andere achtergrondvariabelen dan sekse en subgroep een rol bij de verklaring van de bevindingen in het transversale onderzoek ?

\subsection{Hypothesen bij de verschillende thema's.}

Bij de zes onderscheiden thema's zijn per thema een aantal hypothesen geformuleerd ten aanzien van effecten van het socialisatieproces die optreden in de loop van de coassistentschappen (aangeduid in tabel met term "tijd") en over eventuele verschillen tussen de seksen en de werking van gender (aangeduid in tabel met " $\ \backslash \delta^{\prime \prime)}$ ). Wanneer de hypothese betrekking heeft op de ervaring wordt dit aangegeven met de afkorting "erv.") 


\section{Bij het thema "identificatie"}

Overzicht van hypothesen

Thema 1*identificatie tijd $\quad \begin{aligned} & \text { co-assistenten gaan zich in de loop van hun co-assistentschap- } \\ & \text { pen minder identificeren met patiënten en meer met de artsen- } \\ & \text { opleiders. }\end{aligned}$
Thema $1^{*}$ identificatie $\$ / 8 \quad \begin{aligned} & \text { identificatic vooral met opleiders van mannelijke geslacht; } \\ & \text { vrouwelijke co-assistenten identificeren zich zowel met man- } \\ & \text { nelijke als met vrouwelijke artsen-opleiders, mannelijke co-a- } \\ & \text { ssistenten identificeren zich uitsluitend met mannelijke artsen- } \\ & \text { opleiders. }\end{aligned}$

Thema $1^{*}$ sociale steun $\& / \delta$ vrouwelijke co-assistenten geven duidelijker an sociale steun te wensen dan mannelijke.

Thema $1^{*}$ rolvoorbeel- $९ / \delta$ vrouwen geven duidelijker aan behoefte aan rolvoorbeelden te den hebben dan mannelijke co's.

Uit de beschreven literatuur (Batenburg, 1995; Baneke, 1987; Firth-Cozens, 1990; Fahrenfort, 1985) komt naar voren dat het proces van identificatie met de medische professie voor co-assistenten niet gemakkelijk is en met tal van dilemma's en paradoxen gepaard gaat. Fahrenfort richt de aandacht op de verschuiving van het leken-

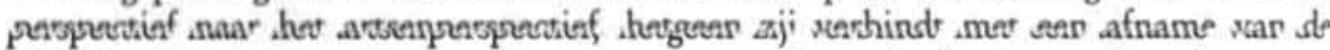
identificatie met de patiënt en daarmee met een afname in de compassie en het meevoelen met het lijden van de patiënt in de richting van een meer gedistantieerd perspectief van de beroepsbeoefenaar. Dit perspectief benoemt zij als een carrièreperspectief (1985).

We veronderstellen dat medisch studenten gedurende de klinische stages geleidelijk het lekenperspectief verruilen voor een perspectief van medisch professional of arts. Co-assistenten zullen zich in de loop van de tijd minder gaan identificeren met patiënten en meer met de artsen-opleiders.

Over de werking van sekse en gender zijn de volgende hypothesen geformuleerd. Omdat op het moment van het onderzoek de hoogste en meest statusrijke rollen in de medische professie worden ingenomen door mannelijke artsen, is het aannemelijk dat mannelijke artsen het sterkst worden opgevat als cultuurdragers van de beroepscultuur. Voor het identificatieproces zal dit inhouden dat co-assistenten zich in ieder geval met mannelijke artsen zullen identificeren. Wij vertrekken vanuit de hypothese dat nieuwelingen zich het sterkste zullen identificeren met de bekleders van de meest statusrijke posities, dus met mannelijke artsen (thema 1).

Omdat vrouwelijke artsen tegenwoordig wel een groeiend aandeel vormen in de groep van assistent-geneeskundigen in opleiding (AGIO's), de groep die meestal het leeuwendeel van de concrete werkbegeleiding van co-assistenten op zich neemt, is het evenwel interessant om te bezien of dit gevolgen heeft voor het identificatieproces.

We nemen verder op grond van psychodynamische inzichten (Chodorow, 1978) aan dat vrouwen en meisjes zich sterker met mannen vereenzelvigen dan mannen en 
jongens dat doen met vrouwen of vrouwelijkheid. We veronderstellen dat dit patroon ook bij co-assistenten aangetroffen wordt hetgeen dan zou betekenen dat mannelijke co-assistenten zich nauwelijks identificeren met vrouwelijke artsen terwijl vrouwelijke co-assistenten zich omgekeerd wel met mannelijke voorbeelden identificeren.

De culturele codes die in de opvoeding tot jongen of meisje besloten zijn, leiden mogelijk tot verschillen ten aanzien van het "mogen" articuleren van de wens naar sociale steun of rolvoorbeelden. Zo nemen we aan dat vrouwen meer ruimte kennen in het uiten van behoefte aan steun of rolvoorbeelden dan mannen. Dit houdt in dat vrouwelijke co-assistenten behoefte aan steun sneller zullen erkennen en ook gemakkelijker laten zien.

Bij bet thema expliciet onderscheid naar sekse

Overzicht van hypothesen

Thema 2

* perceptie erotisering

Thema 2

* perceptie voorkeur voor mannen

Thema 2

* perceptie voorkeur voor mannen

Thema 2

* bewustzijn eigen sekse

Thema 2

* ongewenste intimiteiten tijd de perceptie van erotisering van de betrekkingen in de medische werksetting neemt toe in de loop van de tijd

$\% / 8$ de perceptie van voorkeursbehandeling voor mannen in de medische professie is bij vrouwelijke co-assistenten sterker dan bij mannelijke

tijd de perceptie van voorkeursbehandeling voor mannen in de medische professie neemt toe in de loop van de tijd

9/8 vrouwen worden in de setting van de co-assistentschappen sterker herinnerd aan hun sekse dan mannelijke co's hun man-zijn

१/8 vrouwen hebben meer ervaring met ongewenste intimiteiten dan hun mannelijke collega's

In het thema expliciet onderscheid naar sekse onderzoeken we onder andere de perceptie van co-assistenten van de voorgeleefde cultuur. Naar aanleiding van de bevinding in het beroepscultuuronderzoek (hoofdstuk 6) dat de perceptie verandert naarmate co-assistenten verder vorderen in hun socialisatie tot arts, veronderstellen we dat co-assistenten in de loop van de tijd eventuele erotisering van de betrekkingen in de medische werksetting pregnanter en sterker waarnemen en dat hen een (eventueel bestaande) voorkeursbehandeling voor mannelijke artsen meer zal opvallen.

In het sociale verkeer binnen arbeidsverhoudingen blijken seksestereotypen een grote rol te spelen, zowel in de zelfopvattingen als in de manier waarop mensen worden aangesproken. Komter $(1985,1990)$ sprak van de macht van de vanzelfsprekendheid, die maakt dat de gepriviligeerde positie van mannen nauwelijks geproblematiseerd wordt en dat een dienende, ondersteunende of assistenterende rol van vrouwen als juist en adequaat wordt opgevat. Ook wordt de ongelijkheid tussen de seksen soms geidealiseerd en als een adequate vorm van attractie tussen vrouwen en mannen 
bekrachtigd. Machtsongelijkheid tussen vrouw en man kan dan gemakkelijk worden geromantiseerd. We vooronderstellen dat in de klinische setting van de co-assistentschappen de dynamiek van de macht van de vanzelfsprekendheid functioneert en dat er sprake is van een lichte idealisering en romantisering van sterotype heteroseksuele omgangsvormen tussen de seksen. De associatie tussen arts-zijn en vrouwelijkheid is verder minder gebruikelijk dan die tussen arts-zijn en mannelijkheid, derhalve is het aannemelijk dat vrouwelijke co-assistenten in de setting van de co-assistentschappen sterker aan hun sekse worden herinnerd dan hun mannelijke collega's.

Verder is de kans groot dat vrouwen meer ervaring hebben met ongewenste intimiteiten dan hun mannelijke collega's, vooral in die werkvelden waar vrouwelijke artsen nog sterk in de minderheid zijn.

\section{Bij bet thema "professioneel zelfvertrouwen"}

Overzicht van hypothesen thema 3

Thema 3

- gevoel van competentie

Thema 3

* gevoel eigen competentie

Thema 3

* toegeschreven competentie

Thema 3

* professioneel zelfvertrouwen

\section{Thema 3}

* professioneel zelfvertrouwen

\section{$8 / 8$} in de tijd

tijd

৭/ठ

tijd

१/ठ

de twijfel aan eigen competentie neemt bij mannelijke coassistenten sterker af dan bij vrouwelijke co-assistenten

de twijfel aan de eigen competentie is het grootst bij de start van de co-assistentschappen en neemt af in de loop vas de fase van de co-assistentschappen

vrouwelijke co-assistenten kennen meer twijfel over of ze door de omgeving als competent arts worden gezien, dan hun mannelijke collega's

het professioneel zelfvertrouwen neemt toe in de loop van de co-assistentschappen

het professioneel zelfvertrouwen van mannelijke co-assistenten neemt sterker toe dan dat van vrouwelijke

Het professioneel zelfvertrouwen en gevoel van competentie (thema 3) zal, wanneer alles normaal verloopt waarschijnlijk toenemen in de loop van de fase van de co-assistentschappen. De co-assistent zal na een fase van onzekerheid en twijfel aan de eigen competentie in het begin in de startfase of fase 0 (Fahrenfort, 1985; Groot de, 1987), waarschijnlijk groeien in gevoel van competentie als arts en zelfvertrouwen. Ook zal de co-assistent zich steeds meer aangesproken voelen door de omgeving in de rol van arts, door patiënten maar ook de eigen sociale omgeving, en zal de co-assistent zich steeds meer serieus genomen voelen als arts (toegeschreven competentie).

Op basis van de literatuur waarin barrières voor vrouwelijk artsen zijn beschreven die samenhangen met een seksestereotype benadering, "male-ness van het medisch beroep", die negatieve effecten kan hebben op de coaching en begeleiding van vrouwelijke co-assistenten, veronderstellen we dat de ontwikkeling van het professionele zelfvertrouwen bij vrouwelijke co's zich mogelijk minder voorspoedig ontwikkelt dan bij. 
hun mannelijke collega's. Dit zou dan blijken uit verschil in de ontwikkeling in de tijd van het professioneel zelfvertrouwen van mannelijke en vrouwelijke co-assistenten, die langer geplaagd blijven door twijfel dienaangaande. Ook nemen we aan dat, vanwege het gegeven dat van oudsher het beeld van de dokter overeenkomt met dat van een man, vrouwelijke co-assistenten inschatten dat de omgeving hen minder snel serieus neemt als dokter. $\mathrm{Zij}$ zullen derhalve meer twijfel kennen aan toegeschreven competentie.

\section{Bij bet thema ideaalbeeld-zelfbeeld}

Overzicht van hypothesen

\begin{tabular}{|c|c|c|}
\hline $\begin{array}{l}\text { Thema } 4 \\
\text { * ideaalbeeld }\end{array}$ & erv. & $\begin{array}{l}\text { het beeld van de ideale arts is sterker prototypisch mannelijk } \\
\text { dan vrouwelijk }\end{array}$ \\
\hline $\begin{array}{l}\text { Thema } 4 \\
\text { discrepantie } \\
\text { ideaal-zelfbeeld }\end{array}$ & erv. & $\begin{array}{l}\text { de discrepantie tussen ideaalbeeld en zelfbeeld is groter bij de } \\
\text { dimensie mannelijke aspecten dan bij de dimensie vrouwelijke } \\
\text { aspecten }\end{array}$ \\
\hline $\begin{array}{l}\text { Thema } 4 \\
\text { zelfbeeld }\end{array}$ & $8 / 9$ & $\begin{array}{l}\text { er is een sekse verschil ten aanzien van het zelfbeeld zowel in } \\
\text { het meer prototypisch vrouwelijk ingekleurde als in het meer } \\
\text { mannelijke ingekleurde zelfbeeld }\end{array}$ \\
\hline $\begin{array}{l}\text { Thema } 4 \\
\text { zelfbeeld }\end{array}$ & $\begin{array}{l}\$ / \delta \text { in } \\
\text { de tijd }\end{array}$ & $\begin{array}{l}\text { het zelfbeeld van vrouwelijke co-assistenten wordt in de loop } \\
\text { van de tijd minder prototypisch vrouwelijk }\end{array}$ \\
\hline
\end{tabular}

Omdat het medisch beroep en beroepscultuur is gegrondvest, door mannelijke beroepsbeoefenaren en vrouwen destijds vrij expliciet werden uitgesloten en omdat de cultuurdragers van dit moment (de "helden") nog voornamelijk van het mannelijk geslacht zijn, nemen wij aan dat aan het heersende culturele ideaalbeeld voor de ideale arts meer prototypisch mannelijke dan prototypisch vrouwelijke eigenschappen worden toegeschreven. De oververtegenwoordiging van mannen op de hogere en statusrijke functies in professie en in medische opleiding, zal deze beeldvorming bij co-assistenten mogelijk nog versterken.

Wij zullen twee hypothesen op dit terrein onderzoeken namelijk dat het ideaal van de ideale dokter in de ogen van co-assistenten meer prototypisch mannelijk dan prototypisch vrouwelijk wordt ingekleurd en dat het verschil tussen ideaalbeeld en zelfbeeld groter is ten aanzien van mannelijke aspecten dan van vrouwelijke aspecten.

Wat het zelfbeeld betreft nemen we aan dat vrouwelijke co-assistenten zichzelf sterker herkennen in karakteristiek vrouwelijke en expressieve beschrijvingen en dat mannelijke co-assistenten zichzelf meer herkennen in mannelijke, meer zakelijk en instrumenteel georiënteerde termen ${ }^{2}$.

${ }^{2}$ In het onderzoek van Sieverding (1990) over psychologische barrières voor vrouwelijke artsen, worden de termen instrumenteel respectievelijk expressief gebruikt voor meer mannelijke respectievelijk meer vrouwelijke typering. 
Verder vooronderstellen we onder invloed van de mannencultuur in het medisch beroep een verschuiving in de tijd en wel dat het zelfbeeld van vrouwen minder vrouwelijk wordt.

\section{Bij de themata beroepsoriêntatie en loopbaanoriêntatie}

Overzicht van hypothesen

thema 5

* beroepsoriëntatie

thema 5

- beroepsoriëntatie

thema 5

* beroepsoriëntatie

thema 5 * gevoel van buitenstaan. derschap

thema $5 *$ gevoel van buitenstaan. derschap

thema 6

* loopbaan-oriëntatie

thema 6

- loopbaan-oriëntatie
१/ठ mannelijke co-assistenten bechten in hun toekomstige beroepsuitoefening meer belang aan maatschappelijke erkenning, inkomen en status dan vrouwelijke co's (kostwinnersperspectief)

9/8 vrouwelijk co-assistententen hechten meer waarde aan relationele aspecten (zoals: contact met patiënten, contact met collega's, leuk en boeiend werk) in hun werk dan bun mannelijke collega's

\&/ठ vrouwelijke co-assistenten prefereren een loopbaan met werk in loondienst en in een groepssetting meer dan hun mannelijke colle ga's

tijd het gevoel bij de medische beroepsgroep te gaan horen ("erbij horen") neemt toe naarmate co-assistenten verder vorderen in hun opleiding

$9 / \delta$ 1) vrouwen voelen zich minder "erbij" dan mannen

tijd 2) het veranderingsproces van vrouwelijke co-assistenten gaat op dit punt langzamer dan dat van mannen

१/ठ locus of control ten aanzien van loopbaanwensen

1) mannelijke co-assistenten zijn meer geneigd hun eventuele loopbaansucces toe te schrijven aan machtige anderen dan vrouwen;

2) vrouwelijke co-assistenten zijn geneigd dit sterker toe te schrijven aan het toeval

tijd De loopbaanplannen van co-assistenten worden, naarmate ze verder vorderen in hun opleiding steeds concreter

De opvoeding en geslachtrolsocialisatie van jongen tot man wordt nog steeds gekenmerkt door accentuering van de noodzaak om zich te prepareren op de maatschappelijke rol als kostwinner (Top en Heesink, 1992; Mavis en Hetherington, 1993). Dit maakt het waarschijnlijk dat het kostwinnersperspectief sterker in de beroepsoriëntatie van mannelijke co-assistenten doorklinkt en aanleiding geeft tot een sterkere interesse in inkomen en maatschappelijke status dan bij hun vrouwelijke collega's. Voor vrouwen mag, redererend vanuit de geslachtsrolsocialisatie een sterker accenturering van het beroep als zelfontplooing verwacht kunnen worden.

Op basis van hetzelfde kostwinnersperspectief veronderstellen we bovendien dat mannelijke co-assistenten eerder bezig zijn met het plannen van een beroepsloopbaan dan vrouwelijke co-assistenten.

Wat betreft de loopbaanoriëntatie zullen co-assistenten naarmate ze het einde van hun studie naderen, meer bezig zijn met plannen maken voor hun beroepsloopbaan. 
Op het vlak van loopbaanoriëntatie zou een gendereffect kunnen optreden in de attributies van co-assistenten aangaande hun toekomstige loopbaan en in de factoren die hierbij van betekenis zijn. Steun en support toeschrijven aan machtige anderen als bijvoorbeeld artsen-opleiders in machtige posities, gebeurd door mannelijke co-assistenten mogelijk meer dan door vrouwelijke co-assistenten (thema 6).

Co-assistenten zullen verder naar alle waarschijnlijkheid zich minder buitenstaander gaan voelen en meer lid van de medische professie naarmate de tijd voortschrijdt.

We nemen verder aan dat de assimilatie door vrouwelijke co-assistenten mogelijk als moeizamer wordt ervaren en zij langer het gevoel van een buitenstaander te zijn houden.

\subsection{Het onderzoeksinstrument, validiteit en betrouwbaarheid ${ }^{3}$}

De onderzoeksvragen zijn beantwoord aan de hand van een semi-kwantitatieve transversaal en longitudinaal onderzoek, waarbij gebruik werd gemaakt van vragenlijsten. Omdat in dit onderzoek ook werd gestreefd naar enig kwalitatief materiaal ter illustratie van de ervaringen van studenten tijdens de co-assistentschappen, zijn in de vragenlijsten ook meerdere open vragen opgenomen. De antwoorden op de open vragen geven een verdieping van kwantitatieve data (zie thema "expliciet onderscheid naar sekse"). De vragenlijsten zijn opgebouwd uit een aantal items waarop de onderzoekspopulatie kon antwoorden op een vierpuntsantwoordschaal van 1: volledig eens tot 4: volledig oneens of 1: helemaal niet tot 4: heel goed. Door de gehanteerde schalen kunnen de variabelen gekenmerkt worden als ordinale variabelen. Daarnaast bevat de vragenlijst een aantal nominale variabelen.

Op basis van het literatuuronderzoek, de diepte-interviews en reflectie op eigen ervaringen, werden de vragenlijst-items ontwikkeld en werden bestaande meetinstrumenten gescreend op hun bruikbaarheid voor dit onderzoek naar ontwikkeling van professionele identiteit. Dit resulteerde in het opnemen van de volgende meetinstrumenten de selfesteem-vragenlijst van Rosenbaum (Baardman, 1989) en de locus of control vragenlijst (in de bewerking van Halfens (dissertatie UM 1985)). De betrouwbaarheid van de schalen werd onderzocht door reliabilty testen in het transversale onderzoekmateriaal $(\mathrm{N}=185)$.

Meestal werd binnen het onderzoeksthema eerst een factoranalyse uitgevoerd om de samenhangen op het spoor te komen en werden correlaties berekend. Daarna werden clusters van items omgevormd tot samengestelde variabelen.

\subsection{Operationalisatie en beschrijving van de variabelen}

In de vragenlijst werden de eerder beschreven achtergrondvariabelen te weten sekse, leeftijd, fase van co-assistentschappen, opleiding van vader en moeder, leefsituatie, wel

\footnotetext{
'de instrumentontwikkeling en de opzet van het onderzoek conform het onderzoek naar draaglast en dragkracht en is uitgebreider beschreven in hoofdstuk 7.
} 
of geen extra vooropleiding genoten hebben en wel of geen arts in de familie, geinventariseerd (zie hoofdstuk 8).

\section{Operationalisatie van aspecten van (zelf) evaluatie (thema 1 en 2)}

Thema 1, het proces van identificatie en het onderkennen van eventuele rolvoorbeelden (modeling) werden onderzocht door de onderzoekspopulatie te vragen naar de groepen met wie zij zich identificeren in hun opleidingssituatie aan de universiteit of in de klinische stages of in de medische praktijk. Ook werd gevraag naar de behoefte aan rolvoorbeelden evenals naar de behoefte aan sociale steun vanuit hun sociale omgeving. Deze aspecten werden bevraagd via de variabelen zoals beschreven in figuur 9.5 .

De evaluatie van de seksegebonden praktijken door co-assistenten komt aan de orde in het thema 2 "het expliciet onderscheid maken naar sekse". Hoe gaat het er op de werkvloer concreet aan toe tussen artsen onderling en tussen artsen en hun leerlingen, hun patiënten en ander disciplines ? De percepties van co-assistenten van cultuuraspecten, die samenhangen met gender en onderscheid maken naar sekse, komen nu aan de orde.

Door aandacht te besteden aan het vraagstuk over de manier waarop vrouwelijke en mannelijke co-assistenten worden aangesproken op hun sekse in de context van de kliniek, pogen we meer licht te werpen op de wisselwerking van professionele - en genderidentiteit in de ontwikkelingsgeschiedenis van de medische professional. Deze persoonsarrangementen worden bevraagd met behulp van de variabelen zoals beschreven in figuur 9.6 .

\section{Operationalisatie van "mastery of professioneel zelfvertrouwen" (thema 3)}

Het gevoel van toenemende competentie en zelfvertrouwen, ook wel gevoel van "mastery" genoemd, blijkt van groot belang in het proces van professionele ontwikkeling van artsen en is uitgewerkt in een aantal variabelen (zie figuur 9.7). De variabelen positief en negatief zelfbeeld zijn gebaseerd op de "selfesteem" vragenlijst van Rosenbaum (Baartman, 1989).

\section{Operationalisaties van aspecten van professionele identiteit}

- Ideaalbeeld-zelfbeeld (prototypische vrouwelijk of mannelijk) (thema 4)

- Beroepsoriëntatie (thema 5)

- Loopbaanoriëntatie (thema 6)

Aan de orde komt de mate waarin het beeld van de ideale arts door co-assistenten meer of minder prototypische vrouwelijk of mannelijk wordt ingekleurd. Dit ideaalbeeld wordt in relatie gebracht met het zelfbeeld van co-assistenten. Om de variabelen te construeren werd gebruik gemaakt van de "BEM-sex-role-inventory" zoals toegepast in van Vianen (1984) "Het selectie interview". Een lijst van 28 eigenschappen, die worden geassocieerd met vrouwelijkheid en mannelijkheid werd voorgelegd aan de onderzoekspopulatie. De adjectieven die gelden als geassocieerd met prototypisch mannelijkheid zijn: eerzuchtig, ambitieus, zelfverzekerd, dominant, durf, rationeel, formeel, krachtig, methodisch, logisch denken, groot abstractievermogen. Meer geassocieerd met prototypische vrouwelijkheid zijn de adjectieven: spontaan, aantrekkelijk, 
tactvol, begrijpend, afhankelijk, zachtaardig, overgevoelig, emotioneel, attent, warm, gezellig, gevoelig, nieuwsgierig, zorgzaam (voor variabelen zie figuur 9.8).

Ook ontstaan bij co-assistenten beelden over de inhoud van het medisch werk, over de manier van inrichten van het werk (loondienst en in teamverband, solistisch, vrij ondernemerschap) en de waarde die gehecht wordt aan status en maatschappelijke erkenning en collegiale verhoudingen. Deze aspecten van de professionele identiteit kristalliseren meer en meer uit gedurende de fase van de co-assistentschappen. (Voor variabelen zie figuur 9.9).

Concrete loopbaanplannen en de attributies van co-assistenten ten aanzien van het succes van deze plannen staat nu centraal in thema 6 "loopbaanoriëntatie". We bestuderen de mate waarin co-assistenten reeds bezig zijn met hun toekomstige loopbaan en hoe zij de haalbaarheid van hun beroepswensen inschatten (zie figuur 9.10).

De attributies van co-assistenten over hun kansen in het beroep zijn nog nader onderzocht door gebruik te maken van het bestaande meetinstrument "locus of control", zoals toegepast door Halfens op gezondheidsgedrag (Halfens, 1985).

Mensen schrijven verwachtingen ten aanzien van het al of niet slagen en realiseren van hun loopbaanplannen toe aan verschillende factoren. Zo denkt de eén dat het gewoon een kwestie van geluk is of men een functie of baan naar wens krijgt, terwijl een ander het welslagen op dit punt toeschrijft aan eigen capaciteiten. Weer een ander denkt dat "machtige anderen" de grootste invloed zullen hebben. De respondenten hebben vragen beantwoord die hun inschatting van vermoedelijke oorzaken van succes in hun medische loopbaan verhelderen.

\section{Opzet van het onderzoek}

De opzet van dit onderzoek naar professionele identiteit en de uitvoering hiervan is identitiek aan die van het onderzoek naar de belasting van de inwijding naar draaglast, draagkracht en outcome. Voor een beschrijving van opzet, uitvoering en statistische analyses wordt verwezen naar hoofdstuk 7 , paragraaf 10 en 11. 


\section{Figuur 9.5 (Zelf)evaluatic}

\section{Variabelen met betrekking tot identificatie, modeling en sociale steun}

\section{items 'identificatie'}

- ik identificeet me als co-assistent het meest met patiênten.

- ik identificeer me als co het meest met mannelijke artsen.

- ik identificeer me als co het meest met verpleegkundigen.

- ik identificeer me als co het meest met fysiotherapeuten.

- ik identificeer me als co het meest met vrouwelijke artsen.

- ik identificeer me als co het meest met overigen.

\section{items 'ondersteuning krijgen'}

- ik krijg veel ondersteuning van mijn omgeving bij mijn streven naar het door mij gewenste beroep.

- ik heb behoefte aan een omgeving (partner, vrienden, ouders etc.) die me stimuleert bij het streven naar het door mij gewenste beroep.

variabele 'voorbeelden bebben'

$\alpha=0.46$

- ken je mensen die als voorbeeld voor jouw studiekeuze fungeerden, nog voordat je ging studeren?

- zijn er docenten in je medische opleiding die als voorbeeld fungeerden?

- ken je artsen die in de praktijk werkzaam zijn of waren, die voor jou als voorbeeld dienen of gediend hebben?

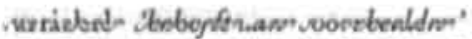

- zo nee, zou je die gehad willen hebben?

- zo nee, zou je voorbeelden gehad willen hebben?

- zo nee, zou je voorbeelden willen hebben? 


\section{Figuur 9.6 (Zelf)evaluatie} Variabelen met betrekking tot expliciet onderscheid naar sekse en genderidentiteit

variabele 'perceptie van erotisering tun de betrekkingen'

$\alpha=0.62$ bestaande uit de volgende items:

- ik heb de indruk dat er veel verliefdheden optreden tussen co-assistenten en artsen.

- ik heb de indruk dat er veel verliefdheden optreden tussen artsen en verpleegkundigen.

- ik wordt gemakkelijk verliefd op opleiders, docenten enz.

- ik bespeur vaak een erotische ondertoon in de omgang met anderen werkzaam in de kliniek.

variabele 'perceptie voorkeursbehandeling voor mannelijke (a.s.) artsen' $r=0.40 ; p \leq 0.001$ - an mannelijke artsen wordt meer competentie toegeschreven dan aan vrouwelijke artsen.

- mannelijke (a.s.) artsen hebben meer kans op een plaats bij een vervolgopleiding.

variabele 'bet voorkomen van ongewenste intimiteiten'

- word je geconfronteerd met ongewenste aanrakingen?

- heb je wel eens een ongewenste intimiteit meegemaakt?

item:

- heb je weleens gehoord van ongewenste intimiteiten t.o.v. je collega's?

Gender-identiteit

(gender 4)

variabele 'bewustzijn van sekse'

- word je vaak door de omgeving aan herinnerd dat je een vrouw of man bent?

$r=0.51 ; p \leq 0.001$

- ben je je tijdens de co-schappen bewust van dat je vrouw of man bent? 


\section{Figuur 9.7 Professioneel zelfvertrouwen}

Variabelen met betrekking tot professioneel zelfvertrouwen en gevoel van competentie

variabele 'positief zelfbeeld'

- ik heb het gevoel dat ik het zo slecht nog niet doe in vergelijking met anderen

- ik heb het gevoel dat ik veel aanleg en goede eigenschappen voor het artsenberoep bezit

- ik kan iets net zo goed voor elkaar krijgen als de meeste andere co-assistenten

- in het algemeen ben ik tevreden met mijzelf

variabele 'negatief zelfbeeld'

$\alpha=0.65$

- over het algemeen heb ik het gevoel dat ik tegenval

- ik zou willen dat ik wat meer respect voor mezelf had

- ik heb vaak het gevoel dat ik nutteloos ben

- soms denk ik dat ik als aanstaand arts helemaal niet deug

variabele 'twiffel aan eigen competentie'

- twijfel je vaker aan je competentic bekwaamheid om een goed arts te worden?

- twijfel je aan de mogelijkheid als volwaardig arts mee te kunnen gaan functioneren?

- ik voel me al een beetje dokter (omgepoold)

variabele 'twijfel ten aanzien van toegeschreven competentie'

- heb je het gevoel dat opleiders twijfelen aan je toekomstige competentie?

- heb je het gevoel dat je omgeving (familie, vrienden) twijfelt aan je toekomstige competentie?

- heb je het gevoel dat patienten twijfelen ans je toekomstige compotentie?

variabele 'voldoen aan patiënt verwachtingen'

$r=0.37 p \leq .01$

- ik heb het gevoel als co-assistent vaak aan de verwachtingen van patiënten te kunnen voldoen

- als co-assistent kan ik een nuttige taak vervullen in de patiëntenzorg 


\section{Figuur 9.8 Aspecten van professionele identiteit} Zelfbeschrijving en eigenschappen van een 'ideale arts'

variabele 'vrouwelijke eigenschappen toegeschreven aan de ideale arts' variabele 'mannelijke eigenschappen toegescbreven aan de ideale arts' variabele 'vrouwelijke eigenschappen toegeschreven aan zichzelf' variabele 'mannelijke eigenschappen toegerchreven aan zichzelf

gemeten met de 'BEM sex-role inventory', waarin van onderstaande eigenschappen men op een 4 puntsschaal dient aan te geven in hoeverre men dit eigenschappen van een ideale arts zijn en in hoeverre die op de respondent van toepassing zijn.

12 eigenschappen, passend bij het mannelijk prototype $(\alpha-0.66)$ : joviaal, groot abstractie-vermogen, eerzuchtig, logisch denken, zelfverzekerd, dominant, rationeel, durf, metbodiscb ambitieus, formeel, kracbtig

14 eigenschappen, passend bij het vrouwelijk prototype $(\alpha-0.69)$ : spontaan, aantrekkelijk, tactvol, begrijpend, afhankelijk, zachtaardig, overgevoelig, emotioneel, attent, warm, gezellig, gevoelig, nieuwsgie. rig, zorgzaam

Bron: Van Vianen (1987) 


\section{Figuur 9.9 Aspecten van professionele identiteit Variabelen met betrekking tot beroepsoriëntatie}

variabele 'belang bechten aan maatschappelijke erkenning' (beroepsbeeld 1)

$\alpha=0.63$

- in welke mate zijn voor je toekomstige beroepsuitoefening de volgende factoren belangrijk:

* maatschappelijke status/erkenning

* wetenschappelijke erkenning

* inkomen

* gezag op basis van deskundigheid

- ik hecht meer waarde aan de carrièremogelijkheden van werk dan aan de inhoud van het werk.

- ik ambieer op termijn een leidinggevende positie

variabele 'als arts in team met solistische' (of professionele inbedding) (beroepsbeeld 2)

$\alpha=0.65$

- ik werk later liever in een groepssetting of teamverband

- ik werk later liever onder supervisie

- ik werk later liever in loondienst

- ik werk liever niet als 'kleine zelfstandige' in een eigen praktijk

variabele 'contact' (beroepsbeeld 3)

$r=0.25 \mathrm{p} \leq 0.001$

- in welke mate zijn voor je toekomstige beroepsuitoefening de volgende factoren belangrijk:

a. goed contact met patiënten

b. goed contact met collega's

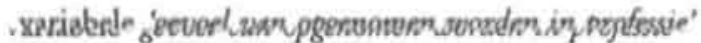

- heb je het gevoel dat je als arts lid wordt van een bepaalde groep

$x=\Omega 24, \gamma^{n} \leq \Omega 0 Q 1$

- heb je het gevoel straks gemakkelijk te worden opgenomen in de beroepsgroep van artsen 


\section{figuur 9.10 Aspecten van professionele identiteit Variabelen met betrekking tot loopbaanoriēntatie}

\section{variabele "concrete loophaanplannen"}

- ik heb veel nagedacht over mijn loopbaan

- ik heb al concrete plannen voor mijn professionele toekomst

- ik diverse activiteiten zoals keuzeonderwijs, stages, onderzoekjes ondernomen om mij te profileren met het oog op mijn toekomstige loopbaan

variabele "baalbaarbeid

$\alpha=0.76$

- ik zie mijn toekomst in het medische beroep vol vertrouwen tegemoet

- de kans dat ik mijn loopbaanwensen kan realiseren, acht ik groot

- als ik plannen maak, ben ik er vrijwel zeker van dat ik ze kan laten slagen

\section{"realiseren loopbaanwensen"}

- als ik mijn loopbaanwensen niet zou kunnen realiseren, zou ik dat vreselijk vinden

variabele "interne locus of control"

$\alpha=0.60$

- of ik wel of niet een baan als arts zal krijgen hangt grotendeels af van mijn bekwaamheid

- wat er in mijn leven zal gebeuren heb ik aardig in de hand

- ik ben meestal in staat om mijn persoonlijke belangen te behartigen

- als ik krijg wat ik wil, is dat meestal omdat ik er hard voor heb gewerkt

- mijn leven wordt bepaald door mijn eigen handelingen

- als mijn belangen botsen met die van een ander, zal ik voor mijn belang vechten

variabele "externe locus of control"

$\alpha=0.70$

- om iets te bereiken in het artsenberoep moet men relaties of een kruiwagen hebben

- ik heb het gevoel dat wat er in mijn beroepsleven gebeurt vooral door invloedrijke personen wordt bepaald

- ook al zou ik goed genoeg zijn, dan zou ik toch geen leidinggevende positie krijgen, als ik niet bij mijn superieuren in de smaak zou vallen

- mijn beroepsleven wordt voornamelijk door invloedrijke anderen beheerst

- mensen zoals ik zien erg weinig kans om hun belangen te behartigen, als deze botsen met belangen van invloedrijke anderen

- om te krijgen wat ik wil, moet ik het de mensen die boven mij staan naar de zin maken

- om mijn plannen te laten slagen, zorg ik ervoor dat ze overeenstemmen met de wensen van mensen, die macht over me hebben

- als mijn belangen botsen met die van een ander, zal ik naar iets anders uitkijken

variabele "toeval als locus of control"

$\alpha=0.77$

- mijn loopbaan wordt in hoge mate bepaald door toevallige gebeurtenissen

- mijn persoonlijke belangen worden vaak door pech gedwarsboomd

- als ik krijg wat ik wil, is dat meestal omdat ik geluk heb

- ik heb gemerkt dat wat uiteindelijke gebeurt toch grotendeels door toeval of lot bepaald wordt

- het is niet altijd verstandig voor mij om te ver vooruit plannen te maken, omdat veel dingen een kwestie van geluk of pech blijken te zijn

- of ik wel of niet een leidinggevend positie krijg, hangt er van af of ik het geluk heb op het juiste moment op de juiste plaats te zijn

het is voornamelijk een kwestie van het noodlot of ik weinig of veel vrienden heb 


\subsection{Samenvatting}

De aandacht in dit hoofdstuk is gevestigd op de ontwikkeling van de professionele identiteit op interactioneel en situationeel niveau is in dit hoofdstuk de aandacht gevestigd. Eerder onderzoek naar het proces van professionele socialisatie heeft wel inzicht gegeven in de dynamiek op interactioneel niveau tussen leerling en diens leeromgeving, maar mist vaak de reflectie op genderwerking. Co-assistenten zullen zich meer of minder gaan identificeren met de artsen-opleiders, hun gedrag als voorbeeld beschouwen en internaliseren en navolgen. Deze processen voltrekken zich deels bewust deels onbewust. Voor co-assistenten is oefenen en ervaring opdoen met het invullen van de beroepsrol belangrijk evenals het ervaren van positieve bekrachtiging door opleiders en sociale omgeving. Het opbouwen van een gevoel van competentie en zelfvertrouwen als arts is wezenlijk voor een evenwichtige professionele identiteit en een positieve houding naar de toekomstige medische loopbaan.

Om binnen dit proces vat te krijgen op de werking van gender werd de samenhang bestudeerd tussen de omgeving, de cultuur en structuur-arrangementen van de medische professie en de persoonsarrangementen als zelfopvattingen en attitudes van co. assistenten.

Aan de vorming van de professionele identiteit gaan processen vooraf als (zelf)evaluatie en het opdoen van professioneel zelfvertrouwen. Deze processen werden bestudeerd aan de hand van het thema "identificatie", en "expliciet onderscheid naar sekse" en het thema "professioneel zelfvertrouwen".

Aan de professionele identiteit als uitkomst van het socialisatieproces kan men aspecten onderscheiden als de relatie van het ideaalbeeld tot het zelfbeeld, de oriëntatie op het beroep en de eigen loopbaan en de genderidentiteit. De balans tussen het concept van de ideale arts en het zelfbeeld bij co-assistenten wordt onderzocht in relatie tot het feminiene of masculiene prototypering. $\mathrm{Bij}$ de oriëntatie op het beroep speelt de verinnerlijking van het kostwinnersperspectief een rol. Het bewustzijn van eigen sekse, een aspect van de genderidentiteit worden belicht en attributies van co-assistenten over hun toekomstige loopbaan.

$\mathrm{Bij}$ elk thema werden een aantal veronderstellingen en hypothesen geformuleerd over sekseverschillen, ontwikkeling in de tijd en genderwerking. 


\section{Hoofdstuk 10}

\section{De ontwikkeling van de professionele identiteit \\ Resultaten en discussie}

\subsection{Inleiding}

Co-assistenten betreden als relatieve nieuwelingen de wereld van de medische professie en worden ondergedompeld in de cultuur van de medische beroepsgroep. In dit onderzoek vatten we de cultuur van de medische professie op als een institutioneel proces van betekenisgeving en waardering, waarin opvattingen circuleren over kwaliteit, over de ideale arts en diens tegendeel, over de normale en gepaste omgang met patiënten, met collega's, over vrouwelijkheid en mannelijkheid etcetera. Naar analogie van andere instituties en arbeidsorganisaties sluit ook de cultuur van de medische professie bepaalde betekenissen uit en activeert andere, hetgeen beschouwd kan worden als een vorm van een machtsproces (Brouns, 1993). Het proces van socialisatie of cultuuroverdracht kan geoperationaliseerd worden als een proces van subjectvorming, van disciplinering en normering.

We zijn zeer benieuwd hoe aanstaande vrouwelijke en mannelijke artsen veranderen door deze onderdompeling tijdens de co-assistentschappen, een periode met een sterk vormende of socialiserende werking. Professionele socialisatie vindt plaats, een proces van vorming van individuele waarden in relatie met de omgeving, die wordt geoperationaliseerd als de cultuur van de medische beroepsgroep. Co-assistenten maken kennis met de waarden van de beroepsgroep, nemen deze meer of minder over en internaliseren de voorgeleefde waarden. In een socialisatieproces worden bepaalde fasen onderscheiden namelijk de inwijdingsfase, de consolideringsfase, de fase van cultuurtoepassing en tot slot die van cultuuroverdracht (Veldman \& Witting, 1990). In dit onderzoek is de andacht gericht op de inwijdingsfase in de medische professio- 
nele cultuur, de co-assistentschappen en de mogelijke veranderingen die optreden in deze beginperiode. In het proces van professionele identificatie hebben we een aantal thema's onderscheiden die we eerder beschreven. De resultaten zullen per thema worden beschreven in de volgende volgorde:

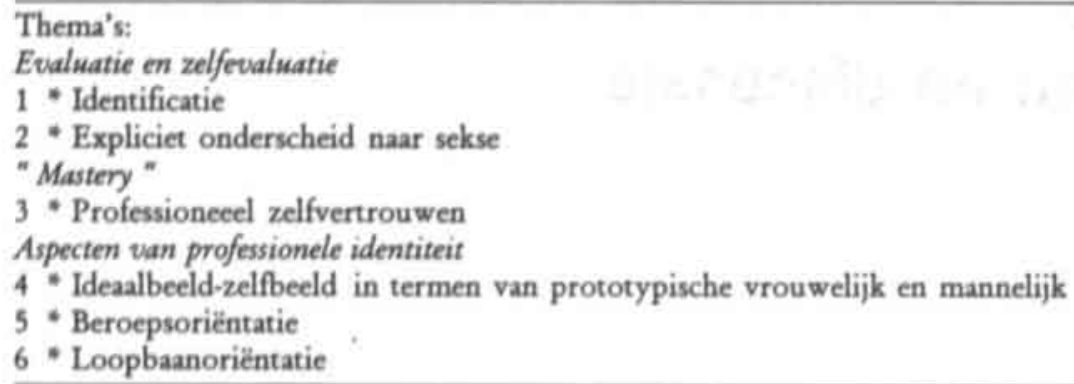

\section{Vraagstellingen}

In dit onderzoek zijn we benieuwd naar of co-assistenten veranderen en in welke rich. ting gedurende deze fase van hun socialisatieproces. Daarnaast beogen we om zicht te krijgen op de werking van "gender" en eventuele reproduktie van genderongelijkheid in dit proces. Bij elk thema dat wordt bestudeerd in het kader van de professionele

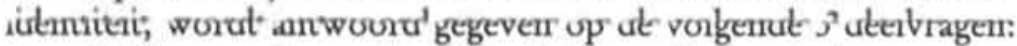

I. Welke ervaringen doen medische studenten in het proces van de professionele identiteit op in de co-assistentschappen?

- Is er sprake van verschillen tussen de onderscheiden subgroepen ?

- Is er sprake van verschillen tussen vrouwelijke en mannelijke co-assistenten

II. Treden er veranderingen op bij medische studenten tijdens de fase van de coassistentschappen?

- Zijn de veranderingen in de tijd verschillend bij de beide seksen ?

- Zijn de veranderingen in de tijd anders in de onderscheiden fasen 0,1 en 2 ?

III. Zijn andere achtergrondvariabelen dan sekse en mate van gevorderdheid van invloed op de onderzochte variabelen ?

\subsection{Respondenten}

De onderzoekspopulatie is dezelfde als de in hoofdstuk 7 en 8 beschreven groep.

De respons in het transversale onderzoek, waarin 170 co-assistenten en 69 precoassistenten (vierdejaars studenten) werden geworven, bedroeg $77 \%(n=185)$. De respons in de onderscheiden groepen co-assistenten en preco-assistenten apart bedraagt $80 \%$ en $70 \%$ respectievelijk. Van de co-assistenten stuurden 137 personen de ingevulde vragenlijsten terug, 75 vrouwen en 62 mannen. De non-respons onder co-assistenten bestaat uit 48 personen en laat een licht overwicht van mannen zien.

Van de preco-assistenten of vierdejaars stuurden 48 personen, waaronder 32 vrouwelijke en 16 mannelijke studenten ( $78 \%$ resp. $57 \%$ ) de vragenlijsten terug. De non-respons bestaat uit 21 personen waarvan 11 vrouwen en 10 mannen. 
De groep co-assistenten-respondenten is in het transversale onderzoek verder onderverdeeld in twee subgroepen namelijk de zogenaamde "beginners" (groep 1), dat wil zeggen co-assistenten die korter dan een jaar bezig zijn met deze klinische fase en de "gevorderden" (groep 2), co-assistenten die een jaar of langer bezig zijn met de fase van de co-assistentschappen.

Tabel 10.1. Groeps- en sekseverdeling van de respondenten

\begin{tabular}{|c|c|c|c|c|c|c|c|}
\hline \multirow[b]{2}{*}{ omschrijving } & \multirow[b]{2}{*}{ groep } & \multicolumn{3}{|c|}{ eerste meting } & \multicolumn{3}{|c|}{ tweede meting } \\
\hline & & $\begin{array}{l}\text { vrouwen } \\
\mathrm{N}(\%)\end{array}$ & $\begin{array}{l}\text { mannen } \\
\mathrm{N}\left(\%_{0}\right)\end{array}$ & $\begin{array}{l}\text { totaal } \\
\mathrm{N}(\%)\end{array}$ & $\begin{array}{l}\text { vrouwen } \\
N(\%)\end{array}$ & $\begin{array}{l}\text { mannen } \\
\mathrm{N}(\%)\end{array}$ & $\begin{array}{l}\text { totaal } \\
\mathrm{N}(\%)\end{array}$ \\
\hline te jaars & 0 & $32(67)$ & $16(33)$ & $48(26)$ & $25(66)$ & $13(34)$ & $38 \quad(30)$ \\
\hline beginnende co's & 1 & $40(50)$ & $40(50)$ & $80(43)$ & $31(53)$ & $27(47)$ & $59 *(47)$ \\
\hline gevorderde co's & 2 & $35(61)$ & $22(39)$ & 57 (31) & $20(69)$ & $9(31)$ & 29 (23) \\
\hline total co's & $1+2$ & $75(55)$ & $62(45)$ & $137(74)$ & i & 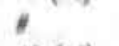 & i. \\
\hline totaal stud. & $0+1+2$ & $106(57)$ & $79(43)$ & $185(100)$ & $76(60)$ & $49(40)$ & $126 *(100)$ \\
\hline
\end{tabular}

- 1 sekse missing.

ter is geen subtotaal gebruikt in het longitudinale onderzoek.

De veranderingen in de tijd werden bestudeerd door een longitudinaal onderzoek uitgevoerd bij een deel van de bestaande steekproef, die dezelfde vragenlijst opnieuw, maar nu een jaar verder gevorderd in hun leertraject in de co-assistentschappen, voorgelegd kregen. De respons van het longitudinale onderzoek bedroeg $70.4 \%$ concreet 126 personen, waarvan 76 vrouwen en 49 mannen. De uitval is beschreven in hoofdstuk 8 (zie pagina...) In bovenstaande tabel 10.1 staat het aantal respondenten in de verschillende subgroepen vermeld.

\subsection{Resultaten transversaal en longitudinaal onderzoek naar (zelf)evaluatie}

Eerst komen de resultaten aan de orde die betrekking hebben op de evaluatie van coassistenten van de leerervaringen die worden opgedaan. De rolvoorbeelden en identificatie-objecten komen aan de orde en de behoefte aan sociale steun. Ook zal de evaluatie door co-assistenten van de seksegebonden praktijken worden onderzocht in die zin dat we bestuderen hoe sekse een rol speelt en op welke wijze sekse wordt bekrachtigd. Naast kwantitatieve gegevens zijn over dit onderwerp ook kwalitatieve gegevens verzameld.

\section{Resultaten thema 1 "identificatie"}

Met wie identificeren co-assistenten zich bet sterkst in de verschillende fasen?

Co-assistenten en studenten blijken zich het sterkst te identificeren met andere artsen, zowel van het vrouwelijke als van het mannelijke geslacht (mean score totale groep "identificatie van vrouwelijke artsen 2.8 , met mannelijke artsen 2.7 ). Ze identificeren zich slechts in geringe mate met patiënten (1.5), verpleegkundigen (1.7) en fysiotherapeuten (1.3).

Er bestaat een verschil tussen groepen studenten in de verschillende stadia van de opleiding (getest met Kruskall Wallis - en Mann-Whitney test) bij de identificatie met 
de patiënt; co-assistenten identificeren zich minder sterk met patiënten dan preco-assistenten, die nog niet begonnen zijn met de medische praktijkstages $(p=.003$ tussen groep 0 (de preco's) en groep 1 en 2 van co-assistenten.

De subgroepen verschillen op de andere punten van identificatie niet van elkaar.

\section{Verschillen mannelijke en vrowwelijke co-assistenten ten aanzien van identificatie?}

Vrouwelijke co-assistenten blijken zich sterker te identificeren met vrouwelijke artsen en mannelijke sterker met mannelijke artsen. Mannelijke co-assistenten blijken zich minder met vrouwelijke artsen te identificeren dan vrouwelijke co-assistenten met mannelijke artsen (zie tabel 10.2).

Co-assistenten identificeren zich niet sterk met patiënten maar nog minder met verpleegkundigen en fysiotherapeuten. Vrouwelijke beginnende co's in subgroep 1 identificeren zich significant sterker met patiënten dan hun mannelijke collega's. Vrouwelijke co's scoren ook hoger op de "identificatie met overigen".

Tabel 10.2 Sekseverschillen in identificatie

\begin{tabular}{|c|c|c|c|c|c|c|c|c|}
\hline \multirow[b]{2}{*}{ identificatie met .... } & \multicolumn{3}{|c|}{$\begin{array}{l}\text { groep 0- } \\
\text { pre-co's }\end{array}$} & \multicolumn{3}{|c|}{$\begin{array}{l}\text { totale groep } \\
\text { co's }\end{array}$} & \multirow{2}{*}{$\begin{array}{l}q / \delta \\
\text { groep } 1 \\
\mathrm{p} \leq\end{array}$} & \multirow{2}{*}{$\begin{array}{l}9 / 8 \\
\text { groep } 2 \\
p \leq\end{array}$} \\
\hline & 88 & $8 \delta$ & $\mathrm{p} \leq$ & 89 & $8 \delta$ & $\mathrm{p} \leq$ & & \\
\hline patiënten & 2.1 & 1.7 & . & 1.4 & 1.6 & . & $*$ & . \\
\hline$\delta \delta$ artsen & 2.3 & 3.1 & ** & 2.5 & 3.0 & * & . & . \\
\hline verpleegkundigen & 1.9 & 1.8 & . & 1.6 & 1.9 & . & . & . \\
\hline fysiotherapeuten & 1.4 & 1.5 & . & 1.3 & 1.3 & . & . & . \\
\hline ণৃ & 3.3 & 2.2 & ** & 3.3 & 2.2 & $* * *$ & $* * *$ & $* * *$ \\
\hline overigen & 2.1 & 1.7 & $*$ & 2.1 & 2.0 & . & . & . \\
\hline
\end{tabular}

Gemiddelde scores en p-waarde sekseverschil (Mann Whitney test); range 1 - 4 (volledig oneens volledig eens); * $\mathrm{p} \leq 0.05^{* *} \mathrm{p} \leq 0.01{ }^{* * *} \mathrm{p} \leq 0.001$

Veranderen co-assistenten ten aanzien van identificatie gedurende de tijd?

Veranderen vrouwen anders dan mannen gedurende de tijd?

De totale groep co-assistenten blijkt zich in de loop van de tijd sterker met patiënten te gaan identificeren. Deze toename moet worden toegeschreven aan vrouwelijk coassistenten in de groep (zie tabel 10.3).

Vrouwelijke co-assistenten gaan zich verder in de loop van de tijd ook sterker met hun mannelijke artsen-opleiders identificeren. Deze verandering wordt niet bij mannelijke co-assistenten (op niveau van totale groep) gezien. Mannelijke co-assistenten gaan zich iets sterker met fysiotherapeuten identificeren, hetgeen met name toegeschreven moet worden an de gevorderde mannelijke co's in groep 2, die hun medische opleidingstudie aan het afronden zijn. 
Tabel 10.3 Identificatie, in de loop van de tijd.

\begin{tabular}{|c|c|c|c|c|c|c|c|c|c|c|c|c|}
\hline identificatie met. & tot. & ९ & రై & f. 0 & $9 \%$ & 80 & f. 1 & 89 & 80 & f. 2 & 89 & $8 \delta$ \\
\hline patiënten & $+*$ & $+4 *$ & . & $\cdot$ & . & . & $++^{*}$ & $+* *$ & . & . & . & \\
\hline $8 \delta$ artsen & . & $+*$ & . & $+*$ & . & . & . & & . & . & . & . \\
\hline verpleegk. & . & . & & . & . & . & . & . & . & . & . & \\
\hline fysiotherapeuten & . & . & $++^{*}$ & . & . & - & & . & . & , & $+*$ & \\
\hline 99 artsen & . & . & . & & . & , & . & . & . & . & . & . \\
\hline overigen & . & . & . & . & . & . & . & . & . & . & . & ... \\
\hline
\end{tabular}

p-waarden van significante verschuivingen in de tijd (Wilcoxon test)

${ }^{*} p \leq 0.05 ;{ }^{* *} p \leq 0.01 ;{ }^{* * *} p \leq 0.001$

Wanneer we de veranderingen in de onderscheiden fasen apart bezien blijkt dat in fase 0 de identificatie met mannelijke artsen een stijging vertoont en fase 1 een toename van de identificatie met de patiënt, hetgeen dan geldt voor het vrouwelijke deel van deze groep co-assistenten.

\section{Rolvoorbeelden}

Ervaren co-assistenten bun docenten in de medische opleiding of praktiserende artsenopleiders als rolvoorbeelden? Hebben ze behoefte aan voorbeelden?

Co-assistenten en preco-assistenten geven aan niet veel rolvoorbeelden aan te treffen (mean $1.7^{\text {) }}$. De verschillende subgroepen verschillen niet op dit punt.

Op de vraag of preco's en co-assistenten behoefte zouden hebben aan rolvoorbeelden, blijkt het gemiddeld antwoord van de totale groep een gematigd nee te zijn (gemiddelde score 2.0).

\section{Sekseverschil?}

Vrouwen en mannen verschillen niet ten aanzien van beide variabelen.

Kloof tussen bet bebben van rolvoorbeelden en behoefte hieraan.

In de totale groep blijkt de discrepantie tussen "behoefte" en het hebben van rolvoorbeelden significant, zowel voor vrouwen als voor mannen.

In groep 0 blijkt uitsluitend bij de vrouwen de kloof significant. Mannen hebben geen voorbeelden en hebben er ook geen behoefte aan; vrouwen hebben ook geen voorbeelden, maar geven aan wel behoefte aan rolvoorbeelden te hebben.

In de groep jongere co-assistenten, die minder ver in de opleiding gevorderd is, blijkt de kloof tussen het hebben en de behoefte groter te zijn dan in de groep verder-gevorderde, die geen rolvoorbeelden heeft en ze ook niet wenst.

Bij deze bevinding moet overigens een methodologische kanttekening worden geplaatst in verband met de validiteit van de vraag naar "voorbeelden willen" die voor respondenten onvoldoende duidelijk was geformuleerd in de vragenlijst.

'schaal: $1=$ weinig tot 4 - veel 
Verandert er in de tijd iets op dit punt?

Uit de data moet geconcludeerd worden dat er niets verandert in de loop van de tijd. Ook bij deze bevinding moet echter bovengenoemde methodologische kanttekening geplaatst te worden en bleek de beantwoording van de vraag naar "voorbeelden willen" een lage respons te vertonen in het longitudinale onderzoek.

\section{Sociale steun}

Krijgen co-assistenten veel steun uit hun persoonlijke omgeving in hun streven om dokter te worden, en bebben ze behoefte aan deze steun?

Co-assistenten verklaren wel degelijk steun uit de omgeving te krijgen (3.3) en hieraan ook behoefte te hebben. Verder blijkt aan deze behoefte voldaan te worden.

Er werd verder geen verschil gevonden (Kruskall-Wallis toets) tussen de subgroepen die in de verschillende ontwikkelingstadia verkeren.

\section{Zijn er significante verschillen tussen vrouwen en mannen?}

Uit de tabel 10.4 blijkt dat in groep 0, de preco-assistenten, geen significant vrouwIman verschil wordt aangetroffen, wel echter in de groep co-assistenten.

Tabel 10.4 Sekseverschillen sociale steun

\begin{tabular}{|c|c|c|c|c|c|c|c|c|}
\hline & \multicolumn{2}{|c|}{ groep 0} & \multirow{2}{*}{$\begin{array}{l}8.8 \\
p \leq\end{array}$} & \multicolumn{3}{|c|}{ totale groep co's } & \multirow{2}{*}{$\begin{array}{l}\text { p groep } 1 \\
\text { ps }\end{array}$} & \multirow{2}{*}{$\begin{array}{l}\text { p groep } 2 \\
p \leq\end{array}$} \\
\hline & 우우 & $8 \delta$ & & १Q & రठ & $\mathrm{p} \leq$ & & \\
\hline steun krijgen & 3.2 & 3.4 & . & 3.3 & 3.0 & ** & ** & . \\
\hline steun wensen & 3.1 & 3.1 & . & 3.2 & 2.8 & * & $*$ & . \\
\hline
\end{tabular}

Gemiddelde scores en significante p-waarde sekseverschil (Mann-Whitney); * $p \leq 0.05{ }^{* *} p \leq 0.01$ *** $\mathrm{p} \leq 0.001$; range 1.4 (volledig oneens - volledig eens).

Vrouwelijke co-assistenten ervaren significant sterker dat ze steun krijgen, dat ze stimulansen krijgen van vrienden, ouders en dergelijke en hieraan ook significant sterker behoefte hebben. Dit vrouw/man verschil ontbreekt in de groep preco-assistenten (groep 0) en gevorderde co-assistenten (groep 2) maar wordt wel aangetroffen in groep 1 , de beginnende co-assistenten.

Het verschil blijkt te zitten in de behoefte aan steun waarbij mannelijke beginnende co's minder behoefte aangegeven.

Zijn er veranderingen in de tijd, en veranderen mannen anders dan vrouwen?

Uit het longitudinaal onderzoek komen geen significante verschillen naar voren ten aanzien van "steun krijgen" en "steun wensen". Bij berekening van de delta-score (verschilscore tussen meting 1-meting 2) blijkt dat het veranderingsproces van vrouwelijke co-assistenten anders is dan dat van mannelijke. Mannelijke beginnende co-assistenten (groep 1) wensen namelijk meer steun in de loop van de tijd, terwijl vrouwelijke co's in deze groep nauwelijks veranderen in dit opzicht. (Bij "steun wensen" bestaat een significant sekseverschil, $\mathrm{p}=.008$ ). 


\section{Resultaten thema 2 "expliciet onderscheid naar sekse en gender-identiteit" Kwantitatieve gegevens}

Om zicht te krijgen op wat de nieuwelingen ervaren en waarnemen op de werkvloer van artsen op het terrein van expliciet onderscheid naar sekse is zowel kwalitatief als kwantitatief materiaal verzameld. Met name bij de kwestie "het al of niet ervaren van ongewenste intimiteiten" of het waarnemen van deze vorm van bejegening richting collega's of patiënten, is door middels open vragen nadere toelichting verkregen. Eerst zullen de kwantitatieve bevindingen gerapporteerd worden en daarna de antwoorden op de open vragen.

Hoe nemen co-assistenten en preco-assistenten de cultuur van de medische professie waar ten aanzien van expliciete aandacht voor sekse? In boeverre is men zich in deze context bewust van de eigen sekse?

Co-assistenten zijn zich enigszins bewust van de eigen sekse in de context van de klinische stages, ze percipiëren nauwelijks een erotisering van de atmosfeer of van de betrekkingen tussen vrouwen en mannen, ze nemen enigszins waar dat er een voorkeur voor mannen bestaat en percipiëren nauwelijks ongewenste intimiteiten richting collega's of patiënten noch geven ze aan zelf deze ervaringen te hebben. Wanneer men de scores ten aanzien van de 3 vragen over "ongewenste intimiteiten" met elkaar vergelijkt, blijken ongewenste intimiteiten richting collega's nog het meest te worden waargenomen.

Vergelijking van de 3 subgroepen laat zien dat deze groepen verschillen ten aanzien van "het zich bewust zijn van eigen sekse" (significant sterker bij co-assistenten dan preco's) en het percipiëren van ongewenst intimiteiten richting patiënten (significant minder waargenomen door gevorderde co-assistenten dan hun jongere collega's).

Tabel 10.5. Expliciet onderscheid naar sekse

\begin{tabular}{|c|c|c|c|c|c|}
\hline Variabele & $\begin{array}{l}\text { preco's } \\
\text { groep } 0\end{array}$ & $\begin{array}{l}\text { co-assistenten } \\
\text { totaal }\end{array}$ & groep 1 & groep 2 & $\begin{array}{l}\text { p-waarde } \\
\leq\end{array}$ \\
\hline bewustzijn van eigen sekse & 2.0 & 2.4 & 2.4 & 2.3 & $*$ \\
\hline erotisering & 1.5 & 1.6 & 1.7 & 1.5 & . \\
\hline voorkeur voor mannen & 2.8 & 2.5 & 2.6 & 2.4 & . \\
\hline ongewenste intimiteiten & 1.3 & 1.2 & 1.2 & 1.2 &. \\
\hline ongewenste intimiteiten collega & 1.3 & 1.5 & 1.5 & 1.4 & . \\
\hline ongewenste intimiteiten patiënt & 1.4 & 1.3 & 1.4 & 1.2 & * \\
\hline
\end{tabular}

Gemiddelde scores en significante groepsverschillen (Kruskall-W/llis toets).

range: 1 - helemaal niet; 4 - heel vaak. " $p \leq 0.05 ;{ }^{* *} p \leq 0.01 ;{ }^{* * *} p \leq 0.001$

\section{Verschillen vrouwelijke en mannelijke co-assistenten op deze punten?}

$\mathrm{Ja}$, er blijkt in de groep co-assistenten een significant sekseverschil te zijn ten aanzien van het herinnerd worden en zich bewust zijn van de eigen sekse.

In alle subgroepen blijkt dit verschil significant behalve bij de preco-assistenten, in de periode voor de klinische stages verkerend. Er blijkt hier sprake te zijn van een effect 
dat met name optreedt wanneer vrouwelijke nieuwelingen de praktijk van de medische beroepsuitoefening binnentreden.

Ook ten aanzien van de "perceptie van een mogelijke voorkeursbehandeling voor mannelijke aanstaande artsen" blijkt een significant man/vrouw verschil te bestaan, vrouwelijke co-assistenten en studenten nemen dit wel waar, hun mannelijke collega's significant minder; verder valt op dat hoe priller/jonger men is wat betreft opleidingsfase hoe sterker het $\mathrm{m} / \mathrm{v}$ verschil is.

Verder blijkt dat vrouwelijke co-assistenten significant meer ervaring hebben met een benadering die als ongewenst intiem wordt ervaren dan mannelijke co-assistenten (in bet transversale onderzoek).

Tabel 10.6 Sekseverschillen (expliciet onderscheid naar sekse en genderidentiteit).

\begin{tabular}{|c|c|c|c|c|c|c|c|c|c|c|c|c|}
\hline \multirow[b]{2}{*}{ variabele } & \multicolumn{3}{|c|}{$\begin{array}{l}\text { preco's } \\
\text { groep } 0\end{array}$} & \multicolumn{6}{|c|}{$\begin{array}{l}\text { co-assistenten } \\
\text { totale groep }\end{array}$} & \multicolumn{3}{|c|}{ groep 2} \\
\hline & 89 & $8 \delta$ & $p \leq$ & 89 & 80 & $\mathrm{p} \leq$ & 89 & $\delta 8$ & $\mathrm{p} \leq$ & 89 & $\delta \delta$ & $p \leq$ \\
\hline bewust van sekse & 2.0 & 1.8 & . & 2.7 & 2.0 & $* * *$ & 2.9 & 1.9 & *4* & 2.5 & 2.0 & $*$ \\
\hline erotisering & 1.5 & 1.5 & . & 1.5 & 1.7 & . & 1.6 & 1.7 & . & 1.5 & 1.6 & . \\
\hline voork. voor mannen & 2.9 & 2.5 & $*$ & 2.7 & 2.3 & $*$ & 2.9 & 2.4 & ** & 2.4 & 2.3 & . \\
\hline ongewenste intim. & 1.3 & 1.2 & . & 1.3 & 1.1 & $* *$ & 1.3 & 1.1 & $* *$ & 1.2 & 1.1 & . \\
\hline ongew intim. collega & 1.3 & 1.2 & . & 1.5 & 1.5 & . & 1.1 & 1.6 & . & 1.5 & 1.4 & . \\
\hline ongew.intim. patiènt & 1.4 & 1,4 & . & 1.2 & 1.3 & . & 1.3 & 1.4 & . & 1.1 & 1.3 & . \\
\hline
\end{tabular}

Gemiddelde scores en signiticante verschillien tussen de seḱsen (getoetst met Mann-Whitney) score range: 1 - helemaal niet; 4 - heel vaak.

${ }^{*} \mathrm{p} \leq 0.05 ;{ }^{* *} \mathrm{p} \leq 0.01 ;{ }^{* * *} \mathrm{p} \leq 0.001$

Vergelijken we het man/vrouw verschil in de (sub)groepen dan blijkt het sekseverschil op twee van de drie thema's verdwenen te zijn, bij de beginnende co-assistenten in vergelijking met de gevorderde co-assistenten. Concreet blijken vrouwen in de groep beginnende co-assistenten een hogere score te vertonen op de variabele "ervaren van ongewenste intimiteiten" en nemen zij wel een voorkeursbehandeling voor mannen waar, maar is dit niet meer het geval in de groep gevorderde co-assistenten.

Wel blijken vrouwen zowel in de groep gevorderde co-assistenten als in de groep van de beginners zich meer bewust van hun sekse dan mannen.

Veranderen co-assistenten in de tijd? Veranderen mannen anders dan vrouwen?

Wanneer we de veranderingen in de tijd bij de totale groep beschouwen zien we een significante toename van het "bewustzijn van de eigen sekse" en wel specifiek bij de vrouwelijke co-assistenten.

Verder valt op dat de perceptie van erotisering in de atmosfeer toeneemt bij de gehele groep co's, maar met name bij de vrouwelijke co-assistenten.

De perceptie dat er in de medische professie een voorkeur voor mannen bestaat blijkt in het jaar van observatie af te nemen, zowel bij vrouwelijke als mannelijke co-assistenten.

Ten aanzien van de "perceptie van ongewenste intimiteiten" blijkt er in de totale groep geen significante verandering op te treden. Daarentegen is dit wel het geval ten aanzien van het "waarnemen van een mogelijke voorkeursbehandeling voor mannelij- 
ke co's of artsen". Op dit punt blijken zowel vrouwelijke als mannelijke co-assistenten een significante afname te vertonen. Gaf men bij de eerste meting aan mogelijk nog enige voorkeursbehandeling voor mannen waar te nemen (score 2,5), bij de tweede meting blijkt iedereen dit minder of niet meer waar te nemen. Deze significante afname tekent zich af bij alle subgroepen.

Tabel 10.7 Veranderingen in de loop van de tijd?

\begin{tabular}{|c|c|c|c|c|c|c|c|c|c|c|c|c|}
\hline variabele & tot & 89 & 80 & fase 0 & 89 & 80 & fase 1 & 89 & ठठ & fase 2 & 88 & ชే \\
\hline bewust van sekse & $+*$ & $+*$ & . & $+* *$ & $+* *$ & . & . & . & . & . & . & . \\
\hline erotisering & $+* *$ & $+*$ & . & . & . & $+*$ & . & . & . & . & . & . \\
\hline voorkeur $\delta 8$ & $* * *$ & $* * *$ & $* * *$ & *** & $* *$ & $* *$ & $+* *$ & $* *$ & $* * *$ & $+* *$ & $\cdots *$ & $* *$ \\
\hline ongewenste int. & $\cdot$ & . & . & . & . & . & $\cdot$ & . & . & $+*$ & $+*$ & , \\
\hline ongew.intim.collega & . & . & . & . & . & . & $+*$ & $+*$ & . & . & . & . \\
\hline ongew.intim.patiënt & . & . & . & . & . & . & . &. & . & . & . & . \\
\hline
\end{tabular}

significante verschillen in de loop van de tijd getoetst met Wilcoxon.

* $\mathrm{p} \leq 0.05 ;{ }^{* *} \mathrm{p} \leq 0.01 ;{ }^{* * *} \mathrm{p} \leq 0.001$

De fasen apart beschouwend, valt op dat entree in de medische beroepswereld met name voor vrouwelijke co-assistenten een significante toename van hun besef van vrouw zijn oplevert. Mannelijke co's in groep 0 laten een dergelijke toename van hun besef van eigen sekse niet zien. Verder valt op dat de mannelijke co's in fase 0 sterker een bepaalde mate van erotisering gaan waarnemen percipiëren in de klnische setting. De perceptie dat in de geneeskunde mogelijk een voorkeur voor mannelijke artsen zou bestaan, vertoont bij alle subgroepen een significante daling, co-assistenten in alle fasen gaan dit minder zien.

Verder geven vrouwelijke co-assistenten in fase 2 een stijging aan in de ervaringen van ongewenste intimiteiten die zij ervaren en geven vrouwelijke co-assistenten in fase 1 aan dat ze meer ongewenste intimiteiten richting collegae zien. Ongewenst intimiteiten richting patiënt worden niet gezien en dit verandert niet in de tijd.

\section{Kwalitatieve gegevens over het voorkomen van ongewenste intimiteiten}

\section{Hebben co-assistenten zelf ervaring met ongewenste intimiteiten?}

$\mathrm{Ja}$, het blijkt dat $6 \%$ en bij de tweede meting $14 \%$ van de ondervraagde vrouwelijke co-assistenten aangeeft bepaalde zaken als ongewenst intiem te hebben ervaren. Bij de eerste meting gaven zes vrouwen $(6 \%)$ aan zelf ervaring te hebben met intimiteiten, die als ongewenst werden ervaren. Er werd enkele keren melding gemaakt van onnodige aanrakingen en aanrakingen langer dan noodzakelijk. De mannelijke co-assistenten rapporteerden geen eigen ervaringen op dit vlak.

Bij de tweede meting vermeldden 11 vrouwelijke respondenten (14\%) van de vrouwelijke populatie eigen ervaringen op het vlak van ongewenste intimiteiten. Ook 2 mannen maakten bij de tweede meting melding van ongewenste intimiteiten. 
Ziet men ongewenste intimiteiten ten opzichte van collega's ?

Het antwoord luidt bevestigend, dertien vrouwelijke co-assistenten (12\%) en 12 mannelijke (15\%) rapporteerden bij de eerste meting dat ze getuige waren van ongewenste intimiteiten richting collega's.

Bij de tweede meting gaven 14 vrouwelijke (18\%) en 12 mannelijke $(22 \%)$ co-assistenten aan gehoord te hebben van ongewenste intimiteiten t.o.v. collega-studenten.

Zowel mannelijke als vrouwelijke co's noemden iets vaker anrakingen dan seksistische opmerkingen. In de voorbeelden die mannen geven, komt vaker het woord"seks..." voor dan in de voorbeelden van de vrouwelijke co's.

Opmerkelijk is dat, zonder dat er expliciet naar gevraagd is, drie keer melding werd gemaakt van ongewenste intimiteiten door patiënten ten opzichte van collega-co-assistenten. Het blijken alleen mannelijke co-assistenten, die hier melding van maken.

\section{Ziet men ongewenste intimiteiten ten opzichte van patiënten?}

Dit blijkt weinig voor te komen. Bij de eerste meting vermeldden vijf mannelijke coassistenten en twee vrouwelijke co-assistenten ongewenste intimiteiten ten opzichte van patiënten, vooral in de vorm van "onnodig" medisch onderzoek.

Eén mannelijke en één vrouwelijke co-assistent beschreven hun indruk dat artsen/opleiders een zekere voorkeur lijken te hebben voor bepaalde patiënten.

Ook medische handelingen kunnen bij co-assistenten de indruk wekken grenzen van het gepaste of gewenste te passeren. Een vrouwelijike co-assistent noteerde:

"slipje omlaag houden (voorbij haargrens) voor opwekken buikbuidreflex ....ik zou dat als ongewenst ervaren, maar betrokken patiënte koppelde dat niet zo terug."

Bij de tweede meting vermeldden negen vrouwelijke en twee mannelijke co-assistenten gehoord te hebben van ongewenste intimiteiten ten opzichte van patiënten.

\subsection{Samenvatting resultaten (zelf) evaluatie}

Co-assistenten identificeren zich vooral met artsen en hoe priller in het opleidingstraject, hoe sterker de identificatie met de patiënt is.

Co-assistenten ervaren hun docenten in de medische opleiding nauwelijks als voorbeelden, noch die uit de universitaire context noch die uit de medische praktijk, maar ze geven ook aan weinig behoefte te hebben aan rolvoorbeelden. Hierbij moet echter de methodologische kanttekening worden gemaakt dat de beantwoording van de vraag naar behoefte aan voorbeelden ("voorbeelden willen") minder betrouwbaar is.

Co-assistenten blijken sociale steun uit hun sociale omgeving zeker te wensen en te apprecieren en ze ontvangen deze steun ook in voldoende mate.

Co-assistenten nemen nauwelijks een erotiserende atmosfeer waar in de contekst van de co-assistentschappen en ze ervaren nauwelijks ongewenste intimiteiten. Wel nemen co-assistenten enige mate van voorkeursbehandeling waar voor mannelijke aanstaande artsen in de geneeskunde. De kwalitatieve gegevens over de ervaringen met ongewenste intimiteiten in de medische setting, geven een minder positieve indruk. Hierin beschrijven co-assistenten verschillende incidenten, uitingen en voorvallen zowel richting vrouwelijke co-assistenten als richting vrouwelijke patiënten. Vrouwelijke co- 
assistenten rapporteren in beide metingen meer ervaringen op dit terrein dan hun mannelijke collega's. De gerapporteerde avances zijn van het bekende heteroseksuele patroon (man richting vrouw).

\section{Focus op sekse verschil}

Er is sprake van een sekseverschil in het proces van identificatie. Vrouwelijke co-assistenten identificeren zich sterker met vrouwelijke artsen en met patiënten (met name vrouwelijke beginners in groep 1) dan de andere sekse. Mannelijke co-assistenten identificeren zich meer met mannelijke artsen dan hun vrouwelijke collega's.

De seksen verschillen enigszins ten aanzien van het belang dat zij hechten aan rolvoorbeelden. De discrepantie tussen behoefte aan rolvoorbeelden en de realiteit in de opleiding is bij vrouwen iets groter dan bij mannen en hangt samen met een grotere behoefte aan rolvoorbeelden van vrouwen.

Ook het ontvangen van sociale steun uit de omgeving blijkt voor de seksen significant te verschillen: vrouwelijke co-assistenten krijgen meer steun en wensen significant meer steun. Opmerkelijk is dat dit sekseverschil wel aanwezig is bij de co-assistenten in de groep 1 (beginners) maar niet bij gevorderde co-assistenten in groep 2.

Verder blijkt dat vrouwelijke co-assistenten significant sterker worden herinnerd aan hun sekse en zij zich hier duidelijker van bewust zijn, terwijl dit voor mannelijke coassistenten nauwelijks speelt. Ervaringen van ongewenste intimiteiten komen bij vrouwen significant meer voor. Ook geldt dat vrouwelijke co-assistenten sterker een voorkeur voor mannen waarnemen dan hun mannelijke collega's. Binnen dit thema valt op dat in de "jongere" groepen als groep 0 en 1 vrouwen vaker van hun mannelijke collega's verschillen dan in de "oudere" en meer gevorderde groep (groep 2).

\section{Focus op verandering in de tijd}

De longitudinale veranderingen in identificatie laten zien dat de identificatie met de patiënten niet afneemt, maar juist toeneemt en dat deze stijging toegeschreven moet worden aan vrouwelijk co-assistenten.

Verder blijken vrouwelijke novieten in fase 0 ook nog in een tweede opzicht te veranderen. $\mathrm{Zij}$ identificeren zich toenemend met mannelijke artsen terwijl mannelijke novieten geen significant verandering op dit punt laten zien. Mannelijk gevorderde coassistenten aan het einde van de studie, blijken zich wel meer met fysiotherapeuten te gaan identificeren.

Zeer opmerkelijk is de toename van het bewustzijn van eigen sekse bij vrouwelijke co-assistenten in fase 0 , wanneer ze het praktijkveld van het medisch beroep betreden. Voor mannelijke co-assistenten kan een dergelijke overgang niet geconstateerd worden.

De perceptie van erotisering neemt toe voor de totale groep co-assistenten, hetgeen met name voor rekening komt van het vrouwelijk deel van deze populatie. De perceptie van voorkeur voor mannelijke artsen blijkt niet de verwachte toename te vertonen maar een significante afname. Deze afname wordt bij beide seksen en in alle fasen aangetroffen. 
Samengevat luidt het antwoord op de vraag "veranderen vrouwelijke co-assistenten anders dan mannelijke co-assistenten" als volgt:

- vrouwelijke co-assistenten gaan zich sterker identificeren met patiënten in de loop van hun co-assistentschappen (alle fasen en fase 1).

- vrouwelijke co-assistenten gaan zich, bij entree in de co-assistentschappen, iets meer identificeren met mannelijke artsen (fase 0 ).

- mannelijke co-assistenten gaan meer steun wensen in de loop van de tijd (fase 1).

- het bewustzijn van sekse neemt bij vrouwelijke co-assistenten wel toe bij het begin van de co-assistentschappen en bij mannen niet.

- vrouwelijke co-assistenten nemen erotisering van de atmosfeer in de klinische setting meer waar dan mannen.

\subsection{Resultaten transversaal en longitudinaal onderzoek naar professioneel zelfvertrouwen}

Om een beeld te krijgen van het zelfvertrouwen en gevoel van competentie en "mastery" onder co-assistenten hebben de respondenten vragen beantwoord met betrekking tot mate van subjectief zelfvertrouwen (selfesteem) en gevoel van twijfel over eigen competentie en de mate waarin zij het gevoel hadden dat anderen aan hun competentie twijfelen.

\section{Ervaren co-assistenten een gevoel van zelfvertrouwen en competentie?}

Verschillen de subgroepen in dit opzicht?

Co-assistenten hebben overwegend een positief beeld van zichzelf en zeker geen negatief zelfbeeld of gebrek aan zelfvertrouwen (zie tabel 10.8). Hoewel de studenten en co-assistenten zeker van zichzelf zijn, is er wel enige (subjectieve) twijfel over hun competentie.

Op het punt van de toegeschreven competentie kennen zij nauwelijks twijfel en ze hebben het gevoel als co-assistent te kunnen voldoen aan de verwachtingen van de patiënt.

Tabel 10.8 Zelfvertrouwen en gevoel van competentie

\begin{tabular}{lllll}
\hline & groep 0 & groep 1 & groep 2 & (K-W) \\
\hline positief zelfbeeld & 3.2 & 3.1 & 3.3 & $*$ \\
negatief zelfbeeld & 1.9 & 2.0 & 1.9 & $*$ \\
twijfel aan eigen competentie & 2.5 & 2.3 & 2.2 & $*$ \\
twijfel over toegeschreven competentie & 1.6 & 1.5 & 1.6 & ** \\
patiënt verwachtingen & -1 & 2.7 & 3.0 & $*$.
\end{tabular}

Gemiddelde scores totale groep co-assistenten en subgroepen, verschil getoetst met Kruskal-W/llis Ranges 1 . 4 (volledig oneens/helemaal niet - volledig eens/heel goed).

${ }^{*} \mathrm{p} \leq 0.05 ;{ }^{* *} \mathrm{p} \leq 0.01 ;{ }^{* * *} \mathrm{p} \leq 0.001$

1 dene vras is nier peateld an precor

Bij vergelijking van de subgroepen blijken deze op twee variabelen significante verschillen te vertonen namelijk ten aanzien van het subjectief gevoel van competentie en het gevoelen te kunnen voldoen aan patiënt-verwachtingen. Pre-co's bleken significant 
meer twijfel over eigen competentie te kennen dan de beginnende of gevorderde co's ( $p \leq 0.05$ Kruskall-Wallis toets).

Het gevoel iets te kunnen betekenen voor de patiënt, hetgeen beschouwd kan worden als een parameter van "mastery", is significant sterker bij de gevorderden. Wat betreft positief en negatief zelfbeeld en toegeschreven competentie komen geen verschillen tussen de verschillende subgroepen naar voren.

Zijn er significante sekseverschillen bij co-assistenten in bet transversaal onderzoek ?

Nee. Met behulp van de Mann-Whitney-U-toets voor non-parametrische variabelen zijn er geen significante verschillen aangetoond tussen vrouwelijke en mannelijke coassistenten.

Hoe veranderen co-assistenten in de tijd ?

We kunnen constateren dat het negatieve zelfbeeld van co-assistenten afneemt en dat het positieve zelfbeeld in de tijd constant blijft, wanneer we ons beperken tot het niveau van de totale groep co-assistenten.

Wanneer we de vrouwelijke en mannelijke co's separaat bekijken, blijken beide subgroepen minder te gaan twijfelen aan hun eigen competentie in de loop van de coassistentschappen. In tabel 10.9 staan de significante toenames en afnames van de scores in de tijd aangegeven.

Tabel 10.9 Zelfvertrouwen en gevoel van competentie

\begin{tabular}{|c|c|c|c|c|c|c|c|c|c|c|c|c|}
\hline & tot. & $\$ ?$ & $80^{\circ}$ & 0 & $9 \%$ & $8 \delta$ & 1 & $\$ \%$ & 88 & 2 & 98 & $8 \delta$ \\
\hline positief zelfbeeld & . & . & . & . & . & . & . & . & . & . & . & \\
\hline negatief zelfbeeld & $\therefore$ & . & . & . & . & . & * & * & . & . & . & * \\
\hline twiffel competentie & $*$ & ** & . & $+* *$ & & $+*$ & . & . & & . & . & .. \\
\hline twiffel toegeschr. comp. & . & . & . & . & . & . & . & . & . & . & . & . \\
\hline patiênt verwachtingen & . & . & . & . & . & . & . & . & . & . & . & . \\
\hline
\end{tabular}

significante verschillen in de loop van de tijd (getoetst met Wilcoxon); - afname + toename * $\mathrm{p} \leq 0.05 ;{ }^{* *} \mathrm{p} \leq 0.01 ;{ }^{* * *} \mathrm{p} \leq 0.001 \mathrm{t}=$ totaal

Wanneer we de veranderingen in de verschillende fasen bestuderen dan zien we in fase $O$ bij het starten met de co-assistentschappen een significante toename van de twijfel aan eigen competentie optreden, zowel bij vrouwelijke als mannelijke novieten. In fase 1 van de co-assistentschappen blijkt het negatieve zelfbeeld te verminderen, met name bij de vrouwelijke co-assistenten.

Op het vlak van positief zelfbeeld, toegeschreven competentie en het gevoel te kunnen voldoen aan verwachtingen van de patiënt treden in de onderscheiden fasen geen veranderingen op.

Uit deze longitudinale bevindingen kan geconcludeerd worden dat het gevoel van competentie van vrouwelijke co-assistenten iets meer fluctuatie kent dan dat van hun mannelijke collega's. 


\subsection{Samenvatting resultaten van professioneel zelfvertrouwen}

Co-assistenten blijken gemiddeld een positief zelfbeeld te hebben en geen twijfel over of ze wel serieus worden genomen in hun rol. Ook hebben ze het gevoel redelijk aan de verwachtingen van de patiënt te kunnen voldoen, zeker geldt dit voor de meer gevorderde co-assistenten.

Het veronderstelde sekseverschil aangaande de vraag of vrouwelijke co-assistenten zich mogelijk minder serieus genomen voelen door hun omgeving in hun rol als aanstaand arts, wordt niet aangetroffen.

De ontwikkeling van het zelfvertrouwen in de loop van de tijd is gunstig. Het negatieve zelfbeeld van co-asssistenten neemt in de loop van de tijd af en het positieve zelfbeeld blijft constant in de tijd, dus de conclusie kan zijn dat het zelfvertrouwen als aanstaand arts groeit, zowel bij vrouwen als bij mannen.

Ook het subjectief gevoel van competentie blijkt verandering in de tijd te vertonen in die zin dat de twijfel bij het begin van de co-assistentschappen toeneemt. In het begin van de stages lijken co-assistenten enige onzekerheid en twijfel aan de eigen bekwaam. heid te kennen. Later neemt dit gevoel van competentie weer toe.

Verder is opmerkelijk dat bij vrouwelijke co-assistenten de parameters van professioneel zelfvertrouwen meer fluctuatie in de loop van de tijd vertonen dan bij mannen.

\subsection{Resultaten transversaal en longitudinaal onderzoek naar aspecten van professionele identiteit}

$\mathrm{Nu}$ zullen een aantal aspecten van de professionele identiteit worden gerapporteerd die werden bestudeerd als thema 4 "ideaalbeeld-zelfbeeld", thema 5 "beroepsoriëntatie" en thema 6 "loopbaanoriëntatie". Het ideaalbeeld in relatie tot het zelfbeeld gedefinieerd als meer of minder mannelijk of instrumenteel respectievelijk vrouwelijk of expressief ingekleurd komt aan de orde. De oriëntatie op het medisch beroep is een ander aspect van professionele identiteit evenals die oriëntatie van co-assistenten op hun loopbaan. Welke rol en betekenis hechten ze aan status en maatschappelijke erkenning, aan het werken in loondienst, als solist of als vrije ondernemer; hoeveel waarde wordt gehecht aan de relationele component in het werken als arts zowel in de collegiale verhoudingen als in de interactie met patiënten. De oriëntatie op de loopbaan is bestudeerd door in te gaan op de mate waarin co-assistenten al bezig zijn met gedachtevorming en planning van hun loopbaan. Verder hebben we de locus of control ten aanzien van de loopbaanplannen bestudeerd, het attributiepatroon van coassistenten over het welslagen van hun loopbaanplannen.

\section{Resultaten thema 4 "Ideaalbeeld/zelfbeeld"}

Hoe beschrijven co-assistenten de ideale arts en hoe verhoudt dit zich tot bun zelfconcept? Uit tabel $10.10 \mathrm{kan}$ men aflezen in welke mate in de ogen van co-assistenten en precoassistenten de ideale arts bekleed is met eigenschappen, die overeenkomst vertonen met het vrouwelijke of het mannelijke prototype. 
Tabel 10.10 Ideaalbeeld en zelfbeeld (BEM sex-role Inventory)

\begin{tabular}{lllll}
\hline & $\begin{array}{l}\text { preco's } \\
\text { groep 0 }\end{array}$ & $\begin{array}{l}\text { co-assistenten } \\
\text { groep 1 }\end{array}$ & groep 2 & p-waarde \\
\hline vrouwelijk ideaalbeeld & 2.8 & 2.8 & 2.8 &. \\
vrouwelijk zelfbeeld & 2.9 & 2.8 & 2.9 & i* \\
mannelijk ideaalbeeld & 3.0 & 2.9 & 2.8 & . \\
mannelijk zelfbeeld & 2.6 & 2.7 & 2.5 &
\end{tabular}

range 1-4 (volledig oneens/helemaal niet - volledig eens/niet goed)

$* \mathrm{p} \leq .01$

Het concept van de ideale dokter bevat voor co-assistenten zowel vrouwelijke als mannelijke eigenschappen. Het ideaalbeeld is iets sterker mannelijk gekleurd dan vrouwelijk.

Het zelfbeeld van co-assistenten is vrouwelijk en in mindere mate ook mannelijk. Wanneer de scores van de subgroepen worden getoetst op onderlinge verschillen blijkt de jongste groep, de preco-assistenten, een significant mannelijker beeld van de ideale dokter te hebben dan de co-assistenten, met name anders dan de gevorderde coassistenten.

Zijn er sekseverschillen in opvattingen over de ideale dokter en bet zelfconcept ? Vrouwelijke en mannelijke co-assistenten stemmen overeen in de opvatting dat de ideale arts enigszins vrouwelijke maar zeker mannelijke eigenschappen moet bezitten. Er blijkt geen sprake van sekseverschil in ideaalbeeld, maar wel in zelfbeeld. Bij de variabele "vrouwelijk zelfbeeld" wordt een significant sekseverschil gevonden in de totale groep en in de groep beginnende co-assistenten (groep 1) in die zin dat vrouwen zich significant sterker in vrouwelijke of expressieve eigenschappen herkennen dan hun mannelijke collega's ( $p \leq .01)$. Dit sekseverschil is niet meer aanwezig is bij de gevorderde co-assistenten. Vrouwen verschillen niet ten aanzien van het mannelijk zelfbeeld.

Discrepantie tussen ideaal en zelfbeeld

Omdat socialisatie inhoudt dat de relatie tussen ideaal en zelf verandert, is de discrepantie tussen zelf-en ideaalbeeld voor de totale groep als ook voor de diverse subgroepen co-assistenten onderzocht. Aannemelijk is dat de discrepantie tussen ideaalbeeld en de eigenschappen die men zichzelf toeschrijft significant is. Het is dus opmerkelijk als dit niet het geval is.

Bestaat er een discrepantie tussen ideaal en zelfconcept bij inkleuring conform bet mannelijke of vrowwelijke prototype? Is er een sekseverschil ?

Bij de totale groep co-assistenten blijkt er een discrepantie tussen ideaal en zelfbeeld te bestaan op de dimensie expressieve of vrouwelijke dimensie als ook op de instrumentele of mannelijke dimensie. Wanneer men de subgroepen van vrouwelijke en mannelijke co-assistenten apart bestudeert, blijkt bij dat mannelijke co-assistenten de discrepantie tussen ideaal en zelfconcept ontbreekt op de vrouwelijke dimensie. Bij vrouwe- 
lijke co-assistenten is discrepantie tussen ideaal en zelfconcept op dit punt wel signifcant.

Tabel 10.11 Sekseverschillen in discrepantic idealbeeld en zelfconcept

sekseverschil totale groep

p-warde (Mann-Whitney)

discrepantie vrouwelijke aspecten $.002^{* *}$

discrepantie mannelijke aspecten

n.s

Hoe veranderen co-assistenten in de tijd en veranderen vrowwen anders dan mannen? Het blijkt dat het ideaalbeeld apart en het zelfbeeld apart noch op de vrouwelijke dimensie noch op de mannelijke dimensie een verandering vertonen in de loop van de co-assistentschappen. De discrepantie tussen beide blijkt wel enige verschuiving in de tijd te vertonen (zie tabel 10.12).

Tabel 10.12 Discrepantie ideaalbeeld/zelfbeeld op dimensie vrouwelijk en mannelijk, p-waarden

\begin{tabular}{lllllllllllll} 
dimensie: & tot & 98 & $\delta 8$ & fase 0 & 98 & $\delta 8$ & fase 1 & 99 & $\delta 8$ & fase 2 & $9 \%$ & $\delta 8$ \\
\hline $\begin{array}{l}\text { vrouwelijk } \\
\text { mannelijk }\end{array}$ & $* * *$ & $* * *$ & $* * *$ & $* * *$ & $* *$ & $* * *$ & $* * *$ & $* *$ & $* * *$ & $* * *$ & $* * *$ & $*$ \\
\hline
\end{tabular}

* $p \leq .05 * P \leq .01 * * p \leq .001$; (Wilcoxon) twee groepen.

Op de dimensie mannelijke eigenschappen blijken de totale groep co-assistenten en de groepen in de verschillende fasen allen een significante verschuiving door te maken. Op de dimensie vrouwelijke eigenschappen blijken vrouwen wel te veranderen (totale groep en groep 0 en 2), maar blijken de mannelijke co-assistenten niet te veranderen, noch op niveau van de totale groep noch in een van de onderscheiden fasen.

Met andere woorden, de kloof tussen mannelijke gekleurd ideaalconcept en zelfconcept vertoont een verschuiving in de tijd in alle fasen en bij beide seksen en de kloof tussen vrouwelijk gekleurd ideaal en zelfconcept verschuift wel bij vrouwelijke co-assistenten en met name bij vrouwelijke afstuderende co-assistenten, maar niet bij mannelijke co-assistenten.

Verder verrassen mannelijke co-assistenten in fase 2 door noch op de vrouwelijke noch op de mannelijke dimensie enige verschuiving te vertonen.

\section{Resultaten thema 5 Beroepsoriëntatie}

Welke opvattingen leven onder co-assistenten en preco-assistenten aangaande beroepsinhoud en inrichting?

Zowel co-assistenten als preco-assistenten blijken de relationele component van de medische beroepsrol zeer belangrijk te vinden. Ze hechten allen aan goede collegiale verhoudingen en goed contact met patiënten.

De maatschappelijke status, die samenhangt met het bekleden van het beroep van arts en de maatschappelijke erkenning, het inkomen en carrière-mogelijkheden worden door co-assistenten als matig belangrijk opgevat. Op dit punt blijkt bij toetsing een 
verschil tussen de subgroepen te bestaan; de beginnende co-assistenten blijken namelijk significant meer waarde hieraan te hechten dan de gevorderde co-assistenten ( $2.2 v s$ 2.5). Dit verschil is significant $(p=0.006)$.

De vraag of de co-assistenten liever in loondienst wilden werken en niet als solist, liet een indifferent antwoord zien (score 2.5). De vraag of de nieuwelingen zich al enigszins opgenomen voelen in de beroepsgroep, werd met een voorzichtig ja beantwoord. In tabel 10.13 zijn de resultaten weergegeven van de preco-assistenten (vierdejaars studenten) en de co-assistenten, opgesplitst in 2 subgroepen.

Tabel 10.13 Beroepsbeeld

\begin{tabular}{lllll}
\hline & preco's & \multicolumn{2}{l}{ co-assistenten } & P-waarde \\
& groep 0 & groep 1 & groep 2 & \\
\hline erkenning & 2.3 & 2.5 & 2.2 & $*$ ** \\
loondienst & 2.5 & 2.4 & 2.5 &. \\
contact & 3.8 & 3.8 & 3.8 &. \\
erbij horen & 2.8 & 3.1 & 3.0 & . \\
\hline
\end{tabular}

gemiddelde scores van de preco's, totale groep co-assistenten, de beginners en de gevorderden en pwarde Kruskall-Wallis toets; Range 1 onbelangrijk- 4 heel belangrijk; ** $p \leq 0.01$.

\section{Verschillen mannelijke en vrouwelijke co-assistenten van elkaar?}

Wanneer we de aandacht richten op verschillen tussen vrouwen en mannen blijkt dat ten aanzien van het belang dat gehecht wordt aan maatschappelijke erkenning, inkomen en carrière een duidelijk vrouw/man verschil in de totale groep co-assistenten bestaat (zie tabel 10.14). Daarnaast bestaat er een significant sekseverschil ten aanzien van de voorkeur voor het werken in loondienst en in teamverband. Mannelijke coassistenten geven duidelijker aan hier geen voorkeur voor te hebben. De vrouwen geven een indifferent antwoord, ze zeggen eigenlijk "ik weet het niet zo goed".

Tabel 10.14 Sekseverschillen in beroepsoriëntatie

\begin{tabular}{|c|c|c|c|c|c|c|c|c|c|c|c|c|}
\hline & \multicolumn{3}{|c|}{ preco-assistenten } & \multicolumn{9}{|c|}{ co-assistenten } \\
\hline & \multicolumn{3}{|c|}{ groep 0} & \multicolumn{3}{|c|}{ totaal } & \multicolumn{3}{|c|}{ groep 1} & \multicolumn{3}{|c|}{ groep 2} \\
\hline & \$? & $\delta \delta$ & $\mathrm{p}$ & 99 & 88 & $\mathrm{p}$ & $\$ 9$ & 88 & p & $\$ 8$ & 88 & P \\
\hline erkenning & 2.2 & 2.6 & ** & 2.3 & 2.5 & ** & 2.4 & 2.6 & $*$ & 2.2 & 2.3 & . \\
\hline loondienst & 2.6 & 2.3 & . & 2.6 & 2.3 & $*$ & 2.5 & 2.3 & . & 2.6 & 2.4 & . \\
\hline contact & 3.8 & 3.8 & . & 3.9 & 3.7 & . & 3.8 & 3.9 & . & 3.8 & 3.8 & . \\
\hline erbij horen & 2.7 & 3.0 & $*$ & 3.1 & 3.1 & . & 3.1 & 3.2 & . & 3.0 & 2.9 & . \\
\hline
\end{tabular}

gemiddelde scores mannen en vrouwen in groep 0 , in totale groep co-assistenten, in groep beginners en groep gevorderden; verschillen getoetst met Mann-Whitney; * $p \leq 0.05$ ** $p \leq 0.01$.

Range 1-4 (onbelangrijk/volledig oneens- heel belangrijk/volledig eens). 


\section{De subgroepen nader beschouwd}

Het valt op dat het aantal variabelen van beroepsoriëntatie waarop sekseverschillen worden gevonden afneemt van pril naar meer gevorderd (zie tabel 10.14). In groep 0 , nog niet begonnen met de co-assistentschapppen, ziet men een significant sekseverschil op de variabele "erkenning" en gevoel van "erbij horen". Mannelijke precoassistenten geven aan meer te hechten aan vormen van (maatschappelijke) erkenning en status en ze hebben sterker een gevoel bij de medische professie te horen dan vrouwen in deze groep. In groep 1 (de beginners) bestaat het sekseverschil ten aanzien van het belang dat de seksen hechten aan maatschappelijk erkenning nog. In groep 2 , gevorderden zijn er geen verschillen meer tussen de seksen op deze punten.

Het belang van goede relationele verhoudingen met collega's en patiënten ("contact") wordt door zowel mannelijke als vrouwelijke co-assistenten hoog geacht.

\section{Veranderen co-assistenten gedurende de tijd?}

De totale groep co-assistenten vertoont geen significante veranderingen in de tijd op de variabelen, die het belang van status en maatschappelijke erkenning, een eventuele voorkeur voor loondienst en teamwork, het belang van de relationele component en het gevoel van "bij de medische stand te horen" betreffen. Wanneer we echter de veranderingen in de onderscheiden fasen bezien, blijkt er toch sprake van verandering in de loop van de tijd.

Tabel 10.15 Veranderingen in de beroepsoriëntatie in de loop van de tijd

\begin{tabular}{|c|c|c|c|c|c|c|c|c|c|c|c|c|}
\hline & \multicolumn{3}{|c|}{ preco-assistenten } & \multicolumn{9}{|c|}{ co-assistenten } \\
\hline & totaal & 98 & 80 & fase 0 & $9 \%$ & $\delta 8$ & fase 1 & 89 & 80 & fase 2 & ९q & $80^{\circ}$ \\
\hline erkenning & . & . & . & . & . & *** & . & . & . & . & . & . \\
\hline loondienst & . & . & . & . & . & . & $+* *$ & . & $+* *$ & . & . & . \\
\hline contact & . & . & . & . & . & . & . & . & . & . & . & . \\
\hline erbij & . & . & . & $+* *$ & $+*$ & &.$*$ & . &.$*$ & $+*$ & . & . \\
\hline
\end{tabular}

significante verschillen in de loop van de tijd getoetst met Wilcoxon

${ }^{*} \mathrm{p} \leq 0.05 ;{ }^{* *} \mathrm{p} \leq 0.01 ;{ }^{* * *} \mathrm{p} \leq 0.001$

De fasen nader beschouwd

In fase 0 zien we dat mannelijke co-assistenten status, maatschappelijke erkenning en inkomen minder belangrijk gaan vinden. Verder valt in fase 0 een significante toename van het gevoel van "bij de medische beroepsgroep te horen" bij vrouwelijke novieten op.

In fase 1 treedt een andere verandering op. Mannelijke co-assistenten geven blijk van een toenemende voorkeur voor loondienst en teamwork. Verder blijken mannelijke co-assistenten in fase 1 , in tegenstelling met hun vrouwelijke collega's uit fase 0 , een afname van het gevoel te vertonen van "bij de medische beroepsgroep te horen". In fase 2 wanneer het einde van hun studie nadert, blijkt dit gevoel van groepslidmaatschap en "erbij horen" bij iedereen weer een significante stijging te vertonen. 
Zijn co-assistenten bezig met bet maken van loopbaanplannen en schatten zij deze als baalbaar in?

Co-asssistenten en preco-assistenten blijken inderdaad bezig te zijn met hun loopbaan, ze blijken concrete plannen te maken voor hun eigen loopbaan en activiteiten te ondernemen zoals het volgen van extra stages of keuzeonderwijs of het doen van onderzoek om zich te profileren. Verder zouden co-assistenten en preco's het erg betreuren als ze deze loopbaanplannen niet zouden kunnen realiseren. De haalbaarheid van de eigen loopbaanplannen wordt door co-assistenten vrij positief ingeschat.

Tabel 10.16 Loopbaanoriëntatie

\begin{tabular}{llllll}
\hline variabele & groep 0 & groep 1 & groep 2 & $\begin{array}{l}\text { P } \\
\text { groepen }\end{array}$ & $\begin{array}{l}\text { p } \\
9 / 8\end{array}$ \\
\hline concrete plannen & 3.0 & 3.0 & 3.1 & n.s & n.s \\
realiseren & 2.8 & 2.8 & 2.9 & n.s & n.s \\
haalbaarheid & 2.8 & 2.9 & 2.8 & n.s & n.s \\
\hline
\end{tabular}

gemiddelde scores van subgroepen, $\mathrm{p}$-waarde groepsverschillen en vrouw/man verschillen n.s. = niet significant

Zijn er verschillen tussen subgroepen of tussen de seksen?

Er blijken geen significante verschillen tussen de co-assistenten in de verschillende subgroepen noch tussen mannelijke en vrouwelijke co-assistenten te zijn (zie tabel 10. 16).

Veranderen de co-assistenten op dit punt in de loop van de tijd ?

De totale groep verandert significant gedurende het jaar coschappen, in die zin dat men meer concrete plannen maakt. Deze toename is met name toe te schrijven aan de vrouwelijke co-assistenten, mannen blijven min of meer gelijk. Met name vrouwelijke co-assistenten in fase 2 maken een significante verandering en gaan meer plannen maken voor hun loopbaan (zie tabel). In fase 2 treedt ook ten aanzien van de "inschatting van haalbaarheid" een betekenisvolle toename op (Wilcoxon p .07 (+stijging)) bij zowel het vrouwelijk deel als het mannelijke deel van deze groep gevorderden. (zie tabel 10.17).

Tabel 10.17 Loopbaanoriëntatie in de loop van de tijd

\begin{tabular}{lllllll}
\hline & totaal & $Q Q$ & $\delta \delta$ & fase 0 & fase 1 & fase 2 \\
\hline concr. plan & $+^{* *}$ & $+^{* * *}$ & n.s. & n.s. & +.08 & $+* *$ \\
realiseren & n.s. & n.s. & n.s. & n.s. & n.s. & n.s. \\
haalbaarheid & n.s. & n.s. & n.s. & n.s. & n.s & +.07 \\
\hline
\end{tabular}

Significante verschillen (Wilcoxon); + - stijging;

" $\mathrm{p} \leq 0.05 ;{ }^{* *} \mathrm{p} \leq 0.01 ;{ }^{* * *} \mathrm{p} \leq .001$; n.s. - niet significant 


\section{Locus of control}

Welk attributie-patroon ligt ten grondslag aan de opvattingen van co-assistenten en preco's over de kans op realisatie van bun loopbaanwensen?

Over de hele linie blijken aanstaande artsen het gevoel te hebben hun loopbaan zelf in de hand te hebben (tabel 10.18). Zij blijken nauwelijks van mening dat loopbaansucces toegeschreven kan worden aan factoren buiten hen zelf - zoals kruiwagens, invloedrijke personen, en botsende belangen - of aan het toeval - zoals "gewoon geluk of pech hebben, noodlot", of op het juiste moment op de juiste plaats zijn".

Ten aanzien van "locus of control" blijken er geen verschillen tussen mannelijke en vrouwelijke co-assistenten te bestaan, behalve in de groep beginners (groep 1) waar vrouwen hun loopbaansucces meer aan interne factoren toeschrijven dan mannen.

Tabel 10.18 Locus of control of attributies aangande loopbaan

\begin{tabular}{|c|c|c|c|c|c|}
\hline & \multirow{2}{*}{$\begin{array}{l}\text { studenten } \\
\text { groep } 0\end{array}$} & \multicolumn{3}{|c|}{ co-assistenten } & \multirow{2}{*}{$\begin{array}{l}\text { p-waarde } \\
\text { sekseverschil }\end{array}$} \\
\hline & & totaal & groep 1 & groep 2 & \\
\hline intern & 3.1 & 3.1 & 3.1 & 3.0 & n.s \\
\hline extern & 2.2 & 2.2 & 2.2 & 2.2 & n.s \\
\hline toeval & 2.2 & 2.0 & 2.0 & 2.0 & n.s \\
\hline
\end{tabular}

gemiddelde scores groep 0 , totale groep co's, de beginners en de gevorderden. Verschillen getoetst met Kruskall-Wallis; p-warde sekseverschil totale groep; range 1 - 4 (volledig oneens - volledig eens).

Uit de longitudinale analyse blijkt dat in de periode van de co-assistentschappen geen significante verandering optreedt in het attributiepatroon inzake het welslagen van de loopbaanplannen oftewel de locus of control.

Wanneer we de bevindingen van de thema's "ideaalbeeld-zelfbeeld (prototypische vrouwelijkheid $\backslash$ mannelijkheid), beroepsoriëntatie \& loopbaanoriëntatie" nog eens op een rij zetten, dan blijkt het volgende.

De ideale arts heeft in de ogen van co-assistenten zowel een vrouwelijke als een mannelijke inkleuring. De ideale arts bezit een aantal prototypisch mannelijke of instrumentele eigenschappen, is zelfverzekerd, dominant, eerzuchtig of ambitieus en moedig, denkt logisch en heeft een groot abstractievermogen, gaat methodisch te werk en is formeel. Tegelijkertijd dient de ideale arts echter ook tactvol en begrijpend, aantrekkelijk, emotioneel, attent, zorgzaam en gevoelig te zijn en warm spontaan in het contact en nieuwsgierig, kortom een meer vrouwelijke of "expressieve" inkleuring te vertonen.

Co-assistenten blijken het relationele aspect van het medisch werk erg belangrijk te vinden. Dit aspect van het werk blijkt belangrijker dan maatschappelijke status, inkomen en erkenning.

Co-assistenten voelen zich verder enigszins lid van de medische beroepsgroep.

Co-assistenten zijn ook bezig met het maken van loopbaanplannen en schatten de haalbaarheid van hun plannen positief in. Ze blijken verder het mogelijk succes van 
hun loopbaan vooral toe te schrijven aan het eigen handelen (interne locus of control). Co-assistenten schrijven minder betekenis toe aan de rol van het toeval of aan de hulp van machtige andere(n) voor het welslagen van hun carrière-plannen.

\section{Focus op sekseverschillen}

Het zelfbeeld van vrouwelijke co-assistenten blijkt, niet onverwacht, sterker vrouwelijk of expressief gekleurd te zijn dan dat van mannen. Het zelfbeeld van vrouwen is daarentegen niet minder mannelijk of instrumenteel dan dat van hun mannelijke collega's. De kloof tussen ideaalbeeld en zelfconcept vertoont eveneens een sekseverschil in die zin dat de kloof op de vrouwelijke of expressieve dimensie bij vrouwelijke co-assistenten wel aanwezig is, maar bij mannen ontbreekt. Bij de mannelijke of instrumentele dimensie is er geen verschil tussen de seksen.

Verder spelen status en inkomen voor mannelijke co-assistenten een grotere rol dan voor de vrouwelijk co-assistenten. Dit sekseverschil komt in alle drie de subgroepen voor, behalve in groep 2, de groep die het meest vergevorderd is in hun medische opleiding. In deze groep vinden mannelijke co assistenten het belang van maatschappelijke status en inkomen minder groot dan in de jongere groepen.

Vrouwelijke co-assistenten blijken een sterkere voorkeur voor loondienst en teamwork te hebben dan hun mannelijke collega's die een meer "autonoom" en zelfsturend arrangement voor hun beroepsuitoefening lijken te prefereren.

In groep 0 , de preco-assistenten blijken vrouwelijke studenten zich sterker een buitenstaander te voelen van de medische beroepgroep dan hun mannelijke medestudenten. Ten aanzien van loopbaanoriëntatie blijkt dat vrouwen en mannen niet verschillen in de mate waarin zij in gedachte bezig zijn met het plannen en voorbereiden van hun loopbaan. Vrouwelijke co-assistenten blijken ook overeen te komen in hun attributiepatroon, wanneer bevraagd over hun denkbeelden over de factoren, die het welslagen van hun loopbaanwensen beïnvloeden. Met andere woorden de locus of control richting loopbaanwensen is bij beide seksen gelijk met die uitzondering dat de vrouwen in groep 1, nog sterker dan hun mannelijke collega's, intern georieënteerd zijn.

\section{Focus op veranderingen in de tijd}

Zelfbeeld en ideaalbeeld los van elkaar bestudeerd blijken geen verschuiving in de tijd te vertonen, maar wanneer beide aan elkaar gekoppeld worden blijkt de kloof tussen ideaal en zelfbeeld wel veranderingen te vertonen. De kloof tussen ideaalconcept en zelfconcept vertoont bij alle co-assistenten op de instrumentele of prototypisch mannelijke dimensie verschuivingen in de loop van de tijd. Ten aanzien van de vrouwelijke dimensie blijken mannelijke co-assistenten geen verschuivingen te vertonen, vrouwen wel. Het lijkt erop dat bij mannelijke co-assistenten ten aanzien van expressieve of vrouwelijke aspecten nauwelijks ontwikkeling optreedt.

De mannelijke co-assistenten in fase 2 aan het eind van de studie verrassen door noch op de instrumentele noch op de expressieve dimensie een significante verschuiving te vertonen.

Ook ten aanzien van beroepsoriëntatie treden enige veranderingen op in de loop van de tijd, maar deze zijn in de diverse fasen verschillend en soms aan elkaar tegengesteld, waardoor op overall niveau soms geen veranderingen te zien zijn. 
Het belang dat mannelijke co-assistenten hechten aan status en inkomen, vertoont een significante afname in fase 0 , de startfase van de co-assistentschappen. De voorkeur voor loondienst en teamwork blijkt een positieve stimulans te krijgen in fase 1, de stabilisatiefase van het inwijdingstraject. Met name mannelijke co-assistenten gaan blijkbaar de voordelen van loondienst en teamwork inzien.

Het subjectief gevoel van lid te zijn van de medische beroepsgroep vertoont een wisselend patroon al naargelang de fase van opleiding; in fase 0 blijken vooral de vrouwelijke novieten zich sterker lid van de professie te gaan voelen, in fase 1 neemt dit gevoe. len weer af, met name bij de mannelijke helft en in fase 2 neemt het gevoel van lid te worden van de beroepsgroep bij de gehele groep en bij beide seksen weer toe.

Het maken van concrete loopbaanplannen neemt toe naarmate co-assistenten verder vorderen in hun opleiding. Vooral vrouwelijke co-assistenten blijken deze stijging te veroorzaken. In fase 2 , de afrondingsfase van de medische opleiding, blijken co-assistenten toenemend met hun loopbaanplanning bezig te zijn. De locus of control vertoont verder geen verandering in de tijd.

\subsection{Meervoudige lineaire regressie analyse}

Om inzicht te krijgen in de vraag of de sekseverschillen en de effecten van mate van gevorderdheid (subgroep), die in de voorgaande paragrafen zijn gerapporteerd als resultaat van de bivariate analyses (Mann Whitney U testen en dergelijke), niet moeten worden toegeschreven aan achtergrondvariabelen die als confounder een rol kunnen spelen, werden additioneel meervoudige lineaire regressie analyses uitgevoerd. Allereerst werd steeds getest of de variabele voldeed aan de voorwaarden van lineariteit en normaliteit voor lineaire regressie.

De vraagstelling die nu aan de orde is, luidt:

Spelen andere achtergrondvariabelen dan sekse en subgroep een rol bij de verklaring van de bevindingen van het transversale onderzoek naar de ontwikkeling van de professionele identiteit ?

Het onderwerp "de ontwikkeling van de professionele identiteit" werd bestudeerd aan de hand van zes thema's namelijk identificatie, expliciet onderscheid naar sekse, professi. oneel zelfvertrowwen en aspecten van professionele identiteit als "ideaalbeeld/zelfbeeld", "beroepsoriëntatie" en "loopbaanoriëntatie". Uit deze diverse thema's werden alleen die variabelen verder onderzocht, die bestonden uit meerdere items die voldoende samenhang vertoonden (reliability test). Deze variabelen zullen in het onderstaande worden opgesomd. 
Variabelen (zelf) evaluatie

"voorbeelden hebben

*voorbeelden willen

*(perceptie) erotisering

*(perceptie) voorkeur voor mannelijke artsen

*(ervaring of perceptie) ongewenst intimiteiten

* bewust-zijn van sekse

Variabelen van professioneel zelfvertrouwen

"positief zelfbeeld

*negatief zelfbeeld

"twijfel eigen competentie

*twijfel aan toegeschreven competentie

"voldoen aan verwachtingen van patiënt

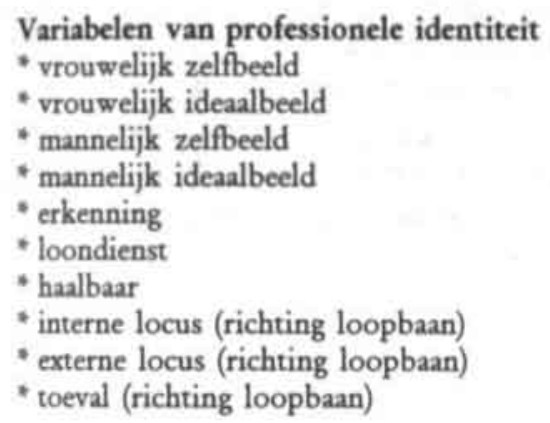

Variabelen van professionele identiteit

* vrouwelijk zelfbeeld

* vrouwelijk ideaalbeeld

* mannelijk zelfbeeld

* mannelijk ideaalbeeld

* erkenning

* loondienst

" haalbaar

* interne locus (richting loopbaan)

- externe locus (richting loopbaan)

* toeval (richting loopbaan)

\author{
Betekenis \\ rolvooorbeelden hebben \\ behoefte aan rolvoorbeelden \\ seksegebonden praktijken \\ idem \\ idem \\ gender-identiteit
}

\begin{abstract}
zelfbewust en met zelfvertrouwen geen zelfvertrouwen

subjectief gebrek aan zelfvertrouwen

negatieve attributie over rol-invulling

positieve attributie over voldoen an verwach-

tingen van patiënten
\end{abstract}
feminien of expressief zelfbeeld
idem idealbeeld
masculien of instrumenteel zelfbeeld
idem idealbeeld
aspect van beroepsoriëntatie
idem
aspect van loopbaanoriëntatie
toeschrijven aan eigen inspanningen
toeschrijven aan invloed van (machtige) ande-
ren toeschrijven aan toeval

De achtergrondvariabelen zijn dezelfde, die in hoofdstuk 8 werden beschreven (zie tabel 10.19). Uit het onderzoek naar onderlinge samenhang van de achtergrondvariabelen is vooral van belang te wijzen op de samenhang tussen sekse en leeftijd en sekse en privé situatie. Vrouwelijke respondenten zijn jonger, vaker alleenstaand en zonder vaste relatie (zie hoofdstuk 8 voor verdere gegevens).

Tabel 10.19 Overzicht achtergrondvariabelen met antwoordcategorieën

\begin{tabular}{|c|c|}
\hline variabelen & antwoordcategorieën \\
\hline 1. sekse & $1=$ man; 2 - vrouw \\
\hline 2. subgroep & $0=$ preco-assistenten; 1 - eerstejaars co-assistenten + tweedejaars \\
\hline 3. leeftijd & in jaren \\
\hline 4. opleiding vader $(v 9.2)$ & 7. puntschaal \\
\hline 5. opleiding moeder ( $\mathrm{v} 9.4)$ & 7. puntschaal \\
\hline 6. privé (v7) & $\begin{array}{l}1=\text { ongebonden; } 2 \text { - woon alleen, wel vaste relatie; } 3 \text { - samenwo- } \\
\text { nend met partner; } 4 \text { - samenwonend met partner en/of kind. }\end{array}$ \\
\hline 7. familie (v8) & familieleden die arts zijn: $0=$ nee; 1 - ja. \\
\hline 8. vooropleiding ( $\mathrm{v} 4.2)$ & $\begin{array}{l}0 \text { - geen paramedische, verpleegkundige, HBO of wetenschappelijke } \\
\text { opleiding voltooid; } 1 \text { - voltooid. }\end{array}$ \\
\hline
\end{tabular}




\section{Resultaten regressie-analyse}

We zullen nu de resultaten bespreken van de regressie-analyses door de volgende vragen te beantwoorden: "worden de verschillen tussen de subgroepen (seksen, preco's, beginners en gevorderden), die werden gevonden in de eerdere bivariate analyses bevestigd door de regressie-analyse ?" en " welke achtergrondvariabelen hebben verder invloed op de onderzochte variabele ?"

De variabelen die betrekking hebben op de evaluatie van indrukken uit de leeromgeving door de co-assistent komen eerst aan de orde. Daarna de variabelen die betrek. king hebben op het professioneel zelfvertrouwen en tot slot de diverse aspecten van professionele identiteit.

\section{Variabelen betreffende (zelf)evaluatie (thema 1 en 2)}

De regressieanalyse toont een significant effect van sekse en mate van gevorderdheid in de opleiding op de variantie van de variabele bewustzijn van sekse, een aspect van genderidentiteit (zie tabel 10.20). Dit betekent dat vrouwen veel meer an hun sekse worden herinnerd dan mannen in het inwijdingstraject en dat, naarmate de co-assistente verder gevorderd raakt in haar opleiding, zij zich meer en meer bewust wordt van haar sekse. Dit komt overeen met de resultaten van de bivariate analyses.

Tabel 10.20 (Zelf) evaluatic

p-waarden regressie-analyses van de variabelen in relatie tot de achtergrondvariabelen.

\begin{tabular}{llll}
\hline afh. variabele & sekse & groep & leeftijd \\
\hline $\begin{array}{l}\text { bewust van sekse } \\
\text { (perceptie) voorkeur voor mannen }\end{array}$ & .000 & .000 & n.s. \\
$\begin{array}{l}\text { (perceptie) erotisering } \\
\text { ongewenste intimiteiten }\end{array}$ & .002 & n.s. & n.s. \\
$\begin{array}{l}\text { voorbeelden willen } \\
\text { voorbeelden hebben }\end{array}$ & $-\#$ & n.s. & $-\#$ \\
\hline
\end{tabular}

de achtergrondvariabelen, die niet genoemd worden, geven geen significante bijdrage

" Er kan niet voldaan worden aan de eisen van normaliteit en lineariteit.

Verder blijkt uit de analyse van de variabele "perceptie voorkeursbehandeling van mannen" een significant effect van sekse, hetgeen bevestiging inhoudt voor de eerdere bevindingen. Vrouwelijke co-assistenten nemen een voorkeursbehandeling voor mannelijke artsen dus meer waar dan mannelijke co-assistenten.

De variabele "perceptie van erotisering "wordt niet beïnvloed door "sekse" of "groep" noch door de andere achtergrondvariabelen. Dit is consistent met eerdere analyses. De behoefte aan rolvoorbeelden blijkt ook geen invloed te ondergaan van sekse of groep en leeftijd blijkt de behoefte aan voorbeelden positief te beïnvloeden. Concreet hoe ouder, des te sterker wordt aangegeven dat men een rolmodel apprecieert. 


\section{Variabelen betreffende "professioneel zelfvertrouwen" (thema 3)}

Tabel 10.21 Professioneel zelfvertrouwen en competentie

p. waarden regressie-analyses van de variabelen in relatie tot de achtergrondvariabelen.

\begin{tabular}{llll}
\hline afh. variabele & sekse & groep & privé \\
\hline positief zelfbeeld & n.s. & $.035^{*}$ & $.023^{*}$ \\
negatief zelfbeeld & n.s. & n.s. & $.041^{*}$ \\
twiffel eigen competentie & n.s. & $.033^{*}$ & n.s. \\
twijfel toegeschreven comp. & n.s. & n.s. & $.014^{* *}$ \\
patiëntverwacht. & n.s. & - & n.s. \\
\hline
\end{tabular}

de achtergrondvariabelen, die niet genoemd worden, geven geen significante bijdrage f variabele groep niet opgenomen in de regressieanalyse vanwege ontbreken van waardes voor groep 0.

Uit de regressie-analyses blijkt op het gebied van gevoel van professioneel zelfvertrouwen en competentie geen verschil te bestaan tussen de mannelijke en de vrouwelijke co-assistenten (zie tabel 10.21). Dit komt overeen met de resultaten uit de bivariate analyses. Mate van gevorderdheid (variabele "groep") en de inrichting van de privé situatie blijken wel van invloed te zijn. Hoe verder gevorderd in fase van de co-assistentschappen hoe meer gevoel van zelfvertrouwen en hoe minder twijfel aan eigen competentie.

Verder blijkt samenleven of een vaste relatie hebben voor co-assistenten een positieve invloed te hebben op het zelfvertrouwen en op de "toegeschreven" competentie, de inschatting over de mate waarin de omgeving haar of hem al serieus neemt als aanstaand arts.

\section{Variabelen betreffende professionele identiteit (thema 4, thema 5, thema 6)}

Tabel 10.22 "Ideaalbeeld-zelfbeeld" meer of minder prototypisch vrouwelijk of mannelijk p. waardes regressie-analyses van de variabelen in relatie tot de achtergrondvariabelen.

\begin{tabular}{lllll}
\hline afh. variabele & sekse & groep & leeftijd & vooropl. \\
\hline vrouwelijk ideaalbeeld & n.s. & n.s. & $.049^{*}$ & n.s. \\
mannelijk ideaalbeeld & n.s. & n.s. & n.s. & n.s. \\
vrouwelijk zelfbeeld & $.001^{* * *}$ & n.s. & n.s. & $.026^{*}$ \\
mannelijk zelfbeeld & n.s. & n.s. & n.s. & n.s. \\
\hline
\end{tabular}

de achtergrondvariabelen, die niet genoemd worden, geven geen significante bijdrage

Het ideaalbeeld van de arts blijkt niet bepaald te worden door de sekse van de respondent (zie tabel 10.22), hetgeen overeenkomt met de gevonden resultaten van de bivariate analyses. Leeftijd heeft wel enige invloed, in die zin dat oudere co-assistenten meer geneigd zijn vrouwelijke eigenschappen toe te schrijven aan de ideale arts dan jongere co-assistenten. Eerder vonden we een sterker mannelijk ideaalbeeld bij preco-assistenten. In de de regressie-analyse wordt wel dezelfde trend gevonden, maar is het verband niet significant. 
Sekse blijkt wel een significante invloed op het vrouwelijk ingekleurd zelfbeeld te hebben in de zin dat vrouwen een significant vrouwelijke zelfbeeld hebben. Mate van gevorderdheid ("groep") heeft geen invloed op het zelfbeeld. Dit alles stemt overeen met de resultaten uit de bivariate analyses. Interessant is dat de mannen en de vrouwen een even sterk mannelijk zelfbeeld hebben. Uit de regressie analyse blijkt verder dat mensen met een (para-medische) vooropleiding een minder sterk vrouwelijk zelfbeeld hebben.

Tabel 10.23 Beroepsoriëntatie

p. waarden regressie-analyses van de variabelen in relatie tot de achtergrondvariabelen.

\begin{tabular}{lllll}
\hline afh. variabele & sekse & groep & privé & fam. \\
\hline erkenning & $.002^{* *}$ & n.s. & n.s. & n.s. \\
loondienst & n.s. & .007 & n.s. & $.014^{*}$
\end{tabular}

de achtergrondvariabelen, die niet genoemd worden, geven geen significante bijdrage

" $\mathrm{Er}$ kan niet voldaan worden aan de eisen van normaliteit en lineariteit.

Uit de bivariate analyses werden bij de variabele "erkenning" een sekse-verschil en een verschil tussen onderscheiden subgroepen gevonden. Door de regressieanalyse wordt het sekseverschil bevestigd, maar invloed van gevorderdheid in de medische opleiding niet (zie tabel 10.23). Vrouwen hechten dus minder waarde aan maatschappelijke status en inkomen dan mannen.

Ook bij de variabele "loondienst" bleek in de bivariate analyse een sekseverschil te bestaan. Dit wordt echter door de regressieanalyse niet bevestigd, maar wel blijkt de mate van gevorderdheid (de achtergrondvariabele "groep") invloed te hebben op deze variabele; hoe verder men in de opleiding is, hoe sterker de voorkeur voor loondienst wordt. Dit is consistent met de eerdere bevindingen.

Uit de regressieanalyse blijkt verder dat het hebben van een dokter in de familie een positieve invloed heeft op de voorkeur voor werken als arts in loondienst.

Tabel 10.24 Loopbaan-oriëntatie, locus of control

p.waarden regressic-analyses van de variabelen in relatie tot de achtergrondvariabelen.

\begin{tabular}{lll}
\hline afh. variabele & sekse & groep \\
\hline interne locus & n.s. & n.s. \\
externe locus & n.s. & n.s. \\
toeval & n.s. & $.006^{* *}$ \\
haalbaarheid & n.s. & n.s. \\
\hline
\end{tabular}

de achtergrondvariabelen, die niet genoemd worden, geven geen significante bijdrage.

Uit de regressieanalyse blijkt evenals uit de bivariate toetsing dat op de verschillende variabelen van locus-of-control geen significant invloed van sekse of "groep" uitgaat Alleen op variabele "toeval" wordt een significante invloed uitgeoefend door de mate van gevorderdheid in de opleiding ("groep"). Dat wil zeggen dat pre-co-assistenten, die nog niet begonnen zijn aan de klinische stages, persoonlijk succes vaker aan toeval toeschrijven dan co-assistenten. Dit is consistent met de eerder bevindingen. 


\section{Samenvattend}

In de meeste gevallen worden de resultaten uit de bivariate analyses bevestigd door de regressie-analyses. Nieuw is het gegeven dat professioneel zelfvertrouwen door de inrichting van de privésituatie wordt beïnvloed; van samenleven of een partner blijkt een positieve invloed uit te gaan op het zelfvertrouwen als arts. De sekse van de respondent blijkt wel van invloed op de perceptie van de seksegebonden praktijken in de opleidingsetting en op het bewustzijn van sekse.

Sekse blijkt eveneens van invloed op de beroepsoriëntatie van de co-assistent namelijk op de waardering voor maatschappelijke status en inkomen tengevolge van het medisch beroep. De voorkeur voor het beoefenen van het medisch beroep in loondient blijkt niet door sekse te worden beïnvloed, maar wel door de mate van gevorderdheid in de opleiding en of de co-assistent andere artsen in de familie heeft.

Het beeld van de ideale arts blijkt niet beïnvloed te worden door de sekse van de respondent. Het zelfbeeld van vrouwen blijkt verder net zo mannelijk of instumenteel van aard te zijn als dat van mannen, maar is wel meer expressief of vrouwelijk ingekleurd.

\subsection{Samenvatting van de resultaten}

Eerst zullen we stil staan bij de kwestie of de hypothesen die in hoofdstuk 9 werden geformuleerd over de verschillende thema's bevestigd worden door de data of verworpren moeten worden. Over het identificatie-proces, de rol van rolvoorbeelden en de ervaringen met en percepties van co-assistenten van "seksegebonden praktijken" werden onder de noemer van (zelf) evaluatie tien (10) hypothesen geformuleerd, zes (6) over mogelijke sekseverschillen en vier (4) over veranderingen in de tijd. Uit het navolgende overzicht blijkt dat in dit onderzoek zeven hypothesen bevestigd kunnen worden en drie verworpen moeten worden. 
Hypothesen over (zelf) evaluatie. Wel of niet bevestigd ?

Hypothese
" thema 1
-co-assistenten gaan zich in de loop hun
co-assistentschappen meer identificeren
met opleiders
type hypothese hypothese wel of niet bevestigd? verandering in hypothese wel bevestigd de tijd

\section{* thema 1}

co-assistenten gaan zich in de loop hun co-assistentschappen minder identificeren met patiënten

\section{"thema 1}

vrouwelijke co-assistenten identificeren

zich zowel met mannelijke als vrouwelijke artsen-opleiders, mannen voornamelijk met mannelijke opleiders.

\section{thema 1}

vrouwelijke co-assistenten geven duide-

verandering in de tijd

$\$ / 8$

৪/ठ

lijker aan sociale steun te wensen dan mannelijke

\section{* thema 1}

vrouwen geven duidelijker aan behoefte aan rolvoorbeelden te hebben dan mannen

\section{* thema 2}

de perceptie van de erotisering (van de betrekkingen in de kliniek) neemt toe in de loop van de tijd

" thema 2

de perceptie van voorkeursbehandeling voor mannen is bij vrouwelijke co-assistenten sterker dan bij mannelijke

\section{* thema 2}

de perceptie van voorkeursbehandeling voor mannen neemt toe in de loop van de tijd

* thema 2

vrouwen worden in de setting van de co-assistentschappen sterker herinnerd an hun sekse dan mannelijke co's

* thema 2

vrouwen hebben meer ervaring met ongewenste intimiteiten dan hun mannelijke collega's verandering in hypothese bevestigd de tijd

hypothese bevestigd

verandering in de tijd

hypothese niet bevestigd; tegendeel

\section{$9 / 8$}

hypothese bevestigd; ook toename in de tijd van de bekrachtiging van gender-identiteit van vrouwen hypothese bevestigd 


\section{Wat was verwacht en is bevestigd over zelf-evaluatie?}

Co-assistenten blijken zich het meest met mannelijke artsen te identificeren, waarmee bevestigd is dat zij vooralsnog de belangrijkste rolmodellen zijn tijdens de klinisch fase voor de nieuwe generatie artsen. Verder blijken vrouwelijke co-assistenten zowel vrouwelijke als mannelijke artsen-opleiders tot voorbeeld te kiezen, maar houden mannelijke co-assistenten het bij hun mannelijke rolvoorbeelden. Conform de vooronderstellingen is het articuleren van behoefte aan sociale steun voor vrouwelijke co-assistenten gemakkelijker dan voor hun mannelijke collega's. Daarentegen blijken noch vrouwelijke co-assistenten noch mannen behoefte aan rolmodellen uit te drukken.

De seksegebonden praktijken zoals deze worden waargenomen en ervaren kwamen bij thema 3 aan de orde. De perceptie van een zekere mate van erotisering van de betrekkingen, in de context van klinische stages, neemt toe in de loop van de tijd, zo blijkt uit het longitudinale onderzoek. Deze bevinding is consistent met de ook in het beroepscultuur aangetroffen toename van perceptie van cultuuraspecten bij meer gevorderde co-assistenten (zie hoofdstuk 6).

Vrouwelijke co-assistenten blijken meer een voorkeursbehandeling voor mannen in de medische professie waar te nemen dan hun mannelijke collega's. Vrouwen blijken sensitief te zijn voor deze vorm van mogelijke discriminatie. Het longitudinale beloop van deze perceptie wijkt af van de verwachting, in die zin dat deze perceptie niet toeneemt, zoals in het beroepscultuur vaker werd gevonden, maar dat er sprake is van een afnemende perceptie van voorkeur voor mannen of discriminatie bij beide seksen en in alle onderscheiden fasen.

Als kanttekening moet hierbij wel worden opgemerkt dat een mogelijke voorkeur voor vrouwen in de medische professie in dit onderzoek niet werd bevraagd.

De genderidentiteit van vrouwelijke co-assistenten blijkt verder, conform de hypothese, sterker bekrachtigd te worden in de context van de klinische stages dan die mannelijke co-assistenten. Deze bekrachtiging valt vooral op in de startfase van de coschappen (fase 0). Er lijkt bij vrouwelijke co-assistenten een ander mechanisme van kracht dan voor hun mannelijke collega's.

Vrouwelijke co-assistenten rapporteren ook meer ervaringen met ongewenste intimiteiten. Uit de antwoorden uit de open vragen over de seksegebonden praktijken blijken vrouw-zijn en vrouwelijkheid zeker aandacht krijgen in de medische beroepsgroep. Negatieve uitingen hierover blijken geen uitzondering te zijn. Ook hierbij moet wel rekening gehouden worden met het gegeven, dat met name vragen zijn gesteld over negatieve uitingen over patiënten en vrouwen en niet over mannelijke patiënten of mannelijke artsen. 
Er werden vijf hypothesen over de ontwikkeling van het professionele zelfvertrouwen geformuleerd, drie over mogelijke sekseverschillen en twee over verandering in de tijd. Uit het onderstaande overzicht blijkt dat slechts twee hypothesen bevestigd kunnen worden en drie moeten worden verworpen.

Hypothesen over professioneel zelfvertrouwen. Wel of niet bevestigd ?

* thema 3

de twijfel aan eigen competentie neemt bij mannelijke co-assistenten sterker af dan bij vrouwelijke co-assistenten

\section{* thema 3}

de twijfel aan de eigen competentie is het grootst in fase 0 bij de start en neemt af in de loop van de fase van de co-assistentschappen

\section{* thema 3}

vrouwelijke co-assistenten kennen meer twijfel over of ze door de omgeving als competent arts worden gezien, dan hun mannelijke collega's

* thema 3

bet professioneel zelfvertrouwen neemt toe in de loop van de co-assistentschappen

\section{* thema 3}

het professioneel zelfvertrouwen van mannelijke coassistenten neemt sterker toe dan dat van vrouwelijke beloop in de tijd van sekseverschil

hypothese niet be vestigd

verandering in de tijd

hypothese bevestigd, fluctuerend beloop in de tijd

$8 / 8$

hypothese niet bevestigd

verandering in de tijd

hypothese bevestigd

\section{$9 / 8$} hypothese niet bevestigd

Wat is verwacht en bevestigd over professioneel zelfvertrouwen ?

Het gevoel van competentie en zelfvertrouwen, dat ook wel "mastery" wordt genoemd, blijkt een voorspoedig beloop te kennen. De co-assistenten blijken zich daadwerkelijk minder onzeker te gaan voelen in de medische beroepsrol. De ontwikkeling van het subjectief gevoel van zelfvertrouwen fluctueert in de loop van de tijd. In de fase waarin co-assistenten de kliniek betreden (fase 0 ) bestaat een gevoel van incompetentie en onzekerheid en ziet men het gevoel van zelfvertrouwen afnemen. Daarna treedt een zekere stabilisatie op van het zelfvertrouwen om in fase 2 de laatste periode van de co-assistentschappen weer toe te nemen. Over het geheel lijkt het gevoel van competentie bij vrouwelijke co-assistenten iets meer fluctuatie te vertonen dan bij mannelijke studenten, maar verder komen de seksen op dit punt overeen.

De attributies van co-assistenten over hoe competent de omgeving haar of hem vindt als (aanstaand) arts, vertonen geen verandering in de tijd. Opmerkelijk is dat bij coassistenten het gevoel te kunnen voldoen aan de verwachtingen van de patiënt geen toename vertoont in de tijd, maar constant blijft.

Over de verschillende aspecten van de professionele identiteit van co-assistenten werden twaalf (12) hypothesen geformuleerd, zes over een mogelijk sekseverschil, drie 
over mogelijke veranderingen in de tijd, een over een ander beloop in de tijd bij de seksen en twee algemene hypothesen. Uit het bovenstaande overzicht blijkt dat drie hypothesen bevestigd kunnen worden, drie worden gedeeltelijk bevestigd en zes hypothesen moeten verworpen worden.

Hypothesen aspecten van professionele identiteit. Wel of niet bevestigd ?

\section{* thema 4}

het beeld van de ideale arts is meer prototypisch mannelijk dan vrouwelijk

- thema 4 de discrepantie tussen ideaalbeeld en zelfbeeld is groter bij de dimensie mannelijke aspecten dan bij de dimensie vrouwelijke aspecten

* thema 4

Vrouwen en mannen verschillen in zelfbeeld zowel op dimensie prototypisch vrouwelijk als ook dimensie prototypisch mannelijk

\section{* thema 4}

het zelfbeeld van vrouwelijke co-assistenten wordt in de loop van de tijd minder prototypisch vrouwelijk

* thema 5

mannelijke co-assistenten hechten in hun toekomstige beroepsuitoefening meer be lang aan maatschappelijke erkenning, inkomen en status dan vrouwelijke co's (kostwinnersperspectief)

\section{"thema 5}

vrouwelijk co-assistententen hechten meer waarde aan relationele aspecten van het beroep (als contact met patiënten en collega's, leuk en boeiend werk) dan hun mannelijke collega's

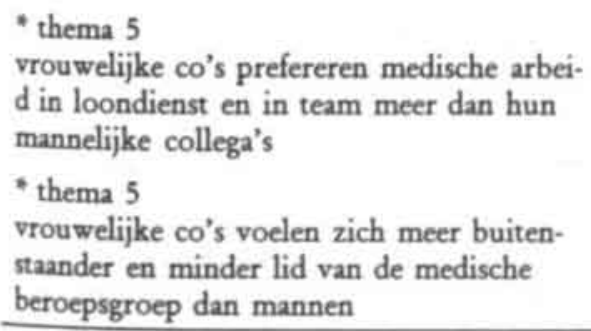

algemeen hypothese niet bevestigd

algemeen hypothese deels bevestigd; bij mannelijke co's

\section{$\delta / 9$}

hypothese deels bevestigd; het zelfbeeld van vrouwen en mannen is even mannelijk; zelfbeeld van mannen minder vrouweljk of expressief dan dat van vrouwen

verandering hypothese niet bevestigd in de tijd
$\$ / \delta$
hypothese bevestigd

hypothese niet bevestigd

\&/8 hypothese bevestigd

९/ठ hypothese niet bevestigd 


\begin{tabular}{|c|c|c|}
\hline $\begin{array}{l}\text { * thema } 5 \\
\text { set gevoel van lid te zijn van de medi- } \\
\text { assistenten verder vorderen in hun oplei- } \\
\text { ding }\end{array}$ & $\begin{array}{l}\text { verandering } \\
\text { in de tijd }\end{array}$ & $\begin{array}{l}\text { hypothese deels bevestigd; } \\
\text { fluctuerend beloop, toename in } \\
\text { fase } 0 \text {, afname in fase } 1 \text { en weer } \\
\text { toename in fase } 2\end{array}$ \\
\hline $\begin{array}{l}\text { - het veranderingsproces van vrouwelijke } \\
\text { co-assistenten gaat op dit punt langzamer } \\
\text { dan dat van mannen }\end{array}$ & $\begin{array}{l}\text { beloop van } \\
\text { seksever. } \\
\text { schil }\end{array}$ & $\begin{array}{l}\text { hypothese niet bevestigd; } \\
\text { tegendeel }\end{array}$ \\
\hline $\begin{array}{l}\text { * thema } 6 \\
\text {-mannelijke co-assistenten zijn geneigd hun } \\
\text { eventuele loopbaansucces meer toe te } \\
\text { schrijven aan machtige anderen (externe } \\
\text { locus of control); vrouwelijke co-assisten- } \\
\text { ten zijn meer geneigd dit toe te schrijven } \\
\text { aan het toeval }\end{array}$ & $9 / 8$ & hypothesen niet bevestigd \\
\hline $\begin{array}{l}\text { - thema } 6 \\
\text {-co-assistenten houden zich, naarmate ze } \\
\text { verder vorderen in hun opleiding, steeds } \\
\text { meer bezig met planning van de eigen } \\
\text { loopbaan }\end{array}$ & $\begin{array}{l}\text { verandering } \\
\text { in de tijd }\end{array}$ & hypothese bevestigd \\
\hline
\end{tabular}

Wat was verwacht over aspecten van professionele identiteit en wordt dit bevestigd? Het concept van de ideale dokter van co-assistenten blijkt androgyn en zowel mannelijk als vrouwelijk te worden ingekleurd.

Bij de beschrijving van het zelfbeeld valt op dat vrouwelijke co-assistenten zichzelf als zowel mannelijk als vrouwelijk beschrijven, terwijl mannelijke co-assistenten zichzelf nauwelijks als vrouwelijk beschrijven. Mannen blijken zich nauwelijks met vrouwen te identificeren maar vrouwen wel met mannen.

Voor de hypothese dat het cultureel ideaal van de arts sterker is bekleed met mannelijke of instumentele karakteristieken dan met feminiene of expressieve, zijn ook aanwijzingen gevonden door de discrepantie tussen ideaalconcept en zelfbeeld op beide dimensies te bestuderen. Voor mannelijke co-assistenten blijkt deze hypothese correct, voor vrouwen niet. Met andere woorden mannelijke co-assistenten beschrijven hun eigen identiteit als verder verwijderd van het stereotype mannelijk ideaal dan van het stereotype vrouwelijk ideaal. Vrouwen vertonen op beide dimensies een significante discrepantie tussen ideaal en zelfconcept.

Ook blijkt de kloof tussen ideaalconcept en zelfconcept bij vrouwelijke co-assistenten in de loop van de tijd te veranderen op zowel de instrumentele of mannelijke als op de expressieve of vrouwelijke dimensie. Bij mannelijke co-assistenten blijkt wel een verandering in de tijd op de instumentele dimensie, maar niet op de expressieve dimensie op te treden.

In de beroepsoriëntatie van co-assistenten vinden we de sporen terug van de geslachtsrol-socialisatie van mannen tot kostwinner. Mannelijke co-assistenten blijken daadwerkelijk sterker op maatschappelijke status, erkenning en inkomen georiënteerd te zijn dan hun vrouwelijke collega's. De geslachtsrolsocialisatie van vrouwen die affiniteit en accentuering van zorg en expressieve aspecten van het beroep doet vermoeden, wordt 
minder eenduidig bevestigd bij co-assistenten. Vrouwelijke co-assistenten blijken minder stereotype vrouwelijk te zijn, dan mannelijke co-assistenten stereotype mannelijk zijn.

Interessant is de bevinding dat de voorkeur voor het werken als arts in loondienst als vorm van beroepsuitoefening samenhangt met de mate van gevorderdheid in de medische opleiding en afkomstig zijn uit een familie met artsen. Een arts in de familie hebben blijkt de voorkeur voor loondienst te bevorderen. Uit de longitudinale analyse blijkt dat mannelijke co-assistenten in de loop van de tijd positiever over werken in loondienst worden.

Het gevoel van co-assistenten dat men meer en meer insider wordt en bij de medische beroepsgroep gaat horen, kent een verloop met ups en downs en vertoont bij vrouwen een ander verloop dan bij mannen. Bij vrouwelijke studenten treedt in fase 0 , bij de start van de co-assistentschappen, een toename op van het gevoel van lid worden en van "erbij horen " bij de groep van artsen. Mannelijke co-assistenten gaan zich in fase 1 net minder sterk insider of horend bij de medische beroepsgroep voelen. In de laatste fase van de co-assistentschappen, de eindfase van de studie, krijgt het gevoel van "erbij horen" en zich lid voelen van de beroepsgroep weer een krachtige impuls. Het zal geen verbazing wekken dat in de loop van de tijd de oriëntatie van co-assistenten op hun loopbaan toeneemt en dat zij meer activiteiten in deze richting gaan ontplooien. Ze hebben ook beelden en opvattingen over de kans van slagen van hun plannen en de factoren die van invloed zijn op deze kansen. De attributies van coassistenten over welke factoren het verloop van hun beroepscarriere gunstig zullen beïnvloeden, blijken redelijk constant in de tijd en geen verandering in de loop van de co-assistentschappen te vertonen. Het attributiepatroon van co-assistenten toont wel een sterke voorkeur voor een "interne locus of control". Zowel vrouwelijke als mannelijke co-assistenten blijken er vanuit te gaan dat het met name van de eigen inspanningen afhangt of men een loopbaan naar wens zal kunnen realiseren. Coassistenten hechten voor het realiseren van hun loopbaanwensen minder belang aan de rol van mogelijke "machtige anderen" en zien ook de rol van toevalsfactoren als klein. Hoe verder men gevorderd is in de medische opleiding, des te minder de coassistent nog gelooft dat toeval een factor van betekenis is voor het verdere verloop van de eigen loopbaan.

\subsection{Beschouwing}

Wat is verrassend of niet verwacht?

Het proces van professionele socialisatie blijkt bij vrouwelijke studenten anders te verlopen dan dit vroeger beschreven werd (Fahrenfort,1985; Becker,1961). Een proces van toenemende medicalisering en zich afwenden van het patiënten-perspectief kon in dit onderzoek niet worden gevonden. Bij vrouwelijke co-assistenten blijkt sprake te zijn van een stijgende identificatie met patiënten parallel met een toenemende identificatie met mannelijke artsen-opleiders. Bij mannelijke co-assistenten blijkt alleen sprake te zijn van een toenemende identificatie met mannelijke artsen-opleiders. We kunnen concluderen dat vrouwelijke co-assistenten in staat blijken tot een meervoudige of 
duale identificatie. Een toenemende identificatie op met artsen-opleiders als representanten van de eigen beroepsgroep, blijkt bij vrouwelijke aanstaande artsen een toenemende vereenzelviging met patiënten niet in de weg te staan. Dit gegeven kan als hoopvol worden beschouwd vanuit het perspectief van kwaliteit van zorg en de toenemende noodzaak voor artsen om meer gelijkwaardigheid, dialoog en onderhandeling in de arts-patiënt relatie in te brengen in combinatie met voldoende empathie. Het blijkt verder voorspoedig te gaan met de ontwikkeling van het professionele zelfvertrouwen en gevoel van competentie, dat zowel bij vrouwelijke als mannelijke co-sssistenten groeit in de loop van de tijd. Vrouwelijke co-assistenten zijn net zo min als hun mannelijke collega's behept met gebrek aan zelfvertrouwen als arts. Noch lijden zij onder twijfel over de vraag of de sociale omgeving hen serieus neemt in de medische beroepsrol. Overigens is het opmerkelijk dat co-assistenten niet vinden dat ze in de loop van de' tijd meer kunnen voldoen aan de verwachtingen van de patiënt. Onverwacht blijkt de inrichting van de privé-situatie wel invloed te hebben op het professionele zelfvertrouwen. Van een permanente binding met een partner (en/of kinderen) blijkt een positieve invloed uit te gaan op de mate van professioneel zelfvertrouwen. Op dit punt is wel belangrijk in herinnering te roepen dat mannelijke respondenten iets vaker samenleven met partner en kind dan vrouwelijke respondenten. Dit kan betekenen dat het verband vooral van toepassing is op mannen.

Deze resultaten over het voorspoedige verloop van de ontwikkeling van het zelfvertrouwen als professional bij vrouwen betekenen een nuancering van de literatuur over belemmerde ontplooïng van vrouwen ten gevolge van de "male-ness" van het medisch beroep of seksestereotype beelden en benadering. De ontwikkeling van het professioneel zelfvertrouwen blijkt bij vrouwelijke studenten in de co-assistentschappen in ieder geval niet belemmerd te zijn.

Wel zeer opmerkelijk is de bevinding dat vrouwelijke co-assistenten bij hun entree in de klinische fase een bekrachtiging ervaren van hun genderidentiteit en zich meer dan in de predoctoraal fase realiseren dat ze vrouw zijn. Was het in de eerder stadia van de medische opleiding blijkbaar geen opmerkelijke zaak, binnen de context van de coassistentschappen blijkt genderidentiteit voor vrouwen een topic te worden.

Deze bevinding en die op het terrein van seksegebonden praktijken in de context van de stages, roepen de vraag op of hier een vorm van reproduktie van sociale ongelijkheid wordt aangetroffen door middel van invloed op het identiteits-arrangement van vrouwen. Vrouw-zijn bekrachtigen in een culturele context van een door mannen gedomineerd beroep, gekenmerkt door mannelijke helden en een overmaat aan mannen in nagenoeg alle hoge functies (verticale seksesegregatie), betekent het bekrachtigen van anders-zijn en afwijken van de norm. Hoewel deze aandacht voor de vrouwelijkheid van co-assistenten in de opleidingscontext niet als onaangenaam hoeft te worden ervaren, lijkt hier sprake van een adder onder het gras.

Wanneer co-assistenten assimileren aan de huidige structuur en cultuur van de professie en tengevolge hiervan de inrichting van het beroep en de onderliggende waarden en normen als vanzelfsprekend gaan zien, zal een versterking van het bewustzijn als vrouw op de langere duur dilemma's en paradoxen kunnen oproepen, omdat het beroep vooralsnog niet is aangepast aan participatie van grote aantallen vrouwen. Vooral voor vrouwelijke aanstaande artsen is de kans groot dat dilemma's als indivi- 
dueel probleem worden gezien en op de eigen persoon worden betrokken en dat niet de context evenzeer wordt geproblematiseerd. Een dergelijk identiteitsarrangement kan de motivatie onder druk zetten en kwetsbaarheid van deze professionals vergroten, wanneer zij de arbeidsmarkt betreden en hun medische loopbaan beginnen. Voor artsen houdt deze volgende fase vaak in op jacht gaan naar de schaarse en door velen begeerde (opleidings)plaatsen die toegang geven tot de begeerde posities in het professionele domein. De kans is groot dat een dergelijk perspectief op de toekomst coassistenten zal nopen tot individuele profilering en competitie met elkaar voor de schaarse opleidingsplaatsen.

De opmerkelijke afname in de waarneming van mogelijk praktijken van bevoordeling van mannelijke artsen, zou conform de inzichten van Benschop (1996), opgevat kunnen worden als een vorm van assimilatie aan de mythe van "gelijke kansen voor iedereen" en "sekseneutraliteit", die vaker wordt beschreven in organisaties. Maar ook andere optie, is mogelijk namelijk dat er daadwerkelijk sprake is van een afname van de bevoordelingen positieve discriminatie van mannelijk studenten.

De bevinding dat seksistische uitingen en denigrerende uitlatingen over vrouwen wel voorkomen en worden opgemerkt door co-assistenten in de setting van de kliniek, stemt tot nadenken. Ook in de literatuur werd hier de afgelopen hier aandacht aan besteed (Nickolson, 1993; Komaromy et al, 1993) en werd meer inzicht verschaft in de negatieve werking van dergelijke uitingen op aanstaande artsen. Het feit dat de spreker vaak geen vervelende bedoelingen heeft, doet helaas aan deze negatieve effecten niets af. Zeker een medische beroepsgroep kan zich op dit vlak geen incorrect gedrag veroorloven en moet zich van dergelijke uitingen onthouden.

In het licht van de wisselwerking tussen cultuur en identiteit is het verder interessant dat de discrepantie tussen zelfbeeld en ideaalbeeld op de mannelijke of instrumentele dimensie groot is en blijft. Bij beide seksen is dit het geval. De indruk ontstaat dat de mannelijke dimensie meer als ideaal functioneert dan de vrouwelijke dimensie in het persoonsarrangement van mannelijke co-assistenten.

Effecten van vroegere socialisatietrajecten in de genderrol van jongen of meisje, kunnen nog aangetroffen worden bij aspecten als het articuleren van behoefte aan steun en oriëntatie op beroepsaspecten als maatschappelijke status en inkomen. Socialisatie als vrouw leidt tot een lagere interne waardering voor status en inkomen dan socialisatie tot kostwinner die meer nog bij jongens wordt gestimuleerd.

De onderzochte aspecten van de professionele identiteit laten zien dat vrouwelijke coassistenten zich net als hun mannelijke collega's voorbereiden en plannen maken voor hun toekomstige loopbaan. De locus of control richting loopbaan blijkt evenmin verschillen tussen mannelijke en vrouwelijke co-assistenten te vertonen en verder ook in de tijd geen verandering te laten zien. Interessant is wel dat medische studenten een hoge score op interne locus of control vertonen en weinig toeschrijven aan toevalsfactoren ${ }^{5}$. Wij vermoeden dat hier sprake is van anticiperende socialisatie en dat personen die arts willen worden via een processen van (zelf)selectie een attitude van sterk vertrouwen op eigen kracht en eigen inzet vertonen. Een houding gebaseerd op een

'In de regressie-analyse blijkt dat de gevorderde studenten, nog minder dan hun jongere collega's, een rol voor het toeval zien weggelegd in de verdere opbouw van hun loopbaan. 
interne locus of control bevordert de ontwikkeling tot daadkrachtige en "self-supportive ${ }^{n}$ artsen, die als rots in de branding voor menigeen kunnen functioneren

\section{Methodische overwegingen}

In het transversale onderzoek was de respons goed (77\%). De onderzochte populatie co-assistenten vormt ongeveer $45 \%$ van de totale groep Maastrichtse co-assistenten en de groep onderzochte pre-co-assistenten of vierdejaars studenten vormt ongeveer $30 \%$ van deze populatie.

De respons in het longitudinale onderzoek is eveneens goed $(70 \%)$. Uit de non-res. pons analyse, die werd uitgevoerd bleek dat de uitval voor het grootste deel verklaard kan worden door het afstuderen van de betrokken co-assistenten tussentijds (tussen meting 1 en 2). Daardoor waren deze afgestudeerden moeilijker vindbaar door verhui. zing, veranderde werkkring en dergelijke. De co-assistenten in de non-responsgroep waren vaker vrouw, iets ouder en vaker samenwonend met partner en/of kind.

$\mathrm{Bij}$ het transversale onderzoek kon geen non-respons analyse worden uitgevoerd, waardoor selectie-bias niet geheel uitgesloten kunnen worden. Vrouwen zijn licht oververtegenwoordigd en lijken zich door dit onderzoek iets meer aangetrokken te hebben gevoeld. Omdat bij nagenoeg alle analyses werd gestratificeerd naar sekse, heeft deze oververtegenwoordiging zelden verstorend effect. Bovendien is in de multiple regressie analyse ook steeds voor andere relevante co-variabelen gecontroleerd. De scores op niveau van de totale groep zijn door de oververtegenwoordiging van vrouwen hierdoor enigszins beïnvloed.

\section{Generaliseerbaarbeid}

De bevindingen van dit onderzoek kunnen gegeneraliseerd worden naar Maastrichtse co-assistenten, maar om uitspraken te doen over de generaliseerbaarheid naar Nederlandse co-assistenten in het algemeen, moet de vraag beantwoord worden of studenten die geneeskunde studeren aan de Universiteit Maastricht niet afwijken van die aan andere universiteiten. Omdat de pre-doctoraal fase van de studie geneeskunde aan de Universiteit Maastricht anders is ingericht dan elders (probleemgestuurd en onderwijs in groepen) is het aannemelijk, dat Maastrichtse preco-assistenten wel sterk verschillen. Maar omdat de inrichting van de co-assistentschappen in Maastricht niet wezenlijk verschilt van die aan andere Nederlandse medische faculteiten, kunnen de bevindingen die betrekkingen hebben op veranderingen gedurende de fase van de klinische stages (de longitudinale bevindingen) naar alle waarschijnlijkheid wel worden generaliseerd naar Nederlandse co-assistenten in het algemeen. 


\subsection{Samenvatting}

Dit deel van het socialisatieonderzoek heeft de ontwikkeling van de professionele identiteit van co-assistenten en de mogelijke reproduktie van genderongelijkheid tot onderwerp. Deze processen vinden plaats gedurende de co-assistentschappen die het karakter dragen van onderdompeling in de cultuur van de gevestigde beroepsgroep (hoofdstuk 5 en 6). Deze onderdompeling beroert en verandert de verschillende lagen van het "zelf" waardoor een nieuwe identiteit ontstaat, die hier wordt aangeduid met de term professionele identiteit. Een van de belangrijkste bouwstenen van de identiteit is het geslacht van een persoon. In de ontwikkeling van de professionele identiteit speelt de sekse van de co-assistent een specifieke en eigen rol. Sekse is een sociaal construct met prototypische kenmerken die sociale interacties structureren, afhankelijk van de cultuur waarin ze spelen (Fischer et al, 1993). Ten behoeve van het onderzoek naar de probleemstelling "hoe verloopt de ontwikkeling van de professionele identiteit van co-assistenten en hoe de impliciete en expliciete werking van gender gedurende de co-assistentschappen, construeerden we een schema op basis van een combinatie van onderzoek van Bucher en Stelling (1977) en Benschop (1996) In dit schema werden zes verschillende thema's verwerkt die op hun beurt het empirisch onderzoek structureerden. De vraagstellingen naar de aard van de ervaringen, de verschillen tussen de seksen en veranderingen in de tijd werden per thema nader uitgewerkt. Bij het thema zelfevaluatie blijkt dat vrouwelijke co-assistenten meer dan hun mannelijke collega's in staat blijken om hun identificatie met de patiënt te handhaven naast een toenemende identificatie met de medische beroepsgroep. Verder blijkt de genderidentiteit van vrouwelijke co-assistenten bij entree in het beroepsveld sterk bekrachtigd te worden. Hiermee wordt impliciet het "anders zijn" van vrouwelijke artsen in de medische professie bekrachtigd, hetgeen op termijn integratie van vrouwen op hun eigen termen kan belemmeren. De seksegebonden praktijken ademen een zekere mate van ambivalentie ten aanzien van vrouwelijkheid in de medische professie en suggereren het bestaan een ideologie van sekse-neutraliteit en gelijke kansen voor de seksen in de geneeskunde. Het oordeel van co-assistenten over eventuele voorkeursbehandeling voor mannelijke artsen vertoont een collectieve verandering op dit punt. Het professioneel zelfvertrouwen van co-assistenten neemt toe en ontwikkelt zich voorspoedig in deze fase. Het concept van de ideale dokter van co-assistenten blijkt androgyn en wordt zowel mannelijk als vrouwelijk ingekleurd te worden. Maar het cultureel ideaal van de arts blijkt toch meer bekleed te zijn met mannelijke of instrumentele karakteristieken dan met feminiene of expressieve. Dit blijkt uit hoe het verschil tussen ideaalconcept en zelfbeeld zich in de loop van de tijd ontwikkelt; ten aanzien van de mannelijke dimensie blijft het verschil groot, bij de vrouwelijke dimensie niet. In de beroepsoriëntatie van co-assistenten vinden we de sporen terug van de geslachtsrol-socialisatie tot kostwinner van mannen. Mannelijke co-assistenten blijken daadwerkelijk sterker op maatschappelijke status, erkenning en inkomen georiënteerd te zijn dan hun vrouwelijke collega's. De geslachtsrolsocialisatie van vrouwen met accentuering op zorg en expressieve aspecten van het beroep wordt minder eenduidig bevestigd bij co-assistenten. Vrouwelijke co-assistenten lijken minder stereotype vrouwelijk dan mannen in de coschappen stereotype mannelijk zijn. 



\section{Hoofdstuk 11}

\section{De co-assistentschappen als broedstoof voor de professionele identiteit Samenhangen nader beschouwd}

\subsection{Inleiding}

Het proces van professionele socialisatie tot arts is, zoals we in de voorgaande hoofdstukken hebben gezien, een complex proces met veel facetten. We beschreven in dit proefschrift het onderzoek naar de pijn en moeite van het aanpassingsproces in het deel over stress en belasting en gingen in op diverse identiteit - en interactie-arrangementen, die in het socialisatieproces tot arts een rol spelen.

We hebben om inzicht te krijgen een aantal thema's onderscheiden aan het onderwerp professionele socialisatie zoals draaglast, draagkracht en outcome in termen van ervaren belasting en motivatie, die de zwaarte van het inwijdingsproces in beeld brengen. Daarna hebben we de ontwikkeling van de professionele identiteit bij de coassistenten bestudeerd aan de hand van thema's als identificatie, perceptie van seksegebonden praktijken, professioneel zelfvertrouwen, ideaalbeeld in relatie tot het zelfbeeld en oriëntatie op beroep en loopbaan.

In dit hoofdstuk zullen we de mogelijke samenhangen bestuderen die bestaan tussen de verschillende variabelen uit deze 9 verschillende thema's die betrekking hebben op het proces van professionele socialisatie.

De eerste vraagstelling betreft het professioneel zelfvertrouwen en luidt "welke variabelen zijn, binnen het raamwerk van de variabelen van het socialisatie-onderzoek, van invloed op het professioneel zelfvertrouwen en gevoel van competentie ?" 
Daarna zullen we ingaan op achtergrond van de perceptie van de seksegebonden prak. tijken, het bewustzijn van eigen sekse als aspect van genderidentiteit en oriëntatie op het medisch beroep. De vraag luidt "welke variabelen zijn, binnen het gekozen raamwerk van invloed op perceptie van seksegebonden praktijken, genderidentiteit en be roepsbeeld? " Als laatste komt aan de orde welke variabelen, binnen het gekozen raamwerk, het optreden van fysieke of psychische vermoeidheid en gebrek aan motivatie bij co-assistenten in de hand werken.

\section{Geoperationaliseerde vraagstellingen:}

A Welke variabelen spelen een rol bij de verklaring van de variantie van professioneel zelfvertrouwen en gevoel van competentie van co-assistenten ?

B Welke yariabelen spelen een rol bij de verklaring van de variantie van het bewustzijn van eigen sekse, de perceptie van seksegebonden praktijken en beeldvorming inzake het beroep?

C Welke variabelen spelen een rol bij de verklaring van de variantie van ervaren vermoeidheid en gebrek an motivatie?

Om vraagstelling A naar verklarende variabelen van professioneel zelfvertrouwen en gevoel van competentie te onderzoeken, werden de volgende afhankelijke variabelen ${ }^{1}$ als uitgangspunt genomen voor verdere analyse met behulp van multiple lineaire regressie:

zelfvertrouwen 1 twijfel aan eigen competentie

zelfvertrouwen 2 twiffel aan toegeschreven competentie

zelfvertrouwen 3 voldoen aan verwachtingen van patiënten (eigen inschatting)

zelfvertrouwen 4 zelfvertrouwen (positief zelfbeeld)

zelfvertrouwen's gebrek aan zelfvertrouwen (negatief zelfbeeld)

Vraagstelling B naar de variabelen, die van invloed zijn op gender-identiteit en seksegebonden praktijken die aan bod kwamen in het thema expliciet onderscheid naar sekse, werd beantwoord door de volgende variabelen verder te analyseren met behulp van multiple lineaire regressie: ${ }^{2}$

gender 1

gender 2

spot 3

gender 4

beroepsbeeld 1

beroepsbeeld 2 bewustzijn van eigen sekse

perceptie van voorkeur voor mannen

perceptie van spot over vrouwen

voorkomen (of ervaren) van ongewenste intimiteiten

belang gehecht aan maatschappelijke status en inkomen

geen voorkeur voor solistisch werken (maar in team en/of loondienst)

Vraagstelling C naar de variabelen die van invloed zijn op de motivatie en ervaren vermoeidheid bij co-assistenten, ook wel genoemd outcome van het inwijdingstraject

${ }^{1}$ Zie voor beschrijving van variabelen hoofdstuk 9

${ }^{2}$ Zie voor beschrijving van variabelen hoofdstuk 9 
genoemd, werd beantwoord door de volgende variabelen verder te analyseren middels multiple lineaire regressie:

vermoeidheid 1 psychische vermoeidheid

vermoeidheid 2 fysieke vermoeidheid

vermoeidheid 3 positieve gestemdheid

twiifel studie

(negatieve) motivatie

beroepsbeeld 4 inschatting van medisch beroep als niet zwaar

\subsection{Methode}

Uit het transversale onderzoek naar stress en ontwikkeling van de professionele identiteit werden de variabelen met een grote interne betrouwbaarheid geselecteerd. Daarnaast werd een aantal achtergrondvariabelen (te weten sekse, leeftijd, opleidingsniveau van ouders, al of niet een arts in de familie hebben, al of niet een extra paramedische opleiding (MBO, HBO, WO) gevolgd hebben, leefsituatie (wel of niet alleengaand) en al of niet begonnen zijn met de co-assistentschappen in de analyse betrokken.

Als eerste stap werd steeds een correlatiematrix gemaakt van elke afhankelijke variabele met alle andere variabelen. Vervolgens werden de variabelen die een significante correlatie ( $p$ kleiner of gelijk <0.05) vertoonden, in een lineair regressiemodel met elkaar in verband gebracht (regressie methode = stepwise; missing = listwise). Er werd gekozen voor de methodiek van de multiple lineaire regressie, omdat de afhankelijke variabelen dan niet gedichotomiseerd hoeven worden en dan minder informatie verloren gaat dan bij de logistische regressie.

Uiteraard werd steeds gecontroleerd of aan de voorwaarden van lineariteit en normaliteit was voldaan (door middel van probability plots).

Samenvattend: de regressie analyses zijn uitgevoerd met die variabelen, die in de bivariate analyse een significante correlatie vertoonden met de gekozen afhankelijke variabele. Per regressie-model staat steeds aangegeven welke variabelen als onafhankelijke zijn ingevoerd in het regressiemodel.

'Zie voor beschrijving van variabelen hoofdstuk 7 
Methodologische tekst en uitleg:

R: multipele correlatiecoëfficiënt

B: het gewicht dat wordt toegekend aan de onafhankelijke variabele om de regressielijn te kunnen berekenen. [Dus in dit geval ( $0.44^{*}$ psychische vermoeidheid $)+(-0.27$ * belasting) etc. - fysieke vermoeidheid (de afhankelijke variabele in dit geval)].

$\mathbf{R}^{\prime}$ in de tabel is ongecorrigeerd, terwiil de $\mathbf{R}^{2}$ adjusted wordt gehanteerd als gecorrigeerde maat voor totale verklaarde variantic.

Belangrijkste parameter in dit regressie-onderzoek is de $\mathrm{R}^{2}$ adjusted omdat er een groot antal onafhankelijke variabelen en een relatief kleine steekproef in de regressie-analyse zijn meegenomen. Rªdjus. ted wordt gebruikt om te corrigeren voor de overlap "verklaarde variantie" die ontstaat in de te verklaren variantie op het moment dat een nieuwe onafhankelijke variabele wordt toegevoegd aan het regressiemodel. De $\mathrm{R}^{2}$ wordt automatisch groter wanneer significante onafhankelijke variabelen aan het model worden toegevoegd. De F-toets wordt beschreven, omdat dit onderzoek veel predictoren bevat. Wanneer dit het geval is, heeft men ook meer t-toetsen verricht voor regressie-gewichten per variabele en is er meer kans op toevalstreffers. De F-toets wordt gebruikt als beschermende toets. Als de F-toets significant is, mag men ook de significante t-toetsen interpreteren.

\subsection{Overzicht van de variabelen}

\begin{tabular}{|c|c|}
\hline \multicolumn{2}{|c|}{ Achtergrondgegevens (8 variabelen) } \\
\hline sekse & $\mathrm{man} / \mathrm{vrouw}$ \\
\hline groep & wel of niet begonnen met de co-assistentschappen \\
\hline leeftijd & in jaren \\
\hline $\begin{array}{l}\text { opleiding vader en } \\
\text { opleiding moeder }\end{array}$ & 7-puntsschaal \\
\hline privé-situatie & wel of niet alleenlevend (zonder partner en/of kind(eren) \\
\hline arts in de familie & ja of nee \\
\hline vooropleiding & $\begin{array}{l}\text { wel of geen paramedische (verpleging of } \mathrm{HBO} \text { of WO- } \\
\text { opleiding) }\end{array}$ \\
\hline
\end{tabular}

Rolvoorbeelden (4 variabelen)

(wel of geen) rolvoorbld. wel of geen rolvoorbeelden hebben

(wel of geen) behoefte

wel of geen behoefte aan rolvoorbeelden

Beroepsidentiteit (8 variabelen)

vrouwelijk ideaalbeeld beeld van ideale arts gestoeld op vrouwelijke prototype ${ }^{4}$

vrouwelijk zelfbeeld mannelijk ideaalbeeld mannelijk zelfbeeld

zelfbeeld gestoeld op vrouwelijk prototype beeld van ideale arts gestoeld op mannelijk prototype zelfbeeld gestoeld op mannelijk prototype

' eigenschappen passend bij vrouwelijk prototype: spontaan, aantrekkelijk, tactvol, begrijpend, afhankelijk, zachtaardig, overgevoelig, emotioneel, attent, warm, gezellig, gevoelig, nieuwsgierig, zorgzam. eigenschappen passend bij mannelijk prototype: eerzuchtig, zelfverzekerd, logisch denken, dominant, rationeel, durf, methodisch, ambitieus, groot abstractievermogen, formeel, krachtig, joviaal. 
beroepsbeeld 1 beroepsbeeld 2

beroepsbeeld 3 beroepsbeeld 4 belang gehecht aan maatschappelijke status en inkomen voorkeur voor loondienst en werken in team (en niet als solist)

voorkeur voor relationele componenten van beroep inschatting van medisch beroep als niet zwaar (attributie)

Loopbaanplannen en locus of control (5 variabelen)

loopbaanplan

haalbaar

interne locus

externe locus

toeval locus bezig zijn met loopbaanplannen

haalbaarheid van loopbaanplannen (inschatting, attributie) interne locus of control ten aanzien van welslagen loopbaanplannen

externe locus of control ten anzien van welslagen loopbaanplannen

toeschrijven aan toeval als bepalend voor welslagen van loopbaanplannen

Professioneel zelfvertrouwen en competentie (S variabelen)

zelfvertrouwen 1 zelfvertrouwen 2 zelfvertrouwen 3

zelfvertrouwen 4 zelfvertrouwen 5 twijfel aan eigen) competentie

twijfel aan toegeschreven competentie

voldoen aan verwachtingen van patiënten (eigen inschatting)

zelfvertrouwen (positief "self-esteem")

geen zelfvertrouwen (negatief "self-esteem")

Genderidentiteit en cultuur ten aanzien van "onderscheid maken op grond van sekse (4 variabelen)

gender 1

gender 2

gender 3

gender 4

Draaglast (3 variabelen) spot 1

spot 2 richting patiënt spot 3 richting vrouw bewustzijn van eigen sekse

perceptie voorkeur voor mannen

perceptie van erotiserende atmosfeer

voorkomen (of ervaren) van ongewenste intimiteiten

spot ervaren door co-assistent

perceptie van spot richting patiënten

perceptie van spot richting vrouwen

Draagkracht (7 variabelen)

verschillende coping stijlen te weten:

coping 1

coping 2

coping 3

coping 4

coping 5 coping door actie en daadkrachtig naar oplossingen te zoeken

coping door het zoeken van sociale steun coping door palliatieve strategieën coping door depressief en vermijdende strategieën coping door uiten van gevoelens 
assertiviteit

examenvrees

Outcome (5 variabelen) vermoeidheid 1 vermoeidheid 2 vermoeidheid 3 twijfel studie beroepsbeeld 4 assertieve opstelling

mate van examenvrees psychische vermoeidheid fysieke vermoeidheid tegendeel van vermoeid, positief gestemd en energiek (negatieve) motivatie inschatting van medisch beroep als niet zwaar

\subsection{Resultaten op de vraagstelling A naar variabelen die het professionele zelfvertrouwen en gevoel van competentie kunnen verklaren}

Om deze vraag te beantwoorden zijn de variabelen uit het onderdeel "professioneel zelfvertrouwen" in een regressiemodel verder onderzocht. In de volgorde van zelfvertrouwen 1 tot en met 5 zullen we de vijf aspecten analyseren. Per variabele wordt eerst kort de uitkomst van het correlatie onderzoek gegeven, dat ten grondslag ligt aan het onderzochte regressiemodel per variabele. Het gevoel van competentie en de inschattingen van de co-assistent over de vraag of de omgeving haar of hem al enigszins serieus neemt als arts komen eerst aan de orde. We bezien of co-assistenten het gevoel hebben al reeds enigszins te kunnen voldoen aan de verwachtingen van patienten. De mate van zelfvertrouwen werd onderzocht met behulp van de "self-esteem" vragenlijst van Rosenbaum, die 2 componenten kent namelijk een positief zelfbeeld (zelfvertrouwen 4) en een negatief zelfbeeld (zelfvertrouwen 5).

\section{Twiffel aan eigen competentie (variabele zelfvertrouwen 1)}

Deze variabele vertoont een significante correlatie met de volgende variabelen:

zelfvertrouwen 2, zelfvertrouwen 3, zelfvertrouwen 4, zelfvertrouwen 5 , mannelijk zelfbeeld, subgroep, interne locus, externe locus, locus toeval, haalbaarheid loopbaanplannen, beroepsbeeld 1 , beroepsbeeld 4 , examenvrees, depressief-vermijdende coping, vermoeidheid 1 , vermoeidheid 2 , assertiviteit, actieve coping stijl, loopbaanplannen. Toen deze variabelen vervolgens in een regressiemodel werden ingevoerd ontstond het volgende beeld:

Tabel 11.1 Regressie-analyse van afhankelijke variabele twijfel aan eigen competentie (variabele "zelfvertrouwen 1")

\begin{tabular}{llll}
\hline & $\mathrm{R}^{2}$ & $\mathrm{~B}$ & $\mathrm{P}$ \\
\hline 1. zelfvertrouwen 5 (negatief selfesteem) & 0.41 & 0.31 & 0.000 \\
2. mannelijk zelfbeeld & 0.49 & -0.23 & 0.001 \\
3. beroepsbeeld 4 (niet zwaar) & 0.53 & -0.23 & 0.003 \\
4. zelfvertrouwen 2 & 0.56 & 0.19 & 0.008 \\
5. zelfvertrouwen 3 & 0.59 & -0.17 & 0.011 \\
\hline
\end{tabular}

$\mathrm{F}(5,103)-28.8, \mathrm{p}<0.000 ; \mathrm{R}^{2}=.59, \mathrm{R}^{2}$ adj. $=0.57$ 
Uit deze analyse blijkt dat $57 \%\left(\mathrm{R}^{2}\right.$ adj.) van de variantie van de variabele twijfel aan eigen competentie verklaard door vijf variabelen. De grootste impact heeft een negatief zelfbeeld oftewel het ontbreken van zelfvertrouwen, deze variabele neemt $41 \%$ van de gebonden variantie voor zijn rekening. Het ontberen van een mannelijk zelfbeeld en de inschatting van het medisch beroep als een zware dobber (beroepsbeeld 4) blijken eveneens de twijfel aan de eigen competentie te versterken (12\% additionele verklaring van de variantie). Een kleine bijdrage wordt nog geleverd door twijfel aan toegeschreven competentie en een gevoel bij de co-assistent niet voldoende te kunnen voldoen aan de verwachtingen van de patiënt.

Twijfel aan toegeschreven competentie (variabele zelfvertrouwen 2)

Deze variabele die de attributies onderzoekt van de co-assistent over hoe zij of hij wordt gezien door de omgeving in de medische beroepsrol, vertoont significante correlaties met de volgende variabelen:

zelfvertrouwen 1, spot 1 , vermoeidheid 1 en 2 , coping stijl 4 (depressief-vermijdend,) geen coping 1, (gebrek aan) assertiviteit, (gebrek aan) mannelijk zelfbeeld, geen belang an status (- beroepsbeeld 1), medisch beroep zien als zwaar (= beroepsbeeld 4 ), voorkeur voor loondienst (- beroepsbeeld 2), examenvrees, (geen) loopbaanplannen hebben en haalbaarheid van loopbaanplannen laag inschatten, zelfvertrouwen 4 en 5 , loopbaansucces toeschrijven aan toeval (locus), twijfel studie, alleenlevend in privésituatie.Toen deze variabelen vervolgens in een regressiemodel werden ingevoerd ontstond het volgende beeld:

Tabel 11.2 Regressie-analyse van afhankelijke variabele twijfel aan toegeschreven competentic (variabele zelfvertrouwen 2)

\begin{tabular}{llll}
\hline & $\mathrm{R}^{2}$ & $\mathrm{~B}$ & $\mathrm{P}$ \\
\hline 1. twijfel studie & 0.21 & 0.26 & 0.001 \\
2. spot 1 & 0.30 & 0.27 & 0.001 \\
3. toeval (locus) & 0.35 & 0.19 & 0.014 \\
4. beroepsbeeld 2 & 0.39 & 0.19 & 0.009 \\
5. zelfvertrouwen 1 & 0.42 & 0.20 & 0.014 \\
\hline
\end{tabular}

$F(5,115)=16.6, p<0.000 ; R^{2}$ adj. $=0.39$

De attributie of inschatting van co-assistenten over de vraag of de omgeving hun in de rol van arts serieus neemt, blijkt voor $39 \%$ verklaard te kunnen worden door 5 variabelen. Motivatie verklaart $21 \%$ van variantie en verder blijkt ook de ervaring van spot en denigrerende benadering als co-assistent de twijfel en onzekerheid over de toegeschreven competentie in de hand te werken. Verder speelt het patroon "toeschrijven van het slagen van de loopbaanplannen aan het toeval" (locus toeval) nog een rol in dit opzicht alsmede een beroepsbeeld met voorkeur voor loondienst en "teamwork". Tot slot blijkt dat wanneer een co-assistent zelf onzeker is en twijfelt aan de eigen bekwaamheid (zelfvertrouwen 1), deze ook twijfel hierover bij de omgeving vermoedt. Gebrek aan motivatie voor de medische studie blijkt dus ook in dit geval de belangrijkste factor te zijn. 


\section{Voldoen aan patiênt-verwachtingen (zelfvertrouwen 3)}

Deze variabele, die betrekking heeft op de inschatting van de co-assistent over de "efficacy" van het eigen handelen richting patiënt (De Vries, 1988) en het voldoen aan diens verwachtingen, vertoont significante correlaties met de volgende variabelen: mannelijk zelfbeeld, privésituatie, vrouwelijk zelfbeeld, zelfvertrouwen 1, 4 en 5, interne locus, inschatting haalbaar, perceptie spot patiënt, beroepsbeeld 4, assertiviteit, het hebben van loopbaanplannen).

Toen deze variabelen vervolgens in een regressiemodel werden ingevoerd ontstond het volgende beeld:

Tabel 11.3 Regressie-analyse van afhankelijke variabele voldoen aan patiënt-verwachtingen (variabele "zelfvertrouwen 3")

\begin{tabular}{llll}
\hline & $R^{2}$ & $B$ & $P$ \\
\hline 1. zelfvertrouwen 1 (twijfel) & 0.20 & 0.34 & 0.000 \\
2. vrouwelijk zelfbeeld & 0.29 & 0.29 & 0.001 \\
3. assertiviteit & 0.33 & 0.22 & 0.009 \\
4. perceptie spot patiènt & 0.38 & -0.21 & 0.010 \\
\hline
\end{tabular}

$\mathrm{F}(4,99)=14.8, \mathrm{p}<0.000 ; \mathrm{R}^{2}$ adj. $=0.35$

De inschatting van de mate waarin co-assistenten voldoen aan de verwachtingen van de patiënt, blijkt voor $35 \%$ verklaard te worden door 4 variabelen. Wanneer coassistenten niet twijfelen aan hun eigen competentie, ze een vrouwelijk zelfbeeld hebben, bovendien assertief zijn en slechts weinig grapjes over patiënten opmerken, dan is de kans groot dat ze van zichzelf het idee hebben, dat ze reeds iets voor patiënten kunnen betekenen.

\section{Zelfvertrouwen en positief professioneel zelfbeeld (zelfvertrouwen 4)}

Deze variabele vertoont significante correlatie zijn de volgende variabelen: actieve coping stijl, assertiviteit, beroepsbeeld 4, zelfvertrouwen 2, depressief vermijdend, beroepsbeeld 1, examenvrees, vermoeidheid 1 en 2, haalbaar, interne locus, mannelijk zelfbeeld, zelfvertrouwen 5 , vermoeidheid 3 , zelfvertrouwen 3 , spot, zelfvertrouwen 2 , toeval locus, twijfel studie, coping $5=$ uiten ergernis, loopbaanplannen). Toen deze variabelen vervolgens in de regressie-analyse werden ingevoerd ontstond het volgende beeld:

Tabel 11.4 Regressie-analyse van afhankelijke variabele positief zelfbeeld (variabele "zelfvertrouwen 4")

\begin{tabular}{llll}
\hline & $\mathrm{R}^{2}$ & $\mathrm{~B}$ & $\mathrm{p}<$ \\
\hline 1. twijfel studie (negatieve motivatie) & 0.30 & -0.23 & 0.009 \\
2. interne locus & 0.43 & 0.23 & 0.005 \\
3. vermoeidheid 3 (positief) & 0.48 & 0.24 & 0.003 \\
4. zelfvertrouwen 3 & 0.52 & 0.19 & 0.006 \\
5. zelfvertrouwen 2 & 0.54 & -0.17 & 0.027 \\
6. mannelijk zelfbeeld. & 0.56 & 0.16 & 0.036 \\
\hline
\end{tabular}

$\mathrm{F}(21,100)=21.6, \mathrm{p}<0.000 ; \mathrm{R}^{2}=.56, \mathrm{R}^{2}$ adj. $=0.54$ 
Een positief zelfbeeld blijkt voor $54 \%$ ( $\mathrm{R}^{2}$ adj.) bepaald te worden door 6 variabelen. $30 \%$ van de variantie wordt verklaard worden door motivatie voor de studie; het ontbreken van twijfels over de medische studie blijkt ook in dit geval van groot belang. Verder blijkt een interne locus of control over het slagen van de eigen loopbaanplannen van belang, naast een positieve gestemdheid, als tegenwicht van fysieke of psychische vermoeidheid. Ook blijken twee eerder besproken parameters van professioneel zelfvertrouwen, namelijk de inschatting te kunnen voldoen aan de verwachtingen van de patiënt en een positieve inschatting over de competentie die de co-assistent wordt toegedicht vanuit de omgeving, het zelfvertrouwen positief te beinvloeden. Tot slot blijkt een mannelijk zelfbeeld het professionele zelfvertrouwen te stimuleren.

\section{Geen zelfvertrouwen of negatief professioneel zelfbeeld (zelfvertrouwen 5)}

Deze variabele blijkt met de volgende variabelen een significante correlatie te vertonen: actieve coping stijl, assertiviteit, beroepsbeeld 4, zelfvertrouwen 2, coping 4 (depressief-vermijdend), gender 2, examenvrees, vermoeidheid 1,2 en 3, haalbaar, interne locus, mannelijk zelfbeeld, zelfvertrouwen 1,3 en 4 , gender 1 , spot, toeval locus, twijfel studie, privé-situatie). Toen deze variabelen vervolgens in een regressiemodel werden ingevoerd ontstond het volgende beeld:

Tabel 11.5 Regressie-analyse van de afhankelijke variabele negatief zelfbeeld (variabele "zelfvertrouwen 5")

\begin{tabular}{llll}
\hline & $\mathrm{R}^{2}$ & $\mathrm{~B}$ & $\mathrm{P}$ \\
\hline 1. twijfel studie (negatieve motivatie) & 0.55 & 0.52 & 0.0000 \\
2. zelfvertrouwen 2 & 0.63 & 0.29 & 0.0001 \\
3. psychische vermoeidheid & 0.65 & 0.15 & 0.048 \\
\hline
\end{tabular}

$\mathrm{F}(3,95)=57,6 \mathrm{p}<0.000 ; \mathrm{R}^{2}$ adj. $=0.63$

Een negatief zelfbeeld blijkt eveneens voor $63 \%$ verklaard te kunnen worden door drie variabelen waarvan motivatie voor de studie reeds $55 \%$ bepaalt. Met andere woorden wanneer een co-assistent geplaagd wordt door twijfel aan de studie, deze ook twijfelt aan het beeld dat de omgeving van haar of hem heeft als aanstaand arts. Als er als dan ook nog sprake is van psychisch belasting, dan is de kans op een negatief zelfbeeld groot voor een medisch student in de context van de klinische stages.

\subsection{Resultaten regressie-analyse vraagstelling B naar variabelen, die genderidentiteit en perceptie van seksegebonden praktijken verklaren.}

Om deze vraag te kunnen beantwoorden hebben we een aantal variabelen nader bestudeerd. Allereerst hebben we de aandacht gericht op de mate waarin de co-assistent zich bewust is van de eigen sekse in de context van de co-assistentschappen (gender-identiteit). Ook de perceptie van seksegebonden praktijken zoals een eventuele voorkeur voor mannelijke beroepsbeoefenaren, ongewenste intimiteiten en spot over vrouwen of hun lichamelijkheid (gender 2 , gender 3 en spot 3 ) komen aan de orde. 
Verder zijn twee beroepsbeelden onder de loep genomen, die deels als complementaire uitwerkingen van onderliggende driffveren voor het medisch beroep opgevat kunnen worden (beroepsbeeld 1 en 2).

\section{Genderidentiteit}

Zich bewustzijn van de eigen sekse en hieraan herinnerd worden, de genderidentiteit, vertoont een significante correlatie met de volgende variabelen privé-situatie, wel of niet begonnen zijn met de co-assistentschappen (groep), sekse, vrouwelijk zelfbeeld, negatief zelfbeeld, gender 4, gender 2, spot, perceptie spot patiënt, perceptie spot vrouwen, coping 2 (-sociale steun), coping 3 (- palliatief)

Tabel 11.6 Regressie-analyse van afhankelijke variabele "gender-identiteit" (variabele "gender" 1)

\begin{tabular}{llll}
\hline & $\mathrm{R}^{2}$ & $\mathrm{~B}$ & $\mathrm{P}$ \\
\hline 1. sekse & 0.20 & 0.41 & 0.000 \\
2. perceptie spot patiënt & 0.30 & 0.19 & 0.016 \\
3. perceptie spot vrouwen & 0.35 & 0.24 & 0.002 \\
4. zelfvertrouwen 5 & 0.39 & 0.17 & 0.015 \\
5. groep & 0.41 & 0.17 & 0.020 \\
\hline
\end{tabular}
$\mathrm{F}(5,125)=17.6, \mathrm{p}<0.000 ; \mathrm{R}^{2}=.41, \mathrm{R}^{2}$ adj $=0.39$

Zich bewust zijn van de eigen sekse en hierop aangesproken worden, wordt voor $39 \%$ verklaard door 5 onafhankelijke variabelen (zie tabel). Vrouwelijke sekse verklaart $20 \%$ van de variantie. Verder blijkt een verband te bestaan met het beluisteren van spot over patiënten en vrouwen en met een negatief zelfbeeld. Tot slot blijkt de factor van "al of niet begonnen zijn met de co-assistentschappen" van invloed, in die zin dat het betreden van de klinische setting het bewustzijn van de eigen sekse versterkt. Samenvattend blijkt ook uit deze analyse dat de vrouwen in de kliniek bekrachtigd worden wat betreft hun sekse en met name bij de entree in de beroepswereld aan hun vrouw-zijn worden herinnerd.

\section{Perceptie van voorkeur voor mannen}

De perceptie van een mogelijke voorkeur in de medische professie voor mannen (gender 2) blijkt een correlatie te vertonen met de volgende variabelen: vrouwelijke sekse, zelfvertrouwen 5, gender 4, toeval locus, gender 1, perceptie spot over vrouwen, vermoeidheid $1 \&$ 2.) 
Tabel 11.7 Regressie-analyse van afhankelijke variabele "perceptie van voorkeur voor mannen" (variabele "gender 2"

\begin{tabular}{llll}
\hline & $\mathrm{R}^{2}$ & $\mathrm{~B}$ & $\mathrm{P}$ \\
\hline 1. perceptie spot vrouw & 0.09 & 0.22 & 0.002 \\
2. sekse & 0.15 & 0.24 & 0.001 \\
3. interne locus & 0.18 & 0.30 & 0.000 \\
4. toeval locus & 0.23 & 0.23 & 0.003 \\
5. vermoeidheid 1 & 0.26 & 0.18 & 0.015 \\
\hline
\end{tabular}

$F(5,159)=10.9, P<0.000 ; R^{2}=.26, R^{2}$ adj $=0.23$

De perceptie van een eventuele voorkeur voor mannelijk co-assistenten of artsen in de context van de klinische stages, blijkt voor $23 \%$ verklaard te worden door 5 variabelen (zie tabel 11.7). Vrouwelijke sekse en gevoel van psychische vermoeidheid blijken deze perceptie in de hand te werken, naast bepaalde attributiestijlen ten aanzien van het welslagen van de eigen loopbaan ${ }^{1}$. Ook blijkt perceptie van voorkeur voor mannen samen te hangen met het beluisteren van spot over vrouwen en haar lichaam.

Het ervaren van ongewenste intimiteiten"

Deze variabele vertoont een significante correlatie met de variabelen: sekse, gender 3, gender 1,perceptie spot over vrouwen).

Tabel 11.8 Regressie-analyse van afhankelijke variabele "ervaren van ongewenste intimiteiten" (variabele "gender 4")

\begin{tabular}{llll}
\hline & $R^{2}$ & $B$ & $P$ \\
\hline 1. perceptie spot over vrouw & 0.09 & 0.20 & 0.007 \\
2. sekse & 0.14 & 0.22 & 0.003 \\
3. gender 3 & 0.16 & 0.15 & 0.042 \\
\hline
\end{tabular}

$\mathrm{F}(3,175)=11.2, \mathrm{P}<0.000 ; \mathrm{R}^{2}=.160, \mathrm{R}^{2}$ adj. $=0.146$

Het ervaren van ongewenste intimiteiten blijkt voor slechts voor $15 \%$ verklaard te worden. De drie variabelen zijn vrouwelijk sekse, het beluisteren van spot over vrouwen in de klinische omgevingen en het waarnemen een erotiserende atmosfeer.

\section{Perceptie van spot over vrouwen of haar lichamelijkheid}

Deze variabele vertoont een significante correlatie met: ontbreken van vrouwelijk ideaalbeeld, spot 1 en 2, gender 1,2 en 3, vermoeidheid 2 .

\footnotetext{
1* Interessant is de bevinding dat perceptie van voorkeur voor mannen wel samenhangt met toeschrijven van loopbaansucces aan eigen inspanningen (interne locus) en ook met toeschrijven aan toevalsfactoren, maar niet met toeschrijven van loopbaansucces aan "machtige anderen" (d.i. externe locus). Hierbij dient men zich te realiseren dat "machtige anderen" in de medische professie vooralsnog grotendeels mannelijk zijn.
} 
Tabel 11.9 Regressie-analyse van afhankelijke variabele "perceptie van spot over vrouwen " (variabele "spot 3")

\begin{tabular}{llll}
\hline & $\mathrm{R}^{2}$ & $\mathrm{~B}$ & $\mathrm{P}$ \\
\hline spot 2 (richting patiënt) & 0.14 & 0.27 & .000 \\
gender 4 & 0.21 & 0.26 & .000 \\
gender 2 & 0.27 & 0.24 & .001 \\
privé & 0.29 & -0.21 & .007 \\
extra-vooropleiding & 0.31 & 0.17 & .027 \\
fem. ideaal & 0.34 & -0.16 & .030 \\
\hline
\end{tabular}

$\mathrm{F}(6,130)=11.2, \mathrm{p}<0.000 ; \mathrm{R}^{2}=.34, \mathrm{R}^{2}$ adj. $=0.31$

Het waarnemen van spot richting vrouwen wordt voor $31 \%$ verklaard door 6 variabelen. Als eerste blijkt een duidelijke samenhang met een andere variabele over spot namelijk het percipiëren van spot richting patiënten. Verder blijkt de ervaring van ongewenste intimiteiten en het waarnemen van een voorkeur voor mannelijk beroepsbeoefenaren de kans op het beluisteren van spot te vergroten. Ook de privé-situatie blijkt verder van belang in die zin dat alleenstaand en ongebonden zijn de perceptie van spot richting vrouwen verhoogt evenals het reeds een andere vooropleiding doorlopen hebben. Tot slot blijkt het ontbreken van een vrouwelijk-ideaalbeeld de kans op het waarnemen van spot over vrouwen te verhogen.

\section{Beroepsbeeld 1}

Een beroepsbeeld waarin maatschappelijke erkenning, status en inkomen een grote rol spelen, blijkt met de volgende variabelen een significante samenhang te vertonen: mannelijk ideaalbeeld, mannelijk zelfbeeld, sekse, zelfvertrouwen 1, zelfvertrouwen 4, interne locus, externe locus, haalbaar, beroepsbeeld 2, beroepsbeeld 4, assertiviteit, coping stijl 1 (actief), coping 5 (uiten ergernis), loopbaanplannen.)

Uit regressie- analyse kwam het volgende beeld naar voren:

Tabel 11.10 Regressie-analyse van afhankelijke variabele "beroepsbeeld met accent op inkomen en maatschappelijke status" (variabele beroepsbeeld 1).

\begin{tabular}{llll}
\hline & $\mathrm{R}^{2}$ & $\mathrm{~B}$ & $\mathrm{p}$ \\
\hline 1. mannelijk zelfbeeld & 0.20 & 0.30 & 0.000 \\
2. sekse & 0.26 & -0.25 & 0.000 \\
3. loopbaanplannen & 0.31 & 0.17 & 0.024 \\
4. externe locus & 0.35 & 0.22 & 0.001 \\
5. haalbaar & 0.37 & 0.17 & 0.036 \\
\hline
\end{tabular}

$\mathrm{F}(5,145)=22.1, \mathrm{p}<0.000 ; \mathrm{R}^{2}=0.37 \%, \mathrm{R}^{2}$ adj. $=0.36 \%$

Een beroepsbeeld waarin maatschappelijke erkenning, status en inkomen een grote rol spelen blijkt voor $36 \%$ te worden verklaard uit vijf variabelen: een mannelijk zelfbeeld, waarin eigenschappen als eerzucht, zelfverzekerdheid, logisch denken, dominantie, durf, methodische en rationele aanpak, ambitie en abstractievermogen een rol spelen. Daarnaast blijken ook mannelijke sekse en het bezig zijn met planning voor de eigen loopbaan van belang naast een positieve inschatting van de haalbaarheid van 
deze plannen en een attributiepatroon, waarbij het slagen van plannen afhankelijk wordt ge(d)acht van machtige anderen, bij de verklaring van een beroepsbeeld waarin het kostwinners-perspectief duidelijk doorklinkt (zie tabel 11.10)

Om de vorige variabele van enig reliëf te voorzien wordt hier ook de regressie-analyse vermeld van de afhankelijke variabele beroepsbeeld 2, die als enigszins complementair an de vorige kan worden opgevat. Deze variabele betreft de voorkeur voor het werken in een team en in loondienst en tegenzin ten aanzien van een solistische beroepsuitoefening.

\section{Beroepsbeeld 2}

Een significante correlatie bestaat met de volgende variabelen:

vrouwelijk ideaalbeeld, vrouwelijk zelfbeeld, zelfvertrouwen 2 , beroepsbeeld 1 , beroepsbeeld 4 , assertiviteit.

Tabel 11.11 Regressie-analyse afhankelijke variabele "beroepsbeeld met accent op loondienst en teamwork" (variabele beroepsbeeld 2)

\begin{tabular}{llll}
\hline & $\mathrm{R}^{2}$ & $\mathrm{~B}$ & $\mathrm{P}$ \\
\hline 1. vrouwelijk ideaalbeeld & 0.06 & 0.20 & 0.010 \\
2. beroepsbeeld 1 & 0.10 & -0.19 & 0.015 \\
3. artsen in familie & 0.14 & 0.21 & 0.005 \\
4. beroepsbeeld 4 & 0.17 & -0.18 & 0.020 \\
\hline
\end{tabular}

$F(4,137)=8.0 p<0.000 ; R^{2}=0.17, R^{2}$ adj. $=0.15$

Slechts $15 \%$ van de variantie kan verklaard worden (zie tabel 11.11). Dat wil zeggen dat, hoewel de voorspelling significant is, deze toch zwak is. Een vrouwelijk ideaalbeeld en een arts in de familie hebben blijken verklarende factoren te zijn. Daarnaast speelt het ontbreken van belang hechten aan maatschappelijke erkenning en inkomen een rol van betekenis in de verklaring van dit type beroepsbeeld, evenals de inschatting van het medisch beroep als zwaar en veeleisend. Opmerkelijk is de bevinding dat het hebben van een arts in de familie de kans op een voorkeur voor solistisch werken verkleint en de voorkeur voor loondienst en "teamwork" vergroot. ${ }^{2}$

\subsection{Resultaten regressie-analyse vraagstelling $\mathrm{C}$ naar variabelen, die de mate van ervaren spot, vermoeidheid en motivatie verklaren.}

Om meer inzicht te verkrijgen in kenmerken van co-assistenten die het risico lopen om in de fase van de klinische stages veel stress of belasting te ervaren hebben we een aantal variabelen op dit vlak verder onderzocht. Omdat het volgen van co-assistentschappen ook een vorm van inwijding is en soms gepaard gaat ervaringen van spot en denigrerende benadering zullen we ook bij deze aspecten stilstaan. Ervaringen op dit

\footnotetext{
${ }^{2}$ Dit roept de vraag op of co-assistenten die omdat zij artsen in de familie hebben (denk aan kinderen uit doktersgezinnen) een alledaagse realiteit van het artsenberoep kennen hetgeen mogelijk sterker motiveert voor loondienst en demotiveen voor het vrije beroep.
} 
terrein werden ook door middel van open vragen onderzocht (zie hfst. 8). Hoewel coassistenten gemiddeld aangeven deze ervaring nauwelijks te hebben in de klinische setting, is het zinnig meer zicht te krijgen op de factoren die de kans op deze ervaring vergroten.

Ook hebben we in hoofdstuk 7 een denkmodel geintroduceerd waarin vermoeidheid en motivatie werden opgevat als resultaat van de balans tussen draaglast en draagkracht. Het is interessant om met behulp van vervolganalyses te bestuderen hoe de samenhang is tussen draaglast, draagkracht en resulterende vermoeidheid en motivatie. We zullen vooral de aandacht richten op de relatie tussen draagkracht en "outcome" als vermoeidheid en motivatie. Draagkracht werd geoperationaliseerd in stijlen van omgaan met problematische situaties of coping stijlen, mate van assertiviteit en examenvrees.

Naast "outcome" in termen van vermoeidheid en motivatie, bestaat er ook een "outcome" in termen van een bepaalde inschatting van de zwaarte van het medische beroep. Ook deze attributie reflecteert iets van de ervaren "burden" of last, die de confrontatie met de medische beroepcultuur mogelijkerwijs met zich meebrengt.

We zullen antwoord zoeken op de vraag naar de samenhang tussen draagkracht en de outcome in termen van vermoeidheid en motivatie.

Ervaring van spot en denigrerende opmerkingen als co-assistent

Deze variabele vertoont een significante correlatie met de volgende variabelen: spot 2 (spot richting patiënten), spot 3 (spot richting vrouwen), coping 4 (depressief vermijdende coping stijl), coping 1 (geen actieve coping stijl) vermoeidheid 1, 2 en 3, en twijfel aan de studie, gender 1 en gender 3, zelfvertrouwen 5, geen 4 zelfvertrouwen 2, locus toeval, geen interne locus, behoefte aan rolvoorbeelden, dokter in de familie. Deze variabelen werden vervolgens in een regressiemodel ingevoerd, hetgeen het volgende beeld oplevert (zie tabel 11.12).

Tabel 11.12 Regressie-analyse van de afhankelijke variabele "ervaring van denigrerende benadering als co-assistent" (variabele "spot 1")

\begin{tabular}{llll}
\hline & $\mathrm{R}^{2}$ & $\mathrm{~B}$ & $\mathrm{P}$ \\
\hline zelfvertrouwen 2 & 0.18 & 0.37 & 0.000 \\
spot richting patiënten & 0.14 & 0.14 & 0.007 \\
gender 3 (perceptie erot.sfeer) & 0.24 & 0.16 & 0.037 \\
gender 1 (genderidenteit) & 0.26 & 0.16 & 0.034 \\
\hline
\end{tabular}

$\mathrm{F}(4,135)=12.24, \mathrm{p}<0.000 ; \mathrm{R}^{2}=26 \%, \mathrm{R}^{2} \mathrm{adj} .=0.26$

Het zelf ervaren van spot wordt voor $26 \%$ verklaard door vier variabelen namelijk twijfel over de bekwaamheid die de omgeving an de co-assistent toeschrijft, het percipiëren van spot aan het adres van patiënten evenals het registreren van een erotiserende atmosfeer in de klinische setting. Ook blijkt tot slot het bewustzijn een vrouw te zijn, aspect van genderidentiteit, de kans op de ervaring van denigrerende bejegening te vergroten. 
Uit het correlatie-onderzoek blijkt dat de vijf variabelen van "outcome" veel samenhang onderling vertonen (zie tabel 11.13). De variabelen fysieke en psychische vermoeidheid vertonen zeer sterke onderlinge samenhang $(r=0.59)$. De variabele "positieve gestemdheid of ervaring van positieve gevoelens", inhoudelijk het tegendeel van psychische en fysieke vermoeidheid, geeft een correlatie met beide van respectievelijk $\mathrm{r}=0.46$ en 0.39 . Ook de variabele twijfel aan studie, die wijst op negatieve motivatie en de variabele beroepsbeeld 4, die een relativerende opvatting van de zwaarte van het medisch vak behelst, vertonen sterke samenhang met de variabelen van vermoeidheid. Verder valt op dat de vijf outcome parameters van belasting ook samenhangen met een depressief vermijdende stijl van coping en met gebrek aan professioneel zelfvertrouwen zoals twijfel aan eigen competentie.

Tabel 11.13 Correlaties $(r>0.35)$ tussen de outcome-variabelen $(x$-as) van vermoeidheid en motivatie $(x-2 s)$ en de overige variabelen ( $y$-as)

\begin{tabular}{|c|c|c|c|c|c|}
\hline variabelen- & $\begin{array}{l}\text { fysieke } \\
\text { vermoeidheid }\end{array}$ & $\begin{array}{l}\text { prych. } \\
\text { vermoeidheid }\end{array}$ & positief & $\begin{array}{l}\text { rwiffel } \\
\text { studie }\end{array}$ & $\begin{array}{l}\text { beroepsbeeld } 4 \\
\text { (zwaar beroep) }\end{array}$ \\
\hline fy. vermoeidheid & $1 . \infty$ & 0.59 & .0 .39 & 0.39 & 0.44 \\
\hline prych. vermoeidheid & 0.59 & 1.00 & 0.46 & 0.55 & -0.44 \\
\hline pos. getemd & 0.39 & 0.46 & $1 . \infty$ & & 0.37 \\
\hline twiffel an studie & 0.39 & 0.55 & 0.45 & 1.00 & 0.46 \\
\hline rwat beroep & -0.44 & -0.44 & 0.37 & 0.46 & $1 . \infty$ \\
\hline zelfvertrouwen (pos. zelfbeeld) & -0.35 & 0.38 & 0.53 & 0.45 & \\
\hline geen zelfvertrouwen (neg. zelfbeeld) & 0.41 & 0.56 & 0.67 & 0.51 & \\
\hline depressief-vermijdende coping & 0.42 & -0.58 & -0.45 & 0.54 & 0.39 \\
\hline zen zelfvertrouwen (twijfel competentie) & 0.41 & 0.37 & 0.55 & & \\
\hline mannelijk zelfbeeld & 0.35 & & & & \\
\hline haalbaar loopbaan & 0.45 & & & & \\
\hline rolvoorbeelden willen & 0.46 & 0.45 & -0.64 & & \\
\hline
\end{tabular}

Vervolgens zullen we het regressie model beschrijven van psychische vermoeidheid, fysieke vermoeidheid en twijfel aan studie als indicator van motivatie.

Tabel 11.14 Regressie-analyse van afhankelijke variabele "psychische vermoeidheid" (variabele vermoeidheid 1)

\begin{tabular}{llll}
\hline & $\mathrm{R}^{2}$ & $\mathrm{~B}$ & $\mathrm{P}$ \\
\hline 1. coping 4 (depressief/vermijdend) & 0.35 & 0.27 & 0.000 \\
2. vermoeidheid 2 (fysiek) & 0.51 & 0.36 & 0.000 \\
3. twijfel aan studie & 0.55 & 0.27 & 0.000 \\
4. coping 1 (actieve) & 0.57 & -0.18 & 0.005 \\
5. spot 2 t.a.v. patiënt & 0.59 & 0.15 & 0.019 \\
\hline
\end{tabular}

$\mathrm{F}(5,128)=33.9, \mathrm{p}<0.000 ; \mathrm{R}^{2}=59 \%, \mathrm{R}^{2} \mathrm{adj} .=0.57$

Uit de tabel blijkt dat de mate van psychische vermoeidheid voor $57 \%$ wordt verklaard door 5 variabelen. De grootste impact heeft een depressief vermijdende coping stijl (35\%). Het ervaren van fysieke of lichamelijke vermoeidheid voegt hieraan nog eens $16 \%$ toe. De resterende $8 \%$ variantie blijkt verklaard te worden door gebrek aan 
motivatie (of twijfel aan studie), het ontbreken van een actieve coping stijl en het beluisteren van spot over patiënten.

Bij bestudering van het regressiemodel van fysieke vermoeidheid vragen wij ons af of deze bevindingen consistent zijn met bovenstaand beeld of dat nog nieuwe inzichten ontstaan.

Tabel 11.15 Regressie-analyse van afhankelijke variabele "fysieke vermoeidheid" (variabele vermoeidheid 2).

\begin{tabular}{llll}
\hline & $\mathrm{R}^{2}$ & $\mathrm{~B}$ & $\mathrm{P}$ \\
\hline 1. vermoeidheid 1 (psychisch) & 0.37 & 0.44 & 0.000 \\
2. beroepsbeeld 4 & 0.43 & -0.27 & 0.000 \\
3. sekse $(\$)$ & 0.47 & 0.17 & 0.006 \\
4. groep & 0.50 & 0.18 & 0.004 \\
5. externe locus & 0.51 & 0.13 & 0.035 \\
\hline
\end{tabular}

$\mathrm{F}(5,132)=28.0, \mathrm{p}<0.000 ; R^{2}$ adj. -0.49

De regressie-analyse van de variabele fysieke vermoeidheid maakt duidelijk dat deze voor het grootste deel bepaald wordt door psychische vermoeidheid $(37 \%)$. Nieuw is dat nog $8 \%$ van de verklaarde variantie wordt toegevoegd door het "ontbreken van een relativerend beroepsbeeld". Dit roept overigens wel de vraag naar kip of ei of oorzaak en gevolg op; wat was er het eerst uitputting ot hooggespannen idẻalèn ten aanzien van het medische beroep.

Ook vrouwelijke sekse en net begonnen zijn met de co-assistentschappen blijken ook fysieke vermoeidheid te verklaren (hetgeen consistent met de literatuur is) naast een externe locus of control.

\section{Twijfel aan studie of negatieve motivatie}

Deze variabele vertoont een significante correlatie met de volgende variabelen: coping 1 (actief), coping 4 (depressief-vermijdend, assertiviteit, beroepsbeeld 4, zelfvertrouwen 1,4 en 5 , examenvrees, vermoeidheid 2 en 3, groep, haalbaar, interne locus, locus toeval, mannelijk zelfbeeld, spot 1 en 2 (richting patiënt), privésituatie, gender 3, loopbaanplan).

Tabel 11.16 Regressie-analyse van afhankelijke variabele "negatieve motivatie" (variabele twijfel aan studie)

\begin{tabular}{llll}
\hline & $\mathrm{R}^{2}$ & $\mathrm{~B}$ & $\mathrm{P}<$ \\
\hline 1 zelfvertrouwen 5 (negatief zelfbeeld) & 0.50 & 0.46 & 0.000 \\
2 depressief/vermijdend coping stij) & 0.53 & 0.16 & 0.051 \\
3 zelfvertrouwen 1 (twijfel eigen competentic) & 0.55 & 0.16 & 0.013 \\
4 vermoeidheid 3 (positief gestemd) & 0.57 & -0.16 & 0.024 \\
5 gender 3 (perceptie) & 0.58 & 0.13 & 0.034 \\
\hline
\end{tabular}

$F(5,119)-33.8, p<0.000 ; R^{2}$ adj. $=0.57$

De twijfel aan de studie is een indicator van gebrek aan motivatie van co-assistenten De variantie van deze variabele blijkt voor $50 \%$ verklaard te worden door gebrek an 
zelfvertrouwen oftewel een negatief zelfbeeld. Daarnaast blijken ook een depressiefvermijdende coping stijl en twijfels over de eigen competentie van belang. Het ontbreken van positieve gestemdheid en de perceptie van een erotiserende atmosfeer in de klinische setting blijken daarenboven nog enige invloed te hebben op weifelende motivatie.

$\begin{array}{ll}\text { DRAAGKRACHT } & \text { OUTCOME of ERVAREN BELASTING } \\ \bullet \text { copingstijlen } & \bullet \text { vermoeidheid } \\ \bullet \text { assertiviteit } & \bullet \text { negatieve motivatie } \\ \bullet \text { examenvrees } & \bullet \text { beeld van beroep als niet zwaar }\end{array}$

\section{De positieve variabelen}

De behandelde variabelen van fysieke en psychische vermoeidheid en twijfel aan studie, geven een indicatie van de zwaarte van de ervaren belasting en stress. Er zijn ook twee variabelen binnen het genoemde cluster van vijf outcome variabelen, die het tegendeel in beeld brengen, namelijk de variabele "positief gestemd zijn" (inhoudelijk het tegendeel van vermoeidheid) en de variabele "relaxed beroepsbeeld", waarmee een attitude wordt uitgedrukt van nuchterheid en relativering ten aanzien van de zwaarte van het beroep van arts.

Wanneer we de regressie-analyse van de "positief gestemdheid" bestuderen, blijkt dat naast psychische - en fysieke vermoeidheid en het ontbreken van een depressief en vermijdende coping stijl van belang is en een positief zelfbeeld. Ook blijkt vrouwelijke sekse van invloed te zijn op de variabele "positief gestemd zijn".

Uit de regressie-analyse van een "relaxed" beroepsbeeld of een beeld van het medisch beroep als niet zwaar blijkt de variantie van deze variabelen voor $53 \%$ te worden bepaald door vijf variabelen. Zelfvertrouwen in de zin van geen subjectieve twijfel aan de eigen bekwaamheid bepaald $32 \%$ van de variantie. Ook het ontbreken van last van fysieke vermoeidheid en geen beroep hoeven doen op het zoeken van sociale steun als coping stijl, blijken een bijdrage aan de verklaring van professioneel zelfvertrouwen te leveren. Tot slot leveren ook loopbaanplannen hebben en een positieve gestemdheid nog een kleine bijdrage. Voor een positief en ontspannen perspectief op de medische beroepsrol is dus een subjectief gevoel van competentie belangrijk.

\subsection{Samenvatting van de resultaten}

Om antwoord te geven op de drie vraagstellingen die in het begin werden geformuleerd zullen we de resultaten eerst samenvatten.

\subsubsection{De verklarende variabelen van professioneel zelfvertrouwen samengevat}

$\mathrm{Om}$ inzicht te krijgen in de achtergrond van het subjectieve gevoel van zelfvertrouwen bij co-assistenten in hun rol van aanstaand arts, werden vijf variabelen onderzocht namelijk zelfvertrouwen 1 (twijfel aan eigen competentie), zelfvertrouwen 2 (twijfel aan toegeschreven competentie), zelfvertrouwen 3 (voldoen aan patiënt-ver- 
wachtingen), zelfvertrouwen 4 (positief self-esteem), zelfvertrouwen 5 gebrek aan zelf. vertrouwen (negatief self-esteem).

Het valt op dat de variabelen in dit thema veel samenhang onderling hebben en dat de verklaarde variantie bij drie van de vijf variabelen groot is. Scores van verklaarde variantie van $57 \%, 54 \%, 63 \%$ in de regressie-analyses laten zien dat het professioneel zelfvertrouwen redelijk verklaard kan worden uit variabelen die in het socialisatieonderzoek (hoofdstuk 7 tot en met 10) werden onderzocht. Uitzonderingen zijn de inschatting van co-assistenten over het voldoen aan de verwachtingen van de patiënt (zelfvertrouwen 3) en de toegeschreven competentie (zelfvertrouwen 2) met een verklaarde variantie van $35 \%$ en $39 \%$. De onderlinge samenhang tussen de variabelen van dit onderdeel is vrij groot.

\begin{tabular}{lll}
\hline variabele & $\mathrm{R}^{2}$ adj & belangrijkste verklarende variabelen \\
\hline zelfvertrouwen 1 & $57 \%$ & $\begin{array}{l}\text { negatief zelfbeeld, geen mannelijk zelfbeeld, beeld van } \\
\text { beroep als zwaar } \\
\text { negatieve motivatie, ervaring van spot, locus of control } \\
\text { zelfvertrouwen 2 }\end{array}$ \\
zelfvertrouwen 3 & $39 \%$ & $\begin{array}{l}\text { geen twijfel aan eigen competentie, vrouwelijk zelfbeeld, } \\
\text { assertiviteit } \\
\text { geen negatieve motivatie, interne locus, positieve gestemd- } \\
\text { heid (tegendeel vermoeidheid) }\end{array}$ \\
zelfvertrouwen 4 & $54 \%$ & \begin{tabular}{l} 
negatieve motivatie en psychische vermoeidheid \\
\hline
\end{tabular}
\end{tabular}

Een belangrijke verklaring voor het zelfvertrouwen en een positief zelfbeeld bij coassistenten in de context van de opleiding blijkt de motivatie voor de medische studie te zijn. Ook een gevoel van "macht en contrôle" ten aanzien van het verder verloop van de eigen loopbaan, zich uitend in een interne locus of control blijkt hierbij van belang. Verder is een mannelijk zelfbeeld voor het professionele zelfvertrouwen van belang. Het ontbreken van zelfvertrouwen oftewel een negatief zelfbeeld wordt ook voor het grootste deel bepaald door de motivatie voor de studie en door psychische vermoeidheid.

Een ander aspect van het zelfvertrouwen als aanstaand arts, namelijk het gevoel te kunnen voldoen aan de verwachtingen van patiënten, kan onder andere verklaard worden door een vrouwelijk zelfbeeld in combinatie met een assertieve houding. De co-assistent moet dan niet geplaagd worden door twijfel aan de eigen bekwaamheid en beluisterd geen spottende taal over patiënten.

De overige twee variabelen van professioneel zelfvertrouwen zijn weer negatief ge steld. Twijfel aan eigen competentie en aan de competentie die de co-assistent denkt dat haar wordt toegescheven, geven uitdrukking aan een onzeker zelfgevoel.

Het subjectief gevoel van competentie of bekwaamheid gedeeltelijk verklaard kan worden uit een mannelijk zelfbeeld en een beeld van het medisch beroep als geen zware dobber. Daarnaast hangt dit gevoel van competentie ook samen met het gevoel 
te kunnen voldoen aan de verwachtingen van patiënten en het ontbreken van een negatief zelfbeeld.

Gebrek aan motivatie en de ervaring als co-assistent denigrerend benaderd te worden, werken onzekerheid over de beoordeling van de omgeving over de eigen invulling van de beroepsrol in de hand. Ook het gevoel van geringe contrôle over de loopbaan speelt hierbij een rol.

\subsubsection{De verklarende factoren van genderidentiteit en perceptie seksegebonden prak- tijken samengevat}

\begin{tabular}{|c|c|c|}
\hline variabele & $R^{2}$ adj & belangrijkste verklarende variabelen \\
\hline gender 1 (bewustzijn sekse) & $39 \%$ & $\begin{array}{l}\text { vrouwelijke sekse, perceptie spot over patiënt en } \\
\text { over vrouwen, negatief zelfbeeld }\end{array}$ \\
\hline gender 2 (perceptie voorkeur $\delta \delta$ ) & $23 \%$ & $\begin{array}{l}\text { perceptie spot over vrouwen, vrouwelijke sekse, } \\
\text { interne locus ten aanzien van loopbaan en locus } \\
\text { toeval }\end{array}$ \\
\hline gender 4 (ongewenste intimiteiten) & $15 \%$ & perceptie spot over vrouwen, vrouwelijke sekse \\
\hline $\begin{array}{l}\text { spot } 3 \text { (perceptie spot over vrou- } \\
\text { wen) }\end{array}$ & $31 \%$ & $\begin{array}{l}\text { perceptie spot over patiënt, perceptie voorkeur } \\
\text { voor } \delta \delta \text {, alleenstaand, extra vooropleiding, } \\
\text { geen vrouwelijk zelfbeeld }\end{array}$ \\
\hline $\begin{array}{l}\text { beroepsbeeld } 1 \text { (georiënteerd op } \\
\text { inkomen en status) }\end{array}$ & $36 \%$ & $\begin{array}{l}\text { mannelijke zelfbeeld, mannelijke sekse, externe } \\
\text { locus richting loopbaan }\end{array}$ \\
\hline $\begin{array}{l}\text { beroepsbeeld } 2 \text { (georiënteerd op } \\
\text { loondienst en teamwork) }\end{array}$ & $15 \%$ & $\begin{array}{l}\text { vrouwelijk ideaalbeeld, geen oriëntatie op status } \\
\text { en inkomen, arts in familie, beroep ingeschat als } \\
\text { zwaar }\end{array}$ \\
\hline
\end{tabular}

\section{Gender en spot}

De verklaarde variantie bij deze variabelen is wisselend, met name bij de variabelen gender 1, spot over vrouwen en beroepsbeeld georiënteerd op inkomen en status is de verklaarde variantie goed.

Vrouwelijke sekse blijkt bij de variabelen gender en spot zijn een factor van betekenis te zijn. Aangesproken worden en een versterking van het bewustzijn van sekse blijkt voor een groot deel bepaald te worden door vrouwelijke sekse en hangt samen met de perceptie van spot over patiënten en over vrouwen. De bekrachtiging van de genderidentiteit van vrouwen gaat samen met een grotere sensitiviteit voor deze uitingen. Genderidentiteit hangt verder samen met een negatief zelfbeeld. Het starten met de co-assistentschappen geeft een impuls aan dit versterkte bewustzijn van sekse bij vrouwen ${ }^{3}$.

'Overigens moet de methodische kanttekening worden geplaatst dat, omdat perceptie van spot over mannen niet bevraagd, het theoretisch mogelijk is dat genderidentiteit ook samenhangt met perceptie van spot over mannen. 
Een soortgelijk patroon treffen we aan bij de perceptie van co-assistenten van een eventuele voorkeursbehandeling voor mannelijke beroepsbeoefenaren. Vrouwen nemen dit meer waar, hetgeen gekoppeld is aan een zekere sensitiviteit voor spot over vrouwen. De bevinding dat perceptie van voorkeur voor mannen wel samenhangt met toeschrijven van loopbaansucces aan eigen inspanningen (interne locus) en ook aan toeschrijven aan toevalsfactoren, maar niet met toeschrijven van loopbaansucces aan "machtige anderen" (d.i. externe locus), is opmerkelijk. Dit roept de vraag op in hoeverre hierin meespeelt dat de "machtige anderen" in de medische professie vooralsnog grotendeels van het mannelijk geslacht zijn en daarmee mogelijk als minder bereikbaar beleefd worden door vrouwelijke aankomende artsen.

Overigens is wel jammer dat we niet de omgekeerde vraag namelijk of er eventueel een voorkeur voor vrouwen bestaat, aan co-assistenten hebben voorgelegd

Ook de ervaring van ongewenste intimiteiten, hoewel slechts in beperkte mate verklaard, wordt bepaald door vrouw-zijn en ook hier weer samenhang met perceptie van spot over vrouwen.

De perceptie van spot over vrouwen geeft zicht op een zekere mate van sensitiviteit oor discriminatoire uitingen en vertoont samenhang met andere variabelen die hierop betrekking hebben als perceptie van deze uitingen richting patiënt en een sfeer van voorkeur voor mannen. Verder zijn vooral co-assistenten die niet samenwonen en geen vrouwelijk ideaal koesteren, gevoelig voor eventuele uitingen van deze aard! Zou van een zekere mate van positieve labeling van vrouwelijke kwaliteiten, dat tot uitdrukking komt in een vrouwelijk ideaalbeeld, een feministische attitude, mogelijk een preventieve werking uitgaan ?

\section{Beroepsbeeld}

Ook bij inkleuring van het beroepsbeeld van de co-assistent, blijkt een mannelijk of vrouwelijke zelfbeeld nog meer dan sekse een factor van betekenis te zijn.

Oriëntatie op inkomen en maatschappelijke status blijken samen te hangen met een mannelijk zelfbeeld en mannelijke sekse. Opmerkelijk is dat ook de attitude ten aanzien van de eigen loopbaan een rol van betekenis speelt. Een combinatie van bezig zijn met het maken van loopbaanplannen, de haalbaarheid hiervan als positief inschatten plus een inschatting dat machtige anderen op het verloop van de loopbaan grote invloed hebben, zijn elementen van deze attitude van oriëntatie op inkomen en maatschappelijke status verklaren. Deze attitude kan met de kostwinners-positie in verband gebracht worden.

Een vrouwelijk zelfbeeld blijkt samenhang te vertonen met een grotere affiniteit voor het beroepsarbeid als arts in teamverband en loondienst. Opmerkelijk is dat dit beroepsperspectief ook meer voorkomt bij co-assistenten die een arts in de nabije familie hebben en die de medische beroepsrol als zwaar inschatten. Mogelijk dat kinderen uit artsen gezinnen door deze ervaring niet meer kiezen voor het medische beroep uitgevoerd in een solistische setting. Een beroepsbeeld georiënteerd op status en inkomen blijkt inderdaad enigszins complementair aan dat georiënteerd op loondienst en teamwork. De resultaten wijzen erop dat affiniteit voor teamwork en loondienst niet samengaan met een attitude die gericht is op inkomen en status. Dit roept 
de vraag op er sprake is van tegengestelde houdingen, namelijk de meer pragmatisch en carrière-gerichte houding en de meer relationele en idealistische attitude.

\subsubsection{Verklarende factoren van mate van vermoeidheid en motivatie samengevat} De verklaarde variantie van de variabelen die als maat voor de vermoeidheid kunnen worden opgevat, blijkt betrekkelijk hoog te zijn. Behalve samenhang met elkaar blijken ze volgende aspecten van invloed op de mate van ervaren belasting:

\begin{tabular}{lll}
\hline variabele & $\mathrm{R}^{2}$ adj & belangrijkste verklarende variabelen \\
\hline $\begin{array}{l}\text { psychische vermoeidheid } \\
\text { fysieke vermoeidheid }\end{array}$ & $49 \%$ & $\begin{array}{l}\text { depressief-vermijdende coping stijl, negatieve moti- } \\
\text { vatie, geen actieve coping stijl }\end{array}$ \\
$\begin{array}{l}\text { vrouwelijke sekse, beginfase van de stages (groep), } \\
\text { twijfel aan studie (negatie- } \\
\text { ve motivatie) }\end{array}$ & $57 \%$ & $\begin{array}{l}\text { geen zelfvertrouwen (50\% door negatief zelfbeeld), } \\
\text { positieve gestemdheid }\end{array}$ \\
$\begin{array}{l}\text { depsief vermijdende coping stijl } \\
\text { beeld van beroep als niet } \\
\text { zwaar (beroepsbeeld 4) }\end{array}$ & $53 \%$ & $\begin{array}{l}\text { geen depressief vermijdende coping stijl, zelfvertrou- } \\
\text { wen (positief zelfvertrouwen), vrouwelijke sekse }\end{array}$ \\
\hline
\end{tabular}

\subsection{Beschouwing}

Zelfvertrouwen blijkt binnen de context van de co-assistentschappen een sterke samenhang te vertonen met motivatie voor de studie.

Ook de locus of control, de manier waarop co-assistenten hun loopbaanontwikkeling toeschrijven, blijkt van invloed te zijn op het professioneel zelfvertrouwen. Een interne locus, de aanname dat men zelf veel invloed heeft op de loop der dingen in de eigen loopbaan, blijkt belangrijk voor het zelfvertrouwen van aanstaande artsen. Verder is opmerkelijk dat een mannelijk zelfbeeld verbonden blijkt te zijn met professioneel zelfvertrouwen en gevoel van competentie.

Interessant is een ander aspect van medische competentie namelijk het gevoel te kunnen voldoen aan de verwachtingen van de patiënt, mede bepaald wordt door een vrouwelijk zelfbeeld, waarin eigenschappen als tact, begrip, zachtzinnigheid, warmte, nieuwsgierigheid en sensitiviteit een grote rol spelen. Deze expressieve eigenschappen zijn van belang in verband met adequaat kunnen omgaan met de verwachtingen van patienten en hen met empathie tegemoet kunnen treden in de arts-patiënt relatie.

Men kan concluderen dat het individuele gevoel van bekwaamheid sterk bepaald wordt door het subjectief gevoel van zelfvertrouwen en een mannelijk zelfbeeld. Met andere woorden, wanneer een co-assistent zichzelf niet eigenschappen als rationaliteit, ambitie, logisch en abstract denken, durf, kracht en dominantie toeschrijft, blijkt de kans op twijfel en onzekerheid over de eigen bekwaamheid veel groter. In deze bevindingen lijkt het androgyne karakter van het medische beroep weerspiegeld; het 
beroep vraagt zowel traditioneel mannelijke of instrumentele als traditioneel vrouwelijke of expressieve eigenschappen.

Ten aanzien van preventie van stress en overbelasting is de bevinding van belang dat met name een depressief vermijdende coping stijl grote betekenis voor de ervaren vermoeidheid. Ook blijkt het ontbreken van motivatie voor de studie en het ontberen van een actief probleemoplossende houding in dit opzicht een probleem te zijn. Vrouw-zijn en het starten met de fase van de co-assistentschappen blijkt de kans op fysieke vermoeidheid te vergroten.

Opmerkelijk is verder dat psychische vermoeidheid bij vrouwelijke co-assistenten de sensitiviteit verhoogt voor het waarnemen van een discriminatoire uitingen en een sfeer van voorkeur voor mannen.

Een positieve en opgeruimde gestemdheid is van grote belang voor een voorspoedige ontwikkeling van het professioneel zelfvertrouwen en deze gestemdheid wordt weer bepaald door vrouwelijke sekse en het ontbreken van een depressief vermijdende manier van coping.

$\mathrm{Na}$ deze bewerkingen kunnen wij de factoren die een negatieve invloed en leiden tot tot stress en vermoeidheid in beeld brengen evenals de factoren die daarentegen een positieve spiraal veroorzaken (zie onderstaand overzicht).

Overzicht

Negatieve wisselwerking

- depressief/vermijdende coping stijl

ontbreken van actieve coping stijl

psychische vermoeidheid

- negatieve motivatie

fysieke vermoeidheid

Positieve wisselwerking

- positief zelfbeeld

positief gestemd zijn

- subjectief gevoel van competentie

relaxed beroepsbeeld 
Deel IV

\section{Slotbeschouwing "Girls in white"}




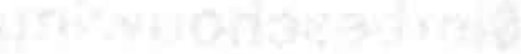




\section{Hoofdstuk 12 Slotbeschouwing}

\section{"Girls in white"}

\subsection{Tijd om de bakens te verzetten}

Het medisch beroep en de medische professie zijn in beweging evenals de eisen die de moderne tijd aan de geneeskunde en haar beoefenaren stelt. Sociale patronen veranderen alsmede de beleving van macht en autoriteit, de opvattingen en rolpatronen van vrouwen en mannen en de maatschappelijke betekenis van gezondheid en ziekte. De euforie over de medische kunst en kunde is de afgelopen decennia enigszins verminderd en de succes-story van de geneeskunde lijkt aan slijtage onderhevig (Illich, 1975; Dunning, 1981; Dupuis, 1998). Een tijdperk waarin de grenzen van de geneeskunde en het medische bedrijf erkend mogen worden, lijkt te zijn aangebroken. Fouten en tekortkomingen in het medisch handelen mogen niet meer toegedekt worden of onbesproken gelaten.

Ook demografische veranderingen hebben effect op de geneeskunde zoals de vergrijzing, die resulteert in een toename van chronische ziekten. Deze verschuivingen in morbiditeitpatroon geven een relativering van de curatieve geneeskunde ten faveure van de care aspecten van het medisch handelen.

Deze veranderingen vragen om innovatie en vernieuwing van het medische beroep en andere accentuering van kwaliteiten in beroepsbeoefenaren dan vroeger.

De onderhandelingshuishouding (De Swaan, 1983; Gremmen \& Westerbeek, 1988) is doorgedrongen in de spreekkamer van de dokter, waar dialoog, voorlichting en overleg steeds vaker de plaats innemen van medisch voorschrift en braaf opvolgen van medisch advies. De behoefte aan artsen, die medische deskundigheid weten te combineren met relationele gerichtheid en communicatieve vermogens neemt snel toe. 
Tegelijkertijd met de beschreven maatschappelijke ontwikkelingen, verandert ook de samenstelling van de medische beroepsgroep ingrijpend. In rap tempo verandert dit professionele domein van een door mannen gedomineerd beroep naar een beroepsveld waarin de meerderheid bestaat uit vrouwelijk beroepsbeoefenaren. Maar verschuift ook de cultuur van de professie ? Men kan zich afvragen of binnen de beroepsgroep of de medische opleidingscontext ook veranderingen optreden als reactie op de geschetste externe en interne veranderingen.

In dit proefschrift stond de wisselwerking tussen leeromgeving als sociaalculturele context en het zich ontwikkelend lid van de medische beroepsgroep in het centrum van de belangstelling. We hebben ons verdiept in de ervaringen van vrouwelijke en mannelijke co-assistenten en deze nader onderzocht en geëvalueerd in het licht van de mogelijke gevolgen voor hun identiteit en professionele oriëntatie.

We zullen de belangrijkste conclusies van de onderzoeken naar professionele socialisatie van aanstaande dokters in deze slotbeschouwing de revue laten passeren en daarbij steeds als vraag voor ogen houden of de medische professie in staat is om het culturele kapitaal van vrouwelijke aanstaande artsen te incorporeren. Ondanks het gegeven dat de empirische gegevens van de onderzoeken reeds enige jaren geleden verzameld werden, lijken ze aan actualiteit nog niet te hebben ingeboet.

De slotbeschouwing is zo opgebouwd dat de volgende onderwerpen aan de orde komen. Eerst zullen we stilstaan bij de wijze waarop de medische beroepscultuur wordt gezien door co-assistenten, de artsen van morgen en hoe deze beroepscultuur door hen wordt gewaardeerd. Ook zullen we ingaan op de kloof tussen de idealen en waarden van de co-assistent en de alledaagse werkelijkheid, zoals deze door hen in de praktijk wordt waargenomen. De inwijdingsperiode in het medisch vak blijkt verder vooral als stimulerend en motiverend te worden ervaren en minder als zwaar en vermoeiend. Co-assistenten veranderen als persoon, ze worden zelfbewuster en meer in staat tot autonoom en zelfstandig handelen. Daarna staan we stil bij de verschillende manieren waarop vrouwen en mannen worden aangesproken in deze socialisatiefase. De relatie genderrol en beroepsrol zullen we nader bezien. Aan het eind van de slotbeschouwing zullen we de bruikbaarheid van het perspectief van de gevestigden en de buitenstaanders evalueren. In de loop van de tijd werd dit denken uitgebreid en herijkt. Tot slot gaan we in op de noodzaak van vernieuwing en innovatie in medische professie en professionele cultuur. We eindigen met de aansporing dat veranderingen nodig zijn, wil het cultureel kapitaal van vrouwen ook voldoende tot haar recht komen in de geneeskunde als professionele domein.

\subsection{Onderzoek naar medische beroepscultuur}

In dit proefschrift werd de blik gericht op de nieuwe generatie in opleiding tot arts, de groep die het antwoord van de medische professie op de geschilderde maatschappelijk ontwikkelingen als het ware belichamen. We hebben deze nieuwe generatie artsen op diverse manieren onder de loep gehouden en bestudeerd. Ten eerste hebben we in het beroepscultuur-onderzoek geprobeerd de medische beroepswereld te bezien vanuit hun perspectief, het perspectief van een nieuweling, die lid wenst te worden van de 
beroepsgroep. Co-assistenten betreden na vier jaar universitair onderwijs de kliniek om "training on the job" in de medische praktijk te ontvangen. Wat zien co-assistenten dan ? De percepties van de nieuwkomers kunnen worden opgevat als waargenomen boodschap van de zittende professie over het collectief ideaal van medische professionaliteit en het passende gedrag voor een arts. We kunnen aannemen dat deze waargenomen alledaagse werkelijkheid en de culturele betekenis van uiterlijke kenmerken, omgangsvormen en gedragscodes, los van de intenties van de professie, een vormende werking hebben op co-assistenten, de artsen-in-opleiding. Individuen moeten een bepaalde prijs betalen om deel te mogen uitmaken van de professie. Keizer zegt hierover "ze moeten hun individualiteit gedeeltelijk opgeven en inruilen voor professionaliteit, een specifieke combinatie van kennis, kunde, temperament en ethos die noodzakelijk is om binnen een bepaalde professie goed te kunnen functioneren" (Keizer, 1997,p 80). De impliciete normen en waarden, die tot uitdrukking komen in de vorm van symbolen, helden en rituelen van de huidige medische beroepsgroep, zullen derhalve gedeeltelijk onafhankelijk van bedoelingen of bewuste evaluatie van het individu verinnerlijkt worden. We stellen dat in het proces van professionele socialisatie een aspect van onvermijdelijkheid zit, dat reflectie op de eigen cultuur noodzakelijk maakt.

Het collectief ideaal over medische professionaliteit van de huidige beroepsgroep, zoals dit wordt waargenomen door co-assistenten, werd onderzocht aan hand van cultuurdimensies, ontleend aan het werk van Hofstede $(1980,1991)$, die werden toegepast op het medisch professionele domein. We onderscheidden in het beroepscultuuronderzoek culturele informatie over de gewenste mate van machtafstand (1) tussen artsen onderling, tussen artsen en hun leerlingen en artsen en hun patiënten. Verder onderscheiden we de mate van de onzekerheidsvermijding (2) die de medische professionele cultuur communiceert, de mate van feminiteit en masculiniteit (3) en de manier van inwijden van nieuwelingen in de eigen medische wereld.

\subsection{Percepties van co-assistenten}

Uit het beroepscultuuronderzoek naar percepties van co-assistenten blijkt dat zij de verhoudingen van artsen onderling als hiërarchisch beschrijven en de verhouding van artsen tot de verpleging als zeer ongelijk. Verder nemen zij een grote afstand waar tussen de beroepsgroep en buitenwereld en zien zij de grootte van de werkkamer, het gebrek aan tijd en medische attributen als aesculaap en witte jas functioneren als zaken die de status verhogen en de afstand richting buitenwacht onderstrepen. Een minder uitgesproken antwoord wordt gegeven op de vraag naar de machtsongelijkheid richting patiënt en in de relatie tussen leerling en arts-opleider.

Men kan concluderen dat de cultuur van de medische professie door co-assistenten wordt opgevat als hiërarchisch en gekenmerkt door een grote mate van machtsongelijkheid. Machtsongelijkheid als cultuurdimensie wordt hierbij gedefinieerd als uitdrukking van de mate waarin de minder-machtige leden van de groep verwachten en accepteren dat de macht ongelijk verdeeld is. Door haar eigen gewoonten en omgangsvormen communiceert de huidige beroepsgroep de betekenis van verschillen in macht 
en positie op de verschillende niveaus van interactie en door haar voorbeeld leert ze haar toekomstige leden hoe om te gaan met deze machtsverschillen.

De toepassing van de culturele dimensie "onzekerheidsvermijding" leidt tot interessate overwegingen over het medische professionele domein. Men kan stellen dat de medische professie een prominente rol vervult in de worsteling van een samenleving met de bedreigingen die uitgaan van ziekte en dood. Deze maatschappelijke rol lijkt in moderne samenlevingen alleen maar groter te worden, getuige de toenemende populariteit van medische programma's in de media en de voortschrijdende proto-professionalisering van moderne burgers (Mulder, 1996; de Swaan,1983). Het werk van Payer (1988) onthulde hoezeer het "antwoord" van de professie op deze worsteling kan verschillen in verschillende landen of culturele gemeenschappen. Anders dan de universele pretenties van de medische wetenschap doen vermoeden, bleken bij verglijking tussen een aantal moderne westerse landen grote verschillen te bestaan in medisch handelen. Zo bleken bij ongeveer gelijke morbiditeitspatronen in Frankrijk heel andere medische diagnoses gesteld te worden of andere behandelingen toegepast te worden dan bijvoorbeeld in Duitsland of Groot Brittannië. Deze vergelijking de onverwachte verschillen liet zien in aanpak van gezondheidsproblemen en ziekten tussen de verschillende nationale contexten, relativeert de universele pretenties van de geneeskunde enigszins.

De mate van onzekerheidsvermijding van een cultuur wordt in ons onderzoek gedeinieerd als mate waarin angst of onzekerheid verdragen kan worden en de mate waarn leden van de cultuur zich bedreigd voelen door onzekere of onbekende situaties. Dit gevoel kan tot uitdrukking komen in nerveuze spanning en in een behoefte aan voorspelbaarheid en reductie van onzekerheid door het functioneren van formele en informele regels. Een cultuur met een geringe mate van onzekerheidsvermijding zal in staat zijn om ontspannen te reageren op onzekere situaties en tolerant reageren op overtreding van regels; "wat onbekend is, wordt niet als bedreigend of beangstigend ervaren, maar nieuwsgierig tegemoet getreden."

Een cultuur met een sterke onzekerheidsvermijding kent daarentegen een emotionele behoefte aan regels en "harde" feiten, vat onzekere of onbekende situaties op als bedreigend en kent een hoge mate van subjectief gevoelen van stress en spanning. In het domein van de geneeskunde functioneren wetenschappelijke kennis en protocollen als "tools", die het medische handelen kunnen onderbouwen en zekerheid kunnen bieden aan professionals. Ook de medische technologie speelt in dit opzicht een rol. De culturele boodschappen over de betekenis van wetenschappelijke kennis en medische technologie en de betekenis van medische protocollen of gedragsvoorschriften kunnen dan ook worden opgevat als aspecten van deze dimensie. De mate waarin artsen geacht worden zich te conformeren aan sociale regels en gedragscodes kan eveneens worden geïnterpreteerd in het licht van onzekerheidsvermijding evenals de ideaaltypische eindtermen die geformuleerd werden ten aanzien van het profiel van de gewenste basisarts (Metz et al, Raamplan, 1994).

Uit ons onderzoek naar beroepscultuur bleek dat de medische professie meer overeenkomst vertoont met een cultuur met sterke onzekerheidsvermijding dan met een lichte mate hiervan. Co-assistenten zien dat gedragsvoorschriften, medische protocollen en medische technologie een grote rol spelen in het professionele domein van 
artsen. Ook nemen zij waar dat het tonen van emoties en kwetsbaarheid voor artsen als ongepast en ongewenst wordt gezien; zowel in de interactie met de patiënt als in de onderlinge contacten van artsen met elkaar blijkt een dergelijke opstelling "not done" te zijn.

\section{Masculiene of feminiene cultuar ?}

Binnen de cultuur van een medische professionele groep worden verder beelden uitgezonden over de betekenis van prestaties en succes en over de noodzaak van zich profileren, excelleren en zich onderscheiden. Hofstede noemt deze culturele dimensie als mate van masculiniteit van een cultuur. De percepties van co-assistenten wijzen bij deze dimensie op een culturele norm binnen de beroepsgroep waarin competitie en zich onderscheiden geen geringe rol spelen. Co-assistenten denken dat het voor een succesvolle loopbaan in het medische beroep nodig is om zichtbare prestaties te leveren, te kunnen concurreren met elkaar en zich in de competitie met collega's te kunnen onderscheiden. Echter de pikorde en het verschil in rangen en standen tussen artsen-groepen gaat naar hun inzicht ook weer niet zo ver, dat artsen-groepen elkaar devalueren of denigrerend over elkaar spreken.

De culturele boodschappen over de betekenis van steun en support van artsen onderling en de kwaliteit van samenwerking, wordt aangeduid met de dimensie mate van feminiteit van een cultuur. Ook werd onderzocht in hoeverre een feminiene norm van toepassing is op de arts-patiënt relatie. Uit het onderzoek blijkt dat co-assistenten de beroepscultuur van artsen als niet-feminien beschrijven. Steun van artsen voor elkaar lijkt in de professionele cultuur geen prioriteit te hebben, persoonlijke besognes van de dokter zelf mogen niet gearticuleerd worden en privé en werk dienen strikt gescheiden te blijven. Wel wordt een grote mate van loyaliteit van artsen onderling waargenomen en hebben co-assistenten de indruk dat een collegiale opstelling wenselijk professioneel gedrag is. Ook de gewoonten van artsen om elkaar aan te spreken als "amice" of "collega" duiden op een ritueel dat de culturele norm van loyaliteit ondersteund. Co-assistenten doen geen duidelijke uitspraak over de vraag of een feminiene norm geldt voor de interactie tussen arts en patiënt en ze bij artsen-opleiders een toegankelijke, luisterende en invoelende attitude als voorbeeld zien.

Tot slot werd de manier waarop nieuwelingen worden ingewijd in de medische beroepsgroep onderzocht. De co-assistenten beleven het proces van introductie in de medische beroepswereld als een confronterende aangelegenheid waarin zij zich enigszins in het diepe gegooid voelen. $\mathrm{Zij}$ hebben de ervaring dat een co-assistent zonder veel begeleiding of coaching spannende opdrachten op zich dient te nemen, zoals spreken in het openbaar en het houden van voordrachten voor een kritisch gehoor van opleiders en dat het niet uitzonderlijk is om verantwoordelijkheid te moeten dragen in medische situaties waar men zich nog niet tegen opgewassen voelt. Coassistenten voelen zich vaak onzeker en weinig voorbereid op de ervaringen in de klinische stages. Ze ervaren de artsen-opleiders vaak als weinig toegankelijk en hebben het gevoel te moeten overleven in een betrekkelijk harde cultuur. Het klimaat in de co-assistentschappen wordt zowel als uitdagend en spannend ervaren, als ook als een sfeer waarin de nieuweling zich getest en op de proef gesteld voelt. 


\subsection{Appreciatie van de medische beroepscultuur door co-assistenten}

De confrontatie met de realiteit van het medische beroep en haar beoefenaren laat coassistenten ook in normatieve zin niet onberoerd.

Socialisatie is het proces waarin de normen en waarden van het individu op een of andere wijze in overeenstemming moeten worden gebracht met die van de omringende cultuur. Om een indruk te krijgen van de waarden en idealen van de nieuwe generatie artsen in de fase van de co-assistentschappen, vroegen we hen naar cen beoordeling en evaluatie van de onderscheiden culturele aspecten.

Uit de resultaten blijkt dat nagenoeg alle cultuurdimensies, die in het onderzoek an bod kwamen, aanleiding geven tot duidelijke oordelen in termen van wenselijk of onwenselijk. Co-assistenten blijken een positieve waardering te hebben voor een geringe machtafstand tussen arts en patiënt en een arts-patiënt relatie te waarderen, waar de patiënt invloed heeft op de behandeling, medisch beleid wordt besproken en ook fouten of twijfels aan de orde kunnen komen. Positief zijn co-assistenten over een geringe machtafstand in hun relatie tot de artsen-opleiders en over een meer feminiene cultuur, waar artsen niet slechts patiënten, maar ook elkaar steun en support verlenen. Omgangsvormen van artsen onderling waar meer ruimte is om zich als persoon en emotioneel te kunnen uiten, zouden co-assistenten zeer wenselijk vinden. Ook een attitude richting patiënt, die gekenmerkt wordt door empathie, toegankelijkheid en een luisterend oor, wordt door hen sterk geapprecieerd. Het blijkt dat vrouwelijke co-assistenten door een dergelijke attitude als arts nog sterker worden angesproken dan mannelijke. Opmerkelijk is wel dat meer gevorderde vrouwelijke co-assistenten weer minder belang hechten aan een dergelijke attitude dan hun zusters, die al verder gevorderd zijn in de opleiding. Verder geven co-assistenten blijk van waardering voor de code van loyaliteit en teamgeest van collega's onderling en voor respectvolle omgangsvormen van artsen onderling.

Afkeurend zijn de co-assistenten over de hiërarchische omgangsvormen, de competitieve sfeer van artsen onderling en de noodzaak zich te moeten onderscheiden. Ook de manier van inwijding, die gebruikelijk is in de medische beroepsgroep, ontmoet bij co-assistenten weinig waardering. Een proces van inwijding dat de nieuweling minder abrupt in de nieuwe wereld stort, zou hen meer aanspreken.

In het beroepscultuuronderzoek namen we aan dat vrouwelijke co-assistenten met name op het normatieve vlak zouden verschillen van hun mannelijke collegae en de verschillende cultuuraspecten anders zouden beoordelen. De seksen bleken echter slechts op een beperkt aantal punten te verschillen.

Vrouwelijke co-assistenten blijken vooral moeite te hebben met de culturele codes, die betrekking hebben op de machtsongelijkheid van artsen onderling, de hiërarchische omgangsvormen, de werking van statussymbolen en de machtafstand tussen leerlingen en artsen-opleiders. Vrouwen keuren de noodzaak tot rivaliseren en zich moeten profileren sterker af dan mannen, evenals het taboe op het uiten van emoties en articuleren van kwetsbaarheid in de professionele rol van arts. Uit het beroepscultuur kunnen we leren dat de kennismaking en inwijding in de medische beroepscultuur onderzoek zowel vrouwelijke en mannelijke nieuwkomers dwingt tot het overbrug- 
gen van een forse kloof tussen hun oorspronkelijke idealen en waarden en die van de cultuur waartoe zij willen toetreden.

\subsection{De kloof tussen ideaal en alledaagse werkelijkheid}

Men kan concluderen dat bij nagenoeg alle cultuuraspecten, die werden onderzocht een grote kloof bestaat tussen het gepercipieerd voorbeeld van de praktiserende professie en het individueel waardeoordeel van co-assistenten. Deze kloof zal in het socialisatietraject tot arts overbrugd moeten worden. Twee cultuuraspecten vormen in dit opzicht een uitzondering, namelijk de machtsongelijkheid tussen artsen en verpleging en de rol van protocollen en medische technologie, een culturele oplossing voor onzekerheid. Hieruit blijkt dat co-assistenten de bestaande machtsongelijkheid tussen artsen en verpleging en de prominente betekenis van protocollen en gestandaardiseerde kennis niet problematiseren.

Een mogelijke verklaring van deze bevindingen kan gevonden worden in de onzekere positie van co-assistenten in de medische hiërarchie en hun wankele professionele identiteit. Mogelijk is met name voor aanstaande dokters een duidelijke afbakening tussen het domein van artsen en de verpleging belangrijk. En wanneer men protocollen en standaardisering van medische kennis opvat als cultureel verankerde remedie tegen de basale onzekerheid, die intrinsiek verbonden is aan het medisch handelen, dan wordt begrijpelijk dat beginners in het medische vak deze remedie omarmen en dankbaar aangrijpen.

Om een indruk te krijgen van de veranderingen in de loop van de tijd, werden de percepties en appreciaties van beginnende co-assistenten vergeleken met die van de meer gevorderde co-assistenten, die de eindstreep van de medische opleiding en het basisartsexamen naderen. Uit de resultaten bleek dat de perceptie van de onderzochte cultuuraspecten verandert en pregnanter wordt, maar de waardering niet of nauwelijks verandert.

De omgang van artsen onderling wordt als meer respectvol maar minder loyaal beschreven door de gevorderde co-assistenten. Gevorderde mannelijke co-assistenten zien de medische professie duidelijker als een cultuur met rangen en standen en een sterk competitieve omgang. Gevorderde vrouwelijke co-assistenten zien de werking van statussymbolen duidelijker en de hiërarchische omgang tussen artsen en verpleging; ook onderkennen zij de rol van de verpleging bij hun eigen opleiding duidelijker dan hun beginnende vrouwelijke collegae en nemen duidelijker een zekere mate van cynisme onder artsen waar.

De waardering van de voorgeleefde cultuur bleek niet veranderd te zijn bij gevorderde co-assistenten, behalve op het punt van de appreciatie van een de feminiene norm van een toegankelijke, communicatieve en luisterende houding van de arts in het contact met de patiënt. Onverwacht blijkt de positieve waardering van met name de vrouwelijke gevorderde co-assistenten voor dit feminiene cultuuraspect te zijn afgenomen in vergelijking met hun jongere zusters. 
Deze resultaten suggereren dat socialisatie in de co-assistentschappen in de loop van de tijd in eerste instantie meer veranderingen op het cognitieve vlak dan op het normatieve vlak lijken te bewerkstelligen, behalve dat vrouwelijke co-assistenten feminiene cultuuraspecten minder gaan waarderen. Als kritische noot dient hier wel te worden opgemerkt dat deze resultaten voortvloeien uit een transversale studie, waardoor niet geheel kan worden uitgesloten, dat groepskenmerken van de groep beginnende en gevorderde co-assistenten de resultaten beïnvloed hebben. Daarom zou het wenselijk zijn om deze kwestie verder te onderzoeken in een longitudinaal design.

\subsection{Het inwijdingsproces van artsen blijkt motiverend en stimulerend}

In een tweede empirisch onderzoek werd het ontwikkelingsproces van de professionele identiteit bij de nieuwe generatie artsen bestudeerd aan de hand van thema's die betrekking hebben op de mate van belasting en stress en op identiteitsontwikkeling als professional. In een transversaal design bestudeerden we sekseverschillen en in een longitudinaal design werden de veranderingen in de tijd, die medische studerten doormaken tijdens de co-assistentschappen bestudeerd.

Uit de resultaten bleek dat de motivatie voor de geneeskunde bij co-assistenten stigt. Deze opleidingsfase houdt een duidelijke stimulans in voor de motivatie van de meeste co-assistenten, maar betekent ook een confrontatie met het "gulzige" karakter van het medisch beroep (Coser, 1978). Het gebrek aan tijd wordt steeds duidelijker voelbaar voor de nieuwelingen en ze krijgen een voorproefje van de dilemma's en keuzen, die artsen moeten maken over de verdeling van tijd over de diverse levensgebieden. Loopbanen in de curatieve geneeskunde leggen namelijk forse claims op tijd en ruimte van artsen en vereisen de bereidheid om werk zeer hoge prioriteit te geven. Interessant is dat de betekenis van de ervaren schaarste aan tijd verschuift in de loop van de co-assistentschappen in de richting van een grotere loyaliteit en "commitment" aan de beroepsrol; beginnende co-assistenten ervaren gebrek aan tijd als problematisch omdat de ruimte voor vrienden en privé minder wordt, maar naarmate ze verder in de opleiding vorderen, blijken ze gebrek aan tijd vooral te labellen als problematisch, omdat studie en beroep onder druk komen te staan. Tijd voor vrienden en privé wordt dan sterker ervaren als een problematische claim van het sociale netwerk. Interessant is in dit verband wel dat vrouwelijke gevorderde co-assistenten een ander patroon laten zien dan andere co-assistenten in die zin dat in deze groep de bereidheid om het beroep altijd hoogste prioriteit te geven scheuren gaat vertonen. Met andere woorden de offerbereidheid lijkt bij vrouwelijke co-assistenten minder groot te worden.

Het inwijdingsproces in de co-assistentschappen blijkt gemiddeld als minder vermoeiend en belastend ervaren te worden dan verwacht. $\mathrm{Er}$ is in dit geval sprake van een beloop dat fluctueert in de tijd; bij de start van de klinische fase blijkt met name de fysieke vermoeidheid toe te nemen, in de midden- of stabilisatie-fase blijkt de ervaren belasting constant te blijven om in de eindfase, wanneer de afronding van de opleiding tot basisarts in zicht komt, weer af te nemen. Dit laatste geldt dan met name voor de psychische belasting. 
Opmerkelijk is verder dat medische studenten een grote preferentie aan de dag leggen voor een actieve copingstijl bij het tegemoet treden van eigen problemen en stress. Vrouwelijke co-assistenten blijken bij tegenslag of problemen naast de neiging om actief en doelgericht naar oplossingen te zoeken, ook graag hun toevlucht te nemen tot het zoeken van sociale steun bij sociale omgeving zoals vrienden. Mannelijke coassistenten blijken naast de actieve copingstijl ook een sterkere voorkeur te hebben voor een palliatieve copingstijl, die het zoeken van afleiding of verstrooiing behelst. Een depressieve en vermijdende copingstijl, die de kans op psychische belasting en burn-out vergroot, zoals bleek uit de regressie-analyse, blijkt gemiddeld genomen weinig voor te komen bij deze populatie co-assistenten. Overigens zou deze parameter geschikt kunnen zijn voor vroegtijdige signalering van studenten, die kans hebben ten prooi te vallen aan overbelasting en hun studie vroegtijdig willen afbreken of op een andere manier dreigen af te haken. In het kader van preventie zou voor deze studenten een specifiek ondersteunend aanbod van persoonlijk of groepsgewijs onderwijs, geschoeid op psychotherapeutische leest, tijdens hun medische opleiding mogelijk zinvol zijn.

\subsection{Attitude-verandering in de richting van meer autonomie en professioneel zelfvertrouwen}

Uit de longitudinale data bleek tot onze verrassing dat co-assistenten in de loop van de klinische fase een duidelijk verandering vertoonden ten aanzien van copingstijlen. Co-assistenten lieten in het longitudinaal onderzoek in alle fasen een stijging zien ten aanzien van geneigdheid tot een actieve copingstijl, alsook tot een sociale copingstijl en tot een palliatieve copingstijl. Behalve de depressief-vermijdende copingstijl vertoonde de longitudinale data op alle punten een stijging van de scores, zowel bij vrouwelijke als mannelijke co-assistenten. We vatten deze verandering op als een attitude-verandering bij co-assistenten, die duidt op een geslaagde socialisatie in de richting van een autonome en assertieve professional, die actief, doelgerichte en probleem-oplossende de "facts of live" tegemoet treedt. In dit verband kan men zich ook afvragen of een "hard" inwijdingsritueel een functie heeft, een ritueel waarin de nieuweling moet tonen in staat te zijn moeilijkheden zonder noemenswaardige hulp te kunnen oplossen.

Ook de mate van zelfvertrouwen als professional ondergaat in de loop van de co-assistentschappen een positieve stimulans, evenals de motivatie voor het vak. Het persoonlijk zelfvertrouwen neemt toe en het subjectief gevoel van competentie als arts vertoont een stijgende lijn, maar kent wel een fluctuerend verloop in de tijd al naar gelang de fase van opleiding. In de startfase blijken co-assistenten enigszins geplaagd door onzekerheid over hun competentie en hun vermogen om een zinvolle bijdrage te leveren aan de patiëntenzorg. Deze empirische data ondersteunen de literatuur, waarin een vorm van basale onzekerheid werd beschreven, die medische studenten overvalt bij aanvang van de praktijkjaren (Lock, 1988; Sieverding,1990; Sinke \& Metz, 1989). $\mathrm{Na}$ de startfase van kennismaking en confrontatie met de praktijk van de medische wereld, neemt de twijfel en onzekerheid over de eigen bekwaamheid en de kwaliteit 
van de eigen rolinvulling af. Opmerkelijk is dat in de regressie-analyse werd gevonden dat subjectieve competentie met name verklaard kan worden uit de mate van motivatie voor het medische beroep en een mannelijk of instrumenteel zelfbeeld. Een mannelijk zelfconcept, dat wordt gekenmerkt door eigenschappen als rationaliteit groot abstractievermogen, jovialiteit, eerzucht, durf en zelfverzekerdheid, dominant en krachtig optreden, blijkt een voorspoedige ontwikkeling in het medisch professionele domein te faciliteren. Het ontberen van dergelijke eigenschappen maakt de kans op een negatief zelfbeeld en gevoel van minderwaardigheid bij co-assistenten groter.

De inschatting van co-assistenten over hun mogelijke bijdrage aan de patiëntenzorg, met andere woorden de inschatting van hun effectiviteit (efficacy) ten aanzien van medische zorg voor patiënten, blijkt daarentegen duidelijke samen te hangen met een vrouwelijk of expressief zelfconcept. Co-assistenten die van zichzelf aannemen dat ze spontaan, begrijpend, zachtaardig, nieuwsgierig, emotioneel, attent en zorgzaam zijn, beoordelen zichzelf als in staat om een zinnige bijdrage te leveren aan de zorg voor patiënten.

Verder gaan sommige groepen co-assistenten zich in de loop van de klinische stages meer als lid van de beroepsgroep ervaren. Het gevoel van meer insider te worden en meer bij de medische professie te gaan horen, vertoont bij zowel vrouwelijke als mannelijke gevorderde co-assistenten, die de studie binnen afzienbare tijd zullen afronden, een stijging. Opmerkelijker is dat dit gevoelen van "erbij horen" ook bij vrouwelijke startende co-assistenten een positieve impuls ondergaat.

\subsection{Het aanleren van de professionele distantie}

Een van de lastige aspecten van het aanleren van de medische beroepsrol is het vinden van de juiste mate van nabijheid en distantie in de relatie met de patiënt. Diverse rituelen en gewoonten zijn beschreven in de medische opleiding die de nieuwkomer nopen tot een houding van affectieve distantie. In de beginjaren zouden de ervaringen op snijzaal, zeker wanneer deze leerervaring zonder begeleiding of reflectie plaatsvindt, medische studenten stimuleren tot een objectiverende en gedistantieerde houding tot het menselijk lichaam. Daarna zouden de ervaringen in de medische stages of co-assistentschappen, met name die in de context van de snijdende vakken en de operatiekamer, het gevoelen van distantie en objectiveren van patiënt verder stimuleren.

$\mathrm{W}_{\mathrm{ij}}$ vonden in ons onderzoek dat studenten, wanneer zij starten met de co-assistentschappen onaangenaam zijn getroffen door de manier van spreken van sommige artsen onderling over patiënten en hun lichamen. Ook viel studenten bij hun entree in de klinische fase op dat in de houding sommigen van de medische beroepsgroep een zekere mate van onderwaardering richting de verpleegkundige beroepsgroep doorklonk. Uit de antwoorden op de open vragen naar eventuele spot of grappen van artsen onderling over patiënten, over vrouwen in het algemeen of vrouwelijke artsen, vrouwelijke patiënten of haar lichamen, werden veel voorbeelden gegeven waaruit bleek dat vooral de trias vrouw-, dik- en patiënt-zijn een dankbaar onderwerp vormt. 
Bij deze bevinding dient men zich wel te realiseren dat niet naar spot over mannen of mannenlichamen werd gevraagd in dit onderzoek.

Uit de regressie-analyse bleek een opmerkelijk verband tussen de gevoeligheid van coassistenten voor laatdunkende uitingen over patiënten of over vrouwen en het ontbreken van een vrouwelijk gekleurd ideaalbeeld bij de co-assistent. Dit roept de vraag op of van een licht feministische attitude mogelijk een beschermende werking uitgaat ten anzien van de sensitiviteit voor discriminatoire uitingen tijdens het functioneren in de beroepscontext.

\subsection{Aanspreken en aangesproken worden}

Wanneer we de groei van de professionele identiteit van aanstaande dokters verder vervolgen, blijken de wegen der seksen zich op een aantal aspecten te gaan scheiden. Als eerste kan een verschil worden geconstateerd in het proces van identificatie en assimilatie van vrouwelijke en mannelijke studenten. In tegenstelling tot vroeger onderzoek naar identificatie van medische studenten (Coombs,1978; Fahrenfort, 1985) blijken vrouwelijke co-assistenten zich in de fase van de klinische praktijk meer met patiënten te identificeren en niet minder en is er geen sprake van toename van de professionele distantie bij hen. De door Fahrenfort beschreven "medicalisering" van de medische student, treedt in ons onderzoek bij vrouwelijke co-assistenten niet op. Tegelijkertijd blijken vrouwelijke co-assistenten zich ook in toenemende mate met mannelijke artsen-opleiders te identificeren. Mannelijke co-assistenten laten op deze punten geen verandering zien, noch een toename noch een afname van de identificatie. We kunnen spreken van een interessant verschil tussen de seksen waarbij het ontwikkelingsproces van vrouwen in de geneeskunde getuigt van meer beweging op het terrein van identificatie in de fase van de co-assistentschappen en vrouwen zich tegelijkertijd zowel met patiënt als met de professie kunnen verbinden. Men zou kunnen spreken van een vermogen tot duale en parallelle identificatie bij vrouwelijke co-assistenten.

Ook blijkt de opleidingscontext een verandering teweeg te brengen bij vrouwelijke co-assistenten in de mate waarin zij zich bewust zijn van hun eigen sekse. Het blijkt dat wanneer co-assistenten de wereld van de medische praktijk betreden, het bewustzijn van gender bij vrouwen sterker wordt en bij mannen niet. Deze stijging van het bewustzijn van gender bij vrouwen wordt in de longitudinale data in alle fasen van de co-assistentschappen gevonden maar is het meest pregnant in de startfase. Deze bevinding kan betekenisvol zijn in het kader van mogelijke reproduktie van genderongelijkheid. In een beroepscontext die vooralsnog wordt gekenmerkt door dominantie van mannen in nagenoeg alle hogere functies en ondervertegenwoordiging van vrouwelijke artsen in rollen als opleider, docent of staflid, is de impliciete norm gebaseerd op de mannelijke dokter. De structurering van de beroepsuitoefening en beroepsopleidingen zijn vooralsnog afgestemd op het idee van een "vrijgestelde kostwinner" met grote offerbereidheid voor het "hogere" ambt.

Het wekt verbazing wanneer in een beroepscultuur vrouw-zijn en vrouwelijkheid worden bekrachtigd, waar de helden voornamelijk van het mannelijk geslacht zijn en 
de structuren van beroepsuitoefening naadloos aansluiten op het stereotype van de "mannelijke kostwinner". Vrouw-zijn heeft in een dergelijke context de betekenis van "anders-zijn" of afwijken van de norm en van de normale professional, waaraan men in de medische professie gewend is.

Wanneer vrouwelijke co-assistenten dus sterker worden aangesproken in hun genderrol, is de kans groot dat hiermee vooral hun "anders-zijn" wordt bekrachtigd. Over de wijze waarop deze sociale dynamiek op het subject en het persoonsarrangement van vrouwelijke artsen op de korte en op de lange termijn inwerkt, kan slechts gespeculeerd worden. Wij schatten in dat deze wijze van verschillend aanspreken van de seksen niet direct een negatieve werking heeft, maar wel op de middellange termin. Voor vrouwelijke artsen is de kans groter om hun genderidentiteit als strijdig te ervaren met hun professionele identiteit, waardoor in het verdere verloop van de (levens)loopbaan het risico op ambivalentie en onzekerheid is verhoogd.

Anders geformuleerd kan vermoed worden dat door de sociale bekrachtiging van vrouwelijkheid van vrouwelijke studenten in een masculiene werkomgeving, de kans verhoogd is dat vrouwen zelf de combinatie van beroepsrol en genderrol als moeizaam gaan reproduceren en zichzelf, meer dan de context, als probleem gaan zien. Omdat in de realiteit van de beroepsuitoefening momenteel daadwerkelijk nog diverse belemmeringen worden aangetroffen (zowel in structuur als cultuur van de geneeskunde) die de ontplooiing van meerdere identiteiten bemoeilijken, is de kans op een "self-fullfilling-prophecy" groot.

\subsection{De mythe van de "sekseneutrale geneeskunde"}

In het onderzoek is ook aandacht besteed aan de vraag of co-assistenten een mogelijke erotiserende atmosfeer aantroffen bij hun kennismaking met de praktijk van het medisch werkveld. Co-assistenten bleken enige mate van erotisering van de betrekkingen in de gezondheidszorg waar te nemen en deze perceptie werd sterker naarmate ze langer in opleiding waren. Deze verandering is consistent met de eerder besproken bevindingen uit het beroepscultuuronderzoek, waarin eveneens bleek dat cultuuraspecten sterker worden waargenomen door meer gevorderde co-assistenten die al langer gesocialiseerd zijn in de geneeskunde. Ook onderzochten wij of co-assistenten een zekere mate van discriminatie of ongelijkwaardigheid tussen de seksen bespeurden. Vooral vrouwelijke co-assistenten blijken bij aanvang van de klinische stages een atmosfeer te proeven die een zekere voorkeur voor mannen uitstraalt.

De perceptie van deze mogelijke voorkeur voor mannen blijkt in het longitudinale onderzoek een opmerkelijke verandering te vertonen. Over de gehele linie blijkt deze perceptie van voorkeur voor mannen af te nemen bij alle co-assistenten naarmate zij verder vorderen in hun opleiding.

Deze opmerkelijke bevindingen kan wijzen op een daadwerkelijke afname van de positieve discriminatie van mannelijke artsen, maar kan ook wijzen op een aanpassingseffect van co-assistenten aan de mythe van de "sekseneutrale geneeskunde", een ideologie over gelijke kansen voor mannen en vrouwen in de geneeskunde, die door Benschop werd gevonden (1996) in haar onderzoek naar de werking van de gelijk- 
heidsideologie in organisaties. Een dergelijke ideologie blijkt het zicht van de organisatieleden op de organisatiepraktijk vaak te belemmeren. In het onderzoek van Benschop bleek de organisatiepraktijk, waarin de verschillen tussen vrouwen en mannen in doorstroming naar hogere functies en in inkomen en status effectief niet kleiner waren geworden, door de organisatieleden ontkend of gebagatelliseerd te worden.

\subsection{Oriēntatie op beroep en beroepsrol}

Waarom worden mensen eigenlijk arts ? De keuze voor een beroep hangt samen met de betekenis die mensen hechten aan onder andere maatschappelijke rol, status en inkomen, aan zelfverwerkelijking en realisatie van idealen en dergelijke. We hebben gezien dat het proces van arts-worden een vorm van identiteitsontwikkeling is, die verschillende lagen van het zelf beroert. In dit onderzoek werd aandacht besteed aan de beroepsoriëntatie in termen van belang van maatschappelijke status en inkomen, belang van loondienst of beroepsuitoefening als solist, maar ook aan de balans tussen ideaalconcept en zelfconcept als arts. Deze concepten werden ingevuld met eigenschappen die passen bij een mannelijke prototype en een vrouwelijke prototype. Uit het onderzoek bleek dat co-assistenten hun ideaalconcept van arts zowel vrouwelijk al mannelijk inkleuren; ze hebben een androgyn ideaalbeeld van de ideale arts, die zowel mannelijke of instrumentele als vrouwelijke of expressieve kwaliteiten moet bezitten. Maar het cultureel ideaal van de medische professie lijkt toch meer met mannelijke of instrumentele karakteristieken bekleed dan met expressieve of feminiene kenmerken. Dit blijkt uit de wijze waarop het verschil tussen ideaalconcept en zelfbeeld zich in de loop van de tijd ontwikkelt. Ten aanzien van de mannelijke dimensie blijft het verschil bij alle co-assistenten groot, bij de vrouwelijke dimensie niet. Met name bij mannen verdwijnt het verschil tussen ideaal en zelf op de vrouwelijke dimensie.

In de beroepsoriëntatie van co-assistenten vinden we bij mannen de sporen terug van de geslachtsrolsocialisatie tot kostwinner. Mannelijke co-assistenten blijken daadwerkelijk sterker op maatschappelijke status, erkenning en inkomen georiënteerd te zijn dan hun vrouwelijke collega's. De geslachtsrolsocialisatie van vrouwen met accentuering op zorg en expressieve aspecten van het beroep wordt minder eenduidig teruggevonden bij co-assistenten. Vrouwelijke co-assistenten lijken minder stereotiep vrouwelijk, terwijl mannelijke co-assistenten wel stereotiep mannelijk zijn.

\subsection{Zijn de resultaten van de empirische studies nog accuraat en actueel?}

De gegevens van de studie naar perceptie van medische beroepscultuur en die naar socialisatie van co-assistenten, zijn begin negentiger jaren verzameld. De instroom van vrouwelijke studenten in de geneeskunde en de uitstroom van vrouwelijke basisartsen lag toen reeds rond de vijftig procent.

Het aantal vrouwelijke geneeskunde studenten is de afgelopen jaren verder gestegen (VSNU, 1997). Nu ligt het percentage vrouwen onder medische studenten rond $60 \%$. Deze studenten worden opgeleid door een beroepsgroep van artsen, waarin deze 
verschuivende man lvrouw verhoudingen vooral op het niveau van de arts-assistenten in opleiding tot specialist een huisarts zichtbaar begint te worden. Van het grote aantal vrouwelijke artsen-in-opleiding zal zeker een bepaalde voorbeeldwerking uitgaan voor co-assistenten. Wanneer we echter het corps van opleiders in zijn totaliteit bezien, blijken de verhoudingen de afgelopen jaren nog niet sterk te zijn veranded. Vrouwelijke artsen als docenten en als rolmodel op hogere posities in opleiding en beroepsgroep zijn nog steeds schaars. Het aantal vrouwelijke hoogleraren in de geneskunde bedraagt 4\% (VSNU, 1997).

We kunnen constateren dat de empirische data zijn verzameld op een moment dat de "vervrouwelijking" van de geneeskunde net duidelijkere vormen begon aan te nemen. We kunnen spreken van een uniek moment in die zin dat deze ontwikkeling, die zich momenteel nog steeds voortzet, toen net zichtbaar was. Deze studies brengen dus en beginpunt in beeld. Het zou interessant en zinnig zijn om in een follow-up onderzo:k deze ontwikkelingen verder op de voet te volgen en te bestuderen of en hoe de socialisatie van studenten hierdoor beïnvloed wordt. Ook de effecten van verbeterngen en interventies in medische onderwijs, die de afgelopen jaren in enkele universiteiten al zijn doorgevoerd (Essed \& Boshuizen,1993) kunnen in vervolgonderzotk bestudeerd worden.

\subsection{Dubbel-buitenstaanderschap voor vrouwelijke co-assistenten. Het functioneert anders.}

Het concept van de gevestigden en de buitenstaanders dat in het begin werd gekozen om de ervaringen van vrouwelijke co-assistenten in hun opvoeding in de geneeskunde als door mannen-gedomineerde beroepscontext te begrijpen, bleek in de loop van het onderzoek tekort te schieten. Onze operationalisatie van buitenstaanderschap in termen van minder professioneel zelfvertrouwen en meer stress en vermoeidheid, werd door het empirisch onderzoek gelogenstraft. Vrouwelijke co-assistenten bleken zeker niet meer last te hebben van stress en vermoeidheid dan hun mannelijke collegae en hadden evenmin last van gebrek aan zelfvertrouwen als zich ontwikkelend arts. We moesten op zoek gaan naar meer verfijnde en genuanceerde inzichten over de processen van produktie van macht en machtsongelijkheid. Het werk van Brouns (1993) en Benschop (1996) heeft hierbij goede diensten bewezen. We moesten toen constateren dat het machtstheoretisch perspectief van de "vis in het water" adequater was om de dynamiek van gender in de socialisatie van co-assistenten te analyseren. De toevoeging van de inzichten en empirische aanpak van Benschop in de hoofdstukken over de ontwikkeling van de professionele identiteit, heeft geresulteerd in een welkome verbreding van het theoretisch perspectief.

Brouns wees op wezenlijke verschillende conceptualiseringen van macht, die niet tot elkaar te herleiden zijn. Namelijk macht beschouwd vanuit het gezichtspunt van macht als biljartbal en macht als vis in het water. Brouns licht deze perspectieven aldus toe "het in de sociale wetenschappen betrekkelijk gebruikelijke biljartbal-perspectief (Lukes, 1974; Weber, 1976) toont macht als kracht werkend langs primaire 
lijnen van bezit, economische positie en kapitaalverdeling ${ }^{1}$. In de tweede benadering van macht die van macht als "vis in het water" staat de relatie van taal en macht centraal. Macht wordt benaderd als toestand, constitutief voor maatschappelijk leven, ze heeft geen centrum maar circuleert via lijnen van vele strategieën en circuleert in netwerken. Deze macht heeft geen oorsprong, maar circuleert in alledaagse praktijken. Het is een vorm van macht die mogelijkheden creëert, mogelijkheden tot subjectiviteit en betekenisgeving. In deze benadering kunnen vragen aan de orde komen die betrekking hebben op de werking van macht via betekenissen van mannelijkheid of vrouwelijkheid, professionaliteit en dergelijke. De machtsverhoudingen tussen de seksen verschijnen in deze benadering als resultaat van machtsbewegingen waaraan zowel vrouwen als mannen onderworpen zijn, in het bijzonder vanwege de noodzaak om subject te zijn in het maatschappelijk leven (Brouns, 1993; p 150).

Bij vervolgonderzoek naar gender en professionele socialisatie in de geneeskunde, zou het wenselijk zijn, om de inzichten van Bourdieu hierbij te betrekken, die spreekt over socialisatie als het tot stand brengen van een bepaalde "habitus". Dit begrip wordt gedefinieerd als het geheel aan innerlijke disposities, duurzame en overdraagbare schema's van waarneming, waardering en handeling (Bourdieu, 1989). De ervaring is een constructie, die afhankelijk is van de systemen van perceptie en appreciatie, dus van de habitus. De habitus is dus een soort praktisch bewustzijn, dat met rationele keuzen niets te maken heeft, wel met gevoel voor het sociale spel. Het is kennis die geen bewustzijn verlangt.

De empirische resultaten van dit onderzoek verschaffen inzicht in de relatie tussen de habitus ${ }^{2}$ van aanstaande artsen en het "veld", het medische professionele domein. Dit domein opgevat als een veld, kan in de theorie van Bourdieu worden beschreven als een relatief autonoom netwerk dat volgens een eigen logica functioneert en waarin verschillende vormen van kapitaal een rol spelen.

Het medische professionele domein (= het veld) structureert de habitus door conditionering en omgekeerd draagt de habitus bij aan de totstandkoming van het veld als wereld die betekenisvol, zinvol en waardevol is en die de moeite waard is om energie in te investeren (Brouns,1993).

Bourdieu beschrijft velden als strijdperken met eigen spel en eigen spelregels en een specifieke vorm van (ongelijk verdeeld) kapitaal, dat voortdurend inzet is van strijd. De gevechten zouden voor een belangrijk deel betrekking hebben op de definitie van

1 Macht vanuit het biljartbal-perspectief is het idee van een centrale macht die beperkingen oplegt aan mindermachtigen en het idee dat macht (al dan niet doelbewust) oorzaak is van gebeurtenissen. Deze conceptualisering van macht kan beschreven worden als iemand of iets heeft macht, als deze in een sociale verhouding de eigen wil kan doorzetten ook tegen iemands weerstand in.

${ }^{2}$ De habitus functioneert op een voorbewust niveau "below the level of consciousness and language, beyond the reach of introspective scrutinity or control by the will". De habitus ontleent zowel zijn constituerende als miskennende kracht aan het gegeven dat mensen handelen vanuit aangeleerde onwetendheid. De sociale wereld verschijnt als vanzelfsprekend, maar feitelijk is de ervaring van de sociale wereld een cognitieve handeling. De ervaring is een constructie die afhankelijk is van de systemen van perceptie en appreciatie, dus van de habitus. De habitus is dus een soort praktisch bewustzijn, dat met rationele keuzen niets te maken heeft, wel met gevoel voor het sociale spel. Het is kennis die geen bewustzijn verlangt. 
het veld zelf en de bepaling van wie wel en wie niet worden toegelaten tot het spel. Het veld is dus tegelijkertijd een strijdveld voor het handhaven en veranderen van de krachtsverhoudingen.

Een dergelijk perspectief op de toename van vrouwelijke artsen in het medisch professionele domein maakt nieuwsgierig naar de balans tussen handhaving van het bestaande en verandering in dit veld.

\subsection{De noodzaak van vernieuwing en innovatie}

De relatie tussen de culturele dimensie van onzekerheidsvermijding en de affiniteit tot innovatie is volgens Hofstede omgekeerd evenredig. Met andere woorden hoe groter de mate van onzekerheidsvermijding van een cultuur, hoe geringer de neiging tot vernieuwing en innovatie. De typering van de medische cultuur als onzekerheidvermijdend is dan ook weinig hoopgevend ten aanzien van het vermogen tot vernieuwing van dit domein. Evenmin is de karakterisering van de geneeskunde als een typische professie in dit opzicht hoopgevend; professies worden veelal als betrekkelijk in zichzelf gekeerde bolwerken beschreven (Klinkert,1978; Freidson, 1975; Krogt van der, 1981). Toch zijn wij na dit onderzoek niet somber.

De nieuwe generatie artsen is veranderd en doordrongen van een nieuwe tijdgeest. Zowel mannelijke als vrouwelijke artsen blijken andere wensen en andere opvattingen in te brengen in de beroepsgroep over werktijden en inrichting van het beroep (Dijkstra, 1992). Ook blijken vrouwen zeer zelfbewust en competent uit de fase van de coassistentschappen te voorschijn te komen, hetgeen zeker van betekenis zal zijn voor de kracht, waarmee deze omvangrijke nieuwe groep in de professie veranderingen kan stimuleren. De kans is groot dat deze nieuwe generatie de verouderde constellaties in het beroep van binnenuit kan bevragen en veranderen.

Maar hiertoe zullen medische professie en opleidingsinstituten ook zelf meer inspanningen moeten verrichten op het terrein van reflectie en analyse van de eigen cultuur. De kennis over de medische beroepsgroep, ontwikkeld door sociale wetenschappers en genderstudies zou meer geabsorbeerd kunnen worden en een rol kunnen spelen in vernieuwing en verbetering van medisch onderwijs en medische praktijk.

Als de invalshoek van cultuur vaker gekozen wordt, zullen opleiders en docenten zich gaan bezinnen op het voorbeeld dat zij door hun "alledaagse" handelen geven. Cultuur als invalshoek biedt tegenwicht aan de neiging van groepen om hun eigen vertrouwde cultuur als maatstaf te nemen en als vanzelfsprekend over te dragen op de nieuwe leden. Het relativeert de eigen codes en mores en leert inzien dat de eigen en bestaande praktijk slechts een van de vele mogelijkheden is.

Het vigerend beeld van professionaliteit, zoals dit wordt waargenomen door co-assistenten kan in grove contouren omschreven worden als dat van een medische expert, die kan omgaan met gezag en autoriteit en die zich gesterkt weet door zekerheden die ontleend kunnen worden aan wetenschappelijke inzichten, technologie en gedragsvoorschriften. De omgang van artsen onderling wordt gezien als enigszins hiërarchisch en weinig steunend of veilig. Ook dienen artsen blijk te geven van het vermogen om zelfstandig moeilijkheden te kunnen overwinnen en zich te kunnen profileren rich- 
ting collega's en verpleging. Ze moeten zowel in staat zijn tot enige mate van competitie, als ook kunnen samenwerken en loyaliteit naar elkaar en de beroepsgroep aan de dag kunnen leggen. Professionaliteit houdt voor co-assistenten in dat persoonlijke aspecten als emoties of zorgen noch in de beroepsrol noch in de beroepsgroep kunnen worden gearticuleerd en dat de scheiding tussen privé en openbaar vrij strikt is.

De percepties en appreciaties van co-assistenten zijn interessant, omdat ze informatie bevatten over vanzelfsprekendheden in medisch beroep en medisch handelen. Het zou wenselijk zijn dat deze informatie van nieuwkomers, ook vanwege de veranderingen in de gezondheidszorg, een aanleiding is voor herbezinning in professie en medische opleidingen en om de functionaliteit van verschillende sociale codes en gewoonten opnieuw met frisse blik te bevragen.

\section{Tot slot}

De medische professie zal zich dienen te bezinnen op haar cultuur van een door mannen gedomineerd beroep en kan de instroom van grote aantallen vrouwelijke professionals begroeten als een kans om het beroep te innoveren en het medisch handelen te vernieuwen en meer in overeenstemming te brengen met de eisen van deze tijd. Er dient meer en beter nagedacht te worden over de voorwaarden waaraan voldaan moet worden, opdat het menselijk kapitaal van komende generaties vrouwelijke artsen daadwerkelijk tot haar recht komt. Vrouwelijke co-assistenten blijken meer dan hun mannelijke collega's te worstelen met de diverse vormen van machtsongelijkheid en hiërarchie, waar ze zich toe moeten verhouden als aspirant-lid van de huidige professie en ze hebben moeite met de competitieve aspecten en de noodzaak tot profileren die beroepsuitoefening in het medische domein met zich meebrengt. Tegelijkertijd blijken vrouwelijke studenten verlies te lijden op het terrein van haar affiniteit met feminiene cultuuraspecten, die in het socialisatieproces enigszins onder druk staan. Voor de kwaliteit van de medische beroepsuitoefening en voor het welbevinden van individuele artsen, zou het positief zijn wanneer vrouwelijke aanstaande artsen hun culturele bagage verbonden aan hun genderrol, zoals relationele gerichtheid, vermogen tot verbinding en samenwerking en communicatie, weten in te brengen in de geneeskunde en deze meerwaarde weten aan te vullen met het vermogen om machtsongelijkheid, gezag en competitie te hanteren.

Om vrouwelijke aanstaande artsen op de kortere termijn te ondersteunen in het proces van opgroeien in een opleidingscontext die vooralsnog wordt gedomineerd door mannen en masculiene idealen, is het mogelijk zinnig om specifiek attitudeonderwijs te ontwikkelen vanuit een genderspecifiek perspectief.

Daarin kan aandacht besteed worden aan de eisen die aanpassing aan de huidige culturele beroepscontext stelt. Voor mannelijke aanstaande artsen lijkt genderspecifiek onderwijs eveneens nuttig om de stereotiepe representatie van mannelijkheid, die wordt aangetroffen in het medisch beroepsveld te bevragen en daarin meer vrijheid te creëren. Een genderspecifieke benadering kan nuttig zijn om mannen de mogelijkheid te bieden de meer feminiene of expressieve aspecten van het zelf tot ontwikkeling te brengen en in te passen in hun professionele handelen. 
Daarnaast zou een meer prominente rol van vrouwelijke artsen in de geneeskunde en in medisch onderwijs en wetenschap zeer aan te bevelen zijn. Mede vanwege de voo:beeldwerking en de positieve invloed die hiervan uit kan gaan ten aanzien van de on: plooiing van vrouwelijke professionals.

Het zou zeer aan te bevelen zijn om voortgaande op de ontwikkelde lijn in dit proeschrift vervolgonderzoek te doen naar de ontwikkelingen die zich momenteel in rep tempo voltrekken in de medische beroepsgroep. Zowel onder co-assistenten als onder arts-assistenten zou vervolg-onderzoek naar socialisatie nuttig zijn om de ontwikkelde inzichten verder te toetsen.

De medische professie gaat interessante tijden tegemoet. 


\section{Referenties}

Acker, J. (1991). Hierarchies, Jobs, Bodies: a theorie of gendered organizations. In Lorber, J., Farell, S.A., The social construction of gender. Newbury Park: Sage.

Adviesgroep Vrouwenhulpverlening, (1990). Advies Functies van de Vroutenbulpverlening. (Advice functions of women's health care). DOP Rijswijk.

Allen, D.I. (1989). Women in medical specialty societies; an update. Journal of the American Medical Association 262 no. 24, pp. 3439-3443.

Allen J. (1994). Doctors and their careers: a new generation. London Policy Studies Institute, (eerdere versie 1988).

Anonymous.(1984). H.S.C.L., Hopkins Symptom Checklist. in Bouman T, Kok A, H.S.C.L. Lisse; Swets en Zeitlinger

Anspach, R.R. (1988). Notes on the Sociology of Medical Discourse: The Language of Case Presentation. Journal of Health and Social Behavior, Vol. 29 (dec.), pp. 357-375

Baardman, J. (1989). Ingebeelde lelijkheid. Dissertatie. VU, uitgeverij Amsterdam.

Baart, I., Baerveldt, M., (eds.) (1986). Dokteren aan vrouwen. De medicalisering van vrouwenlevens. Amsterdam, Netherlands: SUA.

Baerveldt, M. (1996). Niemand kàn meer om de vrouwengezondheidszorg heen. In: Het smelten van de ijsprinses. Vrouwengezondheidszorg in de praktijk ... Wie kan er nog omheen? Utrecht, Netherlands: Aletta, Centrum voor Vrouwengezondheidszorg.

Baker-Miller, J. (1988). Het zelf-in-relatie, nieuwe psychologie voor vrouwenbulpverlening. Eindhoven: De Els Uitgeverij.

Bakker R., Schoenmaker, A., van der Zee H., (red). (1995). Als je de buisarts afschaft, wordt bij met een weer uitgevonden. Vier huisartsen in gesprek over de toekomst van het huisartsenbedrijf.

Bal, R (1992). Health, deviation and daily functions in elderly rbeumatoid arthritis patients.

Proefschrift Maastricht.

Baneke, J. (1987). Studiesucces, persoonlijkheid en stress. Een longitudinaal onderzoek naar persoonsgebonden voorspellers van studiesucces bij geneeskunde studenten. Een onderzoek naar stress bij geneeskunde studenten.

Barnett, R.C., Carr, P., Boisnier, A.D., Ash, A., Friedman, R.H., Moskowitz, M.A., Szalacha, L. (1998). Relationships of gender and career motivation to medical faculty members' production of academic publications. Academic Medicine 73(2), pp. 180-186.

Baszanger, I. (1985). Professional socialization and social controle; from medical students to general practitioners. Social Science and Medicine 20, no. 2, pp. 133-14.

Batenburg V. (1977). Medical students attitudes. Academisch proefschrift.

Batenburg, V. (1995). De terugkommiddag voor co-assistenten: een reflectie. Zoiets laat een scherf in je achter. Bulletin Medisch Onderwijs 14: 32-38

Baxter, N., Cohen, R., McLeod, R. (1996). The impact of gender on the choice of surgery as a career. The American Journal of Surgery 172, pp. 373-376.

Bean, G., Kidder, L.H. (1982). Helping and achieving - compatible or competing goals for men and women in medical school. Social Science and Medicine 16, pp. 1377-1381. 
Becker, H.S., Geer, B., Hudges, E.C., Strauss, A.L. (1961). Boys in white. University of Chicagopress. Bekker, M., Ten Dam, G., Fischer, A. en Willemsen, T. (1993). Psychologie en het subject van vrouwenstudies. Inleiding op het thema "Sekse als sociale categorie". Tijdschrift voor Vroutuenstu. dies 14, pp. 275-27.

Bekker, M. (1993). Vrouwelijkheid in het bijzonder. Van sekse naar een meer gedifferentieerde opvatting van gender-identiteit. Tijdschrift voor Vrowwenstudies 14, pp. 311-321.

Belenky, M.F., Mc Vicker, C. en Goldberger, N.R. (1986). Women's wary of knowing: development of self, voice and mind. New York: Basic.

Bem, S.L. (1981). Gender schema theory: a cognitive account of sex typing. Prycbological Review, 88 , no. 4 , pp. $354-364$.

Bem, S.L. (1981). Bem sex-role inventory. Palo Alto, California: Consulting Psychological Press.

Bender, W. (1979). Kritische momenten in de medische studie - enkele recente onderzoeksgegevens. Medisch Contact 13, pp. 402-403.

Benschop Y. (1996). De mantel der gelijkbeid. Gender in organisaties, Dissertatie. van Gorcum

Bensing, J.M. (1991). Doctor patient communication and the qualitiy of care. An observation study into affective and instumental behaviour in general practice. Utrecht. Netherlands: NIVEL.

Bensing, J.M. (1991). Doctor-patient communication and the quality of care. Social Science and Medicine 32, pp. 1301-1310.

Berg van den, S.A., Rijsenbeek A.P.M.M., Davidse, W., Postma, J.A. en Dols, W.P.M. (1993). Artsen buiten de curatieve zorg. NIPG-TNO.

Berger, PL., Berger, P. (1988) Sociologie. Een biografische opzet. Ambo: Baarn. oorspr. Sociology. Basic Books Inc., New York 1972.

Bergquist, S., Dochac, B. e.a. (1985). Perceptions of freshman medical students of gender differences in medical specialty choice. Journal of Medical Education vol 60, pp. 379. 383.

Bernstein, J., Carmel, S. (1991). Gender differences over time in medical school stressors, anxiety, and the sense of coherence. Sex Roles, vol. 24, nrs. 5/6, pp. 335-34.

Bhargava, G. (1985). Professional identification; a study of female students at a medical school in India. Social Science and Medicine 20, pp. 1169-1175.

Bickel, J. (1989). Materity leave policies for residents: an overview of issues and problems. Academic Medicine 64, no. 9, pp. 898-501.

Bickel, J., Ruffin, A. (1995) Gender-associated differences in matriculating and graduating medical students. Academic medicine. June. vol 70 (6): 551-559

Blackwell, E. (1977). Opening the medical profession to women. New York: Shocker Books.

Borst-Eilers (1998). Vrouwen aan de top. VWWS bulletin. 28 april.3

Bosch, M. (1994). Het geslacht van de wetenschap. Vrouwen en hoger onderwijs in Nederland 18781948. Uitgeverij Sua Amsterdam.

Bosch, M. (1982). Blauwkousen en hobbezakken in een witte jas. De eerste vrouwelijke artsen in Nederland 1872-1913. Jaarboek voor vrowwengeschiedenis 3. J.Blok, M.Elias (red) Nijmegen, pp.6398.

Boshuizen, H.P.A. (1989). De ontwikkeling van de mediscbe expertise. Een cognitief psychologische benadering. Proefschrift RL. Krips repro Meppel.

Bosk, C.L. (1979). Forgive and Remember. Managing Medical Failure.

Bourne, P.G., Wikler N.J. (1978) Commitment and the cultural mandate. Women in medicine. Soc. probl. 25, 430-440

Bourdieu, P. (1989, oorspr.: 1983). Economisch kapitaal, cultureel kapitaal, sociaal kapitaal. In P. Bourdieu Opstellen over smaak, babitus en bet veldbegrip. (gekozen door Dick Pels), Van Gennep Amsterdam, 120-142. Oorspr.: Oekonomisches Kapital, kulturelles Kapital, sociales Kapital. In R Kreckel (red), Soziale Ungleichbeiten, Otto Schwartz en Co, Göttingen.

Bowman, M.A. and Allen, D.I. (1991). Stress and women physicians. (Met name Chapter 8: Physician Stress). Springer-Verlag, New York Berlin Heidelberg Tokyo.

Brand-Valkenburg van den, BWH (1994). Raamplan artsopleiding. Eindtermen van de artsopleiding. Nijmegen, Universitair Publicatiebureau. 
Branch, W., Pels, R.J., Lawrence, R.S., Arky, R. (1990). Becoming a doctor. Critical-incident Reports from third-year medical students. The New England Journal of Medicine, 15, pp. $1130-1132$.

Brink van de Muiden A. (1996). Gender, Healtb and Healtbcare in General Practice, academisch proefschrift, Rijksuniversiteit Utrecht.

Broadhead, R.S. (1980). Multiple identities and the process of their articulation; the case of medical students and their private lives. Studies in symbolic interaction 3, pp. 171-191

Brooks, F. (1998). Women in general practice: responding to the sexual division of labour? Social Science and Medicine 47(2), pp. 181-193.

Brouns, M., Schokker, A. (1990). Arbeidsuraagstukken en sekse. Den Haag: Trendrapport 2 STEO. Ministerie van sociale Zaken en Werkgelegenheid DOP.

Brouns, M. (1993). De bomo economicus als winkeldochter. Tbeorieên over arbeid, macht en sekse. Amsterdam: SUA.

Bruijn, J. de (1989). Haar werk: vrowwenarbeid en arbeidssociologie in bistoriscb en emancipatorisch perspectief. Amsterdam: SUA.

Bruijn de, J. (1991). Omstreden kwaliteit: omtrent vrowwenarbeid en beleid. Oratie, Amsterdam: Vrije Universiteit.

Bruyn-Hundt. M. (1989). Vrowwen op de arbeidsmarkt. Utrecht: Het Spectrum.

Bryant, H.E., Jennett, P.A., Kishinevsky, M. (1991). Gender, family status and career patterns of graduates of the University of Calgary faculty of medicine. Academic 66, no.8, 483-485.

Bucher, R., Stelling, J. (eds.) (1977). Becoming a professional. Sage Library of social research 46.

Burke, R.J. and Richardsen, A.M. (1990). Sources of satisfaction and stress among Canadian physicians. Prychological reports 67 no. 3, pp. 1335-1344.

Burke, R.J. and Richardsen, A.M. (1991). Sex-differences in occupational stress and work satisfaction among physicians. Stress Medicine 7 no.2, pp. 79-86.

Butter, I.H., Carpenter, E.S. et al (1987). Gender hierarchies in the health labor force. International Journal of Health Service, 17, no.1, pp. 133-149.

Butterfield, P.S. (1988). The stress of residency. Archives Internal Medicine. Vol 148.

Carpenter, M (1993). The subordination of nurses in health care: towards a social divisions approach. in Riska, E. enWegar, K. (1993). Gender, Work and Medicine. Women and the medical division of labour. London: Sage

Eassidy, R.C. enSwee, D.E. \& Stuart, M.R. (1983). Teaching biopsycho-ethical medicine in a family practice clerkship. Journal of Medical Education, 58, pp. 778-783.

Chaplin, J. (1988). Feminist counselling in action. Sage publications.

Chodorow, N. (1978). The reproduction of mothering. Psychoanalysis and the sociology of gender. University of California Press, Berkely.

Clark, E., Rieker, P. (1986). Gender differences in relationships and stress of medical and law students. Journal of Medical Education, 61, pp. 32-44.

Cock de, G. (1985). Organisatieklimaat en cultuur. Theorie en praktische toepassing van de organisatieklimaatindex voor profitorganisatie (OKIPO) en de verkorte vorm (VOKIPO). Uitgeverij Acco.

Colombotos, J. (1988). Continuities in the sociology of medical education; an introduction. Journal of Health and Social Behavior, 29, pp. 271-278.

Condor, S. (1993). Denken over sekse als sociale categorie. Tijdschrift voor Vrowwenstudies 14, 280. 294.

Coombs, R.H. (1978). Mastering medicine, professional socialisation in medical school. The Free Press

Coser, L. (1978). Gulzige instituties; patronen van absolute toewijding. Van Loghum Slaterus

Dalman, M.R. (1979). Loopbaanontwikkeling bij vrouwen, gaat dat anders. Scriptie Sociale Pedagogiek. Amsterdam.

Dam ten, Urlings, M., Volman, M. (1991). Sexeverschillen in bet onderwijs, Wolters-Noordhoff

Davidson, L.R (1979) Choice by constraint; the selection and function of specialities among women physicians -in training. Journal of bealth politics,policy and law: 4:200-20 
Davis, S.W. et al. (1984). Sex stereotypes in the self-and ideal descriptions of physicians's assistant students. Journal of Medical Education, 59, pp, 678-680.

Davis, K. (1988). Power under the microscope, dissertatie. Dordrecht: Floris Publications.

Davis, K. (1991). Critical sociology and gender relations. In Davis, K., Leijenaar, M., Oldersma, J., The gender of power. London: Sage.

Doorewaard, H. (1989). De vanzelfsprekende macht van bet management. van Gorcum. Assen/Maastricht.

Delden, P.J. van (1991). Professionals. Kwaliteit van bet beroep. Amsterdam/Antwerpen: Veen.

Dennerstein, L., Lehert, P. (1990). Women in medicine - an overview. In The free woman, womens health in the 1990s. Van Hall, E.V. Everaerd, W.

Dennis, T., Harris, L et al. (1990). Infuences of marital status and parental status on the professional choices of physicians about to enter practice. Academic Medicine, 65, no.12, pp. 775-777.

Dijkstra T. M. (1992). Strijd om tijd. Een onderzoek naar meningen en wensen van basisartsen met betrekking tot hun beroeps- en privéleven. KNMG en Werkgroep Vrouwenstudies RU. Utrecht

Dillner L. (1994). Doctors are more miserable than ever, says report. BMJ 309, 1529.

Doorne-Huiskes, A. van (1986). Loopbanen van vrowwen en mannen: een analyse. Rijksuniversiteit Utrecht.

Drenthe-Schonk, A., Driessen, M., Dijkstra, A.G., Gybels v.d. Warenburg, Tijhuis, V., Weijts, W. (1995). Vrowwen in onderwijs en onderzoek aan de Rijksuniversiteit Limburg. Emancipatiecommissie Rijksuniversiteit Limburg.

Dowling, C. (1989). Perfecte Vrowwen. Vlucht in volmaaktheid. Bert Bakker.

Ducker, D.G. (1980). The Effect of Two Sources of Role Strain on Women Physicians. Sex Roles, 6, no 4 , pp. $549-559$.

Dudley, H.A.F. (1990). Stress in junior doctors - 1. Stress and support. BMJ 301, 75-76.

Duindam, V (1992). Sekse in ontwikkeling. in Psycbologie en sekse. Top, T. \& Heesink, J.(red)

Duivenboden van, Y. (1990). Meer vrouwen in de geneeskunde. Graadmeter, 6, no.10, 3-11.

Du Moulin, M., Heymans, R. \& Noordenbos, G. (1997). Vrouwelijke arts in zwang. Leiden, Universitaire Pers.

Dunning, A.J. (1981). Broeder ezel. Over onvermogen in de geneeskunde. Bunge Utrecht

Dupuis, H.M. enThung, P.J. (1992). Casuistiek L. Dupuis, H.M., Thung, P.J. enKerkhoff, A.H.M. Voordelen van de twiffel, een inleiding tot de gezondheidsethiek. Houten/Zaventem, Bohn Stafleu Van Loghum.

Dupuis, H, M. (1998). Op bet scherpst van de snede. Goed en kwaad in de geneeskunde. Goed en kwaad in de geneeskunde

Durkheim, E. (1960). The division of Labor in Sociology. New York: Free Press (verl. George Simpson).

Editorial (1991). Monopoly of middle-aged men. The Lancet vol. 337 april, pp. 1007-1008.

Eisenberg, C. (1989). Medicine is no longer a man's profession. Or, when the men's club goes coed, it's time to change the regs. The New Engeland Journal of Medicine, 321, no. 22, pp. 1542-1544.

Elias, N, Scotson J.L. (1985). De gevestigden en de buitenstaanders. een studie van de spanningen en machtsverhoudingen tussen twee arbeidersbuurten. Ruward BV. Den Haag.

Elston M. A. (1993). Women doctors in a changing profession: the case of Britain. in Gender, work and medicine. Riska E. en Wegar K.(eds) London: Sage Publications.

Ella, J.W., Pawluch, D. (1988). Medical students and the cadaver in social and cultural context - wbat goes on in the lab? M. Lock and D.R. Gordon (eds.), Biomedicine Examined, Kluwer Academic Publishers, pp. 125-153.

Ellemers, N. (1993). Sociale identiteit en sekse: het dilemma van succesvolle vrouwen. Tijdschrift voor Vrowwenstudies, 14, pp. 322-336.

Es van, A. (1979). Anatomie van het gevoel. Dagboek van een co-assistent. Westbroek.

Everts, G. (1993). Visie vanait de zijkant. Naar een feministische technologie-ethiek. Dissertatie, WHWPublicatie 14. Universiteit Twente. 
Fahrenfort, M. (1985). Een doktersroman. Een verkenning van de ervaringswereld van arts en patiënt op een polikliniek interne geneeskunde. Dissertatie Vrije Universiteit Amsterdam. Amsterdam: VU Uitgeverij.

Feldberg, R en Glenn, E. (1979). Male and female: Job versus gender models in the sociology of work. Social problems, 26 (5), Boston University, pp. 524-535.

Fennema, K., Meyer, D.L.enOwen, N. (1990). Sex of physician: patient's preferences and stereotypes. Journal of Family Practice, 30, pp. 441-446.

Ferris, B.Y. et al. (1979). Suicide among U.S. women physicians, 1967-1972.(controle) A.M.J. Prychiatry 136,5 , pp. $694-696$.

Firth, J. (1986). Levels and sources of stress in medical students. British medical journal, vol 292.

Firth-Cozens, J. (1994). The five years after qualification. The psychopathology of hospital life is keeping women doctors away. British Medical Journal, 309, pp. 1524-1525.

Firth-Cozens, J. (1990). Sources of stress in women junior house officers. BM/, 301, 89-91.

Fischer, A., Frankenhuyzen, C., Rojahn, K. enWillemsen, T. (1993). N. studies, 14, 322-336. De hardnekkigheid van sekse als sociale categorie, een socio-cognitieve benadering. Tijdschrift voor Vrowwenstudies, 14, pp. 295-310.

Floge, L., Merril, D. M. (1986). Tokenism reconsidered: male nurses and female physicians in a hospital setting. Social Forces, 64, no. 4, pp. 925-947.

Fox, N. (1993). Discourse, organisation and the surgical wardround. Sociology of Health and Illness, vol 15, no $1,16$.

Franssen, A.M.J., Persoon, J.M.G., Veling, S. (1982). Verschillend in attitude tussen medische studenten - een vergelijking tussen vierde- en zesdejaars medische studenten in Maastricht en Nijmegen. Medisch Contact, 32, pp. 970-974.

Freidson, E. (1975). Profession of medicine. A study of the sociology of applied knowledge.

Freire, P. (1972). Pedagogie van de onderdrukten. Athos.

Friedland, N., Keinan, G. (1991). The effects of stress, ambiguity tolerance, and trait anxiety on the formation of causal relationships. Journal of Research in Personality, 25, pp. 88-107.

Furnham, A. (1988). Values and vocation choices; a study of value differences in medical-, nursing", and psychology students. Social Science and Medicine, 26, 6, pp. 613-618.

Furnham, A. (1986). Attitudes to the medical specialities; comparing preclinical students' perceptions of nine specialities. Social Science and Medicine, 23, 6, pp. 587-594.

Geis, R.E., Jesilow, P. and Geis, G. (1991). The Amelia-Stern syndrome. A diagnosis of a condition among female physicians. Social Science and Medicine, 33, no. 8, pp. 967-971.

Van Gennep, A. (1960). The rites of passage. The University of Chicago press

Gilligan, C. (1982). Psychological theory and women's development. Harvard University Press.

Godlee, F. (1990). Stress in women doctors - Women should not have to overcome more barriers than men. BMJ, 301, p. 76.

Goffman, E.(1968) Asylums. Hammondsworth. Penquin Books

Goleman, D. (1996). Emotionele inteligentie, emoties als sleutel tot succes. Amsterdam: Contact

Golinger, R.C. (1991). Reasons that medical students seek psychiatric assistance. Academic Medicine, 66 , no. 2, pp. 121-122.

Gordon, D.R. (1988). Clinical science and clinical expertise: changing boundaries between ant and science in medicine. M. Lock and D.R. Gordon (eds.), Biomedicine Examined, Kluwer Academic Publishers, pp. 257-295.

Graat J.M.J.M. (1995) Bewustwording van attitude. in Metz, JCM, Scherpbier AJJA, Vleuten van de CPM (1995). Medisch onderwijs in de praktijk. Van Gorcum \& Comp

Grant, L. et al. (1990). Gender, parenthood and workhours of physicians. Journal of Marriage and the Family, 54, no. 1, pp. 39-49.

Gremmen, C., Westerbeek-van Eerten, J.A. (1988). De kracht van de macht. Theorieen over macht en hun gebruik in vrouwenstudies, Trendrapport STEO. Den Haag.

Groen, M. (1996). Medical technology work, organisation and gender. Dissertatie. Universiteit Maastricht. 
Groot, de L.(1987). Pliable but not receptive: concerning the marginal influence of a medical psychology course on the socialization process of doctors. Medical Education, 21, pp.419-425

Gross, E.(1989). Structural barriers and normative constraints in medical school and premed. American Journal of Sociology, 94, no. 4, pp. 856-859.

Guthrie, E.A., Black, D., Shaw, C.M., Hamilton, J., Creed, F.H., Tomenson, B. (1995).

Embarking upon a medical career: psychological morbidity in first year medical students. Medical Education, 29, pp. 337-341.

Hafferty, F.W. (1988). Theories at the Crossroads: A Discussion of Evolving Views on Medicine as a Profession. The Milbank Quarterly, Vol. 66, Suppl. 2, pp. 202-225.

Halfens, R. (1985). Locus of control. Beheersingsoriëntatie in relatie tot ziekte en gezondheidsgedrag Dissertatie. RL Maastricht.

Hall van, EV. (1992). Feminisering van de geneeskunde, Medisch Contact, 47, 867.

Hall van, EV. (1997). Vrouwen zijn gezonder dan u denkt. Utrecht: Bunge.

Hawkings, A. Noordenbos, G., (1989-1990). Blokkades in het doorstromen van vrouwen naar hogere functies aan de universiteit. Universiteit en Hogeschool, 36, pp. 269-279.

Heiligers, Ph.J.M., Hingstman L., Marree J.T.C. (1997). Inventarisatie deeltijd werken onder artsen. Nivel Utrecht.

Heim, E. (1991). Job stress and coping in health professions. Psychotberapy and Psychosomatics, 55, no. 2-4, pp. $90-99$.

Heins, M. Hendricks, J. Martindale, L et al. (1979) Attitudes of men and women physicians. Am. Journal Public Healtb; 69, 1132-1139

Hendrie, H.C., Clair, D.K., Brittain, H.M., Fadul, P.E. (1990). A study of anxiety/depressive symptoms of medical students, house staff, and their spouses/partners. The Journal of Nervous and Mental Disease, Vol. 178, no. 3, pp. 204-207.

Hermann, C. (1984). Vrowuelijke artsen in Nederland. Een onderzoek naar opleiding en beroepswerkzaamheden van vrouwelijke artsen. Dissertatie KUN. Meppel: Krips Repro.

Herschbach, P. (1991). Stress im Krankenhaus: die Belastungen von Krankenpflege-kraften und Arzten/Arztinnen. Psychotherapie Psychosomatic Medizinische Psychologie 41 no. 5, pp. 176-186.

Heymans, R.J.H.M., Noordenbos, G (1995). Het selectiebeleid van academische ziekenbuizen ten aanzien van vrowwelijke AGIO's en AGNIO's. Rijksuniversiteit Limburg.

Heymans, R.J.H.M., Stevens, F.C.J., Noordenbos, G., Winants, Y (1994). Vrouwen in de medische professie: een onderzoek naar loophaanperspectieven van vrouwen in de klinische geneeskunde. Rijksuniversiteit Limburg.

Heymans, R.J.H.M., Du Moulin M. (1996). Van basisarts tot medische specialist $m / v$. Universiteit Maastricht.

Hilberman, E., Konanc, J., Perez-Reyes, e.a. (1975). Support groups for women in medical school: a first year program. Journal of Medical Education, 50, pp. 867-875.

Hingstman, L., Pool J.B. (1992). Behoefteraming huisartsen. Nivel Utrecht.

Hirschauer, S. (1991). The manufacture of the bodies in surgery. Social Studies of Science, Vol. 21, 279. 319 , Sage London.

Hofstede, G. (1975). Predicting managers'career succes in an international setting: the validity of ratings by training staff versus training peers. in Management International Review. pp 43-50

Hofstede, G. (1991). Allemaal andersdenkenden. Omgaan met cultuurverschillen. Contact.

Hofstede, G. (1980). Culture's Consequences. International differences in work realtaed values. Beverly Hills. C.A. Sage

Hofstede, G. (1991). Cultures and organizations. Software of the mind. University of Limburg. Mc Graw-Hill Book Company UK.

Hofstede, G. (1992). Sekse en organisatiecultuur. in Vroww, Arbeid en Loopbaan. Symposiumbundel. Winants Y, Ruiter E (red). Rijksuniversiteit Limburg pp.16-24.

Hofstede, G., Neuijen, B., Ohayv, D. D., Sanders, G. (1990). Measering Organizational Cultures: A Qualitative and Quantitative Study Across Twenty Cases. Administrative Science Quarterly Hofstede, G. (1983). National cultures revisited. Behavior Science Research, 18, no. 4, 285-304. 
Hojat, M., Gonnella, J.S., Xu, G. (1995). Gender comparisons of young physicians' perceptions of their medical education, professional life, and practice: a follow-up study of jefferson medical college graduates. Academic Medicine, 70(4), pp. 303-312.

Horst van der, H.E., Kruythof C.J. Leeuwen van C.D. et al (1989). Carrieres-barrieres. Verslag themadag over ma loopbaanplanning van vrouwelijke geneeskunde studenten. Vrije Universiteit Amsterdam

Hout van, M. (1983). Op ww gezondbeid. Dagboek van een huisarts in opleiding. Westbroek: Harlekijn.

Huijbers, P M J F (1992). Coping gedrag en gezondheid van ouders van kinderen met CARA. Verslag wetenschapsstage Universtiteit Maastricht

ICRA of Interfacultaire commissie richtlijnen artsexamen (1996). Het artsexamen. Eindrapport Nijmegen.

Illich, I. (1975). Medical nemesis. The expropriation of bealtb. Calder and Boyars, London

Imbos, $\mathrm{T}_{\mathrm{j}}$. (1989). Het gebruik vun einddoeltoetsen bij aunvang van de studie. Dissertatie Rijksuniversiteit Limburg. Drukkerij Alberts Gulpen

Izraeli, D.N. (1988). Burning out in medicine; a comparison of husbands and wives in dual career couples. Journal of Social Behavior and Personality, 3, no. 4, pp. 329-346.

Jacobs, A. (1985) Herinneringen. SUN Nijmegen. (oorspr. Holkema en Warendorf 1924)

Jager de, H. Mok, A.C. (1978). Grondbegindselen der Sociologie. Gezichtspunten en begrippen. Stenfert Kroese NV Leiden

Jansen. W. (1992). Identiteiten in beueging: culturele definiêringen van gender. Nijmegen: Centrum voor Vrouwenstudies.

Jefferys, M. enElston, M.A. (1989). The medical school as a social organisation. Medical Education, 23, pp. 242-251.

Jungbluth, P. (1982). Docenten over onderwijs aan meisjes. Positieve discriminatie met een dubbele bodem

Kanter, R.M. (1977). Men and Women of the Corporation, New York: Basic Books.

Keizer, M. (1993). "Dan wordt bet niets met mij, misschien." Gender en professionaliteit in medische specialismen. Utrecht, SISWO-congres Vrouwen-/Genderstudies.

Keizer, M. (1997). De dokter spreekt. professionaliteit, gender en uitsluiting in de medische specialismen. Proefschrift. Rijksuniversiteit Utrecht. Eburon.

Kleiverda, G. (1989). Vrouwen in de verloskunde en gynaecologie: een kwantitatieve analyse. Nederlands tijdschrift voor obstetrie engynaecologie, 102, pp. 246-249.

Kleiverda, G. (1989). Vrouwen in de verloskunde en gynaecologie: een kwalitatieve analyse. Neder. lands tijdschrift voor obstetrie engynaecologie, 102, pp. 297-299.

Klinkert, J.J. (1978). De arts en zijn professie. In: Aakster, C.W. enKuiper, G., Leerboek medische sociologie.

Klinkert, J.J. (1974). Macht van artsen. Een bezorgde verkenning van een professie. Assen: Van Gorcum enComp. B.V.

KNMG of Koninklijke Nederlandse Maatschappij ter bevordering der Geneeskunst (1989). Rapport van de commissie problematiek van de vrouwelijke arts. Utrecht.

KNMG of Koninklijke Nederlandse Maatschappij ter bevordering der Geneeskunst. (1978) Gedragregels voor artsen. Gebaseerd op datgene wat door de professie verstaan wordt onder zorgvuldig handelen, de beroepsoefening in ruime zin betreffende.

Kohrman, C.H., Lyttle, C.S. et al (1989). National study of internal medicine manpower. XIV: Patterns of residency and fellowship over time, update (1987). Archives of Internal Medicine, 149, no.10, pp. 2179-2185.

Komaromy, M., Bindman, A., Haber, R.J., Sande, M.A. (1993). Sexual harassment in medical training. The New England Joumal of Medicine 328(5), pp. 322-326.

Komter, A. (1985). De macht van de vanzelfsprekendheid in relaties tussen mannen en vrowwen. Den Hag: VUGA.

Komter, A. (1990). De macht van de dubbele moraal. Amsterdam: Van Gennep. 
Komter, A. (1992). Seksestereotypen en macht. in Psycbologie en sekse. Top, T. en Heesink, J.(red)

Koninck de, M., Bergeron, P., Bourbonnais, R. (1997). Women physicians in Quebec. Social Science and Medicine 44(12), pp. 1825-1832.

Konner, M. (1987). Becoming a doctor. A journey of initiation in Medical School. Penquin Books.

Kortenhoeven, D., Doorne-Huiskes van, A., Groenewegen, P.P., Maas, I. (1988). Vestiging van vrouwelijke huisartsen. Een theoretisch model ter verklaring van verschillen tussen vrouwen en mannen. Mens en Maatschappij, 63, 1, pp. 24-43.

Kortenhoeven, D. (1989). Vrowwelijke artsen en vestiging als buisarts. Dissertatie. Bohn, Scheltema, Holkema.

Krogt van der, Th.P.W.M. (1981). Professionalisering en collectieve macht, een conceptueel kader. Dissertatie.

Krol, L.J. (1989). De stille revolutie. Inaugurale rede. Amsterdam

Krol, L.J. (1992). Tarzan en Jane in de medische jungle. Cultuurpatronen in de geneeskunde. Mediscbe Contact, 29.30, pp. 876-879.

Kuipers, L. (1993). Begrensde aspiraties. De aspiraties van jonge vrouwen uit verschillende klassen vergeleken. Paper Vrouwen-Genderstudies 28-29 Okt. SISWO publicatie.

Kumpusalo, E., Mattila, K., Virjo, I., Neittaanmaki, L., Kataja, V., Kujala, S. Jaaskelainen, M., Luthala, R., Isokoski, M. (1991). Medical education and the corresponding professional needs of young doctors: the Finnish Junior Physician 88 Study. Medical Education, 25, 71-77.

Kutner, N.G., Brogan, D. (1990). Gender roles, medical practice roles and ob-gyn. Career choice: a longitudinal study. Women Health, 16, pp. 99-117.

Kuyer, G. (1980). Het geminachte kind. Baarn: Ambo.

Lang, D., Markowitz, M. (1989). Individual-diffference predictors of felt stress among academics seriously considering career change. Work and Stress, 3, no. 4, pp. 305-314.

Lanska, M.J., Lanska, D.J. et al. (1984). Effect of rising percentage of female physicians on projections of physician supply. Jowrnal of Medical Education, 59, pp. 849-855.

Leemeijer, M. (1990). Zorgverantwoordelijkheid ook herverdelen in privé-situatie. Medisch Contact, 45, no. 46, pp. 1367-1368.

Leemeyer M. (1991) Het artsenberoep moet vrouwvriendelijker worden. Tijdscbrift voor politiek en gezondheid, pp. 18-20.

Levin, R.B., Walker Franklin, A.L. (1984). Needs assessment and problem identification of first and second year medical students. Journal of Medical Education 59, no. 11, 908-910.

Levinson, W., Tolle, S.W., Lewis, C. (1989). Women in academic medicine - combining career and family. The New England Journal of Medicine, 321, no. 22, pp. 1511-1517.

Leyenaar, M.H., Saharso, S. (1983). Vrouwen en politieke macht. Trendrapport over vrouwenstudies en emancipatieonderzoek, DOP. Ministerie van sociale zake.

Light, D. (1979). Uncertainty and control in professional training, Journal of Health and Social Behavior, 20, pp. 310-22.

Linn, B.S., Zeppa, R. (1984). Stress in junior medical students: relationship to personality and performance. Journal of Medical Education, vol. 59, Jan., pp. 7-12.

Linn, L.S., Cope, D.W., Leake, B. (1984). The effect of gender and training of residents on satisfaction ratings by patients. Journal of Medical Education, 59, pp. 964-966.

Lippe. T van der, van Doorne-Huiskes J. (1995). Veranderingen in stratificatie tussen mannen en vrouwen? In: Verschuivende ongelijkheid in Nederland: sociale gelaagdheid en mobiliteit. Assen.

Lloyd, C., Gartrell, N.K. (1983). A further assessment of medical school stress. Journal of Medical Education, Vol. 58, Dec., pp. 964-967.

Lock, M. (1988). Introduction. M. Lock and D.R. Gordon (eds.), Biomedicine Examined, Kluwer Academic Publishers, pp. 3-10.

Lock, M., Gordon, D.R. (1988). An introduction to the essays. M. Lock and D.R. Gordon (eds.), Biomedicine Examined, Kluwer Academic Publishers, pp. 11-16.

Long, S.O. (1986). Roles, carees and femininity in biomedicine: women physicians and nurses in Japan. Social Science and Medicine 22, pp. 81-90. 
Lorber, J. (1984). Women physicians. Careers, status and pouver. Tavistock publications New York.

Lorber, J. (1992) Can women physicians ever be true equals in the American medical profession ? Carrent researcb in occupations and professions. vol VI, edited by Judith A. Levy and Gary.

Lorber, J. (1993) Why women never be true equals in the American medical profession. In: Riska E. en Wegar K. (eds) Gender, work and medicine. London: Sage Publications.

Lowenstein, L.M., Phil, D. (1979) The structure and function of graduate medical education. Shapiro, E.C. and L.M Lowenstein (eds.). Becoming a physician. Development of values and attitudes in medicine, pp. 113-138.

Lupton D. (1994). Medicine and culture, Illness, Disease and the body in Western Societio, London: Sage Publications.

Lutterman JA (1995) De assistent-geneeskundige-in-opleiding (AGIO) als docent. Bulletin Mediscb Onderwiys 14: pp. 9-12

Maheux B., P. Delorme et al. (1990) Humanism in medical education: a study of educational needs perceived by trainees of three Canadian schools. Academic medicine. 65 no. 1, pp.41-45.

Marshall, H. en Wetherell M. (1989). Talking about career and genderidentities. In: Skevington S. en Baker, D., The Social Identity of Women. London, Sage.

Martens A.L.J.E. (1990). Cijfers over vrouwelijk artsen. Mediscb Contact, 45, pp. 1371-1374.

Martin, S.C., Parker, R.M. and Arnold, R.M. (1988). Gender and medical socialisation. Journal of bealth and social behavior, 29, no. 4, pp. 333-343.

Maseide, P. (1991). Possibly abusive, often benign, and always necessary. On power and domination in medical practice. Sociology of Health and Illness, Vol. 13, No. 4, pp. 545-561.

Mather, M. (1989). Don't put your daughter, into medicine. BMJ, 298, pp. 1654-1655.

Mavis Hetherington, E.,Parke R.D. (1993) Child psychology. A contempory viewpoint. Fourth edition. Mc Graw-Hill Inc

Mc Cue, (1985). The distress of internship, causes and prevention. The New England Journal of Medicine, Vol 312, No.7, pp. 449-452.

Mc Keique, P.M., Richards, D., Richards, P. (1990). Effect of discrimination by sex and race on the early careers of British medical graduates during 1981-1987. British medical journal 301, no. 6758, pp. $961-964$.

Mc Kay, N.L. (1990). The economic determinants of speciality choice by medical residents, Journal of Health economics 9, no. 3, pp. 335-357.

Mc Keown, T. (1979). The role of medicine. Basil Blackwell. Oxford

Meer van der, J. (1989). Werktijd en kwaliteit van de assistent-geneeskundige in opleiding tot specialist. Nederlands tijdschrift Geneeskunde, 133, no. 28, pp. 1385-1387.

Meeuwesen, L., Ruiter, M., Westerbeek van Eerten, J., Brinkgreve, C. (1991). Vrouwen en gezondheid. Een overzicht naar onderzoek naar gezondheidsklacbten van vrowwen, 1970-1990. The Hague, Netherlands: Derde Trendrapport STEO.

Meeuwesen, L., Schaap, C. en Staak van der, C., (1991). Verbal Analysis of doctor-patient communication. Social Science and Medecine, 32, pp. 1143-1150.

Metz, JCM, (1993). Leren en onderwijzen in de geneeskunde. Bulletin medisch onderwijs 1993,12,p 11-26

Metz, JCM, Bulte JA, Paridon van EJM. (1990). Basisarts: bevoegd en bekwaam. Eindrapport. Beleidsgerichte studies hoger onderwijs en wetenschappelijk onderzoek 23. Ministerie Onderwijs en Wetenschappen. SDU.

Metz, JCM, Pels Rijcker-Erp van Taalman Kip EH, Van den Brand Valkenburg BWM. (1994) Raamplan 1994 artsopleiding. Eindtermen van de artsopleiding. Nijmegen: Universitair Publikatiebureau KUN.

Metz, JCM, Scherpbier AJJA, van der, Vleuten CPM (1995). Medisch onderwijs in de praktijk. Van Gorcum \& Comp.

Meyboom-de Jong B. (1992). Op weg naar een grote minderheid. Medisch Contakt, 47, 29 en 30 juli. 
Miller, J., Lincoln, J.P. en Olson, J. (1981) Rationality and equity in professional networks: gender and race as factors in the stratification of interorganizational systems. American Journal of Sociology, 87, pp. 308-334.

Miller, P., Lloyd, C. (1991). Social support and its interactions with personality and childhood backgrounds as predictors of psychiatric symptoms in Scottish and American medical students. Social Prychiatry and Prychiatric Epidemiology, 26, pp. 171-177.

Mintzberg, H. (1992). Organisatiestructuren. New Yersey: Prentice-Hall.

Michie, S., Sandhu, S. (1994). Stress management for clinical medical students. Medical Education, 28, pp. 528-533.

Mizrahi, T. en Abramson, J. (1985). Sources of Strain Between Physicians and Social Workers: Implications for Social Workers in Health Care Settings. Social Work in Health Care, Vol. 10 (3), Spring, pp. 33-51.

Mizrahi, T. (1984). Managing medical mistakes: ideology, insularity and accountability among internists -in -training. Social Science and Medicine, vol 19, no. 2, pp. 135-146.

Mol, A. (1989) "Sekse" en wetenschap: een vergelijking met twee onbekenden. In Boon, L en de Vries, G. Wetenschapstheorie: de empirische wending. Wolters Noordhoff, Groningen, 97-107.

Mol, A. van Lieshout, P. (1989). Ziek is bet woond niet. Medicalisering, normalisering en verande rende taal van huisartsgeneeskunde en geestelijke gezondheidszorg (1945-1985). Sun, Nijmegen.

Moll, J. (1995) Effecten van curriculum verandering: een reaktie "lachen en huilen" Bulletin Mediscb Onderwijs 14: pp. 13-19.

Monteban, H. Vrugt, A., (1989-1990). Weerstand tegen de voorkeursbebandeling van vrowwen bij werving en selectie voor wetenschappelijke functies. Universiteit en Hogeschool, 36, 280-287.

Mulder, H.C. (1996) Het medisch kunnen. Technieken, keuzen en zeggenschap. Dissertatie. Van Gorcum, Assen.

Mulder, H.J. (1978). De werkwijze van artsen als sociaal gedrag. Aakster, C.W. en Kuiper, G. Leerboek medische sociologie.

Mulder, G., Hofstede, G. (1991). Touvards an emancipatory study of organizational culture. Paper voor 10e EGOS-conferentie 1991 - Women in organizations.

Mumford, E. (1970). From student to psychician. Interns - From students to physicians, Havard University Press, Cambridge, Massachusetts, pp. 118-136.

Mumford, E. (1970). The medical chart. Interns - From students to physicians, Havard University Press, Cambridge, Massachusetts, pp. 137-263.

Nadelson, C.C. (1991) Advancing through the medical hierarchy. Journal of the American medical womens association 46 no.3, Pp. 95-99.

Nicolai, N. (1992). Vrouwenbulpverlening en psychiatrie. Amsterdam: SUA.

Nieuwenhuyzen Kruseman, AC. and Scherpbier, AJJA. (1994) Herziening praktisch medisch onderwijs; vallen en opstaan. In Houtkoop E., Pols, J., Pollemans, MC., Verwijnen, GM. (eds.) Gezond Onderwijs 3. Den Haag Haagse Hogeschool, pp. 195-199.

Nickerson, K.G., Bennett, N.M., Estes, D., Shea, S. (1990) The status of women at one academic centre. JAMA Vol. 264 no. 14 oct., pp. 1813-1817.

Nicolson, P. Welsh,C L. (1993) Sexual harassment, male dominated organization and the role of counselling psychology: the case of medical school. Counselling psycbology Quaterly, vol.4.p 291301.

Noordenbos, G. Winants, Y.(red) (1994) Feiten en Frikties. Sekse-asymmetrieen in zorgsystemen. Congresverslag Vrouwenstudies Rijksuniversiteit Limburg. Maastricht Uniprint.

Noordenbos, G. Gender gap in academe; De positie van vrouwen aan de universiteiten in internationaal perspectief. Universiteit \& Hogeschool, 41,1994-1995: 105-120

Noordenbos, G. (1996) Geslechtsfragen in der Arzt-Patienten-beziehung. Arch. Gynaec. Obstet. 259 suppl 1:6-16

Notman, N. Nadelson, C C. (1973). Medicine. A career conflict for women. Am. J. Pyychiatry;130, $1123-1127$ 
Notzer, N., Brown, S. (1995). The feminization of the medical profession in Israel. Medical Education, 29, pp. $377-381$.

Olkinuora, M., Asp, S. et al. (1990). Stress symptoms, burnout and suicidal thoughts in Finnish physicians. Social psychiatry and prychiatric epidemiology 25, no. 2, pp. 81-86.

Oorschot J.A. van, Jaspers, Fr.C.A., Leeuwen-Seelt van E.I. (1997). De specialist en zijn loopbaan. Medisch Contact SO, pp. 959-961.

Ott, M. (1985). Assepoesters en kroonprinsen. Een onderzoek naar de minderbeidspasitie cuan agentes en verplegers. Amsterdam: SUA.

Otten, R. en Widdershoven, G. (1990). Social change and the perception of risks in medical practice.

Oudijk, C., (1983). Sociale atlas van de vroww. Den Haag: Staatsuitgeverij.

Outshoorn, J. (1989). Een irriterend onderwerp: over verschwivende conceptualiseringen van bet seksever. schil. Nijmegen: SUN.

Oudshoorn, NEG. (1996). Genderscripts in technologie, noodlot of uitdaging. Inaugurele rede Universiteit Twente.

Oudshoorn, N. (1994). Beyond the natural body: an arcbeology of sex bormones. proefschrift. London: Routledge.

Parkes, K.R. (1985). Stressfull episodes reported by first-year student nurses; a descriptive account. Social science Medicine, 20,945-953

Parkhouse, J., Ellin, D.J. (1988). Reasons for doctors, career choice and change of choice. BMI 296, 6, pp. 1651-1653.

Parkhouse, H.F. and Parkhouse, J. (1989). Women, life and medicine; achieving the balance; an account of 1974 women medical graduates in 1987. Community medicine 11,4, pp. 320-335.

Parmley, W.W. (1993) Sexual harassement and other gender issues in medicine. Jowrnal of the American College of Cardiology 22(4), Pp. 1242-1243.

Payer, L. (1988). Medicine and culture. New York: Penquin books.

Philipsen, H. (1988). Gezondheidszorg als project en bejegening. Waarden ten aanzien van ziekte, gezondheid en samenleving. Maastricht: Reprografie R.L.

Philipsen, H. (1985) Rationaliteit en ons oordeel over de verdwijnende patiënt. Gezondheid en samenleving pp. 163-172.

Pitts F. B.Y. et al. (1979). Suicide among U.S. women physicians, 1967-1972. American journal of Psychiatry 136, 5, pp. 694-696.

Pool, J. and Pool, J.J. (1983). Beroepssocialisatie co-assistenten. Mediscb Contact, 22, 655-658.

Projekt Vrouwenhulpverlening van NVAGG (1990). Cultuurverandering op maat. Vrouwenhulpverlening in de Riaggs. Ministerie WVC.

Rathbun, J. (1995). Helping medical students develop lifelong strategies to cope with stress. Academic Medicine 70(11), pp. 995-996.

Rhodes, P.J. (1989). The career aspirations of women doctors who qualified in 1974 and 1977 from a nited Kingdom medical school. Medical Education 23, no.2, pp. 125-135.

Richardsen, A.M. and Burke, R.J. (1991). Occupational stress and job satisfaction among physicians; sex differences. Social Science and Medicine 33, 10, pp. 1178-1187.

Richman, J.A., Flaherty, J.A. (1990). Gender differences in medical student distress: contributions of prior socialization and current role-related stress. Social Science Medicine, 30, 7, pp. 777-787.

Richters, J.M. (1991) De medische antropoloog als verteller en vertaler. 1991 Smart. Heemstede.

Richters, JMA. (1996). Our bodies, our selves? Oratie Rijksuniversiteit Leiden.

Rinke, C.M. (1981). The professional identities of women physicians. JAMA, vol 245, no. 23, pp. 2419-2421.

Riska, E. en Wegar, K. (1993). Gender, Work and Medicine. Women and the medical division of Labour. London: Sage.

Robbins, L., Robbins, E., Katz, S., Geliebter, B. en Stern, M., (1983). Achievement Motivation in Medical Students. Journal of Medical Education 58, pp. 850-858. 
Robins, L., Gruppen, L.D., Alexander, G.L., Fantone, J.C., Davis, W.K. (1997). A predictive model of student satisfaction with the medical school learning environment. Academic Medicine, 72(2), pp. 134-139.

Roeske, N.C. (1985). Life stories as careers; careers as life stories. Perspectives in biology and medicine 28 , no. 2, pp. 229-242.

Roeske, N.A., Lake, K., (1977). Role models for women medical students. Journal of Medical Educati. on, vol. 52, pp. 459-465.

Rosal, M.C., Ockene, L.S., Ockene, J.K., Barrett, S.V., Ma, Y., Herbert, J.R. (1997). A longitudinal study of students' depression at one medical school. Academic Medicine, 72(6), pp. 542-546.

Rouneau, C. (1987). Verschillen tussen vrouwelijke en mannelijke artsen. Bijblijven, 3, no. 7, 26-29.

Rouneau, C. (1994). Doctor's Gender and Patient Care: a study of perceived general prationer behavior during consultations. Thesis Antwerpen.

Rowe, L.L., Carson, N.E. (1989). Women in the medical workforce, Victoria. Australian family physician 18 , no. 4 , pp. $390-393$, p. 395 , pp. 397-399.

Rudisill, R. en Painter, A.F. (1982). Physicians life-style management: a selective for first year medical student. Journal of Medical Education 57, pp. 367-371.

Sanders, G., Neuijen, B., (1988). Bedriffscultuur: diagnose en beinvloeding. Van Gorcum en Comp.bv

Sanders, K., (1991). Vrouwelijke pioniers: vrouwen en mannen met een "mannelijke" bogere beroepsopleiding aan bet begin van hun loopbaan. proefschrift. Groningen.

Schaller, J.G. (1990) The advancement of women in academic medicine. Journal of the American medical association. 264 no.14. 1813-1817.

Schaufeli, W.B. (1993), Maslach, C \& Marek, T (eds). Professional burnout; Recent developmentsin theory and research. New York: Taylor \& Francis.

Scherpenzeel, R., Heineman, J., Noordenbos, G., Winants, Y. (1991) Doorbreking van sexe-stereotypen in het Medisch Onderwijs. Bulletin Mediscb Onderwijs, no. 3.

Schmidt, H.G., Boshuizen, H.P.A. en Norman, G.R. (1992) Reflections on the nature of expertise in medicine. in Keravnou E. (ed.), Deep models form medical knowledge engineering. Amsterdam. Elsevier.

Schmidt, H.G., Boshuizen, H.P.A. (1993) On acquiring expertise in medicine. Educational Psychology Review, 5, pp. 1-17.

Schoon, L. (1988). Catharina van Tussenbroek (1852-1925) in Geleerde vrouwen, negende jaarboek voor Vrowwengeschiedenis 9 red. T. van Loosbroek e.a., pp. 115-120.

Schoon, L. (1995). De Gynaecology als belichaming van vrouwen. Verloskunde en Gynaecologie 1840. 1920. Zutphen: Walburg pers.

Schreier, A.R., Abramovitch, H. (1996). American medical students in Israel: stress and coping. Medical Education, 30, pp. 445-452.

Schreur,P.J.G.,Tellegen, B \& Willige, G. van de (1984).Gezondheid, stress, coping: de ontwikkleing van de Utrechtse Copinglijst, Gedrag, Tijdschrift voor psychologie.12, 101-115

Scott, J., (1986). Gender: a usefull category of historical analysis. In: American Historical Review, pp. 1053-1075.

Shapiro, E.C. and Lowenstein, L.M., (eds.). (1993). Becoming a physician. Development of values and attitudes in medicine, pp. 139-161.

Shapero, A. (1985). Managing professional people. New York: The Free press.

Shye, D. (1991). Gender differences in Israeli physicians career patterns, productivity and family structure. Social Science and Medicine 32, no. 10, pp. 1169-1181.

Sieverding, M., (1990). Psychologische Barrieren in der beruflichen Entwicklung von Frauen. Das beispiel der Medizinerinnen. Stuttgard: Ferdinand Enke Verlag.

Sinke, E. Metz, J.C.M. (1989) Begeleiding van co-assistenten. Bulletin Medisch Onderwijs 8:132-9

Silver, H.K., Glicken, A.D. (1990). Medical student abuse; incidence, severity and significance. JAMA, January 26 , Vol. 263 , no. 4 , pp. 527-532.

Simpson, L.A. and Grant, L. (1991). Sources and magnitude of job stress among physicians. Journal of behavioral medicine 14, no. 1, pp. 27-42. 
Singer, S. (1997). Androgyny: tounards a new therapy of sexuality. London and Henley: Routledge Kegan Paul.

Shorter, E. (1983). A bistory of women's bodies. London: Allen Lane.

Skevington, S. and Baker, D. (ed.) (1989). The Social ldentity of Women, London, Sage publications.

Smith, A.C. en Kleinman, S. (1989). Managing emotions in medical school: student's contacts with the living and the dead. Social Psychology Quarterly, vol. 52, no. 1, pp. 56-69.

Snyder, B.R. (1970). The bidden curriculum. The MIT press Cambridge, Massachusetts and London. Spence, J.T., Helmreich, R.L. (1981). Androgyny versus gender schema: a comment on Bem's gender schema theory. Psychological review 88, no. 4, pp. 365-386.

Spirt, B.A., Rauth, V.A. et al. (1990). Pregnancy and maternity leave: AAWR survey results. Radiology 176, no. 2, pp. $325-328$.

Spreeuwenberg, C. (1990). Vrouwen en professie. Medisch contact 45, no. 46, p. 1363.

Spurgeon, A. en Harrington, J.M. (1989). Work performance and health of junior hospital doctors a review of the literature. WVork \& stress 3, pp. 117-128.

S.R.C. Rapporten (1993) en (1994) en (1995). Rapport betreffende opleidingen en assistentenbestand van de door de S.R.C. erkende opleidingsinrichtingen per 1 januari 1993, resp. 1 januari 1994 resp. 1 jamuari 1995 Utrecht.

Stegeman, J.H. (1990). Meer vrouwen in de geneeskunde, een wezenlijk verandering in de bedrijfstak gezondheidszorg? Medisch Contact 45, pp. 1371-1374.

Stelling, J., Bucher, R. (1973). Vocabularies of realism in professional socialization. Social Science and Medicine, 7, pp. 661-675.

Stelling, J., Bucher, R. (1977) Professional socialisation. Sage

Steward, S.M., Betson, C., Lam, T.H., Marshall, L.B., Lee, P.W., Wong, C.M. (1997). Predicting stress in first year medical students: a longitudinal study. Medical Education 31, pp. 163-168.

Stuyt, P.M.J., (1999). De opkomst van vrouwen en deeltijdarbeid in het medisch beroep. Nederlands Tijdschrift Geneeskunde, 143, pp. 18.

Stuyt, P.M.J., Meer van der, J.W.M. (1997). Assistent-geneeskundigen niet in opleiding (AGNIO's) en ziekenhuisartsen: de paria's in de kliniek? Nederlands Tijdscbrift Geneeskunde, 141, pp. 2251-2252.

Sullivan, P. (1990). Women close in on $50 \%$ share of places in Canada's medical schools. Canadian medical association journal 143 no.8, $781-783$.

Swaan de, A. (1983). De mens is de mens een zorg. Meulenhof, Amsterdam.

Swanson, A.G., Haynes, R.A. et al. (1991). The specialty choices and early career development of 1987 and 1991 US medical school graduates. Academic medicine 66, no.10, 632-647.

Thapar, A. (1989). Psychiatric disorder in the medical profession. British journal of bospital medicine 42 , no. 6 , pp. $480-483$.

Thomas, S.P., Williams, R.L. (1991). Perceived stress, trait anger, modes of anger expression, and health status of college men and women. Nursing Research, sept./oct., vol. 40, no. 5, pp. 303-307.

Thung, P.J. (1992). Casuistiek II. In: Dupuis, H.M., Thung, P.J. en Kerkhoff, A.H.M. Voordelen van de twijfel, een inleiding tot de gezondheidsethiek. Houten/Zaventem, Bohn Stafleu Van Loghum.

Thung, P.J. (1981). Introducing medical students to ethical issues. Medical Education 15, pp. 79-84.

Tiems, A., (ed), (1996). Werkprogramma Vrowwenbulpverlening. De eerste jaren Rijswijk, Netherlands: Ministerie van Volksgezondheid, Welzijn en Sport.

Timmerman, G. (1990). Werkrelaties tussen vrouwen en mannen. Een onderzoek naar ongewenste intimiteiten in arbeidssituaties. Dissertatie. Amsterdam. SUA.

Tomlow, P. (1988). Vrouwen worden beter: Vrouwenbulpverlening aan vrouwen in de medische praktijk. Amsterdam. Universtiteit van Amsterdam.

Top, T. en Heesink, J. (red) (1992). Prychologie en sekse. Bohn Stafleu en Van Loghtum.

Uhlenberg, P., Cooney, M.T. (1990). Male and female physicians: family and career comparisons. Social science and medicine 30, pp. 373-378.

Uliana, R.L., Hubbekk, F.A., Wyle, F.A., Gordon, G.H. (1984). Mood changes during the internship. Journal of Medical Education, vol. 59, febr., pp. 118-123. 
Ulyatt, K., Ulyatt, F.M. (1973). Attitudes of women medical students compared with those of women doctors. British Journal of Medical Education, 7, pp. 152-154.

Veldman, A., Wittink, R.(1990). De kans van slagen, de invloed van culturen en regels op de loopbanen van vrouwen. Leiden/Antwerpen: Stenfert Kroese.

Verheyen, C. (1993). De nomaden stategie. 13 visies op een geemacipeerde samenleving. Emancipatie raad Den Haag. Vita Amsterdam.

Verwey M. (redactie). (1989). "Carriere-Barriere": verslag van themadag loopbaanplanning van vrouwelijke geneeskunde studenten, V.U. Amsterdam.

Vianen van, A. en Velde van der, K.(1993). Doorgroei naar een managementfuctie: een kwestie van ambitie? Tijdschrift voor Vrouwenstudies 14, pp. 337-348.

Vianen, A. van (1987). Het selectie-interview. Over de rol van sekse-sterotypen. Leiden: Werkgroep Arbeidsvraagstukken en Welzijn.

Vianen, A. van (1992). Barrieres voor vrouwen bij selectie en doorstroming. In: Demenint, M.I., Disselen, C.E. Vrouwen, leiderschap en management. Utrecht: Lemma.

Vlerken, A. Meijers, F.(1993) Emancipatoire keuzebegeleiding: tussen wens en werkelijkheid. in Programmaboek Vrowwen lgenderstudies Vrije Universiteit Amsterdan

VNSU (Vereniging Nederlandse Samenwerkende Universiteiten) (1992) en (1997). Onderwijsvisitatie. Onderwijsvisitatie geneeskunde en gezondheidswetenschappen.

Vonk R., Ellemers, N. (1993). De invloed van seksestereotypen op oordelen over mannen en vrouwen. Nederlands tijdschrift voor de psychologie 48, pp. 213-225.

Vries, H. de, Dijkstra, M. Kuhlman, P.(1988) Self-efficacy: the third factor besides attitude and subjective norm as a predictor of behavioural intentions. Health education research, 3, 273-282.

Vries de, B. (1988). Het leven en de leer. Een studie naar de verbinding van leren en werken in de stage. Nijmegen Instituut voor toegepaste Sociale wetenschappen.

Vrugt, A. Nauta, M. (1993). Processen die de carriere- en samenwerkingsmogelijkbeden van vrouwen beperken. Paper Vrouwen- Genderstudies 28-29 Okt. SISWO publicatie.

Vught van, A. (1987). Machtsverschillen tussen vrowwelijke en mannelijke specialisten. Scriptie Amsterdam, VU, Geneeskunde.

Wakeford, R., Warren, V.J. (1989). "Women doctors" career choice and commitment to medicine: implications for general practice". Journal of Royal College of General Practioners 39, 91-95.

Walters, B.C. (1993). Why don't more women choose surgery as a career? Academic Medicine 68(5), pp. 350-351.

Ward, A.W.M. (1982). "Careers of medical women". British Medical Journal, 284-2 jan., pp. 31-33.

Warren, V.J., Wakeford, R.E. (1990). Do medical students get what they expect? A study of possible mismatch between the expectations and experience of medical education and practice. Medical Education 24, no. 2, pp. 178-180.

Wear, D. (1994) Feminism in medical education. Problems and promises. J Am Med Wom Assoc. $49 \mathrm{p}$ 43-47

Weggelaar, M.J., Eynatten, C., Schie van, E.C.M. c.s. (1988). Emancipatie aan bet werk. De positie van vrouwen in arbeidsorganisaties. DWSO Press.

Weggelaar, M.J., Trommel, W.A., Molenaar, F.E. (1988). Doorstroming van vrouwen in bet bedriffleven. in MJ Weggelaar, et al,. Emancipatie an het werk: de positie van vrouwen in arbeidsorganisaties. Leiden: DSWO press.

Weisman, C.S., Teitelbaum, M.A. (1985). Physician gender and the physician-patient relationship: recent evidence and relevant questions. Social Science and Medicine 20, no. 11, pp. 1119-1127.

Welzen van, D.J. (1978), Dokter wonden: een reconstructieschets van de artsenopleiding. Aakster, C.W. en Kuiper, G., Leerboek medische sociologie.

West, C. (1993). Reconceptualizing gender in physician-patient relationships. Social Science and Medicine 36(1), pp. 57-67.

Weyrauch, K.F., Boiko, P.E. en Alvin, P. (1990). Patient sexrole and preference for a male or female physician. Journal of family practice 30, pp. 559-562. 
Wheeler, R., L. Candib and M. Martin. (1990) Part-time doctors: reduced working hours for primary care physicians. Journal of the American medical womens association. 45 no.2, 47-54.

White, B.A. (1990). Women in medicine: a balancing act. Indiana medicine 83, no.3, 198-202.

White, M.S. (1970). Psychological and social barriers to women in science. Science, 170-413-416.

Winants, Y. Ruiter, E (red).(1991) Vroww, Arbeid en Loophaan. Symposiumbundel. Rijksuniversiteit Limburg.

Winants, Y. (1991) Vroww, werk en gezondlbeid. Een driehoeksverhouding. In: Vrouw, Arbeid en Loopbaan. Symposiumbundel. Winants Y, Ruiter E. (red) Rijksuniversiteit Limburg.

Winants, Y. (1992). Een medische loopbaan als topsport. Medisch Contact 29/30, 24 juli.

Winants, Y. (1993) Vrouwelijke artsen voor vrouwelijke patiënten? in Ethiscbe en maatschappelijke aspecten van de gynaecologie en obstetrie. Redactie G.G.M.Essed. Medicom.

Winants, Y. (1993) De duurbetaalde nonsens van het verlengen van de beroepsopleiding tot huisarts. Huisarts en Wetenschap, 36 (9): pp. 300-301.

Winants, Y. (1994) Inwijding van vrouwelijke en mannelijke co-assistenten in de medische beroepscultuur. Feiten en Frikties. Noordenbos,G.\& Winants Y., pp.21-38.

Winants, Y. (1994) Indirecte communicatie in de fase van de co-assistentschappen. Medisch Contact 49, pp. $1436-1437$.

Winants, Y. (1994) Inwijding van co-assistenten in de geneeskunde. Gezond Onderwijs 3. Houtkoop, E., Pols, J., Pollemans, M., Scherpbier, A., Verwijnen, G.(redactie). pp. 187-196.

Winants, Y. (1994) Co-assistentschappen als inwijding in de medische beroepscultuur. Van rijgcorset tot bodystocking? Symposiamverslag Carrieres/harrieres. Vrije Universiteit Amsterdam.

Winants Y, Noordenbos, G., Akker van de M. (1993). Initiation in medical professional culture. Abstract International Congres "Teaching Women and Health in medicine and nursing". London.

Woodward, C.A., M.L. Cohen and B.M. Ferrier. (1990) Career interruptions and hours practiced: comparison between young men and women physicians. Canadian journal of public bealth, 81, 16 20.

Yedidia, M.J., Berry, C.A., Barr, J.K. (1996). Changes in physicians' attitudes towards AIDS during residency training: a longitudinal study of medical school graduates. Journal of Health and Social Bebavior, 37, pp. 179-191.

Yoder, J.D (1991). Rethinking tokenism; looking beyond numbers. Gender and society. 5 no.2, 178 192. 



\section{Bijlage 1 bij hoofdstuk 6}

Tabel 6.8 Overzicht van veranderingen in de tijd (afname of toename).

Veranderingen in perceptie en kloof (tussen perceptie en waafdering) van de medische beroepscultuur

\begin{tabular}{|c|c|c|c|c|}
\hline DIMENSIE & Naam Variabele & perceptic & $\begin{array}{l}\text { beloop perceptie } \\
\text { p-waarde }\end{array}$ & $\begin{array}{l}\text { beloop kloof } \\
\text { p-waarde }\end{array}$ \\
\hline MACHT (M1) & Symbolen machtsaftand & ja & $\begin{array}{l}\text { toename } \\
\text { totale groep } . . \\
\text { vrouwen }\end{array}$ & $\begin{array}{l}\text { toename } \\
\text { totale groep* } \\
\text { mannen "* }\end{array}$ \\
\hline MACHT (M) & Hiërarchie artsen verpleging & ja & $\begin{array}{l}\text { toename } \\
\text { totale groep } \\
\text { vrouwen }\end{array}$ & \\
\hline MACHT (M4) & Geringe afstand opleider-co & licht ja & $\begin{array}{l}\text { afname } \\
\text { totale groep ** } \\
\text { mannen ** }\end{array}$ & \\
\hline RESPECT (R1) & Respectvolle artsen onderling & indiff & $\begin{array}{l}\text { toename } \\
\text { totale groep"* } \\
\text { vrouwen " }\end{array}$ & $\begin{array}{l}\text { toename } \\
\text { totale groept** } \\
\text { vrouwen } * .+ \\
\text { mannen }\end{array}$ \\
\hline ONZ.VERM (O4) & Spot en cynisme & licht ja & $\begin{array}{l}\text { toename } \\
\text { totale groep" } \\
\text { vrouwen" }\end{array}$ & $\begin{array}{l}\text { toename } \\
\text { totale groep } \\
\text { mannen *. }\end{array}$ \\
\hline LOYALITERT (2.1) & Loyaliteit van artsen onderling & ja & $\begin{array}{l}\text { afname } \\
\text { tot.groep"* } \\
\text { mannen" } \\
\text { vrouwen ". }\end{array}$ & $\begin{array}{l}\text { toename } \\
\text { totale groep }\end{array}$ \\
\hline FEMINIEN (F2) & Ruimte emoties artsen onderling & licht ja & $\begin{array}{l}\text { afname } \\
\text { totale groep }\end{array}$ & \\
\hline FEMINIEN (F3) & $\begin{array}{l}\text { Norm luisterende, toegankelijke } \\
\text { arts }\end{array}$ & indiff & $\begin{array}{l}\text { afname } \\
\text { totale groep* }\end{array}$ & $\begin{array}{l}\text { extra info } \\
\text { afname } \\
\text { waardering } \\
\text { vrouwen " }\end{array}$ \\
\hline MASCULIEN (ML1) & Comperitie artsen onderling & indiff & $\begin{array}{l}\text { toename } \\
\text { totale groep } * \\
\text { mannen ** }\end{array}$ & $\begin{array}{l}\text { toename } \\
\text { totale groep } * * . \\
\text { vrouwen * } \\
\text { mannen ** }\end{array}$ \\
\hline MASCULIEN (MI.2) & Noodzaak competitie & ja & & $\begin{array}{l}\text { toename } \\
\text { mannen }\end{array}$ \\
\hline MASCULIEN (ML3) & $\begin{array}{l}\text { Rangen en standen onder artsen } \\
\text { (pikorde) }\end{array}$ & nee & $\begin{array}{l}\text { toename } \\
\text { mannen* }\end{array}$ & \\
\hline INWIJDING (14) & Grote rol verpleging & indiff. & $\begin{array}{l}\text { toename } \\
\text { totale groep* } \\
\text { vrouwen }\end{array}$ & \\
\hline
\end{tabular}

${ }^{1 *} \mathrm{p} \leq 0.05 ; * * \mathrm{p} \leq 0.01 ; * * \mathrm{p} \leq 0.001$

afname perceptie - gevorderde co-assistenten zien het minder dan de beginners

-toename perceptie - gevorderde co-assistenten zien bet meer dan beginners

perceptie: kleiner of gelijk aan $2.2=j a ; 2.3$ - licht ja; 2.4-2.6 - indifferent;

groter of gelijk aan 2.8 - nee, 2.7 is licht nee

-waardering: kleiner of gelijk aan 2.2 - positief of wenselijk; groter dan 2.8 - negatief of onwenselijk 


\section{Samenvatting}

In dit proefschrift wordt getracht licht te werpen op het proces van beroepssocialistie van co-assistenten tot arts en wordt specifieke aandacht besteed aan de ervaringe van vrouwelijke artsen en co-assistenten. Centraal staat de wisselwerking tussen (leeromgeving - of de sociaalculturele context - en het zich ontwikkelende individu. Ve schillen en overeenkomsten in de ervaringen van vrouwen en mannen worden nadr onderzocht en geëvalueerd in het licht van de mogelijke gevolgen voor professione: kwaliteit en identiteit en in het licht van de mogelijke reproduktie van (machts)ve schillen tussen mannelijke en vrouwelijke artsen.

Wij veronderstellen namelijk dat meer kennis van de werking van sekse en gender i het proces van beroepssocialisatie noodzakelijk en nuttig zijn bij het verbeteren e

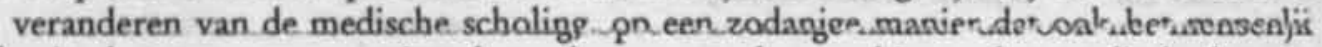
kapitaal van vrouwen optimaal wordt angesproken en binnen het medische beroep tot ontwikkeling kan komen. We hopen dat deze onderzoeken aanknopingspunten opleveren voor eventuele interventies in het medisch onderwijs en de medische beroepsgroep, die het handelen van artsen in het algemeen ten goede komen en de ontplooiingsmogelijkheden van vrouwelijke artsen in het bijzonder.

Dit boek bestaat uit een aantal delen. In deze algemene inleiding wordt de centrale thematiek en de rode draad van dit proefschrift uiteengezet. Dan volgt een eerste theoretisch deel waarin verslag wordt gedaan van de verkenning van verschillende inzichten, theorieën en referentiekaders die werden bestudeerd met betrekking tot genderwerking in de medisch beroepsgroep en het proces van professionele socialisatie van artsen.

Omdat momenteel sprake is van een snelle toename van vrouwelijke studenten en artsen en behoefte bestaat aan inzicht in veranderingen en verbeteringen die mogelijk nodig zijn in opleiding en professionele organisatie om de inbreng van vrouwelijke artsen en studenten te faciliteren, werd de literatuur breed verkend en werden diverse disciplines en stromingen bestudeerd.

In deel I, de theoretische introductie van het proefschrift, komt eerst de positie van vrouwen in de geneeskunde aan de orde, die niet rooskleurig genoemd mag worden. We buigen ons over cijfers en getalsmatige verhoudingen van vrouwelijke en mannelijke artsen en de verschuivingen die zich op dit vlak momenteel voordoen. Diverse verklaringen voor de bestaande machtsasymmetrie tussen de seksen in de geneeskunde worden opgesomd en het perspectief van gender en reproduktie van genderongelijk- 
heid in betaalde arbeid en specifiek in de medische professie worden onderzocht. Omdat beroepssocialisatie binnen de medische opleiding niet alleen voorafgaat aan de medische loopbaan als arts, maar ook het verloop van de verdere loopbaan mede stuurt en de beleving van de professionele artsenrol mede bepaalt, werd de laatste fase van de medische opleiding, de fase van de co-assistentschappen gedetailleerd onder de loep genomen.

Dokter worden en gesocialiseerd worden in de medische beroepsrol is complex omdat het te maken heeft met overdracht van cultuur en noodzaak tot aanpassing evenals met de mogelijkheid van persoonlijke groei en ontwikkeling. Het begrip socialisatie en de diverse uitwerkingen ervan worden beschreven. De fase van de co-assistentschappen blijkt een gevoelige periode te zijn in het vormingsproces van nieuwe medische professionals. De co-assistent betreedt in de klinische fase een nieuwe wereld als hij gaat participeren in de praktijk van het medisch uitvoerend werk. Diverse auteurs worden aan het woord gelaten over de inhoud van de "impliciete boodschap" die in de medische opleiding worden overgedragen aan de nieuwe generatie, in het socialisatieproces.

De nieuweling stapt als een verbaasde reiziger deze wereld binnen en zal de gebruiken en de gewoonten in de medische beroepsgroep sensitiever waarnemen dan artsen, die reeds langere tijd het medisch beroep uitoefenen. De confrontatie met de realiteit van het medische beroep roept over het algemeen ook gevoelens van waardering op bij co-assistenten. Over sommige zaken zullen zij enthousiast zijn, terwijl zij andere negatief zullen beoordelen of zelfs afkeuren.

In deel II, het beroepscultuur-onderzoek staat het perspectief van de co-assistent als waarnemer en beoordelaar centraal, de perceptie en waardering van nieuwkomers van de beroepscultuur van de huidige medische professie. Hoe wordt de realiteit van de medische praktijk van alledag door co-assistenten waargenomen en geëvalueerd ? De doelstelling van dit empirische onderzoek, dat beschreven wordt in hoofdstuk 5 en 6 , is om meer zicht te krijgen op de codes voor sociale omgang en de spelregels, die gelden binnen de medische beroepsgroep, soms ook wel de "hidden curriculum" genoemd. Deze spelregels en codes die worden voorgeleefd door de huidige professie, worden (vaak onbedoeld en onbewust) overgedragen op de nieuwe generatie in het socialisatietraject in de opleiding tot arts.

Het cultuurbegrip, dat in dit deel wordt gehanteerd is ontleend aan Hofstede (1991) en wordt gedefinieerd als het geheel van ideeën, opvattingen, gewoonten en gedragingen, die mensen leren, goedkeuren en overbrengen. Hofstede beschouwt cultuur als 'the collective programming of the mind, which distinguishes one group from another'. In de organisatiekunde wordt cultuur omschreven als de gemeenschappelijke verstandhouding tussen de leden van een organisatie of een beroep over hoe het in hun werkveld dagelijks toegaat. Het betreft het geheel van geschreven en ongeschreven regels dat behalve het sociale verkeer tussen medewerkers of beroepsbeoefenaren onderling, ook het verkeer met derden kanaliseert en vorm geeft (Sanders \& Neuyen, 1988).

Nadat in een kwalitatieve voorfase een karakterisering van de medische beroepscultuur was ontworpen, werd vervolgens een vragenlijst geconstrueerd met gebruikma- 
king van de begrippen en inzichten van Hofstede (1991,1990) en de Cock (1985). Met behulp van deze beroepscultuur-vragenlijst werd inzicht verkregen in de perceptie van co-assistenten van de hen omringende beroepscultuur en hun waardering hiervan. Ve stellen ons de vraag of vrouwelijke co-assistenten verschillen in hun waarneming of hun waardering van de beroepscultuur zoals die op het ogenblik door de mediscie professie wordt gerepresenteerd ? Zou de socialisatie-opdracht voor vrouwelijke $\omega$ assistenten moeilijker zijn dan voor mannelijke nieuwkomers, aannemende dat beroepscultuur van de medische professie mogelijk beter aansluit bij de mannelijke geslachtsrolsocialisatie? Zouden co-assistenten die net zijn gestart met deze fase verschillen in perceptie of waardering van de "voorgeleefde" beroepscultuur van de gevorderde co-assistenten, die hun opleiding bijna afgerond hebben en hun basisarsexamen naderen?

De resultaten van het beroepscultuuronderzoek geven aan dat het beeld, dat de $\omega$. assistenten opdoen van de medische professionele cultuur bii hun, kennismaking met. roepscultuur van de medische professie mogelijk beter aansluit bij de mannelijke geslachtsrolsocialisatie? Zouden co-assistenten die net zijn gestart met deze fase verschillen in perceptie of waardering van de "voorgeleefde" beroepscultuur van de gevorderde co-assistenten, die hun opleiding bijna afgerond hebben en hun basisars- 
wij dachten, ten aanzien van hun waardering. De perceptie wordt pregnanter naarmate co-assistenten verder gevorderd zijn in de co-assistentschappen.

In deel III, het socialisatie-onderzoek, dat aan bod komt in de hoofdstukken 7 tot en met 11, wordt de aandacht vervolgens gericht op de sociaal-psychologische interacties tussen de leerlingen en de opleidingssetting in de co-assistentschappen. Dit empirisch onderzoek naar draaglast, draagkracht en belasting en naar de ontwikkeling van de professionele identiteit bestaat uit een transversaal onderzoek, waarin zowel bivariate als multivariate analyses werden uitgevoerd en een longitudianal onderzoek. Deze longitudinale studie geeft met grote mate van betrouwbaarheid inzicht in de veranderingen in de tijd bij co-assistenten. De bevindingen van transversaal en longitudinaal onderzoek zijn geïntegreerd beschreven in de resultaten-hoofdstukken (hoofdstuk 8 en 10).

De co-assistentschappen worden opgevat als een periode van inwijding in de beroepscultuur van de zittende professie. Welke ervaringen doen co-assistenten op en maken ze veranderingen door in de loop van dit opleidingstraject, dat zowel opleidingsfase als eerste werkervaring is ? In andere onderzoeken (Sieverding, 1990; de Vries, 1988; Vonk, 1993) werd gevonden dat als iemand als leerling of stagiaire voor het eerst een beroepsveld betreedt dit vaak diepe indruk maakt en als confronterend en schokkend wordt ervaren. Deze auteurs spreken van een 'cultuurshock' of 'Berufeintrittshock'. Wordt iets dergelijks ook door co-assistenten ervaren? Ook blijkt dat stagiaires of nieuwkomers zich vaak moeilijk aan de invloed van de opleidingsomgeving kunnen onttrekken en blijkt aanpassing aan deze "tijdelijke" maar indringende realiteit geen sinecure. Soms moeten hiervoor afweermechanismen worden gemobiliseerd die de harmonie in de menselijke psyche niet altijd ten goede komen (Fahrenfort, 1985; Krol, 1992; Groot de, 1987). In het socialisatie-onderzoek werd eerst aandacht besteed aan de mate waarin socialisatie als zwaar of vermoeiend wordt ervaren door co-assistenten.

In hoofdstuk 7 en 8 wordt de balans tussen draaglast, draagkracht en motivatie en vermoeidheid als outcome onder de loep genomen en de verschillen en overeenkomsten op dit vlak tussen vrouwelijke en mannelijke co-assistenten. De inwijdelingen blijken niet onder een hoge mate van vermoeidheid gebukt te gaan. Ook blijkt hun motivatie gedurende de co-assistentschappen niet af te nemen maar een positieve impuls te ondergaan. De veronderstelling dat vrouwelijke co-assistenten mogelijk een grotere belasting zouden ervaren dan hun mannelijk collega's, wordt evenmin bewaarheid. Vrouwelijke co-assistenten blijken de psychische belasting van de inwijding net als hun mannelijke collega's niet als hoog te ervaren, de fysieke belasting wordt wel als iets hoger ervaren door vrouwen, evenals hoofdpijn en eetproblemen die vaker bij hen voorkomen. Daarentegen blijken vrouwelijke coassistenten tegelijkertijd ook meer positieve gevoelens te ervaren.

Het beloop in de tijd van belasting en vermoeidheid ten gevolge van de co-assistentschappen laat interessante verschuivingen zien. Vooral de eindfase van de co-assistentschappen gaat gepaard met gevoelens van opluchting, de ervaren psychische belasting daalt bij beide seksen, de fysieke belasting daalt bij de vrouwelijke co-assistenten en de positieve stemming neemt met name bij de mannelijke co-assistenten toe wanneer de 
eindstreep van de medische opleiding in zicht komt. De motivatie voor het medische vak is ondertussen alleen maar toegenomen.

Onverwacht en verrassend is de bevinding in dit onderzoek dat de draagkracht van co-assistenten gedurende het volgen van de co-assistentschappen in alle groepen een toename laat zien op alle dimensies van coping met uitzondering van de depressiefvermijdende copingstijl. De weerbaarheid en het vermogen om actief en adequaat persoonlijke problemen te lijf te gaan, blijkt in deze inwijding een sterke impuls te hebben gekregen, zowel bij vrouwelijke als bij mannelijke co-assistenten. Alleen de manier waarop vrouwen en mannen hun weerbaarheid invullen blijkt te verschillen; vrouwen geven sterker de voorkeur aan sociaal georiënteerde strategieën zoals het zoeken van sociale steun en het uiten van emoties en mannelijk studenten prefereren meer een palliatieve stijl zoals hun aandacht op vrolijker zaken richten bijvoorbeeld. Ook werd de aard van de belasting van het inwijdingsproces onderzocht, door in te gaan op het gevoel van gebrek aan tijd, de mogelijke gevoelens van stress en ervaringen van denigrerende benadering en behandeling als jongste bediende in de medische beroepswereld. Onverwacht bleken mannelijke co-assistenten meer stress en onlust te ervaren dan vrouwelijke co-assistenten. Co-assistenten bleken zelf over het algemeen geen denigrerende of spottende behandeling te ervaren, maar merkten wel een denigrerende manier van omgaan met patiënten op. Vooral de studenten, die starten met de co-assistentschappen merken dit fenomeen opeens op; deze ervaring kan men opvatten als aspect van een cultuurshock, die vooral vrouwelijke co-assistenten treft. $\mathrm{Zij}$ blijken een denigrerende benadering van patiënten sterker waar te nemen dan hun mannelijke collega's. Dit roept de vraag op of vrouwelijke co-assistenten zich mogelijk sterker of langer blijven identificeren met patiënten.

Naar aanleiding van de bevindingen ontstaat de gedachte dat mannelijke co-assistenten mogelijk "straffer en zwaarder" worden ingewijd dan hun vrouwelijke collega's. Uit de kwalitatieve bevindingen over spot en devaluatie blijkt overigens wel enige ambivalentie van de zittende medische professie richting vrouwelijkheid en vrouwenlichamen, die echter het welbevinden van vrouwen in de fase van de coassistentschappen niet negatief lijkt te beïnvloeden.

Vervolgens stonden we stil bij de ontwikkeling van de professionele identiteit en daarmee samenhangende aspecten in hoofdstuk 9 en 10 . Interacties en communicatie tussen mensen worden sterk beïnvloed door het beeld dat men van de ander heeft en door het beeld dat iemand denkt dat de ander van haar of hem heeft. Beroepssocialisatie kan aanzienlijke veranderingen met zich meebrengen in opvattingen, normen en waarden, maar ook in identiteit of zelf-identificering. Veel eerder onderzoek naar het proces van professionele socialisatie tot arts heeft wel inzicht gegeven in de dynamiek op interactioneel niveau tussen leerling en diens leeromgeving, maar mist vaak de reflectie op gender. Identiteit als vrouw of man en rolvoorschriften voor vrouwen en mannen vloeien voort uit socialisatieprocessen die reeds op zeer jonge leeftijd beginnen. Alhoewel de genderrol diep in de persoonlijkheid is verankerd, moet deze echter niet als statisch of onveranderbaar worden opgevat. Het is van belang om te bestuderen hoe socialisatie tot arts interfereert met de identiteit als man of vrouw in een beroep dat kan worden getypeerd als een door mannen gedomineerd beroep. 
De beroepssocialisatie van co-assistenten heeft het karakter van een onderdompeling in de cultuur van de gevestigde beroepsgroep, die verschillende lagen van het "zelf" beroert en verandert. Hieruit ontstaat een vorm van identificering, een vorm van professionele identiteit en in de ontwikkeling hiervan speelt de sekse van de coassistent een specifieke rol. Sekse is een sociaal construct met prototypische kenmerken die sociale interacties structureren, afhankelijk van de cultuur waarin ze spelen (Fischer et al, 1993). Ten behoeve van het onderzoek naar de vraag naar de manier waarop de ontwikkeling van de professionele identiteit verloopt in relatie tot (impliciete en expliciete) genderwerking in de fase van de co-assistentschappen, construeerden we een schema op basis van een combinatie van onderzoek van Bucher en Stelling (1977) en Benschop (1996).

Co-assistenten gaan zich meer of minder identificeren met de artsen-opleiders en hun gedrag als voorbeeld beschouwen en soms navolgen. Deze processen voltrekken zich deels bewust, deels onbewust. Voor co-assistenten is oefenen en ervaring opdoen met het invullen van de beroepsrol belangrijk, evenals het ervaren van positieve bekrachtiging door opleiders en sociale omgeving. Het opbouwen van een gevoel van competentie en zelfvertrouwen als arts is wezenlijk voor een evenwichtige professionele identiteit en een positieve houding naar de toekomstige medische loopbaan.

Om binnen dit proces van socialisatie tot arts vat te krijgen op de werking van gender werd de samenhang bestudeerd tussen de omgeving, de cultuur en structuurarrangementen van de medische professie en de persoonsarrangementen als zelfopvattingen en attitudes van co-assistenten.

Aan de vorming van de professionele identiteit gaan processen vooraf van zelfevaluatie en evaluatie van de alledaagse praktijk in de opleidingsetting en het opbouwen van voldoende zelfvertrouwen als aanstaand arts. Deze processen werden bestudeerd aan de hand van het thema's "identificatie" en seksegebonden praktijken of "expliciet onderscheid maken naar sekse" en het thema "professioneel zelfvertrouwen". De professionele identiteit werd bestudeerd aan de hand van thema's als relatie van ideaalbeeld van een arts en zelfbeeld, oriëntatie op beroep en loopbaan en de genderidentiteit. De balans tussen het concept van de ideale arts en het zelfbeeld bij co-assistenten werd onderzocht in relatie tot feminiene of masculiene prototypering.

$\mathrm{Bij}$ de oriëntatie op het beroep speelt de verinnerlijking van het kostwinnersperspectief een rol. Het bewustzijn van eigen sekse, een aspect van de genderidentiteit wordt belicht en attributies van co-assistenten over hun toekomstige loopbaan. De vraagstellingen naar de aard van de ervaringen, de verschillen tussen de seksen en veranderingen in de tijd werden per thema nader uitgewerkt.

$\mathrm{Bij}$ het thema zelfevaluatie blijkt dat vrouwelijke co-assistenten meer dan hun mannelijke collega's in staat blijken om hun identificatie met de patiënt te handhaven naast een toenemende identificatie met de medische beroepsgroep. Verder blijkt de genderidentiteit van vrouwelijke co-assistenten bij entree in het beroepsveld sterk bekrachtigd te worden. Hiermee wordt impliciet het "anders zijn" vrouwelijke artsen in de medische professie bekrachtigd, hetgeen op termijn integratie van vrouwen op hun eigen termen kan belemmeren. De seksegebonden praktijken ademen een zekere mate van ambivalentie ten aanzien van vrouwelijkheid in de medische professie en suggereren het bestaan van een ideologie van sekse-neutraliteit en gelijke kansen voor de seksen 
in de geneeskunde. Het oordeel van co-assistenten over eventuele voorkeursbehandeling voor mannelijke artsen vertoont een collectieve verandering op dit punt. Het professioneel zelfvertrouwen van co-assistenten ontwikkelt zich voorspoedig in deze fase en neemt toe.

Het concept van de ideale dokter van co-assistenten blijkt androgyn en zowel mannelijk als vrouwelijk te worden ingekleurd. Maar het cultureel ideaal van de medische professie lijkt toch meer met mannelijke of instrumentele karakteristieken bekleed dan met expressieve of feminiene kenmerken. Dit blijkt uit de wijze waarop het verschil tussen ideaalconcept en zelfbeeld zich in de loop van de tijd ontwikkelt; ten aanzien van de mannelijke dimensie blijft bij alle co-assistenten het verschil groot, bij de vrouwelijke dimensie niet.

In de beroepsoriëntatie van co-assistenten vinden we bij mannen de sporen terug van de geslachtsrol-socialisatie tot kostwinner. Mannelijke co-assistenten blijken daadwerkelijk sterker op maatschappelijke status, erkenning en inkomen georiënteerd te zijn dan hun vrouwelijke collega's. De geslachtsrolsocialisatie van vrouwen met accentuering op zorg en expressieve aspecten van het beroep wordt minder eenduidig teruggevonden bij co-assistenten. Vrouwelijke co-assistenten lijken minder stereotiep vrouwelijk, terwijl mannelijke co-assistenten wel stereotiep mannelijk zijn.

Tot slot werd de onderlinge samenhang van aspecten van socialisatie, die in de verschillende thema's van draaglast, draagkracht en belasting, van zelfevaluatie, professioneel zelfvertrouwen en professionele identiteit waren geoperationaliseerd, geanalyseerd met behulp multivariate analyse-methoden. Er bleken interessante verbanden tussen de onderzochte aspecten te bestaan.

In de slotbeschouwing aan het eind werden de belangrijkste lijnen van het boek verbonden en de belangrijkste inzichten en overwegingen weergegeven. Uit de het beroepscultuur-onderzoek en van het socialisatie-onderzoek kunnen aanbevelingen voor verandering en kansen voor de medische professie en medische opleiding worden afgeleid. Het geheel overziend wordt duidelijk dat er werk aan de winkel is in de medische opleiding en beroepsgroep. Deze tijd, zwanger van veranderingen vraagt om inzet van de professie en de medische opleidingen om zichzelf zodanig te vernieuwen dat de medische zorg optimaal zal kunnen profiteren van het culturele kapitaal van vrouwen. 


\section{Summary}

This thesis attempts to shed light on the professional socialization process of clinical trainees during their training to become doctors, and pays specific attention to the experiences of female doctors and trainees. The focus is on the interaction between the learning environment - or the socio-cultural context - and the developing individual. We have looked more closely at differences and similarities in the experiences of females and males and have assessed these in the light of possible consequences for professional quality and identity and the possible reproduction of differences (in positions of power) between male and female doctors.

Our assumption is that it will be both necessary and useful to gain more knowledge of the effects of sex and gender in the professional socialization process in order to improve and change medical education in such a way that female human capital in medicine will be made full use of and can be manifested within the medical profession. We hope that the study we conducted may provide starting points for interventions in medical education and the medical profession which will generally have a positive effect on the way in which doctors act and will particularly offer female doctors more scope to develop.

This thesis is in several parts. In this general introduction the main theme and the thread of this thesis are set out. Next, the first theoretical part describes the exploration of various views, theories and frames of references which were studied in the context of gender and the professional socialization process of becoming a doctor. Given today's rapid increase in the number of female medical students and doctors and the existing need for insight into the changes and improvements that may be required in education and the organization of the profession to facilitate the contribution made by female doctors and students, we have opted for a wide exploration of literature and have studied various disciplines and trends in medicine. Part I, the theoretical introduction to the thesis, first discusses the position of women in medicine, which can be defined as not very positive. We have looked at figures and ratios between male and female doctors and current shifts. We have included various explanations for the existing imbalance of power between the sexes in medicine and have studied the perspective of gender and the reproduction of gender inequality in paid work and, more specifically, in the medical profession. Given the fact that professional socialization within medical education not only precedes the medical career of a doctor, but is also one of the factors affecting the course of a doctor's 
subsequent career and determine the way in which the professional role of doctor is experienced, we have taken a close look at the last stage of medical education, the stage of clinicial training.

Becoming a doctor and being socialized into the professional medical role is a complex process, as it involves transfer of culture and a need to adapt, as well as an opportunity for personal growth and development. We have described the concept of socialization and its various effects. The clinical training stage turned out to be a key period in the development of new medical professionals. In the clinical stage, trainees enter into a new world when starting to participate in actual medical practice. We have quoted various authors with respect to the contents of the "implicit message" in medical education being passed on to the new generation during the socialization process. The newcomer steps into this world with the amazement of a traveller, and looks at the ways and customs of the current profession as a sensitive observer. Being confronted with the reality of the medical profession generally evokes feelings of disapproval as well as appreciation in trainees.

The research we conducted into the professional culture, which is discussed in part II, chapters 5 and 6 , focuses on the trainee's view as an observer and assessor. By asking how clinical trainees perceive and assess the reality of everyday medical practice we have investigated the way in which newcomers perceive and assess the professional culture. The concept of culture used in this study is taken from the work of Hofstede and is defined as a collection of ideas, views, customs and behaviour which people acquire, approve of and transfer to others. Hofstede regards culture as 'the collective programming of the mind, which distinguishes one group from another', and from this point of view culture is described as the commonly-shared understanding among the members of an organization or a profession of how things are done in their fields.

The aim of this empirical study of the professional culture is to gain a better understanding of all the written and unwritten rules which channel and shape not only social interaction among doctors and between trainers and clinical trainees and medical students, but also interaction with patients and the outside world. These social rules and codes, which are passed on by the current medical profession, serve as a reference and an example for the new generation of medical doctors. They are sometimes called "the hidden curriculum", and are transferred (unintentionally and unconsciously) to the new generation during their medical education.

The questionnaire on professional culture helped us gain insight into how trainees view the professional culture surrounding them and how they assess these perceived cultural aspects. We asked ourselves whether the professional culture, as it is communicated by the current medical profession, is perceived and assessed differently by female trainees. Can we assume that the professional culture of the medical profession ties in better with male socialization? Will the requirement to socialize be more difficult for female trainees than for males? Will trainees who just started their clinical training differ from their more advanced colleagues in their perception and/or assessment of the medical professional culture? 
Our study revealed that the image which trainees develop of the medical professional culture on their first acquaintance with actual practice can be characterized by the key-terms imbalance of power and hierarchical, a certain degree of avoidance of insecurity, non-feminine and slightly masculine. Those questioned experienced the initiation ritual of medical doctors as quite harsh and confronting and characterized it as "being thrown in at the deep end".

We will take a closer look at these findings and provide some further clarification. The medical professional culture turned out to be relatively unequal in terms of positions of power, with hierarchical forms of interaction among doctors, between doctors and nursing staff and between doctors and patients. This great imbalance of power was not appreciated by medical trainees and was most strongly disapproved of by females. The results also showed a reasonably high degree of avoidance of insecurity, which was operationalized as "being obliged to follow protocols" and "the crucial role of technology in diagnostics". However, this was experienced by trainees as acceptable and legitimate. In the same way, the technical atmosphere in hospitals and the fact that doctors are clearly distinguishable from other care providers through subtle external characteristics such as stethoscopes or medical notebooks were assessed as not undesirable.

Furthermore, the trainees characterized the medical professional culture as nonfeminine, as hardly process-oriented, with virtually no forms of interaction among doctors that facilitate mutual support or personal or emotional support towards each other or towards students. This cultural aspect was assessed as undesirable by the subjects; the results show an even stronger disapproval among younger female trainees than among their more advanced female colleagues and their male colleagues.

The medical professional culture was viewed as somewhat masculine, in the sense that the subjects did perceive competitive forms of interaction among doctors and that competition and individual profiling seemed to be prerequisites for a successful medical career. These aspects were disapproved of by the whole group of subjects and aroused strong feelings of dislike particularly among female trainees. On the basis of the findings with regard to whether the culture was perceived as individually-oriented or collective we could make no clear statement; however, we did find that loyalty among doctors was a perceived cultural aspect. Furthermore, the way in which newcomers are initiated into the medical profession was experienced by the new generation as not very gentle. They experienced little support or guidance in the process of getting acquainted with the reality of the medical profession.

Finally, we found, unexpectedly, that the trainees did not, as we had assumed, change on the "appreciation" dimension in the course of their clinical training, but had changed in the way they perceived the culture surrounding them. This perception proved to become more significant as trainees advanced in their clinical training.

The research we conducted into socialization, which is dealt with in part III, chapters 7 to 11 inclusive, focuses on the socio-psychological interaction among the students and the training setting during the clinical training stage. This empirical study of perceived pressure, ability to cope, strain and the development of professional identity comprises a transversal study, in which both bivariate and multivariate analyses were 
made, as well as a longitudinal study. This longitudinal study provides insight into the changes in clinical trainees over time. Chapters 8 and 10, in which the results are discussed, provide an integrated description of the findings of the transversal and the longitudinal study. We regard the clinical training as a period of initiation into the professional culture of the established medical profession. What experiences do clinical trainees gain, and do they undergo any changes during this training course which, apart from being training, also is their first work experience? The studies of Sieverding (1990) and de Vries (1988) show that this first entering into a professional field as a student or a trainee can make a profound impression and is often a shocking experience. These authors talk of of a 'culture shock' or 'Berufeintrittshock'. It is often difficult for trainees or newcomers to withdraw from the influence of the training setting; they have to adapt, in some way or another, to this "temporary" but powerful reality, which usually is no easy task. We first paid attention to the extent to which the socialization process of becoming a doctor during clinical training was experienced as hard and exhausting. Chapters 7 and 8 deal with the balance between perceived pressure, ability to cope and the outcome in terms of motivation or fatigue and the differences and similarities between female and male trainees.

We found that, at this stage, the initiation was not experienced as being very exhausting or hard and that during clinical training the students' motivation was actually boosted. In addition, the hypothesis that female trainees experience greater strain than their male colleagues was not confirmed. Female trainees proved to be more positive than males and did not experience a higher level of psychological strain. However, they did experience a greater physical strain and suffered from headaches and eating problems slightly more frequently than their male colleagues. The findings over time of strain and fatigue resulting from clinical training revealed some interesting shifts. During the final stage of clinical training in particular there were feelings of relief, a decrease in experienced psychological strain among both sexes, a decrease in physical strain among female trainees and increasing optimism among particularly male trainees, now that the end of their medical education was in view. Meanwhile, their motivation for joining the medical profession increased.

An unexpected and suprising result of this study is that the ability of trainees to cope during their clinical training showed an increase on all dimensions of coping, with the exception of the depression-avoiding coping style. Assertiveness and ability to cope with personal problems in an active and appropriate way were found to have been given a strong boost during this initiation among female and male trainees alike. Only the way in which females and males manifested their assertiveness proved to be different; females displayed a stronger preference for socially-oriented strategies such as seeking social support and expressing emotions, whereas male students preferred a more palliative style such as directing their attention on more cheerful matters.

We also investigated the nature of strain during the initiation process, by looking at experienced time pressure, feelings of stress and experiences of having been treated in a demeaning way and as the 'junior clerk' in the medical profession. Unexpectedly, we found that male trainees experienced more stress and discomfort than female trainees. Generally, the trainees proved to have no personal experiences of being belittled or ridiculed; however, they did notice that patients were treated in a 
demeaning way. Particularly students who had just started their clinical training observed this phenomenon; this experience can be regarded as an aspect of the culture shock, which affects female trainees in particular. They displayed a stronger perception of patients being belittled than their male colleagues. This raises the question whether female trainees identify with patients in a stronger way or do so over a longer period of time.

The findings suggest that male medical trainees may be initiated "more strictly" and in a "harder" way than their female colleagues. Furthermore, the qualitative findings with respect to being ridiculed and devalued revealed some ambivalence of the established medical profession towards femininity and the female body, which was noted by female trainees in particular.

In chapters 9 and 10 we took a closer look at the development of professional identity and related aspects. Human interaction and communication are greatly affected by the image a person has of another person and by the image a person believes the other person has of her or him. Professional socialization can bring about considerable changes in views, norms and values, but also in identity or selfidentification. Many previous studies of the professional socialization process of becoming a doctor have provided insight into the dynamics at the level of interaction between students and their learning environment, but they often do not consider gender. A person's identity as a female or male and gender roles for females and males result from socialization processes which start at a very early age. Although the gender role is deeply anchored in a person's personality, it should not be regarded as being static or unchangeable. It is important to do research into the way in which the socialization process of becoming a doctor interferes with a person's identity as a male or female in a profession which can be characterized as a male-dominated. The professional socialization of medical trainees has the characteristics of an immersion in the culture of the established profession, which affects and changes different levels of the self, thus creating a different form of identification and professional identity. In this development of the professional identity, the trainee's gender plays a specific part of its own. Gender is a social construct with prototypical characteristics that structure social interaction, depending on the culture in which it takes place. In order to investigate the way in which professional identity develops in relation to (implicit and explicit) gender effects during the clinical training stage, we constructed a schedule based on the works of Bucher and Stelling (1977) and Benschop (1996). Clinical trainees identify with the doctors who act as their medical trainers to a larger or lesser extent, and take their behaviour as an example, sometimes imitating them. They do so partly consciously and partly unconsciously. Practising and gaining experience in shaping their professional role is important to trainees, as is experiencing positive confirmation from trainers and their social environment. Building feelings of competence and self-confidence as a doctor is essential for a balanced professional identity and a positive attitude towards a future medical career. In order to gain a better understanding of the effects of gender within this socialization process of becoming a doctor, we have investigated the relationship between the environment, the arrangements of the medical profession at a cultural 
and structural level and the arrangements at a personal level, such as self-image and the attitudes of medical trainees.

The formation of professional identity is preceded by processes of self-assessment and assessment of everyday practice in the training setting and by a process of acquiring self-confidence in the professional role of doctor. These processes were investigated on the basis of themes such as "identification", "gender differentiation" and "professional self-confidence". Professional identity was investigated on the basis of themes such as the relationship between idealized image (of a doctor) and self-image, professional orientation and career orientation, and gender identity. The relationship between idealized image and self-image was studied in terms of feminine and masculine prototyping. With respect to professional orientation, attention was paid to the possible internalization of the wage earner perspective, and with respect to career orientation, to trainees' attributions to their own careers as doctors. The questions put to the subjects on experiences, differences between the sexes and changes over time were studied and reported by theme.

With respect to the theme self-assessment, the results revealed that female trainees were better able than their male colleagues to continue identifying with their patients while increasingly identifying with the medical profession. Furthermore, the gender identity of female trainees when entering into the professional field proved to be strongly confirmed. This means an implicit confimation of females being "different" in the medical profession, which in the long term may impede the integration of female doctors in the medical profession on their own terms. The sex-related practices, as perceived in the clinical training stage, revealed a certain extent of ambivalence towards femininity in the profession. The changes over time in the perception of possible preferential treatment of male doctors suggest that in the medical profession there is an ideology that the profession is gender-neutral and offers equal opportunities to everyone.

We found that the image of the ideal doctor among clinical trainees was conceived as being both masculine and feminine and could therefore be characterised as androgynous. However, the discrepancy between idealized image and self-image over time indicated some qualification of this finding. The data show that there continues to be a discrepancy between the ideal and the self among male subjects, but that this difference between the self and the ideal disappears among females. From this it can be inferred that the culturally ideal image of doctors has more masculine or instrumental than feminine or expressive characteristics.

With respect to the professional orientation of trainees we found signs of gender role socialization towards being wage earner among males; they were more strongly oriented towards social status, recognition and income than their female colleagues. The gender role socialization of females with the emphasis on care and expressive aspects was less clear in the professional orientation of female trainees. Female medical trainees seem to be less stereotypically feminine, whereas male medical trainees prove to be stereotypically masculine.

Finally, the relationship between aspects of socialization, which were operationalized in the various themes of perceived pressure, ability to cope, strain, and selfassessment, professional self-confidence and professional identity, were analysed using 
multivariate methods. These revealed interesting relationships between the aspects we investigated.

The final conclusion of this thesis connects the main lines of the thesis and discusses the most important insights gained from this research project. Both the research conducted into the professional culture and the research conducted into socialization can provide recommendations for changes and opportunities for the medical profession and medical education. Generally it can be stated that we, the medical profession, still have a lot of work to do. Modern times, which are full of changes, require great efforts from medical professionals to renew the profession and medical education so that the healthcare system can fully benefit from the cultural capital of females. 


\section{Dankwoord}

De ontwikkelingsgeschiedenis van dit proefschrift is sterk verweven met het opbouwproces van Vrouwenstudies in de geneeskunde en medische faculteit. De motivatie om hieraan mee te werken kwam voort uit enthousiasme over de kracht en de relevantie van dit perspectief op de werkelijkheid en behoefte om bij te dragen aan emancipatie en feminisering van de geneeskunde. In den beginne was ik behept met enige scepsis over de kracht van kennisproduktie en wetenschappelijk onderzoek om maatschappelijke praktijken te veranderen, maar na enige tijd raakte ik toch overtuigd. Wetenschappelijk werk zou in ieder geval helpen om geloofwaardigheid te creëren en de meerwaarde van dit perspectief voor artsen en de medische praktijk zichtbaar te maken.

Eigenzinnig en varend op het kompas van mijn bezieling voor een "goede zaak" vertrok ik, onderwijl support en draagvlak organiserend in een ongeïnteresseerde context, de medische faculteit. Zelfs de meeste elementaire zaken waren in den beginne niet geregeld. In deze startfase heb ik veel steun en loyaliteit ervaren van mensen binnen en buiten de faculteit. Ik noem maatschappelijk geengageerde intellectuelen als Paulien Tomlow, met wie het voor mij allemaal begon in deze universiteit en Louis Boon, die het beginnend clubje Vrouwenstudies Geneeskunde onderdak verleende bij de vakgroep Gezondheidsethiek en Wijsbegeerte. Ik noem Josien Heineman, die hielp bij de opzetten van het onderzoek en die mij introduceerde bij Gerard Essed, die mij als promotor verder zou begeleiden. Ik noem Greta Noordenbos, een geestverwant die zich inzette voor dezelfde idealen en mij leerde het aangename met het nuttige te verenigen. Levendig staat mij nog voor ogen hoe wij in de pioniersfase ons samen op mijn krakkemikkige fiets door Maastricht verplaatsten, terwijl ik enerzijds probeerde de vaart erin te houden (bergop over de kinderkopjes van de Maasbrug) en tegelijkertijd bezig was druk te overleggen met mijn maatje op de bagagedrager over de kwestie hoe de "vrouwenstudies-zaak" het best te (be)dienen. Ook Edward Steur, Leon op 't Hoogh en Hub Ruyters moeten bedankt worden voor hun materiële en immateriële steun (budget en bestaansvoorwaarden). Dank ook aan Tjaart Imbos en Hubert Schouten op wie ik steeds een beroep kon doen voor statistische en methodologische adviezen. Last but not least noem ik Andre Knottnerus, die vanaf het begin daadwerkelijk en effectief Vrouwenstudies heeft ondersteund en zorgde voor fatsoenlijke inbedding in de vakgroep huisartsgeneeskunde. Ook hield hij wanneer de facultaire of universitaire tegenwind sterk was, de sectie Vrouwenstudies Geneeskunde uit de wind. 
Het werd een lange tocht, het zoeken en verkennen van theorieën en al die uitstapjes buiten mijn eigen vakgebied. Steeds op zoek naar interessante inzichten over de hardnekkigheid van de machtsongelijkheid tussen de seksen. Gedreven door een "heilige vuur" was ik begonnen, niet vermoedend dat deze intellectuele zoektocht uiteindelijk meer overeenkomst zou gaan vertonen met een elfstedentocht dan met de 400 meter, meer mijn kwaliteit dan de duursport. Terugblikkend was het een harde leerschool, een tweede inwijding na mijn socialisatie tot arts en huisarts, nu ondergedompeld in de cultuur van wetenschap en kennisproduktie.

Maar deze leerschool heeft mij uiteindelijk wel de weg doen vinden naar de bronnen van creatieve intelligentie en heeft mij teruggevoerd naar het vertrouwen in de kracht van bezieling en engagement.

Ik dank dan ook alle vrouwen die het vuurtje van idealen brandend hebben gehouden, al die studenten geneeskunde en gezondheidswetenschappen, die ik mocht ontmoeten in werk- of studiegroepen Vrouwenstudies. Collega's en studenten zoals Mieke den Hoed, Marieke Steeman, Vera van Loo, Claar Corstens, Rini Rongen, Wies Weyts, Marie-Jose Gregoire vaak allemaal op hun manier bezig met hun eerste eigenzinnige schreden binnen de academische wereld.

Ook de Vereniging voor Nederlandse Vrouwelijke Artsen (VNVA) die vaak een podium bood om mijn denkbeelden te toetsen en mij stimuleerde ze verder te ontwikkelen, moet ik danken. Evenals de vrouwen van Transact, die mij attendeerden op mijn management-vaardigheden en de mogelijkheid boden om ervaring op te doen in organisatie-advies werk. Inspirerende landelijke contacten met de vrouwen van Aletta, Vrouwengezondheidscentrum in Utrecht als Leonoor Nicolai, Ingrid Baart en de vele anderen, ontmoetingen en samenwerken met vrouwelijke intellectuelen als Nellie Oudshoorn, Marianne van de Wijngaard, Ineke Klinge en Francien Swart in de vakanties. Stimulerend was de samenwerking met de redactieleden van de VNVAkrant, met de medewerksters en bestuursleden van het Vrouwengezondheidscentrum te Maastricht en van de abortuskliniek Bourgogne te Maastricht, bedankt Mieke Bruggeman, Yolanda Kicken en Mik Hamers.

Zonder de morele steun van deze vrouwen en de velen die ik niet heb genoemd, had ik het niet kunnen volhouden.

Toen ik op de laatste meters, terwijl het einde in zicht was, door de knieën dreigde te gaan, schoot Frans van der Horst mij te hulp. Maria van Laken las en verbeterde mijn theoretische hoofdstukken en Miep Jennekens hielp mij met haar liefdevol commentaar om nuchter en zakelijk te blijven bij de presentatie van mijn gegevens. Loyale steun kreeg ik tot het laatst van Ernest Kneepkens, die de steken opraapte die ik liet vallen als ouder voor mijn twee grote zonen en mijn kleine prinsje.

De praktische support van mijn onderzoeksassistenten is uiteindelijk cruciaal geweest voor het welslagen van het onderzoek en proefschrift. Zonder de inzet en geweldige kwaliteiten van Jeanne Adriaans, Marianne van den Akker en Joke Oud was dit werk er niet geweest. 


\section{Curriculum vitae}

Yvonne Winants werd op 14 augustus 1953 in Weert geboren. Na het behalen van het eindexamen Gymnasium B in 1971 studeerde zij, na een kort uitstapje naar de studie Biologie, Geneeskunde van 1972 tot 1979 aan de Rijksuniversiteit te Utrecht. Tijdens deze studie volgde zij diverse bijvakken aan de subfaculteit Psychologie en werkte mee aan de oprichting van het Vrouwengezondheidcentrum Aletta te Utrecht. $\mathrm{Na}$ het artsexamen koos zij voor een vervolgopleiding tot huisarts. Deze beroepsopleiding speelde zich af in een dorpspraktijk in Noord-Brabant en werd afgerond in 1981. Later volgde zij blokken van de psychotherapie opleiding van de RINO op het terrein van psycho-analyse en systeemtherapie.

In 1982 trad zij in dienst als wetenschappelijk medewerker van Universiteit Maastricht bij de faculteit Gezondheidswetenschappen, waar zij meewerkte aan opzet en curriculum-ontwikkeling van deze nieuwe faculteit. Zij leverde bijdragen aan Humane Biologie, Gezondheidsvoorlichting, Verplegingswetenschap en Geestelijke Gezondheidkunde en stond aan de wieg van de Emancipatie Commissie van de Universiteit Maastricht. Ook richtte ze met een vrouwelijke collega de Regio Zuid van de Vereniging van Nederlandse Vrouwelijke Artsen op. Naast het werk aan de universiteit werkte ze steeds in deeltijd als waarnemend huisarts.

In 1988 nam ze de uitdaging aan om pioniersarbeid te verrichten op het gebied van Vrouwenstudies onderwijs en onderzoek in de Faculteit der Geneeskunde. Deze taak bleef zij combineren met het praktisch werk in de medische praktijk.

In deze periode werden de fundamenten van dit boek gelegd en werden talrijke lezingen verzorgd en onderwijs en inhoudsdeskundige bijdragen geleverd over uiteenlopende thema's op het terrein van Vrouwenhulpverlening en Vrouwengezondheidszorg.

$\mathrm{Na}$ zes intensieve jaren besloot ze in 1994 opnieuw tot een accentverschuiving in haar loopbaan en aanvaardde zij een deeltijdfunctie als arts-manager van de Arbodienst van de GGD Midden- en Noord-Limburg. In 1997 werd zij gevraagd om te opteren voor een managementfunctie in de geestelijke gezondheidszorg, een oude liefde. De onderzoeksactiviteiten op het gebied van gender en socialisatie tot arts bleef zij daarnaast doorzetten. In 1998 aanvaarde zij, opnieuw in deeltijd, een managementfunctie in psychiatrisch ziekenhuis Vijverdal te Maastricht en een jaar later rondde ze haar proefschrift af. 

In diverse westerse landen doet zich sinds enige jaren in de medische professie een verschuiving voor in de balans tussen de seksen. De beroepsgroep vervrouwelijkt en het aandeel van vrouwelijke artsen is getalsmatig fors gegroeid. Maar hun opmars naar invloedrijke rollen en functies in het medische veld verloopt, net als in diverse andere maatschappelijke sectoren, niet soepel. Het menselijk kapitaal van de nieuwe generatie artsen wordt in de opleiding gevormd.

In het begin van de medische opleiding ligt het accent op het vergaren van medische kennis en vaardigheden. Daarna verandert in de laatste twee jaar van de opleiding het leerproces ingrijpend. Met de co-assistentschappen of klinische stages begint een leerperiode waarin de aanstaande artsen de realiteit van het medische beroep aan den lije ondervinden. Ze waren buitenstaanders van de artsenwereld, maar maken nu als nieuwkomers kennis met de gewoonten, de gebruiken en de vanzelfsprekendheden van deze wereld. Voor het eerst ervaren zij hoe de regels van het sociale spel voor artsen functioneren en hoe het voelt om in de rol van arts de patient tegemoet te treden. Ze worden ondergedompeld in de cultuur van de huidige medische beroepsgroep. die een lange geschiedenis van mannelijke dominantie kent.

Welke impact heeft de confrontatie met deze beroepscultuur op het innerlijk en het gedrag van de vrouwelijke en mannelijke artsen van de toekomst? Een cultuur, die door co-assistenten als machtsongelijk, hiërarchisch en weinig feminien wordt waargenomen.

In dit boek wordt de relatie bestudeerd tussen vorming en socialisatie tot arts en de (re)productie van machtsongelijkheid tussen de seksen in de fase van de co-assistentschappen.

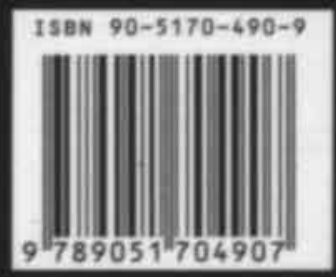

THELA - THESIS 